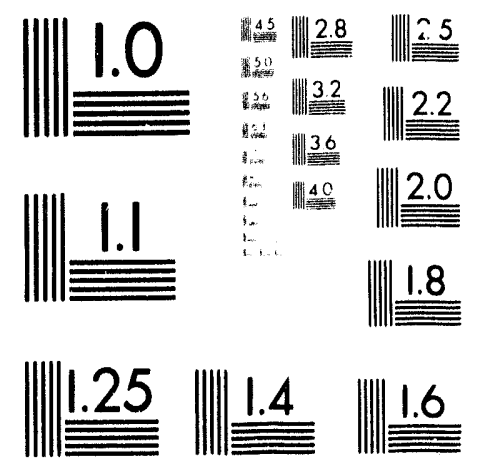



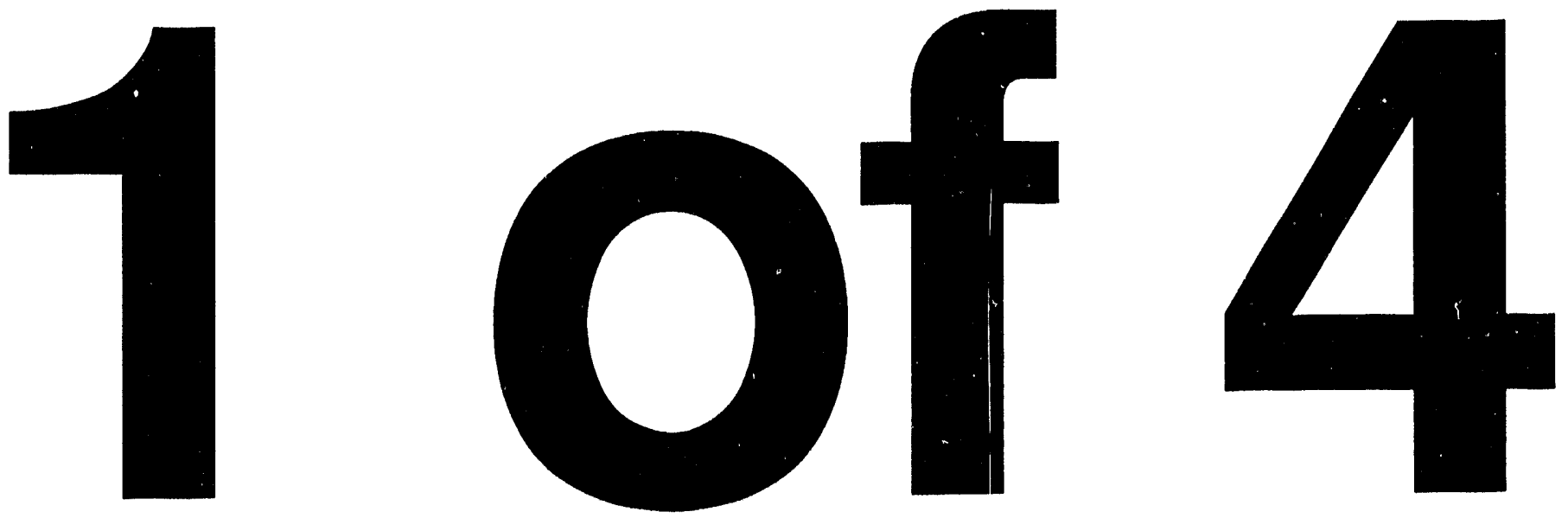


\title{
Tank Characterization Report: Tank 241-C-109
}

\author{
B. C. Simpson \\ G. L. Borshiem \\ L. Jensen
}

Date Published

September 1993

Prepared for the U.S. Department of Energy Office of Environmental Restoration and Waste Management

\section{(2) Westinghouse


WHC-EP-0668

This page intentionally left blank. 
Document Title: Tank Characterization Data Report: Tank 241-C-109

Prepared by:

Prepared by:

Approved by:

Approved by:

nw kne

Nicholas W. Kirch, Manager

Tank Waste Technology Applications

Approved by:

$$
\text { Artimn }
$$

Albert F. Noonan, Manager

Anatytical Evaluation and Reporting

Approved by:

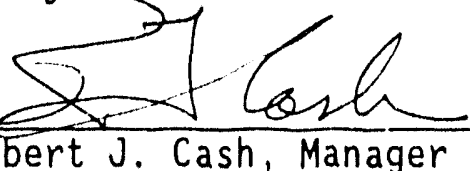

Robert J. Cash, Manager

Ferrocyanide Safety Technology

Approved by:

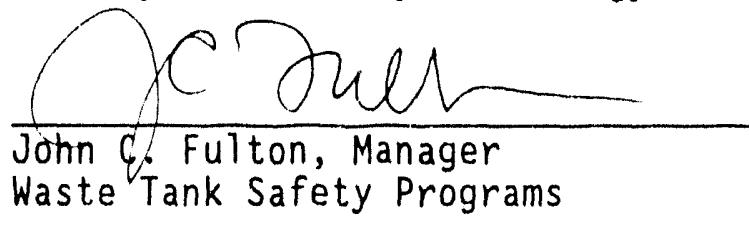

Approved by:

Approved by:

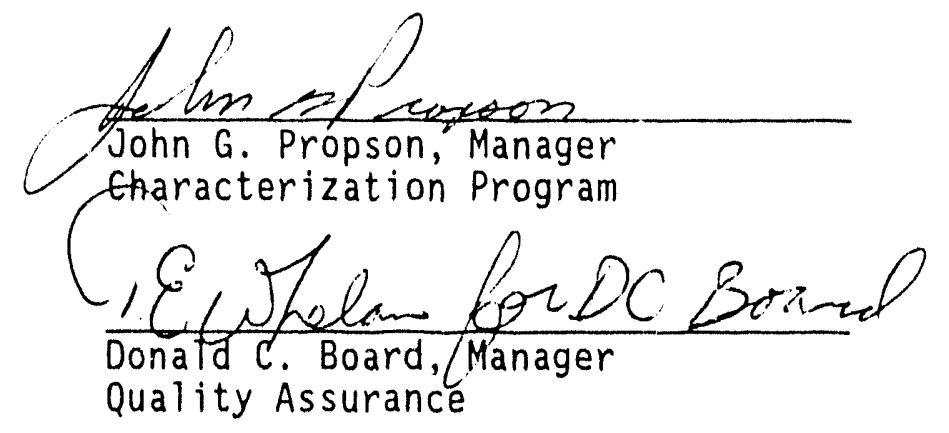

Approved by:

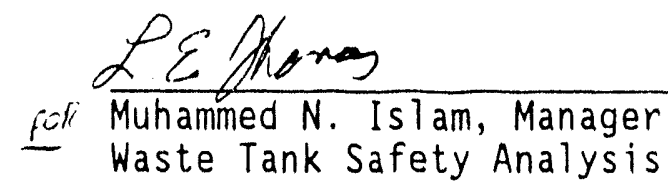

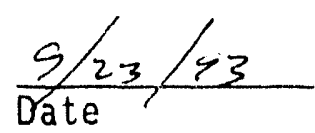

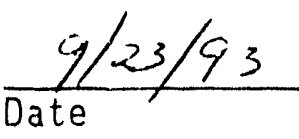

\section{$\frac{9 / 22 / 43}{\text { Date }}$}

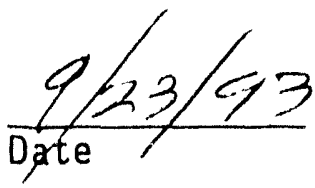

$\frac{9 / 27 / 83}{\text { Date }}$

$\frac{9 / 23 / 93}{\text { Date }}$

$\frac{9 / 22 / 53}{\text { Date }}$
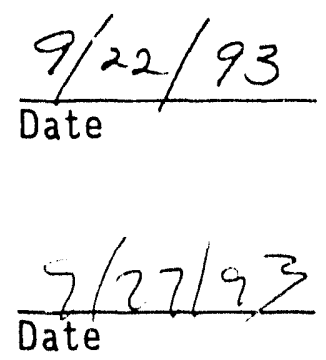

Date
9/23/93 


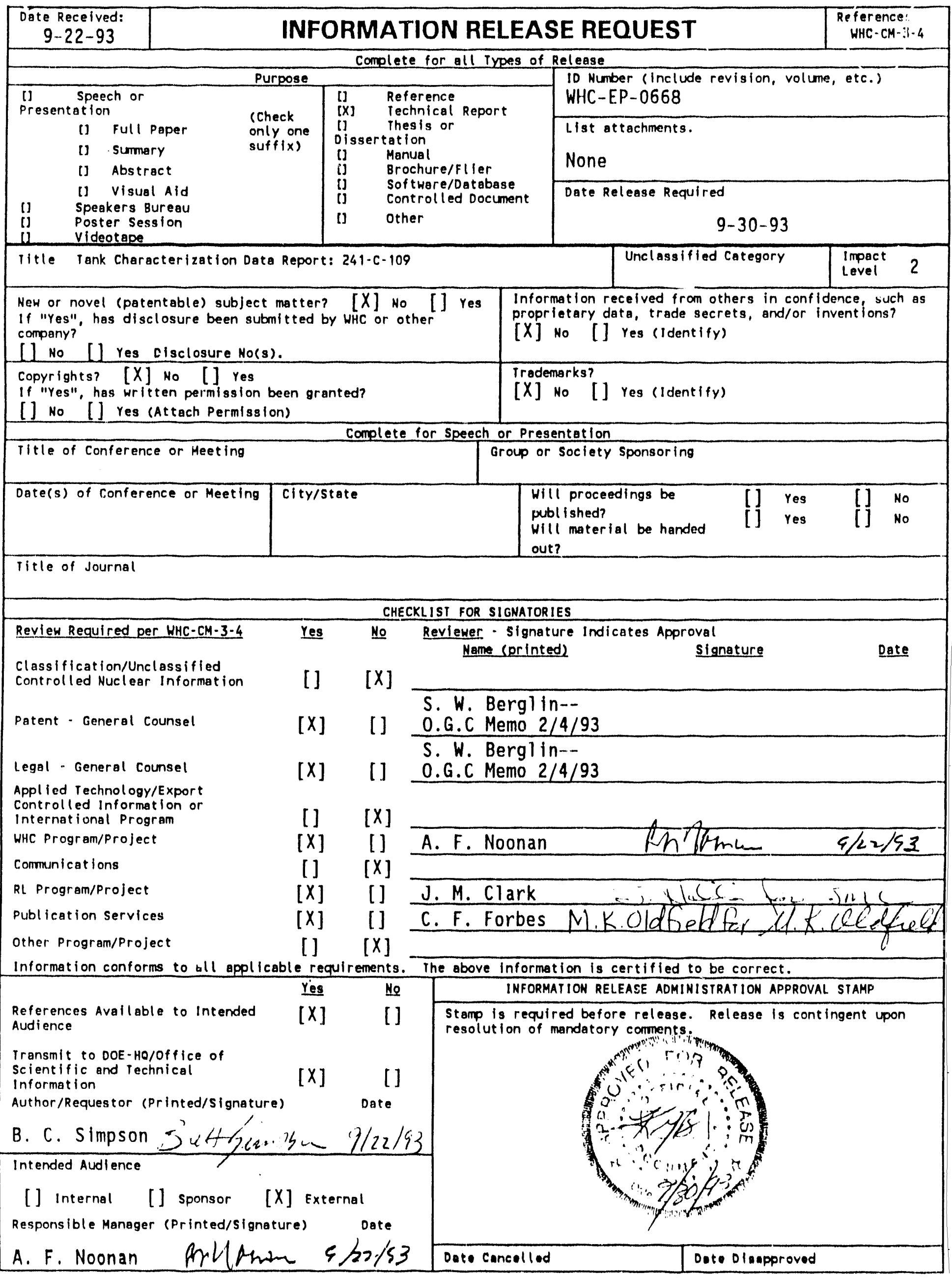




\section{EXECUTIVE SUMMARY}

Single-shell tank 241-C-109 is a Hanford Site Ferrocyanide Watch List tank that was most recently sampled in September 1992. Analyses of materials obtained from tank 241-C-109 were conducted to support the resolution of the ferrocyanide unreviewed safety question (USQ) and to support Hanford Federal Facility Agreement and Consent $\operatorname{Order}^{1}$ (Tri-Party Agreement) Milestone $\mathrm{M}-10-00$.

Analysis of core samples obtained from tank 241-C-109 strongly indicates that the fuel (e.g., ferrocyanide and organic) concentration in the tank waste will not support a propagating exothermic reaction. Analysis of the process history of the tank as well as studies of simulants provided valuable information about the physical and chemical condition of the waste. This information, in combination with the analysis of the tank waste, supports the conclusion that an exothermic reaction in tank 241-C-109 is not plausible. Therefore, the contents of tank 201-C-109 present no imminent threat to the workers at the Hanford Site, the public, or the environment from its ferrocyanide inventory. Because a propagating, exothermic reaction is not. credible, the consequences of this accident scenario, as promulgated by the General Accounting office, are not applicable. ${ }^{2}$

${ }^{1}$ Ecology, EPA, and DOE, 1992, Hanford Federal Facility Agreement and Consent Order, 2 vols., Washington State Department of Ecology, U.S. Environmental Protection Agency, and U.S. Department of Energy, 01ympia, Washington.

"Peach, J. D., 1990, "Consequences of Explosion of Hanford's Single-Shell Tank are Understated," (Letter B-241479 to C. M. Synar, Chairman of Environment, Energy, and Natural Resources Subcommittee, Committee on Government Operations, House of Representatives), GAO/RCED-91-34, General Accounting Office, Washington, D.C. 
It is probable that tank 241-C-109 exceeds the 1,000 g-mol inventory criterion established for placement on the Ferrocyanide Watch List. However, extensive energetic analysis of this waste has determined a maximum exothermic value of $-12.4 \mathrm{cal} / \mathrm{g}$ dry waste, and in most cases, no discernable exotherm was observed. This observation was further substantiated by total cyanide measurements of less than 1.5 dry weight percent. This exothermic measurement is substantially below the established level of concern, $-75 \mathrm{cal} / \mathrm{g}{ }^{1}$. In addition, an investigation of potential mechanisms to generate concentration levels of radionuclides high enough to be of concern (i.e., to cause in-tank self-heating) was performed. No credible mechanism was postulated that could initiate the formation of such concentration levels ${ }^{2}$ in the tank.

Tank 241-C-109 waste is a complex material made up primarily of water and inert salts. The insoluble solids are a mixture of phosphates, sulfates, and hydroxides in combination with aluminum, calcium, iron, nickel, and uranium. Disodium nickel ferrocyanide and sodium cesium nickel ferrocyanide probably exist in the tank; however, there appears to have been significant degradation of this material since the waste was initially settled in the tank. Most of the ${ }^{137} \mathrm{Cs}$ precipitated during the scavenging campaign (1955 to 1957$)^{3}$ appears to still remain in the tank in an insoluble form, probably bound with the remaining ferrocyanide. During the tank's service 1 ife, additional ${ }^{137} \mathrm{Cs}$ and

Jewett, J. R., 1992, "Energy Measurements for Disqual ifying Waste Tanks from Watch Lists," Meeting Minutes, October 22, 1992, Westinghouse Hanford Company, Richland, Washington.

${ }^{2}$ Dickinson, D. R., J. M. McLaren, G. L. Borsheim, and M. D. Crippen, 1993, Credibility of Drying Out Ferrocyanide Tank Waste Sludge by Hot Spots, WHC-EP-0648, Westinghouse Hanford Company, Richland, Washingtoll.

${ }^{3}$ Borsheim, G. L. and B. C. Simpson, 1991, An Assessment of the Inventories of the Ferrocyanide Watchlist Tanks, WHC-SD-WM-ER-133, Rev. O, Westinghouse Hanford Company, Richland, Washington. 


\section{WHIC-EP-0668}

${ }^{90} \mathrm{Sr}$ was deposited after the scavenging campaign. The most prevalent soluble analytes are primarily sodium, nitrate, and nitrite (refer to Table ES-1).

Comparisons of the calculated bulk inventories for various analytes of concern show that tank 241-C-109 is within established operating safety requirements for heat-10ad, organic content, and plutonium inventory. Tank 241-C-109 is considered a sound, non-leaking tank. 
Table ES-1. Characterization Summary for Single-Shell

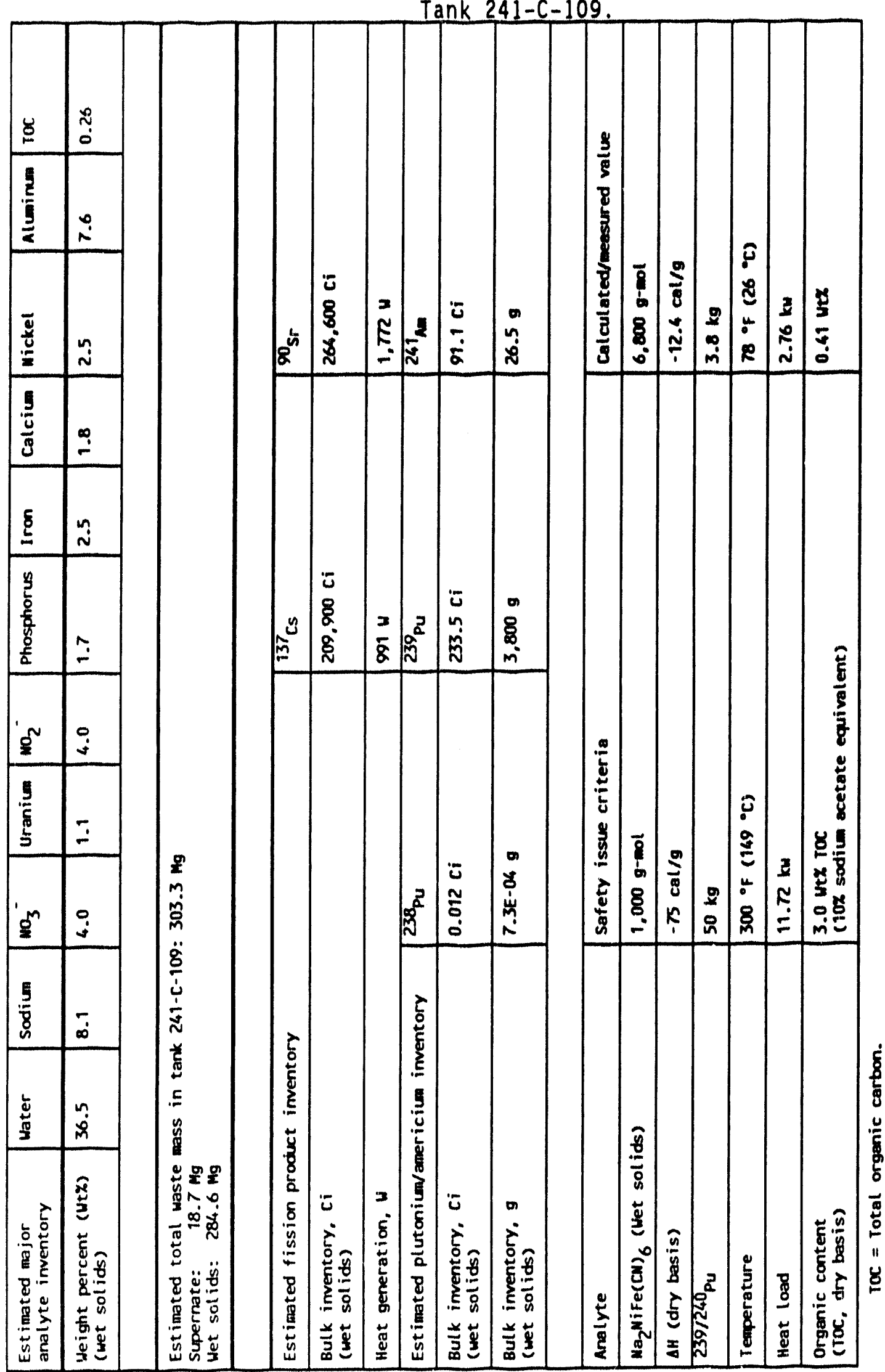


Figure ES-1. Tank 241-C-109 Summary Tank Data.

\section{Tank: 241-C-109}

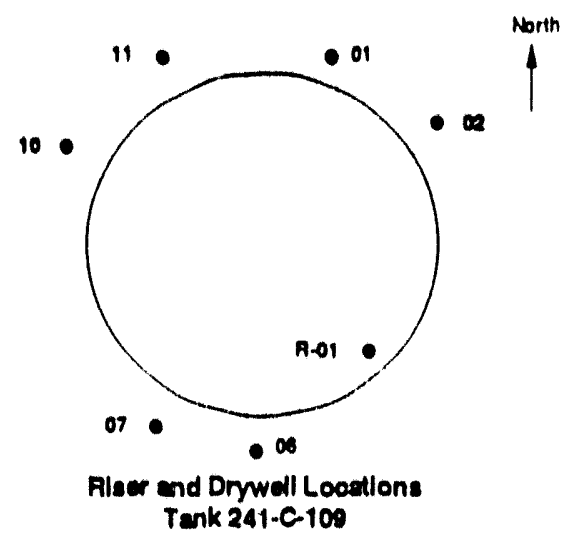

Number of External Drywells: 6

Number of Lateral Wells: None
Tank Description

Type: Single Shell

Constructed: 1944

In-service: $04 / 48$

Out of Service: 1976

Dlameter: $75^{\prime}$

Usable Depth: 16'

Capacity: $530 \mathrm{~K}$ gallons

Bottom shape: Dish

Hanford Coordinates: 43.003' North 48.327' West

Ventlation: Passive

\section{Leak Detectlon System}

Surface Level:

FIC Riser- None

Manual Tape Riser- R.01

LOW RIser(s)- None

\section{Tank Status \\ Watch List: Ferrocyanide \\ Contents}

Type: Non-Complexed Waste

Total Waste: $66 \mathrm{~K}$ gallons

Supernate Volume: $4 \mathrm{~K}$ gallons

Drainable Interstitial Liquid: OK gallons

Isolation Status

Date Interim Stabilized: 11/29/83

Date Interim Isolated: 12/15/82

Surface Level/Leak Status

Integrity Category: Sound

Manual Tape Surface Level: 18.00 Inches (11/23/92)

Last Photographed: 01/30/76

Temperature Status

Highest temperature during 1992:

Comments:

$88 \operatorname{deg} F(09 / 30 / 92)$

Drywell Status

Temperatures are stable.

Comments:

Current drywell profles were stable and consistent with established baseline profles. 
$W H C-E P-0608$

This page intentionally left blank. 


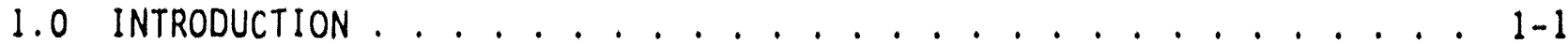

1.1 PURPOSE . . . . . . . . . . . . . . . 1-1

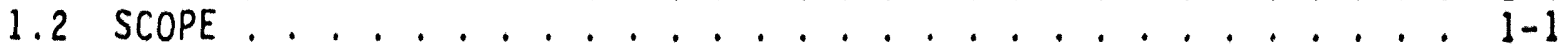

2.0 PRESAMPLING INFORMATION AND EVALUATION ........... $2-1$

2.1 BACKGROUND .................... 2-1

2.1.1 Tank 241-C-109 History . . . . 2-1

2.1.2 Unrevtewed Safety Question Declaration . . . . . . 2-6

2.2 EXPECTED TANK CONTENTS/CONDITIONS . . . . . . . . . . . 2-7

2.3 ANALYTICAL RESULTS FROM SIMULANT STUDIES ......... $2-9$

2.3.1 Simulant Formulation: In Farm 2 Flowsheet Material . 2-9

2.3.2 Simulant Physical Characteristics ........ 2-11

2.3.3 Simulant Chemical Composition ............... 2-12

2.3.4 Energetics Behavior of Ferrocyanide Sludge simulant . . 2-12

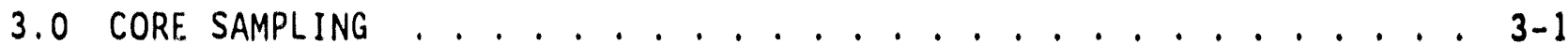

3.1 DESCRIPTION OF SAMPLING EVENT ............ $3-1$

3.2 CHAIN OF CUSTODY ................... $3-1$

4.0 SAMPLE PREPARATION/SAMPLE EXTRUSION ............ . 4-1

4.1 SAMPLE BREAKDOWN PROCEDURE .............. . . 4-1

4.2 HOMOGENIZATION TESTS . . . . . . . . . . . 4-2

4.3 SUBSEGMENT-LEVEL ANALYSES . . . ......... . . 4-3

4.3.1 Rheological and Physical Measurements . . . . . . 4-4

4.3.2 Subsegment Level Archive .............. 4-4

4.3.3 Core Composite Level Analysis .......... 4-5

5.0 ANALYTICAL RESULTS: TANK 241-C-109 . . . . . . . . . 5-1

5.1 TANK 241-C-109 CORE SAMPLE RECOVERY ........ 5-1

5.2 TWRS PROGRAM ELEMENT CHARACTERIZATION SYNOPSIS ...... 5-3

5.2.1 Retrieval Prograni Characterization

Data Summary: Physical Properties . . . . . . . . 5-3

5.2.2 Pretreatment Program Characterization Data
Summary: Bulk Constituent Inventories . . . . . . 5-4

5.2.3 Waste Tank Safety Program Characterization
Data Summary . . . . . 5-4

5.2.4 HWVP Program Characterization Data Summary . . . . 5-6

5.3 TANK 241-C-109 CORE SAMPLE RHEOLOGICAL/

PHYSICAL MEASUREMENTS . . . . . . . . . . 5-11

5.3.1 Shear Strength . . . . . . . . . . 5-11

5.3.2 Shear Stress and Viscosity as Functions

of Shear Rate ............. 5-12

5.3.3 Slurry Flow Properties............. . 5-13

5.3.4 Particle Size Measurement . . . . . . . . . . . 5-15

5.3.5 Settling Behavior of As-Received and

Diluted Samples . . . . . . 5-21

5.4 ANALYTICAL RESULTS--INDUCTIVELY COUPLED PLASMA-

ATOMIC EMISSION SPECTROSCOPY ........... . . 5-23

5.4.1 Inductively Coupled Plasma

Assays--General Comments . . . . . . . . . 5-23 
5.4.2 Liquid Core Composite .............. . 5-26

5.4 .3 Core 47 . . . . . . . . . . . . . . . . 5-26

5.4 .4 Core 48 . . . . . . . . . . . . . . . . . . 5-27

5.4 .5 Core 49 . . . . . . . . . . . . . . . . . . . 5-28

5.5 ANALYTICAL RESULTS--ANION ASSAYS . . . . . . . . . . . . . . . 5-29

5.5.1 Ion Chromatography Assays--General Comments . . . . . . 5-29

5.5.2 Liquid Core Composite .............. . 5-29

5.5.3 Core 47 .................... . 5-30

5.5 .4 Core 48 . . . . . . . . . . . . . . . . . . 5-30

5.5.5 Core 49 . . . . . . . . . . . . . . . . . 5-30

5.6 ANALYTICAL RESULTS--RADIOCHEMISTRY . . . . . . . . . . . . . . . . $5-34$

5.6.1 Radiochemistry Assays--General Comments . . . . . . . . 5-34

5.6.2 Gamma Energy Analys is Results . . . . . . . . . . . 5-34

5.6.3 Total Alpha Analys is and Uranium Assay. . . . . . . . 5-35

5.6.4 Total Beta .. . . . . . . . . . . . . . 5-35

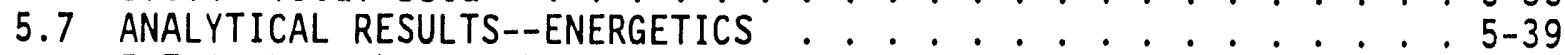

5.7.1 Remarks on the Interpretation of Differential

Scanning Calorimetry/Thermogravimetric

Analys is Data ................. . . 5-40

5.7.2 General Comments on the Differential

Scanning Calorimetry/Thermogravimetric

Analys is Behavior of the Saimples .......... . 5-43

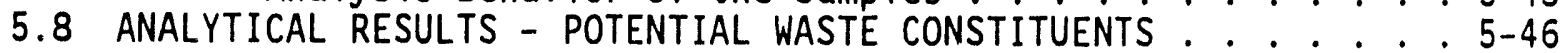

5.8.1 Mass Balances ................... . . 5-46

5.8.2 Suggested Components of Waste Matrix . . . . . . . . . . 5-48

5.8.3 Comparison to Theoretical Estimates

and Simulant Studies .............. . 5-49

5.9 RCRA-TYPE ANALYSIS: DATA VALIDATION/VERIFICATION PROTOCOL . : 5-50

5.9.1 Chemical Data ................. . 5-50

5.9.2 Radiological Data .. . . . . . . . . . . . 5-51

6.0 INTERPRETATION OF ANALYTICAL RESULTS . . . . . . . . . . . . . 6-1

6.1 TANK 241-C-109 WASTE PROFILE . . . . . . . . . . . . . . . . . . . 6-1

6.2 REVIEW OF THE SUBSEGMENT ANALYTE PROFILES . . . . . . . . . . . . . . . . . . . $6-2$

6.2.1 Tank Entrance/Exit Effects

on Analyte Distribution ........... . . 6-3

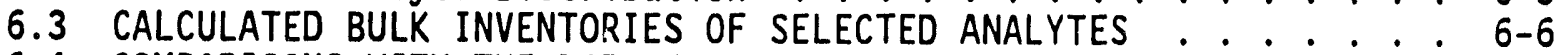

6.4 COMPARISONS WITH THE BORSHEIM/SIMPSON MODEL ESTIMATES . . . . . $6-8$

7.0 QUANTITATIVE/STATISTICAL INTERPRETATION OF THE DATA . . . . . . . . 7-1

7.1 INTRODUCTION . . . . . . . . . . . . . . . . . . . . . 7-1

7.2 MEAN CONCENTRATION ESTIMATES . . . . . . . . . . . . . . . . . . . . $7-5$

7.3 HOMOGENIZATION TEST . . . . . . . . . . . . . . . . . . . . . . . . . . . . $7-7$

7.4 COMPARISON WITH A SIMULATED CORE COMPOSITE MEAN . . . . . . . . $7-8$

7.5 THE SPATIAL VARIANCE AND ANALYTICAL MEASUREMENT VARIANCE $. .7 . \quad . \quad 7-9$

7.6 MULTIPLE COMPARISONS: CORE COMPOSITE

SAMPLES AND SUBSEGMENT SAMPLES ................ . 7-11

7.7 COMPARISON OF RESULTS: SINGLE-SHELL

TANKS 241-C-109 AND 241-C-112................ . 7-15

7.7.1 Comparison of Mean Concentrations . . . . . . . . . . . 7-17

7.7.2 Comparison of Variances . . . . . . . . . . . . 7-17 


\section{WHC-EP-0668 \\ CONTENTS (Continued)}

7.8 SUMMARY OF STATISTICAL INTERPRETATION . . . . . . . . . . . . .

8.0 CONCLUSIONS AND RECOMMENDATIONS .............. . . . . . .

8.1 CONCLUSIONS FROM ANALYTICAL RESULTS . . . . . . .

8.2 CONCLUSIONS FROM ENERGETICS ANALYSIS .......... $8-2$

8.3 RECOMMENDATIONS .................. 8-3

9.0 REFERENCES . . . . . . . . . . . . . . . . . 9-1

\section{APPENDIXES}

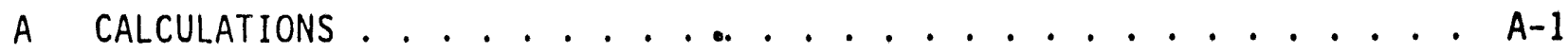
B STATISTICAL INTERPRETATION . . . . . . . . . . . B-1

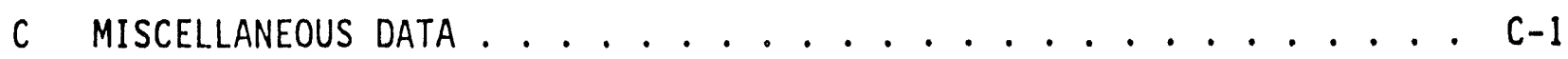
D QUALITY ASSURANCE DOCUMENTATION SUMMARY ........... D-1 
WHC-EP-0668

\section{LIST OF FIGURES}

2-1 Typical Single-Shell Tank Diagram . . . . . . . . . . . 2-2

2-2 In Farm Flowsheet . . . . . . . . . . . . . . . . 2-4

2-3 Solids and Liquid Wastes - Tank 241-C-109........... 2-8

2-4 Ferrocyanide Tank 3-Component Diagram . . . . . . . . . . . 2-14

3-1 Tank 241-C-109 Riser Configuration . . . . . . . . . . 3-2

4-1 Typical Single-Shell Tank Segment Extrusion . . . . . . . . . 4-1

5-1 Current Waste Level of Tank 241-C-109 . . . . . . . . . . . 5-2

5-2 Core 47 Measurements and Observations . . . . . . . . . . . 5-7

5-3 Core 48 Measurements and Observations . . . . . . . . . . 5-8

5-4 Core 49 Measurements and Observations . . . . . . . . . . . . 5-9

5-5 Shear Stress Versus Shear Rate for 1:1 Diluted Sample . . . . . 5-14

5-6 Viscosity Versus Shear Rate for 1:1 Diluted Sample . . . . . . 5-14

5-7 Core 47, Particle Size Number Density . . . . . . . . . . . 5-16

5-8 Single-Shell Tank Core 47, Particle Size Volume Density . . . . . . . . . . . . . . . . 5-18

5-9 Core 48, Particle Size Number Density . . . . . . . . . . . 5-19

5-10 Single-Shell Tank Core 48, Particle Size Volume Density . . . . . . . . . . . . . . . . . 5-19

5-11 Core 49, Particle Size Number Density . . . . . . . . . . . 5-20

5-12 Single-Shell Tank Core 49, Particle Size Volume Density .. . . . . . . . . . . . . . . 5-20

5-13 Settiing Rate Data for Tank 241-C-109

Core 49,1:1 Dilution.................. . 5-22

5-14 Settling Rate Data for Tank 241-C-109

Core 49, 3:1 Dilution .................. 5-22

6-1 Elevation and Plan of Tank 241-C-109 . . . . . . . . . . . . 6-4

6-2 Waste Profile of Tank 24l-C-109... . . . . . . . . . 6-5 
WHC-EP-0668

\section{LIST OF TABLES}

2-1 Expected Concentrations for Characteristic Analytes . . . . . 2-10

2-2 Feed Solution Composition for In Farm 2 Flowsheat . . . . . 2-10

2-3 Summary of In Farm 2 Simulant Characterization Data . . . . . 2-11

2-4 Estimated Composition of Homogenized, Centrifuged,

Ferrocyanide Sludge Simulant . . . . . . . . . . 2-12

2-5 Heats of Reaction of Various Simulants .......... 2-13

3-1 Chain-of-Custody Summary ............... 3-3

4-1 Subseginent-Level Analysis . . . . . . . . . . . . . 4-3

5-1 Tank 241-C-109 Core Sample Description Summary . . . . . . . . 5-1

5-2 Tank 241-C-109 Core Sample Physical Characteristics Summary . . . 5-1

5-3 Retrieval Program . . . . . . . . . . . . . . 5-3

5-4 Trace Analytes of Interest to Pretreatment. . . . . . . . . . 5-4

5-5 Core Composite Transuranics (Fusion Preparation) . . . . . 5-5

5.6 Core Composite Uranium . . . . . . . . . . . . . . . 5-5

5-7 Plutonium Concentration and Isotopic Distribution . . . . . 5-5

5-8 HWVP Process Control Analytes of Concern . . . . . . . . . 5-10

5-9 HWVP Regulatory Operation Analytes of Concern ......... . 5-11

5-10 Power-Law Model Parameters for Tank 241-C-109 Material . . . . . 5-13

5-11 Turbulent Flow Model Calculations ............. . 5-15

5-12 Particle Size Distribution by Number: $89 \%<2 \mu \mathrm{m}$ (all cores) . . . 5-17

5-13 Particle Size Distribution by Volume: $100 \%<70 \mu \mathrm{m}$ (all cores) . . 5-17

5-14 Physical Properties Summary . . . . . . . . . . . . 5-21

5-15 Water Digestion Chemical Composite Data
--ICP Average Values . . . . . . . . . . . . . . 5-24

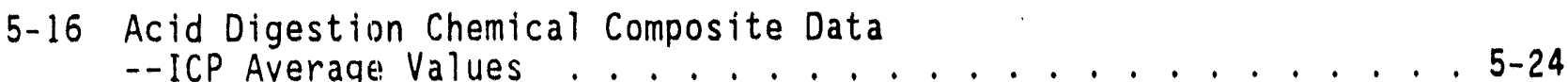

5-1. Fusion Digestion Chemical Composite Data
-ICP Average Values . . . . . . . . . . . . . 5-25 


\section{LIST OF TABLES (Continued)}

5-18 Tank 241-C-109 Core 47 ICP Analyte Trending (Fusion Prep on Subsegments) ............ . 5-25

5-19 Tank 241-C-109 Core 48 ICP Analyte Trending (Fusion Prep on Subsegments) ............. 5-26

5-20 Tank 241-C-109 Core 49 ICP Analyte Trending (Fusion Prep on Subsegments) ............. 5-26

5-21 Anion Assays--Composite Data Results (Water Leach) . . . . . . 5-31

5-22 Tank 241-C-109 Core 47 IC Analyte Trending . . . . . . . . 5-32

5-23 Tank 241-C-109 Core 48 IC Analyte Trending . . . . . . . . . 5-32

5-24 Tank 241-C-109 Core 49 IC Analyte Trending . . . . . . . . . . . . 5-32

5-25 Tank 241-C-109 Core 47 Misc. Analyte Trending . . . . . . . . . 5-33

5-26 Tank 241-C-109 Core 48 Miscellaneous Analyte Trending. . . . . . 5-33

5-27 Tank 241-C-109 Core 49 Miscellaneous Analyte Trending . . . . . . 5-34

5-28 Core Composite Fission Products (Fusion Prep)........ . 5-36

5-29 Liquid Core Composite Fission Products (Acid Prep) . . . . . . . 5-36

5-30 Core Composite Uranium ............. . . . 5-37

5-31 Core Composite Trace Radionucitides . . . . . . . . . . . . . 5-37

5-32 Plutonium Concentration and Isotopic Distribution . . . . . . 5-37

5-33 Core Composite Transuranics (fusion preparation) . . . . . . . 5-38

5-34 Total Alpha Homogenization Test $(\mu \mathrm{Ci} / \mathrm{g})$ (Acid Prep) . . . . . 5-38

5-35 Tank 241-C-109 Core 47 Radionuclide Trending (Fusion Preparation) ............... 5-38

5-36 Tarik 241-C-109 Core 48 Radionucl ide Trending
(Flision Preparation) . . . . . . . . . . . 5-39

5-37 Tank 241-C-109 Core 49 Radionucliog Trending
(Fusion Preparation) ................. 5-39

5-38 Thermogravimetric Analysis Results from Tank 241-C-109............... 5-41 
WHC-EP-0668

LIST OF TABLES (Continued)

5-39 Differential Scanning Calorimetry Energetics Results

from Tank 241-c-109.............. 5-42

5-40 Tank 241-C-109 Core 47 Energetic Comparison . . . . . . . . 5-44

5-41 Tank 241-C-109 Core 48 Energetic Comparison . . . . . . . . . 5-44

5-42 Tank 241-C-109 Core 49 Energetic Comparison . . . . . . . . 5-44

5-43 Tank 241-C-109 Core 47 Energetics Trending . . . . . . . 5-45

5-44 Tank 241-C-109 Core 48 Energetics Trending . . . . . . . . . 5-45

5-45 Tank 241-C-109 Core 49 Energetics Trending . . . . . . . . 5-45

5-46 Adjusted Mass Balanc^: Core 47 Composite . . . . . . . . . . . . . 5-47

5-47 Adjusted Mass Balance: Core 48 Composite . . . . . . . . . . 5-47

5-48 Adjusted Mass Balance: Core 49 Composite. . . . . . . . . . 5-48

5-49 Probable Solids in the Waste Matrix ... . . . . . . . . . 5-48

5-50 Tank 241-C-109 Cumparison of Waste Material with

Simulants for Selected Analytes............ . 5-50

6-1 Energetics Related Analyte Values . . . . . . . . . . . 6-6

$6-2$ Fission Product Inventory . . . . . . . . . . 6-6 6

6-3 Plutonium/Americium Inventory ............. 6-7

6-4 ICP Major Cation Inventory (From Fusion Preparation Results; . . 6-7

6-5 Comparisons of Initial and Revised Borsheim/Simpson Model

Estimates with Values Calculated from Analytical Results ..... 6-7

7-1 Core Composite Data (Units $\mu \mathrm{g} / \mathrm{g}$ Except Radionuclides $\mu \mathrm{Ci} / \mathrm{g}$ ) . . . 7-2

7-2 Subsegment Data (Unites $\mu \mathrm{g} / \mathrm{g}$ Except Radionuclides $\mu \mathrm{Ci} / \mathrm{g}$ ) . . . 7-3

7-3 Homogenization Test Data (Units $\mu \mathrm{g} / \mathrm{g}$ Except Radionuclides $\mu \mathrm{C} i / \mathrm{g}) \ldots \ldots$ 7-4

7-4 Concentration Estimate Statistics (Units $\mu \mathrm{g} / \mathrm{g}$
Except Radionuclide $\mu \mathrm{C} i / \mathrm{g}$ ) . . . . . . . . . . 7-6

7-5 Concentration Estimates Statistics, Drainable Liquid, (Units $\mu \mathrm{g} / \mathrm{g}$ ) ............. . . . . . 


\section{LIST OF TABLES (Continued)}

7-6 Homogenization Test Statistical Results . . . . . . . . . . . 7-8

7-7 Comparison of Simulated Core Composite with the Core Composite . . 7-10

7-8 95 Percent Confidence Interval on $\sigma^{2}(A)$, Analytical Error Variance............... . . 7-12

7-9 95 Percent Confidence Interval on $\sigma^{2}(S)$, Spatial Variance ................. . . . . . . . .

7-10 Tukey's HSO Multiple Comparisons, Core Composite Data (Units $\mu \mathrm{g} / \dot{\mathrm{g}}$ Except Radionuclides $\mu \mathrm{Cl} / \mathrm{g}$ )............ . 7-14

7-11 Subsegment Assignment for Tukey's HSD . . . . . . . . . . . 7-15

7-12 Tukey's HSD Multiple Comparisons, Subsegment Data (Units $\mu \mathrm{g} / \mathrm{g}$ Except Radionuclides $\mu \mathrm{Ci} / \mathrm{g}$ )............ . 7-16

7-13 Core Composite Assignment for Tank Comparison . . . . . . . . . 7-17

7-14 Comparison of Analytical Error Variances, Tanks 241-C-109 and 241-C-112................ 7-18

7-15 Comparison of Spatial Variances, Tanks 241-C-109 and 241-C-112............... 7-20

7-16 Comparison of Percent Variance,

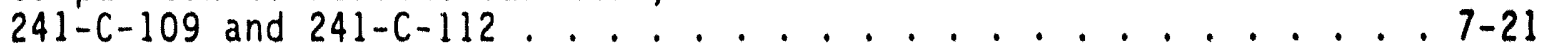

7-17 Relative Standard Deviations from Tanks C-112 and C-109... . . 7-22

8-1 Comparison of Tank 241-C-109 Analyte Values to Safety Issue Criteria.................. 8-3 


\section{LIST OF ACRONYMS}

1C

$A A$

AEA

ANOVA

ASC

CI

CST

$\mathrm{CW}$

DLC

DSC

$E B$

EPA

GAO

GEA

HASM

HDW-EIS

HS

HWVP

IC

ICP

NCAW

PNL

RPD

SST

TC

TGA

TIC

TOC

TOD

Tri-Party

Agreement

TRU

UR

USQ first decontamination cycle

atomic absorption

a)pha energy analysis

analysis of vartance

adiabatic scanning calorimetry

confidence interval

core sampling truck

decladding/coating waste

drainable liquid composites

differential scanning calorimetry

evaporator bottoms

U.S. Environmental Protection Agency

General Accounting Office

gamma energy analysis

Hanford Analytical Services Management

Final Environmental Impact Statement, Disposal of Hanford Defense High-Level, Transuranic and Tank Wastes

hot semiworks

Hanford Waste Vitrification Plant

ion chromatography

inductively coupled plasma - atomic emission spectroscopy

neutralized current acid waste

Pacific Northwest Laboratory

relative percent difference

single-shell tank

total carbon

thermogravimetric analysis

total inorganic carbon

total organic carboli

total oxygen demand

Hanford Federal Facility Agreement and Consent Order transuranic

uranium recovery

unreviewed safety question 
WHC-EP-0668

This page intentionally left blank. 
WHC-EP-0668

TANK CHARACTERIZATION DATA REPORT: TANK 241-C-109

\subsection{INTRODUCTION}

Analysis was conducted on materials obtained from tank $241-c-109$ to support the closure of the ferrocyanide unreviewed safety question (USQ). obtaining measurements that jetermine overall waste energetics is a key step in closing the ferrocyanide USQ and safety issue. In addition, several of the analytes contributing to the energetic properties of the waste need to be measured as a function of position (e.g., total cyanide and nitrate/nitrite present, water content, and the distribution and inventory of ${ }^{137} \mathrm{Cs}$ and ${ }^{90} \mathrm{Sr}$ in the tank). Other objectives that these measurements and inventury estimates support are as follows.

- Complete Hanford Federal Facility Agreement and Consent Order (Tri-Party Agreement) Milestone M-10-00 (Ecology et al. 1992) to sample and analyze two cores from each tank.

- Obtain estimates of both the concentration and total quantity of key analytes relating to other safety issues, such as organics and radionuclides.

- Provide input to risk assessment-based disposal decisions for the waste.

- Implement physical property measurements, such as rheology, bulk density, and particle size. These measurements are necessary for the design and fabrication of retrieval, pretreatment, and final waste disposal systems.

\subsection{PURPOSE}

This report summarizes the avallable information regarding the waste in tank 241-C-109, and arranges this information in a useful format for data users in various internal and external organizations.

\subsection{SCOPE}

This report presents a broad background of preliminary information that was avallable prior to core sampling, and which initially guided the development of the sampling and anaiysis program. This material includes historical information about the ferrocyanide-scavenging program, transfer records, observations from in-tank photographs, and inferences from waste simulant studies. The results of tank 241-C-109 core sample analyses are summarized and presented, along with a statistical interpretation of the data. The information obtained from historical sources and synthetic waste studies are compared with the actual waste measurements in this report. 
WHC-EP-0668

This page intentionally left blank. 
whiC-EP-0008

\subsection{PRESAMPLING INFORMATION AND EVALUATION}

\subsection{BACKGROUND}

Radioactive wastes from defense operations have accumulated at the Hanford Site in underground waste tanks since the 1940's. During the 1950's, additional tank storage space was required to support the United States defense mission. To obtain additional tank storage volume within a short period of time and to minimize construction of additional storage tanks, Hanford Site scientists developed a process to scavenge radiocesium from tank waste liquids (Sloat 1954, Abrams 1956). Ferrocyanide compounds were used in a carrier-precipitation process to scavenge ${ }^{137} \mathrm{Cs}$ and other soluble radionuclides from the Hanford Site waste tanks. This treatment was used on U Plant waste effluent, bismuth phosphate first decontamination cycle waste, and selected wastes that had been previously discharged to the tanks. Some of these wastes had been processed through the 242-B Evaporator prior to scavenging. The radionuclides settled in the waste tanks and the supernate was discharged to the cribs and trenches. As a result of this process, occupied waste volumc $\because$ the waste tanks was greatly reduced, while minimizing the amount of long-lived radionuclides discharged to the ground.

In implementing this process, approximately 140 metric tons of ferrocyanide [as $\mathrm{Fe}(\mathrm{CN})_{6}^{-4}$ ] were added to the tanks. The bulk of the ferrocyanide material is belleved to remain in 18 to 24 single-shell tanks (SSTs). Ferrocyanide is a stable complex of iron(II) ton and cyanide, whose compounds are considered nontoxic because they do not appreciably dissociate in aqueous solutions (Burger 1989). However, recent laboratory data indicates that highly alkal ine solutions can degrade ferrocyanide salts (Babad 1993a,b). In the presence of oxidizing materials such as nitrates and/or nitrites, ferrocyanide compounds can undergo uncontrolled exothermic reactions in the laboratory by heating them to high temperatures (above $280{ }^{\circ} \mathrm{C}$ $\left.\left[540^{\circ} \mathrm{F}\right]\right)$. Because the scavenging process involved precipitating ferrocyanides from solutions containing nitrate and nitrite, the potential for a reactive mixture of ferrocyanides and nitrates/nitrites in the SSTs must be evaluated.

\subsubsection{Tank 241-C-109 History}

Groups of waste tanks that were physically located together and built at the same time are called tank farms at the Hanford Site. The original tank farms ( $B, C, T, U)$ were bullt from 1943 to 1944. Each tank has a diameter of $22.9 \mathrm{~m}(75 \mathrm{ft})$, an operating depth of $5.2 \mathrm{~m}(17 \mathrm{ft})$, and a nominal capacity of 2 million liters $(530,000 \mathrm{gal})$. The basic design of a typical SST is shown in Figure 2-1. The tank was constructed of reinforced concrete with a mild steel liner covering its bottom and sides. The top of the tank is a concrete dome. Tanks such as 241-C-109 were covered by at least $1.8 \mathrm{~m}(6 \mathrm{ft})$ of soll for shielding purposes (Anderson 1990). Tank 24l-C-109 was placed into service in 1946 .

The tanks in the tank farms were connected in groups of three or four and overflowed from one to another (known as a cascade). Tank 241-C-109 is the last tank in a cascade that includes $241-c-107$ and $241-c-108$. 


\section{WHC-EP-UEOS}

Figure 2-1. Typical Single-Shell Tank Diagram.

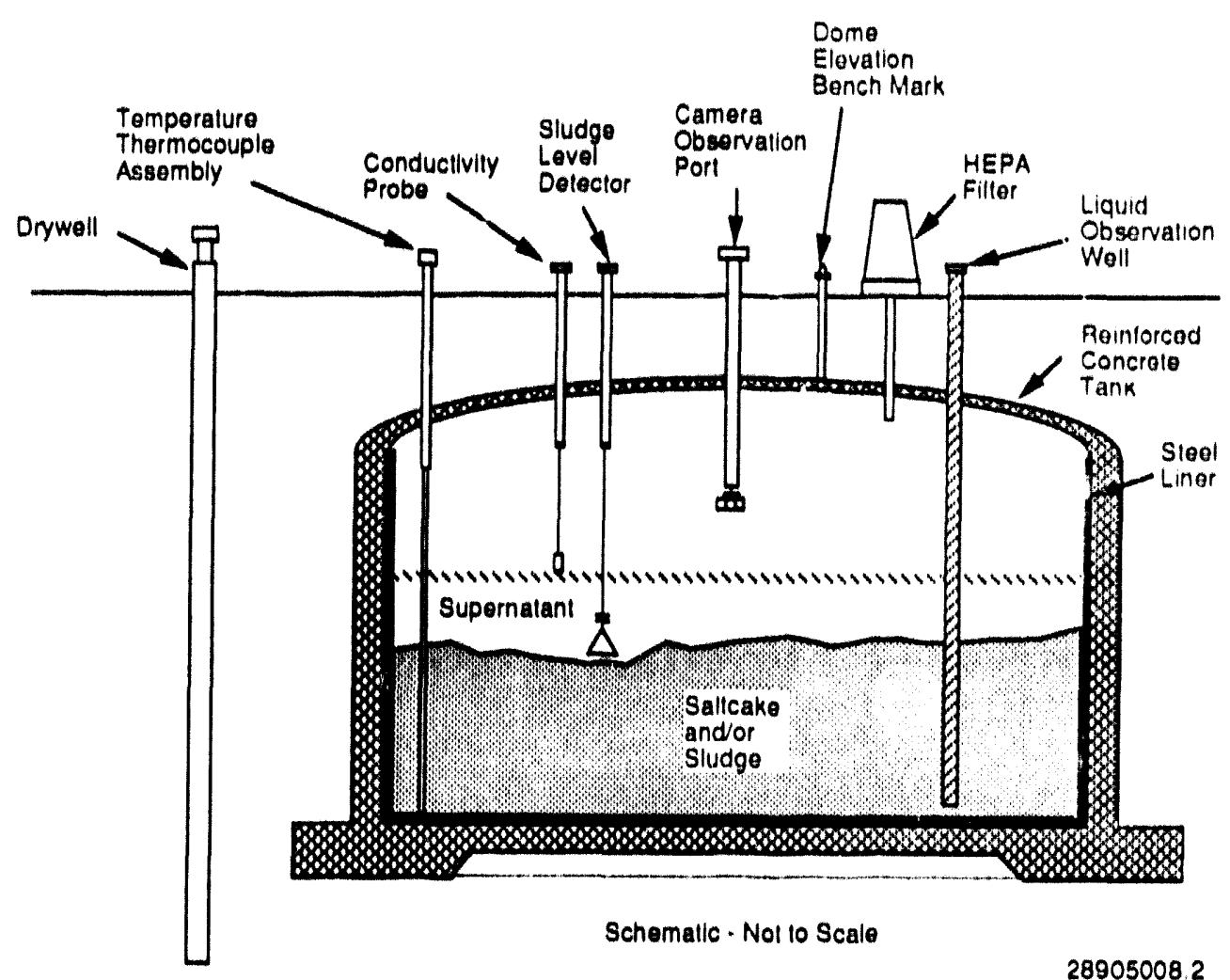

NOTE: Tank 241-C-109 has a dished bottom. 
Cascades served several functions in Hanford Site waste management operations. By cascading tanks, fewer connections needed to be made during waste disposal. Consequently, all three lanks were usable without having to connect the active waste transfer line directly to each individual tank. This handling method reduced the likelihood for personnel exposure to the waste and diminished the chances for a loss of tank integrity because of overflliling. Another benefit of the cascades was clarification of the wastes. When used in this manner, most of the solids in the waste slurries routed to the tanks settled in the first tank (241-C-107), and the clarified liquids cascaded on to the other tanks in the series (241-C-108 and 241-C-109). Supernate from the final tank in a cascade series was sometimes routed to a disposal trench. In this way clarification reduced the potential amount of radiological contamination to the environment.

The first type of waste that tank 241-C-109 received and stored was first decontamination cycle waste from the bismuth phosphate process (1946 to 1952). This waste would be comparatively high in bismuth, phosphate, and aluminum because aluminum decladding waste was combined with 1 t. The supernatant waste was transferred to tank 241-B-106 in 1952, leaving a 38,000-L (10,000-gal) heel, probably mostly solids. The tank was refllled with unscavenged uranium recovery (UR) waste in 1953 (Anderson 1990). The UR waste solids were comparatively high in uranium and iron, and low in bismuth and aluminum. The avallable records do not show whether these wastes were added directly to the tank or through the cascade overflow line from tank 241-C-108. Neither of these waste types had aly significant fuel content or heat-generating radionuclides $\left({ }^{137} \mathrm{Cs}\right.$ or $\left.{ }^{90} \mathrm{~S} r\right)$, that could contribute to the exothermic potential posed by the ferrocyanide wastes.

Beginning in May 1955, unscavenged UR waste already stored in 200 East Area underground tanks at the Hanford Site was routed to the 244-CR vault for scavenging (refer to Figure 2-2). The 244-CR vault factlity contalned stainless steel tanks with chemical addition, agitation, and sampling capabilities. The $\mathrm{pH}$ was adjusted with $\mathrm{HNO}_{3}$ and/or $\mathrm{NaOH}$ to $\mathrm{pH} 9.3 \pm 0.7$, and $\mathrm{Fe}_{\mathrm{e}}(\mathrm{CN})_{6}^{-4}$ and $\mathrm{Ni}^{+2}$ ion was added (generally to $0.005 \mathrm{M}$ each) to precipltate ${ }^{137} \mathrm{Cs}$. If laboratory analys is of the feed tank indicated additional ${ }^{90} \mathrm{Sr}$ decontamination was necessary, calcium nitrate was also added (Sloat 1955). There was also an effort to scavenge ${ }^{60} \mathrm{Co}$ with $\mathrm{Na}_{2} \mathrm{~S}$. From late 1955 until 1958, tank 24l-C-109 was used for settling scavenged ferrocyanide waste. During ferrocyanide-scavenging operations, waste was not cascaded through the tank 241-C-107, $-108,-109$ series. Tank 241-C-109 received the waste slurry in direct transfers from the process vessel (General Electric 1958). The scavenged waste was settled, sampled, and decanted to a crib. The settling tanks for this In Farm scavenged waste were tanks 241-C-108, 241-C-109, $241-C-111$, and $241-C-112$.

The In Farm precipitate comprises approximately 20 to 25 percent of the total ferrocyanide material in the Hanford Site tank farms. This material is expected to possess a much higher ferrocyanide concentration content than the more prevalent $U \mathrm{Plant}$ material (70 percent of the total ferrocyanide material). Analytes that differentiate ferrocyanide waste from other wastes are elevated levels of nickel, calcium, and ${ }^{137} \mathrm{Cs}$. Over time, additional gravity settling may have compressed the waste layers, increasing the 
Figure 2-2. In Farm Flowsheet. Ferrocyanide Production by "In-Farm" Flowsheet

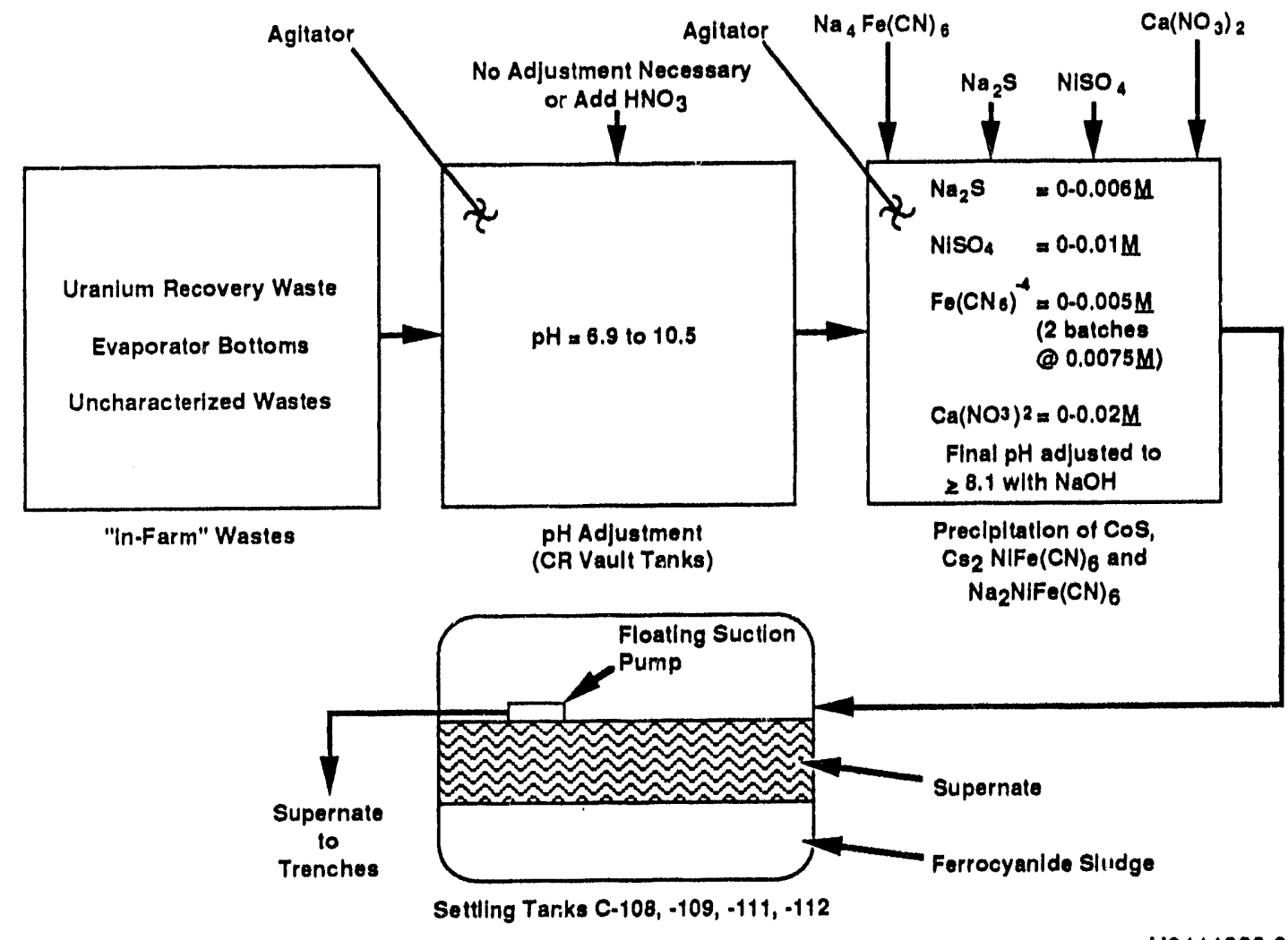

H9111028.29 
concentration of some of these analytes. However, the interactive effects of radiation and high $\mathrm{pH}$ conditions from later waste additions on the waste matrix is largely unknown. Exposure of the waste to these conditions is believed to have degraded the ferrocyanide. However, laboratory results confirming that hypothesis are still pending (Lilga et al. 1992; Babad et a1. 1993a,b).

The first transfer of scavenged waste for settling was in the fourth quarter of 1955. In Farm scavenging was completed in December 1957

(General Electric 1958). The inventory of solids in tank 241-C-109 at the end of the ferrocyanide-scavenging program, as calculated by the Borsheim-Simpson (1991) model, was 413,000 L (109,000 gal) with essentially no free supernate. A revised calculation using more appropriate solid formation values (Appendix A) gives a total inventory of $413,000 \mathrm{~L}(109,000 \mathrm{gal})$ and a solid inventory of $220,000 \mathrm{~L}(58,000 \mathrm{gal})$. The scavenging record (General Electric 1958) gives the overall tank level as $0.89 \mathrm{~m}$ ( $2 \mathrm{ft} 11 \mathrm{in}$.) $(413,000$ $L[109,000$ gail]). A History of the 200 Area Tank Farms (Anderson 1990) reports a total volume of $424,000 \mathrm{~L}(112,000 \mathrm{gal})$, but 1 ists $341,000 \mathrm{~L}(90,000$ gal) of that inventory as solids (the reading previous to this was 193,000 L [51,000 gal]). The waste inventory values believed to be most representative of the solids level (and overall waste inventory) in this timeframe range between 51,000 and $58,000 \mathrm{gal}$. The wide variation in the waste levels between sources is not reassuring and contributes to significant uncertainty regarding tank inventory calculations.

After the end of scavenging in early 1958, tank 241-C-109 remained in active service. However, the tank had relatively limited activity from 1958 to the end of its service life in 1980. In the third and fourth quarters of 1959, a total of $1.57 \mathrm{ML}(415,000$ gal) of highly alkaline cladding waste and evaporator bottoms (wastes known to contain substantial amounts of solids) were added to the tank, but the reported solids inventory $(341,000 \mathrm{~L}$ [90,000 gal]) did not change (Anderson 1990). From the known information, it seems likely there would be an increase of solids and that a transcription error may have occurred. Cladding waste solids would have settled on top of the ferrocyanide sludge aiready present.

Several small transfers with relatively high concentrations of ${ }^{90} \mathrm{Sr}$ occurred after 1958. In $1962,519,000 \mathrm{~L}(137,000 \mathrm{gal})$ of 1 iquid was transferred to the BY Farm. Waste from the strontium semiworks/hot semiworks was then added at different times to the tank, increasing the total volume listed to $2.02 \mathrm{M} \mathrm{L}(535,000 \mathrm{gal})$ at the end of 1964 (the reported solids inventory was sti11 $341,000 \mathrm{~L}[90,000 \mathrm{gal}])$. The listed volumes for the fourth quarter report in 1966 are a total volume of $2.09 \mathrm{M} \mathrm{L}(552,000 \mathrm{gal})$, with a solids volume of $299,000 \mathrm{~L}(79,000 \mathrm{gal})$ (Anderson 1990). While this solids level measurement was the second taken since additional waste was added to the tank following the last scavenging pumpout in 1958, it was the first to use a new electrode to perform the overall volume measurement.

The reported waste volume remained essentially unchanged (between 2.01 and $2.04 \mathrm{ML}[543,000$ and $552,000 \mathrm{gal}])$ until a receipt of $72,000 \mathrm{~L}$ $(19,000 \mathrm{gal})$ from tank $241-\mathrm{C}-203$, and a transfer of $1.50 \mathrm{M} \mathrm{L}(397,000 \mathrm{gal})$ to tank 241-C-104 occurred in the first quarter of 1970. This transfer left a heel of at least $609,000 \mathrm{~L}(161,000 \mathrm{gal})$. A floating suction pump transfer would not have transferred any solids because the maximum reported solids 
level was $413,000 \mathrm{~L}(109,000 \mathrm{gal})$ and it was probably lower than that. In addition, there was no mixing equipment in tank 241-C-109 to move the settled ferrocyanide solids into the overlying solids layer. In the second quarter of 1970, an additional transfer of $1.42 \mathrm{M} \mathrm{L}(375,000$ gal) from tank 241-C-110 was received. Between 1970 and 1975, the reported solids volume fluctuated widely between 401,000 and $235,000 \mathrm{~L}(106,000$ and $62,000 \mathrm{gal})$, and the total volume reported decreased from $2.06 \mathrm{NL}$ to $235,000 \mathrm{~L}(543,000$ to $62,000 \mathrm{gal})$ (Anderson 1990).

Some solids may have been transferred, as the reported tank solids volume decreased from $485,000 \mathrm{~L}(90,000 \mathrm{gal})$ to $299,000 \mathrm{~L}(79,000 \mathrm{gal})$. However, the solids transferred would have been those that settled on top of the ferrocyanide solids (i.e., cladding waste/evaporator bottonis solids; ferrocyanide waste levels are at $\sim 58,000 \mathrm{gal}$ ). The wide fluctuation makes $i t$ difficult to derive any firm conclusions regarding the stratification in the tank. Overall sludge volume in the tank may have decreased somewhat between 1958 and 1975 with further settling and compaction from the weight of overlying solids. Although, the amount of sludge added since the end of the scavenging campaign is not easily quantifiable, it is likely that the measurements are blased high. Floating suction pumps do not transfer solids readily, and the movement of 76,000 to $152,000 \mathrm{~L}(20,000$ to $40,000 \mathrm{gal})$ of solid seems unlikely. With the large amounts of concentrated wastes in this tank, there is the possibility that relatively unsaturated supernatants that were transferred into the tank later in its service life redissolved significant amounts of waste and distributed the material elsewhere in the tank farms. The final solids measurement prior to the end of active service (1980) and the present tank survelllance measurement (1983) are identical, $235,000 \mathrm{~L}(62,000 \mathrm{gal})$, and not much above the estimated ferrocyanide waste level $(220,000 \mathrm{~L}[\sim 58,000 \mathrm{gal}])$. Appendix $A$ has the results of a model that represents the inventory changes in the tanks with various initial conditions and solids formation valves after scavenging operations were completed. Therefore, it is estimated that an additional $15,000 \mathrm{~L}(4,000 \mathrm{gal})$ of solids is remaining from the transfers into the tank on top of the ferrocyanide during its active service.

The last of the major waste types was aluminum cladding waste. These materials would be high in aluminum and silica, with a very high $\mathrm{pH} \quad(>1.0 \mathrm{M}$ $\mathrm{NaOH} ; \mathrm{pH} \geq 14$ ). However, the solids volume contribution to the tank is unknown because the majority of the solids would be deposited in the first tank to receive the wastes, which was not tank 241-C-109. The high pH of this waste is considered a significant factor affecting the state of the waste matrix. Other wastes had discernable impacts on the bulk characteristics of the tank contents as well. The strontium semiworks waste had a small volume of waste added, but would have a very high ${ }^{90} \mathrm{Sr}$ content because it included strontium recovery and purification waste losses. The B Plant ion-exchange waste was primarify liquid and was not expected to contribute significantiy to the solids in the tank.

\subsubsection{Unreviewed Safety Question Declaration}

Efforts have been underway since the mid-1980's to evaluate the potential of a ferrocyanide combustion reaction in Hanford Site SSTs (Burger 1989; Burger and Scheele 1990; Burger 1984). In 1987, the Final Environmental 
Impact Statement, Disposal of Hanford Defense High Level, Transuranic and Tank Wastes, hereinafter referred to as the HDW-EIS (DOE 1987), was issued. In the HDW-EIS, it was projected that the bounding "worst-case" accident in a ferrocyanide tank would be an explosion resulting in a subsequent short-term radiation dose to the public of $200 \mathrm{mrem}$.

A later General Accounting offlce (GAO) study postulated greater worst-case accident consequences, with independently calculated doses one to two orders of magnitude greater than the HDW-EIS (Peach 1990). In September 1990, a special Hanford Site Ferrocyantde Task Team was commisstoned to address all issues involving the ferrocyanide tanks, including the consequences of a potential accident. On October 9, 1990, the Secretary of Energy announced that a supplemental environmental impact statement would be prepared containing an updated analysis of safety issues for the Hanford Site SSTs, including a hypothetical ferrocyanide explosion. In October 1990, the ferrocyanide issue was also declared an USQ because the consequences of the accident scenario (as calculated by the GAO) were outside the bounds of the current safety analyses for SSTs. Furthermore, additional monitoring of tanks with designated USQS was mandated by Public Law 101-510 (1990).

Using a computer model output (Jungfleisch 1984), process knowledge, and transfer records, 24 waste tanks have been identified at the Hanford Site as potentially containing 1,000 g-mol (465 lb) or more of ferrocyanide as the $\mathrm{Fe}(\mathrm{CN})_{6}^{-4}$ ion. On further investigation, six of these tanks are believed to have received less than 1,000 g-mol of ferrocyanide sludge and are therefore candidates for removal from the Watch List (Cash 1993). Tank 241-C-109 is on the Ferrocyanide Watch List because it was a known process tank during the ferrocyanide-scavenging campaigns.

\subsection{EXPECTED TANK CONTENTS/CONDITIONS}

Process knowledge obtained from historical records and waste simulants produced from the scavenging process flowsheets can be used to predict the major constituents and some general physical properties of the waste matrix in the waste tanks. Initially, the differences between the $U$ Plant and In Farm ferrocyanide sludges were not fully appreciated. However, further investigation of the simulants showed that the In Farm process would be expected to precipitate approximately 1.0 to 1.3 vol\% solids, and thus the sludge would have been deposited in the receiver tanks in layers approximately 3.6 to $6.1 \mathrm{~cm}(1.4$ to $2.4 \mathrm{in}$.) thick. This is much less than the 4.25 vol\% and $15-$ to $20-\mathrm{cm}(6-$ to $8-i n$.$) layers expected from the U$ Plant material. In addition, there are some batches of waste that were scavenged and settled in tank 241-C-109 without ferrocyanide addition (scavenged for residual ${ }^{60} \mathrm{Co}$ and ${ }^{90} \mathrm{Sr}$ ). These materials may have some superficial similarity to the ferrocyanide scavenged waste, however, they are expected to have no fuel content and thus, no exothermic potential (the $S^{2 \cdot}$ used in the ${ }^{60} \mathrm{Co}$ scavenging process is believed to have been converted to $\mathrm{SO}_{4}{ }^{2-}$ ). The In Farm scavenged ferrocyanide tanks (such as tank 24l-C-109) are expected to contain relatively soft sludge, which can be push-mode sampled. This expectation was supported by inspection of in-tank photographs. The other waste solids that were added to the tank after the scavenging campaign are also expected to be soft. During its operating history, tank 241-c-109 was never subject to any of the 
Figure 2-3. Soltds and Liquid Wastes - Tank 241-C-109.

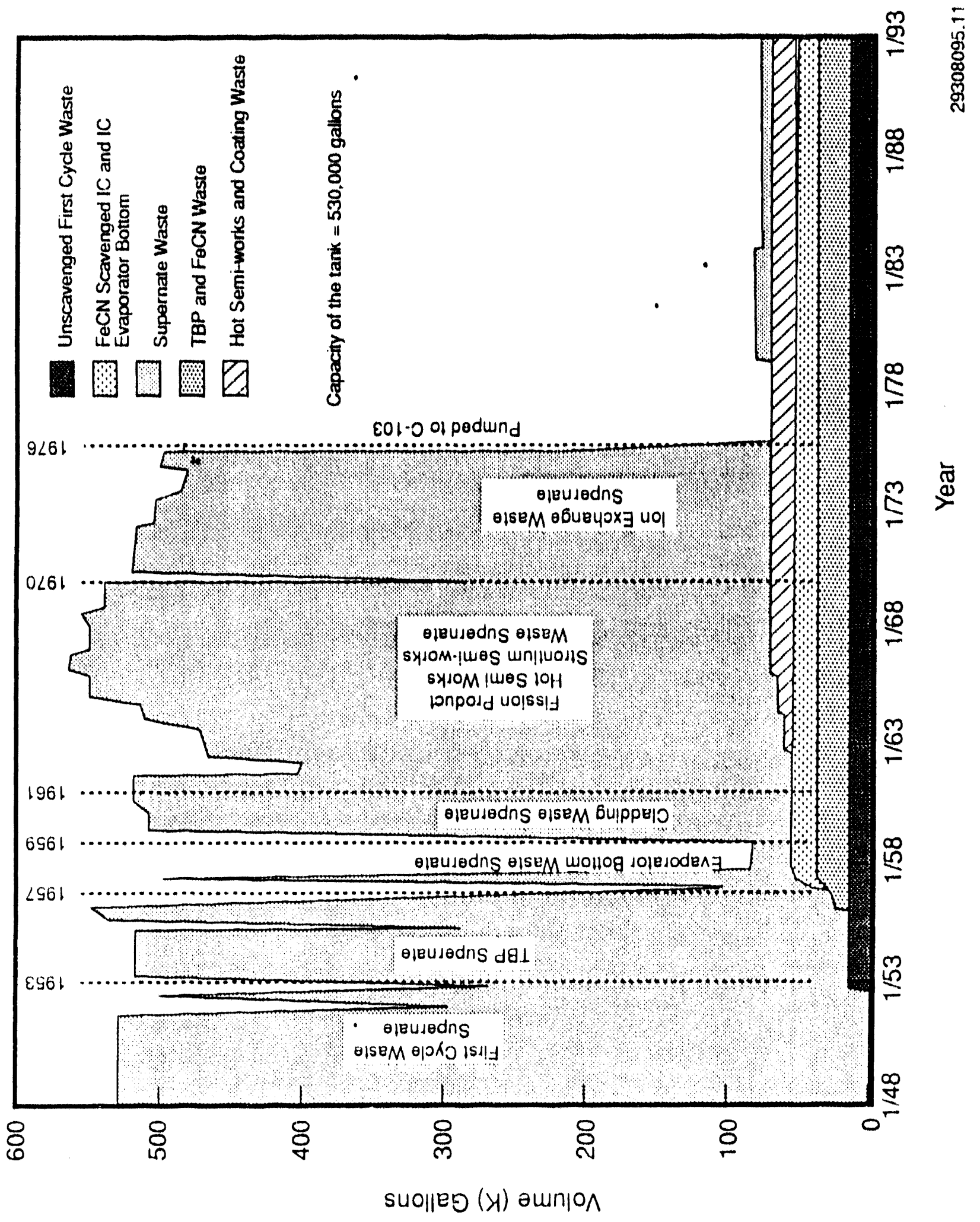


various in-tank solidification processes; consequently, there was no formation of hard salt cake on top of the sludge (as there was in the BY Tank Farm).

The most recent waste inventory report for tank $241-\mathrm{C}-109$ shows $235,000 \mathrm{~L}$ $(62,000 \mathrm{gal})$ of solid waste with an estimated $15,000 \mathrm{~L}(4,000 \mathrm{gal})$ of dratnable liquids (Hanion 1992). These figures transiate to a waste depth of $79.9 \mathrm{~cm}(31.5 \mathrm{in.})$ at the tank centerline. The tank was interim-stabilized in November 1983, and is considered sound. Tank Farm Operations has installed a second thermocouple tree in tank 241-C-109, and the readings between the two thermocouple trees on opposite sides of the tank are consistent. The current waste temperature in tank $241-\mathrm{C}-109^{\circ}$ is $\sim 27^{\circ} \mathrm{C}\left(80^{\circ} \mathrm{F}\right)$, and the est imated heat load in the tank is less than $2.93 \mathrm{~kW}(10,000 \mathrm{Btu} / \mathrm{hr})$. Tank 241-C-109 is considered to have one of the highest ferrocyanide concentrations of all the ferrocyanide Watch List SSTs (Borsheim and Simpson 1991).

In summary, various nickel ferrocyanide complexes (primartly disodium) are expected to be mixed with an interstitial solution containing sodium nitrate and nitrite. Cesium-137 is expected to be present as a mixed salt (probably as NaCsNiFe(CN) $)_{6}$; strontium-90 may be in several potentia) compounds; phosphate, sulfate, or carbonate. Both of these radionuclides have decayed through slightly more than one half-life, and therefore are not as abundant as when the scavenging waste was originally deposited. Other fission products with relatively short half-lives (such as ${ }^{60} \mathrm{Co}$ and ${ }^{106} \mathrm{Ru}$ ) are not expected to be in abundance, especially with the 1 imited number of waste additions for this tank. Hydrated transition metal oxides/hydroxides (including small amounts of transuranics) are also expected because of alkaline conditions. Other lons expected to be present are potassium, calcium, aluminum, and uranium. The supernate and interstitial liquid are expected to contain large amounts of sodium, nitrate, and nitrite ions. Table 2-1 presents some typical concentrations for identifier analytes in the waste streams disposed of in tank 24l-c-109.

\subsection{ANALYTICAL RESULTS FROM SIMULANT STUDIES}

Physical and chemical measurements performed on simulants of ferrocyanide tank waste provide additional information and perspective regarding the condition and properties of the waste in tank 241-C-109.

\subsubsection{Simulant Formulation: In Farm 2 Flowsheet Material}

The In Farm 2 flowsheet material is considered to be an energetically conservative but reasonably close physical and chemical analogue of some of the ferrocyanide precipitate in tank 24l-c-109 as it was deposited in the tank during the scavenging campaign. However, scavenging of evaporated cladding and first-cycle wastes is expected to produce noticeable differences from the uranium-recovered, scavenged TBP waste. In contrast to the results from 241-C-112, close agreement between the simulant properties and the waste measurements (physical and chemical analytes) was not expected. The In Farm 2 flowsheet materials were prepared according to the following instructions (Jeppson and Wong 1993). The feed solution composition is isted in rable 2-2. Deionized water was used for feed solution and chemical addition rialieup.

$$
2-9
$$


Table 2-1. Expected Concentrations for Characteristic Analytes (Schneider 1951; Jeppson and Wong 1993).

\begin{tabular}{|c|c|c|}
\hline Waste type & $\begin{array}{l}\text { Identifier } \\
\text { analytes }\end{array}$ & $\begin{array}{l}\text { Typical process } \\
\text { stream concentration } \\
(\mu g / g \text { wet solids) }\end{array}$ \\
\hline \multirow[t]{4}{*}{$1^{\text {st }}$ Decontamination cycle $(1 C)$} & $B 1$ & 7,100 \\
\hline & $F$ & 9,600 \\
\hline & $U$ & 620 \\
\hline & Si & 2,400 \\
\hline Unscavenged urantum recovery (UR) & U & $1,700-32,500$ \\
\hline \multirow[t]{3}{*}{ Ferrocyanide (FeCN) } & $\mathrm{NI}$ & 18,700 \\
\hline & $\mathrm{Ca}$ & 30,000 \\
\hline & $\mathrm{CN}$ & $91,000-113,000$ \\
\hline \multirow[t]{3}{*}{ Decladding waste $(\mathrm{CW})$} & Al & $72,200-96,200$ \\
\hline & U & $340-450$ \\
\hline & Si & $2,600-3,500$ \\
\hline Hot semiworks (HS) & ${ }^{90} \mathrm{Sr}$ & $\begin{array}{l}\text { No Data - expected } \\
\text { elevated }{ }^{\circ} \mathrm{sr} \text { levels }\end{array}$ \\
\hline
\end{tabular}

Table 2--2. Feed Solution Composition for In Farm 2 Flowsheet.

\begin{tabular}{|l|c|}
\hline \multicolumn{1}{|c|}{ Component } & Concentration \\
\hline Sodium nitrate $\left(\mathrm{NaNO}_{3}\right)$ & $3.75 \mathrm{M}$ \\
\hline Cesium nitrate $\left(\mathrm{CsNO}_{3}\right)$ & $0.00025 \mathrm{M}$ \\
\hline Sodium nitrite $\left(\mathrm{NaNO}_{2}\right)$ & $1.25 \mathrm{M}$ \\
\hline Sodium sulfate $\left(\mathrm{Na}_{2} \mathrm{SO}_{4}\right)$ & $0.17 \mathrm{M}$ \\
\hline Sodium phosphate $\left(\mathrm{Na}_{3} \mathrm{PO}_{4}\right)$ & $0.16 \mathrm{M}$ \\
\hline
\end{tabular}


The product sludge was the precipitate produced when performing the following steps. This procedure mimicked the actual in Farm 2 process that is lllustrated in Figure 2-2. The feed solution was heated to $40^{\circ} \mathrm{C}$ and the $\mathrm{pH}$ adjusted to $9.1 \pm 0.5$. The sodium ferrocyanide was then added to the solution, followed by nickel sulfate. The simulant solution was agitated for l'hour, then struck with calclum nitrate. After the addition of calclum nitrate, the solution was agitated for another hour and allowed to settle. The settling was done for eight days and the supernate was decanted. The remaining sludge was centrifuged at $2,100 \mathrm{~g}$ for 14 hours and $1,820 \mathrm{~g}$ for 7 days in an attempt to simulate 3.6 and 30 gravity-years of settling respectively (Jeppson and Wong 1993). Selected physical properties for the two settled centrifuged sludges are presented in Table 2-3. Table 2-4 presents an estimate of the chemical composition of the In Farm 2 simulant.

\subsubsection{Simulant Physical Characteristics (see Jeppson and Wong 1993)}

Table 2-3. Summary of In Farm 2 Simulant Characterization Data.

\begin{tabular}{|c|c|c|}
\hline Centrifugation & Property & In Farm 2 sludge \\
\hline \multirow{3}{*}{30 gravity/yr } & Water content, sludge & 51 wt\% \\
\hline & pH, supernatant & 9.42 \\
\hline & Bulk density, sludge & $1.39 \mathrm{~g} / \mathrm{mL}$ \\
\hline \multirow{7}{*}{3.6 gravity/yr } & Bulk density, supernate & $1.27 \mathrm{~g} / \mathrm{mL}$ \\
\hline & $\begin{array}{l}\text { Particle density (dried } \\
\text { sludge) }\end{array}$ & $2.38 \mathrm{~g} / \mathrm{mL}$ \\
\hline & $\begin{array}{l}\text { Particle size } \\
\text { distribution, } \\
\text { (by number) }\end{array}$ & $\begin{array}{l}97 \%<2 \mu \mathrm{m} \\
\text { Median diameter*: } 0.76,0.76 \mu \mathrm{m} \\
\text { Acquisition Range: } 0.5-150 \mu \mathrm{m}\end{array}$ \\
\hline & $\begin{array}{l}\text { Particle size } \\
\text { distribution, } \\
\text { (by volume) }\end{array}$ & $\begin{array}{l}100 \%<110 \mu \mathrm{m} \\
\text { Median diameter : } \quad 14.3,16.8 \mu \mathrm{m} \\
\text { Acquisition range: } 0.5-150 \mu \mathrm{m}\end{array}$ \\
\hline & $\begin{array}{l}\text { Hydraulic conductivity } \\
\text { (permeability) }\end{array}$ & $4.0 \times 10^{-7} \mathrm{~cm} / \mathrm{s}$ \\
\hline & Total porosity & $67.9 \%$ \\
\hline & Thermal conductivity & 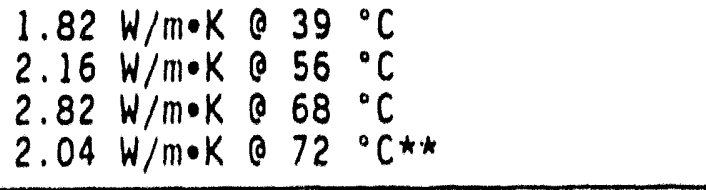 \\
\hline
\end{tabular}

* Two separate measurements.

** Jeppson and Wong (1993) noted an anomalous data point, but were unable to explain the inconsistency of the observation. 


\subsubsection{Simulant Chemical Composition (see Jeppson and Wong 1993)}

Table 2-4. Estimated Composition of Homogentzed, Centrifuged, Ferrocyanide Sludge Simulant.

\begin{tabular}{|c|c|}
\hline Sludge component & $\begin{array}{l}\text { Average In Farm } 2 \\
\text { welght fraction }\end{array}$ \\
\hline Disodium mononickel ferrocyanide: $\mathrm{Na}_{2} \mathrm{~N} 1 \mathrm{Fe}(\mathrm{CN})_{6}$ & 0.101 \\
\hline Sodium nitrate: $\mathrm{NaNO}_{3}$ & 0.174 \\
\hline Sodium nitrite: $\mathrm{NaNO}_{2}$ & 0.051 \\
\hline Sodium hydrogen phosphate: $\mathrm{Na}_{2} \mathrm{HPO}_{4}$ & 0.016 \\
\hline Sodium sulfate: $\mathrm{Na}_{2} \mathrm{SO}_{4}$ & 0.015 \\
\hline Calctum phosphate: $\mathrm{Ca}_{3}\left(\mathrm{PO}_{4}\right)_{3}$ & 0.072 \\
\hline Water & 0.51 \\
\hline Percent mass balance subtotal & 94.0 \\
\hline $\begin{array}{l}\text { Percent unknown-- likely includes } \mathrm{Fe}_{4}\left(\mathrm{Fe}(\mathrm{CN})_{0}\right)_{3}, \mathrm{Fe}(\mathrm{OH})_{3} \text {, } \\
\mathrm{Ni}(\mathrm{OH})_{2} \text {, and other trace compounds from impurities. }\end{array}$ & 6.0 \\
\hline
\end{tabular}

\subsubsection{Energetics Behavior of Ferrocyantde Sludge simulant}

Avallable chemical process information indicates that there were three significantly different types of ferrocyanide waste (Sloat 1954; Schmidt and Stedwell 1954). Nonradioactive waste simulants have been developed and tested using this information. In Farm ferrocyanide waste, accounting for 20 to 25 percent of the total ferrocyanide waste. Was formed from treating waste that was already stored in the tanks. The waste in tank 241-C-109 was produced using the In Farm process. Most of this waste had less inert solids in the waste stream; therefore, it is belleved to have been more concentrated in ferrocyanide than other scavenged wastes. In Farm simulants exhibit propagating exothermic activity when examined by differential and adiabatic scanning calorimetry (DSC and ASC) (Cady 1992; Fauske 1992).

Estimates of tank waste reactivity, which were developed after the ferrocyanide USQ was declared, were based on thermodynamic estimates (Colby and (rippen 1991). Several chemical reaction pathways were evaluated and heats of reaction were determined for each possible reaction from the published heats of formation of the reactants and the products. For the purpose of develuping these estimates, the condition of the reactants is dry solid reagents at standard temperature and pressure in a stoichiometric ratio. The theoretical heats of reaction ranged in value from $\Delta H=-9.6 \mathrm{~kJ} / \mathrm{g}$ to $\Delta H=+19.7 \mathrm{~kJ} / \mathrm{g}$ of $\mathrm{Na}_{2} \mathrm{NiFe}(\mathrm{CN})_{6}$, and are listed below with their corresponding chemical reactions.

(1) $\mathrm{Na}_{2} \mathrm{NiFe}(\mathrm{CN})_{6}+54 \mathrm{NaNO}_{3}+22 \mathrm{H}_{2} \mathrm{O}-\rightarrow-\mathrm{Na}_{2} \mathrm{CO}_{3}+\mathrm{FeO}+\mathrm{NiO}+60 \mathrm{NO}_{2}+44 \mathrm{NaOH}$ $\Delta H^{2}=+19.7 \mathrm{~kJ} / \mathrm{g}$ of $\mathrm{Na}_{2} \mathrm{NiFe}(\mathrm{CN})_{6}$

(2) $\mathrm{Na}_{2} \mathrm{NiFe}(\mathrm{CN})_{6}+14 \mathrm{NaNO}_{3}+2 \mathrm{H}_{2} \mathrm{O}-\cdots-\mathrm{Na}_{2} \mathrm{CO}_{3}+\mathrm{FeO}+\mathrm{NiO}+2 \mathrm{ONO}+4 \mathrm{NaOH}$ $\Delta H^{2}=-0.7 \mathrm{~kJ} / \mathrm{g}$ of $\mathrm{Na}_{2} \mathrm{NiFe}(\mathrm{CN})_{6}$ 


$$
\begin{aligned}
& \text { WHC-EF-0008 } \\
& \cdots 5.5 \mathrm{Na}_{2} \mathrm{CO}_{3}+\mathrm{FeO}+\mathrm{NiO}+7.5 \mathrm{~N}_{2} \mathrm{O}+0.5 \mathrm{CO}_{2} \\
& \Delta H=-6.8 \mathrm{~kJ} / \mathrm{g} \text { of } \mathrm{Na}_{2} \mathrm{NiFe}\left(\mathrm{CN}^{2}\right)_{6} \\
& -\cdots 6 \mathrm{Na}_{2} \mathrm{CO}_{3}+\mathrm{FeO}+\mathrm{NiO}+6 \mathrm{~N}_{2} \mathrm{O}+4 \mathrm{NO} \\
& \Delta H^{2}=-5.7 \mathrm{~kJ} / \mathrm{g} \text { of } \mathrm{Na}_{2} \mathrm{NiFe}(\mathrm{CN})_{6} \\
& \ldots-. \rightarrow 4 \mathrm{Na}_{2} \mathrm{CO}_{3}+\mathrm{FeO}+\mathrm{NiO}+6 \mathrm{~N}_{2}+2 \mathrm{CO}_{2} \\
& \Delta H^{2}=-9.6 \mathrm{~kJ} / \mathrm{g} \text { of } \mathrm{Na}_{2} \mathrm{NiFe}(\mathrm{CN})_{6}
\end{aligned}
$$$$
\text { (3) } \mathrm{Ha}_{2} \mathrm{NiFe}(\mathrm{CN})_{6}+9 \mathrm{NaNO}_{3}
$$$$
\text { (4) } \mathrm{Na}_{2} \mathrm{~N}+\mathrm{Fe}(\mathrm{CN})_{6}+10 \mathrm{NaNO}_{3}
$$$$
\text { (5) } \mathrm{Na}_{2} \mathrm{NiFe}(\mathrm{CN})_{6}+6 \mathrm{NaNO}_{3}
$$

At temperatures below $1700^{\circ} \mathrm{C}\left(3100^{\circ} \mathrm{F}\right)$, the carbonate product is thermodynamically favorable and should predominate (Scheele et al. 1991). Note that considerably lower energy releases are obtained if the reaction is incomplete or if $\mathrm{NO}$ or $\mathrm{NO}_{2}$ is formed rather than $\mathrm{N}_{2}$ or $\mathrm{N}_{2} \mathrm{O}$. A three-component diagram fllustrating the exothermic potential of varlous mixtures of ferrocyanide, nitrate, and inerts is presented in Figure 2-4. Further detall regarding the thermodynamic estimates of these mixtures is presented in colby and Crippen (1991).

The waste simulants prepared using the In Farm and $U$ Plant process flowsheets were tested for chemical activity (Fauske 1992). Chemical and physical analyses of the In Farm and U Plant waste simulants show that they contain an average of 51 and 66 wt\% water, respectively, after centrifugation. The centrifugation was done to represent 30 gravity-years of compaction that may have occurred during storage. This amount of water in the waste matrix presents a tremendous heat sink that must be overcome before any reactions can become self-sustaining. During the DSC examinations, the samples exhibited large endotherms between room temperature and $150^{\circ} \mathrm{C}$ (Jeppson and Wong 1993). Results from thermogravimetric analyses being run at the same time showed a large loss of mass (1.e., evaporation of water) in this same temperature range; thus, reactions were only able to occur in dry or nearly dry sample material (Cady 1992). Average ferrocyanide content of the In Farm 2 waste simulants is approximately 10.1 wet wt\% $(20.6 \mathrm{wt} \%$ dry). Table 2-5 presents the $\Delta H$ found for some simulant materials.

Table 2-5. Heats of Reaction of Various Simulants (Fauske 1992).

\begin{tabular}{|l|l|c|c|}
\hline Material & \multicolumn{1}{|c|}{$\begin{array}{c}\Delta H \\
\text { (From adiabatic } \\
\text { calorimetry) }\end{array}$} & $\begin{array}{c}\text { Wt\% Ferrocyanide } \\
\text { (dry) } \\
{\left[\mathrm{Na}_{2} \mathrm{NiFe}(\mathrm{CN})_{6}\right]}\end{array}$ & $\begin{array}{c}\text { Calculated } \Delta H \\
\text { per gram } \\
\mathrm{Na}_{2} \mathrm{NiFe}(\mathrm{CN})_{6}\end{array}$ \\
\hline U Plant I simulant & $\begin{array}{l}-0.17 \mathrm{~kJ} / \mathrm{g} \text { of dry } \\
\text { material }\end{array}$ & 4.3 & $-3.95 \mathrm{~kJ} / \mathrm{g}$ \\
\hline $\begin{array}{l}\text { U Plant 2 simulant } \\
\text { (Botion fraction) }\end{array}$ & $\begin{array}{l}-0.34 \mathrm{~kJ} / \mathrm{g} \text { of dry } \\
\text { material }\end{array}$ & 8.6 & $-3.95 \mathrm{~kJ} / \mathrm{g}$ \\
\hline $\begin{array}{l}\text { In Farm \& simulant } \\
\text { (Bottom froction) }\end{array}$ & $\begin{array}{l}-1.20 \mathrm{~kJ} / \mathrm{g} \text { of dry } \\
\text { material }\end{array}$ & 25.5 & $-4.71 \mathrm{~kJ} / \mathrm{g}$ \\
\hline
\end{tabular}

The onset temperatures for propagating reactions to take place in the simulants range from $244^{\circ} \mathrm{C}$ to $278^{\circ} \mathrm{C}\left(471\right.$ to $\left.532^{\circ} \mathrm{F}\right)$. However, Arrhenius-type reactions may occur at lower temperatures (Fauske 1992).

NOTE: $4.18 \mathrm{~J}=1 \mathrm{cal}$. 
Figure 2-4. Ferrocyanide Tank 3-Component Diagram.

REACTION PROPAGATION YS CONCENTRATION

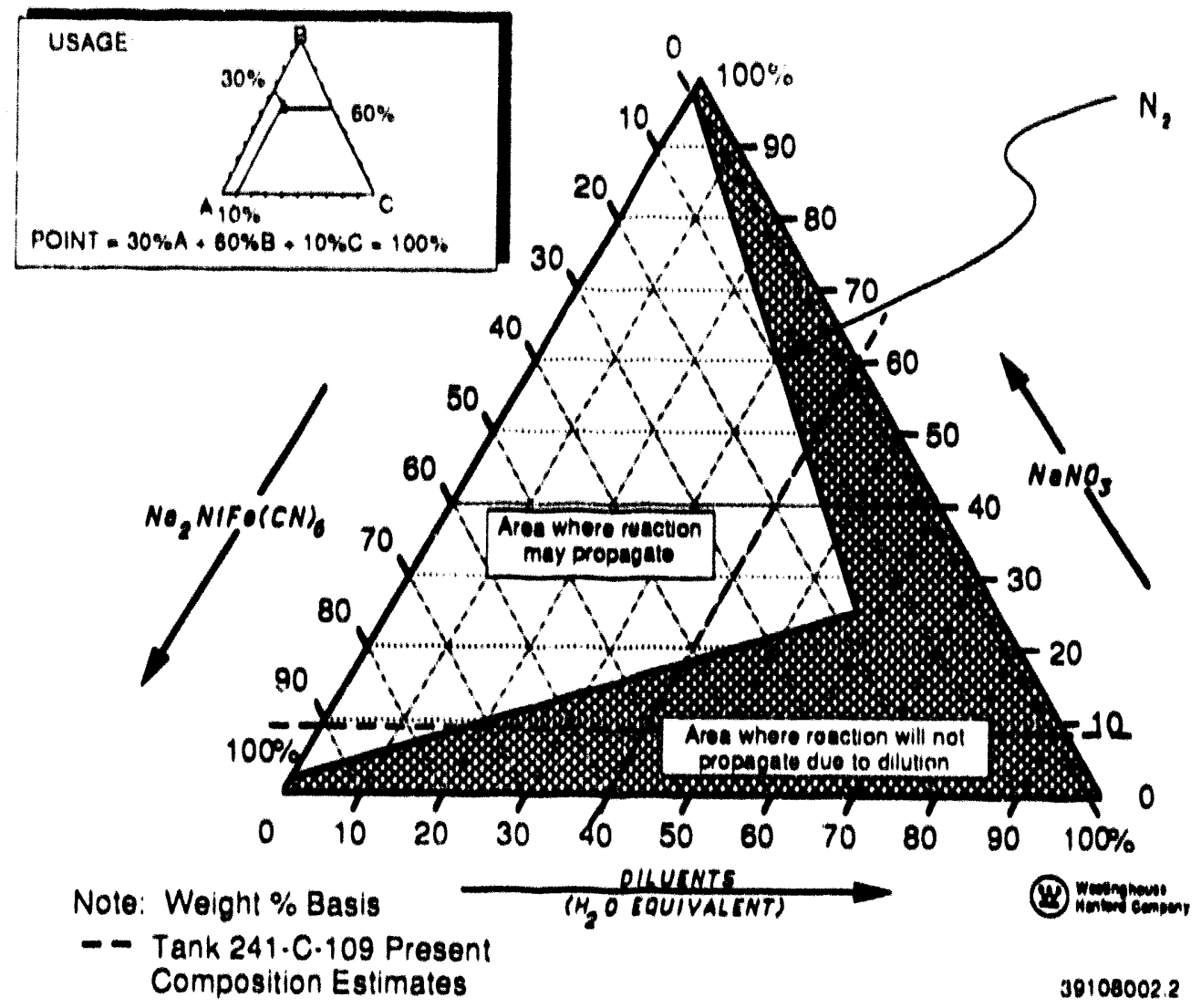


WHC-EP-0668

\subsection{CORE SAMPLING}

\subsection{DESCRIPTION OF SAMPLING EVENT}

Tank 241-C-109 was push-mode core sampled through three risers from September 2, 1992, to September 7, 1992. One segment was expected from each core sample. Core 47 was obtained from riser $\$ 6$. Core 48 was obtained from riser $\$ 7$. Core 49 was obtalned from riser \#2. The core samples from tank 241-C-109 were obtatned using a specially designed core sampling truck (CST). The sampling equipment is mounted on a rotating platform on the CST. Access to the interior of the tank is provided by varlous tank risers. These risers are plpes of various diameters leading into the tank dome from the ground. The riser configuration for tank 241-C-109 is given in Figure 3-1. A review of the tank farm operating records and a fleid inspection of the tank risers determine which risers can be used in the sampling operation. A riser is opened and the CST is positioned over the riser. The sampler is lowered into the tank through the drill string and pushed into the waste.

The sampler is constructed of stainless steel and is $48 \mathrm{~cm}(19 \mathrm{ln}$.$) long,$ with a $2.2-\mathrm{cm}(7 / 8-\mathrm{ln}$.$) inside dlameter, and has a volume of 187 \mathrm{~mL}$ $(0.05 \mathrm{gal})$. Tank Farm Operations has determined that sampling events of one or two segments do not require hydrostatic head balance fluld. Therefore, none was used in this operation, which eliminated any potential problems with sample contamination. When a segment is captured by the sampler, it is sealed within a stalnless steel liner, and the liner is placed within a shipping cask. The shipping casks are approximately $122 \mathrm{~cm}(48 \mathrm{in.})$ tall, $13 \mathrm{~cm}$ $(5 \mathrm{in.})$ in diameter, and have $2.5 \mathrm{~cm}(1 \mathrm{in.})$ of lead shlelding. This degree of shielding and contalnment protects workers from excessive radiological exposure and prevents any liquids from the sample (or the sample itself) from being lost.

The casks were transported to the 325 Analytical Chemistry Laboratory for characterization analysis. This laboratory is operated by Pacific Northwest Laboratory (PNL) in the 300 Area of the Hanford Site.

\subsection{CHAIN OF CUSTODY}

A chain-of-custody record was kept during the sampling event for each segment that was sampled. The chain-of-custody form is a one-page record that is used to ensure that (1) the sample is safely and properly transported from the field to the laboratory, and (2) the correct personnel are involved in the sampling operation and transportation of the sample to the laboratory.

A primary function of the chain-of-custody record is to provide radiation survey data. This is a record of the radiation dose that is emitted from the shipping cask. The dose rates in mrem/hour are measured from the top, sides, and bottom of the cask. These values are recorded on the chain-of-custody form and represent the radiation being emitted directly from the sample. The last item recorded under the radiation survey data is the smearable contamination. Smearable contamination represents the radiation from waste 
Figure 3-1. Tank 241-C-109 Riser Configuration.
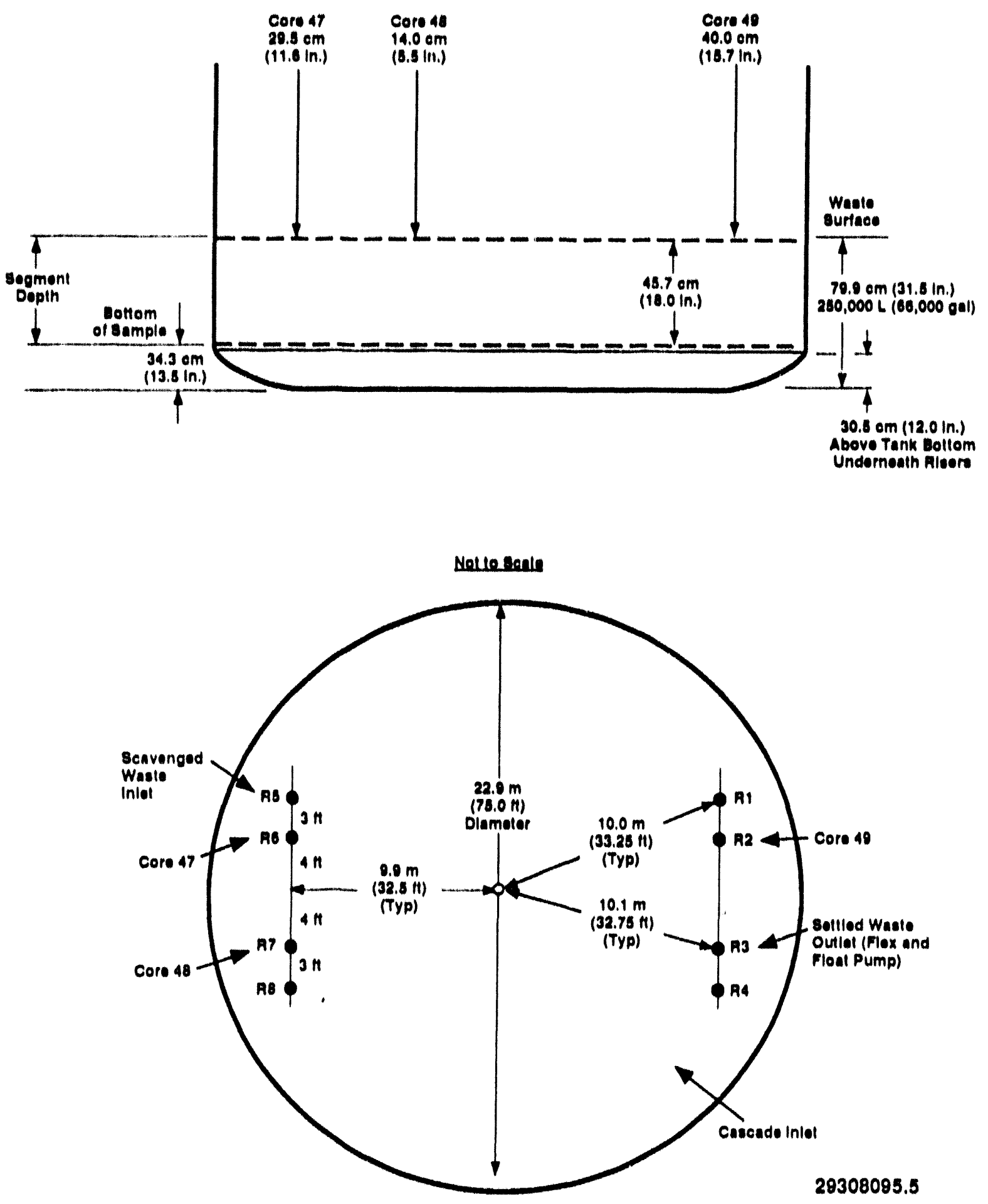
material that is not sealed within the shipping cask; values greater than $100 \mathrm{mrem} /$ hour are considered unsafe. Measurements are made both in the flold and in the laboratory. No smearable contamination was found with these samples.

The chain of custody has several other important functions: (1) to provide a brief description of the cask, sampler, and the expected contents of the sampler (shipment, sample, and cask serial numbers for the specific sampling event); (2) to provide summary information about the analytical sulte that the sample will undergo or reference the salient documentation; (3) to provide traceability for the sample during transport; and (4) to ensure sample integrity on arrival at the laboratory. This information is provided to ensure that each sample can be uniquely identified. A summary of the most pertinent data contained in the chain-of-custody forms for the tank 241-C-109 samples is presented in Table 3-1.

Copies of the chain-of-custody forms are on flle at the Hanford Analytical Services Management (HASM) office. From inspecting the chaln-of-custody records, there appear to be irregularities in the sampling or transport of tank 241-C-109 samples. For example, some liner liquid was found in the core 47 and core 49 samples. The liquid found in the liners is assumed to be from the sampler. These irregularitles merit a sample integrity concern and potential safety concern (1.e., sample containment was compromised). Further investigation and refinement of the sampler design is in progress.

Table 3-1. Chain-of-Custody Summary.

\begin{tabular}{|l|l|l|l|}
\hline Sample & Core 47: 92-069 & Core 48: 92-070 & Core 49: 92-071 \\
\hline Place taken & $211-C-109$ Riser 6 & $241-C-109$ Riser 7 & $241-C-109$ Riser 8 \\
\hline Date taken & $9 / 2 / 92$ to $9 / 4 / 92$ & $9 / 4 / 92$ to $9 / 6 / 92$ & $9 / 6 / 92$ to $9 / 7 / 92$ \\
\hline Date released & $9 / 10 / 92$ & $9 / 10 / 92$ & $9 / 10 / 92$ \\
\hline Time released & $19: 20$ & $19: 20$ & $19: 20$ \\
\hline Sender & L. L. Dean & L. L. Dean & L. L. Dean \\
\hline Receiver & T. K. Andrews & T. K. Andrews & T. K. Andrews \\
\hline Place received & 325 Butlding & 325 Bullding & 325 Bullding \\
\hline Time received & $21: 45$ & $21: 45$ & $21: 45$ \\
\hline $\begin{array}{l}\text { Smearable } \\
\text { contamination }\end{array}$ & $<$ DL alpha & $<$ DL alpha & beta-gamma \\
\hline $\begin{array}{l}\text { Dose rate through } \\
\text { the drill string }\end{array}$ & $1 \mathrm{R} / \mathrm{hr}$ & $2.5 \mathrm{R} / \mathrm{hr}$ & beta-gamma \\
\hline
\end{tabular}

$\angle D L=$ below detection limits 
WHC-EP-0668

This page intentionally left blank. 
WHC-EP-0668

\subsection{SAMPLE PREPARATION/SAMPLE EXTRUSION}

\subsection{SAMPLE BREAKDOWN PROCEDURE}

Because tank 241-C-109 has been identified as a Watch List tank (as described in Section 2.1.2), more extensive analytical measurements are required to resolve the safety concerns associated with this iank. To enhance the resolution of the assays for key analytes, the analysis horizon for characterization was determined to be one-quarter of a segment.

The sampler was removed from the shipping cask directly into the hot cell. At this time, the sampler is placed into the horizontal position. The sample was then loaded into the mechanical extruder and removed by pushing it out from the back of the sampler with a piston. In this case, the sampler is pressed against a fixed piston, forcing the sample into the extrusion tray. If a full sample has been captured, the material nearest the valve (i.e. the bottom end) was from a deeper part of the tank; the material near the piston was closer to the surface. The sample and any liquids were collected on a metal tray. Next, the mass of the segment and the approximate length were recorded. From this information, the bulk densities of the segments can be estimated. The sample volume is determined by measuring the length of the extruded sample using a linear unit volume of $9.85 \mathrm{~mL} /$ in $(3.88 \mathrm{~mL} / \mathrm{cm})$. Each segment was divided into $12-\mathrm{cm}\left(4 \frac{3}{4}-i n.\right)$ subsegments. Figure $4-1$ illustrates how the ferrocyanide SST segment sample was extruded and divided into subsegments. A video record of the extrusions of each of the segments from tank 241-C-109 was made, and color photographs documenting the extruded segments were taken.

Figure 4-1. Typical Single-Shell Tank Segment Extrusion.

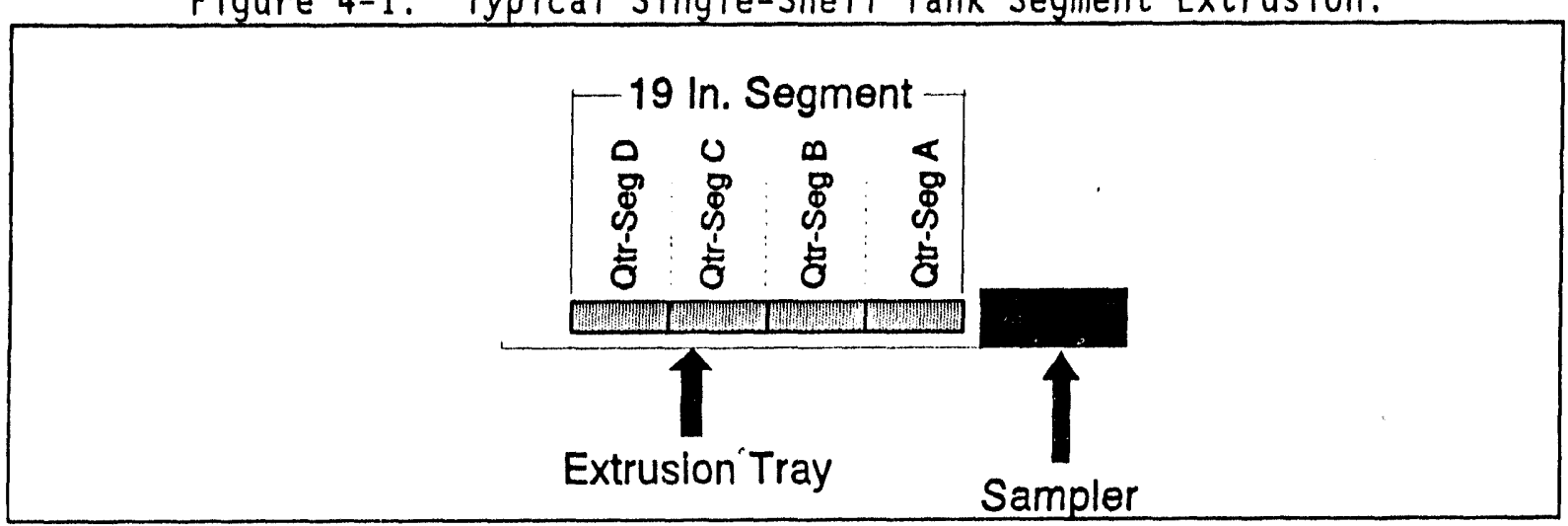

Several different styles of nomenclature are used for distinguishing core samples, sample segments, and subsegments in the existing literature. Two major conventions are used in the documentation relating to ferrocyanide (and core sampling in general). The first is designating the segment with the last two digits of the calendar year (92-) and then numbering the segments sequentially $(-001,-002$, etc.). This system resets itself every calendar year. The second system distinguishes the tank, core, segment, and subsegment. The first (bottom) $12 \mathrm{~cm}\left(4 \frac{3}{4} \mathrm{in}\right.$.) of the extruded sample is assigned to the fourth subsegment and is uniquely identified (Tank ID - Core 
No. - Segment No. - D). The following three $12-\mathrm{cm}\left(4 \frac{3}{4}-\mathrm{in}\right.$.) sections of the extruded segment are labelled as $C, B$, and $A$, respectively. An example of. this naming protocol for the third subsegment from the first core is: 241-C-109-Core 47-Segment 1-B. If the extruded segment is less than $48 \mathrm{~cm}$ (19 in.) long, then the same naming convention applies until no solid material is left to make a complete $12-\mathrm{cm}\left(4 \frac{3}{4}-\mathrm{in}\right.$.) subsegment. The first $12 \mathrm{~cm}$

( $4 \frac{3}{4}$ in.) is be assigned to the $D$ subsegment. This second system of naming is the primary convention used in this report. Where no tank identification is given in this report, it should be understood as meaning tank 241-C-109.

\subsection{HOMOGENIZATION TESTS}

The subsegment and core composite samples are homogenized using a mechanical mixer prior to analysis. This is done so that aliquots removed for analysis will be representative of the entire subsegment or core composite. Aliquots of the homogenized tank waste from Cores 48-10 and 49-10 were taken to determine the efficacy of the homogenization procedure. However, there was not sufficient sample material to perform a homogenization test on core 47. The samples were split into duplicates, acid digested, and assayed by inductively coupled plasma-atomic emission spectroscopy (ICP) and gamma energy analysis (GEA). This procedure is done to determine if the degree of mixing achieved by the as-planned homogenization procedure was sufficient for the remaining samples to be homogenized and prepared for analysis. If the analytes from the aliquots are within a relative percent difference (RPD) of 10 percent, the samples are considered homogenized. If there are several analytes that are not within the specified RPD, the samples are mixed further and re-assayed. Once homogenization was indicated, the remaining samples were homogenized via the required procedure and prepared for analysis.

Core 48 showed significant differences between the means for the top and bottom segments for several major analytes ( $\mathrm{Na}, \mathrm{Al}, \mathrm{Ca}, \mathrm{Ni}$, and $\mathrm{P}$ ). In addition, large RPDs for between the segment samples were observed for $F e, P$, $\mathrm{Si}$, and $\mathrm{Mn}$. Results from the subsegment homogenization test compare well with the core composite values. Core 49 showed no significant differences between the means for the top and bottom segments, but the test did show large RPDs for many elements, with much of the variation occurring in the top sample (RPDs ranging from 21 to $54 \%$ ). These results indicate that acid digestion as a sample preparation was not appropriate, and that potassium hydroxide (KOH) fusion was required to dissolve this material. This behavior was not unexpected because the simulant materials were very resistant to dissolution. There were adequate amounts of Core 49 material remaining to perform another homogenization test using a fusion dissolution sample preparation. The results from this test indicate that some difference remained between the top and bottom samples for $A T$ and $U$, with Fe borderline. The RPDs between replicates for each sample were within established acceptance criteria, except for $\mathrm{Mn}$, which is a trace analyte in this sample matrix. The $\mathrm{KOH}$ fusion preparation step appears to improve the homogenization test analytes, but the remaining differences between the top and bottom sample means indicate some non-homogeneity in the samples. 


\subsection{SUBSEGMENT-LEVEL ANALYSES}

The objectives of subsegment-level analyses are to provide (1) information as a function of depth pertaining to the overall waste energetics, (2) the distribution of ${ }^{137} \mathrm{Cs}$ and ${ }^{90} \mathrm{Sr}$, (3) the concentration and solubility of the $\mathrm{CN}^{\circ}$ present in the sample, and (4) a higher resolution for determining bulk tank composition for certain analytes. To accomplish these goals, the limited suite of analyses listed in Table 4-1 was performed on each homogenized subsegment. These analyses were conducted using the analytical procedures identified in Tables 15-1 and 15-2 of WHC-EP-0210, Rev 3

( $\mathrm{Hill}$ et al. 1991), and as amended in Hill (1991). Brief descriptions of the sample preparation and assay methods are presented. Laboratory procedures used are described in detail in Simiele (1991).

Table 4-1. Subsegment-Level Analysis.

\begin{tabular}{|c|c|c|}
\hline Direct & Fuston dissolution & Water leach \\
\hline $\begin{array}{l}\text { TOC/TIC } \\
\text { TGA } \\
\text { DSC } \\
\text { Total } \mathrm{CN}^{\circ} \\
\mathrm{Wt}_{\mathrm{W}} \mathrm{H}_{2} \mathrm{O}\end{array}$ & $\begin{array}{l}\text { ICP (Metals) } \\
\text { GEA }\left({ }^{137} \mathrm{Cs}\right) \\
{ }^{90} \mathrm{Sr}\end{array}$ & $\begin{array}{l}\text { IC (Anions) } \\
C N^{-} \\
\text {pH } \\
\text { GEA }\end{array}$ \\
\hline $\begin{array}{l}\text { DSC }= \\
\text { GEA }= \\
I C P= \\
\text { TGA }= \\
\text { TIC }= \\
\text { TOC }=\end{array}$ & $\begin{array}{l}\text { ential scanning calor } \\
\text { energy analysis. } \\
\text { ively coupled plasma } \\
\text { oscopy. } \\
\text { gravimetric analysis. } \\
\text { inorganic carbon. } \\
\text { organic carbon. }\end{array}$ & $\begin{array}{l}\text { netry. } \\
\text { atomic emission }\end{array}$ \\
\hline
\end{tabular}

Direct analyses are assays performed on the sample matrix with little or no sample preparation. Several direct analyses were performed relating to the energetic properties of the waste; total organic carbon (TOC), scanning thermogravimetric analysis (TGA), DSC, total cyanide, and gravimetric weight percent water.

The TOC was determined using hot persulfate. A sample is dissolved in a sulfuric acid solution $\left(90{ }^{\circ} \mathrm{C}+\right.$ ) to liberate inorganic carbon (carbonate). Potassium persulfate $\left(\mathrm{K}_{2} \mathrm{~S}_{2} \mathrm{O}_{8}\right)$ is then added, and organic carbon is converted to $\mathrm{CO}_{2}$, which is measured coulometrically. The total organic and total inorganic carbon assays are not considered capable of reliably detecting carbon contained in cyanide compounds in these waste matrices.

Scanning TGA and DSC are useful in determining the thermal stabllity or reactivity of a material. TGA measures the mass of a sample while the temperature of the sample is increased at a constant rate. In DSC analysis, the heat absorbed/evolved over and above the usual heat capacity of the substance is measured while the substance is exposed to a linear increase in temperature. 
Total cyanide analysis was done using a procedure developed at FNL for these-pecific types of samples. The sample was dissolved in a solution of ethylenediaminetetraacetic acid and ethylenediamine and placed in a microdistillation apparatus. The total cyanide content was determined by argentometric titration.

The gravimetric weight percent water was determined by drying the sample for 12 to 24 hours in an oven at 103 to $105^{\circ} \mathrm{C}$ and measuring the difference in the weight of the sample.

Analyses that were performed on fusion-prepared samples were ICP and GEA for radionuclides. Fusion dissolution analyses are assays performed on the sample matrix after it has been fused with potassium hydroxide in a cructble (nickel cructbles were used) and dissolved in acid. This preparation dissolves the entire sample, whereas other sample preparation procedures may not completely dissolve the sample matrix. However, one significant disadvantage of fusion preparation is that large amounts of potassium hydroxide are required to bring a sample into solution. Because of the high dilution factor, trace elements are less likely to be correctly quantified if they are detected at all. Elements that occur in abundance (major metals) or are highly insoluble are likely to be detected better by the fusion results than by any other sample preparation. Generally, fusion dissolution is the preferred method of analyzing radionuclide content, with the exception of ${ }^{14} \mathrm{C}$ and ${ }^{3} \mathrm{H}$ (tritium). However, the sample preparation specified in the test instructions for ${ }^{14} \mathrm{C}$ (water digestion) is iikely not the best for the ferrocyanide waste. Difficulty with dissolving the sample with a water leach and volatility associated with a fusion preparation will bias the ${ }^{14} \mathrm{C}$ results low for both sample preparations. An adequate sample preparation method for ${ }^{14} \mathrm{C}$ is not avallable for this sample matrix; however, ${ }^{14} \mathrm{C}$ is not expected to be a significant contributor to the radionuclide content of the waste.

Water leach (or water digestion) analyses are assays performed after the sample matrix has been digested in distilled/deionized water; the water is then analyzed for soluble analytes. The soluble anions are determined by ion chromatography (IC). The primary anions analyzed in this manner are fluoride, chloride, nitrate, nitrite, phosphate, and sulfate. In addition, free cyanide and $\mathrm{pH}$ were also analyzed from water digestion samples.

\subsubsection{Rheological and Physical Measurements}

Only one 25-mL aliquot (from Core 47) was used for the full suite of rheological and physical measurements. Viscosity, settling properties, fluid behavior, and shear strength were some of the primary characteristics investigated. The sample tested for these properties was not homogenized prior to analysis. Some selected physical measurements were performed on all of the core composites.

\subsubsection{Subsegment Level Archive}

Several analyses (adiabatic calorimetry, ferrocyanide speciation, and total oxygen demand [TOD]) have been identified by the Waste Tank Safety Programs as requiring deve?comental work. A sufficient amount of sample from 
each subsegment has been archived to perform these analyses when the procedures for these analyses have been developed. The adiabatic calorimetry assay will be performed on each subsegment if an exotherm of predetermined parameters is detected by DSC analysis. The boundaries for performing adlabatic calorimetry have been determined to be when the DSC exotherm is greater than $-75 \mathrm{cal} / \mathrm{g}$ and the sample has $15 \mathrm{wt} \%$ water or 1ess; or when the exotherm is greater than $-125 \mathrm{cal} / \mathrm{g}$, even if the sample has greater than 15 wt\% water. Because of sample consumption constraints, the TOD test cannot be run on samples from a subsegment drawn from the same core as a rheology-assayed core.

\subsubsection{Core Composite Level Analysis}

One composite from each core was built and analyzed in accordance with the complete baseline case core composite scenarlo detalled in Section 6.1 of WHC-EP-0210 (H111 et al. 1991) and as amended by H111 (1991). The type and number of analytical tests performed are similar to the suite done on the subsegments but are much more extensive. The free liquids from cores 47 and 49 were combined and analyzed as a separate liquid core composite.

Selected radionuclides were measured on some of the water digestion samples to determine the type and number of water soluble radionuclides. $I C P$ and atomic absorption (AA) spectroscopy were also performed on some of the water digestion samples. These assays were performed to determine the amount of solubie metal cations (ICP) or arsenic, mercury, or selentum (AA). In most cases, these analytes were below the detection limits in the water digestion samples, suggesting that most of the analytes are not water soluble.

Acid digestion is a preparation method where the sample is dissolved in a mixture of nitric and hydrochioric acids. This preparation brings most of the insoluble metals into a solution with a minimum amount of dilution, and is usually best for detecting trace and some major metals. These properties are the reason that acid digestion is generally used as the sample preparation for the homogenization tests. The analyses performed on this preparation were the ICP, GEA, and $A A$ analysis (the $A A$ analysis used nitric acid only). IC analysis was not performed with the acid digestion preparation solution.

Major metals that were well quantified with fusion ICP analys is for tank 24l-c-109 were aluminum, calcium, iron, lead, sodium, and uranium. Phosphorous and sliticon are non-metali ic analytes that were detected by the ICP. In the case of these elements the value from the fusion sample preparation is the more accepted quantity. Although the assay was performed in a nickel crucible, nickel values from the fusion preparation will be reported because they are important to interpreting the overall results. This is done with the understanding that they are biased high. A zirconium crucible was initially recommended for use with these assays to eliminate any potential nickel bias, but the sample matrix reacted with the zirconium during the fusion procedure. Potassium readings from the ICP fusion are not reported because potassium hydroxide was used to dissolve the sample and the potassium results are not important to characterizing the waste. Some of the primary radionuclides that are measured using this sample preparation are neptunium, plutonium, strontium, cesium, and technetium. A total alpha and total beta count were performed on the fusion dissolution samples as well. 
A U.S. Environmental Protection Agency (EPA) Contract Laboratory Procedure (CLP) type organics speciation analysis was performed on the core composites. No CLP target compounds or tentatively identified compounds were detected in levels above accepted quantitation 1imits (HASM 1993) and they were not expected to contribute to the sample matrix.

In previous characterization sampling, the core composites were bullt using quantities of segments based on a proportion of the total weight of sample for the core (Winters et al. 1990a, 1990b). This method assumed that the sample obtained is representative of what is in the tank. However, when partially filled segments are obtained, this procedure assumes that the tank does not contain any waste in this area. Incomplete recovery for a segment is more likely the result of sampling problems rather than voids in the waste.

The approach used in this analysis effort was to composite equal quantities of the homogenized subsegment material and assume that whatever is obtained in a partial subsegment is representative of a whole subsegment. Some inaccuracies may be introduced from this method because of density differences between subsegments. However, the inaccuractes introduced from density differences would probably be small; those deviations are minimal compared to the other errors inherent in core sampling and analysis. If full segments are obtained for the entire core, and the homogenization procedure is satisfactory, there will be little difference between the two approaches. 


\subsection{ANALYTICAL RESULIS: TANK 241-C-109}

\subsection{TANK 241-C-109 CORE SAMPLE RECOVERY}

As shown in Figure $5-1$, the last $3.8 \mathrm{~cm}(1.5 \mathrm{in.})$ of the $48.3-\mathrm{cm}(19-\mathrm{ln}$. sampler does not secure a sample from the bottom segment. In addition, the location of the risers, the dished bottom of the tank, and safety margins in the sampling protocol preclude obtaining samples from the entire waste depth in the tank. Thus, the maximum recovery for the segment from tank 241-C-109 is $3.8 \mathrm{~cm}(1.5 \mathrm{in}$.) above the bit bottom to the waste surface. Segment recoveries were based on the maximum recoverable volume for the segment regardless of solid/liquid ratio. The maximum recoverable amount of sample is $45.6 \mathrm{~cm}(18.0 \mathrm{in.})(177.3 \mathrm{~mL})$. Tables $5-1$ and 5-2 present the initial measurements and observations regarding the core samples on extrusion, and an estimate of the core recovery on a volume basis.

Table 5-1. Tank 241-C-109 Core Sample Description Summary.

\begin{tabular}{|c|c|c|c|c|}
\hline Core No. & Segment & $\begin{array}{l}\text { Core recovery } \\
\text { (volume basis) }\end{array}$ & $\begin{array}{l}\text { Total } \\
\operatorname{mass}(g)\end{array}$ & Comments \\
\hline Core 47 & $92-069$ & $64.5 \%$ & 134 & $\begin{array}{l}\text { Liquid volume was } 11 \mathrm{~mL} \text { i it } \\
\text { contained suspended solids. } \\
\text { Solids portion was } 26.7 \mathrm{~cm} \\
(10.5 \text { in.) long. }\end{array}$ \\
\hline Core 48 & $92-070$ & $30.6 \%$ & 73 & $\begin{array}{l}\text { No liquid captured. Solids } \\
\text { portion was } 14.0 \mathrm{~cm}(5.5 \mathrm{in.}) \\
\text { long. }\end{array}$ \\
\hline Core 49 & $92-071$ & $87.4 \%$ & 182 & $\begin{array}{l}\text { Liquid volume was } 22 \mathrm{~mL} \text {. } \\
\text { Solids were medium brown } \\
\text { color: Solid segment was } \\
41.9 \mathrm{~cm}(13.5 \mathrm{in.}) \text { long. }\end{array}$ \\
\hline
\end{tabular}

NOTE: Sampler linear volume is $9.85 \mathrm{~mL} / \mathrm{in}$.

Table 5-2. Tank 241-C-109 Core Sample Physical Characteristics Summary.

\begin{tabular}{|c|c|c|c|c|c|c|c|}
\hline core two & somber & $\begin{array}{c}\text { Solids } \\
\text { bample moss } \\
\text { (g) }\end{array}$ & $\begin{array}{c}\text { Liquid } \\
\text { sample moss } \\
(g)\end{array}$ & $\begin{array}{c}\text { Solids } \\
\text { sample } \\
\text { volume (mL) }\end{array}$ & $\begin{array}{c}\text { Liquid } \\
\text { sample } \\
\text { volume (mt) }\end{array}$ & $\begin{array}{c}\text { Solids bulk } \\
\text { density } \\
(g / \mathrm{mL})\end{array}$ & $\begin{array}{l}\text { Liquids } \\
\text { bulk } \\
\text { dens } 1 \text { ty } \\
(0 / \mathrm{mL})\end{array}$ \\
\hline core $4 \vec{i}$ & 52.069 & 121 & 13 & 103 & 11 & 1.2 & 1.2 \\
\hline $\cot 648$ & 5.0 .0 & 73 & 0 & 54 & 0 & 1.3 & $N / A$ \\
\hline core is & $9 \cdot 0 \%$ & 158 & 24 & 128 & 22 & 1.2 & 1.1 \\
\hline
\end{tabular}

NoTE: All liquids were captured in the sample liner. 
Figure 5-1. Current Waste Level of Tank 241-C-109.
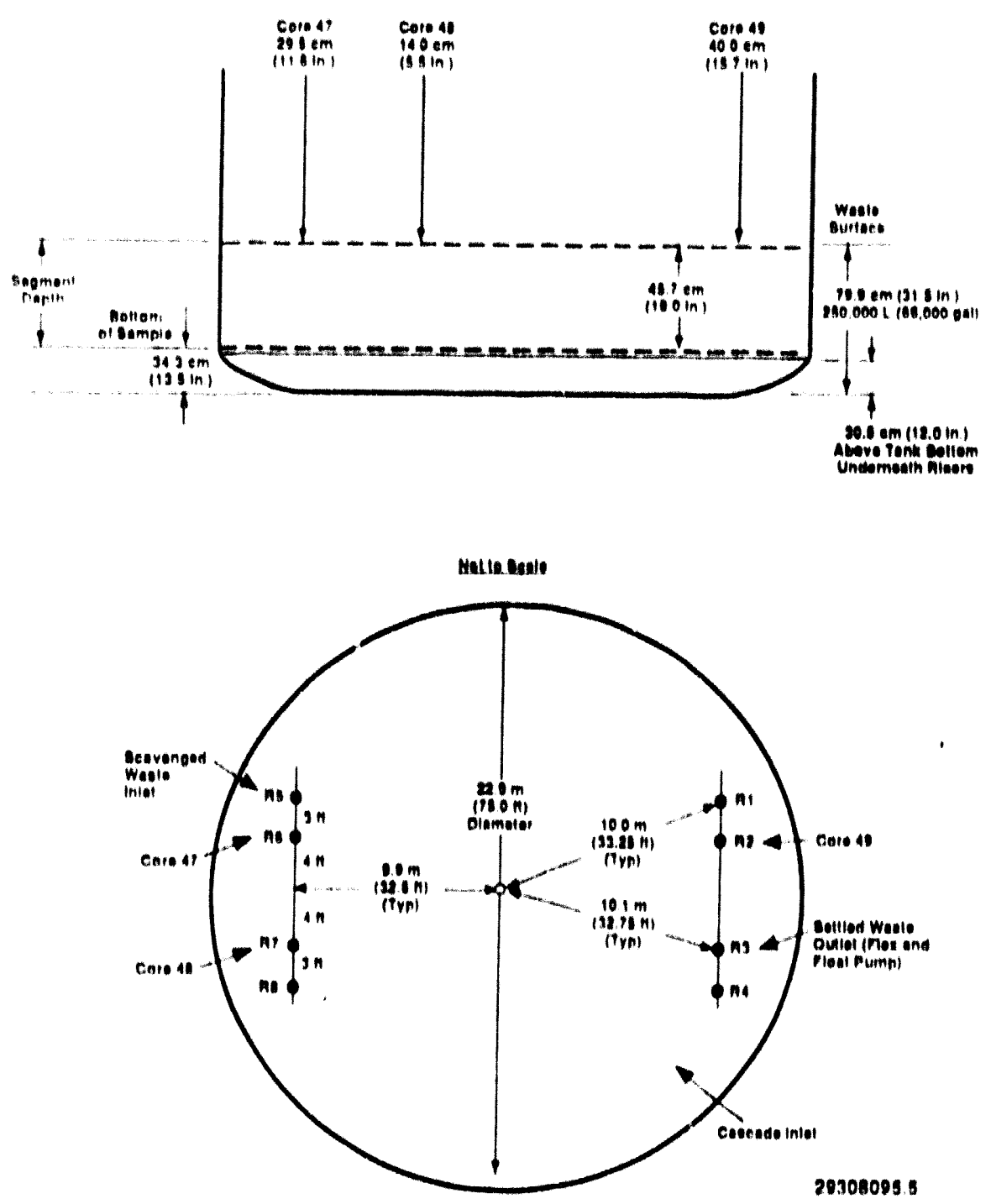

General characteristics of tank $241-C-109$ waste materials are as follows.

- Drainable liquids found in the liner were brownish-yellow in color and contained suspended solids.

- Core samples were generally dark brown in color. The brown solids were streaked through with grey/white material.

- The samples had a firm consistency. They were thick, cohesive sludges that held their shape after extrusion. The core materials all appeared to be saturated with liquid.

Analysis of the samples was performed at the PNL Ana?ytical Chemistry Laboratory. The ful? data package is avallabie from the Hanford Analytical Services lianagement office (HASM 1993). 


\subsection{TWRS PROGRAM ELEMENT CHARACTERIZATION SYNOPSIS}

Inis section provides selected results obtained from core sampling for some of the most pertinent analytes for the various TWRS program elements, including HWVP, Retrieval, Pretreatment, and Waste Tank Safety. Analytes of interest will be reported on a level of resolution commensurate with the avallable data and program direction. These selections were made on the basis of previous consultation with the program in support of other activities or currently documented characterization data needs (Bell 1993). Watch List tanks will have segment or subsegment level analyses reported, whlle non-Watch List tanks are analyzed only on a core composite basis. Generally, analytes of interest to multiple programs will only be reported in one section.

Further detall can be found in the body of the report or in the data packages.

\subsubsection{Retrieval Program Characterization \\ Data Summary: Physical Propertios}

A major objective of the characterization program is to measure the physical properties of the waste to support waste retrleval technology development. The physical characteristics of tank waste are required to develop design criterla for waste retrleval equipment, provide a basis for simulated waste development, and to provide a basis for validation of equipment testing using design criterla and simulated waste. The analytical methods to determine the physical properties of the waste as $1 t$ actually exists in the tank require a substantlal amount (50 to $100 \mathrm{~g}$ ) of unhomogenized sample. In some cases, the limited amount of sample recovered constrains the number of analyses that can be performed.

Performing the rheological/physical measurements once for each stratum of waste in a tank is belleved to be sufficient to characterize the entire tank contents. Selected rheological and physical properties are presented in Table 5-3; further information regarding these analytes can be found in Section 5-3.

Table 5-3. Retrieval Program.

\begin{tabular}{|c|c|}
\hline Analyte & Data range \\
\hline $\begin{array}{l}\text { Specific gravity }(\mathrm{g} / \mathrm{mL}) \\
-- \text { solids } \\
--1 \text { iquids }\end{array}$ & $\begin{array}{l}1.2-1.3 \\
1.1-1.2\end{array}$ \\
\hline Shear strength & 17,300 dynes $/ \mathrm{cm}^{2}$ \\
\hline $\begin{array}{l}\left.\text { Viscosity (cP } 29^{\circ} \mathrm{C}\right) \\
--1: 1 \text { dilution } \\
--3: 1 \text { dilution }\end{array}$ & $\begin{array}{r}80 \text { (nigh shear) }-4,200 \text { (low shear) } \\
3 \text { (high shear) - } 95 \text { (low thear) }\end{array}$ \\
\hline $\begin{array}{l}\text { Particle size ( } \mu \mathrm{m}) \\
\text {-Number distribution } \\
\text {-Nolume distribution }\end{array}$ & $\begin{array}{l}89 \%<2 \mu \mathrm{m} \\
70 \%<85 \mu \mathrm{m}\end{array}$ \\
\hline
\end{tabular}




\subsubsection{Pretreatment Program Characterization Data Summary: Bulk Constituent Inventorios}

The majority of the programmatic decisions pertaining to the design of pretreatment and final disposal systems wlll be based upon the average characteristics of the tank waste. Therefore, the majority of the laboratory analyses will be conducted on representat tve core composites. Llquid composites and strata composites will be built under some circumstances and will be analyzed with fewer assays and, as noted previously, segment (or subsegment) level analyses wlll be performed, when directed.

Table 5-4 presents selected trace analytes of known interest; the Pretreatment Program's data needs are julte extensive and further chemical and radinlogical characterization information can be found in Sections 5.3, 5.4, and 5.5. Currently, methods are boing developed for certain analytes. These developmental assays are then phased in as part of a technology transfer effort. In these cases, samples will be archived unt 11 the requisite method has been developed and implemented, or samples will be shipped between the onsite laboratories (222-S Laboratory and 325 Laboratory) and possibly to offsite laboratories for analysis.

Table 5-4. Trace Analytes of Interest to Pretreatment.

\begin{tabular}{|c|c|c|c|}
\hline Analyte & \multicolumn{3}{|c|}{ Core composite values } \\
\hline $\begin{array}{l}\text { Minor fusion prep ICP analytes }(\mu \mathrm{g} / g) \\
-B \\
\cdots C \mathrm{Cr} \\
-\mathrm{Mg} \\
-\mathrm{Zr}\end{array}$ & $\begin{array}{r}\text { Core } 47 \\
<\text { DL } \\
270 \\
650 \\
<D L\end{array}$ & $\begin{array}{r}\text { Core } 48 \\
<D L \\
260 \\
670 \\
<D L\end{array}$ & $\begin{array}{r}\text { Core } 49 \\
<D L \\
220 \\
340 \\
<D L\end{array}$ \\
\hline pH (Liquid composite) & & & 12.08 \\
\hline pH (Water leach) & 10.8 & 10.1 & 9.4 \\
\hline
\end{tabular}

$I C P=$ Inductively coupled plasma - atomic emission

spectroscopy.

$<D L$ - below detection limits.

\subsubsection{Waste Tank Safety Program Characterization Data Summary}

5.2.3.1 Criticality Safety. The criticality safety program has indicated that plutonium and uranium isotopic analyses on each core composite and the bottom most six inches of each core is required to alleviate the concern for the potential of tank criticality (refer to Tables 5-5, 5-6, and 5-7). For the ferrocyanide tanks, the analyses are performed on the bottom subsegment of the core sample. As requested, the analyses will indicate whether the fissile species have settled in a concentrated layer at the bottom of a tank.

Therefore, upon extruding the last segment in a core, a small aliquot is taken and analyzed for plutonium and uranium isotopic analyses by mass spectroscopy. 
Table 5-5. Core Composite Transuranics (Fusion Preparation).

\begin{tabular}{|c|c|c|c|c|c|c|}
\hline $\begin{array}{l}\text { Core } \\
\text { No. }\end{array}$ & $\begin{array}{c}{ }^{237} N p \\
(\mu C 1 / g)\end{array}$ & $\begin{array}{l}{ }^{238} \mathrm{P}_{U^{*}} \\
(\mu \mathrm{C} / \mathrm{g})\end{array}$ & $\begin{array}{l}{ }^{230} \mathrm{Pu} \\
(\mu \mathrm{Cl} / \mathrm{g})\end{array}$ & $\begin{array}{l}261 \mathrm{Am}_{\mathrm{OEA}} \\
(\mu \mathrm{C} 1 / \mathrm{g})\end{array}$ & $\begin{array}{l}{ }^{24} \mathrm{Am}_{\mathrm{AE}} \\
(\mu \mathrm{C} 1 / \mathrm{g})\end{array}$ & $\begin{array}{l}\text { Total a } \\
(\mu \mathrm{Cl} / \mathrm{g})\end{array}$ \\
\hline Core 47 & $3.65 E-04$ & $4.40 E-05$ & 0.82 & $<0.58$ & 0.32 & 0.992 \\
\hline Core 48 & $3.34 E-04$ & $7.15 E-06$ & 0.063 & $<0.71$ & 0.01 & 0.065 \\
\hline Core 49 & $3.01 E-04$ & $1.11 E-05$ & 0.075 & $<0.35$ & 0.13 & 0.129 \\
\hline
\end{tabular}

* Isotopic quantitation of plutonium is determined by multiplying the total Pu a measurement by its mass fraction.

$A E A$ - Measurement by alpha energy analysis.

GEA - Measurement by gamma energy analysis.

Table 5-6. Core Composite Uranium.

\begin{tabular}{|c|c|c|c|c|}
\hline Core No. & $U_{1 c \rho}$ fustion & $\underset{(\mu g / g)}{U_{p}}$ & $\begin{array}{c}{ }^{236} U \\
\text { Mass } \\
\text { fraction }\end{array}$ & $\begin{array}{c}235 \mathrm{~J} \\
\text { Mass } \\
\text { fraction }\end{array}$ \\
\hline Llquid composite & $\angle D L$ & 3.7 & NM & NM \\
\hline Core 47 & 9,200 & 12,000 & 0.993263 & 0.006573 \\
\hline Core 48 & 24,700 & 27,600 & 0.993038 & 0.006852 \\
\hline Core 49 & 4,700 & 7,500 & 0.993109 & 0.006753 \\
\hline
\end{tabular}

$O L=$ Below detection limits.

FL. - Uranium measurement by laser fluorimetry.

NM - No tsotopic measurement on liquid composite, concentration too low.

Table 5-7. Plutonium Concentration and Isotopic Distribution.

\begin{tabular}{|c|c|c|c|c|c|c|}
\hline Core 1 & $\begin{array}{c}\text { Total Pu } \alpha \\
(\mu \mathrm{C} i / g)\end{array}$ & $\begin{array}{l}{ }^{238} \text { pu Mass } \\
\text { fraction }\end{array}$ & $\begin{array}{l}236 \text { pu Mass } \\
\text { fract ion }\end{array}$ & $\begin{array}{l}{ }^{240} \mathrm{pu} \text { Mass } \\
\text { fraction }\end{array}$ & $\begin{array}{l}241 \text { Pu Mass } \\
\text { fraction }\end{array}$ & $\begin{array}{l}242 \text { Pu Mass } \\
\text { fraction }\end{array}$ \\
\hline Core 47 & 0.88 & 0.00005 & 0.932237 & 0.066256 & 0.001216 & 0.000241 \\
\hline cone & 065 & 011 & 0.976356 & 0.022995 & 0.000364 & 0.000176 \\
\hline Core 49 & 0.079 & 0.00014 & 0.949629 & 0.048786 & 0.001119 & 0.000329 \\
\hline
\end{tabular}

NOTE: There was no Pu measurement on l lquid composite because the concentration was too low. 
5.2.3.2 Ferrocyanide Tanks. During the 1950's, ferrocyanide compounds were used to scavenge ${ }^{137} \mathrm{Cs}$ from the supernate of Hanford Situ waste tanks. The potential for an exothermic reaction in the sodium-cestum-nickel

ferrocyanide/sodium nitrate complex must be evaluated in waste tanks believed to contain 1,000 gram-moles or more of ferrocyanide precipitates. The characterization objectives in support of resolution of this USQ and in support of retrieval, pretreatment, and final disposal systems design are as follows.

- Determine the waste energetics behavior in the tanks.

- Determine the spatial distribution of fuel, ${ }^{137} \mathrm{Cs}$, and ${ }^{90} \mathrm{Sr}$.

- Determine the concentration of total $\mathrm{CN}^{\circ}$ and the speciation of ferrocyanide present in the waste.

- Satisfy the general characterization requtrements for physical, chemical, and radiological analytes.

To achieve the above objectives and to enhance the resolution of the vertical distribution study for key analytes, the analysis horizon for characterization of layering is one quarter of a segment. The data from tank 241-C-109 indicates that the tank meets the present criterion for placement on the Ferrocyanide Watch List (1.e., greater than 1,000 g-mole ferrocyanide (estimated from total cyanide measurements]). Further characterization information regarding this topic can be found in Section 5. The next several figures (Figures 5-2, 5-3, and 5-4) present the values most relevant to evaluate the ferrocyanide USQ and provide values for analytes of importance to the Ferrocyanide Safety Program as a function of position.

\subsubsection{HWVP Program Characterization Data Summary}

The Hanford Waste Vitrification Program has characterization needs in addition to those described for core sampling. Transforming waste into glass is primarlly for the disposal of high-level/TRU solids in a geologic repository. The vitrification process will be performed after the solids have been pretreated. Therefore, core sample information will provide preliminary bounding design conditions for the glass plant. Further characterization for technology development and regulatory compliance will be necessary on the pretreated waste that will be fed to the vitrification plant. The analytical requirements for the HWVP program are identified in the Hanford Waste Vitrification Plant Feed Characterization Requirements (Wagner 1992).

Neutralized current acid waste (NCAW) is expected to be pretreated by a sludge washing process prior to becoming the first feed to HWVP. The high heat waste in tanks $C-105$ and $C-106$ will also be an early feed to HWV and is expected to be pretreated in the same manner (one of the two cores from tank $\mathrm{C}-106$ w 111 be analyzed as an early feed tank). Other tanks, such as 24]-C-109, will be considered for early retrieval and processing, based on technical and programmatic criteria. Some of the characterization objectives in support of design of retrieval, pretreatment, and final disposal systems are as follows. 
Figure 5-2. Core 47 Measurements and Observations.

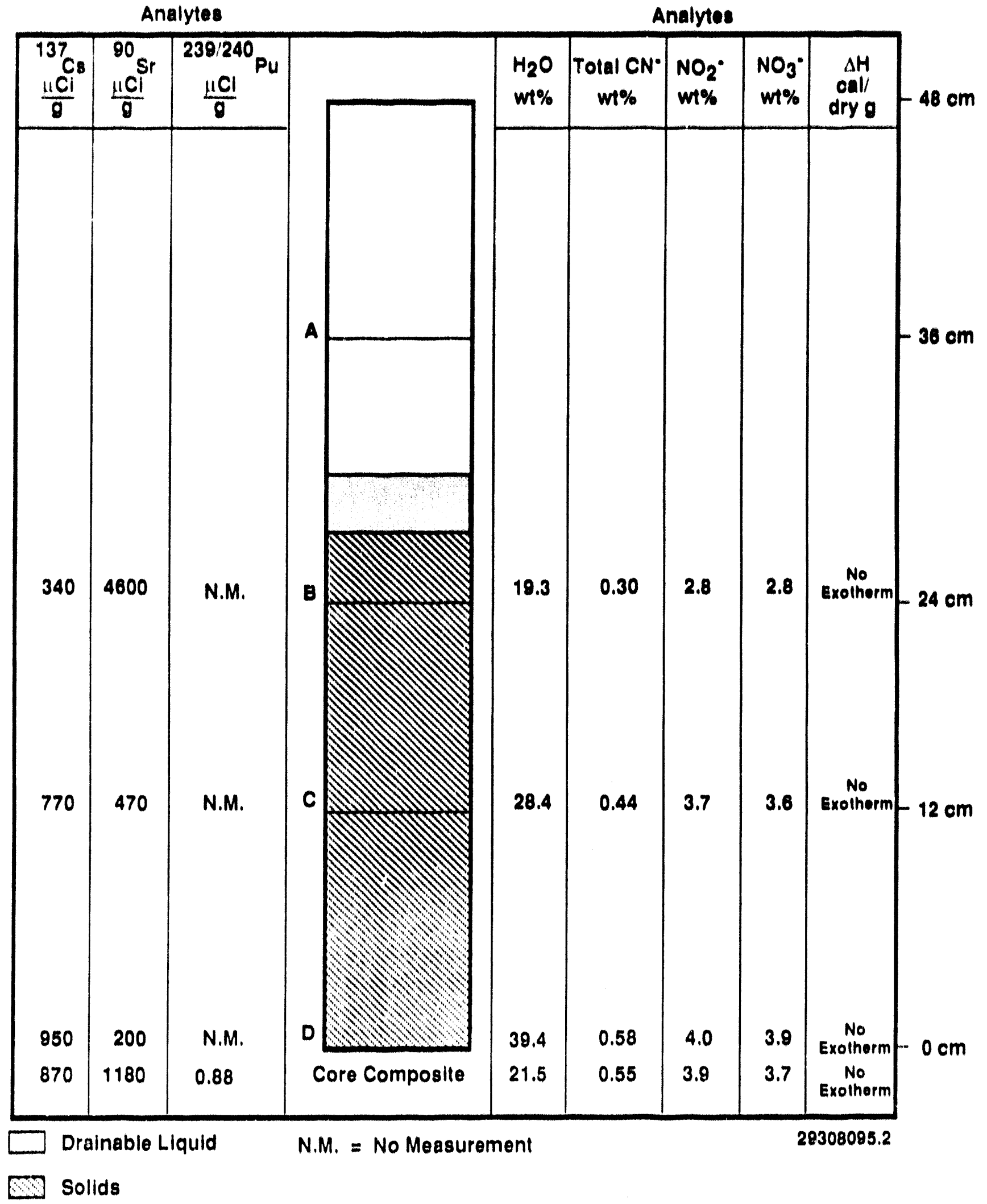


Figure 5-3. Core 48 Measurements and Observations. Analytes Analytes

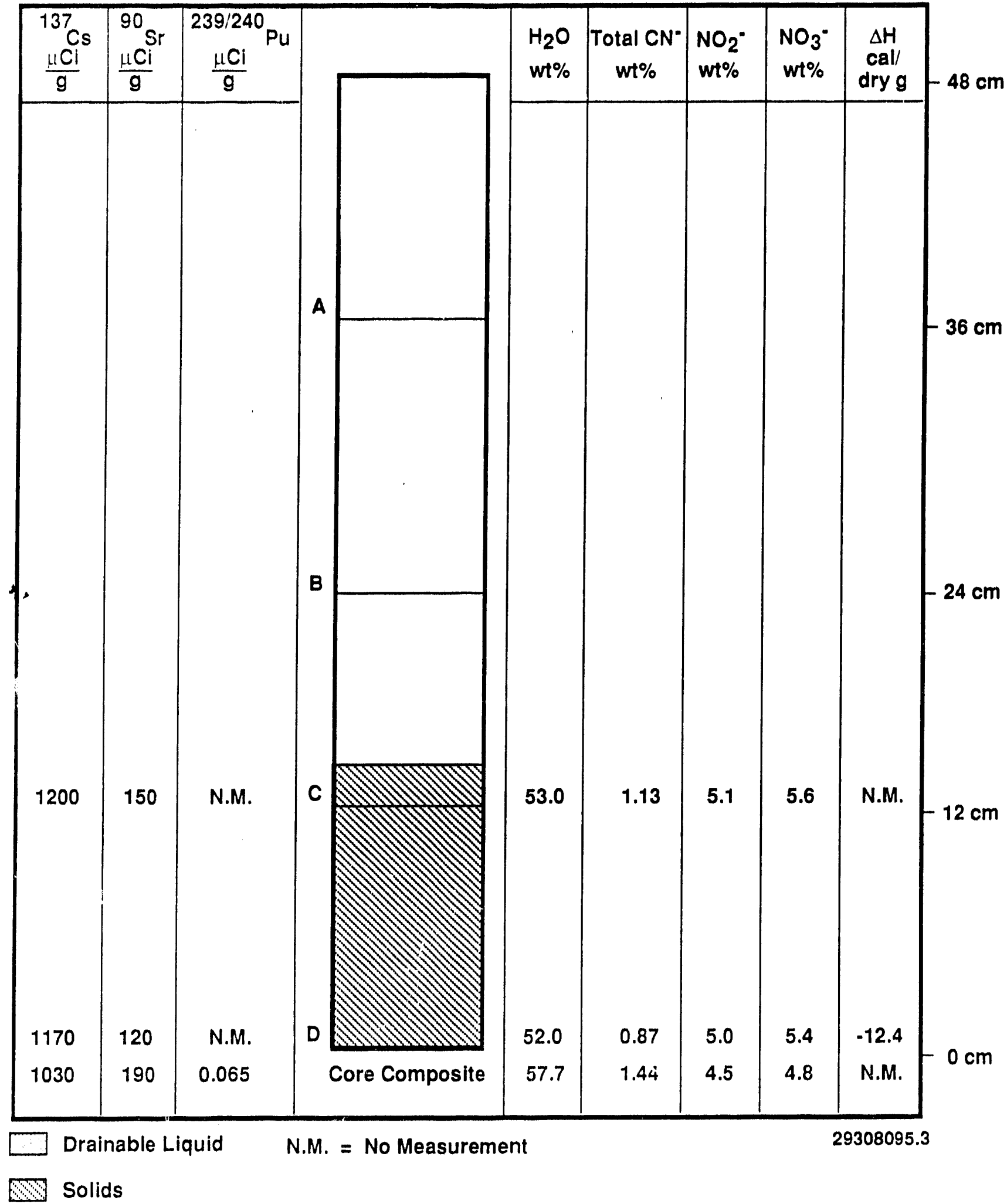


Figure 5-4. Core 49 Measurements and Observations.

Analytes

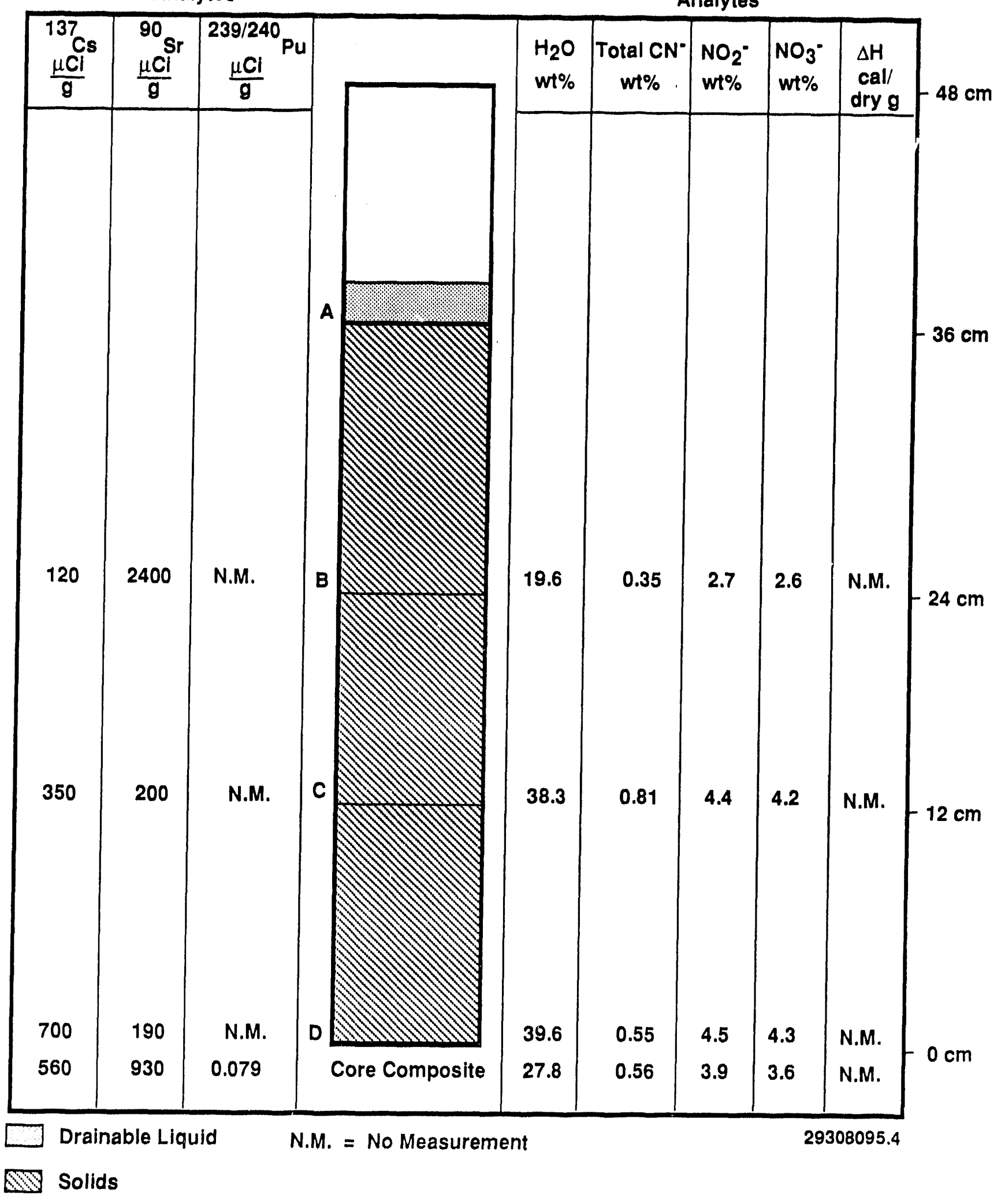


- Provide extensive characterization of the chemical and radiological contents of the waste (solids and supernate) as it currently exists in the tanks to support processibility assessments and to verify whether the composition variability study envelope coverage for key analytes is adequate.

- Provide sufficient data to make an estimate of the waste fraction that will remain after sludge wash pretreatment and become feed for the HWVP.

- Determine the physical and rheological properties of the waste before and after simulated sludge washing to support the design of a waste retrieval system.

- Satisfy the general characterization requirements for physical, chemical, and radiological analytes.

Planned early retrieval of some tanks for HWVP necessitates an increased evaluation of rheological and physical properties of the tank waste. To this end, selected rheological and physical properties are measured on the first and last segments of both cores taken from these specified tanks as a minimum. Rheological measurements will also be performed on other segment material if a unique stratum is identified in the remaining segments.

The analytical program for HWVP not only entails determining whether a waste type is suitable for disposal as glass, but also includes determining the physical and chemical characteristics of the glass for process control purposes and to ensure regulatory compliance. Sampling and analysis plans will be developed on an individual basis for each tank or process batch. The characterization needs for these efforts include analyses for metals, watersoluble anions, radionuclides, semi-volatile organics, and rheological and physical testing for both the HWVP feed and vitrified product.

Presently, tank 241-C-109 is not scheduled as an early feed to the HWVP. However, in recognition that the tank may be considered in the future as a potential early retrieval processing candidate, two selected groups of analytes are presented in this summary; Table 5-8 provides a set of analytes of interest to the vitrification process control, the other (Table 5-9) are analytes of interest to the regulatory permitting of such a facility.

Table 5-8. HWVP Process Control Analytes of Concern.

\begin{tabular}{|l|c|c|c|}
\hline \multicolumn{1}{|c|}{ Analyte } & $\begin{array}{c}\text { Core } 47 \text { composite } \\
(\mu \mathrm{g} / \mathrm{g})\end{array}$ & $\begin{array}{c}\text { Core } 48 \text { composite } \\
(\mu \mathrm{g} / \mathrm{g})\end{array}$ & $\begin{array}{c}\text { Core } 49 \text { composite } \\
(\mu \mathrm{g} / \mathrm{g})\end{array}$ \\
\hline $\mathrm{PO}_{4}^{3-}(\mathrm{IC} / \mathrm{ICP})$ & $22,100 / 61,700^{*}$ & $26,700 / 62,600^{*}$ & $12,800 / 45,300^{\star}$ \\
\hline $\mathrm{F}^{-}$ & 400 & 1,300 & 400 \\
\hline $\mathrm{Cl}^{-}$ & 700 & 800 & 700 \\
\hline $\mathrm{TOC}$ & 2,300 & 3,100 & 2,300 \\
\hline
\end{tabular}

= based on an ICP fusion value for phosphorous and assuming it is present solely as phosphate. 
Table 5-9. HWVP Regulatory Operation Analytes of Concern.

\begin{tabular}{|c|c|c|c|}
\hline Analyte $(\mu \mathrm{g} / \mathrm{g})$ & Core 47 & Core 48 & Core 49 \\
\hline $\mathrm{Hg}$ (Liquid composite) & 8.9 & 6.6 & 6.7 \\
\hline $\begin{array}{l}\mathrm{Pb} \text { (Liquid composite) < } \mathrm{DL} \\
\text { (solid composite, fusion) }\end{array}$ & $\begin{array}{l}\text { N.M. } \\
7,300\end{array}$ & N.M. & $\begin{array}{l}\text { N.M. } \\
820\end{array}$ \\
\hline $\operatorname{Cr}(V I)$ (solid composite, water) & 47 & 37 & $28 *$ \\
\hline Analyte $(\mu \mathrm{Ci} / \mathrm{g})$ & Core 47 & Core 48 & Core 49 \\
\hline $\begin{array}{l}{ }^{14} \mathrm{C} \text { (Liquid composite: } 2.3 E-03 \text { ) } \\
\text { (Solid composite, water) }\end{array}$ & $6.3 E-06$ & $1.8 E-05$ & $3.6 E-05$ \\
\hline $\begin{array}{l}{ }^{99} \mathrm{TC} \text { (Liquid composite: } 1.6 \mathrm{E}-01 \text { ) } \\
\text { (solid composite, fusion) }\end{array}$ & $1.1 E-01$ & $1.2 E-01$ & $9.4 E-02$ \\
\hline $\begin{array}{l}{ }^{3} \mathrm{H} \text { Liquid composite: } 3.29 \mathrm{E}-03 \text { ) } \\
\text { (Solid composite, water) }\end{array}$ & $8.5 E-03$ & $6.4 E-03$ & $6.4 E-03$ \\
\hline
\end{tabular}

* Single data point; other anomalous data point is out of range.

\subsection{TANK 241-C-109 CORE SAMPLE RHEOLOGICAL/PHYSICAL MEASUREMENTS}

Physical properties such as shear strength, viscosity, particle size, and settling properties were measured. These measurements are necessary for the design and fabrication of retrieval, pretreatment, and final waste disposal systems.

\subsubsection{Shear Strength}

The shear strength of the waste from tank 241-C-109 was measured on a combined, unhomogenized sample from Core 47 . The shear strength measurements were made at ambient temperature using a shear vane connected to a viscometer and rotated at $0.3 \mathrm{r} / \mathrm{min}$. Shear strength $\left(\tau_{\mathrm{s}}\right)$ is a semiquantitative measurement of the force required to move the sample. Because shear strength is dependent on sample handling, the measurement was taken without any sample homogenization. The rheology sample was generated by taking small aliquots from the segment of Core 47 at various positions. The aliquots were transferred to a sample jar and allowed to settle for 10 weeks to let the sample recover from the disturbance of sampling and extrusion. The extended delay between sample and analys is was specified because it is believed that the longer the sample sits undisturbed, the more likely it is to return to its (nearly) original condition; therefore, the shear measurement is likely to be more representative. The shear stress $\left(S_{T}\right)$ of the sample was recorded as a function of time and the shear strength was calculated using Equation 1. 


$$
\begin{gathered}
W H C-E P-0668 \\
\tau_{s}=\frac{[8 \tau / 100] * S_{t} * 4.9 E+05}{\frac{\pi * H_{v} * D_{v}^{2}}{2}+\frac{\pi * D_{v}^{3}}{6}}
\end{gathered}
$$

where:

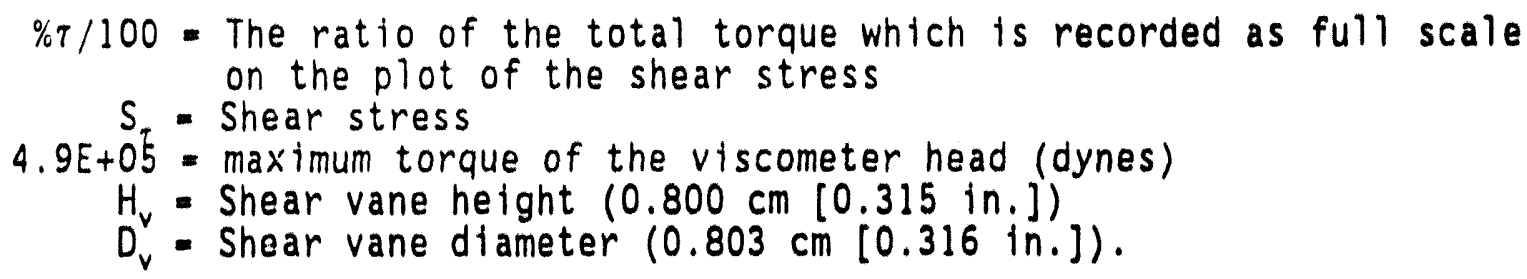
on the plot of the shear stress

$S_{+}=$Shear stress

$4.9 E+05$ - maximum torque of the viscometer head (dynes)

$H_{v}=$ Shear vane height $(0.800 \mathrm{~cm}[0.315 \mathrm{in.}])$

$D_{v}=$ Shear vane diameter $(0.803 \mathrm{~cm}[0.316$ in.]).

Two measurements of $\tau$. were taken, averaging 17,300 dynes $/ \mathrm{cm}^{2}(17,560$ and 17,000 dynes $/ \mathrm{cm}^{2}$ ). The shear stress of the material exceeded the maximum value for the measurement system $(8,500 \mathrm{~Pa})$. However, to take a measurement, the core was rotated at a significantly higher rate than was used in the $\tau$. measurement, causing the measured shear stress to be higher than the actual value. In addition, some drying of the sample may have occurred, also causing the measurement to be higher than its true value.

\subsubsection{Shear Stress and Viscostty as Functions of Shear Rate}

Shear stress and viscosity measurements (as functions of shear rate) were performed on the 1:1 (water:sample) dilution of the sample at ambient hot cell temperatures 29 to $32^{\circ} \mathrm{C}\left(84\right.$ to $\left.90{ }^{\circ} \mathrm{F}\right)$ and at $95^{\circ} \mathrm{C}\left(203^{\circ} \mathrm{F}\right)$. Drying of the sample at $95{ }^{\circ} \mathrm{C}$ posed difficulties in measurement for the 1:1 diluted sample; no results of the rheograms run under these conditions are presented.

The data from the rheograms for the 1:1 dilution were fit to a nonlinear yield power-law model (Equation 2). Sample and duplicate measurements were run at ambient and $95^{\circ} \mathrm{C}$.

$$
S_{i}=\alpha+\beta \gamma^{n}
$$

where:

$$
\begin{aligned}
S_{7} & =\text { shear stress } \\
\alpha & =\text { yield stress (not a fit parameter) } \\
\beta & =\text { consistency factor } \\
\gamma & =\text { shear rate }\left(0 \text { to } 468 \mathrm{~s}^{-1}\right) \\
n & =\text { flow behavior index. }
\end{aligned}
$$

Table 5-10 presents the power law model parameters for the 1:1 sample dilutions at $30^{\circ} \mathrm{C}$. 
Table 5-10. Power-Law Model Parameters for Tank 241-C-109 Material.

\begin{tabular}{|c|c|c|c|c|c|}
\hline Sample & $\begin{array}{c}\text { Temperature } \\
\left({ }^{\circ} \mathrm{C}\right)\end{array}$ & Trial & $\begin{array}{c}\alpha, \text { Yield } \\
\text { stress (Pa) }\end{array}$ & $\begin{array}{c}\text { B, } \\
\text { Consistency } \\
\text { factor (Pa-s) }\end{array}$ & $\begin{array}{c}\text { n, Flow } \\
\text { behavior } \\
\text { index }\end{array}$ \\
\hline $1: 1$ Dilution & 30 & $S$ & 50 & 0.017 & 1 \\
\hline $1: 1$ Dilution & 30 & 0 & 40 & 0.019 & 1 \\
\hline
\end{tabular}

$S$ - Sample

D. Duplicate

Viscosity of the 1:1 diluted sample at low shear (1.e., near zero) ranged between 2,800 and 4,200 cP; the viscosity gradually declined with increasing shear rates to $100 \mathrm{CP} 0468 \mathrm{~s}^{-1}$. The 1:1 dilution of the composite sample exhibited yield-pseudoplastic behavior. Figures 5-5 and 5-6 present data smoothed results for shear stress versus shear rate and viscosity versus shear rate for the 1:1 diluted sample. The 3:1 dilution samples exhibit near Newtonian behavior at the detection 1 imit of the system (2 CP) for shear stress as a function of shear rate. Viscosity of the 3:1 diluted sample at low shear ranged between 12 and $42 \mathrm{CP}$ (avg. $30 \mathrm{cP}$ ); the viscosity rapidly declined with increasing shear rates to approximately $5 \mathrm{CP} Q 100 \mathrm{~s}^{-1}$ and $3 \mathrm{cP}$ 0 $468 \mathrm{~s}^{-1}$. Higher viscosities at higher temperatures for these sample matrices is not unusual, because drying of the sample often has a significant impact on its flow behavior.

Further measurements of the viscosity as a function of shear rate were made on the $3: 1$ dilution samples at $95^{\circ} \mathrm{C}\left(203^{\circ} \mathrm{F}\right)$. The $3: 1$ dilution samples exhibit near Newtonian behavior at the detection ifimit of the system (2 CP) for shear stress as a function of shear rate. Viscosity of the $3: 1^{*}$ diluted sample at low shear ranged between 37 and $95 \mathrm{cP}$ (avg. $\sim 58 \mathrm{cP}$ ). The viscosity rapidiy declines with increasing shear rates to between 5 and $12 \mathrm{CP} C 100 \mathrm{~s}^{. P}$ and approximately $3 \mathrm{cP} @ 468 \mathrm{~s}^{\circ} \mathrm{T}$.

A rheogram for a material with a yield stress has two sections. The first section is a straight line beginning at the origin and climbing up the ordinate. This portion of the rheogram records the material as it acts like a solid or gel. When sufficient force is applied to the material to make the gel yield, the rheogram breaks sharply to the right and records the material's behavior as a fluid. The point on the rheogram at which the sample's behavior transfers from a solid or gel to a fluid is the yield point or yield stress. The consistency factor in this model is analogous to viscosity. The flow behavior index indicates the degree of deviation from Newtonian behavior. For values less than 1, the behavior is considered pseudoplastic

(Bird et al. 1960). Plots of all of the measurements can be found in the full validated data packages (HASM 1993).

\subsubsection{Slurry Flow Properties}

Turbulent flow is necessary to keep particles in suspension and prevent the accumulation of the solids in retrieval and/or pretreatment process 
Figure 5-5. Shear Stress Versus Shear Rate for 1:1 Diluted Sample.

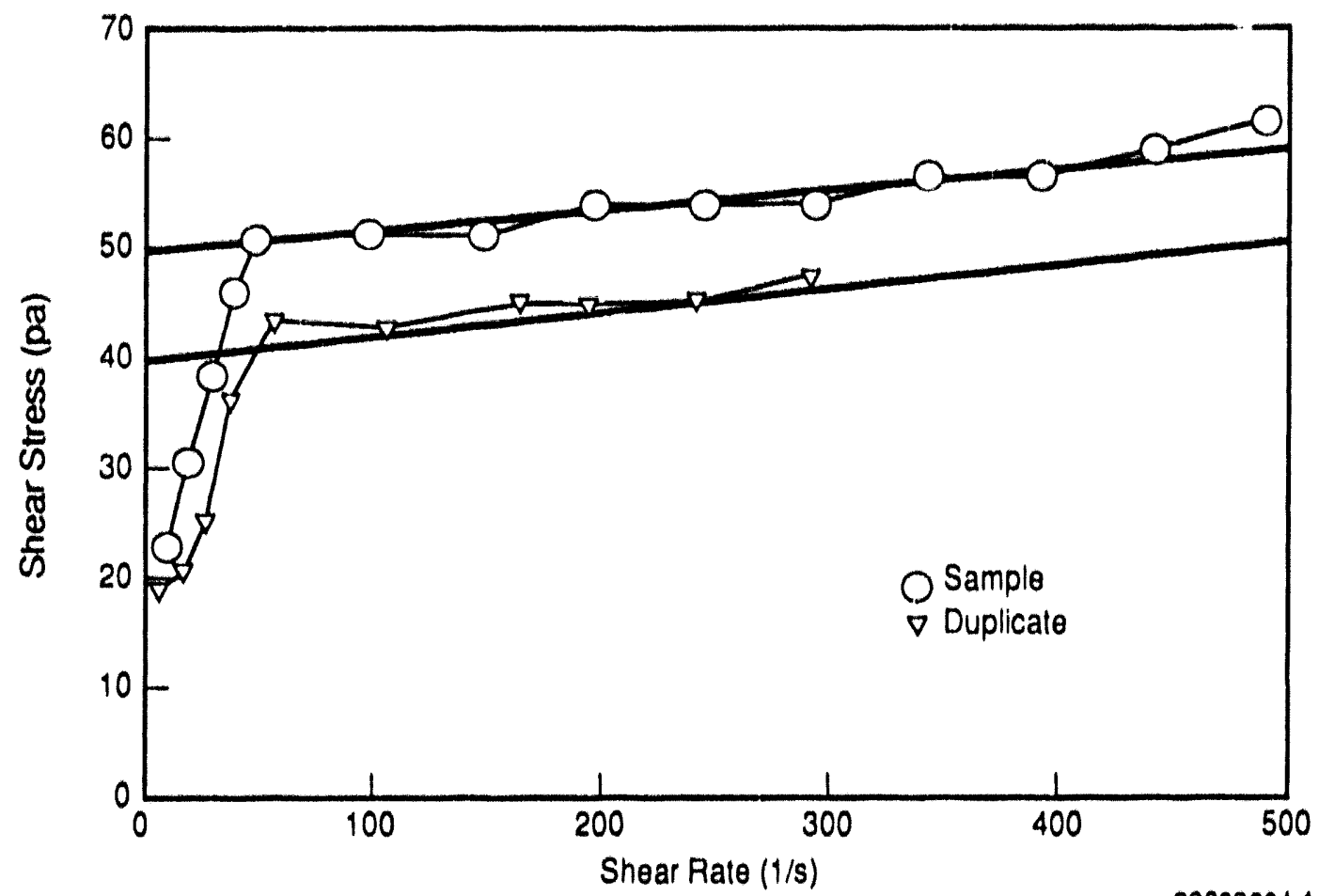

29309004.1

Figure 5-6. Viscosity Versus Shear Rate for 1:1 Diluted Sample.

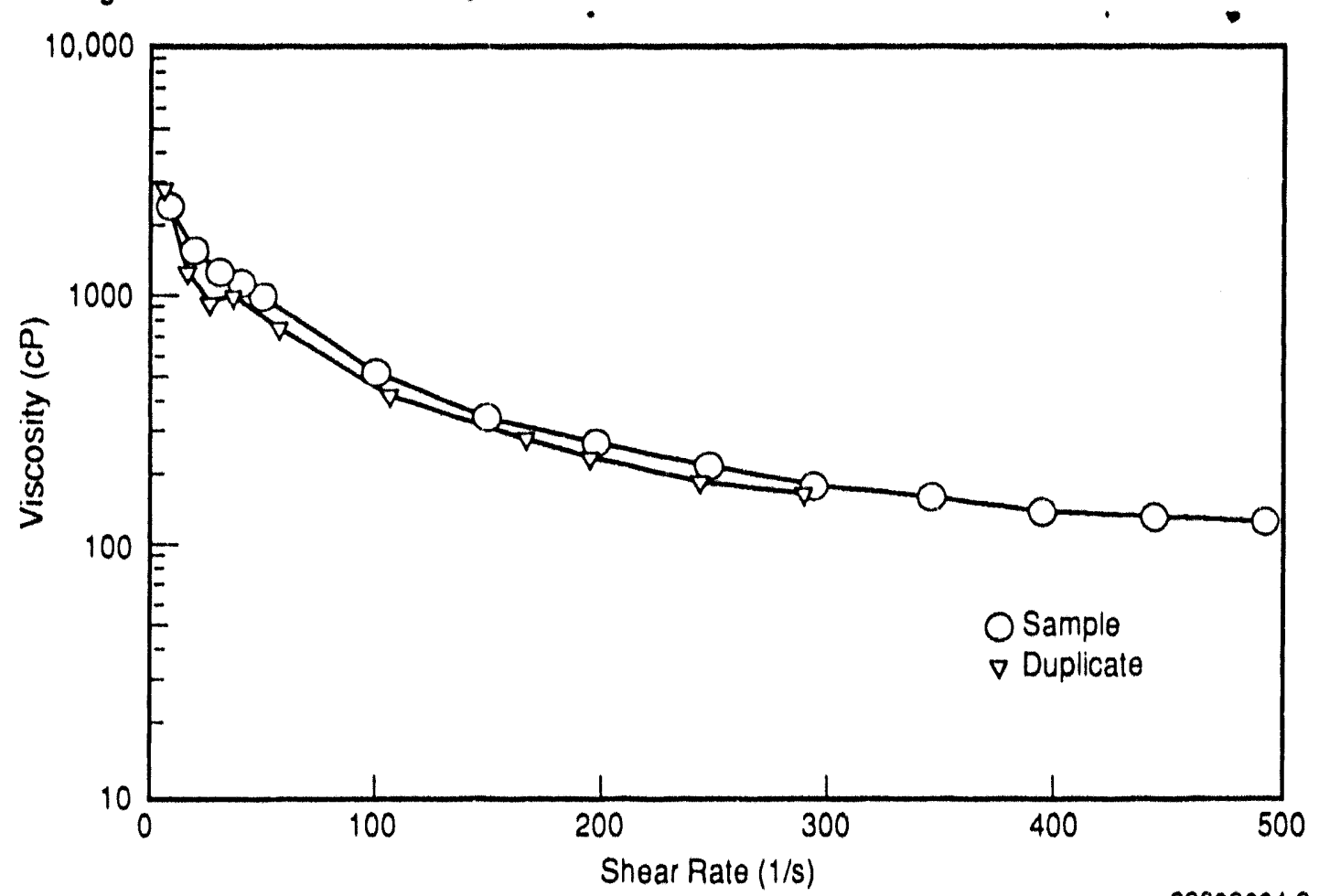


equipment. Characteristics necessary for turbulent flow were calculated for the 1:1 dilution slurry using the parameters determined from measurement and a curve-fitted rheological model (HASM 1993) (refer to Table 5-11).

Table 5-11. Turbulent Flow Model Calculations.

\begin{tabular}{|c|c|c|c|c|c|c|}
\hline Sample & $\begin{array}{c}\text { Temperature } \\
\left({ }^{\circ} \mathrm{C}\right)\end{array}$ & Trial & $\begin{array}{c}\text { Pipe } \\
\text { diameter } \\
(1 \mathrm{n} .)\end{array}$ & $\begin{array}{c}\text { Velocity } \\
(\mathrm{m} / \mathrm{s})\end{array}$ & $\begin{array}{c}\text { Critical } \\
\text { flow rate } \\
(\mathrm{L} / \mathrm{min})\end{array}$ & $\begin{array}{c}\text { Reynolds } \\
\text { number }\end{array}$ \\
\hline $1: 1$ Dllution & $30\left(8^{\circ} \mathrm{F}\right)$ & $\mathrm{S}$ & $2(5.08 \mathrm{~cm})$ & 3.26 & 424 & 12,800 \\
\hline $1: 1$ Dllution & $30\left(8^{\circ} \mathrm{F}\right)$ & $\mathrm{D}$ & $2(5.08 \mathrm{~cm})$ & 3.14 & 405 & 16,900 \\
\hline $1: 1$ Dilution & $30\left(86^{\circ} \mathrm{F}\right)$ & $\mathrm{S}$ & $3(7.62 \mathrm{~cm})$ & 2.90 & 833 & 16,900 \\
\hline $1: 1$ Dilution & $30\left(86^{\circ} \mathrm{F}\right)$ & $\mathrm{D}$ & $3(7.62 \mathrm{~cm})$ & 2.77 & 799 & 14,400 \\
\hline
\end{tabular}

\subsubsection{Particle Size Measurement}

Particle size analysis is performed by placing a small amount of sample in a dispersant, which is the liquid used to disperse and suspend the particles from the solid sample. Samples from all three cores (Cores 47, 48, and 49) were prepared and assayed. The prepared sample was placed in a particle size analyzer. The apparatus measures particle size by passing a thin beam of laser light through the dispersant. The diameter of a particle of matter in the dispersant can be determined by the amount of light that it blocks as the particle passes through the beam. The dimension measured by this method is the value across the short diameter of the particle. This means that if a particle is oblong; the machine estimates the shortest length across the particle (1.e., the width of the oblong shape, not the length). The term "diameter" throughout this text will be used to describe any linear profile of any shape.

An important consideration involving the analysis of particle size is the dispersant used. The primary concern involved with the dispersant is dissolving the particle. Any particles existing in the tank that are soluble in the dispersant will dissolve or decrease in size during the analysis. Depending on the dispersant, the particle size analysis may not represent the true particle size distribution in the tank. In the case of tank 241-C-109, a mixture of water and glycerin was used as the dispersing medium. If a "true" particle size distribution is required, the mother liquor (drainable liquid) of the tank should be used, if possible, because the tank particulates are already in equilibrium with the tank mother liquor. The insolubility of the waste matrix suggests that the particle size data icquired should be acceptable. However, if the ferrocyanide waste has been hydrolyzed by high-pH waste, this assumption may not be completely accurate.

The mean particle size in the number distribution ranges from 0.80 to 1.38 microns in diameter for tank 241-C-109 waste samples. Table 5-12 presents the summary results of the measurements. Plots of the probability number density for each core are presented in Figures 5-7, 5-9, and 5-11 as a number fraction. The number density graph is plotted over the acquisition 
WHC-EP-0668

Figure 5-7. Core 47, Particle Size Number Density.

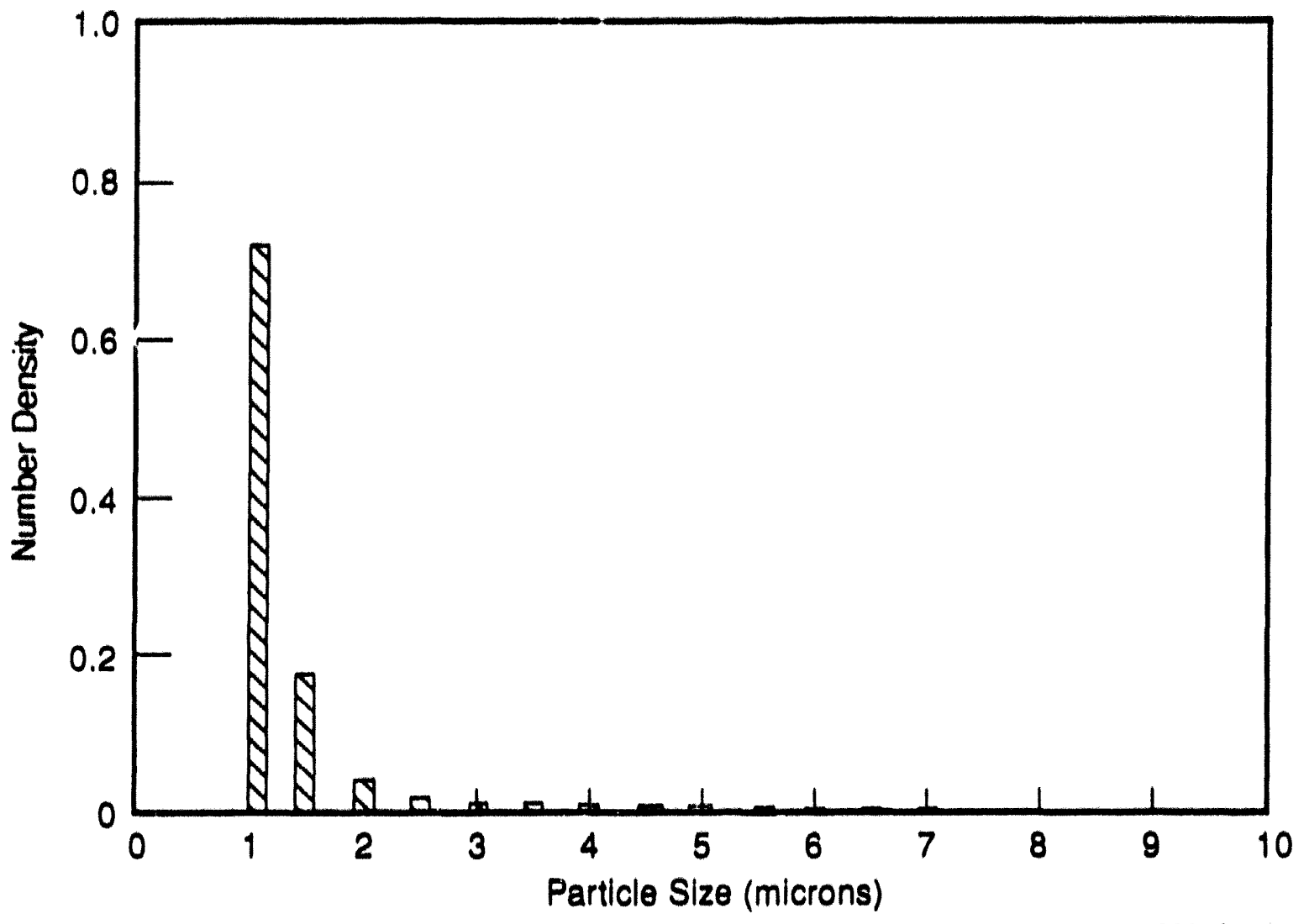

29309004.6 
range of the device (from 0.5 to $150 \mu \mathrm{m}$ ). The numbers of particles in each size range (shown as a percentage of the whole) are graphed agalnst the ir respective size ranges to form a distribution curve. It can be seen from the figures that the most common occurrences (modes) for particle size range between 0.5 and 1.0 microns. The majority (over 88 percent) of the measured particles fit within the narrow band of 0.0 to 2.0 microns.

Table 5-12. Particle Size Distribution by Number: $89 \%<2 \mu \mathrm{m}$ (all cores).

\begin{tabular}{|l|c|c|}
\hline \multicolumn{1}{|c|}{ Sample } & Mean $(\mu \mathrm{m})$ & Medlan $(\mu \mathrm{m})$ \\
\hline Core 47 & 1.14 & 0.85 \\
\hline Core 48 & 0.80 & 0.77 \\
\hline Core 49 & 1.38 & 0.90 \\
\hline
\end{tabular}

The particle size in the volume distribution ranges from $0.0 \mu \mathrm{m}$ to $70 \mu \mathrm{m}$ in diameter between the three cores with relatively wide variation between the means of the these samples $(5.73$ to $37.56 \mu \mathrm{m})$. Table 5-13 presents the summary results of the measurements. Under the assumption that the density of the solid material within the tank is constant, the volume distribution is al so the best estimation of the mass particle size distribution of the tank. The analyzer calculates particle volume as the cube of the diameter. These distributions are presented as figures 5-8, 5-10, and 5-12.

Table 5-13. Particle Size Distribution by Volume: $100 \%<70 \mu \mathrm{m}$ (all cores).

\begin{tabular}{|c|c|c|}
\hline Sample & Mean $(\mu \mathrm{m})$ & Median $(\mu \mathrm{m})$ \\
\hline Core 47 & 37.56 & 38.72 \\
\hline Core 48 & 5.73 & 2.97 \\
\hline Core 49 & 24.47 & 24.08 \\
\hline
\end{tabular}

The volume distribution is represented by a percentage on a probability volume density graph. The average particle size represented in the volume distribution is considerably larger than that in the number distribution. In Core 47 there are relatively few small particles, as most of the particle volume is evenly dispersed within the 0.0 to $70.0 \mu \mathrm{m}$ range. In Core 48 the majority of the particles are much smaller, with particle volumes concentrated in two narrow ranges, the 0.0 to $2.0 \mu \mathrm{m}$ range, and the 9.0 to $20.0 \mu \mathrm{m}$ range. Core 49 is quite similar to core 47 , in that there are relatively few small particles, most of the particles are evenly dispersed within the 10.0 to $60.0 \mu \mathrm{m}$ range.

The disparity between the core sample measurements possibly indicates a difference in waste type. In Core 48, over 50 percent of the volume is contained in particles with a diameter of less than $3 \mu \mathrm{m}$. In the Core 47 and 49 samples over 50 percent of the particle volume is contained in material with a diameter of greater than $20 \mathrm{\mu m}$. In the retrieval and subsequent 
WHC-EP-0668

Figure 5-8. Single-Shell Tank Core 47, Particle Size Volume Density.

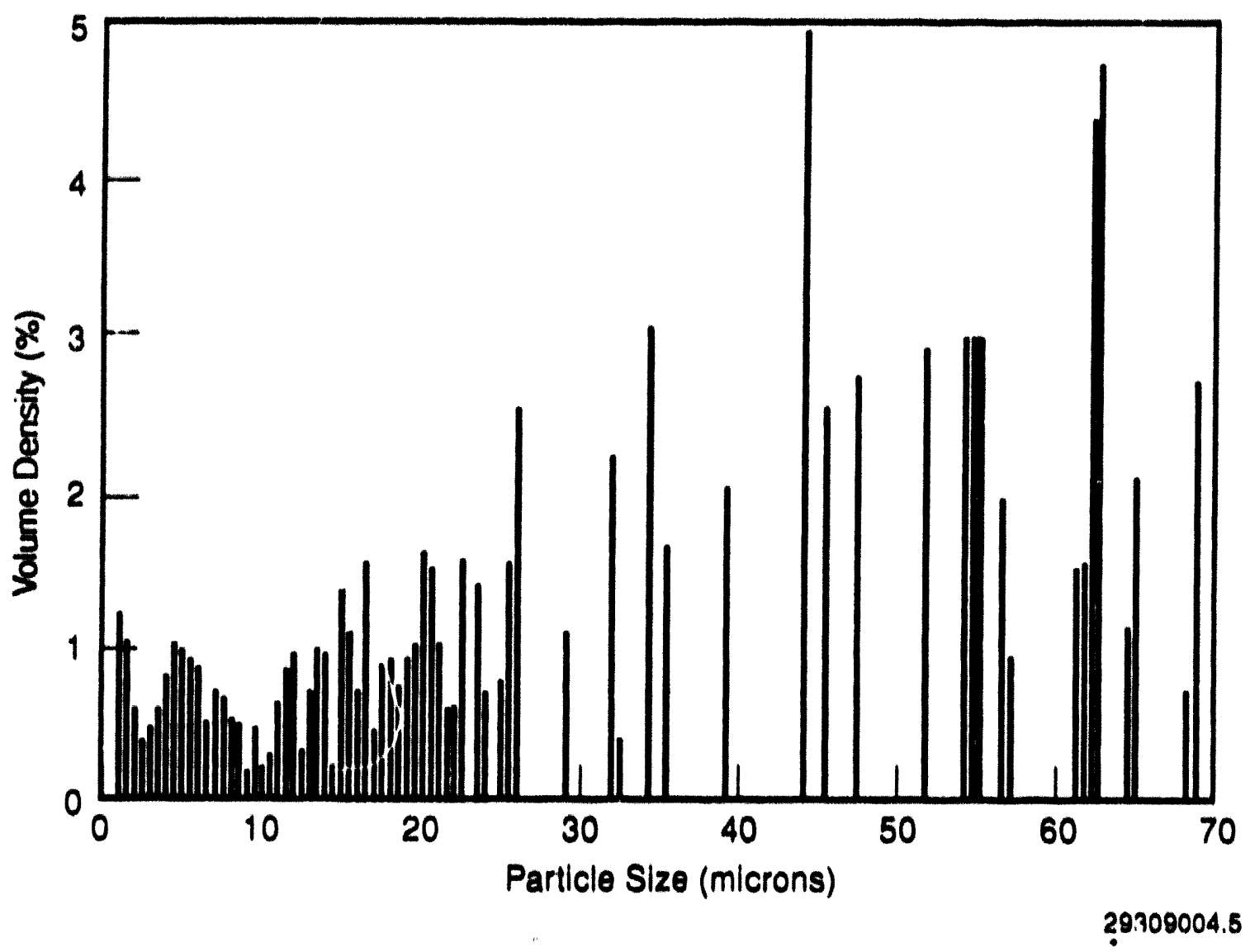


WHC-EP-0668

Figure 5-9. Core 48, Particle Size Number Density.

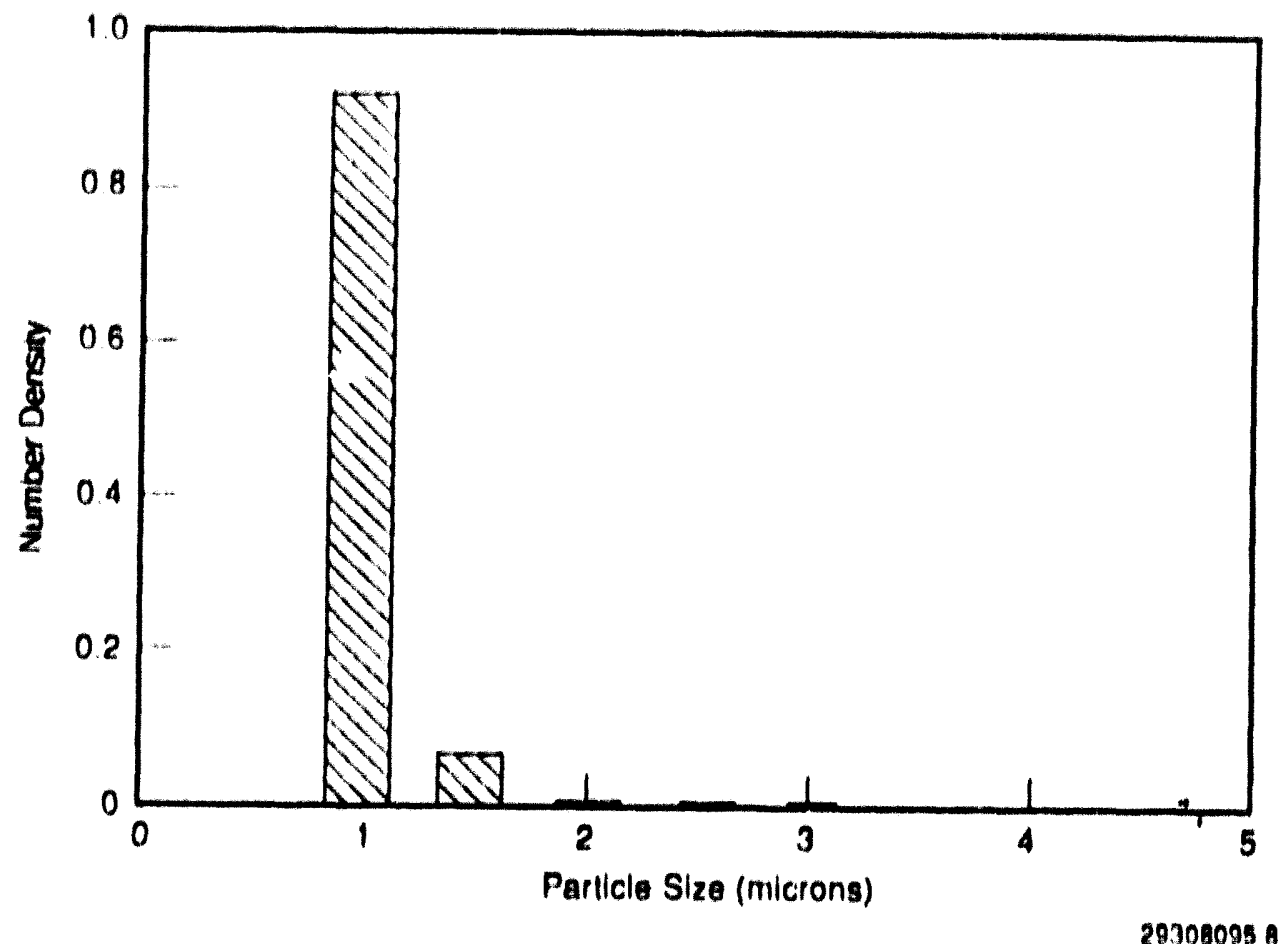

Figure 5-10. Single-Shell Tank Cure 48, Particle Size Volume Density.

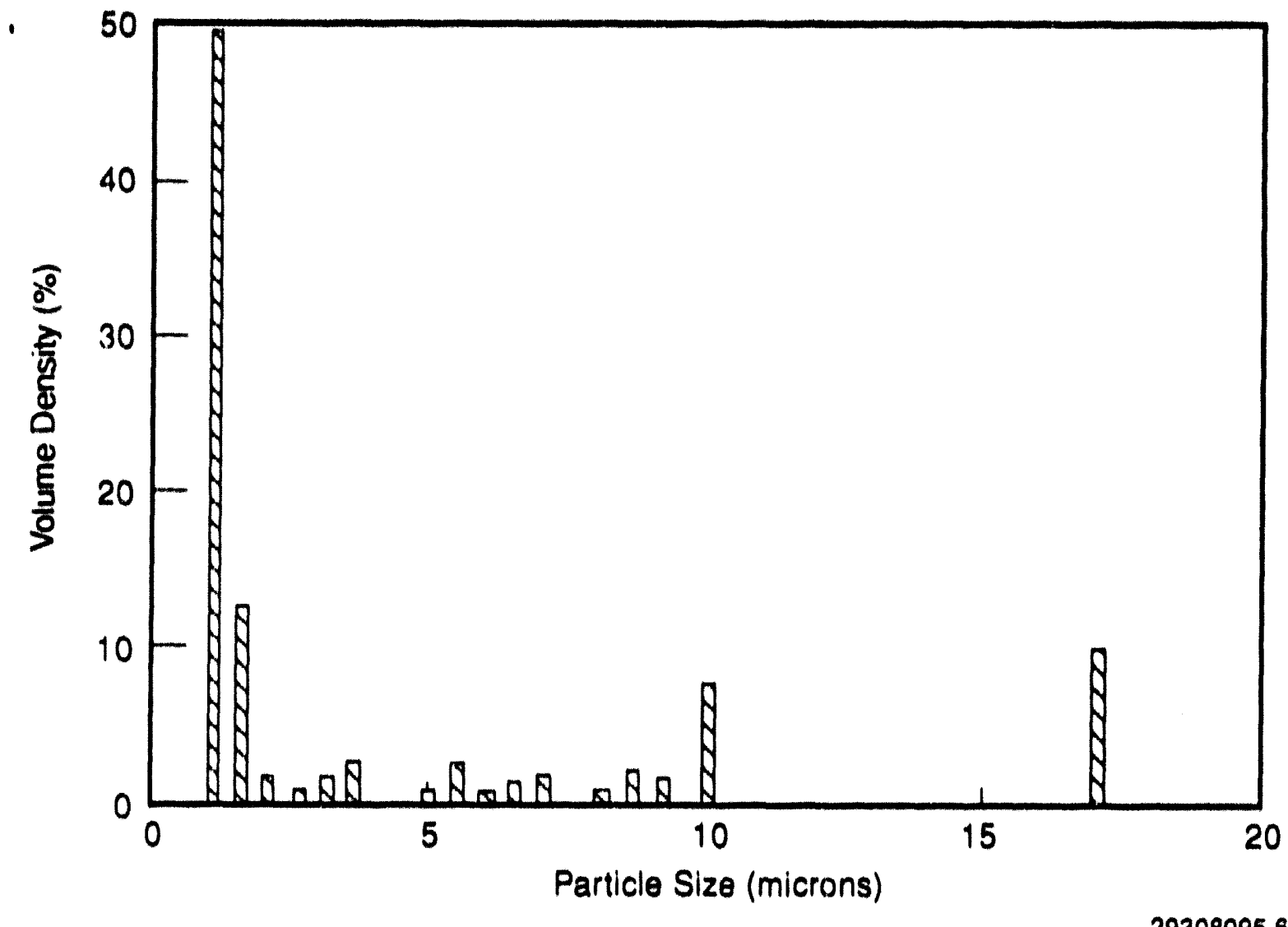


WHC-EP-0668

Figure 5-11. Core 49, Particle Size Number Density.

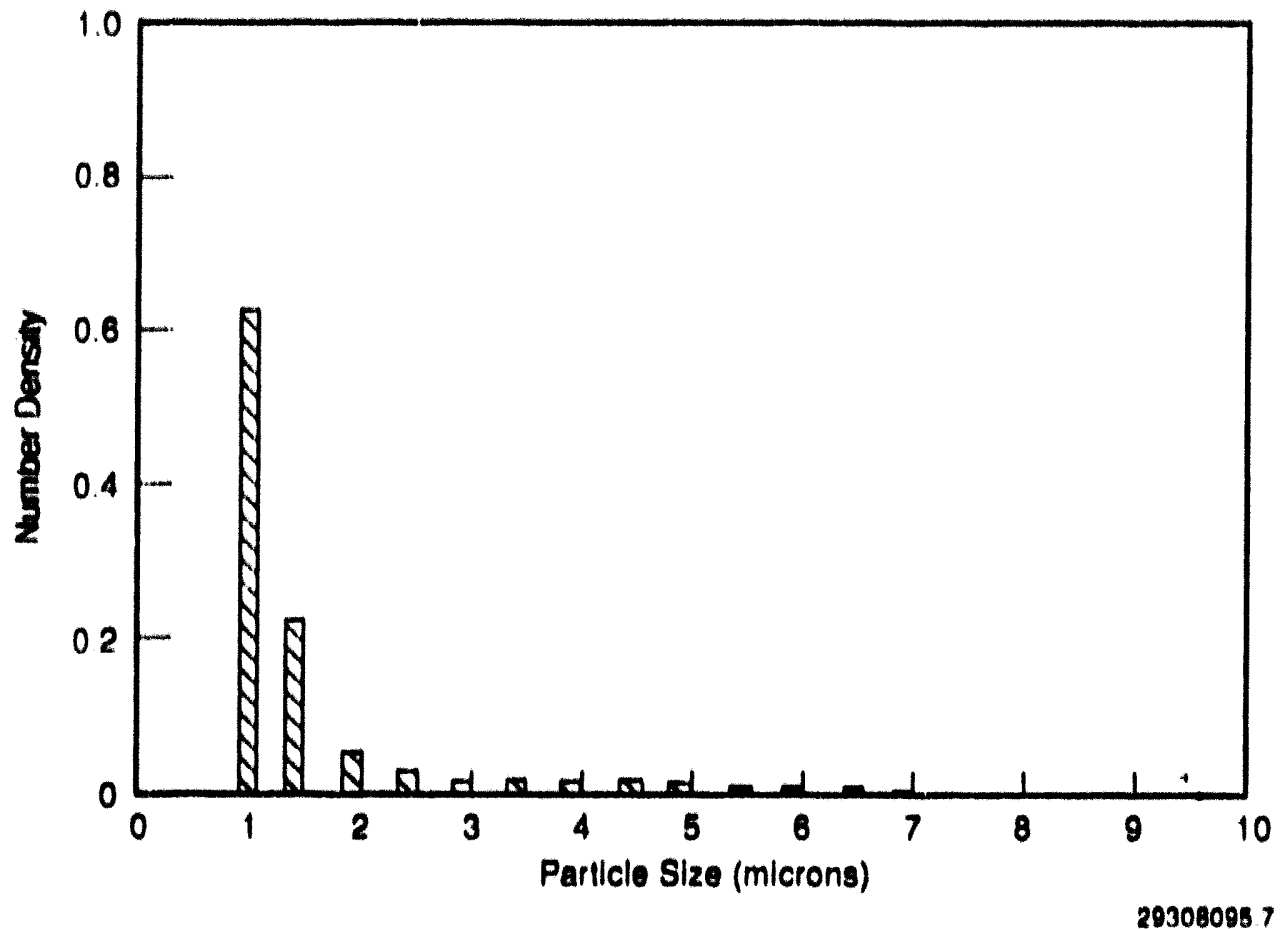

Figure 5-12. Single-Shell Tank Core 49, Particle Size Volume Density.

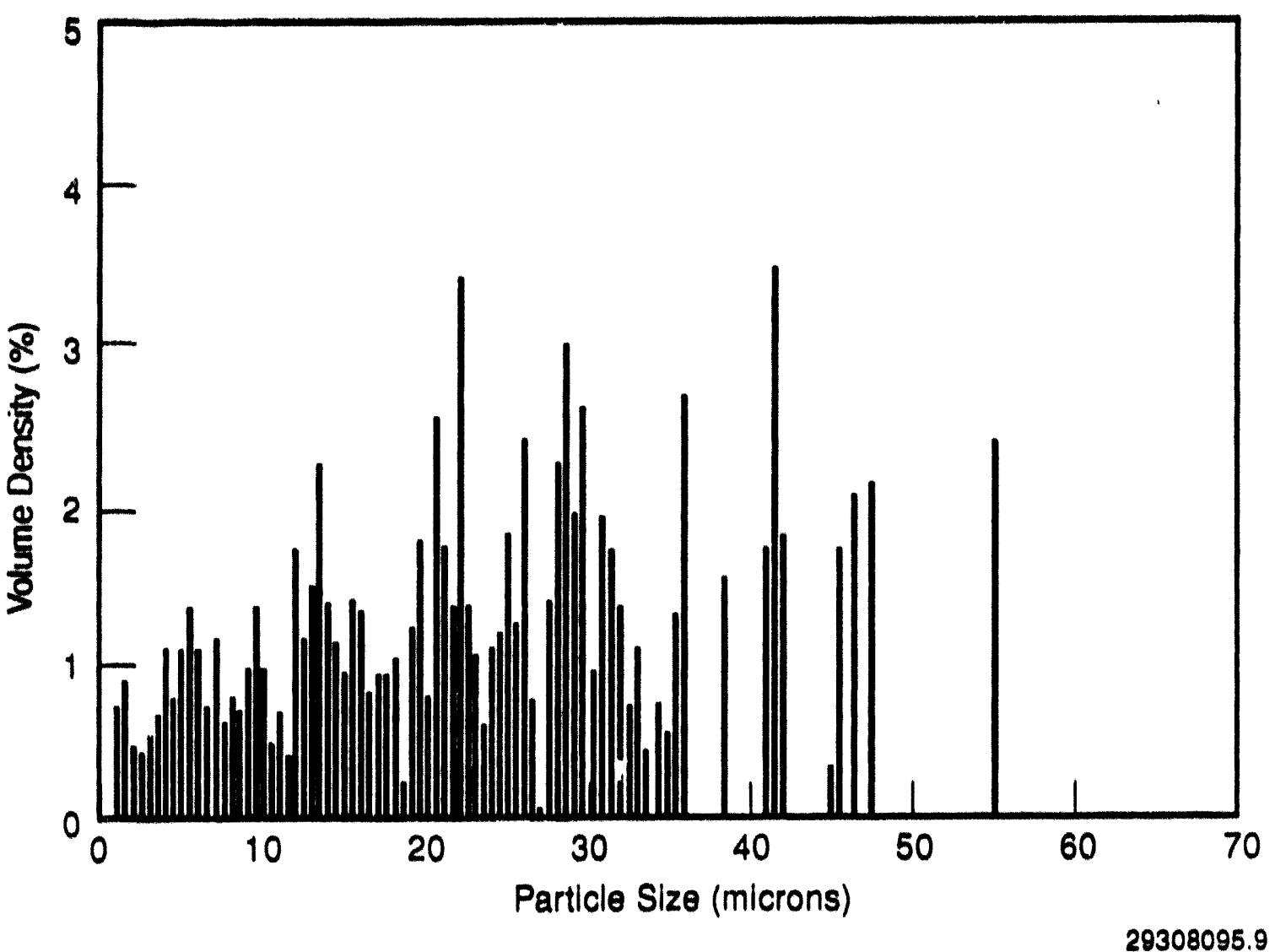


treatment of the tank wastes, it may be destrable to design pumping or flltration systems for the tank particulate. Therefore, the volume distribution of the particles should not be neglected (1.e., particles with diameters of over $20 \mu \mathrm{m}$ should be considered in these designs). In addition, the behavior of the particle size distribution is belleved to have an impact on analytical preciston, especially with small sample sizes and thus should be considered when evaluating analytical results.

\subsubsection{Settling Behavior of As-Recelved and Diluted Samples}

This section analyzes the settling behavior for the as-recelved, $1: 1$, and 3:1 water:sample dilutions. The physical properties reported here include settling rates and volume percent settled sollds, and weight percent and volume percent centrifuged solids. The experimental procedures used to perform these measurements were reported previously (HASM 1993).

The physical properties of the core 47 material and dlluted samples are summarized in Table 5-14.

Table 5-14. Physical Properties Summary.

\begin{tabular}{|c|c|c|c|}
\hline \multirow{2}{*}{ Property } & As-Received & \multicolumn{2}{c|}{ Segment } \\
\cline { 3 - 4 } & & $1: 1$ Dilution & 3:1 \\
Dilution
\end{tabular}

NM - No measurement.

*obtatned from bulk measurements.

Because there was no free liquid with the waste in the sampler, no settling was observed in the as-received segment samples over a period of three days and there was no standing liquid obtained with the samples. Two dilutions (1:1 and $3: 1$ water to sample) were prepared, and the volume percent of settled solids for each of the dilutions are plotted as a function of settling time. Figures 5-13 and 5-14 illustrate the setting behavior over time.

The 1:l dilution reaches a final volume percent settled solids of 88 percent (avg.). Settling cont inues throughout the 3 -day period, but the majority of the settiing is seen in the first 24 hours. The $3: 1$ dilution reaches a final volume percent settled solids of 41 percent (avg.). The majority of the solids settling is complete within 10 hours. 
WHC-EP-0668

Figure 5-13. Settling Rate Data for Tank 241-C-109 core 49, 1:1 Dilution.

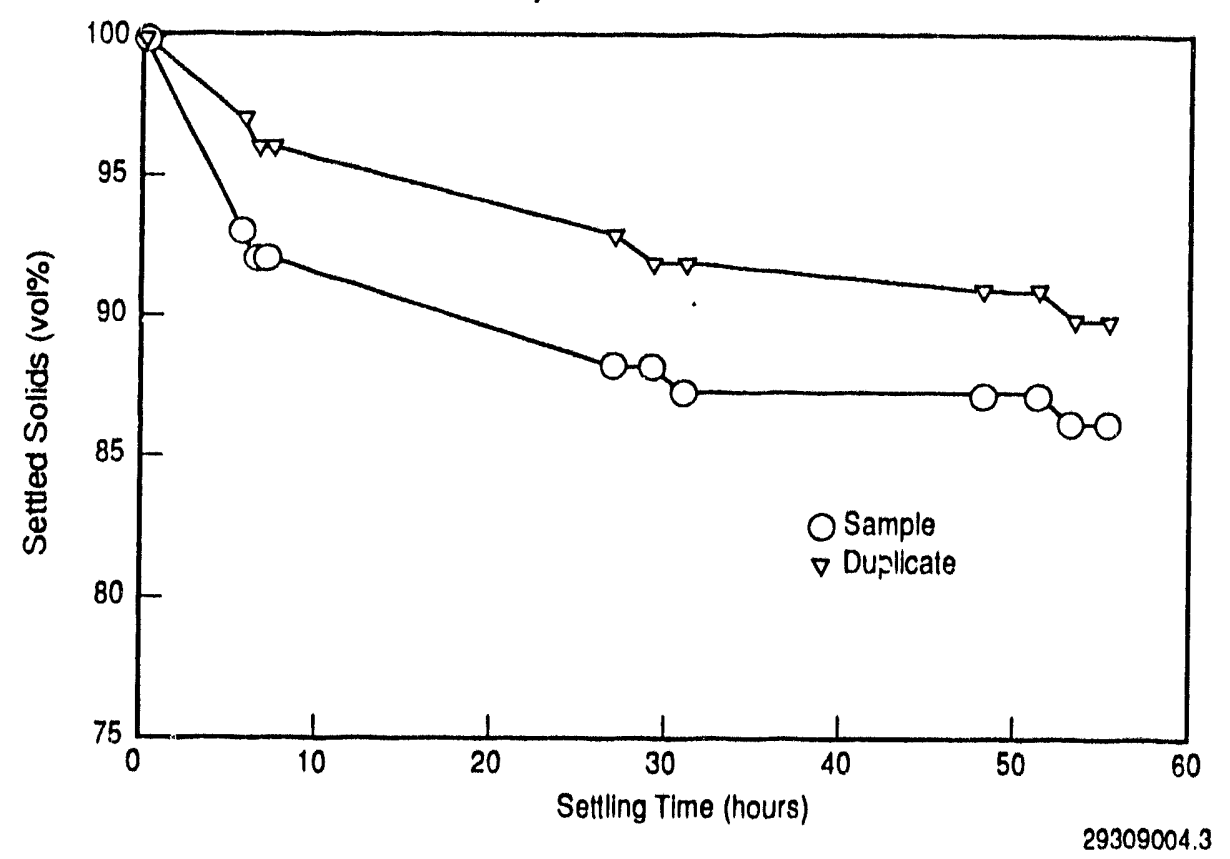

Figure 5-14. Settling Rate Data for Tank 241-C-109 Core 49, 3:1 Dilution.

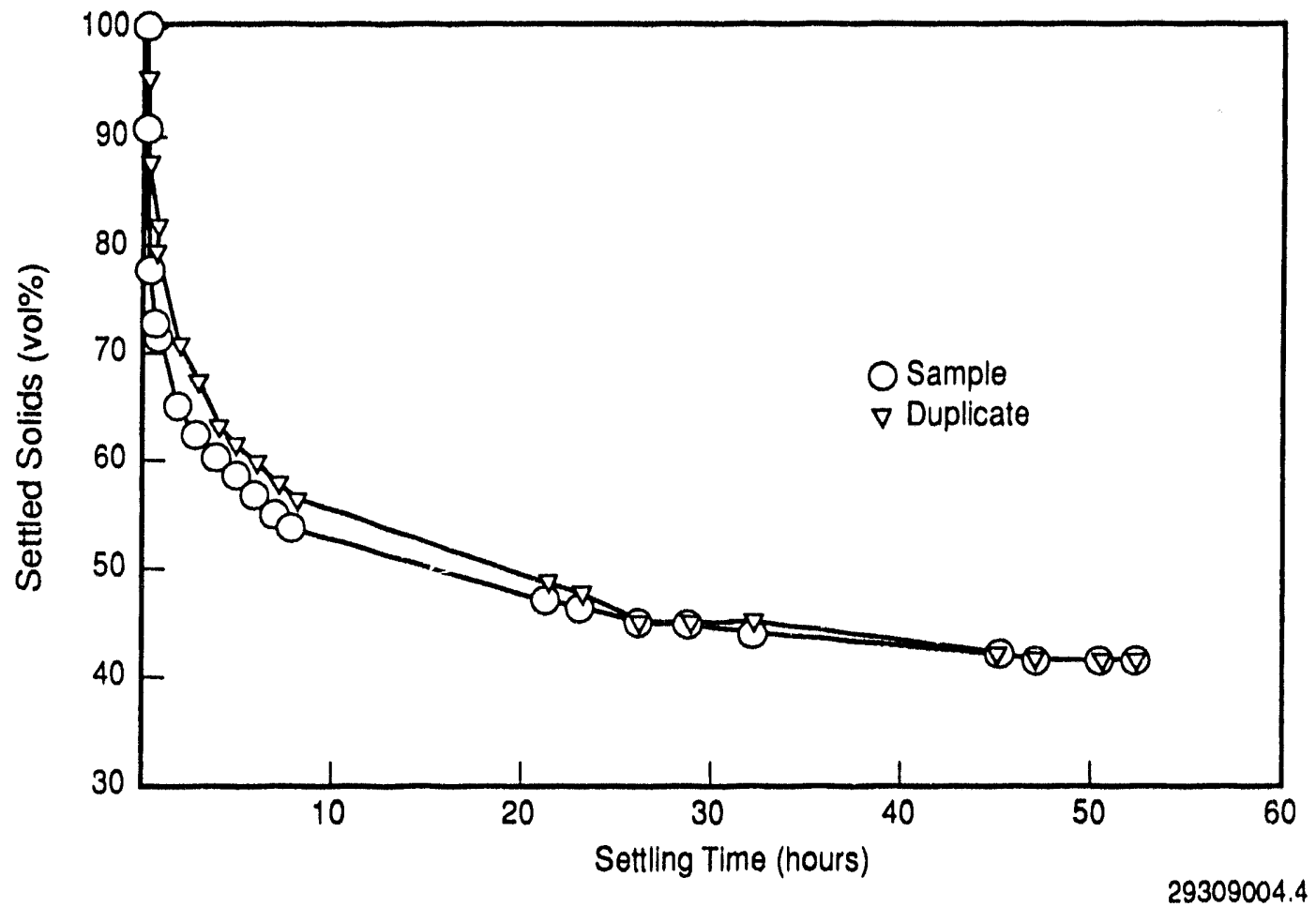




\subsection{ANALYTICAL RESULTS--INDUCTIVELY COUPLED PLASMA- ATOMIC EMISSION SPECTROSCOPY}

\subsubsection{Inductively Coupled Plasma Assays--General Comments}

No online multiple inter-element corrections were performed for matrix interferences. The ICP has built-in correction capability to adjust for moderate matrix interferences. However, this function suffers from significant performance degradation on samples containing weight percent quantities of iron, aluminum, or uranium. Single pass offline corrections were performed to correct for high aluminum, iron, and uranium content in the samples. Corrections for other interfering analytes were done as required. As requested, process blank values have not been subtracted from the reported values (except for quality control results). In the water digestion and liquid composite assays, the single most prevalent element is sodium, by at least an order of magnitude. In the fusion assays, some elements can appear to be at high concentrations because of the large dilution factors required for fusion samples and the complicating factor of the matrix interferences. Those analytes may actually only be present in concentrations marginally above the detection limit. Calcium, selenium, and silicon routinely demonstrated a low bias (i.e., were present at higher concentrations than reported). While selenium is not a major analyte in the waste matrix, calcium and silicon are, and this behavior could marginally affect the interpretation of the results. An estimate of the detection limit for any analyte can be obtained by multiplying the analyte's $\mathrm{JL}$ (detection limit factor, based on dilution) by the appropriate sample " $\mu \mathrm{g} / \mathrm{g}$ factor" found in the data packages. Analytes reported in the data tables are those consistently contributing significant amounts (i.e., generally greater than 0.2 weight \%) to the composition of the waste matrix; average values for the analytes are reported to three significant figures based on two replicates. The full range of ICP analytes can be found in the full data packages (HASM 1993). All reported concentration values are based on grams of wet sample, unless otherwise specified.

Tables 5-15, 5-16, and 5-17 provide ICP analyte concentration information on the core composites as a function of the sample preparation. 
Table 5-15. Water Digestion Chemical Composite Data --ICP Average Values.

\begin{tabular}{|l|c|c|c|c|}
\hline \multicolumn{1}{|c|}{ Analyte } & $\begin{array}{c}\text { Core 47 } \\
(\mu \mathrm{g} / \mathrm{g} \text { sample })\end{array}$ & $\begin{array}{c}\text { Core 48 } \\
(\mu \mathrm{g} / \mathrm{g} \text { samp } \mathrm{e})\end{array}$ & $\begin{array}{c}\text { Core 49 } \\
(\mu \mathrm{g} / \mathrm{g} \text { samp le })\end{array}$ & $\begin{array}{c}\text { Liquid } \\
\text { Composite* }\end{array}$ \\
\hline $\mathrm{Al}$ & 410 & 110 & 105 & 160 \\
\hline $\mathrm{Ca}$ & 180 & 60 & 80 & 210 \\
\hline $\mathrm{Fe}$ & 880 & 1,140 & 920 & 1,680 \\
\hline $\mathrm{Na}$ & 67,800 & 83,500 & 59,900 & 96,900 \\
\hline $\mathrm{Ni}$ & 130 & 30 & 50 & 340 \\
\hline $\mathrm{P}$ & 6,990 & 8,690 & 4,160 & 4,200 \\
\hline $\mathrm{Pb}$ & $<\mathrm{DL}$ & $<\mathrm{DL}$ & $<\mathrm{DL}$ & $<\mathrm{DL}$ \\
\hline $\mathrm{Si}$ & 120 & 200 & 70 & 70 \\
\hline $\mathrm{U}$ & $<\mathrm{DL}$ & $<\mathrm{DL}$ & $\because$ & $<\mathrm{DL}$ \\
\hline
\end{tabular}

*The liquid composite is composed of $11 \mathrm{~mL}$ of liner liquid from

Core 47 and $22 \mathrm{~mL}$ of liner liquid from Core 49 .

$\angle D L=$ below detection limits.

Table 5-16. Acid Digestion Chemical Composite Data --ICP Average Values.

\begin{tabular}{|l|c|c|c|}
\hline Analyte & $\begin{array}{c}\text { Core 47 } \\
(\mu \mathrm{g} / \mathrm{g})\end{array}$ & $\begin{array}{c}\text { Core 48 } \\
(\mu \mathrm{g} / \mathrm{g})\end{array}$ & $\begin{array}{c}\text { Core 49 } \\
(\mu \mathrm{g} / \mathrm{g})\end{array}$ \\
\hline $\mathrm{Al}$ & 72,900 & 6,400 & 83,700 \\
\hline $\mathrm{Ca}$ & 20,000 & 12,600 & 12,300 \\
\hline $\mathrm{Fe}$ & 28,800 & 20,200 & 7,100 \\
\hline $\mathrm{Na}$ & 81,900 & 87,600 & 81,300 \\
\hline $\mathrm{Ni}$ & 14,700 & 15,500 & 11,900 \\
\hline $\mathrm{P}$ & 18,400 & 17,000 & 19,400 \\
\hline $\mathrm{Pb}$ & 8,600 & 610 & 900 \\
\hline $\mathrm{Si}$ & 1,900 & 1,300 & 1,400 \\
\hline $\mathrm{U}$ & 10,700 & 15,000 & 6,300 \\
\hline
\end{tabular}


Table 5-17. Fusion Digestion Chemical Composite Data --ICP Average Values.

\begin{tabular}{|l|c|c|c|}
\hline \multicolumn{1}{|c|}{ Analyte } & $\begin{array}{c}\text { Core 47 } \\
(\mu \mathrm{g} / \mathrm{g})\end{array}$ & $\begin{array}{c}\text { Core } 48 \\
(\mu \mathrm{g} / \mathrm{g})\end{array}$ & $\begin{array}{c}\text { Core } 49 \\
(\mu \mathrm{g} / \mathrm{g})\end{array}$ \\
\hline $\mathrm{Al}$ & 116,800 & 3,600 & 126,600 \\
\hline $\mathrm{Ca}$ & 24,700 & 17,700 & 14,900 \\
\hline $\mathrm{Fe}$ & 21,800 & 22,200 & 9,100 \\
\hline $\mathrm{Na}$ & 87,200 & 100,000 & 76,500 \\
\hline $\mathrm{Ni}{ }^{*}$ & 31,900 & 33,000 & 22,900 \\
\hline $\mathrm{P}$ & 19,900 & 20,200 & 14,600 \\
\hline $\mathrm{Pb}$ & 7,300 & 700 & 820 \\
\hline $\mathrm{Si}$ & 15,800 & 2,200 & 2,300 \\
\hline $\mathrm{U}$ & 9,200 & 24,700 & 4,700 \\
\hline
\end{tabular}

Tables 5-18, 5-19, and 5-20 provide ICP analyte concentrations as a function of depth, f.e., for the subsegments. Subsegment samples labeled "B" are at the top of the tank; samples labeled "C" and "D" are progressively deeper.

Table 5-18. Tank 241-C-109 Core 47 ICP Analyte Trending (Fusion Prep on Subsegments).

\begin{tabular}{|l|c|c|c|c|c|c|c|c|c|}
\hline \multicolumn{1}{|c|}{ Subsegment } & $\begin{array}{c}\mathrm{Al} \\
(\mu \mathrm{g} / \mathrm{g})\end{array}$ & $\begin{array}{c}\mathrm{Cg} \\
(\mu \mathrm{g} / \mathrm{g})\end{array}$ & $\begin{array}{c}\mathrm{Fe} \\
(\mu \mathrm{g} / \mathrm{g})\end{array}$ & $\begin{array}{c}\mathrm{Na} \\
(\mu \mathrm{g} / \mathrm{g})\end{array}$ & $\begin{array}{c}N i * \\
(\mu \mathrm{g} / \mathrm{g})\end{array}$ & $\begin{array}{c}\mathrm{P} \\
(\mu \mathrm{g} / \mathrm{g})\end{array}$ & $\begin{array}{c}\mathrm{Pb} \\
(\mu \mathrm{g} / \mathrm{g})\end{array}$ & $\begin{array}{c}\mathrm{Si} \\
(\mu \mathrm{g} / \mathrm{g})\end{array}$ & $\begin{array}{c}\mathrm{U} \\
(\mu \mathrm{g} / \mathrm{g})\end{array}$ \\
\hline $1 \mathrm{~B}$ & 131,600 & 10,400 & 63,400 & 51,100 & 19,400 & 7,600 & 5,100 & 18,700 & 11,800 \\
\hline $1 \mathrm{C}$ & 120,300 & 18,000 & 20,900 & 63,100 & 22,700 & 12,500 & 2,900 & 6,100 & 6,100 \\
\hline 10 & 32,000 & 28,000 & 15,300 & 102,600 & 25,600 & 30,100 & 14,300 & 22,200 & 5,800 \\
\hline Core Comp. & 116,800 & 24,700 & 21,800 & 87,200 & 31,900 & 19,900 & 7,300 & 15,800 & 9,200 \\
\hline
\end{tabular}

* Nickel concentrations are blased high. Values are derived from ICP fusion performed in a nickel crucible. However, in each case the blank value was an order of magnitude (or greater) less than the measurement. The fusion values are a factor of two greater than the acid digestion values, where both are available. 
Table 5-19. Tank 241-C-109 Core 48 ICP Analyte Trending (Fusion Prep on Subsegments).

\begin{tabular}{|c|c|c|c|c|c|c|c|c|c|}
\hline Subsegment & $\begin{array}{c}A l \\
(\mu g / g)\end{array}$ & $\begin{array}{c}\mathrm{Ca} \\
(\mu g / g)\end{array}$ & $\begin{array}{c}\mathrm{Fe} \\
(\mu g / g)\end{array}$ & $\begin{array}{c}\mathrm{Na} \\
(\mu g / g)\end{array}$ & $\underset{(\mu g / g)}{N / *}$ & $\begin{array}{c}P \\
(\mu g / \theta)\end{array}$ & $\begin{array}{c}P b \\
(\mu g / g)\end{array}$ & $\begin{array}{c}51 \\
(\mu g / \theta)\end{array}$ & $\underset{(\mu \sigma / \theta)}{U}$ \\
\hline 1C & 7,300 & 29,300 & 20,000 & 115,800 & 44,200 & 23,300 & 550 & 2,900 & 16,700 \\
\hline 10 & 9,800 & 16,800 & 21,000 & 102,000 & 24,000 & 20,900 & 690 & 2,200 & 14,400 \\
\hline Core Comp. & 8,600 & 17,700 & 22,200 & 100,000 & 33,300 & 20,200 & 700 & 2,200 & 24,700 \\
\hline
\end{tabular}

Table 5-20. Tank 241-C-109 Core 49 ICP Analyte Trending (Fusion Prep on Subsegments).

\begin{tabular}{|l|c|c|c|c|c|c|c|c|c|}
\hline Subsegment & $\begin{array}{c}\mathrm{Al} \\
(\mu g / g)\end{array}$ & $\begin{array}{c}\mathrm{Ca} \\
(\mu g / g)\end{array}$ & $\begin{array}{c}F \mathrm{e} \\
(\mu g / g)\end{array}$ & $\begin{array}{c}\text { Na } \\
(\mu g / g)\end{array}$ & $\begin{array}{c}N / * \\
(\mu g / g)\end{array}$ & $\begin{array}{c}P \\
(\mu g / g)\end{array}$ & $\begin{array}{c}P b \\
(\mu g / g)\end{array}$ & $\begin{array}{c}S 1 \\
(\mu g / g)\end{array}$ & $\begin{array}{c}U \\
(\mu g / g)\end{array}$ \\
\hline $1 \mathrm{~B}$ & 185,300 & 4,300 & 15,600 & 43,000 & 10,750 & 4,100 & 1,990 & 2,900 & 7,900 \\
\hline $1 \mathrm{C}$ & 95,800 & 18,600 & 4,600 & 62,900 & 31,900 & 11,500 & 370 & 880 & 1,300 \\
\hline 10 & 70,900 & 22,500 & 15,400 & 91,400 & 30,700 & 20,400 & 730 & 1,680 & 12,400 \\
\hline Core Comp & 126,900 & 14,900 & 9,100 & 76,500 & 22,900 & 14,600 & 820 & 2,300 & 4,700 \\
\hline
\end{tabular}

*Nickel concentrations are blased high. Values are derived from ICP fusion performed in a nickel crucible. However, in each case the blank value was an order of magnitude (or greater) less than the measurement. The fusion values are a factor of two greater than the acid digestion values, where both are avallable.

\subsubsection{Liquid Core Composite}

Comparing the results of the ICP assays between the water leach of the core composites $(47,48,49)$ and the liquid composite sample (Table 5-13), the results were found to be somewhat similar. However, because the drainable liquid is composed of liquids assumed to be in equilibrium with material from Cores $47(11 \mathrm{~mL})$ and $49(22 \mathrm{~mL})$ assayed with an acid digestion preparation and that the water leach of the core composites is done at a 100:1 dilution, the similarity is only superficial. The full suite of quality control was performed on the liquid composite sample. While the RPDs were acceptable for all major analytes and percent recovery for the control sample was very good ( 87.9 percent or better); the spike concentration for ferrocyanide, iron, sodium, and nickel was insufficient for percent recovery quantitation.

\section{4 .3 Core 47}

The water leach of the core composite, as noted previously, is similar to the liquid core composite. Major analytes present include sodium and phosphorous, with much lesser amounts of calcium, iron, and nickel. Sodium was approximately one-third less than that measured in the liquid composite, while phosphorous was greater by about one-third. The RPDs were acceptable for all major analytes.

The results from the acid digestion preparation of the core composite samples (Table 5-16) are very good in general for most of the major analytes. Sodium, aluminum, calcium, sodium, nickel, uranium, and phosphorous are all 
WHC-EP-0668

well within acceptable preciston criteria. However, fron, silicon, and lead are all significant contributors to the waste matrix and are outside of the typical 20 percent precision criteria, with the sample showing unexpectedly elevated levels of sllicon and lead. Iron particularly stands out, with an RPD of $\sim 60$ percent. The lower duplicate value $(22,400 \mathrm{ppm})$ agrees well with the fusion results $(20,200 \mathrm{ppm}$ and $23,400 \mathrm{ppm})$. Because most of the other major elements possess relatively good RPDS, which indicates a reasonably homogeneous sample, the anomalous result was attributed to the presence of a particle inclusion (such as rust) in the sample, thus the high iron result should be considered suspect. The lead and silicon results are much higher in core 47 than the other cores; the acid and fusion core composite results for lead are comparable. Recoveries of spike control are generally between 80 percent and 120 percent, except for calcium, selenium, and silicon which demonstrate a low bias. However, the sample spike recoverles for several major and minor analytes indicate that the spiking level is inappropriate.

The results from the fusion preparation core composite and subsegment samples are good. The RPDs are with in acceptable tolerances for all major analytes. Fusion dissolution appears to be necessary to obtain quantitation of aluminum, calcium, sodium, and silicon. Lead, and sliticon remain unusualiy high in this core as compared with the other two cores (concentrations for these analytes are much higher in this core than Cores 48 and 49). Elevated aluminum and silicon values suggest the presence of alumina and silica, but without any other significant changes in the remaining metals, there is no evidence for a refractory-metal-alumina silicate. Nickel also appears to show a high bias (as anticipated from the assay method, using a nickel crucible). The subsegment assays also demonstrate good RPDs for all majcr analytes except for iron throughout (and lead in subsegment 10). Iron routinely demonstrates poor agreement (1.e., RPDs greater than 20 percent) between the sample and the duplicate in this core.

\subsubsection{Core 48}

As noted previously, the water leach of the core composite is generally similar to the liquid core composite (Table 5-15). Major analytes present include sodium and phosphorous, with much lesser amounts of calcium, iron, and nickel. Levels of sodium and iron are very comparable to the liquid composite results. The RPDs were acceptable for all major analytes, except for phosphorous (74.3 percent).

The acid digestion results for the core 48 composite correlate very well with the fusion results (Tables 5-16 and 5-17). The percent differences between the 1-fold and 10-fold dilutions in the duplicate are very close, as was found in core 47 . However, agreement between sample and duplicate for several major analytes (iron, phosphorous, uranium, and calcium) is outside the accepted 20 percent preciston criteria. Furthermore, this may indicate a significant sample inhomogeneity. This behavior was also encountered in sample material obtained from tank 241-C-112. The analyte distribution for this sample is quite different from cores 47 and 49 . The sodium concentration is much higher than aluminum in this sample and the lead and aluminum levels in Core 47 are higher in general by an order of magnitude. 
The sample/duplicate agreement from the fusion preparation core composite and $1 C$ subsegment samples are generally poor (i.e., significantly outside the accepted 20 percent precision criteria). The RPDs are not within acceptable tolerances for several major analytes (aluminum, uranium, and phosphorous in the core composite; iron, sodium, silicon, and phosphorous in the $1 \mathrm{C}$ subsegment). The subsegment 1D assay RPDs are acceptable for all major analytes, except iron. While the good correlation of acid to fusion results indicate that there is little refractory material in this core, fusion dissolution appears to be necessary to obtain quantitation of sodlum, silicon, and uranium. Aluminum content is much lower and uranium is slightly higher than that found in either Core 47 or Core 49. Nickel is again biased high from corrosion of the cruclble during the assay. Lead is low compared to core 47 but comparable to Core 49 . The overall analyte profile appears much more simflar to samples taken from tank 241-C-112 than to the other two cores taken from tank 241-C-109.

\subsubsection{Core 49}

As noted previously, the water leach of the core composite is similar to the liquld core composite. Major analytes present include sodium and phosphorous, with much lesser amounts of calcium, iron, and nickel. Sodium was approximately 40 percent less than that measured in the liquid composite, while phosphorous was about the same. The RPDs were acceptable for all major analytes.

The results from the acid digestion preparation of the core composite samples are consistently poor for all of the major analytes (sodium, aluminum, calclum, sodfum, nickel, iron, siltcon, lead, uranium, and phosphorous). All of these analytes are far outside of the typical 20 percent precision criteria. The large RPDs seen in this sample indicate inhomogenelty and strongly suggest that this sample preparation/assay is not adequate to provide quantitative results for this sample. However, some general trends can be determined by comparison with other cores. Aluminum is high, comparable to Core 47; iron and uranfum concentrations are lower than those in the other two cores; and the lead levels are at the same level as core 48 . The recoveries of the spike control are generally between 80 percent and 120 percent, except for calcium, selenium, and silicon which demonstrate a low bias. However, the sample spike recoveries for several major and minor analytes indicate that the spiking level is inappropriate.

The sample/duplicate agreement from the fusion preparation core composite and subsegment samples are acceptable. The RPDs for the core composites are within established tolerances for all major analytes, except phosphorous. Fusion dissolution appears to be necessary to obtain quantitation of aluminum and silicon. Calclum, lead, and stlicon are much lower in this core as compared with Core 47 (concentrations of these analytes are closer to Core 48). Elevated aluminum and silicon values suggest the presence of alumina and silica, but without any other significant changes in the remaining metals, there is no evidence for a refractory-metal-alumina silicate. Nicke] also appears to show a high bias (again, as anticipated from the assay method, using a nickel crucible). The subsegment assays also demonstrate good RPDs for all major analytes except for iron and calcium (in subsegment 1B). 
WHC-EP-0668

\subsection{ANALYTICAL RESULTS--ANION ASSAYS}

\subsubsection{Ion Chromatography Assays--General Comments}

IC analyses were performed on water-leached samples of the subsegments, core composites, and diluted samples of the liquid composite. Sample blanks indicate no anion contamination from the 325-A hot cell. Because matrix components in some of the samples were found to affect detector performance reversibly during the analysis for free cyanide, a modification to the procedure using pulsed electrode cleaning between sample injections was incorporated to overcome that effect. In addition, the free cyanide assay produced much higher results than those anticipated from the simulant studies. No splke or control standard was used for the free cyanide analysis, as specified in the procedure (Simiele 1991). Therefore, these results may not be representative of the free cyanide in the samples. Quantitation for fluoride (and possibly chloride) was compromised by a co-eluting matrix interference, probably organics of some type. This supposition is supported by the TOC results from the water leach samples. The TOC values, al though not high, are large enough to potentially interfere with fluoride and chloride detection. Further information regarding the IC analytes can be found in the full data packages (HASM 1993).

Table 5-21 shows the concentration of anions for each core composite sample. Similar levels for each of the analytes were found across all three core composites. Tables 5-22, 5-23, and 5-24 provide IC analyte concentrations as a function of depth. Tables 5-25,5-26, and 5-27 provide additional information on other anions (such as total cyanide) as a function of depth. These anions were not determined by the IC method. Reported pH values for the subsegments and core composites are for 1:100 diluted samples; therefore, only the $\mathrm{pH}$ measurement of the liquid composite (direct $\mathrm{pH}$ measurements) is meaningful (Wodrich et a1. 1992). The TOC and total inorganic carbon (TIC) assays are not considered capable of measuring the total cyanide in the waste because they depend on acid dissolutions to perform the analyses.

\subsubsection{Liquid Core Composite}

Except for $F^{*}$, no spike recoveries could be obtained for the anions on the liquid composite because sample concentrations exceeded spike concentrations by a factor of four or more. This behavior indicates various difficulties, such as matrix effects and low spike amounts relative to the sample concentrations. The poor fluoride spike recovery (750 percent) was affected by the low level of the analyte present, the presence of interferences (particularly organic anions), and the low spike levels. All of these factors make interpretation difficult and complicate quantitation of fluoride. Control standard recoveries range from 77 percent to 138 percent for all anions. The results of the liquid composite are consistent to the water-leached core composites and subsegments results, except for nitrate and nitrite. The nitrate and nitrite concentrations are approximately twice as high as those found in the solid samples. Total cyanide found in the sample was found to be unexpectedly high, approximately 5,400 ppm (Table 5-21). 
Currently, there is no established explanation for this behavior. Although the sample was filtered, it is posstbly the result of very small particulates (< $1 \mu \mathrm{m}$ diameter) in suspension in the 1lquid that were not filtered out prior to analysis.

\section{5 .3 Core 47}

There are no splkes directly associated with the core composite material; the splke assoclated with Core $47-18$ is used to verify analytical performance. The RPDs for the sample and duplicate runs for the core composite for each anion were generally excellent ( $<5$ percent), except for phosphate (18 percent), which was still within the 20 percent precision criteria. Spike recoveries ranged between 65 and 121 percent, indicating some minor matrix interferences. Samples exhlbited characteristic poor spike recovery for fluoride ( 65 percent). Control standard recoveries ranged from 81 to 136 percent, indicating that the analysis was in control at the time of the assays. The RPDs for the subsegments were good, generally less than 10 percent, except for chloride and phosphate. However, the phosphate profile for core 47 is very suggestive. The concentration increased significantly as a function of depth, from the 7,100 to $9,600 \mu \mathrm{g} / \mathrm{g}$ range for subsegments $1 B$ and $I C$ (with acceptable RPDs) to the $34,000 \mu \mathrm{g} / \mathrm{g}$ and $55,000 \mu \mathrm{g} / \mathrm{g}$ level for subsegment 10 . Even though the RPD for subsegment 47-10 is high, the results still indicate that the phosphate level is three to seven times higher at the bottom, indicating a different waste type. In addition, this trend is seen for $\mathrm{PO}_{4}^{3 .}$ in Cores 48 and 49 . The general trend observed for all of the anions in this core is increasing concentration from top to bottom.

\subsubsection{Core 48}

There are no spikes directly associated with the core composite material; the spike associated with Core 48-10 is used to verify analytical performance. RPDs for the sample and duplicate runs for the core composite for each anion were generally good (< 15 percent), except for fluoride (138 percent) and phosphate ( 69 percent). This sample generally showed the highest RPDs across all anions, with few exceptions. This poor reproducibility of sample and duplicate is common for inorganic water leach assays on this sample matrix. The sample spike recoveries ranged from 38 percent to 126 percent. The behavior of the fluoride and phosphate spikes was attributed to sample inhomogeneity by the investigator, because 48-10 had high RPDs for these antions. The Core 48 subsegments showed slightly higher concentrations of several analytes than the other cores $\left(\mathrm{NO}_{2}^{-}, \mathrm{NO}_{2}^{\circ}, \mathrm{SO}_{4}^{-2}\right.$, and $\left.\mathrm{Cl}{ }^{\circ}\right)$. Control standard recoveries ranged from 81 percent to 133 percent.

\section{5 .5 Core 49}

There are no spikes directly associated with the core composite material; the RPDs for the sample and duplicate runs for the core composite for each anion were generally good (< 15 percent). Subsegment 49-1C sample spikes were used to verify analytical performance. Sptke recovertes for the antons ranged from 74 percent to 157 percent, indicating some matrix interferences. No 
control standards were run with subsegment 49-1C. The RPDs for the subsegments were very good (< 10 percent) indicating sample homogeneity. Similar analyte proftle behavior to Core 47 is observed, both in general and with regard to phosphate (the $\mathrm{PO}_{4}{ }^{3 \cdot} \mathrm{RPD}$ is better in this case).

Table 5-21. Anton Assays--Composite Data Results.

\begin{tabular}{|c|c|c|c|c|}
\hline Analyte & $\begin{array}{c}\text { Core } 47 \\
(\mu g / g)\end{array}$ & $\begin{array}{c}\text { Core } 48 \\
(\mu g / g)\end{array}$ & $\begin{array}{c}\text { Core } 49 \\
(\mu g / g)\end{array}$ & $\begin{array}{l}\text { Liquid } \\
\text { composite } \\
(\mu g / g)\end{array}$ \\
\hline $\mathrm{NO}_{2}^{-}$ & 39,000 & 45,000 & 39,000 & 71,000 \\
\hline $\mathrm{NO}_{3}^{*}$ & 37,000 & 48,000 & 36,000 & 72,000 \\
\hline $\mathrm{PO}_{4}^{3-}$ & 22,100 & 26,700 & 12,800 & 13,500 \\
\hline $\mathrm{SO}_{4}^{2-}$ & 7,300 & 9,300 & 6,600 & 12,800 \\
\hline $\mathrm{Cl}^{\circ}$ & 700 & 800 & 700 & 1,300 \\
\hline$F^{\circ}$ & 400 & 1,300 & 400 & $<200$ \\
\hline Free $\mathrm{CN}^{\circ}$ & 820 & 1,300 & 550 & 1,340 \\
\hline Total carbon ${ }^{1}$ & 8,000 & 8,700 & 6,700 & 8,800 \\
\hline TOC' & 2,300 & 3,100 & 2,300 & 2,600 \\
\hline$T_{I C^{\prime}}$ & 5,700 & 5,600 & 4,400 & 6,200 \\
\hline Total cyanide & 5,500 & 14,400 & 5,600 & 5,400 \\
\hline$\overline{\mathrm{pH}}$ & 10.75 & 10.08 & 9.37 & $12.08^{3}$ \\
\hline
\end{tabular}

Total carbon, TOC, and TIC are not IC analyses, but are probably present as antons (TOC + TIC - Total carbon). Thus, it seems appropriate to include them with this table.

Total cyanide is not an IC anion. Presently it is a developmental assay; however, the total cyanide assay is important in interpreting the data.

Direct measurement. Free $\left(N^{*}\right)$.

$\mathrm{IC}=$ Ion chromatography $\left(\mathrm{NO}_{2}^{-}, \mathrm{NO}_{3}^{-}, \mathrm{PO}_{4}^{3-}, \mathrm{SO}_{4}^{2-}, \mathrm{Cl}^{\circ}, \mathrm{F}^{\circ}\right.$,

NM - No measurement.

TIC - Total inorganic carbon.

TOC = Total organic carbon.

NOTE: All IC results are obtained from a water leach preparation. 
Table 5-22. Tank 241-C-109 Core 47 IC Analyte Trending.

\begin{tabular}{|c|c|c|c|c|c|c|}
\hline Subsegment & ${ }_{\left(\mu g^{\prime}\right.}^{N_{g}}$ & $\left.{ }_{(\mu \mathrm{g}}^{\mathrm{NO}_{\mathrm{g}}}{ }^{\circ}\right)$ & $\begin{array}{l}\mathrm{PO}_{4}^{3-} \\
(\mu \mathrm{g} / \mathrm{g})\end{array}$ & $\begin{array}{c}\mathrm{SO}_{4}^{2 \cdot} \\
(\mu g / g)\end{array}$ & $\begin{array}{c}\mathrm{Cl}^{\circ} \\
(\mu \mathrm{g} / \mathrm{g})\end{array}$ & $\begin{array}{c}F^{\circ} \\
(\mu g / g)\end{array}$ \\
\hline 18 & 27,900 & 27,600 & 7,300 & 5,100 & 600 & 300 \\
\hline 16 & 37,000 & 36,000 & 9,600 & 7,100 & 700 & 300 \\
\hline 10 & 40,000 & 38,500 & 44,500 & 7,400 & 800 & 300 \\
\hline Core comp. & 39,000 & 37,000 & 22,100 & 7,300 & 700 & 400 \\
\hline
\end{tabular}

Table 5-23. Tank 241-C-109 Core 48 IC Analyte Trending.

\begin{tabular}{|c|c|c|c|c|c|c|}
\hline Subsegment & $\begin{array}{l}\mathrm{NO}_{3}^{*} \\
(\mu \mathrm{g})\end{array}$ & $\begin{array}{c}\mathrm{NO}_{3}^{\circ} \\
(\mu \mathrm{g} / \mathrm{g})\end{array}$ & $\begin{array}{c}\mathrm{PO}_{4}^{3 \cdot} \\
\left(\mu g^{3} / g\right)\end{array}$ & $\begin{array}{c}\mathrm{SO}_{4}^{2-} \\
\left(\mu g^{2-} / g\right)\end{array}$ & $\begin{array}{c}\mathrm{Cl}^{\circ} \\
(\mu g / g)\end{array}$ & $\begin{array}{c}F^{*} \\
(\mu g / g)\end{array}$ \\
\hline 16 & 51,000 & 56,000 & 15,800 & 11,000 & 950 & 500 \\
\hline 10 & 50,000 & 53,500 & 36,000 & 10,000 & 1,000 & 750 \\
\hline Core comp. & 45,000 & 48,000 & 26,700 & 9,300 & 800 & 1,300 \\
\hline
\end{tabular}

Table 5-24. Tank 241-C-109 Core 49 IC Analyte Trending.

\begin{tabular}{|c|c|c|c|c|c|c|}
\hline Subseyment & $\begin{array}{c}\mathrm{NO}_{3}^{\circ} \\
(\mu \mathrm{g} / \mathrm{g})\end{array}$ & $\left.\mathrm{NO}_{\left(\mu{ }^{\circ}\right.}{ }^{\circ}\right)$ & $\begin{array}{l}\mathrm{PO}_{4}^{3 \cdot} \\
(\mu g / g)\end{array}$ & $\begin{array}{c}\mathrm{SO}_{4}^{2-} \\
\left(\mu g^{2-} / g\right)\end{array}$ & $\begin{array}{c}C 1^{\circ} \\
(\mu g / g)\end{array}$ & $\begin{array}{c}F^{\circ} \\
(\mu g / g)\end{array}$ \\
\hline 18 & 26,500 & 25,700 & 6,100 & 4,700 & 500 & $<300$ \\
\hline IC & 44,000 & 42,000 & 8,800 & 8,200 & 800 & 300 \\
\hline 10 & 45,000 & 43,000 & 25,200 & 7,300 & 800 & 1,000 \\
\hline Core comp. & 39,000 & 36,000 & 12,800 & 6,600 & 700 & 400 \\
\hline
\end{tabular}

NOTE: All IC results are obtained from a water leach preparation. 
Table 5-25. Tank 241-C-109 Core 47 Miscellaneous Analyte Trending.

\begin{tabular}{|l|c|c|c|c|c|}
\hline \multicolumn{1}{|c|}{ Subsegment } & $\begin{array}{c}T I C \\
(\mu \mathrm{g} / \mathrm{g})\end{array}$ & $\begin{array}{c}\text { TOC } \\
(\mu \mathrm{g} / \mathrm{g})\end{array}$ & $\begin{array}{c}\text { Free } \mathrm{CN}^{*} \\
(\mu \mathrm{g} / \mathrm{g})\end{array}$ & $\begin{array}{c}\text { Weight\% } \\
\text { Total } \\
\text { Carbon }\end{array}$ & $\mathrm{pH}$ \\
\hline $1 \mathrm{~B}$ & 5,400 & 2,200 & 570 & 0.76 & 8.82 \\
\hline $1 \mathrm{C}$ & 5,200 & 2,000 & 830 & 0.72 & 9.65 \\
\hline 10 & 5,400 & 2,200 & 910 & 0.76 & 10.21 \\
\hline Core comp. & 5,700 & 2,300 & 820 & 0.80 & 10.75 \\
\hline $\begin{array}{l}\text { Direct } \\
\text { (Core comp.) }\end{array}$ & 5,800 & 3,200 & $\mathrm{NA}$ & 0.90 & $\mathrm{NA}$ \\
\hline
\end{tabular}

Table 5-26. Tank 241-C-109 Core 48 Miscellaneous Analyte Trending.

\begin{tabular}{|l|c|c|c|c|c|}
\hline \multicolumn{1}{|c|}{ Subsegment } & $\begin{array}{c}\mathrm{TIC} \\
(\mu \mathrm{g} / \mathrm{g})\end{array}$ & $\begin{array}{c}\mathrm{TOC} \\
(\mu \mathrm{g} / \mathrm{g})\end{array}$ & $\begin{array}{c}\text { Free } \mathrm{CN}^{-} \\
(\mu \mathrm{g} / \mathrm{g})\end{array}$ & $\begin{array}{c}\text { Weight\% } \\
\text { Total } \\
\text { Carbon }\end{array}$ & $\mathrm{pH}$ \\
\hline $1 \mathrm{C}$ & 8,700 & 3,700 & 1,500 & 1.3 & 9.69 \\
\hline 10 & 7,500 & 3,500 & 1,400 & 1.1 & 10.99 \\
\hline Core comp. & 5,600 & 3,100 & 1,300 & 0.87 & 10.08 \\
\hline $\begin{array}{l}\text { Direct } \\
\text { (Core comp.) }\end{array}$ & 5,200 & 3,000 & Not appllcable & 0.72 & Not appl Icable \\
\hline
\end{tabular}

NA - Not applicable.

TIC = Total inorganic carbon.

TOC - Total organic carbon.

Direct - Measurement on a sample with little or no prior sample preparation. 
Table 5-27. Tank 241-C-109 Core 49 Miscellaneous Analyte Trending.

\begin{tabular}{|l|c|c|c|c|c|}
\hline Subsegment & $\begin{array}{c}\text { TIC } \\
(\mu \mathrm{g} / \mathrm{g})\end{array}$ & $\begin{array}{c}\text { TOC } \\
(\mu \mathrm{g} / \mathrm{g})\end{array}$ & $\begin{array}{c}\text { Free } \mathrm{CN} \\
(\mu \mathrm{g} / \mathrm{g})\end{array}$ & $\begin{array}{c}\text { Weight\% } \\
\text { Total Carbon }\end{array}$ & $\mathrm{pH}$ \\
\hline $1 \mathrm{~B}$ & 3,900 & 1,800 & 370 & 0.57 & 10.22 \\
\hline $1 \mathrm{C}$ & 6,600 & 2,200 & 650 & 0.88 & 10.53 \\
\hline 10 & 6,800 & 2,600 & 720 & 0.94 & 10.95 \\
\hline Core comp. & 4,400 & 2,300 & 550 & 0.67 & 9.37 \\
\hline $\begin{array}{l}\text { Direct } \\
\text { (Core comp.) }\end{array}$ & 2,500 & 5,400 & NA & 0.79 & NA \\
\hline
\end{tabular}

NA - Not applicable.

TIC - Total inorganic carbon.

TOC - Total organic carbon.

Direct - Measurement on a sample with little or no prlor sample preparation.

\subsection{ANALYTICAL RESULTS--RADIOCHEMISTRY}

\subsubsection{Radfochemistry Assays--General Comments}

Analyses appear to be consistent. Total beta measurements calculated using ${ }^{\circ} \mathrm{Sr}$ detector effictencles are largely in agreement with the sum of the major beta emitters, ${ }^{90} \mathrm{Sry}$ and ${ }^{137} \mathrm{Cs}$. Similarly, the total alpha values show good agreement with the sum of the neptunium, plutonium, and americium/curium values. Detection of ${ }^{137} \mathrm{Cs}$ and most other radionuclides was observed to be a function of sample preparation. This was attributed to the abllity of the sample preparation to dissolve the waste (KOH fusion dissolves the sample better than acid; acid dissolves the sample better than water). The GEA measurements are too low to show good agreement with alpha energy analysis for $241 \mathrm{Am}$. The GEA analytical values are back-corrected to January 1, 1992, to account for decay.

\subsubsection{Gamma Energy Analysis Results}

The GEA data from the replicate samples of the core composites and subsegments prepared by caustic fusion agree reasonably well ( 110 percent), with the exception of subsegment $49-1 \mathrm{C}$. In general, the ${ }^{137} \mathrm{Cs}$ content is lowest in the 18 subsegments and highest in the 10 subsegments following the general trend observed for several analytes in this core (calcium, sodium, nickel, and $\left.\mathrm{PO}_{4}{ }^{3}\right)$, increasing concentration from top to bottom. This behavior indicates that the ${ }^{33} \mathrm{Cs}$ is concentrated in the lower portion of the cores (and by extension, the tank). In addition, the total CN results directly trend the ${ }^{\$ 37} \mathrm{Cs}$ concentrations (1.e., high total $\mathrm{CN}^{\circ}$ - high ${ }^{137} \mathrm{Cs}$ measurement). The ${ }^{154} \mathrm{Eu},{ }^{55} \mathrm{Eu}$, and ${ }^{24} \mathrm{Am}$ content is above the detection 1 imits only in the $1 B$ subsegments, indicating that these isotopes are in the upper waste levels of Cores 47 and 49 . The GEA agreement between the sample and the 
duplicates for the acld digestion core composites was not as good as that from the fuston sapples ( \pm 20 percent). Water leach and liquid core composite results for ${ }^{3} C s$ and total beta are two orders of magnitude lower than those obtained from fuston assays, Indicating that the fission products are very insoluble. Agreement between the same top and bottom allquots in the homogenization chack samples (prepared by acid digestion) were not good, and differed in some cases by actor of six. which indicates sample inhomogenefty or resistance to dissolution. The agreement in the homogenization check samples prepared by fuston was acceptable in each case.

\subsubsection{Total Alpha Analysis and Urantum Assay}

Total alpha, plutonium, and ${ }^{261}$ Am analyses were performed on the fuston samples of the core composttes and the direct flitered liquid composite. Total alpha measurements were also performed on the homogen ization check samples from subsegments $48-10$ and $49-10$ and the water leach samples from all three cores. The total alpha activity was obtained by drying a small aliquot of fuston-prepared sample on a counting plate and determined using a scintillation detector. The plutontum and americium fractions were separated by solvent extraction or fon exchange and similarly counted.

The plutionium analyses are reported as total alpha plutonium. The process blank was two to three orders of magnitude lower that the samples, indicating littie contamination occurred during sample preparation. Because of the low total alpha concentration for the liquid composite, no speciflc nuclide analyses were performed. The total alpha concentration tends to be somewhat lower than the sum of the individual alpha emitters; the difference is 11kely because of absorption by the salt residue on the counting mounts. Isotoplc resolution of the simples was obtained from thermal 1onization mass spectroscopy. Because the $20 \mathrm{pu}$ concentration was low and the $20 \mathrm{U}$ concentration was relatively high in the core compogites, the uranium contamination interfered with the determination of $20 \mathrm{Pu}$, thus that plutonium isotope was determined from alpha energy analysis. The variation in the plutonium isotopic composition is noteworthy, espectally for $260 \mathrm{Pu}$. Sample and duplicate analyses are generally within acceptable ilimits.

Uranium measurements were obtained from ICP fusion and laser fluorimetry of the three core composites and the llquid composite core. The assays show good agreement between duplicates, and reasonably good agreement between all three cores for both assays. Core 48 again demonstrated the highest RPD (18 percent). The liquid composite had a much lower uranium content than any of the solid core composites. This result is not surprising; because of the alkaline environment of the tanks, the uranium is likely a highly insoluble precipitate. The urantum content varies by a factor of four between the three cores, with Core 48 having the highest concentration and Core 49 having the lowest. There is no observable general trend of the uranium concentration as a function of depth.

\subsubsection{Total Beta}

Total beta, ${ }^{90} \mathrm{Sr}$, and ${ }^{90} \mathrm{TC}$ analyses were performed on the water leach and fuston samples of the core composites and the direct filtered liquid 
compnsite. Strontium-90 measurements were also performed on the fusion prepared samples from 211 of the subsegments. The total beta activity was determined by drying a small aliquot of prepared sample on a beta proportional counter. The ${ }^{90} \mathrm{Sr}$ and ${ }^{99} \mathrm{Tc}$ fractions were separated by solvent extraction or ion exchange and similarly counted. There are generally acceptable levels of agreement between replicates. Preparation blank beta activities for these samples are orders of magnitude lower than the levels found in the samples, again indicating little contamination from preparation in the hot cell.

Most of the beta activity in the tank liquid composite and water leaches of the solid core composites is from ${ }^{139} \mathrm{Cs}$, except for the core 49 water leach composite sample, where ${ }^{90} \mathrm{Sry}$ is the dominant beta emitter. The $90 \mathrm{sr}$ data is consistent between the fusion core composite values and the subsegments from that core. The ${ }^{90} \mathrm{Sr}$ content is much higher in subsegments $47-1 \mathrm{~B}$ and $49-1 \mathrm{~B}$ the in the lower cores, and the general trend of the ${ }^{90} \mathrm{Sr}$ concentration is lower as a function of depth.

Tables 5-28, 5-29, 5-30,5-31, 5-32, 5-33, and 5-34 show the radionuclide concentrations found in the core composite samples. Tables 5-35, 5-36, and 5-37 show fission product concentration and uranium concentrations as a function of depth.

Table 5-28. Core Composite Fission Products (Fusion Prep).

\begin{tabular}{|l|c|c|c|c|c|c|}
\hline Core No. & $\begin{array}{c}{ }^{137} \mathrm{Cs} \\
(\mu \mathrm{Ci} / \mathrm{g})\end{array}$ & $\begin{array}{c}{ }^{90} \mathrm{Sr} \\
(\mu \mathrm{Ci} / \mathrm{g})\end{array}$ & $\begin{array}{c}{ }^{154} \mathrm{Eu} \\
(\mu \mathrm{Ci} / \mathrm{g})\end{array}$ & $\begin{array}{c}{ }^{155} \mathrm{Eu} \\
(\mu \mathrm{Ci} / \mathrm{g})\end{array}$ & $\begin{array}{c}{ }^{60} \mathrm{Co} \\
(\mu \mathrm{Ci} / \mathrm{g})\end{array}$ & $\begin{array}{c}\text { Total } \\
\text { beta } \\
(\mu \mathrm{Ci} / \mathrm{g})\end{array}$ \\
\hline Core 47 & 870 & $:, 180$ & $<0.24$ & $<0.86$ & $<1.4 \mathrm{E}-02$ & 2,750 \\
\hline Core 48 & 1,030 & 190 & $<0.73$ & $<1.20$ & $<2.7 \mathrm{E}-02$ & 1,300 \\
\hline Core 49 & 560 & 930 & 0.36 & $<0.52$ & $<1.4 \mathrm{E}-02$ & 2,300 \\
\hline
\end{tabular}

Table 5-29. Liquid Core Composite Fission Products (Acid Prep).

\begin{tabular}{|l|c|c|c|c|c|c|}
\hline Core No. & $\begin{array}{c}{ }^{137} \mathrm{CS} \\
(\mu \mathrm{Ci} / \mathrm{g})\end{array}$ & $\begin{array}{c}{ }^{90} \mathrm{Sr} \\
(\mu \mathrm{Ci} / \mathrm{g})\end{array}$ & $\begin{array}{c}{ }^{154} \mathrm{Eu} \\
(\mu \mathrm{Ci} / \mathrm{g})\end{array}$ & $\begin{array}{c}{ }^{155} \mathrm{Eu} \\
(\mu \mathrm{Ci} / \mathrm{g})\end{array}$ & $\begin{array}{c}{ }^{60} \mathrm{Co} \\
(\mu \mathrm{Ci} / \mathrm{g})\end{array}$ & $\begin{array}{c}\text { Total } \\
\text { beta } \\
(\mu \mathrm{Ci} / \mathrm{g})\end{array}$ \\
\hline $\begin{array}{l}\text { Liquid } \\
\text { composite }\end{array}$ & 5.61 & $9.9 \mathrm{E}-02$ & $<3.0 \mathrm{E}-04$ & $<2.4 \mathrm{E}-03$ & $1.46 \mathrm{E}-03$ & 5.43 \\
\hline
\end{tabular}


Table 5-30. Core Composite Uranium.

\begin{tabular}{|l|c|c|c|c|}
\hline \multicolumn{1}{|c|}{ Core No. } & $U_{1 \text { icp fusion }}(\mu \mathrm{g} / \mathrm{g})$ & $\begin{array}{c}U_{\mathrm{F}} \\
(\mu \mathrm{g} / \mathrm{g})\end{array}$ & $\begin{array}{c}{ }^{238} \mathrm{U} \\
\text { Mass } \\
\text { fraction }\end{array}$ & $\begin{array}{c}\text { Mass } \\
\text { fraction }\end{array}$ \\
\hline Liquid composite & $<\mathrm{DL}$ & 3.7 & $\mathrm{NM}$ & $\mathrm{NM}$ \\
\hline Core 47 & 9,200 & 12,000 & 0.993263 & 0.006573 \\
\hline Core 48 & 24,700 & 27,600 & 0.993038 & 0.006852 \\
\hline Core 49 & 4,700 & 7,500 & 0.993109 & 0.006753 \\
\hline
\end{tabular}

$<D L=$ Below detection limits.

$F L=$ Uranium measurement by laser fluorimetry.

low.

$N M=$ No isotopic measurement on liquid composite, concentration too

Table 5-31. Core Composite Trace Radionuclides.

\begin{tabular}{|l|c|c|c|}
\hline \multicolumn{1}{|c|}{ Core No. } & $\begin{array}{c}{ }^{99} \mathrm{TC} \\
(\mu \mathrm{Ci} / \mathrm{g})\end{array}$ & $\begin{array}{c}{ }^{3} \mathrm{H} * \star \\
(\mu \mathrm{Ci} / \mathrm{g})\end{array}$ & $\begin{array}{c}{ }^{14} \mathrm{C} \\
(\mu \mathrm{Ci} / \mathrm{g})\end{array}$ \\
\hline Liquid composite* & $1.6 \mathrm{E}-01$ & $3.0 \mathrm{E}-03$ & $2.3 \mathrm{E}-03$ \\
\hline Core 47 & $1.1 \mathrm{E}-011^{\star \star *}$ & $8.5 \mathrm{E}-03$ & $6.3 \mathrm{E}-06$ \\
\hline Core 48 & $1.2 \mathrm{E}-01 * \star \star$ & $6.4 \mathrm{E}-03$ & $1.8 \mathrm{E}-05$ \\
\hline Core 49 & $9.4 \mathrm{E}-02 \star \star \star$ & $6.4 \mathrm{E}-03$ & $3.6 \mathrm{E}-05$ \\
\hline
\end{tabular}

* Liquid composite results obtained from acid digestion. $\star *^{3} \mathrm{H}$ values are biased high from contamination in the hot cell (blank levels ranged from 3.9 E-03 to $6.7 \mathrm{E}-03$ ). $\star \star{ }^{99} \mathrm{Tc}$ core composite values obtained from caustic fusion assay; ${ }^{3} \mathrm{H}$ and ${ }^{14} \mathrm{C}$ values obtained from water digestion.

Table 5-32. Plutonium Concentration and Isotopic Distribution.

\begin{tabular}{|c|c|c|c|c|c|c|}
\hline $\begin{array}{c}\text { Core } \\
\text { No. }\end{array}$ & $\begin{array}{c}\text { Total } \\
\text { plutonium } \\
\alpha \text { activity } \\
(\mu \mathrm{C} / \mathrm{g})\end{array}$ & $\begin{array}{c}238 \mathrm{Pu} \text { Mass } \\
\text { fraction }\end{array}$ & $\begin{array}{c}{ }^{239} \mathrm{Pu} \text { Mass } \\
\text { fraction }\end{array}$ & $\begin{array}{c}{ }^{240} \mathrm{Pu} \text { Mass } \\
\text { fraction }\end{array}$ & $\begin{array}{c}241 \mathrm{Pu} \text { Mass } \\
\text { fraction }\end{array}$ & $\begin{array}{c}242 \mathrm{Pu} \text { Mass } \\
\text { fraction }\end{array}$ \\
\hline Core 47 & 0.88 & 0.00005 & 0.932237 & 0.066256 & 0.001216 & 0.000241 \\
\hline Core 48 & 0.065 & $0.000: 1$ & 0.976356 & 0.022995 & 0.000364 & 0.000176 \\
\hline Core 49 & 0.079 & 0.00014 & 0.949629 & 0.048786 & 0.001119 & 0.000329 \\
\hline
\end{tabular}

No $P$, measurement on liquid composite, concentration too low. 
Table 5-33. Core Composite Transuranics (fusion preparation).

\begin{tabular}{|c|c|c|c|c|c|c|c|}
\hline $\begin{array}{c}\text { Core } \\
\text { No. }\end{array}$ & $\begin{array}{c}{ }^{237} \mathrm{~Np} \\
(\mu \mathrm{Ci} / \mathrm{g})\end{array}$ & $\begin{array}{c}{ }^{238} \mathrm{Pu}^{*} \\
(\mu \mathrm{Ci} / \mathrm{g})\end{array}$ & $\begin{array}{c}{ }^{239} \mathrm{Pu}^{*} \\
(\mu \mathrm{Ci} / \mathrm{g})\end{array}$ & $\begin{array}{c}{ }^{241} \mathrm{Am}_{\mathrm{GEA}} \\
(\mu \mathrm{Ci} / \mathrm{g})\end{array}$ & $\begin{array}{c}{ }^{241} \mathrm{Am}_{\mathrm{AEA}} \\
(\mu \mathrm{Ci} / \mathrm{g})\end{array}$ & $\begin{array}{c}\text { Total } \alpha \\
(\mu \mathrm{Ci} / \mathrm{g})\end{array}$ & $\begin{array}{c}\text { Total } \alpha \\
\text { water } \\
\text { leach } \\
(\mu \mathrm{Ci} / \mathrm{g})\end{array}$ \\
\hline Core 47 & $3.65 \mathrm{E}-04$ & $4.40 \mathrm{E}-05$ & 0.82 & $<0.58$ & 0.32 & 0.992 & $4.84 \mathrm{E}-03$ \\
\hline Core 48 & $3.34 \mathrm{E}-04$ & $7.15 \mathrm{E}-06$ & 0.063 & $<0.71$ & 0.01 & 0.065 & $1.35 \mathrm{E}-04$ \\
\hline Core 49 & $3.01 \mathrm{E}-04$ & $1.11 \mathrm{E}-05$ & 0.075 & $<0.35$ & 0.13 & 0.129 & $6.25 \mathrm{E}-04$ \\
\hline
\end{tabular}

* = Determined from total plutonium alpha and isotopic measurements

$A E A=$ Measurement by alpha energy analysis.

GEA = Measurement by gamma energy analysis.

Table 5-34. Total Alpha Homogenization Test $(\mu \mathrm{Ci} / \mathrm{g})$ (Acid Prep).

\begin{tabular}{|l|l|c|l|c|}
\hline \multirow{2}{*}{ Core 48-1D } & Top-1 & $6.18 \mathrm{E}-02$ & Top-2 & $5.00 \mathrm{E}-02$ \\
\cline { 2 - 5 } & Bottom-1 & $6.74 \mathrm{E}-02$ & Bottom-2 & $5.26 \mathrm{E}-02$ \\
\hline \multirow{2}{*}{ Core 49-1D } & Top-1 & $3.58 \mathrm{E}-02$ & Top-2 & $5.94 \mathrm{E}-02$ \\
\cline { 2 - 5 } & Bottom-1 & $4.46 \mathrm{E}-02$ & Bottom-2 & $5.23 \mathrm{E}-02$ \\
\hline
\end{tabular}

Table 5-35. Tank 241-C-109 Core 47 Radionuclide Trending (Fusion Preparation).

\begin{tabular}{|l|c|c|c|c|c|c|}
\hline \multicolumn{1}{|c|}{ Subsegment } & $\begin{array}{c}{ }^{137} \mathrm{Cs} \\
(\mu \mathrm{Ci} / \mathrm{g})\end{array}$ & $\begin{array}{c}{ }^{90} \mathrm{Sr} \\
(\mu \mathrm{Ci} / \mathrm{g})\end{array}$ & $\begin{array}{c}{ }^{154} \mathrm{Eu} \\
(\mu \mathrm{Ci} / \mathrm{g})\end{array}$ & $\begin{array}{c}{ }^{155} \mathrm{Eu} \\
(\mu \mathrm{Ci} / \mathrm{g})\end{array}$ & $\begin{array}{c}{ }^{241} \mathrm{Am} \\
(\mu \mathrm{Ci} / \mathrm{g})\end{array}$ & $\begin{array}{c}U_{\text {ICP }} \\
(\mu \mathrm{g} / \mathrm{g})\end{array}$ \\
\hline $1 \mathrm{~B}$ & 340 & 4,600 & 0.88 & 1.16 & 0.75 & 11,800 \\
\hline $1 \mathrm{C}$ & 770 & 470 & $<0.13$ & $<0.86$ & $<0.48$ & 6,100 \\
\hline 10 & 950 & 200 & $<0.11$ & $<1.02$ & $<0.55$ & 5,800 \\
\hline Core comp. & 870 & 1,180 & $<0.24$ & $<0.86$ & $<0.58$ & 9,200 \\
\hline $\begin{array}{l}\text { Core comp. } \\
\text { (water } \\
\text { leach) }\end{array}$ & 9.24 & $17.35^{*}$ & $<0.002$ & $<0.008$ & $<0.004$ & $<\mathrm{DL}$ \\
\hline
\end{tabular}

*Value from total beta analysis.

$I C P=$ inductively coupled plasma result. 
Table 5-36. Tank 241-C-109 Core 48 Radionuclide Trending (Fuston Preparation).

\begin{tabular}{|l|c|c|c|c|c|c|}
\hline \multicolumn{1}{|c|}{ Subsegment } & $\begin{array}{c}{ }^{137} \mathrm{CS} \\
(\mu \mathrm{Cl} / \mathrm{g})\end{array}$ & $\begin{array}{c}{ }^{90} \mathrm{Sr} \\
(\mu \mathrm{CH} / \mathrm{g})\end{array}$ & $\begin{array}{c}{ }^{154} \mathrm{Eu} \\
(\mu \mathrm{CH} / \mathrm{g})\end{array}$ & $\begin{array}{c}{ }^{55} \mathrm{Eu} \\
(\mu \mathrm{CH} / \mathrm{g})\end{array}$ & $\begin{array}{c}{ }^{241} \mathrm{Am}_{\text {ged }} \\
(\mu \mathrm{C} 1 / \mathrm{g})\end{array}$ & $\begin{array}{c}\mathrm{U}_{\mathrm{ICP}} \\
(\mu \mathrm{g} / \mathrm{g})\end{array}$ \\
\hline $1 \mathrm{C}$ & 1,200 & 150 & $<0.08$ & $<1.10$ & $<0.59$ & 16,700 \\
\hline 10 & 1,170 & 120 & $<0.10$ & $<1.20$ & $<0.63$ & 14,400 \\
\hline Core comp. & 1,030 & 190 & $<0.73$ & $<1.2$ & $<0.71$ & 24,700 \\
\hline $\begin{array}{l}\text { Core comp. } \\
\text { (water } \\
\text { leach) }\end{array}$ & 9.3 & $8.6 *$ & $<0.0007$ & $<0.008$ & $<0.004$ & $<\mathrm{DL}$ \\
\hline
\end{tabular}

Table 5-37. Tank 241-C-109 Core 49 Radionuclide Trending (Fusion Preparation).

\begin{tabular}{|l|c|c|c|c|c|c|}
\hline \multicolumn{1}{|c|}{ Subsegment } & $\begin{array}{c}{ }^{137} \mathrm{Cs} \\
(\mu \mathrm{Ci} / \mathrm{g})\end{array}$ & $\begin{array}{c}{ }^{90} \mathrm{Sr} \\
(\mu \mathrm{Ci} / \mathrm{g})\end{array}$ & $\begin{array}{c}{ }^{154} \mathrm{Eu} \\
(\mu \mathrm{Ci} / \mathrm{g})\end{array}$ & $\begin{array}{c}{ }^{155} \mathrm{Eu} \\
(\mu \mathrm{Ci} / \mathrm{g})\end{array}$ & $\begin{array}{c}241 \mathrm{Am}_{\mathrm{CEA}} \\
(\mu \mathrm{Ci} / \mathrm{g})\end{array}$ & $\begin{array}{c}\mathrm{U}_{1 \mathrm{ICP}} \\
(\mu \mathrm{g} / \mathrm{g})\end{array}$ \\
\hline $1 \mathrm{~B}$ & 120 & 2,400 & 0.78 & 0.93 & 0.52 & 7,900 \\
\hline $1 \mathrm{C}$ & 350 & 200 & $<0.04$ & $<0.25$ & $<0.14$ & 1,300 \\
\hline $1 \mathrm{D}$ & 700 & 190 & $<0.06$ & $<0.50$ & $<0.27$ & 12,400 \\
\hline Core comp. & 560 & 930 & 0.36 & $<0.52$ & $<0.35$ & 4,700 \\
\hline $\begin{array}{l}\text { Core comp. } \\
\text { (water leach) }\end{array}$ & 5.3 & $8.7^{*}$ & $<0.0020$ & $<0.0060$ & $<0.003$ & $<\mathrm{DL}$ \\
\hline
\end{tabular}

*Value from total beta analysis.

$<D L=$ below detection limit.

ICP = inductively coupled plasma result.

\subsection{ANALYTICAL RESULTS--ENERGETICS}

Scanning TGA and DSC were performed on subsegment and core composite material obtained frum tank 241-C-109. These two thermal analysis techniques are useful in determining the thermal stability or reactivity of a material. In DSC analysis, heat flow over and above the usual heat capacity of the substance is measured while the substance is exposed to a linear increase in temperature, i.e., dT/dt = Constant (where $T$ = temperature, and $t$ = time). While the substance is being heated, air is passed over the waste material to remove any gases being released. The onset temperature for an endothermic or exothermic event on a DSC is determined graphically.

TGA measures the mass of a sample while the temperature of the sample is increased at a constant rate $\left(5{ }^{\circ} \mathrm{C} / \mathrm{m} / \mathrm{n}\right)$. Again, $\mathrm{dT} / \mathrm{dt}$ is constant because the $X$-axis is representative of the running time of the analysis as well as the temperature increase of the sample during analysis. The $Y$-axis represents the weight percent of the sample and is effectively unitless. As with the DSC, 
air is passed over the sample during heating. Any decrease in the weight percent of the sample represents a loss of gaseous matter from the sample either through evaporation or through a reaction that forms gas phase products.

DSC is often used to measure thermal decomposition temperatures, heats of reaction, reaction temperatures, melting points, and solid-solid transition temperatures. TGA is used to measure thermal decomposition temperatures, water content, and reaction temperatures. The two methods often provide complementary information.

\subsubsection{Remarks on the Interpretation of Differential Scanning Calorimetry/Thermogravimetric Analysis Data}

The results of the thermal analyses performed are summarized in Tables 5-38 and 5-39. The observed behavior for each of the samples is similar; there are two significant features on the DSC trace; there are also three distinguishable features on the TGA plots. Because one of the DSC events overlaps the area where two of the TGA events are occurring, there may be more phenomena occurring in this temperature range than the machine is able to resolve clearly. The values presented in the tables do $r$ t exactly match the values recorded on the DSC and TGA plots. This is because interpreting these semi-quantitative analyses requires considerable experience and judgement on the part of the analyst. Although the temperature ranges observed for the varlous transitions in the DSC and TGA assays do not exactly match, the weight losses and thermal events in the observed transitions are considered related and usualiy in the same vicinity.

There is a concern regarding the choice of cover gas affecting the DSC and TGA results. Air was used in the assays instead of an inert gas because that is what the test instructions directed. However, oxygen in the air may contribute to the oxidation of the sample and alter the reaction (Pederson et a1. 1993). This condition is not considered representative of the potential reaction conditions in the tank; therefore, future DSC/TGA tests will be performed under an inert cover gas. Test instructions governing the treatment of these samples are being written and implemented to ensure the proper thermal testing of ferrocyanide waste samples. 
Table 5-38. Thermogravimetric Analysis Results from Tank 241-C-109.

\begin{tabular}{|l|r|r|r|r|}
\hline $\begin{array}{c}\text { Core } \\
\text { sample }\end{array}$ & $\begin{array}{c}\text { Total Wt\% } \\
\text { loss }\end{array}$ & $\begin{array}{c}\text { Transition } 1 \\
\text { Wt\% loss }\end{array}$ & $\begin{array}{c}\text { Transition } \\
\text { Wt\% loss }\end{array}$ & $\begin{array}{c}\text { Transition } \\
\text { Wt\% loss }\end{array}$ \\
\hline & & & & \\
\hline $47-1 B$ & 31.4 & 10.2 & 17.9 & 3.3 \\
\hline $47-1 C$ & 39.3 & 18.0 & 17.6 & 3.7 \\
\hline $47-1 D$ & 28.2 & 19.7 & 6.8 & 1.7 \\
\hline $47-$ Comp. & 33.4 & 14.8 & 14.9 & 3.7 \\
\hline & & & & \\
\hline $48-1 C$ & N.M. & N.M. & N.M. & N.M. \\
\hline $48-1 D$ & 48.1 & 45.1 & 3.2 & -0.2 \\
\hline $48-$ Comp. & NM & NM & NM & NM \\
\hline & & & & \\
\hline $49-1 B$ & 34.1 & 4.2 & 25.8 & 4.1 \\
\hline $49-1 C$ & 46.6 & 29.6 & 14.2 & 2.8 \\
\hline $49-1 D$ & 40.0 & 29.3 & 9.6 & 1.1 \\
\hline $49-$ Comp. & 46.1 & 26.6 & 15.8 & 3.7 \\
\hline
\end{tabular}

Transition 1: $31^{\circ}-150^{\circ} \mathrm{C}$.

Transition 2: $150^{\circ}-425^{\circ} \mathrm{C}$.

Transition 3: $330^{\circ}-500^{\circ} \mathrm{C}$.

These ranges are approprlate and there is some overlap. NM = No measurement.

Comp. = Core composite. 
Table 5-39. Differential Scanning Calorimetry Energetics Pesults from Tank 241-C-109.

\begin{tabular}{|c|c|c|c|c|c|c|c|c|c|}
\hline \multirow[b]{2}{*}{$\begin{array}{c}\text { Core } \\
\text { Sample }\end{array}$} & \multicolumn{3}{|c|}{ Transition 1} & \multicolumn{3}{|c|}{ Transition 2} & \multicolumn{3}{|c|}{ Transition 3} \\
\hline & $\begin{array}{c}\text { Range } \\
\left({ }^{\circ} \mathrm{C}\right)\end{array}$ & $\begin{array}{l}\text { Avg. } \\
\text { onset } \\
\left({ }^{\circ} \mathrm{C}\right)\end{array}$ & $\begin{array}{c}\text { Avg. } \\
\Delta H \\
(\mathrm{~J} / \mathrm{g})\end{array}$ & $\begin{array}{c}\text { Range } \\
\left({ }^{\circ} \mathrm{C}\right)\end{array}$ & $\begin{array}{l}\text { Avg. } \\
\text { onset } \\
\left({ }^{\circ} \mathrm{C}\right)\end{array}$ & $\begin{array}{c}\text { Avg. } \\
\Delta H \\
(J / g)\end{array}$ & $\begin{array}{c}\text { Range } \\
\left({ }^{\circ} \mathrm{C}\right)\end{array}$ & $\begin{array}{l}\text { Avg. } \\
\text { onset } \\
\left({ }^{\circ} \mathrm{C}\right)\end{array}$ & $\begin{array}{c}\text { Avg. } \\
\Delta H \\
(J / g)\end{array}$ \\
\hline $47-1 B$ & $33-150$ & 70 & 350 & $190-338$ & 259 & 1,555 & (a) & N.A. & \\
\hline $47-1 C$ & $35-144$ & 53 & 425 & $167-318$ & 217 & 610 & $380-461$ & 391 & 72 \\
\hline $47-10$ & $34-154$ & 59 & 767 & $190-369$ & 225 & 508 & $369-441$ & 375 & 21 \\
\hline 47-Comp. & $34-150$ & 55 & 785 & $159-330$ & 216 & 1,084 & (a) & N.A. & \\
\hline $48-10$ & $34-196$ & 104 & 1,034 & $249-338$ & 272 & -27 & $336-431$ & 359 & 31 \\
\hline $49-1 B$ & $33-115$ & 40 & 368 & $193-373$ & 270 & 2,188 & (a) & N.A. & \\
\hline $49-1 C$ & $33-197$ & 72 & 658 & $167-316$ & 242 & 565 & (a) & N.A. & \\
\hline $49-10$ & $34-166$ & 71 & 712 & $152-324$ & 225 & 305 & $379-483$ & 394 & 48 \\
\hline 49-Comp. & $34-192$ & 99 & 964 & $190-329$ & 243 & 922 & (a) & N.A. & \\
\hline
\end{tabular}

(a) No quantifiable transition is observed.

NOTE: To convert from J to cal, divide by 4.18 .

NOTE: Negative $\Delta H$ indicates an exotherm.

N.A. = Not applicable.

Comp. - Core composite. 
WHC-EP-0668

\subsubsection{General Comments on the Differential Scanning Calorimotry/Thermogravimetric Analysis Behavior of the Samples}

The first transition in each sample is endothermic, begins at the lower temperature limit of the analysis $\left(30^{\circ} \mathrm{C}\right)$, and is essentialiy complete between $140^{\circ} \mathrm{C}$ and $200^{\circ} \mathrm{C}$. The most 11kely phenomenon occurring in this region are the release of the buik and interstitial water in the core sample material. The endotherms exhibited in this region are substantial (typically, 350 to $1,030 \mathrm{~J} / \mathrm{g})$. These values are per gram of wet sample; if divided by the mass fraction lost during analysis, they typically range from 2,200 to $3,900 \mathrm{~J} / \mathrm{g}$ and correspond generally with the heat of vaporization of water $(2,260 \mathrm{~J} / \mathrm{g})$, although there are some outliers with much higher endotherms. The overali TGA water content does not correspond well with the water loss observed in a gravimetric weight percent solids determination as given in Tables 5-43 to 5-45. However, this disagreement is attributed to phenomenological differences in the materials' reaction to thermal stress of varying intensity.

Additional weight loss and endotherms are routinely detected between $260^{\circ}$ to $300^{\circ} \mathrm{C}$ in the Core 47 and 49 samples. For these samples, the majority of the weight percent change observed in the TGA curve occurs over this temperature range and no exothermic action is observed. This behavior is attributed to the high levels of aluminum in the samples. It is believed that the phenomenon occurring in this region is the dehydration of aluminum hydroxide to alumina and water vapor (Brown and Jensen 1993; Appendix A). Several other reactions are potentialiy associated with this endotherm: melting of $\mathrm{NaNO}_{2}$ and $\mathrm{NaNO}_{3}$ salts, endothermic ferrocyanide reactions with the nitrate and nitrite salts to form $\mathrm{NO}$ and $\mathrm{NO}_{2}$, and water losses of sodium alumina sllicates and other hydrated compounds. Core 48 is unlike the other samples and exhlbits exotherms and weight changes that have been observed in previous thermal analysis studies of tank 241-C-112 waste (Simpson et al. 1993), $\mathrm{Cs}_{2} \mathrm{NiFe}(\mathrm{CN})_{6}$ (Scheele et al. 1991) and other simulant materials (Bechtold 1992; Jeppson 1993). As reported previously, the dried simulant materlals demonstrate much larger exothermic responses than those observed in tank 241-C-109 waste. However, the magnitude of the exotherms observed correlates roughly with the predicted exotherms derived from the amount of cyanide present in the waste (refer to Tables 5-40,5-41 and 5-42), based on the Fauske (1992) determined value of $-3.95 \mathrm{~kJ} / \mathrm{g} \mathrm{Na} 2 \mathrm{NiFe}(\mathrm{CN})_{6}$. The weight losses are attributed to the loss of gaseous reaction products and waters of hydration.

The third transition is very small compared with the other two observed transitions $(<100 \mathrm{~J} / \mathrm{g}$ ), but here the energetic behavior is not readily quantifiable in all of the samples analyzed. A minor weight loss was routinely observed in the samples at temperatures above $300{ }^{\circ} \mathrm{C}$. 
Table 5-40. Tank 241-C-109 Core 47 Energetic Comparison.

\begin{tabular}{|c|c|c|c|c|}
\hline Subsegment & $\begin{array}{l}\text { Wtx Total } \\
\text { cyanide } \\
\text { (dry) }\end{array}$ & $\begin{array}{c}\text { Equivalent Wty } \\
\text { sodfum nickel } \\
\text { ferrocyanide } \\
\text { (dry) }\end{array}$ & $\begin{array}{l}\text { Theoretical heat } \\
\text { of react ton* } \\
\text { (cal/g dry waste) }\end{array}$ & $\begin{array}{l}\text { Measured heat } \\
\text { of reaction*t } \\
\text { (cal/g dry waste) }\end{array}$ \\
\hline$\overline{1 B}$ & 0.30 & 0.61 & -5.8 & No Exotherm \\
\hline 10 & 0.44 & 0.89 & -8.4 & No Exotherm \\
\hline 10 & 0.58 & 1.17 & -11.1 & No Exotherm \\
\hline Composite & 0.55 & 1.11 & -10.5 & No Exotherm \\
\hline
\end{tabular}

Table 5-41. Tank 241-C-109 Core 48 Energattc Comparison.

\begin{tabular}{|l|c|c|c|c|}
\hline Subsegment & $\begin{array}{c}\text { WtK Total } \\
\text { cyanide } \\
\text { (dry) }\end{array}$ & $\begin{array}{c}\text { Equivalent Wtx } \\
\text { sodtum nicke) } \\
\text { ferrocyanide } \\
\text { (dry) }\end{array}$ & $\begin{array}{c}\text { Theoret fcal heat } \\
\text { of reaction } \\
\text { (ca1/g dry waste) }\end{array}$ & $\begin{array}{c}\text { Measured heat } \\
\text { of reaction } \\
\text { (cal/g dry waste) }\end{array}$ \\
\hline $1 C$ & 1.13 & 2.29 & -21.6 & NM \\
\hline 10 & 0.87 & 1.76 & -16.6 & -12.4 \\
\hline Composite & 1.44 & 2.91 & -27.5 & NM \\
\hline
\end{tabular}

Table 5-42. Tank 241-C-109 Core 49 Energetic Compartion.

\begin{tabular}{|l|c|c|c|c|}
\hline Subsegment & $\begin{array}{c}\text { Wt\% Total } \\
\text { cyanide } \\
\text { (dry) }\end{array}$ & $\begin{array}{c}\text { Equivalent Wt\% } \\
\text { sodium nicke) } \\
\text { ferrocyanide } \\
\text { (dry) }\end{array}$ & $\begin{array}{c}\text { Theoretical heat } \\
\text { of react ion* } \\
\text { (cal/g dry waste) }\end{array}$ & $\begin{array}{c}\text { Measured heat } \\
\text { of reaction** } \\
\text { (cal/g dry waste) }\end{array}$ \\
\hline $1 B$ & 0.35 & 0.71 & -6.7 & No Exotherm \\
\hline $1 C$ & 0.81 & 1.64 & -15.5 & No Exotherm \\
\hline 10 & 0.55 & 1.11 & -10.5 & No Exotherm \\
\hline Composite & 0.56 & 1.13 & -10.7 & No Exotherm \\
\hline
\end{tabular}

NM = No measurement.

NOTE: $1 \mathrm{cal}=4.18 \mathrm{~J}$.

*Based on $-3.95 \mathrm{~kJ} / \mathrm{g} \mathrm{Na} \mathrm{NiFe}(\mathrm{CN})_{6}$ (Fauske 1992).

**Endothermic measurements are in Appendix A, Table A-9.

The properties related to energetics are illustrated for each core in Tables 5-43, 5-44, and 5-45. The results for the samples from 48-10, indicates that this sample differs in thermal behavior from most of the other samples, further suggesting a difference in waste type. 
Table 5-43. Tank 241-C-109 Core 47 Energetics Trending.

\begin{tabular}{|l|c|c|c|c|c|c|}
\hline Subsegment & $\begin{array}{c}W t \% \\
\text { Total } \\
\text { cyanide } \\
\text { (dry) }\end{array}$ & $\begin{array}{c}\text { Wt\% Total } \\
\text { organic } \\
\text { carbon }\end{array}$ & $\begin{array}{c}\text { Wt\% } \\
\text { Total } \\
\text { carbon }\end{array}$ & $\begin{array}{c}\text { Wt\% } \\
\text { Water } \\
\text { (Grav.) }\end{array}$ & $\begin{array}{c}\text { Wt\% } \\
\text { Water } \\
\text { (TGA) }\end{array}$ & $\begin{array}{c}\text { Average heat } \\
\text { of react ton } \\
\text { (J/g dry waste) }\end{array}$ \\
\hline $1 B$ & 0.30 & 0.22 & 0.76 & 19.3 & 31.4 & No Exotherm \\
\hline $1 C$ & 0.44 & 0.20 & 0.72 & 28.4 & 39.3 & No Exotherm \\
\hline 10 & 0.58 & 0.22 & 0.76 & 39.4 & 28.2 & No Exotherm \\
\hline Composite & 0.55 & 0.23 & 0.80 & 21.5 & 33.4 & No Exotherm \\
\hline
\end{tabular}

Table 5-44. Tank 241-C-109 Core 48 Energetics Trending.

\begin{tabular}{|l|c|c|c|c|c|c|}
\hline Subsegment & $\begin{array}{c}\text { Wt\% } \\
\text { Total } \\
\text { cyanide } \\
\text { (dry) }\end{array}$ & $\begin{array}{c}\text { Wt\% Total } \\
\text { organic } \\
\text { carbon }\end{array}$ & $\begin{array}{c}\text { Wt\% } \\
\text { Total } \\
\text { carbon }\end{array}$ & $\begin{array}{c}\text { Wt\% } \\
\text { Water } \\
\text { (Grav.) }\end{array}$ & $\begin{array}{c}\text { Wt\% } \\
\text { Water } \\
\text { (TGA) }\end{array}$ & $\begin{array}{c}\text { Average heat } \\
\text { of reaction } \\
\text { (J/g dry waste) }\end{array}$ \\
\hline $1 C$ & 1.13 & 0.37 & 1.24 & 52.8 & NM & NM \\
\hline 10 & 0.87 & 0.35 & 1.10 & 51.6 & 48.1 & -51.9 \\
\hline Composite & 1.44 & 0.31 & 0.87 & 57.7 & NM & NM \\
\hline
\end{tabular}

Table 5-45. Tank 241-C-109 Core 49 Energetics Trending.

\begin{tabular}{|l|c|c|c|c|c|c|}
\hline Subsegment & $\begin{array}{c}\text { Wt\% } \\
\text { Total } \\
\text { cyanide } \\
(\text { dry) }\end{array}$ & $\begin{array}{c}\text { Wt\% Total } \\
\text { organic } \\
\text { carbon }\end{array}$ & $\begin{array}{c}\text { Wt\% } \\
\text { Total } \\
\text { carbon }\end{array}$ & $\begin{array}{c}\text { Wt\% } \\
\text { Water } \\
\text { (Grav.) }\end{array}$ & $\begin{array}{c}\text { Wt\% } \\
\text { Water } \\
(T G A)\end{array}$ & $\begin{array}{c}\text { Average heat } \\
\text { of reaction } \\
\text { (J/g dry waste) }\end{array}$ \\
\hline $1 B$ & 0.35 & 0.18 & 0.57 & 19.6 & 34.1 & No Exotherm \\
\hline $1 \mathrm{C}$ & 0.81 & 0.22 & 0.88 & 38.3 & 46.6 & No Exotherm \\
\hline 10 & 0.55 & 0.26 & 0.94 & 39.6 & 40.0 & No Exotherm \\
\hline Composite & 0.56 & 0.23 & 0.67 & 27.8 & 46.1 & No Exotherm \\
\hline
\end{tabular}

Heats of Reaction are calculated using the TGA wt\% water value.

NOTE: $1 \mathrm{cal}=4.18 \mathrm{~J}$.

Grav. - Water content from gravimetric weight percent water.

$N M=$ Not measured.

$T G A=$ Water content from scanning thermogravimetric analysis.

The TOC and TIC assays are not considered capable of measuring the total cyanide in the waste because they depend on acid dissolutions to perform the analyses. 
WHC-EP-0668

\subsection{ANALYTICAL RESULTS - POTENTIAL WASTE CONSTITUENTS}

\subsubsection{Mass Balances}

A method to help ensure that the data are acceptable is to perform a mass balance on the core composite sample data. This activity functions as a rough quality control check, and also provides insight to some of the properties of the matrix. To do this, the assumption in performing the mass balance is that the antons, cations, and water are all associated in some manner, but the exact chemistry of the association is not considered. Analytes contributing less than 0.2 wt\% (generally trace ICP analytes, $A A$ analytes, and radionuclides) are considered negligible in this assessment. The assays that contributed analytes to the mass balance were the ICP fusion, IC, total carbon, total cyanide assays, and the gravimetrlc wt\% water measurement. The ICP fusion value does not include nickel, which is a significant analyte in the sample but may be biased high. However, for the purpose of this exercise, the nickel value from the respective acid leach preparations will be inserted into the total mass of ICP fusion analytes to account for $i t$.

Without considering the physical and chemical properties of the waste matrix and the context of the process history, the mass balances produced from these assays will be blased low. However, this bias is expected hecause it is known that there are analytes present that were not measured in the analysis of the samples. While the IC anion analysis only measures the water-soluble components; there is a substantial insoluble residue that must contain additional anions. There is no measurement of the sulfide content in any of the assays, even though it has been previously established that 21,600 g-mol of $\mathrm{S}^{-2}$ was used in scavenging ${ }^{60} \mathrm{Co}$. Thus, an additional contribution of $2,300 \mu \mathrm{g} \mathrm{S} \mathrm{S}^{2} / \mathrm{g}$ i.ias been estimated as necessary to close the balance. Bismuth was not reported in the assays, and $\mathrm{BiPO}_{4}$ first cycle waste was recorded as being disposed here, which also introduces a potential shortfall.

Aluminum is likely to be present as $\mathrm{Al}(\mathrm{OH})_{3}$, and other transition metals are also likely to be present as hydroxides or hydrous metal oxides. Netther hydroxide ion or oxide content has been measured in the waste, which introduces additional sources of shortfall in the recovery. Therefore, multipliers for aluminum (2.9), iron (1.6), nickel (1.6), and uranium (1.3) will be used to account for the unmeasured hydroxide or oxygen, which are assumed to be present in combination with these analytes (Appendix A). Only metals making weight percent contributions to the waste matrix will be adjusted in this manner; the trace metals will be assumed to be lost in the error of the major constituents. Adjustments will be made individually for TOC, TIC, and total cyanide. It is assumed that the TOC and TIC assays did not consume or measure any cyanide present. In addition, a significant disparity can be corrected by comparing the spluble phosphorus from the water leach ICP (and assuming that it is $\mathrm{PO}_{4}{ }^{5}$ ), $\mathrm{PO}_{4}{ }^{3 .}$ values from the $\mathrm{IC}$, and the phosphorus from the ICP fusion assay; the phosphate was found to be only 29 to 43 percent soluble (Appendix A). The water leach ICP and IC values agree within 3 percent, strongly suggesting that the soluble phosphurus in the waste matrix is present as $\mathrm{PO}_{4}^{3}$. The process history of the tank also indicates that large amounts of phosphate were used to encourage precipitate formation. Therefore, an assumption that the phosphorus in the fusion assay represents an insoluble $\mathrm{PO}_{4}{ }^{3 .}$ is not unwarranted. Convert the phosphorus in the ICP assay 
to $\mathrm{PO}_{4}^{3 .}$ and add it along with the water soluble phosphate and other antons. A minor accounting shift is now necessary to avoid double counting (subtract the ICP fusion phosphorous value).

Accounting for the analytes in this manner alds in closing agreement and the percent recoveries are between 96.3 percent and 106.1 percent (near quantitative recoveries). However, there remain some aspects of the waste matrices that require examination. Tables 5-46,5-47, and 5-48 present mass balances that have been adjusted to compensate for the contributions of unmeasured (but likely) analytes combined with the measured analytes. There may have been some error introduced from drying of the sample during the preparation of the core composite. In the case of these waste materials, the disparity between the gravimetric water measurement and the TGA water content suggests (1) drying of the sample before the gravimetric assay; (2) incomplete drying during the gravimetric test, which blases the results low; or (3) One or more endothermic events occurring at the same time (chemical reactions or phase transitions resulting in the loss of mass).

Table 5-46. Adjusted Mass Balance: Core 47 Composite.

\begin{tabular}{|c|c|}
\hline Assay & $\begin{array}{c}\text { Concentration } \\
(\mu g / g)\end{array}$ \\
\hline $\begin{array}{l}\text { ICP-Fusion (+ Ni from acid leach; }-P ; \\
\text { Al, } \mathrm{Fe}, \mathrm{NI}, \mathrm{U}, \text { adjustments) }\end{array}$ & 567,600 \\
\hline $\begin{array}{l}\text { IC Antons, (TOC TIC, and } \mathrm{CN}^{*} \text { adjustments; } \\
\left.+\mathrm{P} \text { as } \mathrm{PO}_{4} ;+\mathrm{S}^{2-}\right)\end{array}$ & 212,500 \\
\hline Gravimetric Water & 215,000 \\
\hline Total $(1,000,000 \mu g / g)$ & 995,100 \\
\hline
\end{tabular}

Table 5-47. Adjusted Mass Bailance: Core 48 Composite.

\begin{tabular}{|c|c|}
\hline Assay & $\begin{array}{c}\text { Concentration } \\
(\mu g / g)\end{array}$ \\
\hline $\begin{array}{l}\text { ICP - Fusion (+ } N i \text { from acid leach; }-P ; \\
A 1, \mathrm{Fe}, \mathrm{NI}, \mathrm{U}, \mathrm{SI} \text { adjustments) }\end{array}$ & 241,500 \\
\hline $\begin{array}{l}\text { IC Antons }\left(T O C, T I C \text {, and } C^{\prime} \text { adjustments; }\right. \\
\left.+P \text { as } \mathrm{PO}_{4} ;+S^{2-}\right)\end{array}$ & 242,600 \\
\hline Gravimetric Water & 577,000 \\
\hline Total $(1,000,000 \mu \mathrm{g} / \mathrm{g})$ & $1,061,100$ \\
\hline
\end{tabular}

IC - Ion chromatography.

ICP - Inductively coupled plasma spectroscopy.

TIC - Total inorganic carbon.

TOC - Total organic carhon. 
Table 5-48. Adjusted Mass Balance: Core 49 Composite.

\begin{tabular}{|c|c|}
\hline Assay & $\begin{array}{c}\text { Concentration } \\
(\mu g / g)\end{array}$ \\
\hline $\begin{array}{l}\text { ICP--Fusion (+ } N 1 \text { from acid leach; }-P_{i} \\
A 1, F e, N 1, U, \text { adjustments) }\end{array}$ & 503,700 \\
\hline $\begin{array}{l}\text { IC Antogns (JOC, TIC, CN adjustments; +P } \\
\text { as } \mathrm{PO}_{4}^{*} ;+S^{2} \text { ) }\end{array}$ & 181,600 \\
\hline Gravimetric water & 278,000 \\
\hline Total $(1,000,000 \mu g / g)$ & 963,300 \\
\hline
\end{tabular}

\subsubsection{Suggested Components of Maste Matrix}

The actual composition of the waste matrix is quite complex, and trace amounts of various compounds probably exist in the tank. However, with some simple assumptions regarding how the anions and cations wlll combine, a list of the most probable compounds that exist in the waste matrix and contribute significantly to its overall makeup can be developed.

Table 5-49 is a condensed version of a more general chart found on page D-147 in the Handbook of Chemistry and Physics 64th Ed. (Weast 1984). It provides solubility data on some of the most common antons and cations.

Table 5-49. Probable Solids in the Waste Matrix.

\begin{tabular}{|c|c|c|c|c|c|c|c|c|}
\hline & $\mathrm{NO}_{2}^{\circ}$ & $\mathrm{NO}_{3}^{\circ}$ & $\mathrm{PO}_{4}^{3-}$ & $\mathrm{SO}_{4}^{2 \cdot}$ & $\mathrm{OH}^{*}$ & 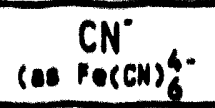 & $\mathrm{CO}_{3}{ }^{2-}$ & $s^{2-}$ \\
\hline $\mathrm{Al}^{+3}$ & & & PPT & & PPT & PPT & & $N L$ \\
\hline $\mathrm{Ca}^{+2}$ & & & PPT & PPT & & & PPT & \\
\hline $\mathrm{Fe}^{+2,+3}$ & & & & & PPT & PPT & PPT & PPT \\
\hline \multicolumn{9}{|l|}{$\mathrm{Na}^{+}$} \\
\hline $\mathrm{N1}^{+2}$ & & & PPT & & $\overline{P P T}$ & PPT & PPT & PPT \\
\hline$u^{+6}$ & & $\mathrm{NL}$ & PPT & PPT & PPT & & & PPT \\
\hline
\end{tabular}

PPT - Prectpitate forms.

$N L$ - Precipitate formation not 1 lkely under tank conditions. 
Frum the earlier tables and process information, chloride, sulfide, and even ferrocyanide will not be signiflcant mass contributors to the waste matrix. Sulfide and cyantde precipltates are significant because they provide a potential fuel source. However, it is generally belleved that the sulfides were eventually converted to sulfates. Sodlum, $\mathrm{NO}_{2}^{\circ}$, and $\mathrm{NO}_{3}$ are highly soluble, and thus probably do not contribute much to the insoluble sollds. However, sodium, nitrate, and nitrite contribute significantly to the overall solids content of the waste (dissolved + insoluble solids). In addition, they represent three of the four most prevalent analytes, after water, in the waste. No analytical measurement of hydroxide was made, but it is known that in the process history of tank 241-C-109, basic solutions were added routinely to the tank. The following is a list of likely candidates for the insoluble solids.

- Aluminum hydroxide, $\mathrm{Al}(\mathrm{OH})_{3}$

- Aluminum phosphate, $\mathrm{AlPO}_{4}$

- Aluminum oxide, $\mathrm{Al}_{2} \mathrm{O}_{3}$

- Aluminum sillicate, $3 \mathrm{Al}_{2} \mathrm{O}_{3} \cdot 2 \mathrm{~S}^{2} \mathrm{O}_{2}$

- Tetraaluminum ferrocyanide, $\mathrm{AT}_{4}\left[\mathrm{Fe}(\mathrm{CN})_{6}\right]_{3}$

- Calctum phosphate, $\mathrm{Ca}_{3}\left(\mathrm{PO}_{4}\right)_{2}$

- Calctum sulfate, CaSO

- Calcium carbonate, $\mathrm{CaCO}_{3}$

- Iron carbonate, $\mathrm{FeCU}_{3}$

- Iron(II) hydroxide, $\mathrm{Fe}(\mathrm{OH})$

- Iron(III) hydroxide, $\mathrm{Fe}(\mathrm{OH})_{3}$

- Iron(II) phosphate, $\mathrm{Fe}_{3}\left(\mathrm{PO}_{4}\right)_{2}$

- Iron(III) phosphate, $\mathrm{FePO}_{4}$

- Iron sulfide, fes

- Iron(III) ferrocyanide, $\mathrm{Fe}_{4}\left[\mathrm{Fe}(\mathrm{CN})_{6}\right]_{3}$

- Disodium nickel ferrocyanide, $\mathrm{Na}_{2} \mathrm{~N} \mathrm{FF}_{\mathrm{F}}(\mathrm{CN})_{6}$

- Nickel carbonate, $\mathrm{NiCO}_{3}$

- Nickel sulfide, NiS

- Nickel hydroxide, Ni(OH)

- Dinlckel ferrocyanide, $\mathrm{NT}_{2} \mathrm{Fe}(\mathrm{CN})_{6}$

- Uranyl phosphate, $\mathrm{UO}_{2} \mathrm{HPO}_{4} \cdot 4 \mathrm{H}_{2} \mathrm{O}$

- Uranyi hydroxide, $\mathrm{UO}_{2}^{2}(\mathrm{OH})_{2}$

- Uranyi sulfide, UO,S

- Uranyl sulfate, $2\left(\mathrm{CO}_{2} \mathrm{SO}_{4}\right) \cdot 7 \mathrm{H}_{2} \mathrm{O}$.

The ${ }^{137} \mathrm{Cs}$ present is st 111 apparently bound with the ferrocyanide, and the ${ }^{90} \mathrm{Sr}$ is probably bound with phosphate, carbonate, or sulfate.

\subsubsection{Comparison to Theoretical Estimates and Simulant Studies}

Agreement between synthetic sludge propertfes and observed waste material characteristics is within the constraints of the synthetic recipes and assumptions regarding chemical behavior in tank 241-c-109. Table 5-50 compares some properties and analyte concentrations of the waste materlals and comparable simulants. 


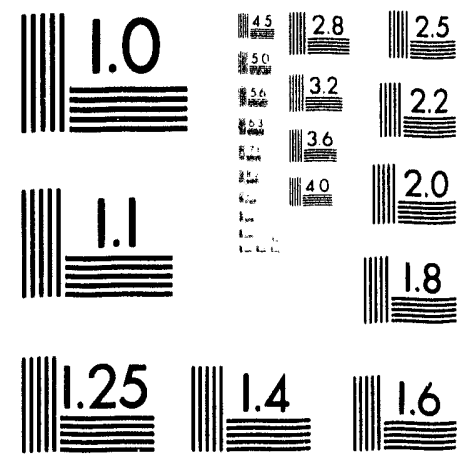



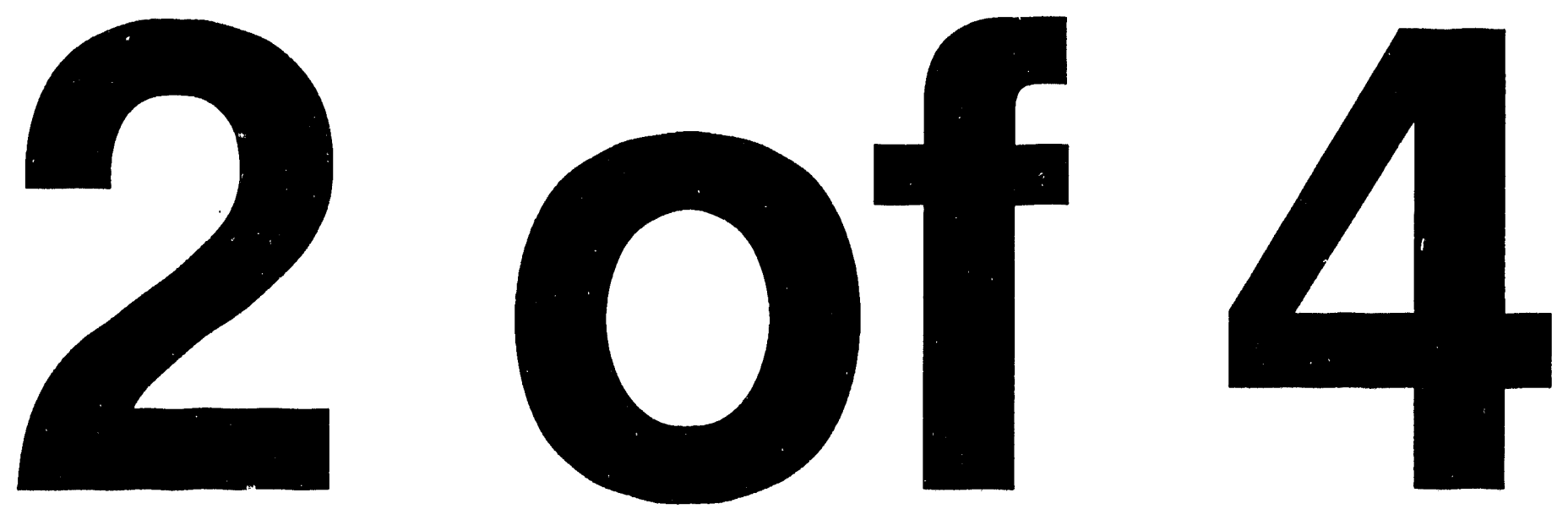
Table 5-50. Tank 241-C-109 Comparison of Waste Material with Simulants for Selected Analytes.

\begin{tabular}{|c|c|c|c|c|}
\hline Analyte & $\begin{array}{l}\text { In Farm } 2 \\
\text { simulant } \\
\text { values }\end{array}$ & $\begin{array}{c}\text { Core } 47 \text { values } \\
\text { subsegment range } \\
\text { (composite } \\
\text { value) }\end{array}$ & $\begin{array}{l}\text { Core } 48 \text { values } \\
\text { subsegment range } \\
\text { (composite value) }\end{array}$ & $\begin{array}{l}\text { Core } 49 \text { values } \\
\text { subsegment range } \\
\text { (composite value) }\end{array}$ \\
\hline $\mathrm{Ni} u g / g^{*}$ & 18,700 & $\begin{array}{c}19,400 \text { to } 25,600 \\
(31,900)\end{array}$ & $\begin{array}{c}44,000 \text { to } 24,000 \\
(33,000)\end{array}$ & $\begin{array}{c}10,800 \text { to } 31,900 \\
(22,900)\end{array}$ \\
\hline $\begin{array}{l}\text { Wt\% } \mathrm{H}_{2} \mathrm{O} \\
\left(\mathrm{Grav}^{\prime}\right)\end{array}$ & 51 & $\begin{array}{c}19.3 \text { to } 39.4 \\
(21.5)\end{array}$ & $\begin{array}{c}51.6 \text { to } 52.8 \\
(57.7)\end{array}$ & $\begin{array}{c}34.1 \text { to } 46.6 \\
(46.1)\end{array}$ \\
\hline $\begin{array}{l}\text { Wt\% } \\
\text { Total } \\
\text { Cyanide } \\
\text { dry basis }\end{array}$ & $\begin{array}{l}9.1 \text { to } \\
11.3\end{array}$ & $\begin{array}{c}0.30 \text { to } 0.58 \\
(0.55)\end{array}$ & $\begin{array}{c}0.87 \text { to } 1.13 \\
(1.44)\end{array}$ & $\begin{array}{c}0.35 \text { to } 0.81 \\
(0.56)\end{array}$ \\
\hline $\begin{array}{l}\Delta H \\
\mathrm{~J} / \text { dry g }\end{array}$ & $-1,200$ & $\begin{array}{c}\text { No detectable } \\
\text { exotherm }\end{array}$ & -51.9 (NM) & $\begin{array}{c}\text { No detectable } \\
\text { exotherm }\end{array}$ \\
\hline $\begin{array}{l}\text { Density } \\
\mathrm{g} / \mathrm{ml}\end{array}$ & $1.39 * *$ & $N M(1.2)$ & $N M(1.3)$ & $\mathrm{NM}(1.1)$ \\
\hline
\end{tabular}

*Nickel analysis is biased high. Values are derived from ICP fusion performed in a nickel crucible. However, in each case the blank value was an order of magnitude (or greater) less than the measurement. The fusion values are usually twice the acid digestion values, for the core composite measurements.

**Centrifuged for 30 gravity years.

Grav. = gravimetric assay.

$\mathrm{NM}=$ Not measured.

\subsection{RCRA-TYPE ANALYSIS: DATA VALIDATION/VERIFICATION PROTOCOL}

\subsubsection{Chemical Data}

Data validation procedures for chemical data were in place during the analys is of tank 241-C-109. The data validation and verification procedures followed to ensure reliable data for RCRA-type samples are described in detail in WHC-CM-5-3, Sample Management and Administration, Section 2.0. A brief list of the requirements for data packages are as follows:

- Requested versus reported analyses

- Analysis holding times

- Matrix spike/matrix spike duplicate analysis

- Surrogate recoveries

- Duplicate analysis

- Analytical blank analysis

- Additional QA/QC oversight, as designated in the SOW

- Initial and continuing instrument calibration

- GC/MS Tune criteria (GC/MS analysis) 
- Internal standards (GC analysis)

- Laboratory control samples (LCS)

- Interference check sample (ICP).

When determining the quality of the chemical data for tank 24l-C-109, it is useful to consider the results of several of the quality control assays. $B l a n k s$, matrix spikes, duplicates, and control samples can all provide further insight to the data and its reliability. Potential sample contamination problems are addressed using analytical blanks. Confounding effects of the sample matrix are resolved using matrix spike results. Duplicate analys is compares the difference between the replicate samples, providing an indication of laboratory precision (and in some cases, sample heterogeneity). The laboratory control sample offers a monitor of overall performance of an analytical method in all steps of the analysis. Overall, there were few problems with the data validation and compliance with established quality control criteria. The 241-C-109 samples were generally free from calibration and contamination errors. In addition, the interference control standards, matrix spike, laboratory control standard, and holding time requirements were largely met. In some cases, the poor sample/duplicate agreement observed in some of the assays was attributed to significant sample heterogeneity. In almost all cases, no significant problems were found, and the data obtained was qualifiable and usable in characterizing the tank contents. Appendix $D$ contains a summary of the most relevant quality assurance data.

\subsubsection{Radiological Data}

Similarly, the data validation and verification procedures followed to ensure reliable data for radioactive, high-level, RCRA-type samples are also described in detail in WHC-CM-5-3, Sample Management and Administration, Section 2.4. They differ somewhat from the requirements for chemical data. A brief list of the requirements for data packages are as follows:

- Chain of custody

- Requested versus reported analyses

- Efficiency checks

- Laboratory control samples (LCS)

- Initial calibration

- Preparation blank analysis

- Matrix spikes/tracers/carriers

- Additional QA/QC oversight, as designated in the SOW

- Duplicate analysis

- Background checks.

When determining the quality of the radiological data for tank 241-C-109, it is also useful to consider the results of several of the quality control assays. Chain-of-custody, calibrations, efficiency and background checks, blanks, matrix spikes/tracers/carriers, duplicate analyses, and laboratory control samples can all provide further insight to the data and its reliability. Potential sample contamination problems or loss of sample control are addressed in using a chain-of-custody. Initial calibrations, efficiency and background checks, and analytical blanks ensure that the equipment is operating correctly and further address contamination problems. Confounding effects of the sample matrix are resolved using matrix 
spike/tracers/carriers. Duplicate analysis compares the difference between the replicate samples, providing an indication of laboratory precision (and in some cases, sample heterogeneity). The laboratory control sample offers a monitor of overail performance of an analytical method in all steps of the analysis. In the case of the radiological data, there were several problems with the data validation and compliance with established quality control criteria. The 241-C-109 chain-of-custody documentation showed liner liquid apparentiy came from two samples (Cores 47 and 49 ) thus, sample integrity was compromised. With the degree of sample containment and isolation these samples have, there was no danger of significant sample contamination or excessive exposure risk. However, this incident does demonstrate some shortcomings of the present sampler. The sample blank results further indicated that samples were generally free from contamination errors (tritium was an exception). Additionally, there are several problems in compliance with the established $Q C$ criteria for initial calibrations, efficiency checks, matrix spike/iracers/carriers, and the use of laboratory control standards for these samples. In many cases, the radiological data obtained was determined to be not qualifiable and unusable in characterizing the tank contents during the validation procedure. On further investigation, it was found that this finding is true only because of the discrepancies in quality control criteria between the PNL Technical Task Plan and the governing validation documentation WHC-EP-0210 (Winters et al. 1990). These concerns were addressed and responded to in the PNL TTP, which outlined the alternative quality control criteria that would be adhered to during the analysis of the samples. WHC agreed to the criteria outlined in the PNL TTP and a formal audit response has been issued to clarify the matter further (Appendix D). For the purposes of characterization and data interpretation stated in this document, the data are deemed acceptable for use. 
WHC-EP-0668

\subsection{INTERPRETATION OF ANALYTICAL RESULTS}

\subsection{TANK 241-C-109 WASTE PROFILE}

Tank 241-C-109 received several major types of waste likely to deposit solids during its operating history. The waste types in chronological order are as follows:

- Bismuth phosphate first decontamination cycle waste (1C)

- Unscavenged uranium recovery waste from U Plant and ferrocyanidescavenged waste ( $\mathrm{FeCN}$ ) from scavenging of UR waste initially stored in other tanks

- Ferrocyanide-scavenged supernatants from BY Tank Farm that required additional scavenging for ${ }^{60} \mathrm{Co}$ and ${ }^{90} \mathrm{Sr}$ without ferrocyanide

- Ferrocyanide-scavenged waste (FeCN) IC Evaporator Bottoms (EB) from scavenging of evaporator processed $1 C, C W$, and UR waste initially stored in other tanks

- Decladding/coating (CW) and hot semiworks (HS) wastes.

A relatively large volume of $B$ Plant ion-exchange waste was received after these solids-bearing wastes. These last wastes would not be expected to contribute large amounts of solids to the tank. This section will attempt to identify the location of the tank waste solids, thereby allowing estimates of the tank inventory for various analytes of importance.

To identify the waste profile, the approach taken was that the subsegment assays were examined for analytes distinct to the waste types disposed in the tank, and that information was combined with what is known regarding the tank's process history. The first waste placed in the tank, via the cascade inlet from tank 241-C-108 was $\mathrm{BiPO}_{4} 1 \mathrm{C}$ waste. This waste would be comparatively high in bismuth, phosphate, and aluminum because aluminum decladding waste was combined with it. The $1 C$ solids volume was measured as $38,000 \mathrm{~L}(10,000 \mathrm{gal})$ in 1952 (Anderson 1990). This volume would amount to approximately $25.4 \mathrm{~cm}$ ( $10 \mathrm{in}$.) in the dished tank bottom. The tank was filled with unscavenged uranium recovery wastes in 1953. This waste was scavenged and routed to tank $241-\mathrm{C}-112$ in 1955 .

The tank then received ferrocyanide-scavenged waste. The solids from this waste would be high in nickel, calcium, cyanide (as ferrocyanide), ${ }^{137} \mathrm{Cs}$, and uranium, al though the uranium may have settled out in the tank originally receiving the UR waste. Because some of the ferrocyanide waste feed was concentrated $I C$ and $C W$ wastes (EBS), the waste could also be high in aluminum. During this time several batches of the concentrated wastes that were scavenged for ${ }^{60} \mathrm{Co}$ and ${ }^{50} \mathrm{Sr}$ were processed without ferrocyanide. However, further processing with ferrocyanide continued until the end of scavenging in early 1958. The estimated solids volume in tank $241-C-109$ at the end of the scavenging program was between 216,000 and $341,000 \mathrm{~L}(57,000$ and 90,000 gal). This would amount to 41.1 to $71.6 \mathrm{~cm}(16.2$ to 28.2 in.) distributed eveniy across the tank. 
The last major waste type was evaporated aluminum cladding waste. While these materials would be high in aluminum and silica, the solids volume of this waste is unknown. The grey/white solids seen in the video recordings of the core extrusions are believed to be cladding waste, and the tan/dark brown solids are thought to be ferrocyanide sludge. Their observed position during extrusion agrees with the historical record. The volume of strontium semiworks waste was small and probably would not have been visually detectable. However, it would have had a relatively high ${ }^{90} \mathrm{Sr}$ content because it included strontium recovery and purification waste losses. This characteristic would be readily observable in the radiochemistry analyses.

\subsection{REVIEW OF THE SUBSEGMENT ANALYTE PROFILES}

The following conclusions are drawn from review of the subsegment analyses presented in Section 5.0.

\section{Core 47}

Chemical analyses indicate this material is ferrocyanide waste, al though the wastes scavenged were mostly evaporated 1C (with some CW wastes).

The relatively high nickel, calcium, and ${ }^{137} \mathrm{Cs}$ levels in the composites and the analyte profiles in the subsegments lead to this conclusion. The extremely high aluminum values are attributed to concentrated $I C$ and coating wastes (both scavenged and unscavenged) deposited in the tank. The phosphate/phosphorus profile indicates very little $\mathrm{BiPO}_{4}^{-} 1 \mathrm{C}$ waste in the upper portions of the tank. Phosphate/phosphorus routinely demonstrate an increasing concentration profile as a function of depth. In addition, the total cyanide analysis indicates residual cyanide in the waste al though the measured cyanide concentration is much lower than that expected from simulant information. However, the DSC traces show no discernable exotherm in the temperature range where the In Farm simulants begin to show reactions. Instead, the overall energy ielease is highiy endothermic, postulated to be from the decomposition of aluminum hydroxide to alumina and water. ${ }^{H} \mathrm{High}{ }^{90} \mathrm{Sr}$ values in 47-1B indicate hot semiworks/strontium semiworks and the ${ }^{90} \mathrm{Sr}$ values decrease dramatically as a function of depth.

\section{Core 48}

Because the amount of solids recovered from this core was $14.0 \mathrm{~cm}$ ( $5.5 \mathrm{in.}$ ) (assumed to be subsegment 10); thus, the waste origin is somewhat indeterminate. Chemical analyses indicate this material is ferrocyanide waste, the relatively high nickel, calcium, and ${ }^{137} \mathrm{Cs}$ levels in the composites and the analyte profiles in the subsegments support this conclusion. However, none of the primary analytes (e.g., nickel, aluminum, calcium, and phosphate), match the other two cores well as composites or the subsegment profiles. The waste from this core has the highest total overall cyanide content and lowest aluminum concentration. It exhibits a minor exotherm in the temperature range where the In Farm simulants begin to show reactions. This material is much more reminiscent of the sample cores from tank 241-C-112 than of the samples from tank $241-c-109$. The relatively $10{ }^{90} \mathrm{Sr}$ values and the lack of a high value on top of the sample suggest this segment was acquired from deeper in the tank than the other samples. 
WHC-EP-0668

\section{Core 49}

Chemical analyses indicate this material is ferrocyanide waste although the wastes scavenged were mostly evaporated IC (with some CW wastes), much similar to Core 47. The relatively high nickel, calcium, and ${ }^{37}$ Cs levels in the composites and the analyte profiles in the subsegments lead to this conclusion and there is relatively close correspondence between the two cores. The extremely high aluminum values are attributed to concentrated $1 \mathrm{C}$ and coating wastes (both scavenged and unscavenged) deposited in the tank. The phosphate/phosphorus profile indicates very little IC waste in the upper portions of the tank. Phosphate/phosphorus routinely demonstrate an increasing concentration profile as a function of depth. In addition, the total cyanide analysis indicates residual cyanide in the waste al though the measured cyanide concentration is much lower than that expected from simulant. information. However, the DSC traces show no discernable exotherm in the temperature range where the In Farm simulants begin to show reactions. Instead, the overall energy release is highly endothermic, postulated to be from the decomposition of aluminum hydroxide to alumina and water. $\mathrm{High}{ }^{90} \mathrm{Sr}$ values in 49-1B indicate HS/strontium semiworks and the ${ }^{80} \mathrm{Sr}$ values decrease dramatically as a function of depth.

\subsubsection{Tank Entrance/Exit Effects on Analyte Distribution}

Figure 6-1 shows an elevation and a plan of where the core samples were taken. Important items to note are that Cores 0,7 and 48 were taken from risers near the ferrncyanide waste inlet, while Core 49 was obtained near the waste pumpout riser. The decant "float and flex" pump contained a 6.1-m $(20-\mathrm{ft})$ section of flexible hose that could traverse a relatively wide area on that side of the tank. The cascade fill line (where $\mathrm{BIPO}_{4}$ IC waste entered the tank) is closer to the Core 49 sample point than to the Core 47 and 48 risers. The elevation view shows this is a shallow-dish bottom tank and the bottom of the core samples were $34.3 \mathrm{~cm}(13.5 \mathrm{in}$.$) above the centerline inside$ bottom of the tank. Also shown is the waste surface, measured from the centerline as $79.9 \pm 1.3 \mathrm{~cm}(31.5 \pm 0.5 \mathrm{in}$.$) . Figure 6-2$ shows a representation of the overall waste profile of tank $241-C-109$ and the assumed volumes, boundaries, and positions of the various individual layers as they are believed to exist.

As new wastes entered the tank and distributed themselves across the tank, the solids under and around the tank pumpout (Core 49) could have been distuibed (and occasionally soilds transferred) in behavior simflar to the last in-first out principle. However, an inspection of the analyte profiles and model results indicated that disturbance and transfer of ferrocyanide solids did not appear to occur in tank 241-C...109; the waste did not accumulate to levels that the floating suction pump encountered. It is belleved that the material beneath the waste inlet (Cores 47 and 48 ) would have been disturbed initially but over time large stratified layers resistant to mixing would have eventually build up. The $P B$ and $S i$ rich materials initially settled in the tank, not being as flocculent or as easily suspended as the ferrocyanide solids, may have settled out initially near the inlet. Thus the influence of the waste inlet and outlet locations provides insight to the analyte and waste profiles between Cores 47 and 49 . 
Figure 6-1. Elevation and Plan of Tank 241-C-109.
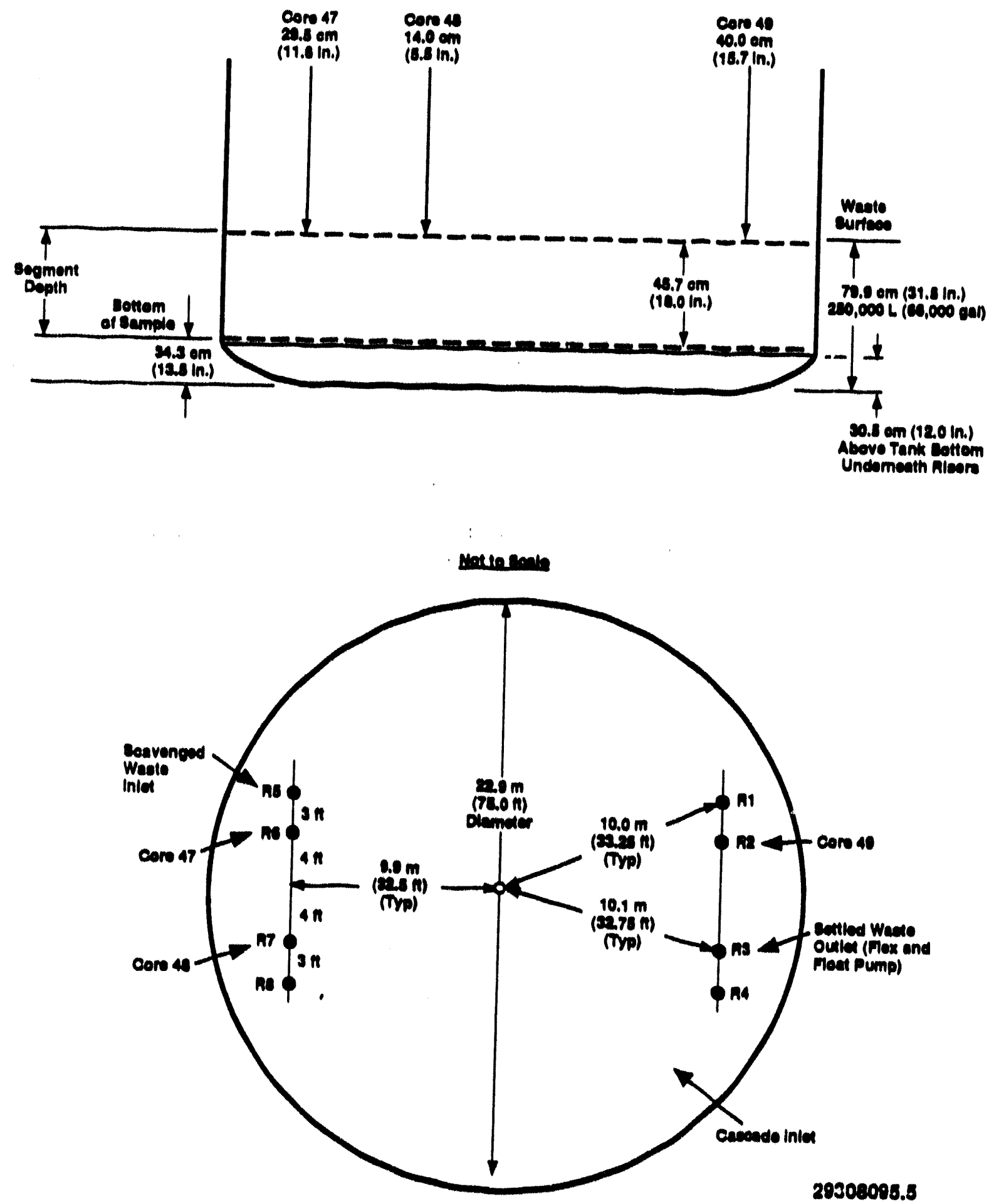
Figure 6-2. Waste Proftle of Tank 241-C-109.

Not to Scalo

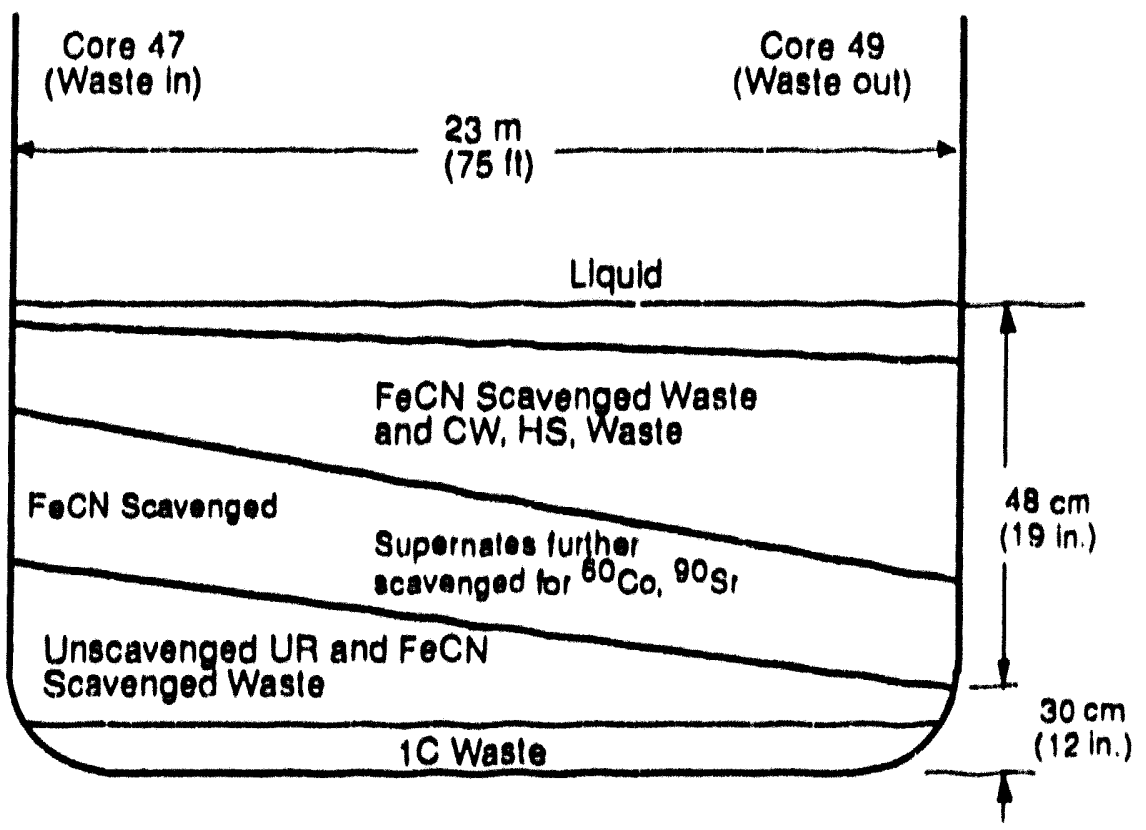

29306095 .

- Dished Bottom: First cycle $\mathrm{BIPO}_{4}$ waste or unscavenged urantum recovery (UR) waste $39,000 \mathrm{~L}(10,000$ gal)

- Tank Layer 1: Scavenged UR and IC waste 75,000 L (19,800 gal)

- Tank Layer 2: Non-FeCN scavenged, evaporator-processed IC and CW waste $65,900 \mathrm{~L}(17,400 \mathrm{ga} 1)$

- Tank Layer 3: Evaporator-processed (CW) ferrocyanide scavenged waste and Hot Semiworks waste $56,000 \mathrm{~L}(14,800 \mathrm{gal})$

- Supernatant: $17,000 \mathrm{~L}(4,500$ gal). 
The ${ }^{137} \mathrm{Cs}$ concentrations vary within a factor of two in the core composites, which is not surprising given the amount of waste that was scavenged without ferrocyanide and its dilutive effect. In addition, the Core 48 waste material appears to be much different in composition than the other two cores, further contributing to the difference. However, the ${ }^{137} \mathrm{Cs}$ concentration as a function of depth in cores 47 and 49 shows profiles consistent with the wastes believed to be associated with the subsegments; low ${ }^{33} \mathrm{C} S$ values for unscavenged, wastes (IC and HS), higher ${ }^{13}{ }^{C S}$ values for ferrocyanide wastes. The ${ }^{137} \mathrm{Cs}$ profile shows an increasing trend as a function of depth in both cores. The ${ }^{90} \mathrm{Sr}$ concentration for both cores shows an extremely skewed concentration profiles as a function of depth, however, there are no consistently high ${ }^{80} \mathrm{Sr}$ values localized around the pumpout riser, as seen in tank 241-C-112,, suggesting that the waste buildup in this tank was not as extensive and the pump did not disturb the waste. The ${ }^{90} \mathrm{Sr}$ concentration is extremely high in the top subsegment and then the concentration falls dramaticaliy, which corresponds with the historical fill pattern. The lack of a high ${ }^{90} \mathrm{Sr}$ concentration in Core 48 suggests that the sample was obtained from a deeper section of the tank and no surface material was taken.

The upper subsegments of Cores 47 and 49 have extremely high aluminum concentrations. The concentrations seen were initially unexpected, until further investigation revealed that they were evaporator processed $1 \mathrm{C}$ and $\mathrm{CW}$ (unscavenged UR waste was expected). These concentrations may be typical for evaporator-processed cladding wastes that were deposited on top of the ferrocyanide wastes. Aluminum al so shows similar distribution behavior to ${ }^{\circ} \mathrm{sr}$; a high concentration initially that decreases as a function of depth. It is expected that the bulk of the BiFD, $1 C$ waste lies below the depth that can be core sampled through the avallable risers. However, the phosphorous and phosphate profiles indicated from the analytical results strongly suggest first decontamination cycle waste is present.

\subsection{CALCULATED BULK INVENTORIES OF SELECTED ANALYTES}

Several safety issues are defined by certain bulk amounts or weight percent of a given analyte. Tables 6-1 through 6-4 present the calculated bulk amounts of some selected analytes and their weight percent contribution to the waste matrix. The gross waste inventory in the tank is estimated to be $303,000 \mathrm{~kg}(284,000 \mathrm{~kg}$ wet solid, and $19,000 \mathrm{~kg}$ of drainable liquid).

Appendix $A$ presents the data, assumptions, and calculations used to determine the following values. Estimated volumes, average analyte concentrations, and density measurements for each hypothesized region were used to develop bulk inventory values.

The bulk inventory of disodium nickel ferrocyanide in the wet solids is $6,800 \mathrm{~g}-\mathrm{mol}$, assuming the calculated inventory of total cyanide is present as that analyte. Molar ratios for ferrocyanide, nitrate, and nitrite in the wet solids (assuming this value for ferrocyanide) are 1: $27.2: 36.4$. 
Table 6-1. Energettcs Related Analyte Values.

\begin{tabular}{|l|c|c|c|c|c|}
\hline & TOC & Total cyanide & $\mathrm{NO}_{2}^{-}$ & $\mathrm{NO}_{3}^{-}$ & $\mathrm{H}_{2} \mathrm{O}$ \\
\hline Bulk inventory (Mg) & 0.81 & 1.12 & 13.1 & 13.3 & 122 \\
\hline $\begin{array}{l}\text { Weight percent } \\
\text { (total) }\end{array}$ & 0.27 & 0.37 & 4.32 & 4.38 & 40.22 \\
\hline $\begin{array}{l}\text { Bulk inventory, } \\
\text { wet solids (Mg) }\end{array}$ & 0.76 & 1.10 & 11.8 & 11.9 & 109 \\
\hline $\begin{array}{l}\text { Weight percent } \\
\text { (wet solids) }\end{array}$ & 0.27 & 0.39 & 4.14 & 4.19 & 38.22 \\
\hline
\end{tabular}

'Water content combines interstitial and free water (i.e., supernate). TOC = Total organic carbon.

Table 6-2. Fission Product Inventory.

\begin{tabular}{|l|c|c|}
\hline & ${ }^{137} \mathrm{Cs}$ & ${ }^{90} \mathrm{Sr}$ \\
\hline $\begin{array}{l}\text { Bulk inventory (Ci) } \\
\text { (wet solids) }\end{array}$ & 221,600 & 269,900 \\
\hline Heat generation (w) & 1,046 & 1,808 \\
\hline
\end{tabular}

The total heat load of the tank is 2,854 W. The volumetric heat generation rate for the waste in the tank based on the solids volume is $1.2 \mathrm{E}-02 \mathrm{~W} / \mathrm{L}$.

Table 6-3. Plutonium/Americium Inventory.

\begin{tabular}{|l|c|c|c|}
\hline & ${ }^{238} \mathrm{Pu}$ & ${ }^{239} \mathrm{Pu}$ & ${ }^{241} \mathrm{Am}$ \\
\hline $\begin{array}{l}\text { Bulk Inventory (Ci) } \\
\text { (wet solids) }\end{array}$ & 0.012 & 232.9 & 90.9 \\
\hline Bulk Inventory (g) & $7.3 \mathrm{E}-04$ & 3,800 & 26.5 \\
\hline
\end{tabular}


Table 6-4. ICP Major Element Inventory (From Fusion Preparation Results).

\begin{tabular}{|l|c|c|c|c|c|c|c|c|c|}
\hline & $\mathrm{Al}$ & $\mathrm{Ca}$ & $\mathrm{Fe}$ & $\mathrm{Na}$ & $\mathrm{N} 1$ & $\mathrm{P}$ & $\mathrm{Pb}$ & $\mathrm{Si}$ & $\mathrm{U}$ \\
\hline $\begin{array}{l}\text { Bulk inventory } \\
\text { (Mg) }\end{array}$ & 19.8 & 5.5 & 6.3 & 23.9 & 7.6 & 5.1 & 1.1 & 2.2 & 2.9 \\
\hline $\begin{array}{l}\text { Weight percent } \\
\text { (wet solids) }\end{array}$ & 7.0 & 1.9 & 2.2 & 8.4 & 2.7 & 1.8 & 0.4 & 0.8 & 1.0 \\
\hline
\end{tabular}

\subsection{COMPARISONS WITH THE BORSHEIM/SIMPSON MODEL ESTIMATES}

Calculations of the ${ }^{137} \mathrm{Cs}$, nickel, and $\mathrm{Fe}(\mathrm{CN})_{6}^{4 \cdot}$ inventories are analytes appropriate for comparison with the model. Assumptions regarding the tank used in the calculations for the analytical estimates, and the calculations themselves, are presented in Appendix A. Table 6-5 presents comparisons of the calculated values with the original and revised Borsheim/Simpson (1991) values after scavenging was finished.

Table 6-5. Comparisons of Initial and Revised Borsheim/Simpson Model Estimates with Values Calculated from Analytical Results.

\begin{tabular}{|l|c|c|c|c|c|}
\hline \multicolumn{1}{|c|}{ Analyte } & \multicolumn{2}{|c|}{ Borsheim/Simpson } & \multicolumn{2}{|c|}{ Revised Borsheim/Simpson } & $\begin{array}{c}\text { Analytical } \\
\text { Estimates }\end{array}$ \\
\hline & Retained & Input & $\begin{array}{c}1.0 \\
\text { (retained) vo1\% }\end{array}$ & $\begin{array}{c}1.5 \\
\text { (retained) vol\% }\end{array}$ & $\begin{array}{c}\text { (from } \\
\text { Section 6.3) }\end{array}$ \\
\hline $\mathrm{Ni}$, moles & 30,200 & 47,300 & $77,800^{1}$ & $77,800^{1}$ & $\begin{array}{c}131,700 \\
68,900^{2}\end{array}$ \\
\hline $\begin{array}{l}737 \mathrm{Cs}, \mathrm{kCi} \\
\text { (decayed to 1993) }\end{array}$ & 91.1 & 142.6 & 142.6 & 142.6 & 221.6 \\
\hline $\begin{array}{l}\mathrm{Fe}(\mathrm{CN})_{6}^{-4}, \\
\text { moles }\end{array}$ & 30,200 & 47,300 & 47,300 & 47,300 & 6,800 \\
\hline
\end{tabular}

Includes the ${ }^{60} \mathrm{Co}$ scavenging contribution.

${ }^{2}$ Based on an average of the ICP acid leach core composites.

Several assumptions must be made to calculate the tank contents before making comparisons to the Borsheim/Simpson model predictions for selected analytes. In addition, several assumptions of that model must be examined because they affect the original predictions regarding the waste in the tanks. These assumptions are that (1) 4.25 vol\% solids formation occurs (which is representative of the U Plant materials, but found not to be representative of the In Farm waste), (2) no additional settling or compaction; (3) negligible waste transfer (input/output) effects; and (4) transfers after the scavenging program did not meaningfully affect the condition of the waste. However, at 
the time they were obtained, these data and assumptions were the best available. As the ferrocyanide program evolved, more and better data became available.

The development of the model provided some preliminary understanding to the condition and distribution of the waste in the tank. Generally, the model gave values that were within \pm 50 percent of the values calculated from the analytical results. Where agreement was not good, further investigation found reasonable sources for the difference. The range of values developed from the model was adequate for defining initial conditions and bounding values; however, for analytes $1 \mathrm{ike}{ }^{90} \mathrm{Sr}$ and ferrocyanide itself, further process history contributed meaningfully to the present inventory in the tank, as determined from laboratory analysis. While further clarification was provided by physical and chemical characterization of flowsheet materials and aging and energetics studies, in this case the flowsheets are only a general guide to the energetics behavior. There are fundamental differences in the make-up of TBP waste and $I C$ and $C W$ wastes. The model functioned well within the constraints placed on its operation and it remains flexible enough to run further trials with new parameters, which have been done and are presented in Appendix A.

As noted previously, the analytical nickel values are biased high, perhaps as much as 100 percent, by the use of a nickel crucible in the ICP fusion assay. In addition, ${ }^{60}$ Co scavenging was done in several of the batches that were settled in tank 241-C-109, adding to the nickel inventory but not contributing to the ferrocyanide content. Approximately $30,500 \mathrm{~g}-\mathrm{mol}$ of additional nickel was added to the tank in these process runs. Therefore, the nickel inventory determined from Borsheim/Simpson (1991) should be adjusted upwards by that amount to account for the additional nickel, because the model only accounted for nickel deposited with ferrocyanide. Agreement between the model values and the analysis-based estimates closes when the analytical bias is considered and with inventory adjustments from the cobalt-scavenging contribution. The ICP acid digestion assay values for the core composites provide concentration values in reasonable agreement with calculated estimates but do not provide a profile of the waste. With all of the caveats associated with it, the nickel assay provides no more than a bounding condition for the ferrocyanide inventory as well as indicating that ferrocyanide was (or is) present.

Values for ${ }^{137} \mathrm{Cs}$ from Borsheim/Simpson (1991) only loosely bound the inventories calculated from the analytical results. The calculated inventory can vary somewhat depending on which core's density and concentration values are used in the computation. While no overt biases were found in the analysis, the concentrated nature of some wastes disposed to tank 241-C-109 may have a ${ }^{137} \mathrm{Cs}$ concentrations high enough to confound inventory estimates and are biased low.

A large degree of uncertainty is associated with the amount of ferrocyanide waste that may have been disposed to the cribs. The original model run had a large amount of solids being discharged, even though the available records indicate that the discharged effluent had only traces of suspended solids in it. The model basis of 4.25 volume percent solids was responsible for this solids loss, and that percentage has been determined to be flawed for this waste type. Simulant studies indicate that while 
4.25 volume percent was an accurate simulation of the $U$ Plant scavenging process, an appropriate solids formation value for the In Farm process is 1.0 to 1.5 volume percent (Jeppson and Wong 1993). This additional information is used to develop better model parameters and waste inventory estimates. A rerun of the model using these new solids formation parameters gives significantly better agreement.

The ferrocyanide inventory calculated from the total cyanide analysis remains $6,800 \mathrm{~g}-\mathrm{mol}$. The revised model value for the estimated remaining ferrocyanide of $47,300 \mathrm{~g}$-mol (the estimated total ferrocyanide used in processing waste through tank $241-(-109)$ is significantly higher than that determined from analytical results. This total cyanide measurement, along with the energetic results, suggests a degradation or aging mechanism of some type. 
WHC-EP-0668

\subsection{QUANTITATIVE/STATISTICAL INTERPRETATION OF THE DATA}

\subsection{INTRODUCTION}

This section contains the results of a statistical analysis of data from three core samples taken from tank 241-C-109. Core 47 consisted of three subsegments (denoted by $B, C$, and $D$ ), core 48 consisted of two subsegments $(C$ and $D)$, and core 49 consisted of three subsegments ( $B, C$, and $D)$. The analyticai results from the cores were used to obtain estimates of the mean concentration of analytes in the waste. In addition, the data was used to evaluate the Analytical Chemistry Laboratory's ability to homogenize subsegments and to construct core composite samples. Composite samples for each core were made from homogenized subsegment waste and a single composite sample was made from the drainable liquids. Two measurements, the sample and the duplicate, were taken from each core composite and subsegment aliquot. For the homogenization test, additional samples and duplicates were taken from two different locations within a single aliquot.

To reduce the amount of time and effort necessary to perform a meaningful statistical analysis, a reduced number of analytes of interest were selected. The analytes of interest from the inductively coupled plasma (ICP) analyses ire aluminum, calcium, iron, sodium, nickel, lead, uranium, and phosphorous. The ICP acid digestion and water leach analyses were performed on the composite core samples. The ICP potassium hydroxide fusion dissolution analyses were performed on both the subsegments and core composite samples. Radiochemical results for the core composite samples were reported for uranium, ${ }^{238} \mathrm{Pu},{ }^{239} / 240 \mathrm{Pu},{ }^{137} \mathrm{Cs}$, and ${ }^{90} \mathrm{Sr}$. A radjochemistry analys is on the subsegments was performed only for ${ }^{137} \mathrm{Cs}$ and ${ }^{90} \mathrm{Sr}$. Each subsegment and core composite sample was analyzed by ion chromatography (IC) for chloride, nitrite, nitrate, phosphate, and sulfate; total cyanide $\left(\mathrm{CN}^{*}\right)$ was determined by an independent procedure. In the following tables (and in Appendix $C$ ), the data are identified by the analysis method and the type of sample preparation (e.g., the notation ICP.acid.Al refers to an ICP analysis, acid digestion for al uminum). The core composite sample results are contained in Table 7-1. The subsegment sample results are contained in Table 7-2. The homogenization test results are contained in Table 7-3. Appendix $C$ contains graphic depictions of the data for core composite and subsegment samples.

A close examination of the data reveal several potential anomalies. The following core composite sample results were an order of magnitude different (lower or higher) than other corresponding core composite sample results.

- Core 48 ICP.acid.A1

- Core 47 ICP.acid.Pb

- Core 48 ICP. fusion.Al

- Core 49 ICP.fusion. Pb

- Core 47 total alpha Pu

- Core $47 \mathrm{Pu}-239 / 240$. 
Table 7-1. Core Composite Data (Units $\mu \mathrm{g} / \mathrm{g}$ Except Radionuclides $\mu \mathrm{C} / \mathrm{g}$ ).

\begin{tabular}{|c|c|c|c|c|c|c|}
\hline Core & \multicolumn{2}{|c|}{47} & \multicolumn{2}{|c|}{48} & \multicolumn{2}{|c|}{49} \\
\hline Analys is & 1 & 2 & 1 & 2 & 1 & 2 \\
\hline $\begin{array}{l}\text { ICP.acid.AI } \\
\text { ICP.acid.Ca } \\
\text { ICP.acid.Fe } \\
\text { ICP.acid. Na } \\
\text { ICP.acid.Ni } \\
\text { ICP.acid.Pb } \\
\text { ICP.acid.U } \\
\text { ICP.acid.P }\end{array}$ & $\begin{array}{l}7.41 e+04 \\
1.95 e+04 \\
3.52 e+04 \\
8.15 e+04 \\
1.46 e+04 \\
9.96 e+03 \\
1.05 e+04 \\
1.84 e+04\end{array}$ & $\begin{array}{l}7.16 e+04 \\
2.05 e+04 \\
2.24 e+04 \\
8.22 e+04 \\
1.49 e+04 \\
7.25 e+03 \\
1.10 e+04 \\
1.84 e+04\end{array}$ & $\begin{array}{l}6.24 e+03 \\
1.44 e+04 \\
1.39 e+04 \\
8.16 e+04 \\
1.63 e+04 \\
5.86 e+02 \\
1.27 e+04 \\
1.45 e+04\end{array}$ & $\begin{array}{l}6.60 e+03 \\
1.07 e+04 \\
2.65 e+04 \\
9.35 e+04 \\
1.47 e+04 \\
6.26 e+02 \\
1.74 e+04 \\
1.96 e+04\end{array}$ & $\begin{array}{l}9.59 e+04 \\
1.38 e+04 \\
8.39 e+03 \\
6.58 e+04 \\
1.31 e+04 \\
9.99 e+02 \\
7.10 e+03 \\
1.17 e+04\end{array}$ & $\begin{array}{l}7.15 \mathrm{e}+04 \\
1.08 \mathrm{e}+04 \\
5.90 \mathrm{e}+03 \\
9.68 \mathrm{e}+04 \\
1.06 \mathrm{e}+04 \\
7.28 \mathrm{e}+02 \\
5.43 \mathrm{e}+03 \\
2.71 \mathrm{e}+04\end{array}$ \\
\hline $\begin{array}{l}\text { ICP. fusion. } A 1 \\
\text { ICP. fusion. } \mathrm{Ca} \\
\text { ICP. fusion. Fe } \\
\text { ICP. fusion. } \mathrm{Na} \\
\text { ICP. fusion. } \mathrm{Pb} \\
\text { ICP. fusion. } \mathrm{U} \\
\text { ICP. fusion.P }\end{array}$ & $\begin{array}{l}1.15 e+05 \\
2.44 e+04 \\
2.02 e+04 \\
8.71 e+04 \\
7.22 e+03 \\
8.75 e+03 \\
2.02 e+04\end{array}$ & $\begin{array}{l}1.19 e+05 \\
2.49 e+04 \\
2.34 e+04 \\
8.72 e+04 \\
7.34 e+03 \\
9.61 e+03 \\
1.96 e+04\end{array}$ & $\begin{array}{c}7.28 e+03 \\
1.68 e+04 \\
2.38 e+04 \\
1.07 e+05 \\
N A \\
2.78 e+04 \\
2.22 e+04\end{array}$ & $\begin{array}{c}9.86 e+03 \\
1.85 e+04 \\
2.06 e+04 \\
9.33 e+04 \\
N A \\
2.17 e+04 \\
1.82 e+04\end{array}$ & $\begin{array}{l}1.20 e+05 \\
1.45 e+04 \\
9.27 e+03 \\
8.18 e+04 \\
8.03 e+02 \\
5.59 e+03 \\
1.77 e+04\end{array}$ & $\begin{array}{c}1.34 \mathrm{e}+05 \\
1.52 \mathrm{e}+04 \\
8.94 \mathrm{e}+03 \\
7.13 \mathrm{e}+04 \\
8.44 \mathrm{e}+02 \\
\mathrm{NA} \\
1.14 \mathrm{e}+04\end{array}$ \\
\hline $\begin{array}{l}\text { ICP.water. } A I \\
\text { ICP. water. Ca } \\
\text { ICP.water. Fe } \\
\text { ICP.water. Na } \\
\text { ICP. water. NI } \\
\text { ICP.water.P }\end{array}$ & $\begin{array}{l}3.36 e+02 \\
1.73 e+02 \\
8.85 e+02 \\
6.60 e+04 \\
1.40 e+02 \\
6.35 e+03\end{array}$ & $\begin{array}{l}4.88 e+02 \\
1.94 e+02 \\
8.72 e+02 \\
6.96 e+04 \\
1.09 e+02 \\
7.63 e+03\end{array}$ & $\begin{array}{c}N A \\
5.93 e+01 \\
1.13 e+03 \\
8.92 e+04 \\
3.34 e+01 \\
1.19 e+04 \\
\end{array}$ & $\begin{array}{c}N A \\
5.97 e+01 \\
1.15 e+03 \\
7.79 e+04 \\
2.85 e+01 \\
5.46 e+03\end{array}$ & $\begin{array}{c}N A \\
8.92 e+01 \\
8.88 e+02 \\
5.89 e+04 \\
5.28 e+01 \\
4.42 e+03\end{array}$ & $\begin{array}{c}N A \\
6.62 e+01 \\
9.44 e+02 \\
6.09 e+04 \\
5.28 e+01 \\
3.90 e+03\end{array}$ \\
\hline $\begin{array}{l}\text { Chloride } \\
\text { Nitrite } \\
\text { Nitrate } \\
\text { Phosphate } \\
\text { Sulfate } \\
\text { Total cyanide } \\
\end{array}$ & $\begin{array}{l}7.00 e+02 \\
3.80 e+04 \\
3.70 e+04 \\
2.01 e+04 \\
7.20 e+03 \\
5.60 e+03\end{array}$ & $\begin{array}{l}7.00 \mathrm{e}+02 \\
4.00 \mathrm{e}+04 \\
3.70 \mathrm{e}+04 \\
2.40 \mathrm{e}+04 \\
8.10 \mathrm{e}+02 \\
5.41 \mathrm{e}+03\end{array}$ & $\begin{array}{l}8.00 e+02 \\
4.20 e+04 \\
4.50 e+04 \\
3.59 e+04 \\
8.90 e+03 \\
1.41 e+04 \\
\end{array}$ & $\begin{array}{l}8.00 \mathrm{e}+02 \\
4.80 \mathrm{e}+04 \\
5.10 \mathrm{e}+04 \\
1.75 \mathrm{e}+04 \\
9.60 \mathrm{e}+03 \\
1.46 \mathrm{e}+04\end{array}$ & $\begin{array}{l}7.00 \mathrm{e}+02 \\
3.80 \mathrm{e}+04 \\
3.50 \mathrm{e}+04 \\
1.35 \mathrm{e}+04 \\
6.20 \mathrm{e}+03 \\
5.64 \mathrm{e}+03\end{array}$ & $\begin{array}{l}7.00 e+02 \\
3.90 e+04 \\
3.70 e+04 \\
1.20 e+04 \\
6.90 e+03 \\
5.59 e+03\end{array}$ \\
\hline $\begin{array}{l}\text { U ( } \mu g / g) \\
\text { Total alpha } \\
\text { (Pu) } \\
\text { Sr-90 } \\
\text { Pu-238 } \\
\text { Pu-239/240 } \\
\text { Cs-137/water } \\
\text { Cs-137/fusion }\end{array}$ & $\begin{array}{l}1.17 \mathrm{e}+01 \\
8.05 \mathrm{e}-01 \\
1.05 \mathrm{e}+03 \\
4.40 \mathrm{e}-05 \\
8.04 \mathrm{e}-01 \\
9.07 \mathrm{e}+00 \\
8.70 \mathrm{e}+02\end{array}$ & $\begin{array}{c}1.22 \mathrm{e}+01 \\
9.49 \mathrm{e}-01 \\
1.30 \mathrm{e}+03 \\
\mathrm{NA} \\
9.48 \mathrm{e}-01 \\
9.40 \mathrm{e}+00 \\
8.77 \mathrm{e}+02\end{array}$ & $\begin{array}{l}3.00 \mathrm{e}+01 \\
6.95 \mathrm{e}-02 \\
1.90 \mathrm{e}+02 \\
7.15 \mathrm{e}-06 \\
6.95 \mathrm{e}-02 \\
7.95 \mathrm{e}+00 \\
1.11 \mathrm{e}+03\end{array}$ & $\begin{array}{c}2.51 \mathrm{e}+01 \\
6.66 \mathrm{e}-02 \\
1.90 \mathrm{e}+02 \\
\mathrm{NA} \\
6.66 \mathrm{e}-02 \\
1.07 \mathrm{e}+01 \\
9.52 \mathrm{e}+02\end{array}$ & $\begin{array}{l}7.63 e+00 \\
6.59 e-02 \\
8.77 e+02 \\
1.11 e-05 \\
6.58 e-02 \\
5.61 e+00 \\
5.47 e+02\end{array}$ & $\begin{array}{r}7.42 \mathrm{e}+00 \\
9.21 \mathrm{e}-02 \\
9.86 \mathrm{e}+02 \\
\mathrm{NA} \\
9.20 \mathrm{e}-02 \\
4.95 \mathrm{e}+00 \\
5.66 \mathrm{e}+02\end{array}$ \\
\hline
\end{tabular}


Table 7-2. Subsegment Data (Unites $\mu \mathrm{g} / \mathrm{g}$ Except Radionuclides $\mu \mathrm{C} / \mathrm{g}$ ).

\begin{tabular}{|c|c|c|c|c|c|c|c|c|c|c|c|c|c|c|c|c|}
\hline \multirow{3}{*}{19} & 10 & 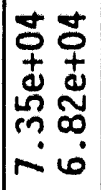 & 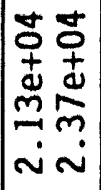 & 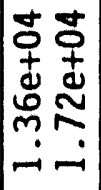 & 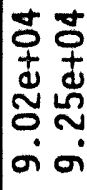 & 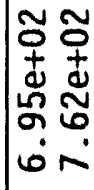 & 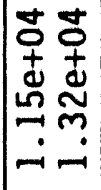 & 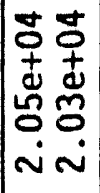 & $\mid \begin{array}{cc}0 & 0 \\
+ & + \\
0 & \pm \\
0 & 8 \\
0 & 0 \\
\infty & \infty\end{array}$ & 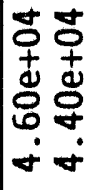 & 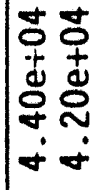 & 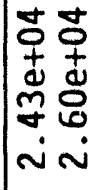 & 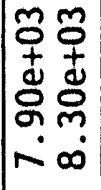 & 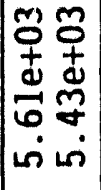 & 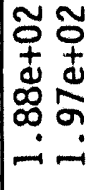 & 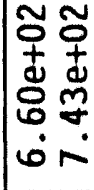 \\
\hline & U & 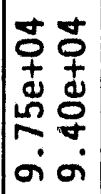 & 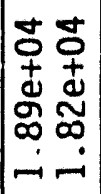 & 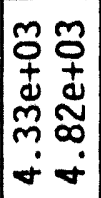 & 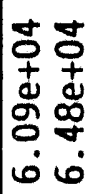 & $\frac{\$}{z} \frac{1}{z}$ & $\$ \Xi$ & 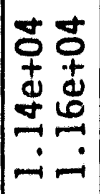 & 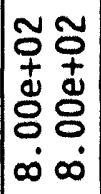 & $\mid \begin{array}{ll}0 & 0 \\
0 & 0 \\
+ & 1 \\
0 & 8 \\
\sim & 0 \\
ن & 0 \\
ن & 0\end{array}$ & 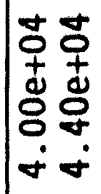 & 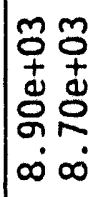 & 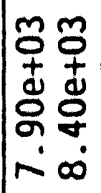 & 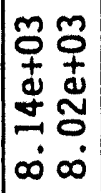 & 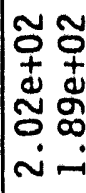 & 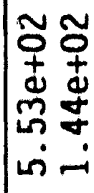 \\
\hline & $\infty$ & 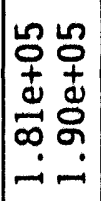 & 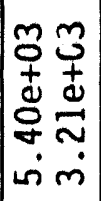 & 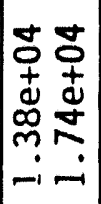 & 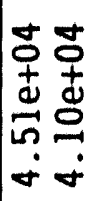 & $\mid \begin{array}{cc}m & 3 \\
0 & 0 \\
+ & + \\
0 & 0 \\
0 & 8 \\
\sim & 9 \\
\sim & -1\end{array}$ & 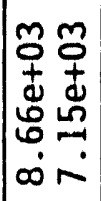 & 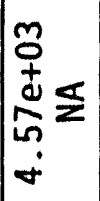 & 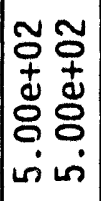 & 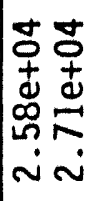 & 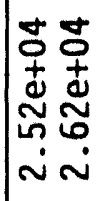 & 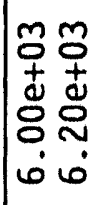 & 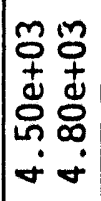 & 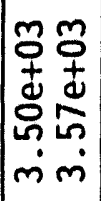 & 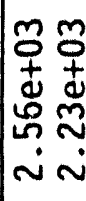 & 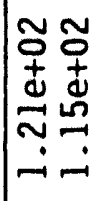 \\
\hline & 0 & 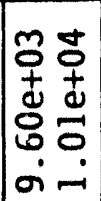 & 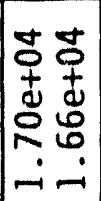 & 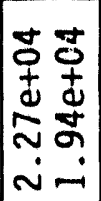 & 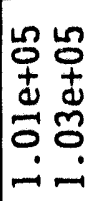 & 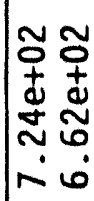 & 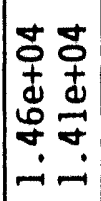 & 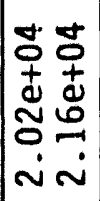 & 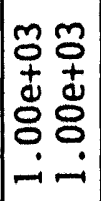 & 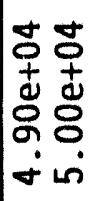 & 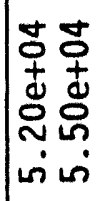 & 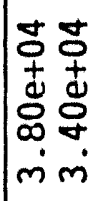 & 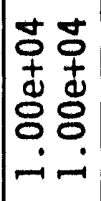 & 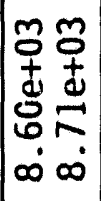 & 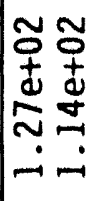 & 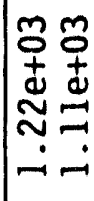 \\
\hline & u & 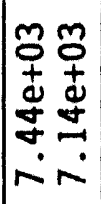 & 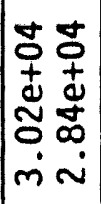 & 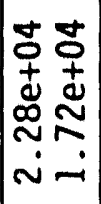 & 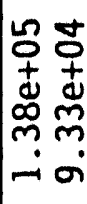 & $\sum \leqq$ & 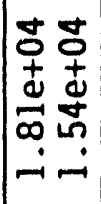 & 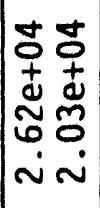 & 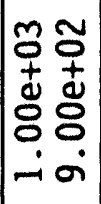 & 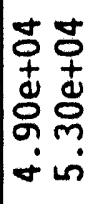 & 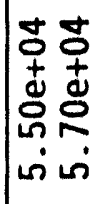 & 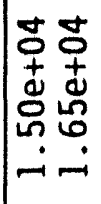 & 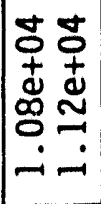 & 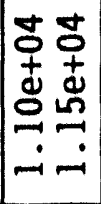 & 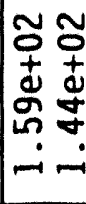 & 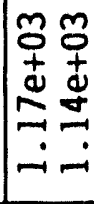 \\
\hline \multirow{3}{*}{18} & 10 & 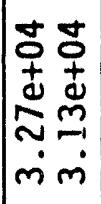 & 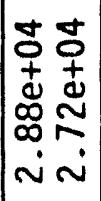 & 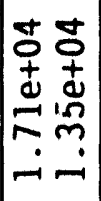 & 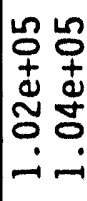 & 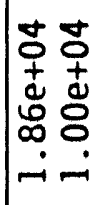 & 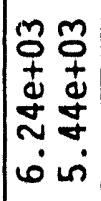 & 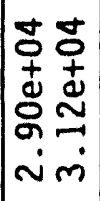 & $\mid \begin{array}{cc}0 & 0 \\
+ & 0 \\
0 & + \\
0 & 0 \\
0 & 0 \\
\infty & 1 \\
\infty\end{array}$ & 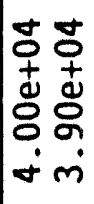 & 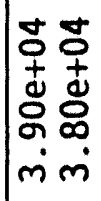 & 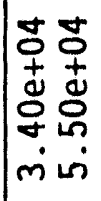 & 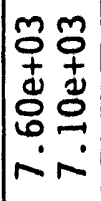 & 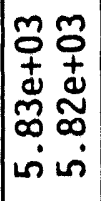 & 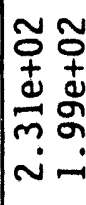 & $\mid \begin{array}{cc}0 & 0 \\
1 & + \\
0 & 0 \\
& \stackrel{\sim}{\sim} \\
\sigma & \sigma\end{array}$ \\
\hline & 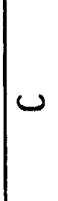 & 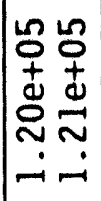 & 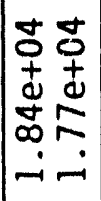 & 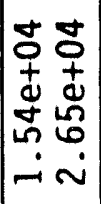 & 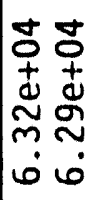 & 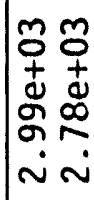 & 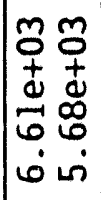 & 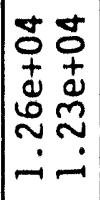 & 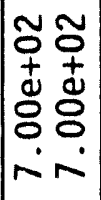 & $\begin{array}{ll} & 0 \\
0 & 0 \\
+ & + \\
0 & d \\
0 & 0 \\
& 0 \\
\dot{m} & \dot{0}\end{array}$ & $\mid \begin{array}{ll} & 0 \\
0 & 0 \\
+ & + \\
0 & 0 \\
0 & 0 \\
0 & 0 \\
\dot{m} & \dot{0}\end{array}$ & 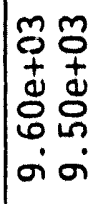 & 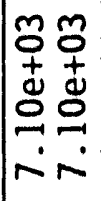 & 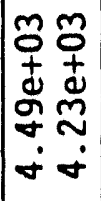 & 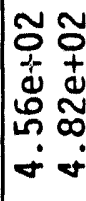 & 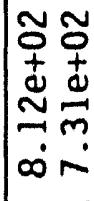 \\
\hline & $\infty$ & 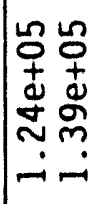 & 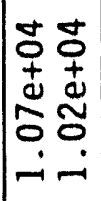 & 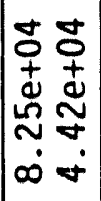 & 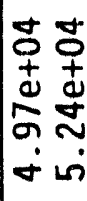 & 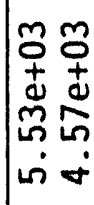 & 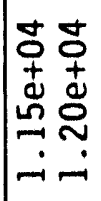 & 㔯 & 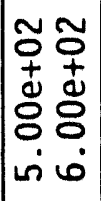 & 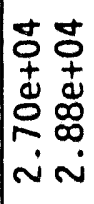 & 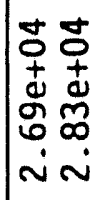 & 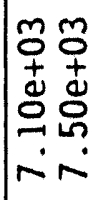 & 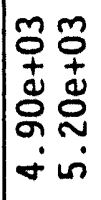 & 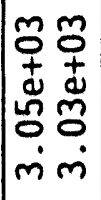 & 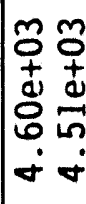 & 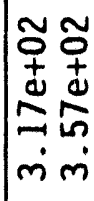 \\
\hline نَ & 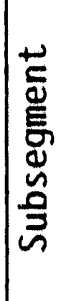 & 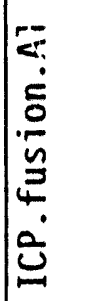 & 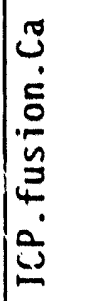 & 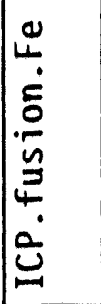 & 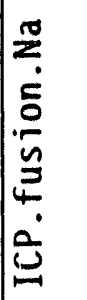 & 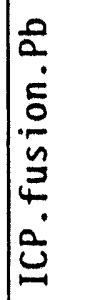 & $\frac{0}{\tilde{c}}$ & $\frac{5}{5}$ & $?$ & 12 & لـ & $\begin{array}{l}0 \\
0 \\
\frac{0}{0} \\
0 \\
0 \\
0\end{array}$ & $\stackrel{+}{\mathscr{\pi}}$ & 音 & 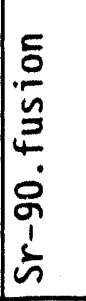 & $\begin{array}{l}\tilde{m} \\
\tilde{1} \\
\dot{y}\end{array}$ \\
\hline
\end{tabular}


Table 7-3. Homogenization Test Data (Units $\mu \mathrm{g} / \mathrm{g}$ Except Radionuclides $\mu \mathrm{Ci} / \mathrm{g}$ ).

\begin{tabular}{|c|c|c|c|c|}
\hline Core & \multicolumn{2}{|c|}{48} & \multicolumn{2}{|c|}{49} \\
\hline Subsegment & $D$ & $D$ & $D$ & $D$ \\
\hline Location & 1 & 2 & 1 & 2 \\
\hline ICP.acid.AI & $\begin{array}{l}8.73 e+03 \\
7.89 e+03\end{array}$ & $\begin{array}{l}9.45 e+03 \\
8.84 e+03\end{array}$ & $\begin{array}{l}3.94 e+04 \\
4.66 e+04\end{array}$ & $\begin{array}{l}4.18 e+04 \\
4.68 e+04\end{array}$ \\
\hline ICP.acid.Ca & $\begin{array}{l}1.53 e+04 \\
1.42 e+04\end{array}$ & $\begin{array}{l}1.73 e+04 \\
1.56 e+04\end{array}$ & $\begin{array}{l}1.46 e+04 \\
1.94 e+04\end{array}$ & $\begin{array}{l}1.69 e+04 \\
1.87 e+04\end{array}$ \\
\hline ICP.acid.Fe & $\begin{array}{l}2.38 e+04 \\
1.37 e+04\end{array}$ & $\begin{array}{l}1.78 e+04 \\
1.68 e+04\end{array}$ & $\begin{array}{l}8.85 e+03 \\
1.15 e+04\end{array}$ & $\begin{array}{l}9.05 e+03 \\
1.12 e+04\end{array}$ \\
\hline ICP.acid. $\mathrm{Na}$ & $\begin{array}{l}1.16 e+05 \\
1.21 e+05\end{array}$ & $\begin{array}{l}9.93 e+04 \\
1.06 e+05\end{array}$ & $\begin{array}{l}1.16 \mathrm{e}+05 \\
8.66 \mathrm{e}+04\end{array}$ & $\begin{array}{l}8.80 e+04 \\
8.01 e+04\end{array}$ \\
\hline ICP.acid.Ni & $\begin{array}{l}1.71 e+04 \\
1.56 e+04\end{array}$ & $\begin{array}{l}1.94 e+04 \\
1.74 e+04\end{array}$ & $\begin{array}{l}1.19 e+04 \\
1.56 e+04\end{array}$ & $\begin{array}{l}1.29 e+04 \\
1.48 e+04\end{array}$ \\
\hline ICP.acid.Pb & $\begin{array}{l}6.17 e+02 \\
5.68 e+02\end{array}$ & $\begin{array}{l}7.23 e+02 \\
6.45 e+02\end{array}$ & $\begin{array}{l}4.85 e+02 \\
6.70 e+02\end{array}$ & $\begin{array}{l}5.08 e+02 \\
6.16 e+02\end{array}$ \\
\hline ICP.acid.U & $\begin{array}{l}1.54 e+04 \\
1.45 e+04\end{array}$ & $\begin{array}{l}1.74 e+04 \\
1.55 e+04\end{array}$ & $\begin{array}{l}9.71 e+03 \\
1.34 e+04\end{array}$ & $\begin{array}{l}1.00 e+04 \\
1.21 e+04\end{array}$ \\
\hline ICP.acid.P & $\begin{array}{l}2.69 e+04 \\
3.08 e+04 \\
\end{array}$ & $\begin{array}{l}1.96 \mathrm{e}+04 \\
2.29 \mathrm{e}+04 \\
\end{array}$ & $\begin{array}{l}3.23 e+04 \\
1.86 e+04\end{array}$ & $\begin{array}{l}2.09 e+04 \\
1.75 e+04 \\
\end{array}$ \\
\hline ICP.fusion. Al & $\begin{array}{l}\text { NA } \\
\text { NA }\end{array}$ & $\begin{array}{l}\text { NA } \\
\text { NA }\end{array}$ & $\begin{array}{l}6 . \overline{17 e+04} \\
6.30 \mathrm{e}+04\end{array}$ & $\begin{array}{l}5.31 e+04 \\
5.59 e+04\end{array}$ \\
\hline ICP. fusion. Ca & $\begin{array}{l}N A \\
N A\end{array}$ & $\begin{array}{l}N A \\
N A\end{array}$ & $\begin{array}{l}2.17 e+04 \\
2.22 e+04\end{array}$ & $\begin{array}{l}2.14 \mathrm{e}+04 \\
2.17 \mathrm{e}+04\end{array}$ \\
\hline ICP. fusion.Fe & $\begin{array}{l}\text { NA } \\
\text { NA }\end{array}$ & $\begin{array}{l}\text { NA } \\
\text { NA }\end{array}$ & $\begin{array}{l}1.37 \mathrm{e}+04 \\
1.41 \mathrm{e}+04\end{array}$ & $\begin{array}{l}1.28 e+04 \\
1.28 e+04\end{array}$ \\
\hline ICP. fusion. $\mathrm{Na}$ & $\begin{array}{l}\text { NA } \\
\text { NA }\end{array}$ & $\begin{array}{l}N A \\
N A\end{array}$ & $\begin{array}{l}9.08 e+04 \\
9.05 e+04 \\
\end{array}$ & $\begin{array}{l}9.02 e+04 \\
8.92 e+04\end{array}$ \\
\hline ICP. fusion. Ni & $\begin{array}{l}\text { NA } \\
\text { NA }\end{array}$ & $\begin{array}{l}\text { NA } \\
\text { NA }\end{array}$ & $\begin{array}{l}N / A \\
N / A\end{array}$ & $\begin{array}{l}N / A \\
N / A\end{array}$ \\
\hline ICP.fusion. $\mathrm{Pb}$ & $\begin{array}{l}N A \\
N A\end{array}$ & $\begin{array}{l}N A \\
N A\end{array}$ & $\begin{array}{l}6.25 e+02 \\
7.45 e+02\end{array}$ & $\begin{array}{l}6.46 e+02 \\
6.50 e+02\end{array}$ \\
\hline ICP. fusion.U & $\begin{array}{l}\text { NA } \\
\text { NA }\end{array}$ & $\begin{array}{l}N A \\
\text { NA }\end{array}$ & $\begin{array}{l}1.23 e+04 \\
1.31 e+04\end{array}$ & $\begin{array}{l}1.08 \mathrm{e}+04 \\
1.18 \mathrm{e}+04\end{array}$ \\
\hline ICP. fusion.P & $\begin{array}{l}\text { NA } \\
\text { NA }\end{array}$ & $\begin{array}{l}\text { NA } \\
\text { NA }\end{array}$ & $\begin{array}{l}1.87 e+04 \\
1.91 e+04\end{array}$ & $\begin{array}{l}1.95 e+04 \\
1.86 e+04\end{array}$ \\
\hline Cs-137. fusion & $\begin{array}{l}N A \\
N A\end{array}$ & $\begin{array}{l}N A \\
N A\end{array}$ & $\begin{array}{l}7.13 e+02 \\
7.50 e+02 \\
\end{array}$ & $\begin{array}{l}6.96 e+02 \\
7.00 e+02\end{array}$ \\
\hline Cs-137.acid & $\begin{array}{l}8.52 e+00 \\
1.66 e+01\end{array}$ & $\begin{array}{l}8.81 e+00 \\
1.43 e+01\end{array}$ & $\begin{array}{l}3.54 e+01 \\
4.34 e+01\end{array}$ & $\begin{array}{l}1.93 e+01 \\
2.74 e+01\end{array}$ \\
\hline
\end{tabular}


Core 47 subsegment $1 B$ results for ICP. fusion. Fe is at least twice as large as its duplicate and all other subsegment data for this analyte.

The following subsegments were different by an order of magnitude (10wer or higher) than other corresponding subsegment results.

- Core 48 subsegments $I C$ and 10 for ICP. fus.AT

- Core 47 and 48 subsegment $1 B$ for fusion.Sr-90.

There is no direct evidence that the results noted above are because of analytical measurement errors. Consequently, the statistical analysis was performed on the data as it is reported in Tables 7-1, 7-2, and 7-3.

\subsection{MEAN CONCENTRATION ESTIMATES}

One objective of the characterization effort was to estimate the analyte concentrations in the waste. This task was accomplished by computing the mean concentrations and 95 percent confidence intervals (CIs) on the mean concentrations. The estimated inventory and CI on the inventory of an ana?yte are the corresponding mean concentration estimates and CI multiplied by the volume of waste in the tank. Bulk inventory estimates based on these values are not given in this document. Table 7-1 contains the core composite data used to compute the mean concentration estimates and the CIs. The NA symbol indicates that the data were not avallable. Results for ${ }^{238} \mathrm{Pu}$ were not included in any computations because there were no duplicate measurements.

The concentration estimates are given in the form of 95 percent CIs on the mean concentration. It is assumed that each sample and duplicate is analyzed independently of one another. The two analytical results are used to estimate the analytical measurement error. Because of the hierarchical structure of the data, the analytical measurement error (variance) alone is not the appropriate error term to use in computing the CIs. A Iinear combination of the analytical measurement variance and spatial variance is the appropriate variance of the mean for the CIs. The variance of the mean is obtained from the analysis of vartance (ANOVA) corresponding to the model. The formulas used to calculate these CIs are given in Jensen and Whitcher (1993). Table 7-4 contains the summary statistics, by analyte, for ICP acid digestion, ICP water leach, ICP KOH\Ni fusion dissolution, radiochemistry, and IC analyses.

Table 7-5 contains the summary statistics for the drainable liquid composite sample. The summary statistics are as follows.

- $y=$ Arithmetic mean of the concentration data

- $\partial^{2}(y)=$ Estimated variance of $y$

- $\quad d f=$ Degrees of freedom associated with BMS

- $95 \% \mathrm{LL}=$ Lower limit to the 95 percent CI on the mean

- $95 \%$ UL - Upper limit to the 95 percent CI on the mean

For some analytes, the lower confidence limit ( $95 \%$ LL) was negative. Because concentrations are strictly greater than or equal to zero, any negative 95 percent $L L$ values were set equal to zero. 
The estimated variance of the mean $\left[\partial^{2}(\bar{y})\right]$ is very large relative to the mean for most of the analytes. One cause is the large differences between core composite samples; 1.e., the large spatial varlability. In Section 7.6, the analytical results from the core composite samples are compared to determine if there are significant differences between cores. A similar comparison is also made between the subsegments within each core.

Table 7-4. Concentration Estimate Statistics (Units $\mu \mathrm{g} / \mathrm{g}$ Except Radionuclide $\mu \mathrm{C} 1 / \mathrm{g}$ ).

\begin{tabular}{|c|c|c|c|c|c|}
\hline Analyte & 9 & $\sigma^{2}(9)$ & $d f$ & $\begin{array}{l}\text { 95\% Lower } \\
\text { Ifmit }\end{array}$ & $\begin{array}{l}95 \% \text { Upper } \\
1 \text { Imit }\end{array}$ \\
\hline $\begin{array}{l}\text { ICP.acid.Al } \\
\text { ICP.acid.Ca } \\
\text { ICP.acid. Fe } \\
\text { ICP.acid. Na } \\
\text { ICP.acid. NI } \\
\text { ICP.acid.Pb } \\
\text { ICP.acid. U } \\
\text { ICP.acid.P }\end{array}$ & $\begin{array}{l}5.43 e+04 \\
1.50 e+04 \\
1.87 e+04 \\
8.36 e+04 \\
1.40 e+04 \\
3.36 e+03 \\
1.07 e+04 \\
1.83 e+04\end{array}$ & $\begin{array}{l}5.84 e+08 \\
6.38 e+06 \\
3.96 e+07 \\
4.02 e+06 \\
1.23 e+06 \\
6.89 e+06 \\
6.40 e+06 \\
4.73 e+05\end{array}$ & $\begin{array}{l}2 \\
2 \\
2 \\
2 \\
2 \\
2 \\
2 \\
2\end{array}$ & $\begin{array}{l}0.00 e+00 \\
4.10 e+03 \\
0.00 e+00 \\
7.49 e+04 \\
9.27 e+03 \\
0.00 e+00 \\
0.00 e+00 \\
1.53 e+04\end{array}$ & $\begin{array}{l}1.58 e+05 \\
2.58 e+04 \\
4.58 e+04 \\
9.22 e+04 \\
1.88 e+04 \\
1.47 e+04 \\
2.16 e+04 \\
2.13 e+04\end{array}$ \\
\hline $\begin{array}{l}\text { ICP. fus. } A 1 \\
\text { ICP. fus. } \mathrm{Ca} \\
\text { ICP. fus. Fe } \\
\text { ICP. fus. } \mathrm{Na} \\
\text { ICP. fus. } \mathrm{Pb} \\
\text { ICP. fus. U } \\
\text { ICP. fus. } P\end{array}$ & $\begin{array}{l}8.40 e+04 \\
1.91 e+04 \\
1.77 e+04 \\
8.79 e+04 \\
4.05 e+03 \\
1.47 e+04 \\
1.82 e+04\end{array}$ & $\begin{array}{l}1.43 e+09 \\
8.50 e+06 \\
1.85 e+07 \\
4.64 e+07 \\
1.04 e+07 \\
3.72 e+07 \\
3.29 e+06\end{array}$ & $\begin{array}{l}2 \\
2 \\
2 \\
2 \\
1 \\
2 \\
2\end{array}$ & $\begin{array}{l}0.00 e+00 \\
6.52 e+03 \\
0.00 e+00 \\
5.86 e+04 \\
0.00 e+00 \\
0.00 e+00 \\
1.04 e+04\end{array}$ & $\begin{array}{l}2.47 e+05 \\
3.16 e+04 \\
3.62 e+04 \\
1.17 e+05 \\
4.51 e+04 \\
4.09 e+04 \\
2.60 e+04\end{array}$ \\
\hline $\begin{array}{l}\text { ICP.water. } \mathrm{Ca} \\
\text { ICP.water. Fe } \\
\text { ICP.water. Na } \\
\text { ICP.water. NI } \\
\text { ICP.water. } \mathrm{P}\end{array}$ & $\begin{array}{l}1.07 e+02 \\
9.78 e+02 \\
7.04 e+04 \\
6.94 e+01 \\
6.61 e+03\end{array}$ & $\begin{array}{l}1.49 e+03 \\
6.61 e+03 \\
4.82 e+07 \\
7.98 e+02 \\
1.74 e+06\end{array}$ & $\begin{array}{l}2 \\
2 \\
2 \\
2 \\
2\end{array}$ & $\begin{array}{l}0.00 e+00 \\
6.28 e+02 \\
4.05 e+04 \\
0.00 e+00 \\
9.31 e+02\end{array}$ & $\begin{array}{l}2.73 \mathrm{e}+02 \\
1.33 \mathrm{e}+03 \\
1.00 \mathrm{e}+05 \\
1.91 \mathrm{e}+02 \\
1.23 \mathrm{e}+04\end{array}$ \\
\hline $\begin{array}{l}\text { Chloride } \\
\text { Nitrite } \\
\text { Nitrate } \\
\text { Phosphate } \\
\text { Sulphate } \\
\text { Total cyanide }\end{array}$ & $\begin{array}{l}7.33 e+02 \\
4.08 e+04 \\
4.03 e+04 \\
2.05 e+04 \\
7.70 e+03 \\
8.46 e+03\end{array}$ & $\begin{array}{l}1.11 e+03 \\
4.36 e+06 \\
1.48 e+07 \\
1.68 e+07 \\
6.48 e+05 \\
8.39 e+06\end{array}$ & $\begin{array}{l}2 \\
2 \\
2 \\
2 \\
2 \\
2\end{array}$ & $\begin{array}{l}5.90 e+02 \\
3.18 e+04 \\
2.38 e+04 \\
2.85 e+03 \\
4.24 e+03 \\
0.00 e+00\end{array}$ & $\begin{array}{l}8.77 e+02 \\
4.98 e+04 \\
5.69 e+04 \\
3.81 e+04 \\
1.12 e+04 \\
2.09 e+04\end{array}$ \\
\hline $\begin{array}{l}U(\mu \mathrm{g} / g) \\
\text { Tot.Alpha.Pu } \\
\text { Sr-90 } \\
\text { Pu-239/240 } \\
\text { Cs-137. water } \\
\text { Cs-137. fusion }\end{array}$ & $\begin{array}{l}1.57 \mathrm{e}+01 \\
3.41 \mathrm{e}-01 \\
7.66 \mathrm{e}+02 \\
3.41 \mathrm{e}-01 \\
7.95 \mathrm{e}+00 \\
8.20 \mathrm{e}+02\end{array}$ & $\begin{array}{l}3.69 e+01 \\
7.17 e-02 \\
8.77 e+04 \\
7.16 e-02 \\
1.78 e+00 \\
1.95 e+04\end{array}$ & $\begin{array}{l}2 \\
2 \\
2 \\
2 \\
2 \\
2\end{array}$ & $\begin{array}{l}0.00 \mathrm{e}+00 \\
0.00 \mathrm{e}+00 \\
0.00 \mathrm{e}+00 \\
0.00 \mathrm{e}+00 \\
2.21 \mathrm{e}+00 \\
2.20 \mathrm{e}+02\end{array}$ & $\begin{array}{l}4.18 e+01 \\
1.49 e+00 \\
2.04 e+03 \\
1.49 e+00 \\
1.37 e+01 \\
1.42 e+03\end{array}$ \\
\hline
\end{tabular}


Table 7-5. Concentration Estimates Statistics, Drainable Liquid, (Units $\mu \mathrm{g} / \mathrm{g}$ ).

\begin{tabular}{|l|c|c|c|c|c|}
\hline \multicolumn{1}{|c|}{ Analyte } & $y$ & $\sigma^{2}(y)$ & $\begin{array}{c}\text { Degrees of } \\
\text { freedom }\end{array}$ & $\begin{array}{c}95 \% \text { Lower } \\
1 \text { Imlt }\end{array}$ & $\begin{array}{c}95 \% \text { Upper } \\
1 \text { Imit }\end{array}$ \\
\hline ICP.acid.AI & $1.57 e+02$ & $1.50 e+01$ & 1 & $1.08 e+02$ & $2.06 e+02$ \\
ICP.acid.Ca & $2.09 e+02$ & $1.74 e+01$ & 1 & $1.56 e+02$ & $2.62 e+02$ \\
ICP.acid.Fe & $1.67 e+03$ & $5.56 e+02$ & 1 & $1.38 e+03$ & $1.97 e+03$ \\
ICP.acid.Na & $9.69 e+04$ & $2.66 e+01$ & 1 & $9.69 e+04$ & $9.70 e+04$ \\
ICP.acid.Ni & $3.44 e+02$ & $1.03 e+01$ & 1 & $3.03 e+02$ & $3.84 e+02$ \\
ICP.acid.Pb & NA & NA & NA & 0.00 & 0.00 \\
ICP.acid.U & NA & NA & NA & 0.00 & 0.00 \\
ICP.acid.P & $4.20 e+03$ & $9.65 e+02$ & 1 & $3.80 e+03$ & $4.59 e+03$ \\
\hline Chloride & $1.30 e+03$ & NA & NA & NA & NA \\
Nitrite & $7.10 e+04$ & NA & NA & NA & NA \\
Nitrate & $7.20 e+04$ & NA & NA & NA & NA \\
Phosphate & $1.35 e+04$ & NA & NA & NA & NA \\
Sulphate & $1.28 e+04$ & NA & NA & NA & NA \\
\hline
\end{tabular}

\subsection{HOMOGENIZATION TEST}

Another task in the characterization effort was to evaluate the ability of the Analytical Chemistry Laboratory to homogenize subsegments. Subsegment $D$, from Cores 47,48 , and 49 , was homogenized and arbitrarily divided into two parts. One subsample was obtained from each part. Two aliquots were taken from each subsample and prepared for chemical analysis. The homogenization test data is given in Table 7-3. ICP acid digestion and fusion dissolution analyses were conducted on the samples for the following analytes: aluminum, iron, sodium, nickel, lead, urantum, and phosphorus, Acid digestion and fusion dissolution results were also reported for ${ }^{137} \mathrm{Cs}$.

Because of the nested structure (subsamples within segments, aliquots within subsamples) within the data, a hierarchical statistical model was fit to the data. A description of this type of model is contained in snedecor and Cochran (1980). Such a model is used to estimate different components of variability in the data. The total variability in the data is decoupled into three components; one because of variability between subsegments, one because of the varlability between samples taken from different locations on each homogenized subsegment $\left[\sigma^{2}(L)\right]$, and one because of the analytical measurement error $\left[\sigma^{2}(A)\right]$. The analytical measurement error accounts for the differences between aliquots taken from the same location.

To quantify the contribution of $\sigma^{2}(L)$ (the component of variability because of location or homogenization), the ANOVA corresponding to the hierarchical model is used. From the ANOVA, a test is constructed to determine if $\sigma^{2}(L)$ is significantly different from zero. If $\sigma^{2}(L)$ is significantly different from zero, then the laboratory does not have the ability to homogenize subsegments. If $\sigma^{2}(L)$ is not significantly different. from zero, then the laboratory has the ability to homogenize core segments. 
The reason underlying this test is that if $\sigma^{2}(L)=0$, then the mean concentrations at the two locations are equal, 1.e., there is no difference between the locations.

The F-test is used to determine whether or not $\sigma^{2}(L)$ is significantly different from zero. The $p-v a l u e s$ (the attalned level of significance) from thiese tests are given in Table 7-6. If the $p$-value is smaller than 0.05 , then $\sigma^{2}(L)$ is significantly different from zero. In all but one case (ICP. fus.AI). the $p$-values are greater than 0.05 . This indicates that except for this analyte, $\sigma^{2}(L)$ is not significantly different from zero. Based on the results of this statistical test, it can be concluded that the Analytical Chemistry Laboratory can adequately homogentze core segments. However, it needs to be noted that there is no reference value avallable to check the degree of homogenization. That is, the differences between the results from the two locations must be within two percent of each other. If such a value were avallable, the conclusions in this section may not be valid.

Table 7-6. Homogenization Test Statistical Results.

\begin{tabular}{|l|c|c|c|c|c|c|c|c|c|}
\hline \multicolumn{10}{|c|}{ Test: $\sigma^{2}(L)=0$-value } \\
\hline Analyte & Aluminum & Calcium & Iron & Sodium & Nickel & Lead & Uranlum & Phosphorus & TS $C$ \\
\hline Acid & 0.890 & 0.649 & 0.922 & 0.229 & 0.551 & 0.572 & 0.667 & 0.290 & 0.214 \\
\hline Fusion & 0.036 & 0.389 & 0.072 & 0.216 & NA & 0.606 & 0.164 & 0.706 & 0.092 \\
\hline
\end{tabular}

\subsection{COMPARISON WITH A SIMULATED CORF COMPOSITE MEAN}

The ability of the Analytical Chemistry Laboratory to make core composite samples from the individual subsegment samples was also evaluated. Core composite samples were formed by combining aliquots from each homogenized subsegment in the core. Each subsegment is weighted equally in the composite sample. Each core composite sample was homogenized, and a sample and duplicate value were obtained. A simulated core composite (SCC) was statistically constructed to compare to the corresponding core composite sample results. For each analyte and each core, the SCC s are the average of the subsegment results. This mean or average is denoted by $\bar{y}(w)$. The $w$ is used because $\bar{y}(w)$ is generally a welghted mean. However, in this case the welghts are all equal.

For each core, the comparison between the core composite and the SCC is made by computing a CI on the difference between the SCC and the mean of the composite sample. If zero is in the $\mathrm{Cl}$, then the laboratory can construct core composite samples satisfactorily (i.e., the SCC cannot be statistically distinguished from the core composite sample mean). If zero is not in the CI, then the laboratory cannot satisfactorily construct core composites (i.e., the 
two means are significantly different). The Cl for this difference is (LL, UL) where the lower $11 \mathrm{~m} 1 \mathrm{t}$ (LL) and upper 1 imit (UL) values are

$$
L L=[\bar{y}(w)-\bar{y}(c)]-t \sqrt{\sigma^{2}[\bar{y}(w)-\bar{y}(c)]}, U L=[\bar{y}(w)-\bar{y}(c)]+t \sqrt{\sigma^{2}[\bar{y}(w)-\bar{y}(c)]}
$$

where:

$$
\begin{aligned}
& g(c) \text { - Mean of the two core composite sample results } \\
& \partial^{2}[g(w)-g(c)] \text { - Percant } 1 \text { le point from student's the estimated variance of the difference. }
\end{aligned}
$$

Appendix $C$ outlines the mothod used to calculato $\sigma^{2}[g(w)-g(c)]$. The estimated variance $\sigma^{2}[g(w)-g(c)]$ was calculated using the data from all three cores because of the 1 imited information avallable. The degrees of freedom (df) assoclated with t were calculated using Satterthwalte's approximation (Snedecor and Cochran 1980). In the above equations, $g(w)$ and $g(c)$ should have a subscript indicating the core. To simplify the notation, the subscript was onitted.

Table 7-7 contains summary statistics for all chree cores, including the 95 percent $\mathrm{CI}$ interval (LL, UL) on the difference between the SCC mean and the core composite mean. Ali of the CIs on this difference contain zero. This indicates that there is no significant difference between the two means (1.e.. the Analytical Chemistry Laboratory can construct a core composite sample from material simflar to cores 47,48, and 49). Note that the CIs on, the difference between the two means tends to be rather wide; 1.e., $L L=-10^{9}$ or $-10^{4}$ and $U L=+10^{3}$ or $+10^{4}$. The reason for this extrame width is the magnitude of the estimated variance $\sigma^{2}[g(w)-g(c)]$ and the small number of df. Because the variance is large, the two means would have to be extremely different before zero is not in the $\mathrm{Cl}$.

\subsection{THE SPATIAL VARIANCE AMD AMALYTICAL MEASUREMENT VARIANCE}

Using the hierarchical structure of the core composite data, the spatial variance and the analytical measurement variance can be separated from each other. The spatial varlance is a measure of the varlability between cores. The analytical measurement variance includes among other things, the segment homogenization error, the sample handling error, and the chemical analysis error. This variance is a function of the difference between the analytical results on the sample and duplicate values.

The size of the analytical measurement variance and the spatial variance, along with the df, determines the width of the CIs. The estimate of the varlance of the mean is a linear function of the spatial and analytical measurement vartances. To help judge the magnitude of these two variance components, this section contains explicit estimates of gach variance and CIs for each variance. Estjmates of the spatial variance $\left[\sigma^{2}(S)\right]$ and analytical measurement variance $\left[\sigma^{2}(A)\right]$ were obtained for each analyte using the Restricted Maximum Likel thood Estimation. This method is discussed in further 
WHC-EP-0668

Table 7-7. Comparison of Simulated Core Composite with the Core Composite.

\begin{tabular}{|c|c|c|c|c|c|c|c|}
\hline ore & Analyte & $g(w)$ & $g(c)$ & $\begin{array}{c}\sigma^{2}[g(w)- \\
g(c)]\end{array}$ & $\begin{array}{l}\text { Degreas } \\
\text { of } \\
\text { freedom }\end{array}$ & $\begin{array}{l}\text { 95\% Lower } \\
\text { Timit }\end{array}$ & $\begin{array}{c}95 \% \\
\text { Upper } \\
1 \text { imit }\end{array}$ \\
\hline 47 & $\begin{array}{l}\text { ICP. fus. Al } \\
\text { ICP. fus. Ca } \\
\text { ICP. fus. Fe } \\
\text { ICP. fus. Na } \\
\text { ICP. fus. Pb } \\
\text { ICP. fus. U } \\
\text { ICP. fus.P } \\
\text { ChIoride } \\
\text { NItrite } \\
\text { NItrate } \\
\text { Phosphate } \\
\text { SuIfate } \\
\text { Total Cyanide } \\
\text { Sr-90 } \\
\text { Cs-137. fus }\end{array}$ & $\begin{array}{l}9.46 e+04 \\
1.88 e+04 \\
3.32 e+04 \\
7.23 e+04 \\
7.41 e+03 \\
7.92 e+03 \\
1.68 e+04 \\
6.67 e+02 \\
3.48 e+04 \\
3.40 e+04 \\
2.05 e+04 \\
6.50 e+03 \\
4.41 e+03 \\
1.75 e+03 \\
6.85 e+02 \\
\end{array}$ & $\begin{array}{l}1.17 e+05 \\
2.47 e+04 \\
2.18 e+04 \\
8.72 e+04 \\
7.28 e+03 \\
9.04 e+03 \\
1.99 e+04 \\
7.00 e+02 \\
3.90 e+04 \\
3.70 e+04 \\
2.21 e+04 \\
7.30 e+03 \\
5.51 e+03 \\
1.18 e+03 \\
8.74 e+02 \\
\end{array}$ & $\begin{array}{l}5.79 \\
4.75 \\
1.60 \\
4.08 \\
3.00 \\
1.15 \\
3.41 \\
1.50 \\
4.40 \\
9.11 \\
1.16 \\
3.80 \\
2.89 \\
1.09\end{array}$ & $\begin{array}{l}3 \\
6 \\
8 \\
7 \\
2 \\
2 \\
9 \\
5 \\
7 \\
5 \\
7 \\
5 \\
2 \\
9 \\
5 \\
\end{array}$ & $\begin{array}{l}-2 . \\
-1 . \\
-6 . \\
-2 . \\
-4 . \\
-1 . \\
-3 . \\
-1.5 \\
-2.9 \\
-2.9 \\
-5.8 \\
-2.5 \\
-1.7 \\
-1.0\end{array}$ & $\begin{array}{l}1.10 \theta+04 \\
4.05 e+04 \\
3.29 e+04 \\
2.37 e+04 \\
4.50 e+04 \\
1.02 e+04 \\
2.81 e+02 \\
1.15 e+04 \\
2.160+04 \\
2.39 e+04 \\
4.21 e+03\end{array}$ \\
\hline 48 & $\begin{array}{l}\text { ICP. fus. AI } \\
\text { ICP. fus. Ca } \\
\text { ICP. fus. Fe } \\
\text { ICP. fus. Na } \\
\text { ICP. fus. Pb } \\
\text { ICP. fus. U } \\
\text { ICP. fus. P } \\
\text { Chloride } \\
\text { NItrite } \\
\text { Nitrate } \\
\text { Phosphate } \\
\text { Sulfate } \\
\text { Total cyanide } \\
\text { Sr-90 } \\
\text { Cs-137. fus } \\
\end{array}$ & $\begin{array}{l}8.56 e+03 \\
2.30 e+04 \\
2.05 e+04 \\
1.09 e+05 \\
6.93 e+02 \\
1.55 e+04 \\
2.21 e+04 \\
9.75 e+02 \\
5.03 e+04 \\
5.48 e+04 \\
2.59 e+04 \\
1.05 e+04 \\
9.95 e+03 \\
1.36 e+02 \\
1.16 e+03 \\
\end{array}$ & $\begin{array}{l}8.57 \theta+03 \\
1.77 e+04 \\
2.22 \theta+04 \\
1.00 e+05 \\
N A \\
2.47 e+04 \\
2.02 \theta+04 \\
8.00 e+02 \\
4.50 e+04 \\
4.80 e+04 \\
2.67 e+04 \\
9.25 e+03 \\
1.44 e+04 \\
1.90 \theta+02 \\
1.03 \theta+03 \\
\end{array}$ & $\begin{array}{l}6.53 e+09 \\
5.84 e+07 \\
2.12 e+08 \\
5.42 e+08 \\
4.83 e+07 \\
1.18 e+08 \\
4.63 e+07 \\
2.08 e+04 \\
5.95 e+07 \\
1.15 e+08 \\
1.49 e+08 \\
4.73 e+06 \\
3.05 e+07 \\
1.50 e+06 \\
1.49 e+05 \\
\end{array}$ & $\begin{array}{c}4 \\
7 \\
8 \\
7 \\
N A \\
2 \\
9 \\
5 \\
6 \\
5 \\
8 \\
5 \\
3 \\
9 \\
5\end{array}$ & \begin{tabular}{|c|}
$-2.24 e+05$ \\
$-1.27 e+04$ \\
$-3.52 e+04$ \\
$-4.62 e+04$ \\
$N A$ \\
$-5.60 e+04$ \\
$-1.35 e+04$ \\
$-1.96 e+02$ \\
$-1.36 e+04$ \\
$-2.08 e+04$ \\
$-2.90 e+04$ \\
$-4.34 e+03$ \\
$-2.20 e+04$ \\
$-2.82 \theta+03$ \\
$-8.64 e+02$
\end{tabular} & $\begin{array}{l}2.24 e+05 \\
2.35 e+04 \\
3.18 e+04 \\
6.39 e+04 \\
N A \\
3.76 e+04 \\
1.73 e+04 \\
5.46 e+02 \\
2.41 e+04 \\
3.43 e+04 \\
2.73 e+04 \\
6.84 e+03 \\
1.32 e+04 \\
2.72 e+03 \\
1.12 e+03\end{array}$ \\
\hline 49 & $\begin{array}{l}\text { ICP. fus.AI } \\
\text { ICP. fus. Ca } \\
\text { ICP. fus. Fe } \\
\text { ICP. fus. Na } \\
\text { ICP. fus. Pb } \\
\text { ICP. fus. U } \\
\text { ICP. fus.P } \\
\text { Chloride } \\
\text { Nitrite } \\
\text { Nitrate } \\
\text { Phosphate } \\
\text { Sulfate } \\
\text { Total cyanide } \\
\text { Sr-90 } \\
\text { Cs-137.fus }\end{array}$ & $\begin{array}{l}1.17 \theta+05 \\
1.51 \theta+04 \\
1.19 \theta+04 \\
6.58 \theta+04 \\
1.36 \theta+03 \\
1.24 \theta+04 \\
1.21 \theta+04 \\
7.00 e+02 \\
3.83 \theta+04 \\
3.69 e+04 \\
1.34 \theta+04 \\
6.97 e+03 \\
5.71 \theta+03 \\
9.28 \theta+02\end{array}$ & \begin{tabular}{|l|}
$1.27 e+05$ \\
$1.49 e+04$ \\
$9.10 e+03$ \\
$7.65 e+04$ \\
$8.23 e+02$ \\
$5.59 e+03$ \\
$1.46 e+04$ \\
$7.00 e+02$ \\
$3.85 e+04$ \\
$3.60 e+04$ \\
$1.28 e+04$ \\
$6.55 e+03$ \\
$5.62 e+03$ \\
$9.32 e+02$
\end{tabular} & $\begin{array}{l}5.79 e+09 \\
4.75 e+07 \\
1.60 e+08 \\
4.08 e+08 \\
3.45 \theta+07 \\
1.18 \theta+08 \\
3.41 \theta+07 \\
1.50 e+04 \\
4.40 e+07 \\
9.11 \theta+07 \\
1.16 e+08 \\
3.80 e+06 \\
2.89 e+07 \\
1.09 e+06\end{array}$ & $\begin{array}{l}3 \\
6 \\
8 \\
7 \\
3 \\
2 \\
9 \\
5 \\
7 \\
5 \\
7 \\
5 \\
2 \\
0\end{array}$ & $\begin{array}{l}-2.51 e+05 \\
-1.66 e+04 \\
-2.64 e+04 \\
-5.85 e+04 \\
-1.82 e+04 \\
-4.00 e+04 \\
-1.57 e+04 \\
-3.14 e+02 \\
-1.59 e+04 \\
-2.36 e+04 \\
-2.49 e+04 \\
-4.59 e+03 \\
-2.30 e+04 \\
-2.36 e+03 \\
-1.05 e+03\end{array}$ & $\begin{array}{l}2.33 e+05 \\
1.71 e+04 \\
3.19 e+04 \\
3.70 e+04 \\
1.92 e+04 \\
5.36 e+04 \\
1.08 e+04 \\
3.14 e+02 \\
1.55 e+04 \\
2.54 e+04 \\
2.61 e+04 \\
5.43 e+03 \\
2.32 e+04 \\
2.36 e+03\end{array}$ \\
\hline
\end{tabular}

df - Degrees of freedom. 
detall in Harville (1977). In addition, general methods have been outlined that can be used to obtain CIs for $\partial^{2}(S)$ and $\partial^{2}(A)$ (Snedecor and Cochran 1980). These CI techniques are the methods used in this document. The CI for $\partial^{2}(S)$ is approximate, however the CI for $\partial^{2}(A)$ is exact.

Tables 7-8 and 7-9 contain estimates of the variance components and thetr 95 percent CIs. For 85 percent of the analytes (28 out of 33 ), the estimates of spatial variance are larger than those for the analytical error. This large spatial varlability contributes to the extreme width of the CI for the mean concentrations and the $\mathrm{Cl}$ on the difference between the mathematicallyderived core composite and the actual core composite sample.

\subsection{MULTIPLE COMPARISONS: CORE COMPOSITE SAMPLES AND SUBSEGMENT SAMPLES}

A group of statistical methods known as multiple comparisons can be used to determine whether or not there are significant differences between core composite samples and between subsegment samples. These differences 1.111 help determine the heterogeneity or layers within the waste. In addition, if significant differences exist between the core composite samples or the subsegment samples, this will help explain the extreme width of the CIs; $1 . e .$, it will help explain the large spattal vartability. The multiple comparison procedure known as Tukey's Honestly Significant Difference (HSD) (Petersen 1985) was used. The HSD procedure determines if there are significant differences between core composite samples and between subsegment samples. The core composite samples and subsegment samples that are not significantly different from each other can then be grouped together.

For each analyte, HSD comparisons were made between the means of the core composite samples. These comparisons, along with the means for each core composite sample, are contained in Table 7-10. The symbols $\alpha$ and $B$ are used to indicate groupings. The means of core composite samples with the same symbol cannot be statistically distinguished from each other. Core composite samples with different symbols are significantly different from each other. For a given analyte, the core composite samples with an $\alpha$ have a smaller mean concentration that the core composite samples with a $B$. A dash indicates that nc data were available. The HSD comparisons are not based on the spatial variance. They are however, a function of the analytical measurement varlance.

From Table 7-10, it is evident that the mean concentration of 12 out of 31 (39 percent) analytes are not significantly different between the cores. That is, for these analytes there is no evidence of heterogeneity within the waste. For the remaining 19 (61 percent) analytes there is a significant difference between the mean concentrations. This indicates significant heterogeneity or spatial variability within the waste. These significant differences inflate the between core variance (spatial variance). This inflated variance helps explain why the CIs are so wide. 
Table 7-8. 95 Percent Confidence Interval on $\sigma^{2}(A)$, Analytical Error Variance.

\begin{tabular}{|c|c|c|c|c|}
\hline Analyte & $\partial^{2}(A)$ & $\begin{array}{l}\text { degrees of } \\
\text { freedom }\end{array}$ & $\begin{array}{l}95 \% \text { Lower } \\
1 \text { l mit }\end{array}$ & $\begin{array}{l}95 \% \text { Upper } \\
1 \text { imit }\end{array}$ \\
\hline $\begin{array}{l}\text { ICP.acid.AI } \\
\text { ICP. acid.Ca } \\
\text { ICP.acid. Fe } \\
\text { ICP. acid. Na } \\
\text { ICP. acid. NI } \\
\text { ICP.acid.Pb } \\
\text { ICP. acid.U } \\
\text { ICP.acid.P }\end{array}$ & $\begin{array}{l}1.00 e+08 \\
3.91 e+06 \\
5.45 e+07 \\
1.20 e+08 \\
1.47 e+06 \\
1.23 e+06 \\
4.18 e+06 \\
2.75 e+07\end{array}$ & $\begin{array}{l}3 \\
3 \\
3 \\
3 \\
3 \\
3 \\
3 \\
3\end{array}$ & $\begin{array}{l}3.21 e+07 \\
1.25 e+06 \\
1.75 e+07 \\
5.89 e+07 \\
4.72 e+05 \\
3.96 e+05 \\
1.34 e+06 \\
1.41 e+07\end{array}$ & $\begin{array}{l}1.39 \mathrm{e}+09 \\
5.43 \mathrm{e}+07 \\
7.57 \mathrm{e}+08 \\
2.55 \mathrm{e}+09 \\
2.04 \mathrm{e}+07 \\
1.71 \mathrm{e}+07 \\
5.81 \mathrm{e}+07 \\
6.09 \mathrm{e}+08 \\
\end{array}$ \\
\hline $\begin{array}{l}\text { ICP. fus. Al } \\
\text { ICP. fus. Ca } \\
\text { ICP. fus. Fe } \\
\text { ICP. fus. Na } \\
\text { ICP. fus. Pb } \\
\text { ICP. fus. U } \\
\text { ICP. fus. P }\end{array}$ & $\begin{array}{l}3.71 e+07 \\
6.47 e+05 \\
3.38 e+06 \\
4.97 e+07 \\
3.71 e+03 \\
9.45 e+06 \\
9.43 e+06 \\
\end{array}$ & $\begin{array}{l}3 \\
3 \\
3 \\
3 \\
2 \\
2 \\
3 \\
\end{array}$ & $\begin{array}{l}1.19 e+07 \\
2.08 \mathrm{e}+05 \\
1.08 \mathrm{e}+06 \\
1.59 \mathrm{e}+07 \\
1.00 \mathrm{e}+03 \\
2.57 \mathrm{e}+06 \\
3.03 \mathrm{e}+06 \\
\end{array}$ & $\begin{array}{l}5.15 e+08 \\
8.98 e+06 \\
4.70 e+07 \\
6.90 e+08 \\
1.47 e+05 \\
3.74 e+08 \\
1.31 e+08 \\
\end{array}$ \\
\hline $\begin{array}{l}\text { ICP. water. } \mathrm{Ca} \\
\text { ICP. water. Fe } \\
\text { ICP. water. } \mathrm{Na} \\
\text { ICP. water. } \mathrm{Ni} \\
\text { ICP. water. } \mathrm{P}\end{array}$ & $\begin{array}{l}1.67 e+02 \\
6.20 e+02 \\
2.40 e+07 \\
1.66 e+02 \\
7.27 e+06 \\
\end{array}$ & $\begin{array}{l}3 \\
3 \\
3 \\
3 \\
3 \\
\end{array}$ & $\begin{array}{l}5.35 e+01 \\
1.99 e+02 \\
7.70 e+06 \\
5.33 e+01 \\
2.33 e+06 \\
\end{array}$ & $\begin{array}{l}2.32 e+03 \\
8.62 e+03 \\
3.33 e+08 \\
2.31 e+03 \\
1.01 e+08 \\
\end{array}$ \\
\hline $\begin{array}{l}\text { Chloride } \\
\text { Nitrite } \\
\text { Nitrate } \\
\text { Phosphate } \\
\text { Sulphate } \\
\text { Total cyanide } \\
\end{array}$ & $\begin{array}{c}0.00 \\
6.83 e+06 \\
6.67 e+06 \\
5.93 e+07 \\
1.70 e+05 \\
2.14 e+04 \\
\end{array}$ & $\begin{array}{l}3 \\
3 \\
3 \\
3 \\
3 \\
3 \\
\end{array}$ & $\begin{array}{c}0.00 \\
2.19 e+06 \\
2.14 e+06 \\
1.90 e+07 \\
5.45 e+04 \\
6.88 e+03 \\
\end{array}$ & $\begin{array}{c}0.00 \\
9.49 \mathrm{e}+07 \\
9.26 \mathrm{e}+07 \\
8.24 \mathrm{e}+08 \\
2.36 \mathrm{e}+06 \\
2.98 \mathrm{e}+05 \\
\end{array}$ \\
\hline $\begin{array}{l}U(\mu \mathrm{g} / \mathrm{g}) \\
\text { Tot.Alpha.Pu } \\
\text { Sr-90 } \\
\text { Pu-239/240 } \\
\text { Cs-137. Water } \\
\text { Cs-137. fuston }\end{array}$ & $\begin{array}{l}4.05 e+00 \\
3.57 e-03 \\
1.24 e+04 \\
3.57 e-03 \\
1.35 e+00 \\
4.23 e+03\end{array}$ & $\begin{array}{l}3 \\
3 \\
3 \\
3 \\
3 \\
3\end{array}$ & $\begin{array}{l}1.30 e+00 \\
1.15 e-03 \\
3.98 e+03 \\
1.15 e-03 \\
4.34 e-01 \\
1.36 e+03\end{array}$ & $\begin{array}{l}5.63 e+01 \\
4.9 \varepsilon e-02 \\
1.72 e+05 \\
4.96 e-02 \\
1.88 e+01 \\
5.87 e+04\end{array}$ \\
\hline
\end{tabular}


Table 7-9. 95 Percent Confidence Interval on $\sigma^{2}(S)$, Spatial Variance.

\begin{tabular}{|c|c|c|c|c|c|}
\hline Analyte & $\sigma^{2}(S)$ & $\begin{array}{c}\text { degrees of } \\
\text { freedom }\end{array}$ & p-value & $\begin{array}{l}95 \% \text { Lower } \\
1 \text { imit }\end{array}$ & $\begin{array}{c}95 \% \text { Upper } \\
1 \text { imit }\end{array}$ \\
\hline $\begin{array}{l}\text { ICP.acid.Al } \\
\text { ICP.acid.Ca } \\
\text { ICP.acid.Fe } \\
\text { ICP.acid. Na } \\
\text { ICP.acid.NI } \\
\text { ICP.acid.Pb } \\
\text { ICP.acid.U } \\
\text { ICP.acid.P }\end{array}$ & $\begin{array}{c}1.70 \mathrm{e}+09 \\
1.72 \mathrm{e}+07 \\
9.14 \mathrm{e}+07 \\
0.00 \\
2.95 \mathrm{e}+06 \\
2.00 \mathrm{e}+07 \\
1.71 \mathrm{e}+07 \\
0.00\end{array}$ & $\begin{array}{l}2 \\
2 \\
2 \\
2 \\
2 \\
2 \\
2 \\
2\end{array}$ & $\begin{array}{l}0.008 \\
0.048 \\
0.130 \\
0.882 \\
0.110 \\
0.009 \\
0.053 \\
0.939\end{array}$ & $\begin{array}{c}2.57 e+08 \\
0.00 \\
0.00 \\
0.00 \\
0.00 \\
2.92 e+06 \\
0.00 \\
0.00\end{array}$ & $\begin{array}{l}6.91 e+10 \\
7.54 e+08 \\
4.66 e+09 \\
3.84 e+08 \\
1.45 e+08 \\
8.16 e+08 \\
7.57 e+08 \\
3.40 e+07\end{array}$ \\
\hline $\begin{array}{l}\text { ICP. fus. } A 1 \\
\text { ICP. fus. Ca } \\
\text { ICP. fus. Fe } \\
\text { ICP. fus. Na } \\
\text { ICP. fus. Pb } \\
\text { ICP. fus. U } \\
\text { ICP. fus.P }\end{array}$ & $\begin{array}{l}4.27 e+09 \\
2.52 e+07 \\
5.39 e+07 \\
1.14 e+08 \\
2.08 e+07 \\
9.80 e+07 \\
5.16 e+06\end{array}$ & $\begin{array}{l}2 \\
2 \\
2 \\
2 \\
1 \\
2 \\
2\end{array}$ & $\begin{array}{l}0.001 \\
0.003 \\
0.009 \\
0.097 \\
0.000 \\
0.052 \\
0.270\end{array}$ & $\begin{array}{l}1.08 \mathrm{e}+09 \\
5.50 \mathrm{e}+06 \\
7.73 \mathrm{e}+06 \\
0.00 \\
4.13 \mathrm{e}+06 \\
0.00 \\
0.00\end{array}$ & $\begin{array}{l}1.69 e+11 \\
1.01 e+09 \\
2.19 e+09 \\
5.48 e+09 \\
2.13 e+10 \\
4.26 e+09 \\
3.85 e+08\end{array}$ \\
\hline $\begin{array}{l}\text { ICP.water. } \mathrm{Ca} \\
\text { ICP.water. } \mathrm{Fe} \\
\text { ICP.water. } \mathrm{Na} \\
\text { ICP.water. } \mathrm{Ni} \\
\text { ICP.water. } \mathrm{P}\end{array}$ & $\begin{array}{l}4.40 e+03 \\
1.95 e+04 \\
1.32 e+08 \\
2.31 e+03 \\
1.60 e+06\end{array}$ & $\begin{array}{l}2 \\
2 \\
2 \\
2 \\
2 \\
\end{array}$ & $\begin{array}{l}0.004 \\
0.003 \\
0.037 \\
0.011 \\
0.364\end{array}$ & $\begin{array}{c}8.52 e+02 \\
4.03 e+03 \\
0.00 \\
2.89 e+02 \\
0.00\end{array}$ & $\begin{array}{l}1.77 e+05 \\
7.83 e+05 \\
5.70 e+09 \\
9.45 e+04 \\
2.03 e+08\end{array}$ \\
\hline $\begin{array}{l}\text { Chloride } \\
\text { Nitrite } \\
\text { Nitrate } \\
\text { Phosphate } \\
\text { Sulphate } \\
\text { Total cyanide } \\
\end{array}$ & $\begin{array}{l}3.33 e+03 \\
9.67 e+06 \\
4.10 e+07 \\
2.08 e+07 \\
1.86 e+06 \\
2.52 e+07 \\
\end{array}$ & $\begin{array}{l}2 \\
2 \\
2 \\
2 \\
2 \\
2 \\
\end{array}$ & $\begin{array}{l}0.000 \\
0.149 \\
0.032 \\
0.321 \\
0.015 \\
0.000 \\
\end{array}$ & $\begin{array}{c}9.03 e+02 \\
0.00 \\
0.00 \\
0.00 \\
1.58 \mathrm{e}+05 \\
6.78 \mathrm{e}+06 \\
\end{array}$ & $\begin{array}{l}1.32 \mathrm{e}+05 \\
5.13 \mathrm{e}+08 \\
1.75 \mathrm{e}+09 \\
1.96 \mathrm{e}+09 \\
7.66 \mathrm{e}+07 \\
9.94 \mathrm{e}+08 \\
\end{array}$ \\
\hline $\begin{array}{l}U(\mu \mathrm{g} / \mathrm{g}) \\
\text { Tot.A7pha.Pu } \\
\text { Sr-90 } \\
\text { Pu-239/240 } \\
\text { Cs-137. water } \\
\text { Cs-137. fusion }\end{array}$ & $\begin{array}{l}1: 09 e+02 \\
2.13 e-01 \\
2.57 e+05 \\
2.13 e-01 \\
4.66 e+00 \\
5.63 e+04\end{array}$ & $\begin{array}{l}2 \\
2 \\
2 \\
2 \\
2 \\
2 \\
\end{array}$ & $\begin{array}{l}0.004 \\
0.001 \\
0.006 \\
0.001 \\
0.064 \\
0.012 \\
\end{array}$ & $\begin{array}{l}2.12 \mathrm{e}+01 \\
5.06 \mathrm{e}-02 \\
4.45 \mathrm{e}+04 \\
5.04 \mathrm{e}-02 \\
0.00 \\
6.66 \mathrm{e}+03 \\
\end{array}$ & $\begin{array}{l}4.37 \mathrm{e}+03 \\
8.50 \mathrm{e}+00 \\
1.04 \mathrm{e}+07 \\
8.48 \mathrm{e}+00 \\
2.10 \mathrm{e}+02 \\
2.30 \mathrm{e}+06 \\
\end{array}$ \\
\hline
\end{tabular}


Table 7-10. Tukey's HSD Multiple Comparisons, Core Composite Data (Units $\mu \mathrm{g} / \mathrm{g}$ Except Radionuclides $\mu \mathrm{Ci} / \mathrm{g}$ ).

\begin{tabular}{|c|c|c|c|c|c|c|c|}
\hline \multirow{2}{*}{ Core } & \multicolumn{3}{|c|}{ Group } & \multicolumn{3}{|c|}{ Mean } & \multirow{2}{*}{ RSD } \\
\hline & 47 & 48 & 49 & 47 & 48 & 49 & \\
\hline $\begin{array}{l}\text { ICP.acid.AI } \\
\text { ICP.acid.Ca } \\
\text { ICP.acid.Fe } \\
\text { ICP.acid. Na } \\
\text { ICP.acid.Ni } \\
\text { ICP.acid.Pb } \\
\text { ICP.acid.U } \\
\text { ICP.acid.P }\end{array}$ & $\begin{array}{l}\beta \\
\alpha \\
\alpha \\
\alpha \\
\alpha \\
\alpha \\
\alpha \beta \\
\alpha\end{array}$ & $\begin{array}{l}\alpha \\
\alpha \\
\alpha \\
\alpha \\
\alpha \\
B \\
B \\
\alpha\end{array}$ & $\begin{array}{l}\beta \\
\alpha \\
\alpha \\
\alpha \\
\alpha \\
\beta \\
\alpha \\
\alpha\end{array}$ & $\begin{array}{l}7.3 e+04 \\
2.0 e+04 \\
2.9 e+04 \\
8.2 e+04 \\
1.5 e+04 \\
8.6 e+03 \\
1.1 e+04 \\
1.8 e+04\end{array}$ & $\begin{array}{l}6.4 e+03 \\
1.3 e+04 \\
2.0 e+04 \\
8.8 e+04 \\
1.6 e+04 \\
6.1 e+02 \\
1.5 e+04 \\
1.7 e+04\end{array}$ & $\begin{array}{l}8.4 e+04 \\
1.2 e+04 \\
7.1 e+03 \\
8.1 e+04 \\
1.2 e+04 \\
8.6 e+02 \\
6.3 e+03 \\
1.9 e+04\end{array}$ & $\begin{array}{l}18 \% \\
13 \% \\
39 \% \\
16 \% \\
9 \% \\
33 \% \\
19 \% \\
36 \%\end{array}$ \\
\hline $\begin{array}{l}\text { ICP. fus.AI } \\
\text { ICP. fus.Ca } \\
\text { ICP. fus. Fe } \\
\text { ICP. fus. Na } \\
\text { ICP. fus.Pb } \\
\text { ICP. fus.U } \\
\text { ICP. fus.P }\end{array}$ & $\begin{array}{l}B \\
B \\
B \\
\alpha \\
B \\
\alpha \\
\alpha\end{array}$ & $\begin{array}{l}\alpha \\
\alpha \\
B \\
\alpha \\
- \\
\alpha \\
\alpha\end{array}$ & $\begin{array}{l}B \\
\alpha \\
\alpha \\
\alpha \\
\alpha \\
\alpha \\
\alpha\end{array}$ & $\begin{array}{l}1.2 e+05 \\
2.5 e+04 \\
2.2 e+04 \\
8.7 e+04 \\
7.3 e+03 \\
9.2 e+03 \\
2.0 e+04\end{array}$ & $\begin{array}{c}8.6 e+03 \\
1.8 e+04 \\
2.2 e+04 \\
1.0 e+05 \\
N A \\
2.5 e+04 \\
2.0 e+04\end{array}$ & $\begin{array}{l}1.3 e+05 \\
1.5 e+04 \\
9.1 e+03 \\
7.7 e+04 \\
8.2 e+02 \\
2.8 e+03 \\
1.5 e+04\end{array}$ & $\begin{array}{c}7 \% \\
4 \% \\
10 \% \\
8 \% \\
1 \% \\
28 \% \\
17 \%\end{array}$ \\
\hline $\begin{array}{l}\text { ICP.water. } \mathrm{Ca} \\
\text { ICP.water. } \mathrm{Fe} \\
\text { ICP.water. } \mathrm{Na} \\
\text { ICP. water. } \mathrm{Ni} \\
\text { ICP.water. } \mathrm{P}\end{array}$ & $\begin{array}{c}B \\
\alpha \\
\alpha B \\
B \\
\alpha\end{array}$ & $\begin{array}{l}\alpha \\
\beta \\
\beta \\
\alpha \\
\alpha\end{array}$ & $\begin{array}{l}\alpha \\
\alpha \\
\alpha \\
\alpha \\
\alpha\end{array}$ & $\begin{array}{l}1.8 e+02 \\
8.8 e+02 \\
6.3 e+04 \\
1.2 e+02 \\
7.0 e+03\end{array}$ & $\begin{array}{l}6.0 e+01 \\
1.1 e+03 \\
8.4 e+04 \\
3.1 e+01 \\
8.7 e+03\end{array}$ & $\begin{array}{l}7.8 e+01 \\
9.2 e+02 \\
6.0 e+04 \\
5.3 e+01 \\
4.2 e+03\end{array}$ & $\begin{array}{l}12 \% \\
3 \% \\
7 \% \\
19 \% \\
41 \%\end{array}$ \\
\hline $\begin{array}{l}\text { Chloride } \\
\text { Nitrite } \\
\text { Nitrate } \\
\text { Phosphate } \\
\text { Sulphate } \\
\text { Total cyanide }\end{array}$ & $\begin{array}{l}\alpha \\
\alpha \\
\alpha \\
\alpha \\
\alpha \\
\alpha\end{array}$ & $\begin{array}{l}\beta \\
\alpha \\
\beta \\
\alpha \\
\beta \\
B\end{array}$ & $\begin{array}{l}\alpha \\
\alpha \\
\alpha \\
\alpha \\
\alpha \\
\alpha\end{array}$ & $\begin{array}{l}7.0 e+02 \\
3.9 e+04 \\
3.7 e+04 \\
2.2 e+04 \\
7.3 e+03 \\
2.8 e+03\end{array}$ & $\begin{array}{l}8.0 e+02 \\
4.5 e+04 \\
4.8 e+04 \\
2.7 e+04 \\
9.3 e+03 \\
2.1 e+02\end{array}$ & $\begin{array}{l}7.0 \mathrm{e}+02 \\
3.9 \mathrm{e}+04 \\
3.6 \mathrm{e}+04 \\
1.3 \mathrm{e}+04 \\
6.6 \mathrm{e}+03 \\
2.8 \mathrm{e}+03 \\
\end{array}$ & $\begin{array}{c}0 \% \\
6 \% \\
6 \% \\
38 \% \\
5 \% \\
167 \% \\
\end{array}$ \\
\hline $\begin{array}{l}U(\mu g / g) \\
\text { Tot.ATpha.Pu } \\
\text { Sr-90 } \\
\text { Cs }-137 \text {. water } \\
\text { Cs-137. fusion }\end{array}$ & $\begin{array}{l}\alpha \\
B \\
B \\
\alpha \\
B\end{array}$ & $\begin{array}{l}B \\
\alpha \\
\alpha \\
\alpha \\
B\end{array}$ & $\begin{array}{l}\alpha \\
\alpha \\
B \\
\alpha \\
\alpha\end{array}$ & $\begin{array}{l}1.2 e+01 \\
8.8 e-01 \\
1.2 e+03 \\
9.2 e+00 \\
8.7 e+02\end{array}$ & $\begin{array}{l}2.8 e+01 \\
6.8 e-02 \\
1.9 e+02 \\
9.3 e+00 \\
1.0 e+03\end{array}$ & $\begin{array}{l}7.5 \mathrm{e}+00 \\
7.9 \mathrm{e}-02 \\
9.3 \mathrm{e}+02 \\
5.3 \mathrm{e}+00 \\
5.6 \mathrm{e}+02\end{array}$ & $\begin{array}{l}13 \% \\
18 \% \\
15 \% \\
15 \% \\
8 \%\end{array}$ \\
\hline
\end{tabular}

RSD = Relative standard deviation.

Examples of the interpretation of the HSD comparisons are as follows. In Table 7-10, aluminum (ICP.acid) has an $\alpha$ for core 48 and a B for core 47 and 49 . That is, the mean concentration of aluminum in core 48 is significantly different from the mean concentration in core 47 and 49 . The mean concentration of aluminum in core 47 and 49 cannot be distinguished from each other. Another example is uranium (ICP.acid). In Table 7-10, core 48 has a $B$, core 49 has an $\alpha$, and core 47 has an $\alpha \beta$. That is, the mean concentration of uranium for core 48 is significantly different from the mean concentration in core 49 . Core 47 has both symbols $\alpha$ and $B$. Thus, the mean concentration of uranium is not significantly different from the mean concentration in core 48 and it is not significantly different from the mean concentration in core 49. 
There were three subsegment samples from cores 47 and 49 (denoted by $B$, $C$, and $D$ ) and two from core 48 (denoted by $C$ and $D$ ). The relative location of the subsegments are given in the Table 7-11.

Table 7-11. Subsegment Assignment for Tukey's HSD.

\begin{tabular}{|c|c|c|c|}
\hline Core & 47 & 48 & 49 \\
\hline Subsegment & $B$ & & $B$ \\
& $C$ & $C$ & $C$ \\
& $D$ & $D$ & $D$ \\
\hline
\end{tabular}

Tukey's HSD procedure was also used to make comparisons between the individual subsegment means. These comparisons, along with subsegment means, are given in Table 7-12. For a given analyte, the relative locations of the subsegments have the form given in the above table. The symbols used to denote groupings of means concentrations are $a, \beta, \gamma, \delta, c$, and $\phi$. A dash indicates that no data were available. The interpretation and ranking of the groupings are identical to that given for Table 7-10.

The results given in Table 7-12 appear to be complicated. A partial explanation is as follows. The multiple comparisons indicate that the three subsegments between cores 47 and 49 match for sodium, lead, chloride, nitrate, phosphate, and ${ }^{137} \mathrm{Cs}$. Subsegments $B$ and $D$ match between cores 47 and 49 for iron, nitrite, sulfate, and total cyanide. Subsegments $C$ and $D$ match between cores 47,48 , and 49 for iron and ${ }^{90} \mathrm{Sr}$. This is some evidence of layers in the waste. The multiple comparisons for the other analytes indicate waste heterogeneity. As previously stated, such differences inflate the spatial variance. There may be patterns in Table 7-12, other than those indicated, showing layers within the waste.

\subsection{COMPARISON OF RESULTS: SINGLE-SHELL TANKS 241-C-109 AND 241-C-112}

This section contains a comparison of summary statistics computed from core composite data from tanks 241-C-109 and 241-C-112. Comparisons are made on the mean concentration, the analytical measurement variance, and the spatial variance. Comparisons are also presented for the relative standard deviations and the two variances as a percent of the total variance.

Appendix $C$ contains graphs of the data from tank 241-C-109 and 241-C-112. Each core from tank 241-C-109 is paired, according to location within the tank, with a core from tank 241-C-112. Table 7-13 shows this pairing. 
Table 7-12. Tukey's HSD Multiple Comparisons, Subsegment Data (Units $\mu \mathrm{g} / \mathrm{g}$ Except Radionuclides $\mu \mathrm{C} / \mathrm{g}$ ).

\begin{tabular}{|c|c|c|c|c|c|c|c|}
\hline \multirow{2}{*}{ Core } & \multicolumn{3}{|c|}{ Group } & \multicolumn{3}{|c|}{ Mean } & \multirow{2}{*}{ RSD } \\
\hline & 47 & 48 & 49 & 47 & 48 & 49 & \\
\hline ICP.fus.AT & $\begin{array}{l}\epsilon \\
\epsilon \\
B\end{array}$ & $\begin{array}{l}\alpha \\
\alpha\end{array}$ & $\begin{array}{l}\phi \\
\delta \\
y\end{array}$ & $\begin{array}{l}1.3 e+05 \\
1.2 e+05 \\
3.2 e+04\end{array}$ & $\begin{array}{l}7.3 e+03 \\
9.8 e+03\end{array}$ & $\begin{array}{l}1.9 e+05 \\
9.6 e+04 \\
7.1 e+04\end{array}$ & $6 \%$ \\
\hline ICP.fus.Ca & $\begin{array}{l}\bar{B} \\
\gamma \\
\epsilon\end{array}$ & $\begin{array}{l}\epsilon \\
y\end{array}$ & $\begin{array}{c}\alpha \\
\gamma^{\delta} \\
\delta\end{array}$ & $\begin{array}{l}1.0 e+04 \\
1.8 e+04 \\
2.8 e+04\end{array}$ & $\begin{array}{l}2.9 e+04 \\
1.7 e+04\end{array}$ & $\begin{array}{l}4.3 e+03 \\
1.9 e+04 \\
2.3 e+04\end{array}$ & $6 \%$ \\
\hline ICP.fus.Fe & $\begin{array}{l}\bar{\beta} \\
\alpha \\
\alpha\end{array}$ & $\begin{array}{l}\alpha \\
\alpha\end{array}$ & $\begin{array}{l}\alpha \\
\alpha \\
\alpha\end{array}$ & $\begin{array}{l}6.3 e+04 \\
2.1 e+04 \\
1.5 e+04\end{array}$ & $\begin{array}{l}2.0 e+04 \\
2.1 e+04 \\
\end{array}$ & $\begin{array}{l}1.6 e+04 \\
4.6 e+03 \\
1.5 e+04\end{array}$ & $46 \%$ \\
\hline ICP.fus. Na & $\begin{array}{c}\alpha \beta \\
\alpha \beta \gamma \\
\gamma \delta\end{array}$ & $\begin{array}{c}\delta \\
y \delta\end{array}$ & $\begin{array}{c}\alpha \\
\alpha \beta \gamma \\
\beta \gamma \delta\end{array}$ & $\begin{array}{l}5.1 e+04 \\
6.3 e+04 \\
1.0 e+05\end{array}$ & $\begin{array}{l}1.2 e+05 \\
1.0 e+05\end{array}$ & $\begin{array}{l}4.3 e+04 \\
6.3 e+04 \\
9.1 e+04\end{array}$ & $14 \%$ \\
\hline ICP.fus.Pb & $\begin{array}{l}\alpha \\
\alpha \\
\alpha\end{array}$ & $\bar{\alpha}$ & $\bar{\alpha}$ & $\begin{array}{l}5.0 e+03 \\
2.9 e+03 \\
1.4 e+04\end{array}$ & $\begin{array}{c}N A \\
6.9 e+02\end{array}$ & $\begin{array}{c}2.0 e+03 \\
N A \\
7.3 e+02\end{array}$ & $50 \%$ \\
\hline ICP.fus.U & $\begin{array}{c}\gamma \delta \\
\alpha \beta \\
\alpha \\
\end{array}$ & $\begin{array}{c}\epsilon \\
\delta \epsilon\end{array}$ & $\begin{array}{c}\alpha \beta \gamma \\
- \\
y^{8}\end{array}$ & $\begin{array}{l}1.2 e+04 \\
6.1 e+03 \\
5.8 e+03\end{array}$ & $\begin{array}{l}1.7 e+04 \\
1.4 e+04 \\
\end{array}$ & $\begin{array}{c}7.9 \mathrm{e}+03 \\
\mathrm{NA} \\
1.2 \mathrm{e}+04\end{array}$ & $9 \%$ \\
\hline ICP.fus.P & $\begin{array}{c}- \\
\alpha \beta \\
\delta\end{array}$ & $\begin{array}{l}y \\
y\end{array}$ & $\bar{\alpha}$ & $\begin{array}{c}N A \\
1.2 e+04 \\
3.0 e+04\end{array}$ & $\begin{array}{l}2.3 e+04 \\
2.1 e+04\end{array}$ & $\begin{array}{c}\text { NA } \\
1.1 \mathrm{e}+04 \\
2.0 \mathrm{e}+04\end{array}$ & $9 \%$ \\
\hline Chloride & $\begin{array}{c}\alpha \beta \\
B y \\
y\end{array}$ & $\begin{array}{c}\delta \epsilon \\
\epsilon\end{array}$ & $\begin{array}{c}\alpha \\
\gamma \delta \\
y \delta\end{array}$ & $\begin{array}{l}5.5 e+02 \\
7.0 e+02 \\
7.5 e+02\end{array}$ & $\begin{array}{l}9.5 e+02 \\
1.0 e+03 \\
\end{array}$ & $\begin{array}{l}5.0 \mathrm{e}+02 \\
8.0 \mathrm{e}+02 \\
8.0 \mathrm{e}+02\end{array}$ & $6 \%$ \\
\hline Nitrite & $\begin{array}{l}\alpha \\
\beta \\
B Y\end{array}$ & $\begin{array}{c}\epsilon \\
\delta \epsilon\end{array}$ & $\begin{array}{l}\alpha \\
\gamma \\
y \delta\end{array}$ & $\begin{array}{l}2.8 e+04 \\
3.7 e+04 \\
4.0 e+04\end{array}$ & $\begin{array}{l}5.1 e+04 \\
5.0 e+04\end{array}$ & $\begin{array}{l}2.6 e+04 \\
4.4 e+04 \\
4.5 e+04\end{array}$ & $4 \%$ \\
\hline Nitrate & $\begin{array}{c}\alpha \\
\beta \\
\gamma \beta\end{array}$ & $\begin{array}{l}\delta \\
\delta\end{array}$ & $\begin{array}{c}\alpha \\
\beta y \\
y\end{array}$ & $\begin{array}{l}2.8 e+04 \\
3.6 e+04 \\
3.9 e+04 \\
\end{array}$ & $\begin{array}{l}5.6 e+04 \\
5.4 e+04 \\
\end{array}$ & $\begin{array}{l}2.6 e+04 \\
4.2 e+04 \\
4.3 e+04 \\
\end{array}$ & $4 \%$ \\
\hline Phosphate & $\begin{array}{l}\alpha \\
\alpha \\
\gamma\end{array}$ & $\begin{array}{l}\alpha \beta \\
\beta Y\end{array}$ & $\begin{array}{c}\alpha \\
\alpha \\
\alpha \beta \gamma\end{array}$ & $\begin{array}{l}7.3 e+03 \\
9.6 e+03 \\
4.5 e+04\end{array}$ & $\begin{array}{l}1.6 e+04 \\
3.6 e+04 \\
\end{array}$ & $\begin{array}{l}6.1 e+03 \\
8.8 e+03 \\
2.5 e+04\end{array}$ & $28 \%$ \\
\hline Sulfate & $\begin{array}{l}\alpha \\
\beta \\
\beta \gamma\end{array}$ & $\begin{array}{l}\epsilon \\
\delta\end{array}$ & $\begin{array}{l}\alpha \\
y \\
y\end{array}$ & $\begin{array}{l}5.1 e+03 \\
7.1 e+03 \\
7.4 e+03\end{array}$ & $\begin{array}{l}1.1 e+04 \\
1.0 e+04\end{array}$ & $\begin{array}{l}4.7 e+03 \\
8.2 e+03 \\
8.1 e+03\end{array}$ & $3 \%$ \\
\hline Total cyanide & $\begin{array}{l}\alpha \\
\beta \\
\gamma\end{array}$ & $\begin{array}{l}\epsilon \\
\delta\end{array}$ & $\begin{array}{l}\alpha \\
\delta \\
\gamma\end{array}$ & $\begin{array}{l}3.2 e+03 \\
4.4 e+03 \\
5.8 e+03\end{array}$ & $\begin{array}{l}1.1 e+04 \\
8.7 e+03\end{array}$ & $\begin{array}{l}3.5 e+03 \\
8.1 e+03 \\
5.5 e+03\end{array}$ & $3 \%$ \\
\hline $5 r-90$ & $\begin{array}{l}\delta \\
\beta \\
\alpha \beta\end{array}$ & $\begin{array}{c}\alpha \beta \\
\alpha\end{array}$ & $\begin{array}{l}r \\
\alpha \beta \\
\alpha \beta\end{array}$ & $\begin{array}{l}4.6 e+03 \\
4.7 e+02 \\
2.2 e+02\end{array}$ & $\begin{array}{l}1.5 e+02 \\
1.2 e+02\end{array}$ & $\begin{array}{l}2.4 e+03 \\
2.0 e+02 \\
1.9 e+02\end{array}$ & $8 \%$ \\
\hline Cs-137. fusion & $\begin{array}{c}\alpha \beta \\
B y \delta \\
y \delta\end{array}$ & $\begin{array}{l}\delta \\
\delta\end{array}$ & $\begin{array}{l}\alpha \\
\alpha \beta \\
\beta \gamma\end{array}$ & $\begin{array}{l}3.4 e+02 \\
7.7 e+02 \\
9.5 e+02\end{array}$ & $\begin{array}{l}1.2 e+03 \\
1.2 e+03\end{array}$ & $\begin{array}{l}1.2 e+02 \\
3.5 e+02 \\
7.0 e+02\end{array}$ & $16 \%$ \\
\hline
\end{tabular}

RSD $=$ Relative standard deviation. 
Table 7-13. Core Compostte Assignment for Tank Comparison.

\begin{tabular}{|c|c|c|c|}
\hline Tank & Pair 1 & Pair 2 & Pair 3 \\
\hline $241-C-109$ & Core 49 & Core 48 & Core 47 \\
$241-C-112$ & Core 34 & Core 35 & Core 36 \\
\hline
\end{tabular}

To help compare the two sets of data, paired cores have the same symbols.

\subsubsection{Comparison of Mean Concentrations}

For the analytes of interest in tank 241-C-109, the mean concentration $(y)$ and the varlance of the mean concentration $\left[0^{2}(y)\right]$ are presented in Table 7-4. These summary statistics are based on the core composite data. The corresponding results for tank 241-C-112 are contained in Simpson, Borsheim, and Jensen (1993). To test the equality of the mean concentration of the analytes in the two tanks, a 95 percent CI was computed on the difference between the two mean concentrations. The test of equality of mean concentrations is if zero is in the CI, then the two means cannot be distinguished from each other at the 0.05 level of significance. If zero is not in the CI the two means are significantly different from each other.

A 95 percent CI on the difference between the mean concentrations was computed for 29 analytes. The CI was based on Cochran's approximation to the Behrens-Fisher problem (Snedecor and Cochran 1980). Zero was in all of the intervals. Because of the magnitude of the variances of the difference, $\partial^{2}[P(C 109)-g(C 112)]-\partial^{2}[g(C 109)]+\partial^{2}[g(C 112)]$ and the small number of $d f$, the width of the CIs was very large. The lower 11 mits of the intervals tended to be $-10^{5}$ or $-10^{4}$ and the upper 1 imits tended to be $+10^{5}$ or $+10^{4}$. These intervals are a function of both the analytical measurement variance and the spatial variance.

To reduce the magnitude of the width of the CIs, they were also computed using only the analytical measurement variance. The new lower 1 imits of the intervals were reduced to $-10^{4}$ or $-10^{3}$ and the upper 1 imits were reduced to $+10^{4}$ or $+10^{3}$. Zero was in all but two of the new CIs. The two intervals that did not contain zero were for aluminum (ICP. fusion) and $238 / 26 \mathrm{Pu}$. Tables containing the CIs on the difference are not given in this document.

The interpretation of these results is that except for possibly aluminum (ICP. fusion) and ${ }^{239 / 240} \mathrm{Pu}$, the mean concentration of the analytes in the two tanks cannot be distinguished from each other. It needs to be emphasized that these comparisons are based on very large spatial and analytical measurement variances and very small df. Consequently, such comparisons may not be meaningful.

\subsubsection{Comparison of Variances}

The estimates of the analytical measurement variances $\left[\partial^{2}(A)\right]$ for both tank 241-C-109 and 241-C-112 are given in Table 7-14. A special form of the F-test (Snedecor and Cochran 1980) was used to test the equality of these two 
Table 7-14. Comparison of Analytical Error Variances, Tanks 241-C-109 and 241-C-112.

\begin{tabular}{|c|c|c|c|c|c|}
\hline Tank & \multicolumn{2}{|c|}{$C-109$} & \multicolumn{2}{|c|}{$C-112$} & \\
\hline Analyte & $\sigma^{2}(A)$ & $d f$ & $\sigma^{2}(A)$ & $d f$ & $p$-value \\
\hline $\begin{array}{l}\text { ICP.acid.AI } \\
\text { ICP.acid.Ca } \\
\text { ICP.acid. Fe } \\
\text { ICP.acid. Na } \\
\text { ICP.acid. NI } \\
\text { ICP.acid.Pb } \\
\text { ICP.acid.U } \\
\text { ICP.acid.P }\end{array}$ & $\begin{array}{l}1.00 e+08 \\
3.91 e+06 \\
5.45 e+07 \\
1.20 e+08 \\
1.47 e+06 \\
1.23 e+06 \\
4.18 \theta+06 \\
2.75 e+07\end{array}$ & $\begin{array}{l}3 \\
3 \\
3 \\
3 \\
3 \\
3 \\
3 \\
3\end{array}$ & $\begin{array}{l}3.10 e+07 \\
1.44 e+06 \\
2.76 e+07 \\
2.39 e+07 \\
1.06 e+06 \\
2.41 e+04 \\
1.10 e+08 \\
3.83 e+06\end{array}$ & $\begin{array}{l}3 \\
3 \\
3 \\
3 \\
3 \\
3 \\
3 \\
3\end{array}$ & $\begin{array}{l}0.180 \\
0.217 \\
0.294 \\
0.294 \\
0.399 \\
0.004 \\
0.012 \\
0.070\end{array}$ \\
\hline $\begin{array}{l}\text { ICP. fus.AI } \\
\text { ICP. fus. Ca } \\
\text { ICP. fus. Fe } \\
\text { ICP. fus. Na } \\
\text { ICP. fus.Pb } \\
\text { ICP. fus. U } \\
\text { ICP. fus.P }\end{array}$ & $\begin{array}{l}3.71 e+07 \\
6.47 e+05 \\
3.38 e+06 \\
4.97 e+07 \\
3.71 e+03 \\
9.45 e+06 \\
9.43 e+06\end{array}$ & $\begin{array}{l}3 \\
3 \\
3 \\
3 \\
2 \\
2 \\
3\end{array}$ & $\begin{array}{l}5.67 e+05 \\
1.56 e+05 \\
9.81 e+06 \\
3.96 e+06 \\
1.47 e+05 \\
1.64 e+07 \\
1.37 e+05\end{array}$ & $\begin{array}{l}2 \\
2 \\
2 \\
2 \\
2 \\
2 \\
2\end{array}$ & $\begin{array}{l}0.015 \\
0.200 \\
0.192 \\
0.075 \\
0.025 \\
0.366 \\
0.014\end{array}$ \\
\hline $\begin{array}{l}\text { ICP. water. } A \text { I } \\
\text { ICP.water. } \mathrm{Ca} \\
\text { ICP. water. } \mathrm{Fe} \\
\text { ICP. water. } \mathrm{Na} \\
\text { ICP. water. } \mathrm{NI} \\
\text { ICP. water. } \mathrm{U} \\
\text { ICP. water. } \mathrm{P}\end{array}$ & $\begin{array}{c}N A \\
1.67 \mathrm{e}+02 \\
6.20 \mathrm{e}+02 \\
2.40 \mathrm{e}+07 \\
1.66 \mathrm{e}+02 \\
\mathrm{NA} \\
7.27 \mathrm{e}+06\end{array}$ & $\begin{array}{c}\text { NA } \\
3 \\
3 \\
3 \\
3 \\
N A \\
3\end{array}$ & $\begin{array}{l}3.05 e+04 \\
3.78 e+04 \\
3.43 e+03 \\
5.11 e+08 \\
1.29 e+03 \\
2.60 e+06 \\
1.13 e+07\end{array}$ & $\begin{array}{l}2 \\
2 \\
2 \\
2 \\
2 \\
2 \\
2\end{array}$ & $\begin{array}{l}\text { NA } \\
0.000 \\
0.099 \\
0.017 \\
0.065 \\
\text { NA } \\
0.345\end{array}$ \\
\hline $\begin{array}{l}\text { Chloride } \\
\text { Nitrite } \\
\text { Nitrate } \\
\text { Phosphate } \\
\text { Sulphate } \\
\text { Total cyanide }\end{array}$ & $\begin{array}{c}N A \\
6.83 e+06 \\
6.67 e+06 \\
5.93 e+07 \\
1.70 e+05 \\
2.14 e+04\end{array}$ & $\begin{array}{c}N A \\
3 \\
3 \\
3 \\
3 \\
3\end{array}$ & $\begin{array}{c}2.50 e+04 \\
1.33 e+08 \\
2.41 e+08 \\
1.10 e+08 \\
6.25 e+06 \\
N A\end{array}$ & $\begin{array}{c}2 \\
2 \\
2 \\
2 \\
2 \\
N A\end{array}$ & $\begin{array}{l}\text { NA } \\
0.019 \\
0.008 \\
0.298 \\
0.008 \\
\text { NA }\end{array}$ \\
\hline $\begin{array}{l}U(\mu g / g) \\
\text { Tot.Alpha.Pu } \\
\text { Sr-90 } \\
\text { Pu-238 } \\
\text { Pu-239/240 } \\
\text { Cs-137. water } \\
\text { Cs-137. fusion }\end{array}$ & $\begin{array}{c}4.05 e+00 \\
3.57 e-03 \\
1.24 e+04 \\
N A \\
3.57 e-03 \\
1.35 e+00 \\
4.23 e+03\end{array}$ & $\begin{array}{c}3 \\
3 \\
3 \\
N A \\
3 \\
3 \\
3\end{array}$ & $\begin{array}{c}5.30 \mathrm{e}+07 \\
N A \\
1.36 \mathrm{e}+03 \\
1.60 \mathrm{e}-05 \\
2.69 \mathrm{e}-05 \\
\mathrm{NA} \\
2.31 \mathrm{e}+02\end{array}$ & $\begin{array}{c}2 \\
N A \\
2 \\
2 \\
2 \\
N A \\
2\end{array}$ & $\begin{array}{c}0.000 \\
N A \\
0.101 \\
N A \\
0.007 \\
N A \\
0.001\end{array}$ \\
\hline
\end{tabular}


variances. The $p$-value, which is the attained level of significance of the F-test, is also given in Table 7-14. If the attained level of significance is less than 0.025 (in this spectal test), then the two analytical measurement variances are significantly different from each other at the 0.05 level of significance. In 13 out of 28 tests ( 46 percent) the analytical measurement variances were significantly different from each other for the two tanks.

The equality of the spatial variances for the two tanks was tested in a similar manner. Table 7-15 contains the estimates of the spatial variances $\left[\hat{\sigma}^{2}(S)\right]$ and the p-values for the $F$-test. The spatial variances were significantly different from each other in only four out of 25 tests (16 percent). These variances were significantly different for urantum (ICP.acid), for nickel (ICP. Water) and for uranium and 239/240 Pu. The spatial variances cannot be distinguished from each other for the other analytes.

The implication of these results are that, at least for these two tanks, the degree of heterogeneity in the waste is very simflar. The analytical measurement error is not consistent between the two tanks, even though the data were analyzed by the same laboratory. These results must be interpreted with caution, because there are only two df associated with each spatial variance and two or three df for each analytical measurement variance. The $d f$ are very small.

Results given in Tables 7-16 and 7-17 may help in the interpretation of the relative magnitude of the estimates of the analytical and spatial variances. For both tanks 241-C-109 and 241-C-112, Table 7-16 gives $\partial^{2}(A)$ and $\hat{\sigma}^{2}(S)$ as a percent of the total variance associated with any observation. That is, $\% \hat{\sigma}^{2}(A)=100 * \hat{\sigma}^{2}(A) /\left[\hat{\sigma}^{2}(A)+\hat{\sigma}^{2}(s)\right]$ and $\% \hat{\sigma}^{2}(S)=100 * \hat{\sigma}^{2}(S) /\left[\hat{\sigma}^{2}(A)+\hat{\sigma}^{2}(s)\right]$. Generaliy, $\partial^{2}(s)$ represents the greatest percentage of the total variability for both tanks 241-C-112 and 241-C-109. The relative standard deviations (RSDs) for both tanks are given in Table 7-17. An RSD is a standard deviation expressed as a percent of the mean concentration. That is, $\operatorname{RSD}(\bar{y})=100 * \hat{\sigma}(\bar{y}) / \bar{y}$, $\operatorname{RSD}(A)=100 * \hat{\sigma}(A) / \bar{y}$, and $\operatorname{RSD}(S)=100 * \hat{\sigma}(S) / \bar{y}$. The $\operatorname{RSD}(A)$ appears to be relatively consistent between the two tanks. The RSD(S) appears to be variable with no apparent pattern.

\subsection{SUMMARY OF STATISTICAL INTERPRETATION}

For 16 out of 17 analytes, the variability between sampling locations could not be distinguished from zero. Based on the results of this statistical test, it is concluded the Analytical Chemistry Laboratory can satisfactorily homogenize core segments.

Based on the large spatial variance and analytical measurement variance, the comparisons showed that the Analytical Chemistry Laboratory's ability to construct core composite samples was satisfactory.

In 28 out of 33 cases ( 85 percent) the spatial variability in the core composite samples was larger than the analytical error. 
Table 7-15. Comparison of Spatial Variances,

Tanks 241-C-109 and 241-C-112.

\begin{tabular}{|c|c|c|c|c|c|}
\hline Tank & \multicolumn{2}{|c|}{$c-109$} & \multicolumn{2}{|c|}{$c-112$} & \multirow[b]{2}{*}{$p$-value } \\
\hline Analyte & $\partial^{2}(S)$ & $\begin{array}{l}\text { Degrees of } \\
\text { freedom }\end{array}$ & $\hat{\sigma}^{2}(S)$ & $\begin{array}{l}\text { Degrees of } \\
\text { freedom }\end{array}$ & \\
\hline $\begin{array}{l}\text { ICP.acid.AI } \\
\text { ICP.acid.Ca } \\
\text { ICP.acid.Fe } \\
\text { ICP.acid. Na } \\
\text { ICP.acid. Ni } \\
\text { ICP.acid.Pb } \\
\text { ICP.acid.U } \\
\text { ICP.acid.P }\end{array}$ & $\begin{array}{l}1.70 e+09 \\
1.72 e+07 \\
9.14 e+07 \\
0.00 \\
2.95 e+06 \\
2.00 e+07 \\
1.71 e+07 \\
0.00\end{array}$ & $\begin{array}{l}2 \\
2 \\
2 \\
2 \\
2 \\
2 \\
2 \\
2\end{array}$ & $\begin{array}{l}3.67 e+08 \\
2.49 e+07 \\
0.00 \\
2.66 e+08 \\
1.55 e+07 \\
2.28 e+06 \\
1.56 e+09 \\
4.52 e+07\end{array}$ & $\begin{array}{l}2 \\
2 \\
2 \\
2 \\
2 \\
2 \\
2 \\
2\end{array}$ & $\begin{array}{l}0.178 \\
0.408 \\
N A \\
N A \\
0.160 \\
0.102 \\
0.011 \\
\text { NA }\end{array}$ \\
\hline $\begin{array}{l}\text { ICP. fus. Al } \\
\text { ICP. fus.Ca } \\
\text { ICP. fus. Fe } \\
\text { ICP. fus. Na } \\
\text { ICP. fus. Pb } \\
\text { ICP. fus. U } \\
\text { ICP. fus.P }\end{array}$ & $\begin{array}{l}4.27 e+09 \\
2.52 e+07 \\
5.39 e+07 \\
1.14 e+08 \\
2.08 e+07 \\
9.80 e+07 \\
5.16 e+06\end{array}$ & $\begin{array}{l}2 \\
2 \\
2 \\
2 \\
1 \\
2 \\
2\end{array}$ & $\begin{array}{l}4.70 e+08 \\
4.09 e+07 \\
1.65 e+07 \\
5.24 e+08 \\
3.98 e+06 \\
1.78 e+09 \\
8.04 e+07\end{array}$ & $\begin{array}{l}2 \\
2 \\
2 \\
2 \\
2 \\
2 \\
2\end{array}$ & $\begin{array}{l}0.099 \\
0.382 \\
0.234 \\
0.179 \\
0.149 \\
0.052 \\
0.060\end{array}$ \\
\hline $\begin{array}{l}\text { ICP. water. } A I \\
\text { ICP. water. Ca } \\
\text { ICP. water. Fe } \\
\text { ICP. water. Na } \\
\text { ICP. water. NI } \\
\text { ICP. water. U } \\
\text { ICP. water.P }\end{array}$ & $\begin{array}{c}N A \\
4.40 e+03 \\
1.95 e+04 \\
1.32 e+08 \\
2.31 e+03 \\
N A \\
1.60 e+06\end{array}$ & $\begin{array}{c}N A \\
2 \\
2 \\
2 \\
2 \\
N A \\
2\end{array}$ & $\begin{array}{l}7.06 e+04 \\
0.00 \\
2.26 e+05 \\
5.01 e+08 \\
8.56 e+04 \\
4.55 e+06 \\
3.50 e+07\end{array}$ & $\begin{array}{l}2 \\
2 \\
2 \\
2 \\
2 \\
2 \\
2\end{array}$ & $\begin{array}{c}N A \\
N A \\
0.079 \\
0.209 \\
0.026 \\
N A \\
0.044\end{array}$ \\
\hline $\begin{array}{l}\text { Chloride } \\
\text { Nitrite } \\
\text { Nitrate } \\
\text { Phosphate } \\
\text { Sulphate } \\
\text { Total cyanide }\end{array}$ & $\begin{array}{l}3.33 e+03 \\
9.67 e+06 \\
4.10 e+07 \\
2.08 e+07 \\
1.86 e+06 \\
2.52 e+07\end{array}$ & $\begin{array}{l}2 \\
2 \\
2 \\
2 \\
2 \\
2\end{array}$ & $\begin{array}{l}5.25 e+04 \\
1.04 e+08 \\
2.21 e+08 \\
2.97 e+08 \\
9.17 e+06 \\
N A\end{array}$ & $\begin{array}{r}2 \\
2 \\
2 \\
2 \\
2 \\
\text { NA }\end{array}$ & $\begin{array}{l}0.060 \\
0.085 \\
0.156 \\
0.065 \\
0.168 \\
\text { NA }\end{array}$ \\
\hline $\begin{array}{l}U(\mu \mathrm{g} / \mathrm{g}) \\
\text { Tot.Alpha.Pu } \\
\text { Sr-90 } \\
\text { Pu-238 } \\
\text { Pu-239/240 } \\
\text { Cs-137. water } \\
\text { Cs-137. fusion }\end{array}$ & $\begin{array}{c}1.09 e+02 \\
2.13 e-01 \\
2.57 e+05 \\
N A \\
2.13 e-01 \\
4.66 e+00 \\
5.63 e+04\end{array}$ & $\begin{array}{c}2 \\
2 \\
2 \\
N A \\
2 \\
2 \\
2\end{array}$ & $\begin{array}{c}2.88 e+09 \\
N A \\
2.96 e+06 \\
7.81 e-03 \\
4.15 e-03 \\
N A \\
2.47 e+03\end{array}$ & $\begin{array}{c}1 \\
\text { NA } \\
2 \\
2 \\
2 \\
N A \\
2\end{array}$ & $\begin{array}{l}0.000 \\
\text { NA } \\
0.080 \\
\text { NA } \\
0.019 \\
\text { NA } \\
0.042\end{array}$ \\
\hline
\end{tabular}


Table 7-16. Comparison of Percent Vartance, 241-C-109 and 241-C-112.

\begin{tabular}{|c|c|c|c|c|}
\hline $\operatorname{Tank}$ & $C-109$ & $c-112$ & $C-109$ & $c-112$ \\
\hline Analyte & $x 0^{2}(A)$ & $x 0^{2}(A)$ & $x \sigma^{2}(S)$ & $x \sigma^{2}(5)$ \\
\hline $\begin{array}{l}\text { ICP.acId.AI } \\
\text { ICP.acId.Ca } \\
\text { ICP.acId.Fe } \\
\text { ICP.acId. Na } \\
\text { ICP.acId.NI } \\
\text { ICP.acId.Pb } \\
\text { ICP.acId.U } \\
\text { ICP.acId.P }\end{array}$ & $\begin{array}{c}6 \% \\
19 \% \\
37 \% \\
100 \% \\
33 \% \\
6 \% \\
20 \% \\
100 \%\end{array}$ & $\begin{array}{l}8 \% \\
5 \% \\
100 \% \\
8 \% \\
6 \% \\
1 \% \\
7 \% \\
8 \%\end{array}$ & $\begin{array}{l}94 \% \\
81 \% \\
63 \% \\
0 \% \\
67 \% \\
94 \% \\
80 \% \\
0 \%\end{array}$ & $\begin{array}{l}92 \% \\
95 \% \\
0 \% \\
92 \% \\
94 \% \\
99 \% \\
93 \% \\
92 \%\end{array}$ \\
\hline $\begin{array}{l}\text { ICP. fus. } A I \\
\text { ICP. fus. } \mathrm{Ca} \\
\text { ICP. fus. Fe } \\
\text { ICP. fus. } \mathrm{Na} \\
\text { ICP. fus. } \mathrm{Pb} \\
\text { ICP. fus. } U \\
\text { ICP. fus. P }\end{array}$ & $\begin{array}{l}1 \% \\
3 \% \\
6 \% \\
30 \% \\
0 \% \\
9 \% \\
65 \%\end{array}$ & $\begin{array}{l}0 \% \\
0 \% \\
37 \% \\
1 \% \\
4 \% \\
1 \% \\
0 \%\end{array}$ & $\begin{array}{l}99 \% \\
97 \% \\
94 \% \\
70 \% \\
100 \% \\
91 \% \\
35 \%\end{array}$ & $\begin{array}{l}100 \% \\
100 \% \\
63 \% \\
99 \% \\
96 \% \\
99 \% \\
100 \%\end{array}$ \\
\hline $\begin{array}{l}\text { ICP.water. } A \text { I } \\
\text { ICP. water. } C \text { a } \\
\text { ICP. water. Fe } \\
\text { ICP. water. Na } \\
\text { ICP. water. NI } \\
\text { ICP.water. U } \\
\text { ICP. water.P }\end{array}$ & $\begin{array}{c}N A \\
4 \% \\
3 \% \\
15 \% \\
7 \% \\
N A \\
82 \%\end{array}$ & $\begin{array}{l}30 \% \\
100 \% \\
1 \% \\
51 \% \\
1 \% \\
36 \% \\
24 \%\end{array}$ & $\begin{array}{l}N A \\
96 \% \\
97 \% \\
85 \% \\
93 \% \\
N A \\
18 \%\end{array}$ & $\begin{array}{l}70 \% \\
0 \% \\
99 \% \\
49 \% \\
99 \% \\
64 \% \\
76 \%\end{array}$ \\
\hline $\begin{array}{l}\text { Chloride } \\
\text { Nitrite } \\
\text { Nitrate } \\
\text { Phosphate } \\
\text { Sulphate } \\
\text { Total cyanide }\end{array}$ & $\begin{array}{l}0 \% \\
41 \% \\
14 \% \\
74 \% \\
8 \% \\
0 \%\end{array}$ & $\begin{array}{l}32 \% \\
56 \% \\
52 \% \\
27 \% \\
41 \% \\
N A\end{array}$ & $\begin{array}{c}100 \% \\
59 \% \\
86 \% \\
26 \% \\
92 \% \\
100 \%\end{array}$ & $\begin{array}{l}68 \% \\
44 \% \\
48 \% \\
73 \% \\
59 \% \\
N A\end{array}$ \\
\hline $\begin{array}{l}\text { Urantum }(\mu \mathrm{g} / \mathrm{g}) \\
\text { Tot.Alpha.Pu } \\
\text { Sr-90 } \\
\text { Pu-238 } \\
\text { Pu-239/240 } \\
\text { Cs-137. water } \\
\text { Cs-137. fusion }\end{array}$ & $\begin{array}{l}4 \% \\
2 \% \\
5 \% \\
N A \\
2 \% \\
22 \% \\
7 \%\end{array}$ & $\begin{array}{l}2 \% \\
N A \\
0 \% \\
0 \% \\
1 \% \\
N A \\
9 \%\end{array}$ & $\begin{array}{l}96 \% \\
98 \% \\
95 \% \\
N A \\
98 \% \\
78 \% \\
93 \%\end{array}$ & $\begin{array}{c}98 \% \\
\text { NA } \\
100 \% \\
100 \% \\
99 \% \\
\text { NA } \\
91 \%\end{array}$ \\
\hline
\end{tabular}


Table 7-17. Relative Standard Deviations

from Tanks $\mathrm{C}-112$ and $\mathrm{C}-109$.

\begin{tabular}{|c|c|c|c|c|c|c|}
\hline Tank & $c-109$ & $C-112$ & $c-109$ & $c-112$ & $c-109$ & $c-112$ \\
\hline Analyte & $\operatorname{RSO}(9)$ & $\operatorname{RSD}(9)$ & $\operatorname{RSD}(A)$ & $\operatorname{RSD}(A)$ & RSD (S) & $\mathrm{RSD}(\mathrm{S})$ \\
\hline $\begin{array}{l}\text { ICP.acId.AI } \\
\text { ICP.acId.Ca } \\
\text { ICP.acId.Fe } \\
\text { ICP.acId. Na } \\
\text { ICP.acId.NI } \\
\text { ICP.acId.Pb } \\
\text { ICP.acId.U } \\
\text { ICP.acId.P }\end{array}$ & $\begin{array}{l}44 \% \\
17 \% \\
34 \% \\
2 \% \\
8 \% \\
78 \% \\
24 \% \\
4 \%\end{array}$ & $\begin{array}{l}46 \% \\
17 \% \\
10 \% \\
11 \% \\
18 \% \\
34 \% \\
40 \% \\
17 \%\end{array}$ & $\begin{array}{l}18 \% \\
13 \% \\
39 \% \\
13 \% \\
9 \% \\
33 \% \\
19 \% \\
29 \%\end{array}$ & $\begin{array}{c}23 \% \\
7 \% \\
24 \% \\
5 \% \\
8 \% \\
6 \% \\
18 \% \\
9 x\end{array}$ & $\begin{array}{c}76 \% \\
28 \% \\
51 \% \\
0 \% \\
12 \% \\
133 \% \\
39 \% \\
0 \%\end{array}$ & $\begin{array}{l}78 \% \\
30 \% \\
0 \% \\
18 \% \\
30 \% \\
59 \% \\
68 \% \\
29 \%\end{array}$ \\
\hline $\begin{array}{l}\text { ICP. fus. Al } \\
\text { ICP. fus. } \mathrm{Ca} \\
\text { ICP. fus. Fe } \\
\text { ICP. fus. } \mathrm{Na} \\
\text { ICP. fus. } \mathrm{Pb} \\
\text { ICP. fus. U } \\
\text { ICP. fus. P }\end{array}$ & $\begin{array}{l}45 \% \\
15 \% \\
24 \% \\
8 \% \\
80 \% \\
42 \% \\
10 \% \\
\end{array}$ & $\begin{array}{l}46 \% \\
18 \% \\
10 \% \\
12 \% \\
39 \% \\
30 \% \\
18 \% \\
\end{array}$ & $\begin{array}{l}7 \% \\
4 \% \\
10 \% \\
8 \% \\
2 \% \\
21 \% \\
17 \% \\
\end{array}$ & $\begin{array}{l}3 \% \\
2 \% \\
11 x \\
2 x \\
13 x \\
5 x \\
1 x \\
\end{array}$ & $\begin{array}{l}78 \% \\
26 \% \\
41 \% \\
12 \% \\
113 \% \\
67 \% \\
12 \% \\
\end{array}$ & $\begin{array}{l}82 \% \\
32 \% \\
15 \% \\
22 \% \\
68 \% \\
52 \% \\
32 \% \\
\end{array}$ \\
\hline $\begin{array}{l}\text { ICP. water. } A I \\
\text { ICP. water. } C a \\
\text { ICP.water. Fe } \\
\text { ICP. water. Na } \\
\text { ICP. water. NI } \\
\text { ICP.water. } \\
\text { ICP.water. } P\end{array}$ & $\begin{array}{l}N A \\
36 \% \\
8 \% \\
10 \% \\
41 \% \\
N A \\
20 \%\end{array}$ & $\begin{array}{l}33 \% \\
11 \% \\
23 \% \\
18 \% \\
24 \% \\
65 \% \\
36 \%\end{array}$ & $\begin{array}{l}N A \\
12 \% \\
3 \% \\
7 \% \\
19 \% \\
N A \\
41 \%\end{array}$ & $\begin{array}{l}34 \% \\
58 \% \\
5 \% \\
26 \% \\
5 \% \\
74 \% \\
33 \%\end{array}$ & $\begin{array}{l}N A \\
62 \% \\
14 \% \\
16 \% \\
69 \% \\
N A \\
19 \%\end{array}$ & $\begin{array}{l}51 \% \\
0 \% \\
41 \% \\
25 \% \\
43 \% \\
98 \% \\
59 \%\end{array}$ \\
\hline $\begin{array}{l}\text { Chloride } \\
\text { Nitrite } \\
\text { Nitrate } \\
\text { Phosphate } \\
\text { Sulphate } \\
\text { Total cyanide }\end{array}$ & $\begin{array}{l}5 \% \\
5 \% \\
10 \% \\
20 \% \\
10 \% \\
34 \%\end{array}$ & $\begin{array}{l}15 \% \\
16 \% \\
18 \% \\
35 \% \\
17 \% \\
\text { NA }\end{array}$ & $\begin{array}{c}0 \% \\
6 \% \\
6 \% \\
38 \% \\
5 \% \\
2 \%\end{array}$ & $\begin{array}{l}16 \% \\
24 \% \\
25 \% \\
34 \% \\
21 \% \\
N A\end{array}$ & $\begin{array}{l}8 \% \\
8 \% \\
16 \% \\
22 \% \\
18 \% \\
59 \%\end{array}$ & $\begin{array}{l}23 \% \\
22 \% \\
24 \% \\
56 \% \\
25 \% \\
\text { NA }\end{array}$ \\
\hline $\begin{array}{l}\text { U ( } \mu \mathrm{g} / \mathrm{g}) \\
\text { Tot.Alpha.Pu } \\
\text { Sr-90 } \\
\text { Pu-238 } \\
\text { Pu-239/240 } \\
\text { Cs-137. water } \\
\text { Cs-137. fuston }\end{array}$ & $\begin{array}{l}39 \% \\
78 \% \\
39 \% \\
N A \\
78 \% \\
17 \% \\
17 \%\end{array}$ & $\begin{array}{l}52 \% \\
N A \\
44 \% \\
110 \% \\
86 \% \\
N A \\
5 \%\end{array}$ & $\begin{array}{l}13 \% \\
18 \% \\
15 \% \\
N A \\
18 \% \\
15 \% \\
8 \%\end{array}$ & $\begin{array}{l}11 \% \\
N A \\
2 \% \\
6 \% \\
9 \% \\
N A \\
2 \%\end{array}$ & $\begin{array}{c}66 \% \\
135 \% \\
66 \% \\
N A \\
135 \% \\
27 \% \\
29 \%\end{array}$ & $\begin{array}{c}78 \% \\
N A \\
79 \% \\
137 \% \\
107 \% \\
N A \\
7 \%\end{array}$ \\
\hline
\end{tabular}

RSD = Relative standard deviation. 
There is no significant difference between the composite sample means for 12 of 31 ( 39 percent) analytes and they were signiflcantly different in 19 out of 31 (61 percent) of the analytes. The comparisons between the subsegments indicates layering within the waste for some analytes and that the waste is very heterogeneous for other analytes. These types of heterogeneity influence the magnitude of the spatial variabllity.

Because of the large spatial and analytical measurement variances and small $\mathrm{df}$, the mean concentrations cannot be distingulshed from each other. For most of the analytes, the spatial variances cannot be distingulshed from each other. Although the analytical results came from the same laboratory, the analytical measurement varlances were significantly different for 13 out of 28 ( 46 percent) analytes. 


\section{WHC-EP-0668}

This page intentionally left blank. 
WHC-EP-0668

\subsection{CONCLUSIONS AND RECOMMENDATIONS}

\subsection{CONCLUSIONS FRON ANALYTICAL RESULTS}

Analyses of the waste show a very small number of analytes comprising a large portion of the waste. Water is the single largest analyte, making up 38.6 percent of the total mass. There is relatively little supernatant in the tank (less than 6 percent of the total mass). Seven elements (aluminum, calclum, iron, sodium, nickel, phosphorus, and uranium) constitute approximately 25 percent of the solids mass. They also represent over 95 percent of the total cations. Two antons ( $\mathrm{NO}_{2}^{\circ}$ and $\mathrm{NO}_{3}^{*}$ ) constitute approximately 8 percent of the solids mass. The fraction of the total anions that nitrate and nitrite represent cannot be adequately determined because the analytical method measured only soluble anions. The total cyanide content was measured and found to be less than 1.5 percent (dry basis) in each core and for the tank as a whole.

The only significant gamma emitter found in the waste was ${ }^{137} \mathrm{Cs}$. Although ${ }^{80} \mathrm{Co}$ was also precipitated during the scavenging process, it has decayed below any level of concern and does not contribute to the heat load of the tank. No meaningful regional concentrations (hot spots) of radielsotopes or fuel were detected along the vertical axts in either core. The ${ }^{137} \mathrm{Cs}$ concentrations were comparable between Core 47 and Core 49 and the regions with high nickel concentrations correlated with the ${ }^{137} \mathrm{Cs}$ activity. These observations are consistent with the historical information regarding the ferrocyanide-scavenging process and the ICP element distribution through the subsegments. The other major source of radlological activity was ${ }^{90} \mathrm{Sr}$, which decreased significantly as a function of depth in both core 47 and core 49 , as expected from the flll history. Heat-load calculatjons are further evidence supporting the contention that the relatively high ${ }^{90} \mathrm{Sr}$ concentrations are belleved to be a phenomenon particular to the upper several inches of the waste. The bulk waste temperature in the tank, obtained from two thermocouple trees, ranges between $23^{\circ}$ to $26^{\circ} \mathrm{C}\left(74^{\circ}\right.$ to $\left.78^{\circ} \mathrm{F}\right)$. Comparisons of heat-load calculations, using the temperature profiles from the thermocouple trees and heat loads based on isotope concentrations, agree within 27 percent and are considered reasonable (Cash et al. 1993; Appendix $C$ ). The radiological activity of tank 241-C-109 waste material was relatively low (ranging from 1 to $2.5 \mathrm{R} / \mathrm{hr}$, measured through the drill string). No significant radiological activity was found in the drainable liquid in the tapk or in the water or acid digestion of the samples. This shows that ${ }^{90} \mathrm{Sr}$ and ${ }^{37} \mathrm{Cs}$ are quite insoluble.

Cores 47 and 49 appear to have concentrated decladding waste and hot semiworks effluent disposed on top of IC, IC EBs and CW that was scavenged, sometimes with ferrocyanide, sometimes not, overlying a heel bismuth phosphate first decontamination cycle waste heel. However, no firm evidence of $B 1 \mathrm{PO}_{4}-1 \mathrm{C}$ waste was ever found from the assays. The phosphate and phosphorous profiles although suggestive, are not conclusive. The water content, particle size distribution, DSC/TGA behavior, and aluminum concentration in these two cores are different than the tank 241-C-112 core samples or the In Farm simulant behavior. First decontamination cycle and $1 C$ EBs mixed with decladding waste rather than uranjum recovered TBP waste was the primary waste that was scavenged. Proflles of ${ }^{90} \mathrm{Sr}$ (decreasing as a function of depth) and Cesium-137 (increasing as a function of depth) profiles agree with fill 
historles. No discernable exothermic behavior was detected in these samples, even though there were measurable quantitles of cyanide present. This lack of observed energetic behavior was attributed to the aluminum content of the waste; the primary reaction occurring between $260^{\circ}$ and $300{ }^{\circ} \mathrm{C}$ is belleved to be the dehydration of aluminum hydroxide.

Indications from Core 48 data show that material has physical and chemical propertles corresponding to those expected for ferrocyanide waste. Water content, particle size distribution, DSC/TGA behavior, nickel and total cyanide concentration are consistent with the 241-C-112 values. However, again in this case, DSC results from the suspected ferrocyanide waste in tank 241-C-109 indicate that the material is considerably less energet ic than the corresponding waste simulant or the theoretical as-deposited values.

Results of aging studies now underway on flowsheet simulants may demonstrate that radiolytic, hydrolytic, and thermal processes in the tanks over the last 35 years have combined to dissolve, dilute, and destroy the reactive ferrocyanide compounds. The data from tank 241-C-109 strongly indicate that the waste lacks the fuel concentration to sustain any propagating exothermic behavior and a heat source intense enough to trigger a reaction is absent.

\subsection{CONCLUSIONS FRON ENEREETICS ANALYSIS}

Ferrocyanide simulants made by the In Farm flowsheet are more reactive than ferrocyanide wastes derived from other processes. The waste in tank 241-C-109 and the other C Farm tanks, representing 20 to 25 percent of the ferrocyanide inventory added to the tanks, was made by a similar process and was a potential cause for concern. However, if the In Farm simulants contained at least 15 weight percent water, that moisture content precluded an uncontrolled, propagating reaction (Fauske 1992).

Three core samples were obtained from tank 241-C-109. While all three cores were broken down into smaller subsegments and examined for reactivity using DSC, none of the samples exhibited any propagating behavior. The samples had a molsture content ranging from 19 to 58 wt\% water and a heat of reaction ranging from no discernable exotherm to $-51.9 \mathrm{~J} / \mathrm{g}$ dry material $(0.0$ to $-12.4 \mathrm{cal} /$ dry $\mathrm{g})$. The onset temperatures for the endotherms were between $217^{\circ}$ and $270^{\circ} \mathrm{C}$. The onset temperatures for the observed exotherm was $272^{\circ} \mathrm{C}$, close to that predicted by the simulants. The simulant may have represented some of the waste as it was initlally precipitated in the tank; several of the physical and chemical properties of the simulants are quite close to those of Core 48 waste. However, much of the waste that was scavenged was quite different from the material in tank 241-C-112. In addition, further chemical analysis indicates that the waste material has a total cyanide content much lower than expected from the simulant formulations and, correspondingly, tank 24l-C-109 waste material is not as energetic as the analogous waste simulants. Tank 24l-C-109 sample matertal is neariy 24 times less chemically reactive than the comparable In Farm simulant material (tank 241-C-109 waste: $-0.05 \mathrm{~kJ} / \mathrm{g}$; In Farm 1 simulant: $-1.20 \mathrm{~kJ} / \mathrm{g}$ ). The causes of this behavior are hypothesized to be long-term exposure to radiation fields and additional high $\mathrm{pH}$ cladding waste. Both of these conditions appear to degrade the ferrocyanide complexes. 
Calculations of the bulk waste inventory and inventories for several analytes of interest to the various safety issues (ferrocyanide, $\mathrm{NO}_{2}^{-}, \mathrm{NO}_{3}^{-}$, ${ }^{137} \mathrm{Cs},{ }^{90} \mathrm{Sr}$, plutonium, and water) were made. The calculated buik inventory of ferrocyanide $(6,800 \mathrm{~g}$-mol) was far in excess of the 1,000 g-mol Ferrocyanide Watch List criteria, but the energetics results indicate that particular criteria do not account for the dispersion of the ferrocyanide in the waste (i.e., the concentration may be too low to support a self-sustaining reaction). None of the other calculated bulk inventory values exceeded any level of concern (refer to Table 8-1).

Analytical evidence from tank 241-C-109 suggests the risk from ferrocyanide compounds in Hanford Site high-level waste tanks is acceptable and that a propagating exothermic ferrocyanide reaction is incredible.

Table 8-1. Comparison of Tank 241-C-109 Analyte Values to Safety Issue Criteria.

\begin{tabular}{|l|l|l|}
\hline \multicolumn{1}{|c|}{ Analyte } & \multicolumn{1}{|c|}{$\begin{array}{c}\text { Safety issue } \\
\text { criteria }\end{array}$} & \multicolumn{1}{|c|}{$\begin{array}{c}\text { Calculated/ } \\
\text { measured value }\end{array}$} \\
\hline $\mathrm{Na}_{2} \mathrm{NiFe}(\mathrm{CN})_{6}$ & $1,000 \mathrm{~g}$-mol & $6,800 \mathrm{~g}$-mol \\
\hline$\Delta \mathrm{H}$ (dry basis) & $-75 \mathrm{cal} / \mathrm{g}$ & $-12 \mathrm{cal} / \mathrm{g}^{*}$ \\
\hline $239 / 240 \mathrm{Pu}$ & $50 \mathrm{~kg}$ & $3.8 \mathrm{~kg}$ \\
\hline Temperature & $300^{\circ} \mathrm{F}\left(149^{\circ} \mathrm{C}\right)$ & $29^{\circ} \mathrm{C}\left(85^{\circ} \mathrm{F}\right)$ \\
\hline Heat load & $11.72 \mathrm{~kW}$ & $2.85 \mathrm{~kW}$ \\
\hline $\begin{array}{l}\text { Organic content } \\
\text { (ToC, Dry basis) } \\
\text { (10\% sodium acetate } \\
\text { equivalent) }\end{array}$ & $3.0 \mathrm{wt} \% \mathrm{TOC}$ & $0.45 \mathrm{wt} \% \mathrm{TOC}$ \\
\hline
\end{tabular}

${ }^{1}$ (Lindsey 1986; RHO 1988; Boyles 1992; Reep 1992). *Only observed exotherm in several measurements.

\subsection{RECOMMENDATIONS}

The following recommendations are made based on the data and analyses presented in this report and the goals of the characterization effort.

- The Watch List criteria for the Ferrocyanide waste tank USQ should be expanded so that it includes concentration or energetics based measurements.

- Tank 241-C-109 should be removed from the Ferrocyanide Watch List. If removal cannot be effected, the tank should be declared safe for interim-safe storage, so that routine tank farm operations can be performed. 
- An analysis for the formate anion should be done on the water soluble material to aid in confirming that the ferrocyanide has degraded.

- In future sample analyses, the DSC assay should be performed under an inert atmosphere to better represent the waste conditions in the tank. 


\subsection{REFERENCES}

Abrams, R. B., 1956, History: Metal Recovery Waste Scavenging Program, HW-43066, General Electric Company, Richland, Washington.

Anderson, J. D., 1990, A History of the 200 Area Tank Farms, WHC-MR-0132, Westinghouse Hanford Company, Richland, Washington.

Babad, H., B. C. Simpson, R. J. Cash, M. A. Lilga, 1993a, The Role of Aging in Resolving the Ferrocyanide Safety Issue, WHC-EP-0599, Westinghouse Hanford Company, Richland, Washington.

Babad, H., D. M. Camaioni, M. A. Lilga, W. D. Samuels, D. M. Strachan, 1993b, Tank Waste Chemistry - A New Understanding of Waste Aging, WHC-SA-1694-FP, Westinghouse Hanford Company, Richland, Washington.

Bechtold, D. B., 1992, "Analysis of In-Plant Ferrocyanide Solids," Internal Memo 12110-PC92-014, Westinghouse Hanford Company, Richland, Washington.

Be11, K. E., 1993, Tank Waste Remediation System Tank Waste Characterization Plan, WHC-SD-WM-PNL.047, Rev. 1, Westinghouse Hanford Company, Richland, Washington.

Bird, R. B, W. E. Stewart, E. N. Lightfoot, 1960, Transport Phenomena, John Wiley and Sons. New York, New York.

Borsheim, G. L. and B. C. Simpson, 1991, An Assessment of the Inventories of the Ferrocyanide Watchlist Tanks, WHC-SD-WM-ER-133 Rev. 0, Westinghouse Hanford Company, Richland, Washington.

Boyles, V. C., 1992, Operating Specifications for Single-Shell Waste Storage Tanks, OSD-T-151-00013 Rev D-1, Westinghouse Hanford Company, Richland, Washington.

Brown, T. M., L. Jensen, 1993, Tank Characterization Report for Single-Shell Tank 241-U-110, WHC-EP-0643, Westinghouse Hanford Company, Richland, Washington.

Burger, L. L., 1984, Complexant Stability Investigation, Task 1, Ferrocyanide Solids, PNL-5441, Pacific Northwest Laboratories, Richland, Washington.

Burger, L. L., 1989, Complexant Stability Investigation, Task 1-Ferrocyanide solids, PNL-5441, Pacific Northwest Laboratory, Richland, Washington.

Burger, L. L., and R. D. Scheele, 1990, The Reactivity of $\mathrm{Cs}_{2} \mathrm{NiFe}(\mathrm{CN})_{6}$ Towards Nitrate and Nitrite Salts, PNL-7550, Pacific Northwest Laboratory, Richland, Washington.

Cady, H. H., 1992, Evaluation of Ferrocyanide/Nitrate Explosive Hazard, LA-12589-MS, Los Alamos National Laboratory, Los Alamos, New Mexico. 
Cash, R. J., 1993, Ferrocyanide Safety Program - Removal of Six Tanks from Ferrocyanide Tank List, (letter 9259120 to J. H. Anttonen, January 14, 1993), Westinghouse Hanford Company, Richland, Washington.

Cash, R. J., G. T. Dukelow, and C. J. Forbes, 1993, Quarterly Report on Defense Nuclear Facilities Safety Board Recommendation 90-7 for the Period Ending December 31, 1992, WHC-EP-0474-7, Westinghouse Hanford Company, Richland, Washington.

Colby, S. A., and M. D. Crippen, 1991, Graphical Presentation of Ferrocyanide Tank Compositions, WHC-SA-1304-FP, Westinghouse Hanford Company, Richland, Washington.

DOE, 1987, Final Environmental Impact Statement, Disposal of Hanford Defense High-Level Transuranic Wastes, Hanford Site, Richland, Washington, DOE/EIS-0113, Vol. 1 through 5, U.S. Department of Energy, Washington, D.C.

Ecology, EPA, and DOE, 1992, Hanford Federal Facllity Agreement and Consent Order, 2 vols., Washington State Department of Ecology,

U.S. Environmental Protection Agency, U.S. Department of Energy, Olympia, Washington.

Fauske, H. K., 1992, Adiabatic Calorimetry and Reaction Propagation Rate Tests with Synthetic Ferrocyanide Materials Including U Plant-1, U Plant-2, In Farm 1, In Farm 2 and Vendor-Procured Sodium Nickel Ferrocyanide, Fauske \& Associates, Inc., Burr Ridge, Illinols.

General Electric, 1958, Record of Scavenged TBP Waste, General Electric Company, Richland, Washington.

Hanlon, B. M., 1992, Tank Farm Surveillance and Waste Status Summary Report for September 1992, WHC-EP-0182-39, Westinghouse Hanford Company, Richland, Washington.

Harville, D. A., 1977, "Maximum Likel thood Approaches to Variance Component Estimation and to Related Problems," Journal of the American Statistical Association, p.p. 320-340.

HASM, 1993, Single-Shell Tank Characterization Project and Safety Analysis Project Core 47, 48 and 49, Validation Report Tank 241-C-109, WHC-SD-WM-DP-036, Westinghouse Hanford Company, Richland, Washington.

Hill, J. G., W. I. Winters, B. C. Simpson, J. W. Buck, P. J. Chamberlain, and V. L. Hunter 1991, Waste Characterization Plan for the Hanford Site Single-Shell Tanks--Appendix I: Test Plan for Sampling and Analysis of Ten single-Shell Tanks, WHC-EP-0210 Rev. 3, Westinghouse Hanford Company, Richland, Washington.

Hill, J. G., 1991, Modified Test Plan for the Ferrocyanide Single-Shell Tanks, 241-C-112, C-109 and T-107, Correspondence No. 915211, Westinghouse Hanford Company, Richland, Washington. 
Husa, I. E., R. E. Raymond, R. K. Welty, S. M. Griffith, B. M. Hanion, R. R. Rios, and N. J. Vermeulen, 1993, Hanford Site Waste Storage Tank Information Notebook, WHC-EP-0625, Westinghouse Hanford Company, Richland, Washington.

Jensen, L. and B. J. Whitcher, 1992, "Statistical Analysis of Tank 241-U-110 Data, IV: Concentration Estimates," Internal Memo 12100--PLT92-068, West inghouse Hanford Company, Richland, Washington.

Jeppson, D. W. and J. J. Wong, 1993, Ferrocyanide Waste simulant Characterization, WHC-EP-0631, Westinghouse Hanford Company, Richland, Washington.

Jungfleisch, F. M., 1984, TRAC: A Preliminary Estimation of the Waste Inventories in Hanford Tanks Through 1980, SD-WM-TI-057, Rockwell Hanford Operations, Richland, Washington.

Lilga, M. A., M. R. Lumetta, W. F. Riemath, R. A. Romine, and G. F. Schiefelbein, 1992, "Ferrocyanide Safety Project, Subtask 3.4, Aging Studies FY 1992, Annual Report," PNL-8387 UC-721, Pacific Northwest Laboratory, Richland, Washington.

Lindsey, D. W., 1986, Operating Specifications for Single-Shell Waste Storage Tanks, OSD-T-151-00013, Rockwell Hanford Operations, Richland, Washington.

National Defense Authorization Act for Fiscal Year 1991, Public Law 101-510, Section 3137, "Safety Measures for Waste Tanks at Hanford Nuclear Reservation," November 5, 1990.

Peach, J. D., 1990, "Consequences of Explosion of Hanford's Single-Shell Tanks Are Understated," (Letter B-241479 to C. M. Synar, Chatrman of Environment, Energy and Natural Resources Subcommittee, Committee on Government Operations, House of Representatives), GAO/RCED-91-34, General Accounting Office, Washington, D.C.

Pederson, L. R., H. Babad, S. A. Bryan, A. J. Schmidt, 1993, Autogeneous Hydrothermal Oxidation in Simulated Hanford Double-Shell Tank Wastes, PNL-SA-22181, Pacific Northwest Laboratory, Richland, Washington.

Petersen, R. G., 1985, Design and Analys is of Experiments, First Edition, Marcel Dekker, Inc., New York, New York.

Reep, I. E., 1992, Status Report on Resolution of Waste Tank Safety Issues at the Hanford Site, WHC-EP-0600, Westinghouse Hanford Company, Richland, Washington.

RHO, 1988, Criticality Prevention Specifications for Waste Storage Tanks and Associated Equipment, CPS-T-149-00010, Rockwell Hanford Operations, Richland, Washington. 
Scheele, R. D., L. L. Burger, J. M. Tingey, S. A. Bryan, G. L. Borsheim, B. C. Simpson, R. J. Cash, and H. H. Cady, 1991, "Ferrocyantde-Containing Waste Tanks: Ferrocyanide Chemlstry and Reactivity," in the Proceedings of Environmental Restoration 91, University of Arizona, Tucson, Arizona.

Schmidt, W. C., and M. J. Stedwe11, 1954, Production Test 221-T-18 Scavenging of First Cycle Waste, HW-33252, General Electric Company, Richland, Washington.

Schneider, K. J. 1951, Flow Sheets and Flow Diagrams of Precipitation Separations Process, HW-23043, General Electric Company, Richland, Washington.

Simiele, C. J., 1991, Single-Shell Tank Phase 1A/1B Procedure Compendium, WHC-MR-0213, Westinghouse Hanford Company, Richland, Washington.

Sloat, R. J., 1954, TBP Plant Nickel Ferrocyanide Scavenging Flowsheet, HW-30399, General Electric Company, Richland, Washington.

Sloat, R. J., 1955, In Farm Scavenging Operating Procedure and Control Data, HW-38955 Rev. 1, General Electric Company, Richland, Washington.

Simpson, B. C., G. L. Borsheim, L. Jensen, 1993, Tank Characterization Data Report: Tank 241-C-112, WHC-EP-0640, Westinghouse Hanford Company, Richland, Washington.

Snedecor, G. W., and W. G. Cochran, 1980, Statistical Methods, Seventh Edition, Iowa State University Press, Ames, Iowa.

Wagner, 1992, Hanford Waste Vitrification Plant Feed Characterization Requirements, WHC-SD-HWV-SM-001, Rev. 4, Westinghouse Hanford Company, Richland, Washington.

Weast, R., 1984, Handbook of Chemistry and Physics, 64th Ed., CRC Press, Boca Raton, Florida.

Winters, W. I., L. Jensen, L. M. Sasaki, R. L. Weiss, J. F. Keller, A. J. Schmidt, and M. G. Woodruff 1990a, Waste Characterization Plan for the Hanford site Single-Shell Tanks, WHC-EP-0210 Rev. 1, Westinghouse Hanford Company, Richland, Washington.

Winters, W. I., L. Jensen, L. M. Sasaki, R. L. Weiss, J. F. Keller, A. J. Schmidt, and M. G. Woodruff 1990b, Waste Characterization Plan for the Hanford Site Single-Shell Tanks, WHC-EP-0210 Rev. 2, Westinghouse Hanford Company, Richland, Washington.

Wodrich, D. D., G. S. Barney, G. L. Borsheim, D. L. Becker, W. C. Carlos, M. J. Klem, J. L. Ryan, R. E. Van der Cook, 1992, Summary of Single-Shell Waste Tank Stability, WHC-EP-0347 Supplement, Westinghouse Hanford Company, Richland, Washington. 
WHC-EP-0668

APPENDIX A

CALCULATIONS

APP A-1 
WHC-EP-0668

This page intentionally left blank.

APP A-11 


\section{APPENDIX A: CALCULATIONS}

Theoretical Energetic Behavior of $\mathrm{C}-109$ Waste:

Assume 1.0 and 1.5 vol\% precipitate formation; use waste volumes generated from Borshetm-Simpson spreadsheet model.

Ferrocyanide waste volume: $\quad 1.0$ vol\% $-25,000$ gallons

Q 1.5 vol\% $-37,500$ gallons

Input mole of ferrocyanide: $\quad 47,300 \mathrm{~g}-\mathrm{mol} \mathrm{Na}_{2} \mathrm{~N}+\mathrm{Fe}(\mathrm{CN})_{6}$

Calculated moles

ferrocyanide remaining: $\quad 01.0$ and 1.5 vol\% $=47,300 \mathrm{~g}-\mathrm{mol} \mathrm{Na}_{2} \mathrm{NiFe}(\mathrm{CN})_{6}$

Analytical estimate $\quad 38,400 \mathrm{~g}-\mathrm{mol} \mathrm{Na}_{2} \mathrm{NiFe}(\mathrm{CN})_{6}$

derived from $\mathrm{Ni}$ content

(discounting $\mathrm{Ni}$ from ${ }^{60} \mathrm{Co}$ scavenging,

and using the acid ICP composite values)

$(14,033 \mu \mathrm{g} \mathrm{Ni} /$ wet $\mathrm{g}) *(1 \mathrm{~g} / \mathrm{lE}+06 \mu \mathrm{g}) *(\mathrm{~g}-\mathrm{mol} \mathrm{Ni} / 58 \mathrm{~g}) *(284.6 \mathrm{Mg})=68,900 \mathrm{~g}-\mathrm{mol} \mathrm{N1}$

$\mathrm{N} 1$ from non-FeCN scavenging: $30,500 \mathrm{~g}-\mathrm{mol}$; thus $68,900-30,500=38,400 \mathrm{~g}-\mathrm{mol} \mathrm{N1}$ and $(38,400 \mathrm{~g}-\mathrm{mol} \mathrm{Ni}) \star\left(1 \mathrm{~g}-\mathrm{mol}_{\mathrm{Na}} \mathrm{NiFe}(\mathrm{CN})_{6} / \mathrm{g}-\mathrm{mol} \mathrm{Ni}\right)=38,400 \mathrm{~g}-\mathrm{mol}^{\mathrm{Na}} \mathrm{Na}_{2} \mathrm{NiFe}(\mathrm{CN})_{6}$

Bulk Mass of Ferrocyanide waste (Density $=1.20 \mathrm{~g} / \mathrm{mL}$ ):

$(25,000 \mathrm{gal}) *(3785 \mathrm{~mL} / \mathrm{gal}) *(1.20 \mathrm{~g} / \mathrm{mL})=1.14 \mathrm{E}+08 \mathrm{~g}$ waste

$(37,500 \mathrm{gal}) *(3785 \mathrm{~mL} / \mathrm{gal}) *(1.20 \mathrm{~g} / \mathrm{mL})=1.70 \mathrm{E}+08 \mathrm{~g}$ waste

Mass of Ferrocyanide in Ferrocyanide waste:

$(47,300 \mathrm{~g}-\mathrm{mol}) *(316.7 \mathrm{~g} / \mathrm{g}-\mathrm{mol}) \cdot 1.50 \mathrm{E}+07 \mathrm{~g} \mathrm{Na}_{2} \mathrm{NiFe}(\mathrm{CN})_{6}$

Weight Percent Ferrocyanide in waste (range):

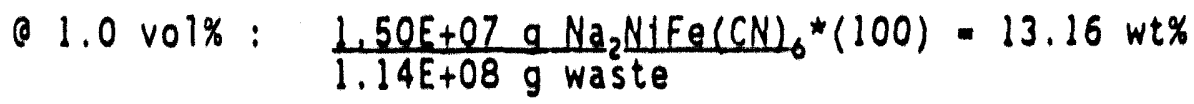

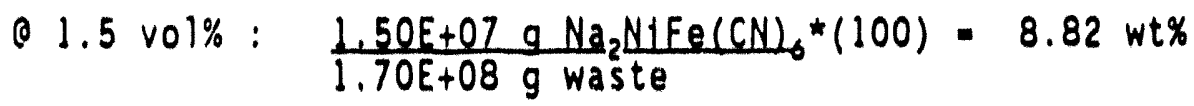

Assume $37 \%$ average water content, $63 \%$ solids

(Average of Core 47 and Core 49 TGA measurements)

Weight Percent Ferrocyanide (Dry basis)

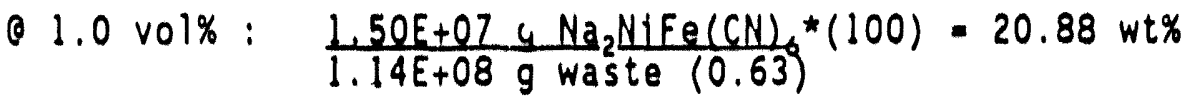

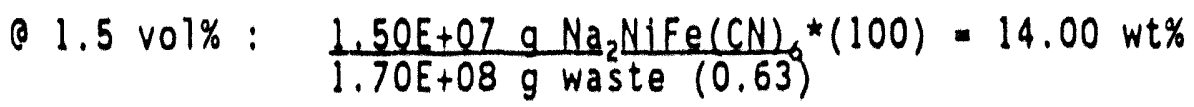


Table A-1. Energetic Properties of Waste Simulants (Fauske 1992).

\begin{tabular}{|c|c|c|c|}
\hline Simulant & $\begin{array}{c}\text { Ferrocyanide Content } \\
\text { (Dry basis) }\end{array}$ & $\left(\mathrm{kJ} / \mathrm{g} d \mathrm{dry}_{\text {simulant }}\right.$ simulant) & $\left(\mathrm{kJ} / \mathrm{g} \mathrm{Narr}_{2} \mathrm{NiFe}(\mathrm{CN})_{6}\right)$ \\
\hline U Plant-1 & $4.3 \mathrm{wt} \%$ & -0.17 & -3.95 \\
\hline U Plant-2 & $8.6 \mathrm{wt} \%$ & -0.34 & -3.95 \\
\hline In Farm-1 & $25.5 \mathrm{wt} \%$ & -1.20 & -4.71 \\
\hline
\end{tabular}

A direct, linear relationship can be assumed between the ferrocyanide (or cyanide) content of the waste and the energy content of the material.

$\left.\Delta H_{\text {sample }}=\left(W t \% \mathrm{Na}_{2} \mathrm{~N} 1 \mathrm{Fe}(\mathrm{CN})_{6}\right) *\left(-3.95 \mathrm{KJ} / \mathrm{g} \mathrm{Na} \mathrm{NIFe}_{2} \mathrm{CN}\right)_{6}\right)$

Therefore, the theoretical energetic behavior of the waste as it was initially stored in tank 241-C-109 is between:

$$
\begin{aligned}
& (14.00 \%) *(-3.95)=-0.55 \mathrm{KJ} / \mathrm{g} \text { waste; or } 132 \mathrm{cal} / \mathrm{g} \text { dry waste } \\
& (20.88 \%) *(-3.95)=-0.82 \mathrm{KJ} / \mathrm{g} \text { waste; or } 197 \mathrm{cal} / \mathrm{g} \text { dry waste }
\end{aligned}
$$

The basis for the exothermic potential of the reaction is $-3.95 \mathrm{~kJ} / \mathrm{g}$ $\mathrm{Na}_{2} \mathrm{NiFe}(\mathrm{CN})_{6}$. This value is used for several reasons. The measurement of the two $U$ Plant simulants was performed on much larger samples, thus is not as sensitive to rounding and experimental error. In addition, the measured gaseous products from the U Plant reaction were 0.075 moles produced out of a theoretical 0.11 moles; this represents a release fraction of $68.2 \%$, suggesting incomplete or less efficient combustion. There are several alternative reaction paths, however, the most reactive thermodynamic pathway has a $\Delta H$ of $-9.6 \mathrm{KJ} / \mathrm{g} \mathrm{Na} \mathrm{NiFe}(\mathrm{CN})_{6}$. Therefore a reaction efficiency for this waste matrix is $(-3.95 /-9.6) * 100 * 41.1 \%$. It can be assumed that the release fraction and reaction efficiency in the waste matrix would not be any greater than that exhibited by the simulants. However, greater heats of reaction can be expected from mixtures with higher fuel contents, as long as there is sufficierit oxidizer. This behavior is expected because factors contributing to combustion efficiency are more favorable: (1) a higher fuel/oxidant interface and (2) fewer solid diluents. This may be why the In Farm-l simulant exhibits a higher heat of reaction than the $U$ Plant simulants.

Determination of ${ }^{137} \mathrm{Cs}$ values from Revised Borsheim/Simpson Model:

The approximate amount of ${ }^{137} \mathrm{C}$ s processed through $241-C_{-13} 109$ during the scavenging campaign was $319,000 \mathrm{Cl}$. The half-life of ${ }^{137} \mathrm{Cs}$ is 30.17 years. The decay period for the waste is assumed to be 35 years (1958-1993). The decay factor for this timespan is thus:

$e^{\cdot(\ln 2 / 30.17) * 35}=0.4475$

Therefore, the ${ }^{137} \mathrm{Cs}$ remaining from the scavenging campaign is $(319,000 \mathrm{Cl}) *(0.4475)=142,800 \mathrm{Ci}$ 
The amount of ${ }^{137} \mathrm{Cs}$ captured in the tank is assumed to be directly proportional to the amount of ferrocyanide waste solids retalned, however in each case, there were no transfers of solids out of the tank. Therefore, the inventory of ${ }^{137} \mathrm{Cs}$ remaining from the scavenging campaign does not change.

\section{Comparison of Actual Waste Values with Theoretical Estimates}

Total cyanide values can provide estimates of ferrocyanide content; and this derived ferrocyanide content can be used to determine the energy content of the sample (assuming all cyanide detected is present as ferrocyanide).

$$
\frac{\left(316.7 \mathrm{~g} / \mathrm{g}-\mathrm{mol}_{\mathrm{Na}} \mathrm{NHFe}(\mathrm{CN})\right)^{*}}{\left(156 \mathrm{~g} \mathrm{CN} / \mathrm{g}-\mathrm{mol} \mathrm{Na}_{2} \mathrm{NiFe}(\mathrm{CN})_{6}\right.} \text { (WtX c antoe) }=W t X \mathrm{Na}_{2} \mathrm{NiFe}(\mathrm{CN})_{6}
$$

and using the derived ferrocyanide value in the previousiy described energetic relationship:

$\left.\Delta H_{\text {anple }}=\left(\mathrm{WtX} \mathrm{Na}_{2} \mathrm{NiFe}(\mathrm{CN})_{6}\right) *(-3.95 \mathrm{KJ} / \mathrm{g} \mathrm{Na} \mathrm{NiFe} \mathrm{CN})_{6}\right)$

Conversely, the energy content of the waste is a reasonable indicator of the ferrocyanide content in the waste. By rearranging Equation (1)

$\frac{\Delta 4}{-3.95} \mathrm{KJ}_{9} \mathrm{Na}_{2} \mathrm{NIFe}(\mathrm{CN})_{6}$ - WtX $\mathrm{Na}_{2} \mathrm{NiFe}(\mathrm{CN})_{6}$

However, because of the semi-quantitative nature of the DSC assay, values obtained in this manner are likely no better than qualitative results ( $\pm 100 x)$ for low fuel concentrations/small exotherms. For samples with high fuel contents (and consequently, exhibiting strong exotherms), the values are considered much more accurate. In this case, the samples are exhibiting strong endothermic behavior making a comparison even more difficult. However, even with the endotherms observed, if the fuel concentration was present at its theoretical level, exotherms would be observed.

\section{Calculation of Bulk Inventories for Analytes of Importance}

From the distribution of the solids and liquids in the samples, the measurements from tank farm survelliance, and the analyte profiles from the quarter-segments, an overall tank profile can be visualized (Figure A-1). These observations from the tank suggest that there are distinct regions in the tank, each possessing a specific volume and characteristic compositions. For the first interpretation, these regions are:

- Dished Bottom: First decontamination cycle $\mathrm{BIPO}_{4}$ waste or unscavenged Uranium Recovery (UR) waste.

- Tank Layer 1: Unscavenged UR wasto and Ferrocyanide-scavenged Uranium Recovery (FeCN) waste.

- Tank Layer 2: ferrocyanide-scavenged supernates from BY Farm scavenged for ${ }^{90} \mathrm{Sr}$ and ${ }^{80} \mathrm{Co}$ without ferrocyanide. 
- Tank Layer 3: Ferrocyan1de-scavenged waste, plus Coating Waste, Hot Semiworks, and IC Evaporator Bottoms.

- Supernatant.

The volumes for each region were derived as follows:

- O1shed Bottom: 10,000 gallons $(39,000 \mathrm{~L})$

This is the volume of waste recorded in the dish at the time prior to scavenging.

- Tank Layer 1: 19,800 gallons $(75,000 \mathrm{~L})$

Calculate a volume using a slab 1.5 subsegments high.

$(2,750 \mathrm{gallons} / \mathrm{inch}) *(4.75 \mathrm{in}$./subsegment $) *[0.5 *(1.5+0$ subsegments $)]$

- 19,600 gallons. Compare with model estimate at 1.5 volx $=19,840$ gallons; use higher value ( 3 sig. figures).

- Tank Layer 2: 10,300 gallons $(39,000 \mathrm{~L})$

Est imate derived from two batchas of nonferrocyanide scavenged solids using a model value of 1.5 volx solid formation.

- Tank Layer 3: 21,900 gallons (83,000 L)

Three batches of ferrocyanide scavenged solids using model estimates of 1.5 volx solid formation (17,600 gallons) plus residual solids from additional waste transfers. Extreme ${ }^{\circ} \mathrm{Sr}$ values are only found in upper subsegment (HS discharge). In addition, large amounts of transferred waste that had solids settled out prior to their introduction were also transferred to the tank. The ${ }^{9}$ Sr-containing volume was calculated using an estimated 2.5 vol\% solids $(3,300 \mathrm{gal})$ and the supernatant as having an estimated 0.125 volx solids (1,000 gal).

Total Solids Volume $=62,000$ gallons $(235,000 \mathrm{~L})$

- Supernatant: 4,500 gallons $(17,000 \mathrm{~L})$

Calculate a volume using a slab 1.1 inches high on the Core 47 side and 2.2 inches high on the core 49 side. $(2,750$ gallons/inch $) *(1.1$ in. $)+(0.5) *(2,750$ gallons $) *(1.1$ in. $)=4,500$ gallons.

Total Waste Volume: $\quad 66,500$ gallons

Check calculated volume with tank survelllance records: 66,000 gallons

Percent Difference $=\frac{66.500-66,000 * 100}{66,000} *+0.8 \%$

Using these volumes and a bulk density of $1.20 \mathrm{~g} / \mathrm{mL}$ for the sollds and $1.10 \mathrm{~g} / \mathrm{mL}$ for the supernatant, masses for the various regions can be calculated. Also, representative concentrations for the various analytes from each of the regions can be developed. 
Figure A-1. Waste Profile of Tank 241-C-109.

Not to Scale

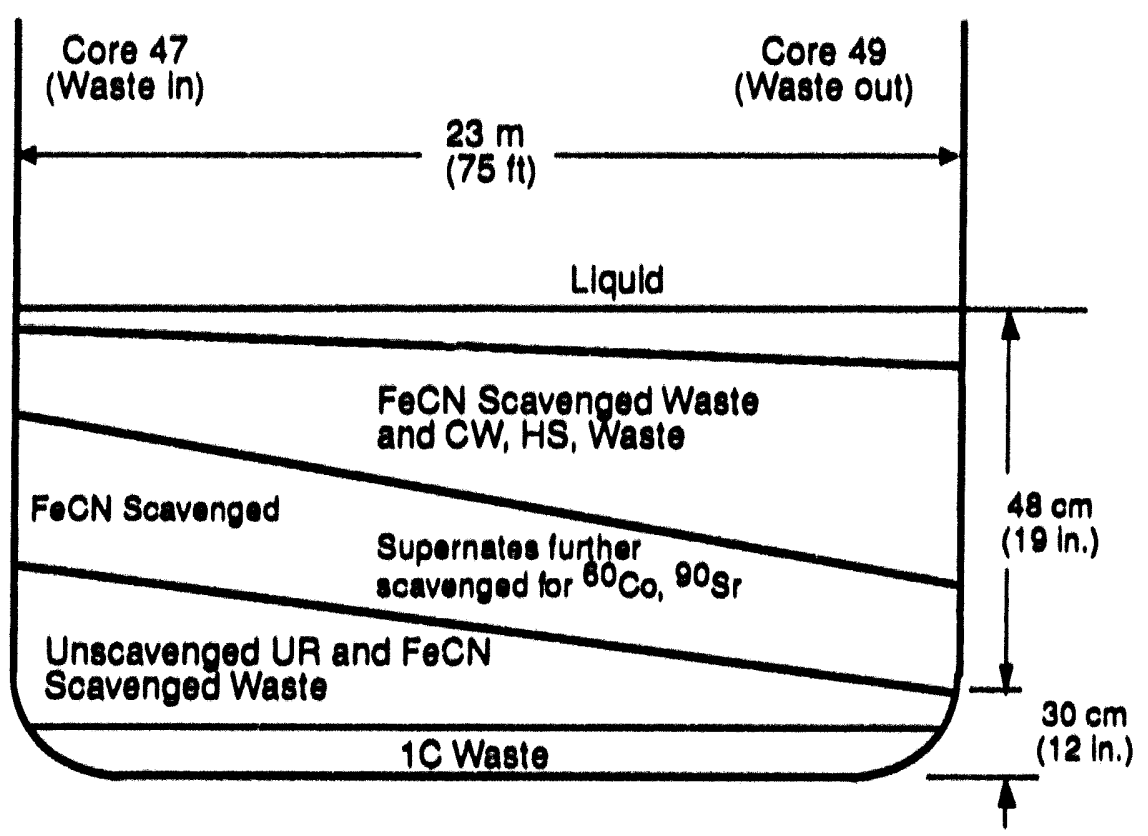

29308008.1

- Dished Bottom: First decontamination cycle $\mathrm{BIPO}_{4}$ waste or unscavenged Urantum Recovery (UR) waste.

- Tank Layer 1: Unscavenged and Ferrocyanide-scavenged Urantum Recovery ( $\mathrm{FeCN}$ ) waste.

- Tank Layer 2: Scavenged supernates from BY Farm scavenged for ${ }^{90} \mathrm{Sr}$ and ${ }^{60} \mathrm{CO}$ without ferrocyanide.

- Tank Layer 3: Ferrocyanide scavenging waste, plus Coating Waste, Hot Semiworks, and IC Evaporator Bottoms.

- Supernatant. 
Table A-2. Basis for Bulk Inventory Calculations.

\begin{tabular}{|l|c|c|l|}
\hline Tank Region & $\begin{array}{c}\text { Volume } \\
(g a l l o n s)\end{array}$ & $\begin{array}{c}\text { Mass } \\
(\mathrm{Mg})\end{array}$ & $\begin{array}{c}\text { Concentration Values Used for } \\
\text { Inventory Est Imate }\end{array}$ \\
\hline Dished Bottom & 10,000 & 46.8 & Core 47-10 \\
\hline Tank Layer 1 & 19,800 & 90.0 & Avg. Core 48-1C and 48-10 \\
\hline Tank Layer 2 & 10,300 & 44.9 & $\begin{array}{l}\text { Avg. Core 47-1C and 49-1C and } \\
49-10\end{array}$ \\
\hline Tank Layer 3 & 21,900 & 95.5 & Avg. Core 47-18 and Core 49-1B \\
\hline Supernatant & 4,500 & 18.7 & Llquid Compos 1te \\
\hline Total & 66,500 & 303.3 & \\
\hline
\end{tabular}

Tables A-3 through A-7 show the concentration values used to calculate the inventory estimates and the calculated bulk inventories for selected analytes.

Compare ICP water leach phosphorous value with IC phosphate value.

formula weights: $\quad P: 31 ; \mathrm{PO}_{4}{ }^{3 \cdot}: 95$

Multiplier to

convert $P$ to $\mathrm{PO}_{4}: \quad \frac{95 \mathrm{~g} \mathrm{PO}^{3} \cdot / \mathrm{g}-\mathrm{mol}}{31 \mathrm{~g} / \mathrm{P} / \mathrm{gO}}=3.1$

Since phosphates were used extensively in waste processing, assume all insoluble $\mathrm{P}$ is present as $\mathrm{PO}_{4}{ }^{3}$; subtract fusion $\mathrm{ICP} P$ value and add corrected amount to $\mathrm{PO}_{4}$.

Phosphorous Percent Soluble:

Core $47-\frac{-6.990 * 100}{19,900} \cdot 35.1 \%$

Core $48-\frac{-8.690 * 100}{20,200}=43.0 \%$

Core $49--\frac{4.160 * 100}{14,600} \cdot 28.5 \%$ 14,600 
WHC-EP-0668

Table A-3. Bulk Inventory Basis for Energetics Analytes.

Region

Dish

Layer 1

Layer 2

Layer 3

Supernatant

Totals
Volume

(L) 39000 75000 39000 83000 17000 Mass

(g) 46800000 97500000 44850000 95450000 18700000

$253000 \quad 303300000$
TOC Total CN

(ug/g)

2200 3600

2300

2000

2600 $(u g / g)$

5800

10000

6000

3300

5400
NO2

(ug/g)

40000

51000

42000

27000

71000
NO3

$(u g / g)$

38500

522000

40300 - 354000

$26700^{\circ} \quad 195000$

$72000 \quad 707000$ 
WHC-EP-0668

Table A-4. Calculated Inventories for Energetic Analytes.

\begin{tabular}{|c|c|c|c|c|c|c|c|}
\hline Region & $\begin{array}{l}\text { Volume } \\
\text { (L) }\end{array}$ & $\begin{array}{l}\text { Mass } \\
(g)\end{array}$ & $\begin{array}{c}\text { TOC } \\
\text { (g) }\end{array}$ & $\begin{array}{c}\text { Total CN } \\
\text { (g) }\end{array}$ & $\begin{array}{c}\mathrm{NO} 2 \\
\text { (g) }\end{array}$ & $\begin{array}{c}\mathrm{NO3} \\
\text { (g) }\end{array}$ & $\begin{array}{c}\mathrm{H} 2 \mathrm{O} \\
\text { (g) }\end{array}$ \\
\hline Dish & 39000 & 46800000 & 102960 & 164493 & 1872000 & 1801800 & 18439200 \\
\hline Layer 1 & 75000 & 97500000 & 351000 & 466050 & 4972500 & 5343000 & 50895000 \\
\hline Layer 2 & 39000 & 44850000 & 103155 & 173839 & 1883700 & 1807455 & 15876900 \\
\hline Layer 3 & 83000 & 95450000 & 190900 & 253563 & 2577150 & 2548515 & 18612750 \\
\hline Supernatant & 17000 & 18700000 & 48620 & 29587 & 1327700 & 1346400 & 13220900 \\
\hline Mass Wet Solids & 236000 & $2.85 E+08$ & $7.48 E+05$ & $1.06 E+06$ & $1.13 E+07$ & $1.15 E+07$ & $1.04 E+08$ \\
\hline$W t \%$ & & & 0.26 & 0.37 & 3.97 & 4.04 & 36.48 \\
\hline Total Content & 253000 & 303300000 & $7.97 E+05$ & $1.09 E+06$ & $1.26 E+07$ & $1.28 E+07$ & $1.17 E+08$ \\
\hline Wt\% (wet) & & & 0.26 & 0.36 & 4.17 & 4.24 & 38.59 \\
\hline
\end{tabular}




\section{WHC-EP-0668}

Table A-5. Bulk Inventory Basis for Cesium-137 and Strontium-90.

\begin{tabular}{|c|c|c|c|c|c|c|c|}
\hline Region & $\begin{array}{l}\text { Volume } \\
\text { (L) }\end{array}$ & $\begin{array}{l}\text { Mass } \\
\text { (g) }\end{array}$ & $\begin{array}{l}\text { Cs-137 } \\
\text { (uCl/g) }\end{array}$ & $\begin{array}{l}\mathrm{Sr}-90 \\
(\mathrm{uCl} / \mathrm{g})\end{array}$ & $\begin{array}{l}\text { Cs-137 } \\
\text { (Ci) }\end{array}$ & $\begin{array}{l}\mathrm{Sr}-90 \\
(\mathrm{Cl})\end{array}$ & \\
\hline Dish & 39000 & 46800000 & 950 & 200 & 44460 & 9360 & \\
\hline Layer 1 & 75000 & 97500000 & 1190 & 135 & 116025 & 13163 & \\
\hline Layer 2 & 39000 & 44850000 & 610 & 290 & 27359 & 13007 & \\
\hline Layer 3 & 83000 & 95450000 & 230 & 2400 & 21954 & 229080 & \\
\hline Supernatant & 17000 & 18700000 & 5.6 & 0.1 & 105 & 2 & \\
\hline Totals & 253000 & 303300000 & & & 209901.7 & 264610.8 & \\
\hline Heat Load (w) & & & & & 990.7361 & 1772.892 & 2763.62894 \\
\hline Heat Load (BTU/hr) & & & & & 3379.417 & 6059.588 & 9439.00661 \\
\hline
\end{tabular}

(In Layer 3, only the value from Core 49 was used--the partition of the core into subsegments grossly distorted the concentration after homogenization)

Compare values with method using an average of the core composite values

Cs-137

$(0.082 \mathrm{Cl} / \mathrm{g})^{*}(285,000,000 \mathrm{~g})=233,700 \mathrm{Cl}$
$\mathrm{Sr}-90$

$(0.077 \mathrm{Cl} / \mathrm{g})^{*}(285,000,000 \mathrm{~g})=218,500 \mathrm{Cl}$ 


\section{WHC-EP-0668}

Table A-6. Bulk Inventory Basis for ICP Analyses.

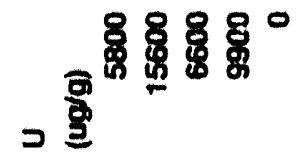

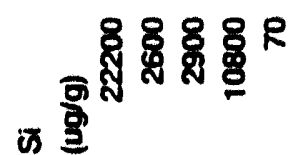

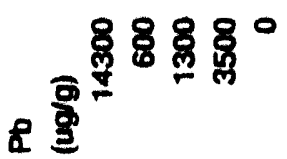

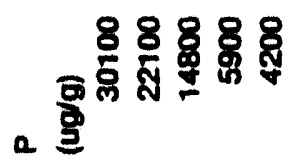

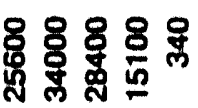

$$
\begin{aligned}
& \text { 之要 } \\
& \text { 电 } \\
& \text { 8. } \\
& \text { 必哥 }
\end{aligned}
$$

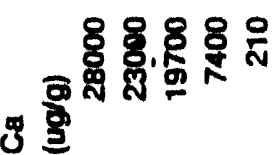

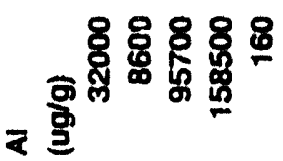

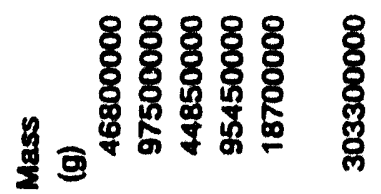

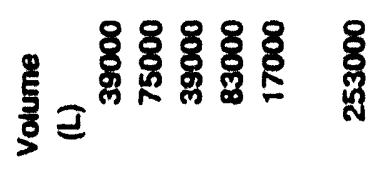

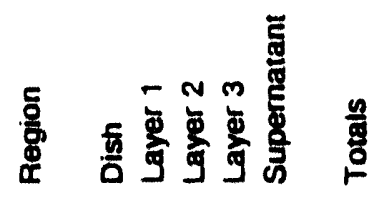

$$
\text { APP } A-10
$$




\section{WHC-EP-0668}

Table A-7. Calculated Inventories for ICP Analyses.
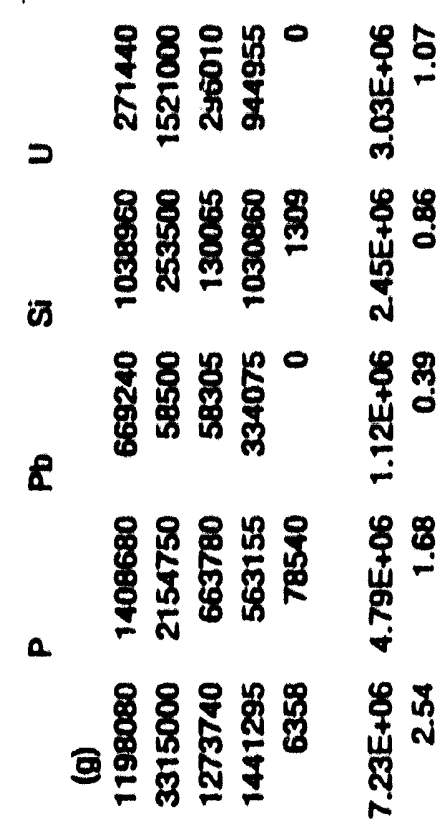

2

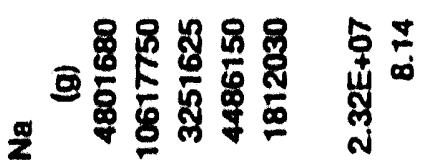

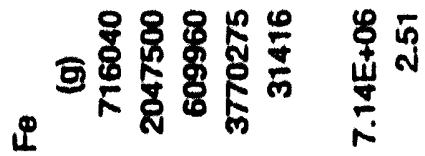

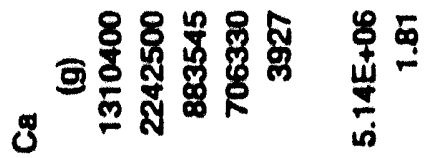

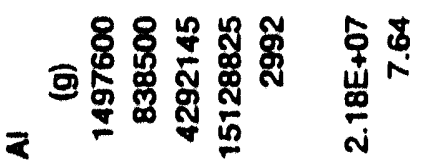

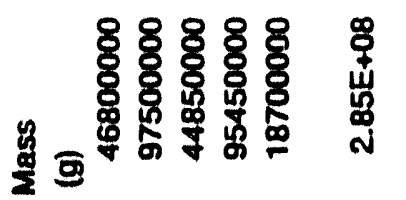

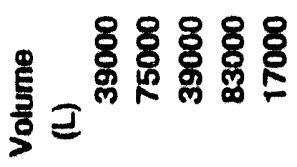

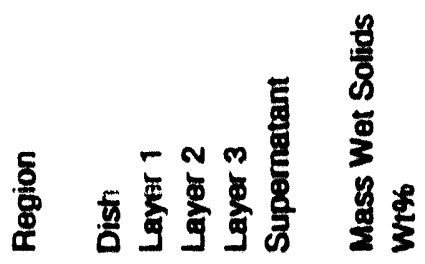


Table A-8. Comparison of Water Leach ICP Phosphorous Value with IC Phosphate Value.

\begin{tabular}{|c|c|c|c|c|}
\hline Sample & $\begin{array}{c}\text { Water Leach P } \\
\text { ICP value } \\
(\mu \mathrm{g} / \mathrm{g})\end{array}$ & $\begin{array}{c}\text { Converted } \mathrm{PO}^{3 \cdot} \text { value } \\
\text { derived from ICP } \\
(\mu \mathrm{g} / \mathrm{g})\end{array}$ & $\begin{array}{c}\mathrm{IC} \mathrm{PO}_{4}{ }^{3 \cdot} \text { Value } \\
(\mu \mathrm{g} / \mathrm{g})\end{array}$ & $\begin{array}{c}\text { Percent } \\
\text { Difference }\end{array}$ \\
\hline Core 47 & 6,990 & 21,420 & 22,100 & 3.2 \\
\hline Core 48 & 8,690 & 26,630 & 26,700 & 0.30 \\
\hline Core 49 & 4,160 & 12,750 & 12,800 & 0.40 \\
\hline
\end{tabular}

To correct mass balance for unanalyzed hydroxide content, multiply analyte concentration by multiplier.

Other multipliers:

Aluminum; assume aluminum is present predominantly as $\mathrm{Al}(\mathrm{OH})_{3}$.

Formula weights: $\quad A l: 27 ; \mathrm{Al}(\mathrm{OH})_{3}: 78$

Multiplier to

convert Al to $\mathrm{Al}(\mathrm{OH})_{3}: \frac{78 \mathrm{~g} \mathrm{Al}(\mathrm{OH})_{3} / \mathrm{g}-\mathrm{mol}}{27 \mathrm{~g} \mathrm{Al} / \mathrm{g}-\mathrm{mol}}=2.9$

Iron; assume iron is present predomillantly as $\mathrm{Fe}(\mathrm{OH})_{2}$.

Formula weights: $\quad \mathrm{Fe}: 56 ; \mathrm{Fe}(\mathrm{OH})_{2}: 90$

Multiplier to

convert $\mathrm{Fe}$ to $\mathrm{Fe}(\mathrm{OH})_{2}: 90 \mathrm{~g} \mathrm{Fe}(\mathrm{OH})_{2} / \mathrm{g}-\mathrm{mol}=1.6$

$56 \mathrm{~g} \mathrm{Fe} / \mathrm{g}-\mathrm{mol}^{2}$

Nickel; assume nickel is present predominantly as $\mathrm{Ni}(\mathrm{OH})_{2}$.

Formula weights: $\quad \mathrm{N1}: 58 ; \mathrm{Ni}(\mathrm{OH})_{2}: 92$

Multiplier to

convert $\mathrm{Ni}$ to $\mathrm{Ni}(\mathrm{OH})_{2}: 22 \mathrm{~g} \mathrm{Ni}(\mathrm{OH})_{2} / \mathrm{g}-\mathrm{mol}=1.6$ $\left.58 \mathrm{~g} \mathrm{Ni} / \mathrm{g}-\mathrm{mo}_{0}\right]$

Uranium; assume uranium is present predominantly as $\mathrm{UO}_{2}(\mathrm{OH})_{2}$.

Formula weights: $\quad U: 238 ; \quad \mathrm{UO}_{2}(\mathrm{OH})_{2}: 304$

Multiplier to

convert $\mathrm{U}$ to $\mathrm{UO}_{2}(\mathrm{OH})_{2}: \frac{304 \mathrm{~g} \mathrm{VO}}{238 \mathrm{~g} \mathrm{~V} / \mathrm{g}-\mathrm{mol}_{2}} 2 \mathrm{Lg}-\mathrm{mol}=1.3$ 
Total Carbon; assume carbon is present in three forms, and that the TOC and TIC assays did not consume or measure any cyanide:

Organic carbon (as acetate):

Inorganic carbon (as carbonate): $\mathrm{CO}_{3}$

Formula weights: $\mathrm{C}: 12 ; \mathrm{C}_{2} \mathrm{H}_{3} \mathrm{O}_{2}^{\circ}: 59 ; \mathrm{CO}_{3}{ }^{2-}: 60$

Multiplier to

convert TOC to acetate:

$$
\frac{59 \mathrm{~g} \mathrm{C}_{2} \mathrm{H}_{3} \mathrm{O}_{2}-\mathrm{g} \mathrm{g}-\mathrm{mol}}{24 \mathrm{gC} / \mathrm{g}-\mathrm{mol}}=2.45
$$

Multiplier to convert

TIC to carbonate:

$$
\frac{60 \mathrm{~g} \mathrm{CO}_{32} \cdot \frac{\mathrm{gg}-\mathrm{mol}}{12 \mathrm{gC} / \mathrm{g}-\mathrm{mol}}-5}{-5}
$$

Potential endotherm in 241-C-109:

Consider the reaction

$$
\begin{array}{ll}
2 \mathrm{Al}(\mathrm{OH})_{3} & 300^{\circ} \mathrm{C} \\
2(-304.2) & \mathrm{Al}_{2} \mathrm{O}_{3}+3 \mathrm{H}_{2} \mathrm{O} \\
2 & -407.35 \quad 3(-32.57)
\end{array}
$$

$\Delta H_{f}(\mathrm{kcal} / \mathrm{mol})$

thus, the heat of reaction, $\Delta H_{r \times n}=\Delta H_{f}$ products $-\Delta H_{f}$ resctants

$$
=(-407.95)+(-97.71)-(-608.4)
$$

- $+102.74 \mathrm{kcal}$

Therefore, $\Delta H$ for each $\mathrm{g}$-mol Al $(\mathrm{OH})_{3}$ is $102.74 / 2$ or $51.37 \mathrm{kcal} / \mathrm{g}-\mathrm{mol} \mathrm{Al}(\mathrm{OH})_{3}$. Now, at $100,000 \mu \mathrm{g} \mathrm{Al} / \mathrm{g}$ wet sample $=10 \mathrm{wt \%} \mathrm{Al}$

$(0.1 \mathrm{~g} \mathrm{Al} / \mathrm{g}$ wet sample $) *\left(\mathrm{~g}-\mathrm{mol} A l(\mathrm{OH})_{3} / 27 \mathrm{~g} \mathrm{Al}\right) *\left(51.37 \mathrm{kcal} / \mathrm{g}-\mathrm{mol} \mathrm{Al}(\mathrm{OH})_{3}\right)$ * $(4181 \mathrm{~J} / \mathrm{kca} 1)=795 \mathrm{~J} / \mathrm{g}$ wet sample $\mathrm{O} 10 \mathrm{wt \%} \mathrm{Al}$

The degree of agreement between the calculated and average observed endotherms indicates that they are not solely attributable to the decomposition of aluminum hydroxide. However, it appears that this reaction may contribute significantly to the observed endothermic behavior. 
Table A-9. Energetic Calculations.

\begin{tabular}{|l|c|c|c|c|}
\hline Sample & WtK AI & $\begin{array}{c}\text { Calculated Al }(\mathrm{OH})_{3} \\
\text { Endotherm } \\
(\mathrm{J} / \mathrm{g})\end{array}$ & $\begin{array}{c}\text { Avg. Measured } \\
\text { Heat of React ion } \\
(\mathrm{J} / \mathrm{g})\end{array}$ & $\begin{array}{c}\text { Theoret fal } \\
\text { X Total } \\
\text { Endotherm }\end{array}$ \\
\hline $47-18$ & 13.2 & 1049 & 1555 & 67.5 \\
\hline $47-1 \mathrm{C}$ & 12.0 & 954 & 610 & 156.4 \\
\hline $47-10$ & 3.2 & 254 & 508 & 50.0 \\
\hline $47-$ Comp. & 11.7 & 930 & 1084 & 85.8 \\
\hline & & & & \\
\hline $49-1 B$ & 18.5 & 1471 & 2188 & 67.2 \\
\hline $49-1 \mathrm{C}$ & 9.6 & 763 & 565 & 135.0 \\
\hline $49-10$ & 7.1 & 564 & 305 & 184.9 \\
\hline $49-$ Comp. & 12.7 & 1010 & 922 & 109.5 \\
\hline
\end{tabular}

Typical process stream calculations:

Coating Waste: Calculate wt\% $(\mu \mathrm{g} / \mathrm{g})$ composition of $\mathrm{Al}, \mathrm{S1}$, and U. Use composition given on $\mathrm{pg} .8$ of $\mathrm{HW}-23043$ and reduce water content.

7,900 lbs total 6,154 lbs water
1,746 lbs solute

Assume $\mathrm{NaAlO}_{2} \rightarrow-\rightarrow \mathrm{Al}(\mathrm{OH})_{3}(\mathrm{~s}) ; \mathrm{NaSiO}_{3}$ precipitates as well, other compounds remain in solution.

Dry solids mass $=638 \mathrm{lbs} \mathrm{NaAlO}_{2} * 78$ lb $\mathrm{Al}(\mathrm{OH})_{3} / \mathrm{mol}+27 \mathrm{lb} \mathrm{NaSiO}=633.9 \mathrm{lb}$ 82 if $\mathrm{NaAlO}_{2} / \mathrm{mol}$

Analyte mass: 27 lb Al/78 lb Al $(\mathrm{OH})_{3} * 606.9 \mathrm{lbs} \mathrm{Al}(\mathrm{OH})_{3}=210$ lbs Al 28 ib Si/99 ib NaSiO ${ }_{3}^{*} 27$ ib $\mathrm{NaSiO}_{3}=7.3$ ib Si 
WHC-EP-0668

Table A-10. Borsheim-Simpson Model Run at 1.0 volx.

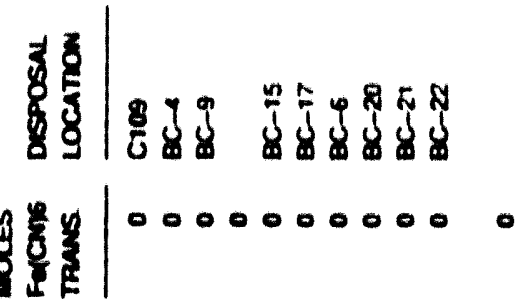

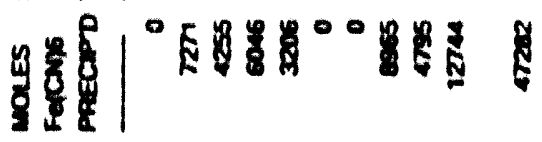

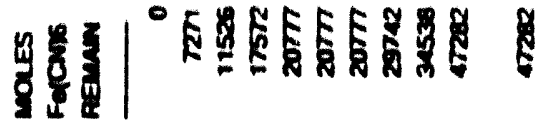

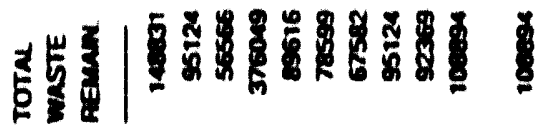

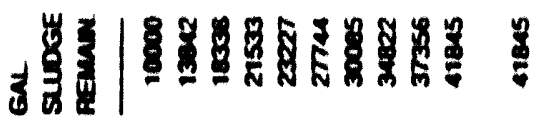

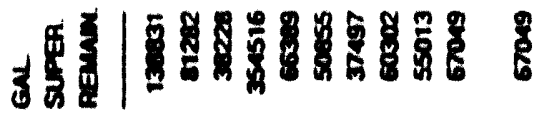

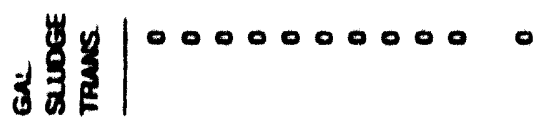

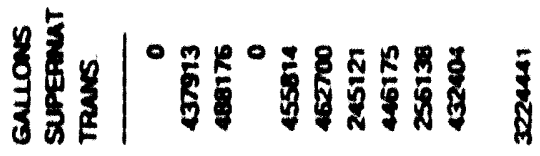

Hit Hintitin!

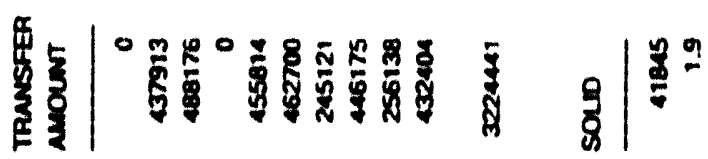

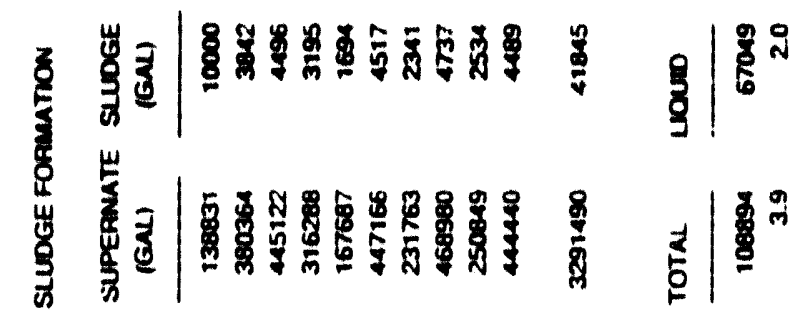

,

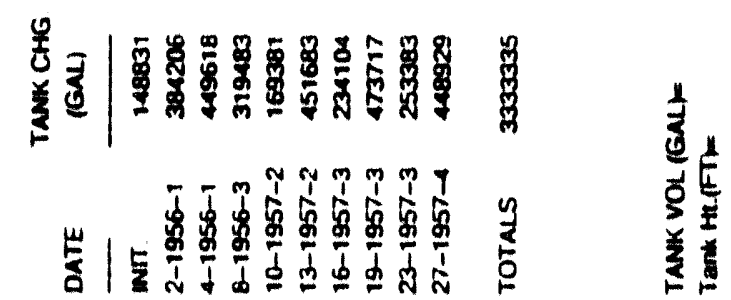


Table A-11. Borshe1m-Simpson Model Run at 1.0 vol\%, Post-Scavenging.

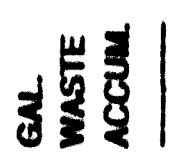

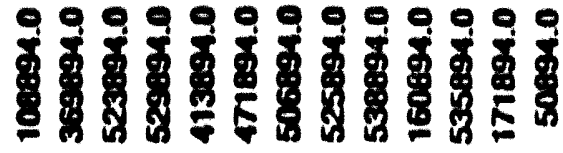

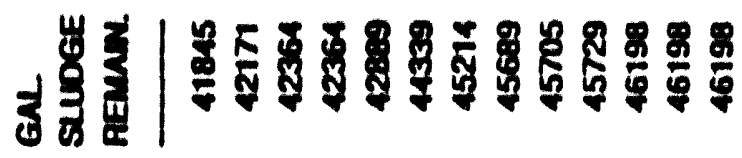

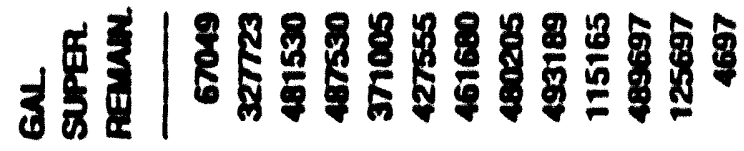

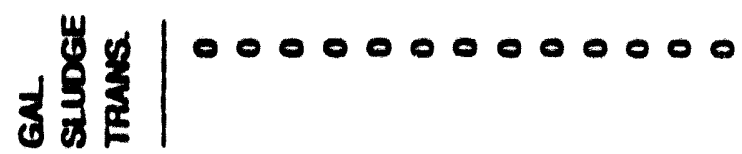

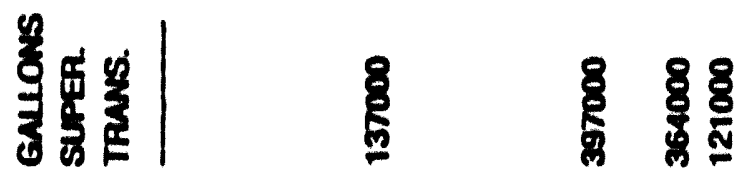

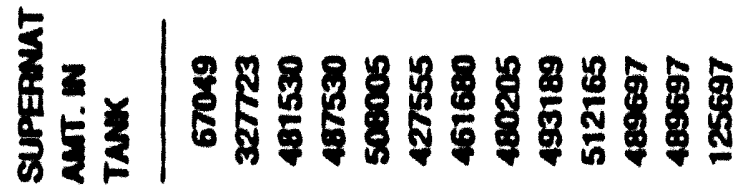

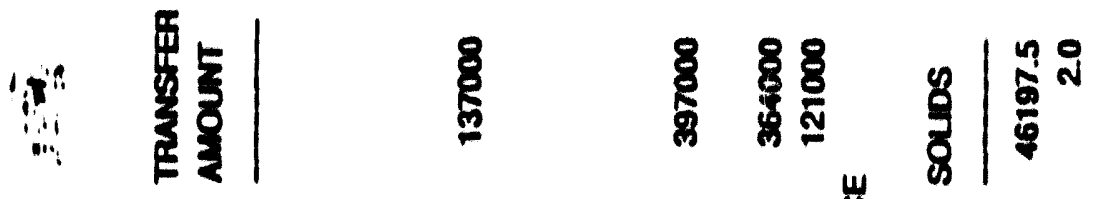

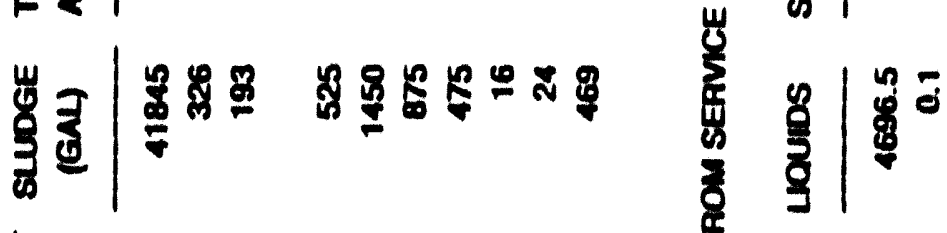

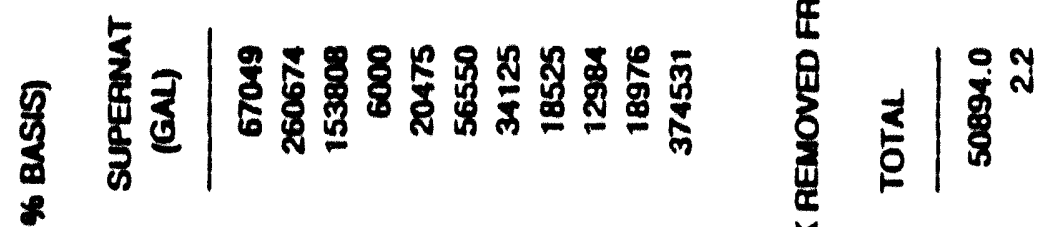

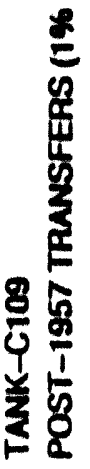

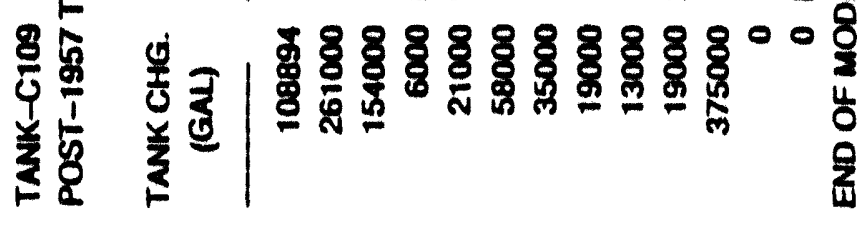

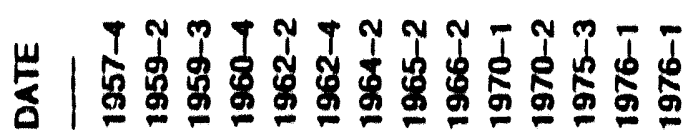


WHC-EP-0668

Table A-12. Borsheim-S1mpson Model Run at 1.5 vol\%.

范|

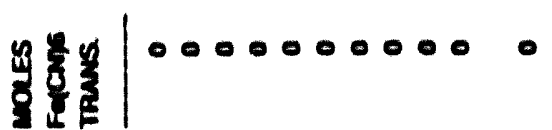

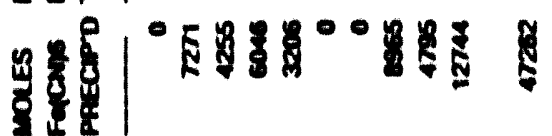

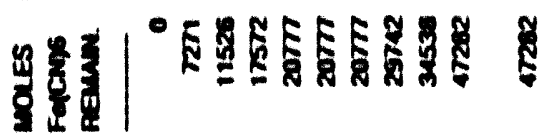

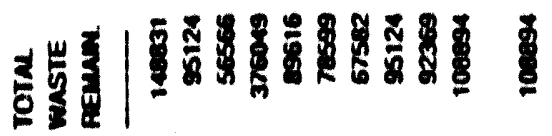

3ำ

ว

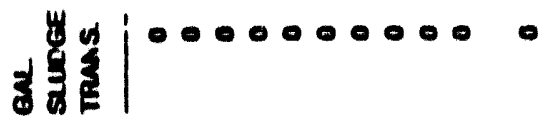

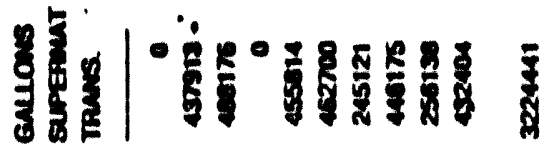

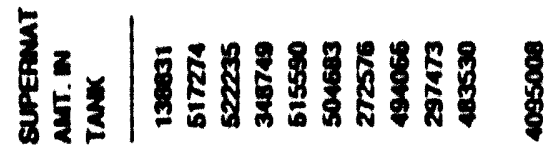

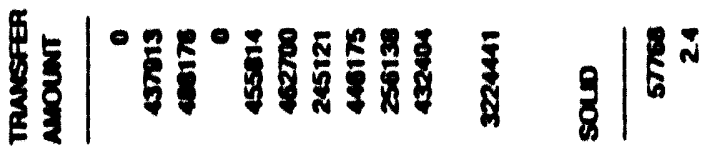

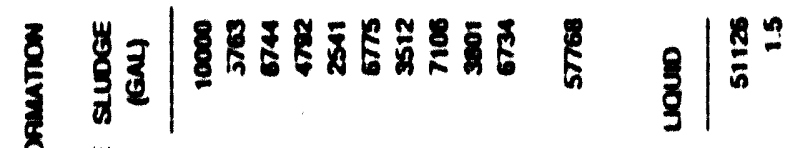

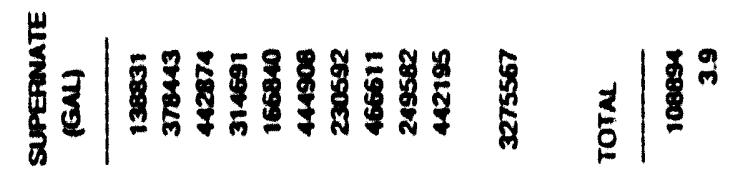

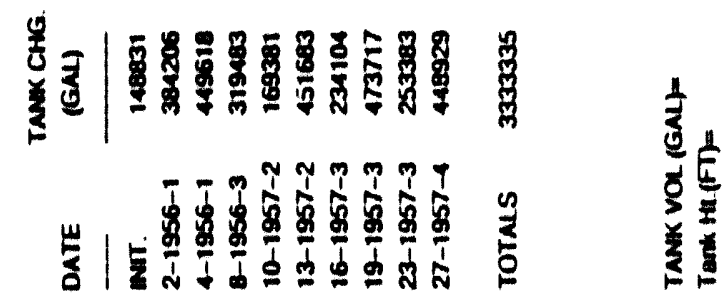


Table A-13. Borsheim-Simpson Model Run at 1.5 vol\%, Post Scavenging. s"

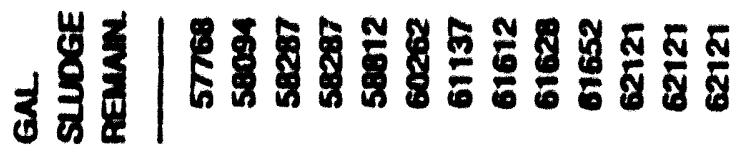

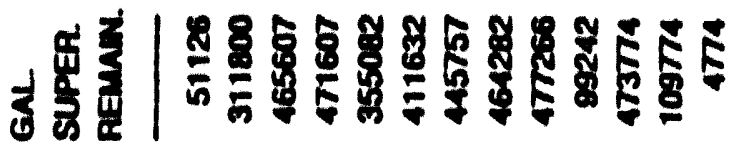

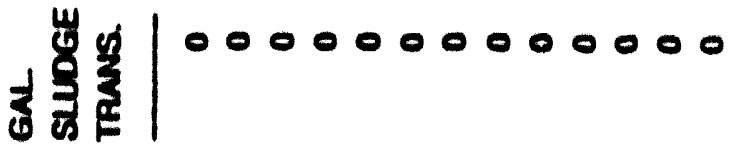

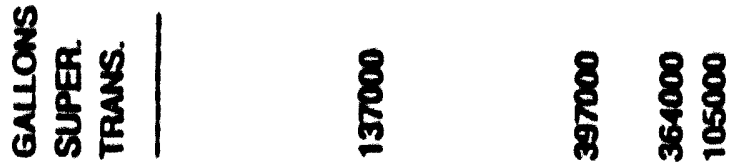

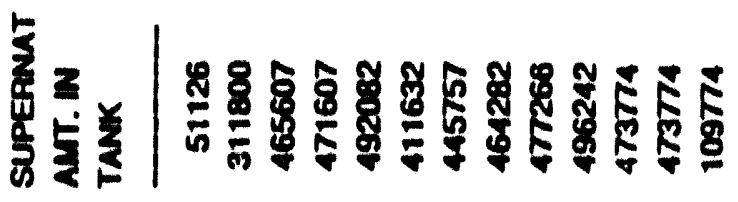

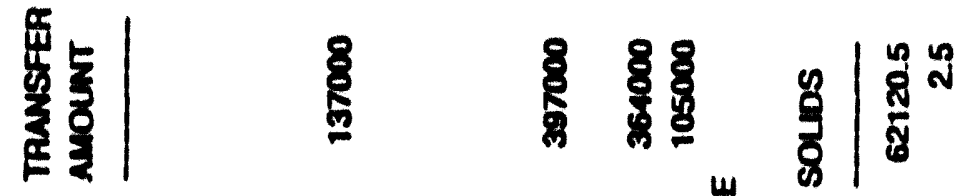

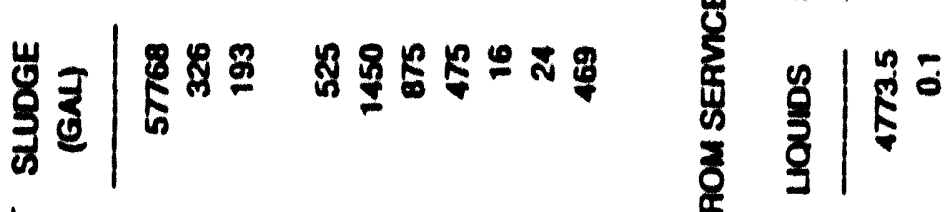

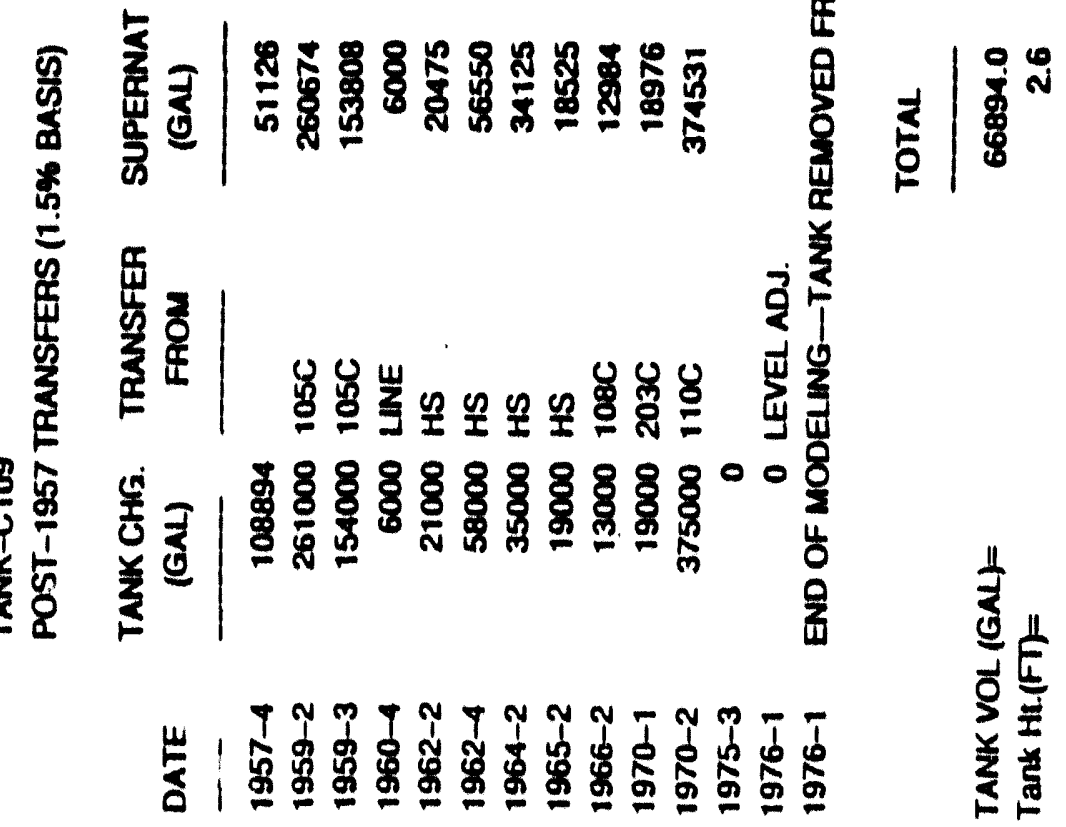


WHC-EP-0668

Table A-14. Typical Analyte Concentrations in Precipitated Coating Waste

\begin{tabular}{|l|l|l|l|l|l|}
\hline Analyte & $\begin{array}{l}\text { Mass } \\
(\text { lbs })\end{array}$ & Dry Wtx & $\begin{array}{l}\text { Concentrat Ion } \\
(\mu g / d r y g)\end{array}$ & $\begin{array}{l}\text { Concentration } \\
\left(\begin{array}{l}\text { 40\% water } \\
(\mu g / g)\end{array}\right.\end{array}$ & $\begin{array}{l}\text { Concentration } \\
\text { So\% water } \\
(\mu g / g)\end{array}$ \\
\hline A1 & 210 & 33.1 & 331,000 & 198,600 & 165,500 \\
\hline$S 1$ & 7.66 & 1.21 & 12,100 & 7,260 & 6,050 \\
\hline$U$ & 1 & 0.16 & 1,600 & 960 & 800 \\
\hline
\end{tabular}

Neutralized IC Waste: Calculate wtX ( $\mu \mathrm{g} / \mathrm{g}$ ) composition of B1, S1, F, and U; use composition given on $\mathrm{pg} .32$ of $\mathrm{HW}-23043$.

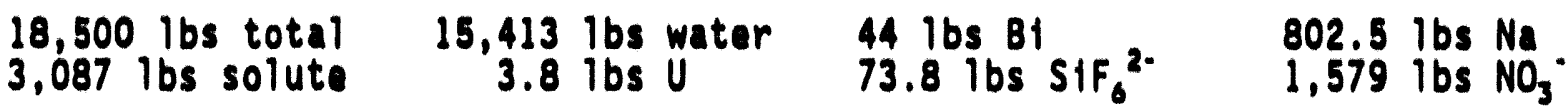

Assume $\mathrm{NO}_{3}{ }^{\circ}$ is present as $\mathrm{NaNO}_{3}$, thus $\frac{1.579 .51 \mathrm{bs} * 453.6 \mathrm{~g} / \mathrm{lb}}{2}=1.5 \mathrm{M} \mathrm{NO}{ }^{\circ}$ $2,040 \mathrm{ga} 1 * 3.785 \mathrm{~L} / \mathrm{ga} 7 * 62 \mathrm{~g} / \mathrm{mol}$

$1.5 \square$ is not near saturation; water and nitrate do not precipitate.

The amount of sodium that precipitates is that not associated with the nitrate: Total moles of sodium $=802.5 \mathrm{lbs} / 23 \mathrm{lb} / \mathrm{mol}$ or $34.9 \mathrm{lb}-\mathrm{mol}$

$1.579 .5 \mathrm{lbs} \mathrm{NO}_{3}^{\circ}-25.5 \mathrm{lb}-\mathrm{mol}$ nitrate (and assoctated sodium) $62 \mathrm{los} / \mathrm{mol}$

Mass of sodfum nitrate in solution: $25.5 \mathrm{lb}-\mathrm{mol} \star 85 \mathrm{lb} / 1 \mathrm{~b}-\mathrm{mol}=2,165 \mathrm{lbs}$.

Therefore, $(34.9-25.5 \mathrm{lb}-\mathrm{mol}) \approx 23 \mathrm{lb} \mathrm{Na} / \mathrm{lb}-\mathrm{mol}=216.7$ lbs $\mathrm{Na}$ precipitate and $585.816 \mathrm{Na}$ remain in solution. If everything but the $\mathrm{NaNO}_{3}$ and water precipitate, then the mass of dry solids $=18,500 \mathrm{lbs}-(15,413+2,165)$. 922 lbs.

Table A-15. Typical Analyte Concentrations in Precipitated IC Waste.

\begin{tabular}{|l|c|c|c|c|c|}
\hline Analyte & Mass & Ory WtK & $\begin{array}{c}\text { Ory } \\
\text { Concentrat ion } \\
(\mu g / g)\end{array}$ & $\begin{array}{c}\text { Concentrat fon } \\
\text { O50 water } \\
(\mu g / \text { wet g) }\end{array}$ & $\begin{array}{c}\text { Concentration } \\
\text { O 40\% water } \\
(\mu \mathrm{g} / \text { wet g) }\end{array}$ \\
\hline $\mathrm{BI}$ & 44 & 4.77 & 47,700 & 23,850 & 28,620 \\
\hline $\mathrm{S1}$ & 14.6 & 1.58 & 15,800 & 7,900 & 9,480 \\
\hline $\mathrm{F}$ & 59.2 & 6.42 & 64,200 & 32,100 & 38,520 \\
\hline$U$ & 3.8 & 0.41 & 4,100 & 2,050 & 2,460 \\
\hline
\end{tabular}


UR waste: Calculate wtK $(\mu \mathrm{g} / \mathrm{g})$ composition of $U$ at a density of 1.3. Use flowsheet composition given on $\mathrm{pg}$. 5 of HW-30399. Uranium concentrations w111 range from 0.007 to 0.14 (flowsheet concentrations to $20 x$ flowsheet) or approximately 1.67 to $33.32 \mathrm{~g} \mathrm{U} / \mathrm{L}$.

Wtx urantum would then range from $1.67 * 100 / 1,300-0.128 \%$ or $1,280 \mu g / g$ to $33.32 \star 100 / 1,300=2.5 \%$ or $25,000 \mu 9 / 9$. These would increase by 25 to $30 x$, if the original water content of the sludge (-75 wtx) decreased to 50 wtX. 
WHC-EP-0668

APPENDIX B

STATISTICAL INTERPRETATIONS

APP B-i 
WHC-EP-0668

This page intentionally left blank. 
From: Process Laboratories and Technology

12100-PLT93-070.R1

Phone: 3-4034/3-2779 T6-07/T6-07

Date: $\quad$ August 18, 1993

Subject: STATISTICAL ANALYSIS OF TANK 241-C-109 DATA

To:

B. C. Simpson

R2-12

$\begin{array}{ll}\text { CC: H. Babad } & \text { R2-78 } \\ \text { G. L. Borsheim } & R 2-11 \\ \text { D. A. Dodd } & T 6-50 \\ \text { J. G. Hil1 } & R 2-12 \\ \text { D. A. Reynolds } & R 2-11 \\ \text { L. M. Sasaki } & \text { R2-12 }\end{array}$

J. P. Sloughter

T6-07

R. L. Weiss

$\mathrm{H} 4-23$

T. L. Welsh

W. I. Winters

KMR:LJ F†Te/LB

T6-07

T6-50

L. Masaki R2-12

Attached to this revised letter is a report entitled "Siatistical Characterization Report for Single-Shell Tank 241-C-109." Format and minor text revisions were made to the original report issued August 13, 1993. The minor text changes are redlined. This report contains a statistical evaluation of the core composite data and the subsegment data from the three core samples. The six topics addressed are as follows:

- Estimates of the mean concentration of analytes found in the single-shell tank and confidence intervals (CI) on the mean

- The results of a statistical test used to determine the Analytical Chemistry Laboratory's (325 Building) ability to homogenize solid core segments

- The results of a statistical test conducted to determine the Analytical Chemistry Laboratory's ability to construct core composite samples from subsegment samples

- Estimates of the spatial variance and the analytical measurement variance and their CIs

- The results of a multiple comparisons procedure applied to the core composite samples and to the subsegment samples

- A comparison of results from tanks 241-C-109 and 241-C-112.

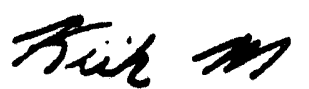

K. M. Remund, Advanced Statistician Process Laboratories and Technology

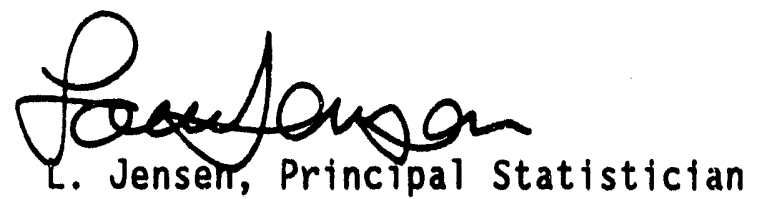

Process Laboratories and Technology

114

Attachment

APP B-1 
WHC-EP-0668

Attachment to 12100-PLT93-070.R1

\section{Statistical Characterization Report}

for

Single-Shell Tank 241-C-109

Page 1 of 52 
WHC-EP-0668

\section{Statistical Characterization Report for Single-Shell Tank 241-6-109}

\subsection{SUMMARY}

This report contains the results of a statistical analysis of data from three core samples taken from single-Shell Tank (SST) 241-C-109 (C109). Six topics are addressed; they are given in Section 3 through section 8.

Section 3 contains mean concentration estimates of several analytes found in the SST. In addition, 95\% confidence intervals (CI) on the mean concentration are also given.

Section 4 contains the results of a statistical test conducted to determine the Analytical Chemistry Laboratory's (325 Building) ability to homogenize solid core segments. For 16 out of 17 analytes, the variability between sampling locations could not be distinguished from zero. Based upon the results of this statistical test, it is concluded that the Analytical Chemistry Laboratory can satisfactorily homogenize core segments.

Section 5 contains the results of a statistical test conducted to determine the Analytical Chemistry Laboratory's ability to construct core composite samples from subsegment samples. Based upon the large spatial variance and analytical measurement variance, the comparisons showed that the Analytical Chemistry Laboratory's ability to construct core composite samples was sat isfactory.

Section 6 contains estimates of the spatial variance (variability between cores) and the analytical measurement variance associated with the core samples. CIs are given for both variances. In 28 out of 33 cases (85\%) the spatial variability in the core composite samples was larger than the analytical error.

Section 7 contains the results of a multiple cimparisons procedure applied to the means from the core composite samples arid to the means from the subsegment samples. There is no significant difference between the composite sample means for 12 of $31(39 \%)$ analytes and they were significantly different in 19 out of 31 (61\%) of the analytes. The comparisons between the subsegments indicates "layering" within the waste for some analytes and that the waste is very heterogeneous for other analytes. These types of heterogeneity influence the magnitude of the spatial variability.

Section 8 contains a comparison of results from tanks 241-C-109 and 241-C-112. Due to large spatial and analytical measurement variances and small degrees of freedom, the mean concentrations cannot be distinguished from each other. For most of the analytes, the spatial variances cannot be distinguished from each other. Even though the analytical results came from the same laboratory, the analytical measurement variances were significantly different for 13 out of 28 (46\%) analytes. 
Appendix 1 contains tables listing the data and the summary statistics. Appendix 2 contains plots of the core composite sample data and subsegment data. Appendix 3 contains plots comparing core composite sample data and subsegment sample data from SSTs $241-C-109$ and 241-C-112.

\subsection{INTRODUCTION}

Three cores samples (cores 47, 48 and 49) were taken from SST C109. Core 47 consisted of three subsegments (denoted by $B, C$, and $D$ ), core 48 consisted of two subsegments ( $C$ and $D$ ), and core 49 consisted of three subsegments ( $B, C$, and D). The results from a chemical analysis of the cores was used to obtain est imates of the mean concentration of analytes in the waste. In addition, the data was used to evaluate the Analytical Chemistry Laboratory's ability to homogenize subsegments and to construct core composite samples.

Composite samples for each core were made from homogenized subsegment waste. A single composite sample was also made from all of the drainable liquids. Two samples, the sample and the duplicate, were taken from each core composite and subsegment. For the homogenization test, additional samples and duplicate samples were taken from two different locations within the mixed waste.

The laboratory results from SST C109 samples are given in Appendix 1 . The analytes of interest from the Inductively Coupled Plasma (ICP) analyses are $\mathrm{A} 1, \mathrm{Ca}, \mathrm{Fe}, \mathrm{Na}, \mathrm{NI}, \mathrm{Pb}, \mathrm{U}$, and $\mathrm{P}$. The ICP acid digestion, and water leach analyses were performed on all composite core samples. The ICP KNH/NI fusion dissolution analyses were performed on the subsegments and core composite samples. Radio chemistry results on core composite samples were reported for U, Pu-238, Pu-239/240, Cs-137, and Sr-90. A radio chemistry analysis on the subsegments was performed only for $\mathrm{Cs}_{-137}$ and $5 \mathrm{r}-90$. Each subsegment and core composite sample was analyzed by Ion Chromatography (IC) for Chioride, Nitrite, Nitrate, Phosphate, Sulfate and Total Cyanide (CN). In the tables in Appendix 1, the data is identifled by the analysis method and the type of dissolution; e.g., the notation ICP.acid.Al refers to aluminum, acta digestion and an ICP analysis.

The core composite sample results are contained in Table 1. Table 2 contains the subsegment sample results. The homogenization test results are contained in Table 3.

Appendix 2 graphically shows the data for core composite and subsegment samples.

A close examination of the data revealed several potential anomalies. These potential anomalies are listed below.

The following core composite sample results were an order of magnitude different (lower or higher) than other core composite sample results:

- core 48 ICP.acid.AI

- core 47 ICP.acid.Pb

- core 48 ICP. fusion.AI 
- core 49 ICP. fusion.Pb

- core 47 Total Alpha Pu

- core $47 \mathrm{Pu}-239 / 240$.

Core 47 subsegment 18 result for ICP. fusion.Fe is at least twice as large as its duplicate and all other subsegment data for this analyte.

The following subsegments were different by an order of magnitude (lower or higher) than other subsegment results:

- core 48 subsegments $1 C$ and 10 for ICP. fus.AI

- core 47 and 48 subsegment $1 B$ for fusion.Sr-90.

There is no direct evidence that the results noted above are due to analytical measurement errors. Consequently, the statistical analysis was performed on the data as it is reported in Tables 1, 2, and 3 .

\subsection{MEAN CONCENTRATION ESTIMATES}

A task outlined in the Waste Characterization Plan was to estimate the analyte concentrations in the waste (Winters, 1990). They were estimated by computing mean concentrations and $95 \% \mathrm{CIs}$ on the mean concentrations. The estimate of the inventory and CI on the inventory of an analyte, are the corresponding mean concentration estimates and CI multiplied by the volume of waste in the tank. These estimates are not given in this document.

Table 1 contains the core composite data used to compute the mean concentration estimates and the CIs. The "NA" symbol indicates that the data was not available. Results for Pu-238 were not included in any computations since there were no duplicate measurements.

\subsection{Statistical Methods}

The concentration estimates are given in the form of $95 \%$ CIs on the mean concentration. It is assumed that each sample and duplicate sample are analyzed independently of one another. The two analytical results are used to estimate the analytical measurement error. Due to the hierarchical structure of the data, the analytical measurement error (variance) alone is not the appropriate error term to use in computing the CIs. A i inear combination of the analytical measurement variance and spatial variance is the appropriate variance of the mean for the CIS. The variance of the mean is obtained from the analysis of variance (ANOVA) corresporiding to the model. Brown (1993), Appendix G, gives the formula used to calculate these CIs.

\subsection{Statistical Results}

Table 4 contains the summary statistics, by analyte, for ICP acid digestion, ICP water leach, ICP KOH $\backslash N$ i fusion dissolution, radio chemistry, and IC 
WHC-EP-0668

analyses. Table 5 contains the summary statistics for the drainable liquid composite sample. The summary statistics are as follows:

$\begin{array}{ll}g & \text { arithmetic mean of the concentration data } \\ \sigma^{2}(9) & \text { estimated variance of } g \\ \mathrm{df} & \text { degrees of freedom associated with BMS } \\ 95 \% \mathrm{LL} & \text { lower limit to the } 95 \% \mathrm{CI} \text { on the mean } \\ 95 \% \mathrm{UL} & \text { upper limit to the } 95 \% \mathrm{CI} \text { on the mean. }\end{array}$

For some analytes the lower confidence limit (95\% LL) was negative. Since concentrations are strictly greater than or equal to zero, any negative $95 \% \mathrm{LL}$ values were set equal to zero.

The estimated variance of the mean $\left(\partial^{2}(g)\right)$ is very large relative to the mean for most of the analytes. One cause is the large differences between core compostte samples; 1.e., the large spatial variabllity. In Section 7 on multiple comparisons, the analytical results from the core composite samples are compared to determine if there are significant differences between cores. A similar comparison is also made between the subsegments within each core.

\subsection{HOMOGENIZATION TEST}

A second task in applying the Waste Characterization Plan was to evaluate the ability of the Analytical Chemistry Laboratory to homogenize subsegments (Winters, 1990).

Subsegment $D$, from cores 47,48 , and 49 , was homogenized and arbitrarily divided into two parts. One subsample was obtained from each part. Two al iquots were taken from each subsample and prepared for chemical analysis. The homogenization test data is given in Table 3. ICP acid digestion and fusion dissolution analyses were conducted on the samples for the following analytes: $\mathrm{Al}, \mathrm{Ca}, \mathrm{Fe}, \mathrm{Na}, \mathrm{Ni}, \mathrm{Pb}, \mathrm{U}$, and $\mathrm{P}$. Acid digestion and fusion dissolution results were also reported for Cs-137.

\subsection{Statistical Methods and Results}

Due to the nested structure (subsamples within subsegments, al iquots within subsamples) with in the data, a hierarchical statistical model was fit to the data. Snedecor (1980), page 284, contains a description of this type of model. Such a model is used to estimate different components of variability in the data. The total variability in the data is decomposed into three components: one due to variablilty between subsegments, one due to the variability between samples taken from different locations on each homogenized subsegment $\left(\sigma^{2}(L)\right)$, and one due to the analytical measurement error $\left(\sigma^{2}(A)\right)$. The analytical measurement error accounts for the differences between al iquots taken from the same location. 
To quantify the contribution of $\sigma^{2}(L)$ (the component of varlability due to location or homogenization), the ANOVA corresponding to the hierarchical model is used. From the ANOVA, a test is constructed to determine if $\sigma^{2}(L)$ is significantly different from zero. If $\sigma^{2}(L)$ is significantly different from zero, then the laboratory does not have the abllity to homogentze subsegments. If $\sigma^{2}(L)$ is not significantly different from zero, then the laboratory has the abilfty to homogenize core segments. The reason underlying this test is that if $\sigma^{2}(L)=0$, then the mean concentrations at the two locations are equal; 1.8. , there is no difference between the locations.

The F-test is used to determine whether or not $\sigma^{2}(L)$ is significantly different from zero. The p-values (the attained level of significance) from these tests are given in Table 6. If the $p$-value is smaller than 0.05 , then $\sigma^{2}(L)$ is significantly different from zero. In all but one case (ICP.fus.AI), the p-valugs are greater than 0.05 . This indicates that, except for this analyte, $\sigma^{2}(L)$ is not significantly different from zero. Based upon the results of this statistical test it can be concluded that the Analytical Chemistry Laboratory can adequately homogenize core segments. However, it needs to be noted that there is no reference value avallable to check the degree of homogentzation; e.g., the differences between the results from the two locations must be within $2 \%$ of each other. If such a value were avallable, the conclusions in this section may not be valid.

\subsection{COMPARISON WITH A SIMULATED CORE COMPOSITE MEAN}

Another task in applying the Waste Characterization Plan was to evaluate the ability of the Analytical Chemistry Laboratory to make core composite samples from the individual subsegment samples (Winters, 1990). Core composite samples were formed by combining samples from each homogenized subsegment in the cure. Each subsegment is weighted equally in the composite sample. Each core composite sample was homogentzed, and a sample and duplicate sample obtained.

A simulated core composite (SCC) was statistically constructed to compare to the corresponding core composite sample results. For each analyte and each core, the SCCS are the average of the subsegment results. This mean or average is denoted by $g(w)$. The " $w$ " is used since $g(w)$ is generally a weighted mean. However, in this case the weights are all equal.

\subsection{Statistical Methods}

For each core, the comparison between the core composite and SCC is made by computing a CI on the difference between the SCC and the mean of the composite sample. If zero is in the $\mathrm{Cl}$, then the laboratory can construct core composite samples satisfactorily (1.e., the SCC cannot be statistically distinguished from the core composite sample mean). If zero is not in the CI, then the laboratory cannot satisfactorlly construct core composites (1.e., the two means are significantly different). 
The $\mathrm{Cl}$ for this difference is (LL, UL) where the lower $11 \mathrm{mit}$ (LL) and upper limit (UL) values are

$$
L L=[\bar{y}(w)-\bar{y}(c)]-t \sqrt{\sigma^{2}[\bar{y}(w)-\bar{y}(c)]}, \quad U L=[\bar{y}(w)-\bar{y}(c)]+t \sqrt{\sigma^{2}[\bar{y}(w)-\bar{y}(c)]}
$$

where

$$
\begin{array}{ll}
g(c) & \text { mean of the two core composite sample results, } \\
t & \text { percentile point from Student's } t \text { distribution, and } \\
\sigma^{2}[g(w)-g(c)] & \text { is the estimated variance of the difference. }
\end{array}
$$

Appendix 4 , outlines the method used to calculate $\sigma^{2}[g(w)-g(c)]$. The estimated varlance $\sigma^{2}[g(w)-g(c)]$ was calculated using the data from ali three cores because of the 1 imited information avallable. The degrees of freedom (df) assoclated with "t" were calculated using Satterthwalte's approximation (Snedecor, 1980, page 228). In the above equations, $g(w)$ and $g(c)$ should have a subscript indicating the core. To simplify the notation, the subscript is omitted.

\section{b.2 Statistical Results}

Table 7 contains summary statistics for all three cores, including the 95\% CI interval (LL,UL) on the difference between the SCC mean and the core composite mean. All of the CIs on this difference contain zero. This indicates that there is no significant difference between the two means (i.e., the Analytical Chemistry Laboratory can construct a core composite sample from material similar to cores 47, 48, and 49).

It needs to be pointed out that (see Table 7) the CIs on the difference between the two means tend to be rather wide; 1.e., LL= $-10^{5}$ or $-10^{4}$ and UL$+10^{3}$ or $+10^{4}$. The reason for this extreme width is the magnitude of the est tmated variance $\sigma^{2}[\rho(w)-g(c)]$ and the small number of degrees of freedom. Since the variance is large, the two means would have to be extremely different before zero in not in the $\mathrm{Cl}$.

\subsection{THE SPATIAL VARIANCE AND AMALYTICAL MEASUREMENT VARIANCE}

Using the hierarchical structure of the core composite data, the spatial varlance and the analytical measurement variance can be separated from each other. The spatial variance is a measure of the varlability between cores. The analytical measurement variance includes, among other things, the segment homogenization error, the sample handling error, and the chemical analysis error. This vartance is a function of the difference between the analytical results on the sample and duplicate sample.

The size of the analytical measurement variance and the spatial variance, along with the degrees of freedom, determine the width of the CIs. The 
estimate of the variance of the mean is a linear function of the spatial and analytical measurement variances. To help judge the magnitude of these two varlance components, this section contains explicit estimates of each variance and Cis for each vartance.

\subsection{Statistical Methods}

Estimates of the spatial variance $\left(O^{2}(S)\right)$ and analytical measurement variance $\left(\partial^{2}(A)\right)$ were obtained for each analyte using Restricted Maximum Likel thood Estimation. This method is discussed by Harville (1977). Snedecor (1980), page 246, outlines methods that can be used to ob:ain CIs for $\partial^{2}(S)$ and $\partial^{2}(A)$. These CI techniques are the methods used in this document. The CI for $\partial^{2}(S)$ is approximate. The CI for $\tilde{o}^{2}(A)$ is exact.

\subsection{Statistical Results}

Tables 8 and 9 contain estimates of the variance components and their $95 \%$ CIs. For $85 \%$ of the analytes (28 out of 33 ), the estimates of spatial variance are larger than those for the analytical error. This large spatial varlabllity contributes to the extreme width of the Cl for the mean concentrations, and the Cl on the difference between the synthetic core composite and the core composite sample.

Section 8 contains estimates of relative standard devtations of the mean, the analytical measurement varlance, and the spatial variance. In addition, Section 8 also contains estimates of the contribution of $\sigma^{2}(A)$ and $\partial^{2}(S)$ to the total varlance.

\subsection{MULTIPLE COMPARISONS: CORE COMPOSITE SAMPLES AND SUBSEGMENT SAMPLES}

A group of statistical methods known as multiple comparisons can be used to determine whether or not thare are significant differences between core composite samples and between subsegment samples. These differences will aid in determining heterogeneity or layers within the waste. In addition, if significant differences exist between the core composite samples or the subsegment samples, then this will help explain the extreme width of the CIs; 1.e., it will help explain the large spatial variabllity.

\subsection{Statistical Methods}

The multiple comparison procedure known as Tukey's Honestly Significant Difference (HSD) (Petersen, 1985, page 78) was used. The HSD procedure determines if there are significant differences between core composite samples and between subsegment samples. The core composite samples and subsegment samples that are not significantly different from each other $c$ an then be grouped together.

\subsection{Statistical Results}

For each analyte, HSD comparisons were made between the means of the core composite samples. These comparisons, along with the means for each core 
composite sample, are contained in Table 10. The symbols a and $B$ are used to indicate groupings. The means of core composite samples with the same symbol cannot be statistically distinguished from each other. Core composite samples with different symbols are significantly different from each other. For a given analyte, the core composite samples with an a have a smaller mean concentration than the core composite samples with a $B$. A dash indicates that no data was avallable. The HSD comparisons are not based upon the spatial varlance; they are however, a function of the analytical measurement variance.

From Table 10, it is evident that the mean concentration of 12 out of 31 (39\%) analytes are not significantly different between the cores. That is, for these analytes there is no evidence of heterogenelty within the waste. For the remaining $19(61 \%)$ analytes there is a signiflcant difference between the mean concentrations. This indicates significant heterogeneity or spatial varlabllity within the waste. These significant differences inflate the between core varlance (spatial variance). This inflated varlance helps explain why the CIs are so wide.

Examples of the interpretation of the HSD comparisons are as follows. In Table 10, Al (ICP.acld) has an a for core 48 and a $B$ for core 47 and 49 . That is, the mean concentration of $A l$ in core 48 is significantly different from the mean concentration in core 47 and 49 . The mean concentration of $A 1$ in core 47 and 49 cannot be distinguished from each other. Another example is $U$ (ICP.acid). In Table 10, core 48 has a $B$, core 49 has an $\alpha$, and core 47 has an $\alpha \beta$. That $1 s$, the mean concentration of $U$ for core 48 is significantly different from the mean concentration in core 49 . Core 47 has both symbols $\alpha$ and $B$. So that the mean concentration of $U$ is not significantly different from the mean concentration in core 48 and it is not significantly different from the mean concentration in core 49.

There were three subsegment samples from cores 47 and 49 (denoted by $B, C$, and $D$ ) and two from core 48 (denoted by $C$ and $D$ ). The relative location of the subsegments are given in the following table.

\begin{tabular}{|c||c|c|c|}
\hline Core & 47 & 48 & 49 \\
\hline Subsegment & $B$ & & $B$ \\
& $C$ & $C$ & $C$ \\
& $D$ & $D$ & $D$ \\
\hline
\end{tabular}

Tukey's HSD procedure was also used to make comparisons between the individual subsegment means. These comparisons, along with subsegment means, are given in Table 11. For a given analyte, the relative locations of the subsegments have the form given in the above table. The symbols used to denote groupings of means concentrations are $a, A, y, \delta, C$, and. A dash indicates no data was avallable. The interpretation and ranking of the groupings is identical to that given for Table 10. 
The results given in Table 11 appear to be complicated. A partial explanation is as follows. The multiple comparisons indicate that the three subsegments between cores 47 and 49 match for $\mathrm{Na}, \mathrm{Pb}$, Chloride, Nitrate, Phosphate, and Cs-137. Subsegments $B$ and $D$ match between cores 47 and 49 for $\mathrm{Fe}$, Nitrite, Sulphate and Total $C N$. Subsegments $C$ and $D$ match between cores 47,48 , and 49 for $\mathrm{Fe}$ and Sr-90. This is some evidence of "layers" in the waste. The multiple comparisons for the other analytes indicate waste heterogenelty. As was stated above, such differences inflate the spatial variance. There may be patterns in Table 11, other than those indicated, showing "layers" within the waste.

\subsection{COMPARISON OF RESULTS: SST 241-C-109 and 241-C-112}

This section contains a comparison of summary statistics computed from core composite data from tanks $\mathrm{C} 109$ and $\mathrm{C} 112$. The comparison is made on the mean concentration, the analytical measurement variance, and the spatial variance. Comparisons are also presented for the relative standard devtations and the two varlances as a percent of the total variance.

Appendix 3 contains graphs of the data from $\mathrm{C} 109$ and $\mathrm{C} 112$. Each core from Clog is palred, according to location within the tank, with a core from C112. The following table shows this pairing:

\begin{tabular}{|c||c|c|c|}
\hline Tank & Pair 1 & Pair 2 & Pair 3 \\
\hline C109 & Core 49 & Core 48 & Core 47 \\
C112 & Core 34 & Core 35 & Core 36 \\
\hline
\end{tabular}

To alde in the visual comparisons between the two sets of data, paired cores have the same symbols.

\subsection{Comparison of Mean Concentrations}

For the analytes of interest in tank $(109$, the mean concentration $(5)$ and the variance of the mean concentration $\left(\hat{\sigma}^{2}(\bar{y})\right)$ are presented in Table 4 . These summary statistics are based upon the core composite data. Tables 7 to 11 of Appendix B, Simpson (1993), contain the corresponding results for tank C]12.

To test the equality of the mean concentration of the analytes in the two tanks, a $95 \% \mathrm{Cl}$ on the difference between the two mean concentrations was computed. The test of equality of mean concentrations is: if zero is in the $\mathrm{Cl}$, then the two means cannot be distinguished from each other at the 0.05 level of significance. If zero is not in the Cl, the two means are significantily different from each other.

A 95\% CI on the difference between the mean concentrations was computed for 29 analytes. The CI was based on Cochran's approximation to the Behrens-Fisher problem (Snedecor, 1980, page 97). Zero was in all of the intervals. Due to 
the magnitude of the vartances of the difference, $\theta^{2}[9(C 109)-g(C 112)]=$ $\sigma^{2}[\rho(C 1 O g)]+\sigma^{2}[\rho(C 112)]$ and the small number of degrees of freedom, the width of the Cls was very large. The lower limits of the interyals tended to be $-10^{5}$ or $-10^{4}$ and the upper 1 imits tended to be $+10^{3}$ or $+10^{4}$. These intervals are function of both the analytical measurement variance and the spatial vartance.

The CIs were also computed using only the analytical masurement vartance. The new lower limits of the intervals were reduced to $-10^{6}$ or $-10^{3}$ and the upper limits reduced to $+10^{4}$ or $+10^{3}$. Zero was in all but two of the new CIs. The two intervals that did not contain zero were for Al (ICP. fuston) and Pu239/240. Tables containing the CIs on the difference are not given in this document.

The interpretation of these results are that, except for possibly Al (ICP.fusion) and Pu-239/240, the mean concentration of the analytes in the two tanks cannot be distingulshed from each other. It needs to be emphasized that these comparisons are based upon very large spatial and analytical measurement variances and very small degrees of freedom. Consequently, such comparisons may not be meaningful.

\subsection{Compartson of Vartances}

The estimates of the analytical measurement variances $\left(\sigma^{2}(A)\right.$ ) for both $C 109$ and C112 are glven in Table 12. A speclal form of the F-test, (Snedecor, 1980 , page 98) was used to test the equality of these two variances. The p-value, which is the attained level of signiflcance of the $F$-test, is also given in Table 12. If the attained level of significance is less than 0.025 (in this special test), then the two analytical measurement varlances are significantly different from each other at the 0.05 level of significance. In 13 out of 28 tests (46\%) the analytical measurement variances were significantly different from each other for the two tanks.

The equality of the spatial variances for the two tanks was tested in a similar manner. Table 13 contains the estimates of the spatial variances $\left(\sigma^{2}(S)\right)$ and the p-values for the F-test. The spatial varlances were significantly different from each other in only 4 out of 25 tests $(16 \%)$. These variances were significantly different for $U$ (ICP.acid), for $N I$ (ICP.water) and for $U$ and Pu-239/240. The spatial varlances cannot be distinguished from each other for the other analytes.

The implication of these results are that, at least for these two tanks, the degree of heterogeneity in the waste is very similar. The analytical measurement error is not consistent between the two tanks, even though the data was analyzed by the same laboratory. These results must be interpreted with caution, since there are only two degrees of freedom associated with each spatial varlance and two or three degrees of freedom for each analytical measurement variance. The degrees of freedom are very small.

Results given in Tables 14 and 15 may help in the interpretation of the relative magnitude of the estimates of the analytical and spatial variances. Table 14 gives, for both tanks CIOg and C112, $\partial^{2}(A)$ and $\partial^{2}(S)$ as a percent of 
the total variance assocjated with any observation. That is, $\% \hat{\sigma}^{2}(A)=100 * \partial^{2}(A) /\left[\partial^{2}(A)+\partial^{2}(S)\right]$ and $\% \partial^{2}(S)=100 * \partial^{2}(S) /\left[\partial^{2}(A)+\partial^{2}(S)\right]$. Generally, $\partial^{2}(s)$ represents the greatest percentage of the total variability for both C112 and C109.

The relative standard deviations (RSDs) for both tanks are given in Table 15. An RSD is a standard deviation expressed as a percent of the mean concentration. That is, $\operatorname{RSD}(y)=100 * \theta(\bar{y}) / \bar{g}, \operatorname{RSD}(A)=100 * \theta(A) / \bar{y}$, and $R S D(S)=100 * \sigma(S) / \bar{g}$. The $R S D(A)$ appears to be relatively consistent between the two tanks. The RSD(S) appears to be variable with no apparent pattern.

\subsection{REFERENCES}

Brown, T. M., and L. Jensen, 1993, Tank Characterization Report for single-Shell Tank 241-U-110, WHC-EP-0643, Rev. 0, Westinghouse Hanford Company, Richland, Washington.

Harville, D. A., 1977, "Maximum Likelihood Approaches to Variance Component Estimation and to Related Problems," Journal of the American Statistical Association, pp. 320-340.

Petersen, R. G., 1985, Design and Analysis of Experiments, First Edition, Marcel Dekker, Inc., New York.

Simpson, B. C., et a1., 1993, Tank Characterization Data Report: 241-C-112, WHC-EP-0640, Westinghouse Hanford Company, Richland, Washington.

Snederor, G. W. and Cochran, W. G., 1980, Statistical Methods, Seventh Edition, Iowa State University Press, Ames, Iowa.

Winters, W. I., et al., 1990, Waste Characterization Plan for the Hanford Site Single-She 11 Tanks, WHC-EP-0210, Rev. 1, Westinghouse Hanford Company, Richland, Washington. 
WHC-EP-0668

APPENDIX 1: TABLES OF DATA AND STATISTICAL RESULTS 
Table 1. Core Composite Data (Units $\mu \mathrm{g} / \mathrm{g}$ Except Radionuclides $\mu \mathrm{C} / \mathrm{g}$ ).

\begin{tabular}{|c|c|c|c|c|c|c|}
\hline Core & \multicolumn{2}{|c|}{47} & \multicolumn{2}{|c|}{48} & \multicolumn{2}{|c|}{49} \\
\hline Analvels & 1 & 2 & 1 & 2 & 1 & 2 \\
\hline 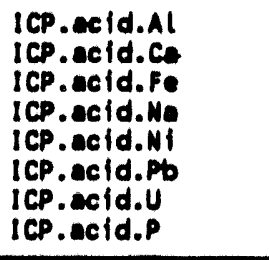 & $\begin{array}{l}7.410+04 \\
1.950+04 \\
3.520+04 \\
8.150+04 \\
1.460+04 \\
9.960+03 \\
1.050+04 \\
1.840+04\end{array}$ & $\begin{array}{l}7.160+04 \\
2.050+04 \\
2.260+04 \\
8.220+04 \\
1.490+04 \\
7.250+03 \\
1.100+04 \\
1.840+04\end{array}$ & $\begin{array}{l}6.24 e+03 \\
1.44 e+04 \\
1.39 e+04 \\
8.16 e+04 \\
1.63 e+04 \\
5.86 e+02 \\
1.27 e+04 \\
1.45 e+04\end{array}$ & $\begin{array}{l}6.60 e+03 \\
1.07 \omega+04 \\
2.65 e+04 \\
9.35 \theta+04 \\
1.47 \theta+04 \\
6.260+02 \\
1.74 \theta+04 \\
1.96 \omega+04\end{array}$ & $\begin{array}{l}9.590+04 \\
1.380+04 \\
8.390+03 \\
6.580+04 \\
1.310+04 \\
9.990+02 \\
7.10 e+03 \\
1.17 e+04\end{array}$ & $\begin{array}{l}7.15 e+04 \\
1.08 c+04 \\
5.90 e+03 \\
9.68 e+04 \\
1.06 e+04 \\
7.280+02 \\
5.43 e+03 \\
2.710+04\end{array}$ \\
\hline $\begin{array}{l}\text { ICP. fusion. Al } \\
\text { ICP. fusion. Co } \\
\text { ICP. fusion. Fe } \\
\text { ICP. fusion. Ha } \\
\text { ICP. fusion. Ph } \\
\text { ICP. fusion.U } \\
\text { ICP. fusion.P }\end{array}$ & $\begin{array}{l}1.15 e+05 \\
2.1440+04 \\
2.020+04 \\
8.710+04 \\
7.220+03 \\
8.750+03 \\
2.020+04\end{array}$ & $\begin{array}{l}1.190+05 \\
2.490+04 \\
2.340+04 \\
8.720+04 \\
7.340+03 \\
9.610+03 \\
1.96 e+04\end{array}$ & $\begin{array}{l}7.28 e+03 \\
1.68 e+04 \\
2.38 e+04 \\
1.07 e+05 \\
\mathrm{NA} \\
2.780+04 \\
2.22 e+04\end{array}$ & $\begin{array}{c}9.86 e+03 \\
1.85 e+04 \\
2.06 e+04 \\
9.33 e+04 \\
N A \\
2.170+04 \\
1.82 \theta+04\end{array}$ & $\begin{array}{l}1.200+05 \\
1.450+04 \\
9.270+03 \\
8.180+04 \\
8.030+02 \\
5.590+03 \\
1.770+04 \\
\end{array}$ & $\begin{array}{l}1.34 e+05 \\
1.52 e+04 \\
8.94 e+03 \\
7.13 e+04 \\
8.44 e+02 \\
\mathrm{NA} \\
1.14 e+04\end{array}$ \\
\hline $\begin{array}{l}\text { ICP.water.Al } \\
\text { ICP.water.CE } \\
\text { ICP.water.Fe } \\
\text { ICP. water. } \mathrm{NA} \\
\text { ICP. water. } \mathrm{NI} \\
\text { ICP. weter.P }\end{array}$ & $\begin{array}{l}3.36 e+02 \\
1.73 e+02 \\
8.85 e+02 \\
6.600+04 \\
1.40 e+02 \\
6.350+03\end{array}$ & $\begin{array}{l}4.88 e+02 \\
1.94 e+02 \\
8.72 e+02 \\
6.96 e+04 \\
1.09 e+02 \\
7.63 e+03\end{array}$ & $\begin{array}{c}\text { NA } \\
5.93 e+01 \\
1.13 e+03 \\
8.92 e+04 \\
3.34 e+01 \\
1.19 e+04\end{array}$ & $\begin{array}{c}\text { NA } \\
5.97 e+01 \\
1.15 e+03 \\
7.79 e+04 \\
2.85 e+01 \\
5.66 e+03\end{array}$ & $\begin{array}{c}\mathrm{NA} \\
8.92 e+01 \\
8.88 e+02 \\
5.890+04 \\
5.280+01 \\
4.420+03\end{array}$ & $\begin{array}{c}\mathrm{NA} \\
6.62 e+01 \\
9.44 e+02 \\
6.09 e+04 \\
5.28 e+01 \\
3.90 e+03\end{array}$ \\
\hline $\begin{array}{l}\text { Chloride } \\
\text { Nitrite } \\
\text { Nitrate } \\
\text { Phosphate } \\
\text { sulfate } \\
\text { Total CN }\end{array}$ & $\begin{array}{l}7.000+02 \\
3.800+04 \\
3.700+04 \\
2.010+04 \\
7.200+03 \\
5.600+03\end{array}$ & $\begin{array}{l}7.00 e+02 \\
4.00 e+04 \\
3.70 e+04 \\
2.40 e+04 \\
8.10 e+02 \\
5.41 e+03\end{array}$ & $\begin{array}{l}8.00 e+02 \\
4.20 e+04 \\
4.50 e+04 \\
3.590+04 \\
8.900+03 \\
1.410+04\end{array}$ & $\begin{array}{l}8.00 e+02 \\
4.80 e+04 \\
5.10 e+04 \\
1.75 e+04 \\
9.60 e+03 \\
1.46 e+04\end{array}$ & $\begin{array}{l}7.00 e+02 \\
3.80 e+04 \\
3.50 e+04 \\
1.35 e+04 \\
6.20 e+03 \\
5.64 e+03\end{array}$ & $\begin{array}{l}7.00 e+02 \\
3.90 \omega+04 \\
3.70 e+04 \\
1.20 e+04 \\
6.90 \omega+03 \\
5.59 e+03\end{array}$ \\
\hline $\begin{array}{l}U \text { ( } \mu g / g) \\
\text { Total Alpha (Pu) } \\
\text { Sr-90 } \\
\text { Pu-238 } \\
\text { Pu-239/240 } \\
\text { Cs-137/water } \\
\text { Cs-137/funion }\end{array}$ & $\begin{array}{l}1.170+01 \\
8.05 e-01 \\
1.050+03 \\
4.400-05 \\
8.040-01 \\
9.070+00 \\
8.700+02\end{array}$ & $\begin{array}{c}1.22 e+01 \\
9.490-01 \\
1.300+03 \\
\mathrm{MA} \\
9.48 \mathrm{e}-01 \\
9.40 e+00 \\
8.770+02\end{array}$ & $\begin{array}{l}3.00 e+01 \\
6.95 e-02 \\
1.90 e+02 \\
7.15 e-06 \\
6.95 e-02 \\
7.95 e+00 \\
1.11 e+03\end{array}$ & $\begin{array}{l}2.51 e+01 \\
6.66 e-02 \\
1.90 e+02 \\
N A \\
6.66 e-02 \\
1.07 e+01 \\
9.52 e+02\end{array}$ & $\begin{array}{l}7.63 e+00 \\
6.59 e-02 \\
8.770+02 \\
1.11 e-05 \\
6.58 e-02 \\
5.610+00 \\
5.470+02\end{array}$ & $\begin{array}{c}7.42 e+00 \\
9.21 e-02 \\
9.86 e+02 \\
\text { NA } \\
9.20 e-02 \\
4.95 e+00 \\
5.66 e+02\end{array}$ \\
\hline
\end{tabular}


Table 2. Subsegment Data (Units $\mu \mathrm{g} / \mathrm{g}$ Except Radionuclides $\mu \mathrm{C} 1 / \mathrm{g}$ ).

\begin{tabular}{|c|c|c|c|c|c|c|c|c|}
\hline Core & \multicolumn{3}{|c|}{47} & \multicolumn{2}{|c|}{48} & \multicolumn{3}{|c|}{49} \\
\hline Subserment & 8 & C & $D$ & C & $D$ & $B$ & C & $D$ \\
\hline ICP.fusion.Al & $\begin{array}{r}1.240+05 \\
1.39 e+05 \\
\end{array}$ & $\begin{array}{r}1.20 e+05 \\
1.210+05 \\
\end{array}$ & $\begin{array}{l}3.27 e+04 \\
3.13 e+04 \\
\end{array}$ & $\begin{array}{l}7.44 \theta+03 \\
7.14 \theta+03 \\
\end{array}$ & $\begin{array}{l}9.600+03 \\
1.010+04 \\
\end{array}$ & $\begin{array}{l}1.810+05 \\
1.900+05 \\
\end{array}$ & $\begin{array}{l}9.750+04 \\
9.400+04 \\
\end{array}$ & $\begin{array}{l}7.35 e+04 \\
6.820+04 \\
\end{array}$ \\
\hline ICP.fusion.ce & $\begin{array}{l}1.070+04 \\
1.020+04 \\
\end{array}$ & $\begin{array}{l}1.840+04 \\
1.770+04 \\
\end{array}$ & $\begin{array}{r}2.880+04 \\
2.720+04 \\
\end{array}$ & $\begin{array}{l}3.02 \theta+04 \\
2.84 \theta+04 \\
\end{array}$ & $\begin{array}{r}1.70 e+04 \\
1.66 e+04 \\
\end{array}$ & $\begin{array}{l}5.400+03 \\
3.210+03 \\
\end{array}$ & $\begin{array}{l}1.89 e+04 \\
1.82 e+04 \\
\end{array}$ & $\begin{array}{l}2.13 e+04 \\
2.37 e+04 \\
\end{array}$ \\
\hline ICP. fusion.Fe & $\begin{array}{l}8.250+04 \\
4.420+04 \\
\end{array}$ & $\begin{array}{l}1.54 e+04 \\
2.65 e+04 \\
\end{array}$ & $\begin{array}{r}1.710+04 \\
1.350+04 \\
\end{array}$ & $\begin{array}{l}2.28 e+04 \\
1.720+04 \\
\end{array}$ & $\begin{array}{l}2.270+04 \\
1.940+04 \\
\end{array}$ & $\begin{array}{l}1.38 e+04 \\
1.74 e+04 \\
\end{array}$ & $\begin{array}{l}4.330+03 \\
4.82 e+03 \\
\end{array}$ & $\begin{array}{l}1.360+04 \\
1.720+04 \\
\end{array}$ \\
\hline ICP.fusion.Na & $\begin{array}{l}4.97 e+04 \\
5.24 e+04 \\
\end{array}$ & $\begin{array}{l}6.32 e+04 \\
6.29 e+04 \\
\end{array}$ & $\begin{array}{l}1.020+05 \\
1.040+05 \\
\end{array}$ & $\begin{array}{l}1.38 e+05 \\
9.33 e+04 \\
\end{array}$ & $\begin{array}{l}1.010+05 \\
1.03 e+05 \\
\end{array}$ & $\begin{array}{l}4.510+04 \\
4.100+04 \\
\end{array}$ & $\begin{array}{l}6.090+04 \\
6.480+04 \\
\end{array}$ & $\begin{array}{l}9.02 e+04 \\
9.25 e+04 \\
\end{array}$ \\
\hline ICP.fusion.Pb & $\begin{array}{l}5.53 e+03 \\
4.570+03 \\
\end{array}$ & $\begin{array}{l}2.990+03 \\
2.780+03 \\
\end{array}$ & $\begin{array}{r}1.860+04 \\
1.000+04 \\
\end{array}$ & $\begin{array}{l}\text { NA } \\
\text { NA } \\
\end{array}$ & $\begin{array}{l}7.26 e+02 \\
6.62 e+02 \\
\end{array}$ & $\begin{array}{l}2.07 e+03 \\
1.900+03 \\
\end{array}$ & $\begin{array}{l}\text { NA } \\
\text { NA }\end{array}$ & $\begin{array}{l}6.950+02 \\
7.620+02\end{array}$ \\
\hline ICP. fusion.U & $\begin{array}{l}1.15 e+04 \\
1.20 e+04 \\
\end{array}$ & $\begin{array}{l}6.61 e+03 \\
5.68 c+03 \\
\end{array}$ & $\begin{array}{l}6.24 e+03 \\
5.440+03 \\
\end{array}$ & $\begin{array}{l}1.810+04 \\
1.540+04 \\
\end{array}$ & $\begin{array}{l}1.460+04 \\
1.410+04 \\
\end{array}$ & $\begin{array}{l}8.66 e+03 \\
7.15 e+03 \\
\end{array}$ & $\begin{array}{l}\text { NA } \\
\text { NA }\end{array}$ & $\begin{array}{l}1.15 e+04 \\
1.320+04 \\
\end{array}$ \\
\hline ICP.fusion.P & $7.89^{\mathrm{NA}}$ & $\begin{array}{r}1.26 e+04 \\
1.23 e+04 \\
\end{array}$ & $\begin{array}{l}2.90 e+04 \\
3.12 e+04 \\
\end{array}$ & $\begin{array}{l}2.62 e+04 \\
2.03 e+04 \\
\end{array}$ & $\begin{array}{l}2.02 e+04 \\
2.16 e+04 \\
\end{array}$ & $\begin{array}{c}4.570+03 \\
\mathrm{NA}\end{array}$ & $\begin{array}{l}1.14 e+04 \\
1.16 e+04 \\
\end{array}$ & $\begin{array}{l}2.050+04 \\
2.030+04 \\
\end{array}$ \\
\hline Chloride & $\begin{array}{l}5.000+02 \\
6.000+02 \\
\end{array}$ & $\begin{array}{l}7.000+02 \\
7.000+02 \\
\end{array}$ & $\begin{array}{l}8.000+02 \\
7.000+02 \\
\end{array}$ & $\begin{array}{l}1.00 e+03 \\
9.00 e+02 \\
\end{array}$ & $\begin{array}{l}1.000+03 \\
1.000+03 \\
\end{array}$ & $\begin{array}{l}5.000+02 \\
5.00 e+02 \\
\end{array}$ & $\begin{array}{l}8.000+02 \\
8.00 e+02 \\
\end{array}$ & $\begin{array}{l}8.000+02 \\
8.000+02 \\
\end{array}$ \\
\hline Mitrite & $\begin{array}{l}2.700+04 \\
2.88 e+04 \\
\end{array}$ & $\begin{array}{l}3.700+04 \\
3.700+04 \\
\end{array}$ & $\begin{array}{l}4.000+04 \\
3.900+04 \\
\end{array}$ & $\begin{array}{l}4.90 e+04 \\
5.30 e+04 \\
\end{array}$ & $\begin{array}{l}4.90 e+04 \\
5.00 e+04 \\
\end{array}$ & $\begin{array}{l}2.58 e+04 \\
2.71 e+04 \\
\end{array}$ & $\begin{array}{l}4.20 e+04 \\
4.50 e+04 \\
\end{array}$ & $\begin{array}{l}4.600+04 \\
4.400+04 \\
\end{array}$ \\
\hline Nitrate & $\begin{array}{l}2.690+04 \\
2.830+04 \\
\end{array}$ & $\begin{array}{l}3.600+04 \\
3.600+04 \\
\end{array}$ & $\begin{array}{l}3.900+04 \\
3.80 e+04 \\
\end{array}$ & $\begin{array}{l}5.50 e+04 \\
5.70 e+04 \\
\end{array}$ & $\begin{array}{l}5.20 e+04 \\
5.50 e+04 \\
\end{array}$ & $\begin{array}{l}2.520+04 \\
2.62 e+04 \\
\end{array}$ & $\begin{array}{l}4.000+04 \\
4.400+04 \\
\end{array}$ & $\begin{array}{l}4.400+04 \\
4.200+04 \\
\end{array}$ \\
\hline Phosphate & $\begin{array}{l}7.100+03 \\
7.500+03 \\
\end{array}$ & $\begin{array}{l}9.60 e+03 \\
9.500+03 \\
\end{array}$ & $\begin{array}{r}3.400+04 \\
5.500+04 \\
\end{array}$ & $\begin{array}{l}1.50 e+04 \\
1.65 e+04 \\
\end{array}$ & $\begin{array}{l}3.800+04 \\
3.400+04 \\
\end{array}$ & $\begin{array}{l}6.00 e+03 \\
6.20 e+03 \\
\end{array}$ & $\begin{array}{l}8.900+03 \\
8.700+03 \\
\end{array}$ & $\begin{array}{l}2.430+04 \\
2.600+04 \\
\end{array}$ \\
\hline sulfate & $\begin{array}{l}4.900+03 \\
5.200+03 \\
\end{array}$ & $\begin{array}{l}7.10 e+03 \\
7.10 e+03 \\
\end{array}$ & $\begin{array}{l}7.600+03 \\
7.100+03 \\
\end{array}$ & $\begin{array}{l}1.08 \theta+04 \\
1.12 \theta+04 \\
\end{array}$ & $\begin{array}{l}1.000+04 \\
1.000+04 \\
\end{array}$ & $\begin{array}{r}4.50 e+03 \\
4.80 e+03 \\
\end{array}$ & $\begin{array}{l}7.90 e+03 \\
8.40 e+03 \\
\end{array}$ & $\begin{array}{l}7.90 e+03 \\
8.30 e+03 \\
\end{array}$ \\
\hline Total CN & $\begin{array}{l}3.05 e+03 \\
3.03 e+03 \\
\end{array}$ & $\begin{array}{l}4.490+03 \\
4.23 e+03 \\
\end{array}$ & $\begin{array}{l}5.830+03 \\
5.82 \theta+03 \\
\end{array}$ & $\begin{array}{l}1.100+04 \\
1.150+04 \\
\end{array}$ & $\begin{array}{l}8.60 e+03 \\
8.71 e+03 \\
\end{array}$ & $\begin{array}{l}3.500+03 \\
3.570+03 \\
\end{array}$ & $\begin{array}{l}8.14 e+03 \\
8.02 e+03 \\
\end{array}$ & $\begin{array}{l}5.61 e+03 \\
5.43 e+03 \\
\end{array}$ \\
\hline sr-90.fustion & $\begin{array}{r}4.600+03 \\
4.510+03 \\
\end{array}$ & $\begin{array}{l}4.560+02 \\
4.820+02 \\
\end{array}$ & $\begin{array}{l}2.31 e+02 \\
1.99 e+02 \\
\end{array}$ & $\begin{array}{l}1.59 e+02 \\
1.440+02 \\
\end{array}$ & $\begin{array}{l}1.27 e+02 \\
1.14 e+02 \\
\end{array}$ & $\begin{array}{l}2.56 e+03 \\
2.23 e+03 \\
\end{array}$ & $\begin{array}{l}2.02 e+02 \\
1.89 e+02 \\
\end{array}$ & $\begin{array}{l}1.88 e+02 \\
1.97 e+02 \\
\end{array}$ \\
\hline Cs-137.fusion & $\begin{array}{l}3.170+02 \\
3.570+02 \\
\end{array}$ & $\begin{array}{l}8.12 e+02 \\
7.31 e+02 \\
\end{array}$ & $\begin{array}{l}9.71 e+02 \\
9.23 e+02 \\
\end{array}$ & $\begin{array}{l}1.17 e+03 \\
1.14 \mathrm{e}+03 \\
\end{array}$ & $\begin{array}{l}1.22 e+03 \\
1.11 e+03 \\
\end{array}$ & $\begin{array}{l}1.210+02 \\
1.150+02 \\
\end{array}$ & $\begin{array}{l}5.53 e+02 \\
1.44 e+02 \\
\end{array}$ & $\begin{array}{l}6.60 e+02 \\
7.43 e+02 \\
\end{array}$ \\
\hline
\end{tabular}

NA: Not available 
Table 3. Homogenization Test Data (Units $\mu \mathrm{g} / \mathrm{g}$ Except Radionuclides $\mu \mathrm{Ct} / \mathrm{g}$ ).

\begin{tabular}{|c|c|c|c|c|}
\hline \multirow{2}{*}{$\begin{array}{l}\text { Core } \\
\text { subesment }\end{array}$} & \multicolumn{2}{|c|}{48} & \multicolumn{2}{|c|}{49} \\
\hline & $D$ & 0 & $D$ & $D$ \\
\hline Locetion & 1 & 2 & $i$ & 2 \\
\hline$|c \cdot c e| d . A \mid$ & $\begin{array}{r}8.73 e n 03 \\
7.800+03 \\
\end{array}$ & $\begin{array}{l}9.450+03 \\
8.840+03 \\
\end{array}$ & $\begin{array}{l}3.960+04 \\
4.660+06 \\
\end{array}$ & $\begin{array}{r}4.180+04 \\
4.680+04 \\
\end{array}$ \\
\hline ICP.ectaldeo & $\begin{array}{l}1.530+04 \\
1.420+04\end{array}$ & $\begin{array}{l}1.730+04 \\
1.560+04 \\
\end{array}$ & $\begin{array}{l}1.460+04 \\
1.940+04\end{array}$ & $\begin{array}{l}1.690+04 \\
1.870+04 \\
\end{array}$ \\
\hline ICP.ecld.fe & $\begin{array}{l}2.380 * 04 \\
1.370+04 \\
\end{array}$ & $\begin{array}{r}1.78 e+04 \\
1.68 e+04 \\
\end{array}$ & $\begin{array}{l}8.85 e+03 \\
1.15 e+06 \\
\end{array}$ & $\begin{array}{l}9.050+03 \\
1.120+04 \\
\end{array}$ \\
\hline ICP.scld.No & $\begin{array}{l}1.160+05 \\
1.210+05 \\
\end{array}$ & $\begin{array}{l}9.930+04 \\
1.060+05 \\
\end{array}$ & $\begin{array}{l}1.160 * 05 \\
8.660+04 \\
\end{array}$ & $\begin{array}{r}8.800+04 \\
8.010+04 \\
\end{array}$ \\
\hline ICP.AcId.NI & $\begin{array}{l}1.710+04 \\
1.56 e+04 \\
\end{array}$ & $\begin{array}{r}1.94 e+04 \\
1.74 e+04 \\
\end{array}$ & $\begin{array}{l}1.190+04 \\
1.560+04 \\
\end{array}$ & $\begin{array}{r}1.29 e+04 \\
1.48 e+04 \\
\end{array}$ \\
\hline ICP.Acid.Pb & $\begin{array}{l}6.170+02 \\
5.680+02 \\
\end{array}$ & $\begin{array}{l}7.23 e+02 \\
6.45 e+02 \\
\end{array}$ & $\begin{array}{l}4.850+02 \\
6.70 e+02 \\
\end{array}$ & $\begin{array}{l}5.080+02 \\
6.160+02 \\
\end{array}$ \\
\hline ICP. Acid.U & $\begin{array}{r}1.540+04 \\
1.450+04 \\
\end{array}$ & $\begin{array}{l}1.74 e+04 \\
1.55 e+04 \\
\end{array}$ & $\begin{array}{l}9.710+03 \\
1.340+04 \\
\end{array}$ & $\begin{array}{l}1.000+04 \\
1.210+04 \\
\end{array}$ \\
\hline ICP.ecid.P & $\begin{array}{l}2.690+04 \\
3.080+04 \\
\end{array}$ & $\begin{array}{r}1.960+04 \\
2.290+04 \\
\end{array}$ & $\begin{array}{l}3.230+04 \\
1.86 e+04 \\
\end{array}$ & $\begin{array}{l}2.03+04 \\
1.750+04 \\
\end{array}$ \\
\hline ICP.fuation.Al & $\begin{array}{l}\text { NA } \\
\text { NA }\end{array}$ & $\begin{array}{l}\text { MA } \\
\text { NA }\end{array}$ & $\begin{array}{l}6.170+04 \\
6.30 e+04 \\
\end{array}$ & $\begin{array}{l}5.310+04 \\
5.590+04 \\
\end{array}$ \\
\hline ICP. fuation.co & MA & $\begin{array}{l}\text { NA } \\
\text { NA }\end{array}$ & $\begin{array}{l}2.170+04 \\
2.22 e+04 \\
\end{array}$ & $\begin{array}{l}2.140+04 \\
2.170+04 \\
\end{array}$ \\
\hline ICP.fusion.fe & $\begin{array}{l}\text { MA } \\
\text { NA }\end{array}$ & $\begin{array}{l}\text { NA } \\
\text { NA } \\
\end{array}$ & $\begin{array}{l}1.370+04 \\
1.440+04 \\
\end{array}$ & $\begin{array}{r}1.280+04 \\
1.280+04 \\
\end{array}$ \\
\hline ICP.fusion. Na & MA & $\begin{array}{l}\text { NA } \\
\text { NA }\end{array}$ & $\begin{array}{l}9.08 e+04 \\
9.05 e+04 \\
\end{array}$ & $\begin{array}{l}9.020+04 \\
8.920+04 \\
\end{array}$ \\
\hline ICP.furion.MI & $\underset{M A}{M A}$ & $\begin{array}{l}\text { NA } \\
\text { NA }\end{array}$ & $\begin{array}{l}W / A \\
N / A\end{array}$ & $\begin{array}{l}N / A \\
N / A\end{array}$ \\
\hline ICP.fusion.Pb & $\begin{array}{l}\text { NA } \\
\text { NA }\end{array}$ & $\begin{array}{l}\text { NA } \\
\text { NA }\end{array}$ & $\begin{array}{l}6.25 e+02 \\
7.45 e+02 \\
\end{array}$ & $\begin{array}{l}6.460+02 \\
6.500+02 \\
\end{array}$ \\
\hline ICP.fusion.U & $\begin{array}{l}\text { MA } \\
\text { MA }\end{array}$ & $\begin{array}{l}\text { NA } \\
\text { NA }\end{array}$ & $\begin{array}{l}1.230+04 \\
1.310+04 \\
\end{array}$ & $\begin{array}{r}1.080+04 \\
1.180+04 \\
\end{array}$ \\
\hline ICP.fusion.P & $\begin{array}{l}\text { NA } \\
\text { NA }\end{array}$ & $\begin{array}{l}\text { NA } \\
\text { NA }\end{array}$ & $\begin{array}{l}1.870+04 \\
1.910+04 \\
\end{array}$ & $\begin{array}{l}1.95 e+04 \\
1.86 e+04 \\
\end{array}$ \\
\hline Cs-137. fuation & $\begin{array}{l}\text { MA } \\
\text { NA }\end{array}$ & $\begin{array}{l}\text { NA } \\
\text { NA } \\
\end{array}$ & $\begin{array}{l}7.13 e+02 \\
7.50 e+02 \\
\end{array}$ & $\begin{array}{l}6.960+02 \\
7.000+02 \\
\end{array}$ \\
\hline Cs-137. acid & $\begin{array}{l}8.520+00 \\
1.660+01 \\
\end{array}$ & $\begin{array}{l}8.810+00 \\
1.43 e+01 \\
\end{array}$ & $\begin{array}{l}3.54 e+01 \\
4.34 e+01 \\
\end{array}$ & $\begin{array}{r}1.930+01 \\
2.740+01 \\
\end{array}$ \\
\hline
\end{tabular}

MA: Not available 
Table 4. Concentration Estimate Statistics (Units $\mu \mathrm{g} / \mathrm{g}$ Except Radionuclides $\mu \mathrm{C} 1 / \mathrm{g}$ ).

\begin{tabular}{|c|c|c|c|c|c|}
\hline Anelyte & 9 & $a^{2}(9)$ & $d f$ & $95 \times 4$ & $95 x$ UL \\
\hline 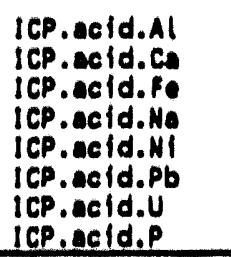 & $\begin{array}{l}5.430+04 \\
1.500+04 \\
1.870+04 \\
8.360+04 \\
1.400+04 \\
3.360+03 \\
1.070+04 \\
1.83+04\end{array}$ & $\begin{array}{l}5.84 e+08 \\
6.38 e+06 \\
3.96 e+07 \\
4.02 e+06 \\
1.23 e+06 \\
6.89 e+06 \\
6.40 e+06 \\
4.73 e+05\end{array}$ & $\begin{array}{l}2 \\
2 \\
2 \\
2 \\
2 \\
2 \\
2 \\
2 \\
\end{array}$ & $\begin{array}{l}0.00 e+00 \\
4.10 e+03 \\
0.00 e+00 \\
7.490+04 \\
9.270+03 \\
0.00 e+00 \\
0.00 e+00 \\
1.53 e+04\end{array}$ & $\begin{array}{l}1.580+05 \\
2.58 e+04 \\
4.580+04 \\
9.22 e+04 \\
1.880+04 \\
1.470+04 \\
2.160+04 \\
2.13 e+04\end{array}$ \\
\hline $\begin{array}{l}\text { ICP. fus.Al } \\
\text { ICP. fus. Ce } \\
\text { ICP. fus. Fe } \\
\text { ICP. fus. Ne } \\
\text { ICP. fus.Pb } \\
\text { ICP. fu. U } \\
\text { ICP. fus.P }\end{array}$ & $\begin{array}{l}8.40 e+04 \\
1.91 e+04 \\
1.77 e+04 \\
8.79 e+04 \\
4.05 e+03 \\
1.47 e+04 \\
1.82 e+04\end{array}$ & $\begin{array}{l}1.43 e+09 \\
8.500+06 \\
1.85 e+07 \\
4.640+07 \\
1.040+07 \\
3.720+07 \\
3.290+06\end{array}$ & $\begin{array}{l}2 \\
2 \\
2 \\
2 \\
1 \\
2 \\
2 \\
\end{array}$ & $\begin{array}{l}0.00 e+00 \\
6.520+03 \\
0.000+00 \\
5.860+04 \\
0.000+00 \\
0.000+00 \\
1.040+04 \\
\end{array}$ & $\begin{array}{l}2.470+05 \\
3.160+04 \\
3.620+04 \\
1.170+05 \\
4.510+04 \\
4.090+04 \\
2.600+04 \\
\end{array}$ \\
\hline $\begin{array}{l}\text { ICP. water. Ca } \\
\text { ICP. water. Fe } \\
\text { ICP. Water. Ne } \\
\text { ICP. water. NI } \\
\text { ICP.water.P }\end{array}$ & $\begin{array}{l}1.07 e+02 \\
9.780+02 \\
7.04 c+04 \\
6.94 c+01 \\
6.61 e+03 \\
\end{array}$ & $\begin{array}{l}1.490+03 \\
6.61 c+03 \\
6.82 a+07 \\
7.98 a+02 \\
1.74 c+06 \\
\end{array}$ & $\begin{array}{l}2 \\
2 \\
2 \\
2 \\
2 \\
\end{array}$ & $\begin{array}{l}0.000+00 \\
6.280+02 \\
4.050+04 \\
0.000+00 \\
9.310+0 ?\end{array}$ & $\begin{array}{l}2.73 e+02 \\
1.33 e+03 \\
1.00 \omega+05 \\
1.91 e+02 \\
1.230+04\end{array}$ \\
\hline $\begin{array}{l}\text { Chloride } \\
\text { Nitrite } \\
\text { Nitrate } \\
\text { Phosphote } \\
\text { sulphate } \\
\text { Total CH }\end{array}$ & $\begin{array}{l}7.330+02 \\
4.080+04 \\
4.03 e+04 \\
2.05 e+04 \\
7.700+03 \\
8.460+03 \\
\end{array}$ & $\begin{array}{l}1.110+03 \\
4.36 e+06 \\
1.48 c+07 \\
1.68 c+07 \\
6.48 c+05 \\
8.39 e+06 \\
\end{array}$ & $\begin{array}{l}2 \\
2 \\
2 \\
2 \\
2 \\
2 \\
2\end{array}$ & $\begin{array}{l}3.90 e+02 \\
3.180+04 \\
2.38 e+04 \\
2.850+03 \\
4.240+03 \\
0.000+00 \\
\end{array}$ & $\begin{array}{l}8.770+02 \\
4.980+04 \\
5.690+04 \\
3.810+04 \\
1.120+04 \\
2.090+04\end{array}$ \\
\hline $\begin{array}{l}U(\mu g / g) \\
\text { Tot.Alphe.Pu } \\
8 r-90 \\
\text { Pu-239, } 21,0 \\
\text { Cs.137. water } \\
\text { Cs-137. fusion }\end{array}$ & $\begin{array}{l}1.570+01 \\
3.410-01 \\
7.66 e+02 \\
3.410-01 \\
7.95 e+00 \\
8.200+02 \\
\end{array}$ & $\begin{array}{l}3.69 e+01 \\
7.17 e-02 \\
8.77 e+04 \\
7.16 e-02 \\
1.78 e+00 \\
1.95 e+04\end{array}$ & $\begin{array}{l}2 \\
2 \\
2 \\
2 \\
2 \\
2 \\
2 \\
\end{array}$ & $\begin{array}{l}0.000+00 \\
0.000+00 \\
0.000+00 \\
0.000+00 \\
2.210+00 \\
2.200+02 \\
\end{array}$ & $\begin{array}{l}4.18 a+01 \\
1.49 a+00 \\
2.04 a+03 \\
1.49 a+00 \\
1.37 e+01 \\
1.42 e+03\end{array}$ \\
\hline
\end{tabular}

Table 5. Concentration Estimates Statistics, Drainable Liquid, (Units $\mu \mathrm{g} / \mathrm{g}$ ).

\begin{tabular}{|c|c|c|c|c|c|}
\hline Anslyte & 9 & $g^{2}(8)$ & $d f$ & $95 \% \mathrm{LL}$ & $95 \%$ UL \\
\hline $\begin{array}{l}\text { ICP.acid.Al } \\
\text { ICP.acid.Co } \\
\text { ICP.acid. Fe } \\
\text { ICP.acid. Na } \\
\text { ICP.acid.NI } \\
\text { ICP.acid.Pb } \\
\text { ICP.acid.U } \\
\text { ICP.acid.P }\end{array}$ & $\begin{array}{c}1.37 e+02 \\
2.09 e+02 \\
1.67 e+03 \\
9.69 \omega+04 \\
3.440+02 \\
\mathrm{NA} \\
\mathrm{NA} \\
4.200+03\end{array}$ & $\begin{array}{c}1.50 e+01 \\
1.74 e+01 \\
5.56 e+02 \\
2.66 e+01 \\
1.03 e+01 \\
\mathrm{NA} \\
\mathrm{NA} \\
9.65 e+02\end{array}$ & $\begin{array}{c}1 \\
1 \\
1 \\
1 \\
1 \\
\text { NA } \\
\text { NA } \\
1\end{array}$ & $\begin{array}{c}1.080+02 \\
1.560+02 \\
1.380+03 \\
9.690+04 \\
3.03 e+02 \\
0.00 \\
0.00 \\
3.800+03 \\
\end{array}$ & $\begin{array}{c}2.06 e+02 \\
2.62 e+02 \\
1.97 e+03 \\
9.70 e+04 \\
3.84 e+02 \\
0.00 \\
0.00 \\
4.59 e+03\end{array}$ \\
\hline $\begin{array}{l}\text { Chloride } \\
\text { Nitrite } \\
\text { Nitrate } \\
\text { Phosphate } \\
\text { Sulphate }\end{array}$ & $\begin{array}{l}1.30 \omega+03 \\
7.10 \omega+04 \\
7.20 c+04 \\
1.35 e+04 \\
1.28 e+04\end{array}$ & $\begin{array}{l}\text { NA } \\
\text { NA } \\
\text { NA } \\
\text { NA } \\
\text { NA }\end{array}$ & $\begin{array}{l}\text { NA } \\
\text { NA } \\
\text { NA } \\
\text { NA } \\
\text { NA }\end{array}$ & $\begin{array}{l}\text { NA } \\
\text { NA } \\
\text { NA } \\
\text { NA } \\
\text { NA }\end{array}$ & $\begin{array}{l}\text { NA } \\
\text { NA } \\
\text { NA } \\
\text { NA } \\
\text { NA }\end{array}$ \\
\hline
\end{tabular}

NA: Not available 
Table 6. Homogenization Test Statistical Results.

\begin{tabular}{|c|c|}
\hline Analyte & $\begin{array}{c}\text { Tests } \sigma^{2}(L)=0 \\
\text { pevalue }\end{array}$ \\
\hline ICP.ACId,Al & 0.890 \\
\hline ICP.ectd.Ce & 0.649 \\
\hline ICP,ecld, Fe & 0.922 \\
\hline ICP.Acid.Me & 0.229 \\
\hline ICP.ecid.Mi & 0.551 \\
\hline ICP. $a c i d, P b$ & 0.572 \\
\hline ICP.Acld,U & 0.667 \\
\hline ICP.ecid.P & 0.290 \\
\hline 1CP.fue.Al & 0.036 \\
\hline ICP.fus.ce & 0.389 \\
\hline ICP.fus.te & 0.072 \\
\hline ICP. fue. Me & 0.216 \\
\hline ICP.fue.po & 0.606 \\
\hline ICP. fus.U & 0.164 \\
\hline ICP. fus.P & 0.706 \\
\hline Cs.137. fus & 0.214 \\
\hline Cs-137.acid & 0.092 \\
\hline
\end{tabular}


Table 7. Comparison of Simulated Core Composite with the Core Composite.

\begin{tabular}{|c|c|c|c|c|c|c|c|}
\hline Core & Anolve & $\rho(H)$ & $g(c)$ & $\theta^{2}(g(w)-g(c))$ & $d f$ & $95 x+1$ & $95 \times$ UL \\
\hline 47 & 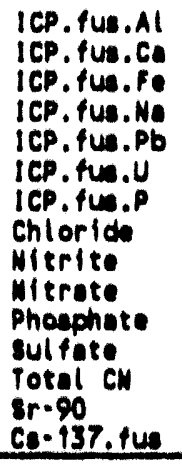 & $\begin{array}{l}9.460+04 \\
1.86 e+04 \\
3.32 e+04 \\
7.23 e+04 \\
7.410+03 \\
7.920+03 \\
1.680+04 \\
6.67 e+02 \\
3.480+04 \\
3.400+04 \\
2.050+04 \\
6.500+03 \\
4.410+03 \\
1.730+03 \\
6.850+02 \\
\end{array}$ & $\begin{array}{l}1.170+05 \\
2.470+04 \\
2.180+04 \\
8.720+04 \\
7.280+03 \\
9.040+03 \\
1.900+04 \\
7.000+02 \\
3.900+04 \\
3.700+04 \\
2.210+04 \\
7.300+03 \\
3.510+03 \\
1.180+03 \\
8.740+02 \\
\end{array}$ & $\begin{array}{l}5.790+09 \\
4.750+07 \\
1.600+08 \\
4.080+08 \\
3.00 e+07 \\
1.150+08 \\
3.410+07 \\
1.500+04 \\
4.40 e+07 \\
9.110+07 \\
1.160+08 \\
3.80 e+06 \\
2.89 e+07 \\
1.090+06 \\
1.19 e+05 \\
\end{array}$ & $\begin{array}{l}3 \\
6 \\
8 \\
7 \\
2 \\
2 \\
9 \\
5 \\
7 \\
5 \\
7 \\
5 \\
2 \\
9 \\
5\end{array}$ & 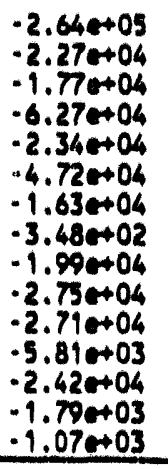 & $\begin{array}{l}2.20 e+05 \\
1.10 e+04 \\
4.05 e+04 \\
3.29 e+04 \\
2.37 e+04 \\
4.50 e+04 \\
1.02 e+04 \\
2.81 e+02 \\
1.15 e+04 \\
2.16 e+04 \\
2.390+04 \\
4.21 e+03 \\
2.20 e+04 \\
2.93 e+03 \\
6.980+02 \\
\end{array}$ \\
\hline 48 & $\begin{array}{l}\text { ICP. fus.Al } \\
\text { ICP. fus. Ca } \\
\text { ICP. fus. Fe } \\
\text { ICP. fus. No } \\
\text { ICP. fus. Pb } \\
\text { ICP. fue.U } \\
\text { ICP. fus.P } \\
\text { Chloride } \\
\text { NItrite } \\
\text { Nitrate } \\
\text { Phosphate } \\
\text { sulfate } \\
\text { Totel CN } \\
\text { Sr. } 90 \\
\text { Cs. } 137 . \text { fue }\end{array}$ & $\begin{array}{l}8.36 e+03 \\
2.30 e+04 \\
2.05 e+04 \\
1.090+05 \\
6.930+02 \\
1.55 e+04 \\
2.210+04 \\
9.750+02 \\
5.03 c+04 \\
5.480+04 \\
2.590+04 \\
1.050+04 \\
9.95 e+03 \\
1.36 e+02 \\
1.160+03 \\
\end{array}$ & $\begin{array}{l}0.370+03 \\
1.77 e+04 \\
2.220+04 \\
1.00 e+05 \\
N A \\
2.470+04 \\
2.020+04 \\
8.000+02 \\
4.50 e+04 \\
4.800+04 \\
2.67 e+04 \\
9.250+03 \\
1.440+04 \\
1.90 e+02 \\
1.03 e+03 \\
\end{array}$ & 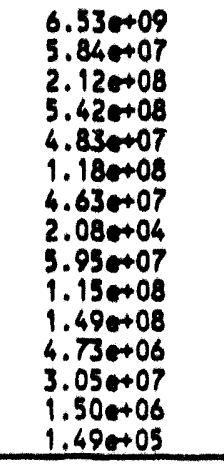 & $\begin{array}{c}4 \\
7 \\
8 \\
7 \\
4 A \\
2 \\
9 \\
5 \\
6 \\
5 \\
8 \\
5 \\
3 \\
9 \\
5 \\
\end{array}$ & $\begin{array}{r}-2.240+05 \\
-1.270+04 \\
-3.520+04 \\
-4.620+04 \\
N A \\
-5.600+04 \\
-1.350+04 \\
-1.960+02 \\
-1.360+04 \\
-2.080+04 \\
-2.900+04 \\
-4.340+03 \\
-2.200+04 \\
-2.820+03 \\
-8.640+02 \\
\end{array}$ & $\begin{array}{l}2.240+05 \\
2.350+04 \\
3.180+04 \\
6.390+04 \\
14 A \\
3.760+04 \\
1.730+04 \\
5.460+02 \\
2.410+04 \\
3.430+04 \\
2.73 e+04 \\
6.840+03 \\
1.32 \theta+04 \\
2.72 \theta+03 \\
1.120+03 \\
\end{array}$ \\
\hline 49 & $\begin{array}{l}\text { ICP. fus. Al } \\
\text { ICP. fus. Ca } \\
\text { ICP. fus. Fe } \\
\text { ICP. fus. Na } \\
\text { ICP. fus. Pb } \\
\text { ICP. fus. } \\
\text { ICP. fus. } \\
\text { Chloride } \\
\text { Mitrite } \\
\text { Nitrate } \\
\text { Phosphate } \\
\text { Sulfate } \\
\text { Total CN } \\
\text { Sr-90 } \\
\text { CE-137. fus }\end{array}$ & $\begin{array}{l}1.17 e+05 \\
1.510+04 \\
1.190+04 \\
6.580+04 \\
1.360+03 \\
1.240+04 \\
1.210+04 \\
7.000+02 \\
3.83 e+04 \\
3.690+04 \\
1.340+04 \\
6.970+03 \\
5.710+03 \\
9.280+02 \\
3.890+02\end{array}$ & $\begin{array}{l}1.27 e+05 \\
1.490+04 \\
9.10 e+03 \\
7.65 e+04 \\
8.230+02 \\
5.59 e+03 \\
1.460+04 \\
7.000+02 \\
3.85 e+04 \\
3.600+04 \\
1.280+04 \\
6.550+03 \\
5.620+03 \\
9.320+02 \\
5.570+02\end{array}$ & $\begin{array}{l}5.79 e+09 \\
4.75 e+07 \\
1.60 e+08 \\
4.08 e+08 \\
3.45 e+07 \\
1.18 e+08 \\
3.41 e+07 \\
1.50 e+04 \\
4.40 e+07 \\
9.11 e+07 \\
1.16 e+08 \\
3.80 e+06 \\
2.89 e+07 \\
1.09 e+06 \\
1.190+05 \\
\end{array}$ & $\begin{array}{l}3 \\
6 \\
8 \\
7 \\
3 \\
2 \\
9 \\
5 \\
7 \\
5 \\
7 \\
5 \\
2 \\
9 \\
5\end{array}$ & $\begin{array}{l}-2.510+05 \\
-1.660+04 \\
-2.64 \theta+04 \\
-5.850+04 \\
-1.820+04 \\
-4.000+04 \\
-1.570+04 \\
-3.140+02 \\
-1.590+04 \\
-2.360+04 \\
-2.490+04 \\
-4.590+03 \\
-2.300+04 \\
-2.360+03 \\
-1.050+03 \\
\end{array}$ & $\begin{array}{l}2.33 e+05 \\
1.710+04 \\
3.19 e+04 \\
3.70 e+04 \\
1.92 e+04 \\
5.36 e+04 \\
1.08 e+04 \\
3.14 e+02 \\
1.55 e+04 \\
2.54 e+04 \\
2.610+04 \\
5.43 e+03 \\
2.32 e+04 \\
2.36 e+03 \\
7.19 e+02 \\
\end{array}$ \\
\hline
\end{tabular}

NA: Not available 
Table 8. 95\% Confidence Interval on $\sigma^{2}(A)$, Analytical Error Variance.

\begin{tabular}{|c|c|c|c|c|}
\hline Analyes & $\partial^{2}(A)$ & $d f$ & $95 \times 44$ & $95 x$ UL. \\
\hline 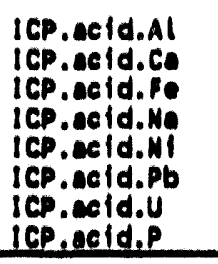 & $\begin{array}{l}1.000+08 \\
3.910+06 \\
5.450+07 \\
1.200+08 \\
1.670+06 \\
1.230+06 \\
4.180+06 \\
2.730+07\end{array}$ & $\begin{array}{l}3 \\
3 \\
3 \\
3 \\
3 \\
3 \\
3 \\
3 \\
\end{array}$ & $\begin{array}{l}3.21 e+07 \\
1.250+06 \\
1.73 e+07 \\
3.890+07 \\
4.720+05 \\
3.960+05 \\
1.340+06 \\
1.410+07\end{array}$ & $\begin{array}{l}1.390+09 \\
5.430+07 \\
7.570+08 \\
2.55 e+09 \\
2.040+07 \\
1.710+07 \\
5.810+07 \\
6.09 e+08\end{array}$ \\
\hline 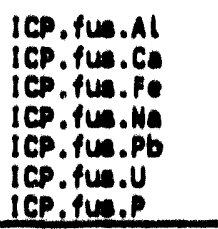 & $\begin{array}{l}3.710+07 \\
6.470+05 \\
3.38+006 \\
4.97++07 \\
3.710+03 \\
9.45++06 \\
9.430+06\end{array}$ & $\begin{array}{l}3 \\
3 \\
3 \\
3 \\
2 \\
2 \\
3 \\
\end{array}$ & $\begin{array}{l}1.19 e+07 \\
2.080+05 \\
1.080+06 \\
1.59 e+07 \\
1.000+03 \\
2.570+06 \\
3.03 e+06\end{array}$ & 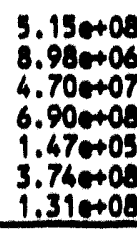 \\
\hline $\begin{array}{l}\text { ICP. water. Ca } \\
\text { ICP. water. Pe } \\
\text { ICP. water. Na } \\
\text { ICP. water. NI } \\
\text { ICP, water. }\end{array}$ & $\begin{array}{l}1.670+02 \\
6.200+02 \\
2.400+07 \\
1.660+02 \\
7.270+06\end{array}$ & $\begin{array}{l}3 \\
3 \\
3 \\
3 \\
3 \\
\end{array}$ & $\begin{array}{l}5.350+01 \\
1.990+02 \\
7.700+06 \\
5.330+01 \\
2.330+06\end{array}$ & $\begin{array}{l}2.32 e+03 \\
8.62 e+03 \\
3.33 e+08 \\
2.31 e+03 \\
1.01 e+08\end{array}$ \\
\hline $\begin{array}{l}\text { Chloride } \\
\text { Nitrite } \\
\text { Mitrate } \\
\text { Phosphate } \\
\text { sulphate } \\
\text { Iotal CM }\end{array}$ & $\begin{array}{c}0.00 \\
6.830+06 \\
6.670+06 \\
5.930+07 \\
1.700+05 \\
2.140+04\end{array}$ & $\begin{array}{l}3 \\
3 \\
3 \\
3 \\
3 \\
3\end{array}$ & $\begin{array}{c}0.00 \\
2.190+06 \\
2.140+06 \\
1.90+07 \\
5.45+04 \\
6.88+03\end{array}$ & $\begin{array}{c}0.00 \\
9.690+07 \\
9.260+07 \\
8.240+08 \\
2.360+06 \\
2.980+05\end{array}$ \\
\hline $\begin{array}{l}U(\mu g / g) \\
\text { Tot.Alphe.pu } \\
8 r-90 \\
\text { Pu-239/240 } \\
\text { C8-137. Water } \\
\text { Ce-137. fustion }\end{array}$ & $\begin{array}{l}4.05 e+00 \\
3.57 e-03 \\
1.24 c+04 \\
3.57 e-03 \\
1.35 e+00 \\
4.23 e+03\end{array}$ & $\begin{array}{l}3 \\
3 \\
3 \\
3 \\
3 \\
3 \\
\end{array}$ & $\begin{array}{l}1.30 e+00 \\
1.15 e-03 \\
3.98 e+03 \\
1.15 e-03 \\
4.34 e-01 \\
1.36 e+03\end{array}$ & $\begin{array}{l}5.63 e+01 \\
4.96 e \cdot 02 \\
1.720+05 \\
4.96 e \cdot 02 \\
1.880+01 \\
5.870+04\end{array}$ \\
\hline
\end{tabular}


Table 9. 95\% Confidence Interval on $\sigma^{2}(S)$, Spatial Varlance.

\begin{tabular}{|c|c|c|c|c|c|}
\hline Anclyte & $\dot{0}^{2}(8)$ & df & pevalue & $95 \times 46$ & $93 \times 4 \mathrm{~L}$ \\
\hline 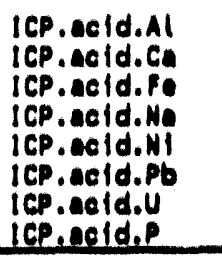 & $\begin{array}{c}1.700+09 \\
1.720+07 \\
9.140+07 \\
0.00 \\
2.950+06 \\
2.000+07 \\
1.710+07 \\
0.00\end{array}$ & $\begin{array}{l}2 \\
2 \\
2 \\
2 \\
2 \\
2 \\
2 \\
2 \\
\end{array}$ & $\begin{array}{l}0.008 \\
0.040 \\
0.130 \\
0.882 \\
0.110 \\
0.009 \\
0.053 \\
0.939 \\
\end{array}$ & $\begin{array}{c}2.370+08 \\
0.00 \\
0.00 \\
0.00 \\
0.00 \\
2.920+06 \\
0.00 \\
0.00\end{array}$ & $\begin{array}{l}6.91 e+10 \\
7.340+08 \\
4.66 e+09 \\
3.840+08 \\
1.450+08 \\
8.160+08 \\
7.570+08 \\
3.400+07\end{array}$ \\
\hline $\begin{array}{l}\text { ICP. fus.Al } \\
\text { ICP. fus. Co } \\
\text { ICP. fus. Fe } \\
\text { ICP. fus. Ne } \\
\text { ICP. fus. Pb } \\
\text { ICP. fus. } \\
\text { ICP. fue. }\end{array}$ & $\begin{array}{l}4.270+09 \\
2.520+07 \\
5.390+07 \\
1.140+08 \\
2.080+07 \\
9.800+07 \\
5.160+06\end{array}$ & $\begin{array}{l}2 \\
2 \\
2 \\
2 \\
1 \\
2 \\
2 \\
\end{array}$ & $\begin{array}{l}0.001 \\
0.003 \\
0.009 \\
0.097 \\
0.000 \\
0.052 \\
0.270 \\
\end{array}$ & $\begin{array}{c}1.080+09 \\
3.300+06 \\
7.730 * 06 \\
0.00 \\
4.130+06 \\
0.00 \\
0.00 \\
\end{array}$ & $\begin{array}{l}1.69+11 \\
1.01+009 \\
2.19+09 \\
5.48+09 \\
2.130+10 \\
4.26+09 \\
3.85+08\end{array}$ \\
\hline $\begin{array}{l}\text { ICP. water. Co } \\
\text { ICP. water. Fe } \\
\text { ICP. water. Ne } \\
\text { ICP. water. NI } \\
\text { ICP. water. }\end{array}$ & $\begin{array}{l}4.400+03 \\
1.950+04 \\
1.320+08 \\
2.310+03 \\
1.600+06\end{array}$ & $\begin{array}{l}2 \\
2 \\
2 \\
2 \\
2 \\
\end{array}$ & $\begin{array}{l}0.006 \\
0.003 \\
0.037 \\
0.011 \\
0.364 \\
\end{array}$ & $\begin{array}{c}8.520+02 \\
4.03+03 \\
0.00 \\
2.890+02 \\
0.00 \\
\end{array}$ & $\begin{array}{l}1.770+05 \\
7.830+05 \\
5.700+00 \\
9.450+04 \\
2.030+08\end{array}$ \\
\hline $\begin{array}{l}\text { Chlorlde } \\
\text { Nitrite } \\
\text { Nitrote } \\
\text { Phosphote } \\
\text { sulphote } \\
\text { Totel CH }\end{array}$ & $\begin{array}{l}3.330+03 \\
9.670+06 \\
4.100+07 \\
2.080+07 \\
1.860+06 \\
2.320+07\end{array}$ & $\begin{array}{l}2 \\
2 \\
2 \\
2 \\
2 \\
2 \\
\end{array}$ & $\begin{array}{l}0.000 \\
0.149 \\
0.032 \\
0.321 \\
0.015 \\
0.000 \\
\end{array}$ & $\begin{array}{c}9.030+02 \\
0.00 \\
0.00 \\
0.00 \\
1.580+05 \\
6.780+06 \\
\end{array}$ & $\begin{array}{l}1.320+03 \\
5.130+08 \\
1.730+09 \\
1.96+09 \\
7.66+07 \\
9.940+08\end{array}$ \\
\hline $\begin{array}{l}U(\mu g / g) \\
\text { Tot.Alphe.Pu } \\
\text { sr-90 } \\
\text { Pu-239/240 } \\
\text { Ce-137. water } \\
\text { Ce-137. fuation }\end{array}$ & $\begin{array}{l}1.09 e+02 \\
2.13 e-01 \\
2.570+05 \\
2.130-01 \\
4.66+00 \\
5.63 e+04\end{array}$ & $\begin{array}{l}2 \\
2 \\
2 \\
2 \\
2 \\
2 \\
\end{array}$ & $\begin{array}{l}0.004 \\
0.001 \\
0.006 \\
0.001 \\
0.064 \\
0.012\end{array}$ & $\begin{array}{l}2.120+01 \\
5.060-02 \\
4.450+04 \\
5.040-02 \\
0.00 \\
6.660+03\end{array}$ & $\begin{array}{l}4.37+03 \\
8.50 \div 00 \\
1.04+07 \\
8.480+00 \\
2.100+02 \\
2.30+06\end{array}$ \\
\hline
\end{tabular}


Table 10. Tukay's HSD Multiple Comparisons, Core Composite Data (Units $\mu \mathrm{g} / \mathrm{g}$ Except Radionuclides $\mu \mathrm{C} 1 / \mathrm{g}$ ).

\begin{tabular}{|c|c|c|c|c|c|c|c|}
\hline \multirow{2}{*}{ Core } & \multicolumn{3}{|c|}{ orous } & \multicolumn{3}{|c|}{ Meen } & \multirow{2}{*}{ Rso } \\
\hline & 47 & 48 & 49 & 47 & 48 & 49 & \\
\hline 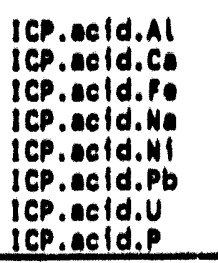 & $\begin{array}{l}1 \\
a \\
a \\
a \\
a\end{array}$ & $\begin{array}{l}a \\
a \\
a \\
a \\
a\end{array}$ & $\begin{array}{l}0 \\
0 \\
0 \\
0 \\
0\end{array}$ & $\begin{array}{l}7.30+04 \\
2.00+04 \\
2.90+04 \\
8.20+04 \\
1.30+04 \\
8.60+03 \\
1.10+04 \\
1.80+04 \\
\end{array}$ & $\begin{array}{l}6.40+03 \\
1.30+04 \\
2.00+04 \\
8.80+04 \\
1.60+04 \\
6.10+02 \\
1.50+04 \\
1.70+04\end{array}$ & $\begin{array}{l}8.4 e+04 \\
1.2 e+04 \\
7.1 e+03 \\
8.10+04 \\
1.2 e+04 \\
8.60+02 \\
6.3 e+03 \\
1.90+04\end{array}$ & $\begin{array}{l}18 x \\
13 x \\
39 x \\
16 x \\
9 \% \\
33 x \\
10 x \\
36 x \\
\end{array}$ \\
\hline $\begin{array}{l}\text { ICP. fus.Al } \\
\text { ICP. fus. Co } \\
\text { ICP. fus. Fe } \\
\text { ICP. fus. Ne } \\
\text { ICP. fus.Pb } \\
\text { ICP. fus. U } \\
\text { ICP. fus.p }\end{array}$ & $\begin{array}{l}1 \\
0 \\
0 \\
0\end{array}$ & $\begin{array}{l}a \\
\vdots \\
0 \\
0\end{array}$ & $\begin{array}{l}1 \\
a \\
a \\
0 \\
0\end{array}$ & $\begin{array}{l}1.2 e+05 \\
2.5 e+04 \\
2.20+04 \\
8.7+04 \\
7.3 e+03 \\
9.20+03 \\
2.00+04\end{array}$ & $\begin{array}{l}8.60+03 \\
1.80+04 \\
2.20+04 \\
1.00+05 \\
N A \\
2.30+04 \\
2.00+04\end{array}$ & $\begin{array}{l}1.3 e+05 \\
1.5 e+04 \\
9.1 e+03 \\
7.70+04 \\
8.20+02 \\
2.80+03 \\
1.50+04\end{array}$ & $\begin{array}{l}7 x \\
4 x \\
10 x \\
8 x \\
1 x \\
28 x \\
17 x \\
\end{array}$ \\
\hline $\begin{array}{l}\text { ICP. water. Co } \\
\text { ICP. water. Pe } \\
\text { ICP. water. Wa } \\
\text { ICP. water. NI } \\
\text { ICP. water.P }\end{array}$ & $\begin{array}{l}b \\
a \\
a \\
a\end{array}$ & $\begin{array}{l}a \\
0 \\
a\end{array}$ & $\begin{array}{l}a \\
a \\
a\end{array}$ & $\begin{array}{l}1.8 e+02 \\
8.8 e+02 \\
6.8 c+04 \\
1.2 e+02 \\
7.0 e+03 \\
\end{array}$ & $\begin{array}{l}6.00+01 \\
1.10+03 \\
8.40+04 \\
3.10+01 \\
8.70+03\end{array}$ & $\begin{array}{l}7.80+01 \\
9.20+02 \\
6.00+04 \\
5.30+01 \\
4.20+03\end{array}$ & $\begin{array}{c}12 x \\
3 x \\
7 x \\
19 x \\
618 \\
\end{array}$ \\
\hline $\begin{array}{l}\text { Chlorlde } \\
\text { Nitrite } \\
\text { Mitrate } \\
\text { Phoophote } \\
\text { sulphate } \\
\text { Total CN } \\
\end{array}$ & $\begin{array}{l}a \\
a \\
a \\
a\end{array}$ & 8 & $\begin{array}{l}a \\
a \\
a \\
a \\
a \\
a\end{array}$ & $\begin{array}{l}7.00+02 \\
3.90+04 \\
3.70+04 \\
2.20+04 \\
7.30+03 \\
2.80+03 \\
\end{array}$ & $\begin{array}{l}8.00+02 \\
4.50+04 \\
4.80+04 \\
2.70+04 \\
9.30+03 \\
2.10+02\end{array}$ & $\begin{array}{l}7.00+02 \\
3.90+04 \\
3.60+04 \\
1.30+04 \\
1.60+03 \\
2.80+03\end{array}$ & $\begin{array}{r}0 x \\
6 x \\
6 x \\
38 x \\
5 x \\
167 x \\
\end{array}$ \\
\hline 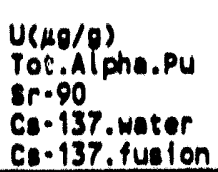 & 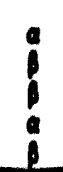 & $\begin{array}{l}b \\
a \\
a \\
a\end{array}$ & $\begin{array}{l}a \\
a \\
a \\
a \\
a\end{array}$ & $\begin{array}{l}1.2 e+01 \\
8.80 \cdot 01 \\
1.20+03 \\
9.20+00 \\
8.7 e+02\end{array}$ & $\begin{array}{l}2.80+01 \\
6.80-02 \\
1.90+02 \\
9.30+00 \\
1.00+03\end{array}$ & $\begin{array}{l}7.50+00 \\
7.90 \cdot 02 \\
9.30+02 \\
5.30+00 \\
5.60+02\end{array}$ & $\begin{array}{l}13 x \\
18 x \\
15 x \\
15 x \\
8 x\end{array}$ \\
\hline
\end{tabular}

MAI Not ovallable 
Table 11. Tukey's HSD Multiple Comparisons, Subsegment Data (Units $\mu \mathrm{g} / \mathrm{g}$ Except Radionuclides $\mu \mathrm{C} 1 / \mathrm{g}$ ).

\begin{tabular}{|c|c|c|c|c|c|c|c|}
\hline \multirow{2}{*}{ Core } & \multicolumn{3}{|c|}{ oras } & \multicolumn{3}{|c|}{ Mean } & \multirow{2}{*}{ nso } \\
\hline & 47 & 48 & 49 & 47 & 68 & 10 & \\
\hline ICP.fUE.AI & & & 8 & $\begin{array}{r}1.30+05 \\
1.20+05 \\
3.20+06 \\
\end{array}$ & $\begin{array}{l}7.30+03 \\
9.80+03 \\
\end{array}$ & $\begin{array}{r}1.9+05 \\
9.60+04 \\
7.10+04\end{array}$ & $6 x$ \\
\hline ICP.fUS.CA & $y$ & i & 8 & $\begin{array}{r}1.00+04 \\
1.80+06 \\
2.80+04 \\
\end{array}$ & $\begin{array}{l}2.90+04 \\
1.70+04 \\
\end{array}$ & $\begin{array}{r}4.30+03 \\
1.90+04 \\
2.30+04 \\
\end{array}$ & $6 x$ \\
\hline ICP.fus.te & 2 & & $a$ & $\begin{array}{l}6.30+06 \\
2.10+06 \\
1.50+06\end{array}$ & $\begin{array}{l}2.00 * 04 \\
2.10 * 04\end{array}$ & $\begin{array}{l}1.60+04 \\
6.60+03 \\
1.30+04\end{array}$ & $46 x$ \\
\hline ICP.tus.Ne & of & y & by & $\begin{array}{l}5.10+04 \\
6.30+04 \\
1.00+05 \\
\end{array}$ & $\begin{array}{l}1.20+05 \\
1.00+05 \\
\end{array}$ & $\begin{array}{r}4.30+04 \\
6.30+04 \\
9.10+04 \\
\end{array}$ & $14 x$ \\
\hline ICP.fus.pb & - & & $\dot{0}$ & $\begin{array}{r}3.00+03 \\
2.90+03 \\
1.40+04 \\
\end{array}$ & $6.2_{e+02}^{M A}$ & $\begin{array}{c}2.00+03 \\
7.3 e+02 \\
\end{array}$ & $50 x$ \\
\hline ICp.fus.U & $\begin{array}{l}y \\
0 \\
0\end{array}$ & 8 & $\begin{array}{l}a p y \\
\text { is }\end{array}$ & $\begin{array}{l}1.20+04 \\
6.10+03 \\
3.80+03 \\
\end{array}$ & $\begin{array}{l}1.70006 \\
1.40+06 \\
\end{array}$ & $\begin{array}{c}7.9 * 03 \\
\mathrm{NA} \\
1.20+04 \\
\end{array}$ & $\boldsymbol{x}$ \\
\hline ICP.fua.p & & & & $\begin{array}{c}\mathrm{NA} \\
1.20+04 \\
3.00+04\end{array}$ & $\begin{array}{l}30+06 \\
l e+06\end{array}$ & $\begin{array}{c}\mathrm{NA} \\
1.10+04 \\
2.00+04\end{array}$ & $9 x$ \\
\hline chlortas & $\left.\right|_{y} ^{a}$ & 1 & $\begin{array}{l}0 \\
y \\
y\end{array}$ & $\begin{array}{r}3.5 e+02 \\
7.0 e+02 \\
7.5 e+02 \\
\end{array}$ & $\begin{array}{l}9.50+02 \\
1.00+03 \\
\end{array}$ & $\begin{array}{r}3.00 * 02 \\
8.00 * 02 \\
8.00+02 \\
\end{array}$ & $6 x$ \\
\hline Wierite & & se & $\begin{array}{r}1 \\
y \\
\end{array}$ & $\begin{array}{l}2.80+04 \\
3.70+04 \\
4.00+04 \\
\end{array}$ & $\begin{array}{l}3.10+06 \\
3.00+0 h\end{array}$ & $\begin{array}{l}2.6004 \\
4.4004 \\
4.30+04\end{array}$ & $4 x$ \\
\hline Mitrate & 4 & 8 & $\begin{array}{c}a \\
1 y \\
\end{array}$ & $\begin{array}{l}2.80+04 \\
3.60+04 \\
3.9+04 \\
\end{array}$ & $\begin{array}{l}3.60+04 \\
5.40+04 \\
\end{array}$ & $\begin{array}{l}2.60+04 \\
4.20+04 \\
4.30+04 \\
\end{array}$ & $4 x$ \\
\hline Phosphate & 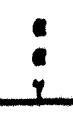 & if & abr & $\begin{array}{l}7.30 * 03 \\
9.60+03 \\
4.50+04 \\
\end{array}$ & $\begin{array}{r}04 \\
.04 \\
\end{array}$ & $\begin{array}{l}6.10+03 \\
8.80+03 \\
2.50+04\end{array}$ & $28 x$ \\
\hline sulfate & 8 & 8 & $\begin{array}{l}1 \\
y \\
y\end{array}$ & $\begin{array}{l}5.10403 \\
7.1 e+03 \\
7.40+03 \\
\end{array}$ & $\begin{array}{l}1.10+04 \\
1.00+04\end{array}$ & $\begin{array}{l}4.70+03 \\
8.20+03 \\
8.10+03 \\
\end{array}$ & $3 x$ \\
\hline Total CN & 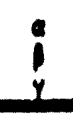 & ! & & $\begin{array}{l}3.2 e+03 \\
4.4 e+03 \\
3.8 \omega+03\end{array}$ & $\begin{array}{l}1.10+04 \\
8.70+03\end{array}$ & $\begin{array}{l}3.50+03 \\
8.10+03 \\
5.50+03\end{array}$ & $3 x$ \\
\hline $8 r .90$ & 8 & $a$ & $a$ & $\begin{array}{l}4.60+03 \\
4.70+02 \\
2.20+02 \\
\end{array}$ & $\begin{array}{r}1.5 e+02 \\
1.20+02 \\
\end{array}$ & $\begin{array}{l}2.4 e+03 \\
2.00+02 \\
1.9 e+02 \\
\end{array}$ & $8 x$ \\
\hline Cu-137. Puston & $\begin{array}{l}\text { op } \\
\text { Oy } \\
y \delta\end{array}$ & $\delta$ & ab & $\begin{array}{r}3.40+02 \\
7.70+02 \\
9.50+02 \\
\end{array}$ & $\begin{array}{l}1.20+03 \\
1.20+03 \\
\end{array}$ & $\begin{array}{l}1.20+02 \\
3.50+02 \\
7.0 e+02 \\
\end{array}$ & $16 x$ \\
\hline
\end{tabular}

NA: Not ovellable 
Table 12. Comparison of Analytical Error Varlances, 241-C-109 and 241-C-112.

\begin{tabular}{|c|c|c|c|c|c|}
\hline Iank & $c .109$ & & 6.112 & & \\
\hline Analyte & $\partial^{2}(A)$ & $d f$ & $\partial^{2}(A)$ & $d f$ & pevalue \\
\hline 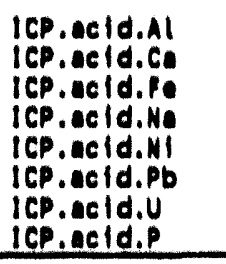 & $\begin{array}{l}1.00 e+08 \\
3.91 e+06 \\
5.45 e+07 \\
1.20 e+08 \\
1.47 e+06 \\
1.23 e+06 \\
4.18 e+06 \\
2.73 e+07 \\
\end{array}$ & $\begin{array}{l}\mathbf{3} \\
\mathbf{3} \\
\mathbf{3} \\
\mathbf{3} \\
\mathbf{3} \\
\mathbf{3} \\
\mathbf{3} \\
\mathbf{3} \\
\end{array}$ & $\begin{array}{l}3.100+07 \\
1.640+06 \\
2.760+07 \\
2.390+07 \\
1.06 e+06 \\
2.410+04 \\
1.100+08 \\
3.03 e+06 \\
\end{array}$ & $\begin{array}{l}\mathbf{3} \\
\mathbf{3} \\
\mathbf{3} \\
\mathbf{3} \\
\mathbf{3} \\
\mathbf{3} \\
\mathbf{3} \\
\mathbf{3} \\
\end{array}$ & $\begin{array}{l}0.180 \\
0.217 \\
0.294 \\
0.294 \\
0.399 \\
0.004 \\
0.012 \\
0.070 \\
\end{array}$ \\
\hline $\begin{array}{l}\text { ICP. fue. Al } \\
\text { ICP. fus. Ce } \\
\text { ICP. fus. fe } \\
\text { ICP. fue. Me } \\
\text { ICP. fus. Pb } \\
\text { ICP. fus. U } \\
\text { ICP. fus. }\end{array}$ & 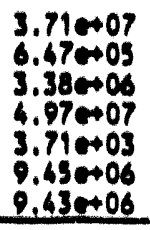 & $\begin{array}{l}3 \\
3 \\
3 \\
3 \\
2 \\
2 \\
3 \\
\end{array}$ & $\begin{array}{l}3.670+05 \\
1.560+05 \\
9.810+06 \\
3.960+06 \\
1.470+05 \\
1.640+07 \\
1.370+05\end{array}$ & $\begin{array}{l}2 \\
2 \\
2 \\
2 \\
2 \\
2 \\
2 \\
\end{array}$ & $\begin{array}{l}0.013 \\
0.200 \\
0.192 \\
0.073 \\
0.025 \\
0.366 \\
0.014 \\
\end{array}$ \\
\hline $\begin{array}{l}\text { ICP. water.AI } \\
\text { ICP. water. Ce } \\
\text { ICP. water. Pe } \\
\text { ICP. water. Ne } \\
\text { ICP. water. NI } \\
\text { ICP. water.U } \\
\text { ICP. water.P }\end{array}$ & $\begin{array}{c}\text { NA } \\
1.67 * 02 \\
6.20002 \\
2.400+07 \\
1.66 \oplus 02 \\
\mathrm{NA} \\
7.27 \oplus 06\end{array}$ & $\begin{array}{l}\text { NA } \\
3 \\
3 \\
3 \\
3 \\
\text { NA } \\
3 \\
\end{array}$ & $\begin{array}{l}3.05 e+04 \\
3.780+04 \\
3.630+03 \\
5.110+08 \\
1.290+03 \\
2.600+06 \\
1.130+07\end{array}$ & $\begin{array}{l}2 \\
2 \\
2 \\
2 \\
2 \\
2 \\
2 \\
\end{array}$ & $\begin{array}{l}\mathrm{NA} \\
0.000 \\
0.099 \\
0.017 \\
0.065 \\
\mathrm{NA} \\
0.345 \\
\end{array}$ \\
\hline $\begin{array}{l}\text { Chlorlde } \\
\text { Nitrlte } \\
\text { Nitrate } \\
\text { Phosphete } \\
\text { Sulphate } \\
\text { Totel CY } \\
\end{array}$ & $\begin{array}{c}\text { NA } \\
6.83 *+06 \\
6.670+06 \\
5.93 e+07 \\
1.700+05 \\
2.140+04 \\
\end{array}$ & $\begin{array}{l}\text { NA } \\
3 \\
3 \\
3 \\
3 \\
3 \\
\end{array}$ & $\begin{array}{c}2.500+04 \\
1.330+08 \\
2.410+08 \\
1.100+08 \\
6.250+06 \\
\mathrm{NA}\end{array}$ & $\begin{array}{l}2 \\
2 \\
2 \\
2 \\
2 \\
\text { MA } \\
\end{array}$ & $\begin{array}{l}\text { MA } \\
0.019 \\
0.008 \\
0.298 \\
0.008 \\
\text { MA }\end{array}$ \\
\hline 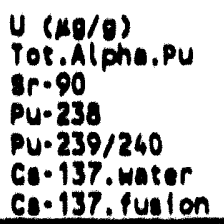 & $\begin{array}{c}4.050+00 \\
3.570-03 \\
1.26 e+04 \\
\mathrm{NA} \\
3.570 .03 \\
1.35 e+00 \\
6.23 e+03\end{array}$ & $\begin{array}{l}3 \\
3 \\
3 \\
\mathrm{MA} \\
3 \\
3 \\
3\end{array}$ & $\begin{array}{l}3.300+07 \\
\mathrm{MA} \\
1.360+03 \\
1.600-05 \\
2.690 .03 \\
\mathrm{NA} \\
2.310+02\end{array}$ & $\begin{array}{l}2 \\
M A \\
2 \\
2 \\
2 \\
\text { MA } \\
2\end{array}$ & $\begin{array}{l}0.000 \\
N A \\
0.101 \\
\text { NA } \\
0.007 \\
\text { NA } \\
0.001\end{array}$ \\
\hline
\end{tabular}

Wat Not ovallable 
Table 13. Comparison of Spatial Vartances, 241-C-109 and 241-C-112.

\begin{tabular}{|c|c|c|c|c|c|}
\hline Ienk & $c .109$ & & $c .112$ & & \\
\hline Analyte & $\nu^{2}(x)$ & $d f$ & $d^{2}(s)$ & $d f$ & D.velue \\
\hline 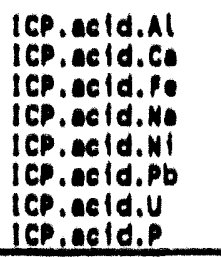 & $\begin{array}{l}1.70 * 09 \\
1.720+07 \\
9.160 * 07 \\
0.00 \\
2.930 * 08 \\
2.00 * 07 \\
1.710+07 \\
0.00\end{array}$ & $\begin{array}{l}2 \\
2 \\
2 \\
2 \\
2 \\
2 \\
2 \\
2 \\
\end{array}$ & $\begin{array}{c}3.670+08 \\
2.490+07 \\
0.00 \\
2.660+08 \\
1.550+07 \\
2.280+06 \\
1.560+09 \\
4.520+07\end{array}$ & $\begin{array}{l}2 \\
2 \\
2 \\
2 \\
2 \\
2 \\
2 \\
2 \\
\end{array}$ & $\begin{array}{c}0.178 \\
0.608 \\
\text { NA } \\
\text { NA } \\
0.160 \\
0.102 \\
0.011 \\
\text { NA }\end{array}$ \\
\hline 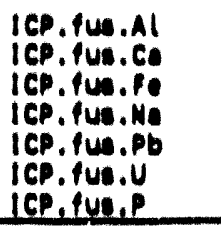 & $\begin{array}{l}4.270+00 \\
2.320 * 07 \\
5.390007 \\
1.160+08 \\
2.080+07 \\
9.800+07 \\
5.160+06\end{array}$ & $\begin{array}{l}2 \\
2 \\
2 \\
2 \\
2 \\
1 \\
2 \\
2 \\
\end{array}$ & $\begin{array}{l}4.700+08 \\
6.090+07 \\
1.650+07 \\
3.240+08 \\
3.980+06 \\
1.780+09 \\
8.040+07 \\
\end{array}$ & $\begin{array}{l}2 \\
2 \\
2 \\
2 \\
2 \\
2 \\
2 \\
2 \\
2\end{array}$ & $\begin{array}{l}0.099 \\
0.362 \\
0.236 \\
0.179 \\
0.149 \\
0.052 \\
0.060 \\
\end{array}$ \\
\hline 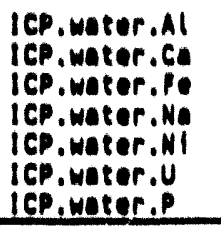 & $\begin{array}{c}\mathrm{MA} \\
6.600+03 \\
1.93+06 \\
1.320008 \\
2.310+03 \\
1.600+06 \\
\end{array}$ & $\begin{array}{l}\mathrm{MA} \\
2 \\
2 \\
2 \\
2 \\
2 \\
\mathrm{NA} \\
2 \\
\end{array}$ & $\begin{array}{l}7.060+04 \\
0.00 \\
2.260+05 \\
3.010+08 \\
8.360+06 \\
4.550+06 \\
3.500+07 \\
\end{array}$ & $\begin{array}{l}2 \\
2 \\
2 \\
2 \\
2 \\
2 \\
2 \\
2 \\
2\end{array}$ & $\begin{array}{l}M A \\
N A \\
0.079 \\
0.209 \\
0.026 \\
N A \\
0.044 \\
\end{array}$ \\
\hline $\begin{array}{l}\text { Chlorlde } \\
\text { WItrite } \\
\text { Nitrate } \\
\text { Phouphate } \\
\text { sulphote } \\
\text { Potel Cy }\end{array}$ & $\begin{array}{l}3.33 * 03 \\
9.67 * 06 \\
4.10 * 07 \\
2.08 * 07 \\
1.86 * 06 \\
2.320 * 07\end{array}$ & $\begin{array}{l}2 \\
2 \\
2 \\
2 \\
2 \\
2 \\
\end{array}$ & $\begin{array}{c}3.25 e+04 \\
1.04 e+08 \\
2.210+08 \\
2.970+08 \\
9.170+06 \\
\mathrm{NA}\end{array}$ & $\begin{array}{l}2 \\
2 \\
2 \\
2 \\
2 \\
\text { MA } \\
\end{array}$ & $\begin{array}{l}0.080 \\
0.085 \\
0.156 \\
0.065 \\
0.160 \\
11\end{array}$ \\
\hline 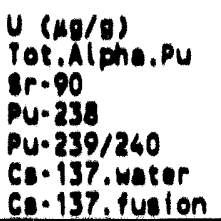 & $\begin{array}{l}1.090 * 02 \\
2.130 .01 \\
2.570+05 \\
2.130 .01 \\
1.660+00 \\
3.63 e+06\end{array}$ & $\begin{array}{l}2 \\
2 \\
2 \\
M A \\
2 \\
2 \\
2\end{array}$ & $\begin{array}{l}2.80+09 \\
\mathrm{NA} \\
2.96 e+06 \\
7.810 .03 \\
6.15 e .03 \\
\mathrm{NA} \\
2.67 e+03\end{array}$ & $\begin{array}{l}1 \\
M A \\
2 \\
2 \\
2 \\
M A \\
2\end{array}$ & $\begin{array}{l}0.000 \\
M A \\
0.080 \\
M A \\
0.019 \\
M A \\
0.042\end{array}$ \\
\hline
\end{tabular}

MA: Nor ovallable 


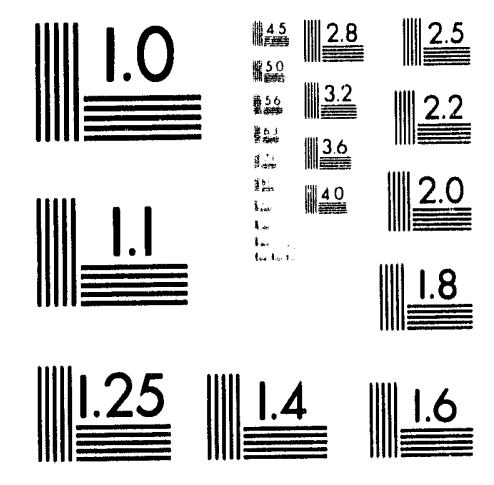



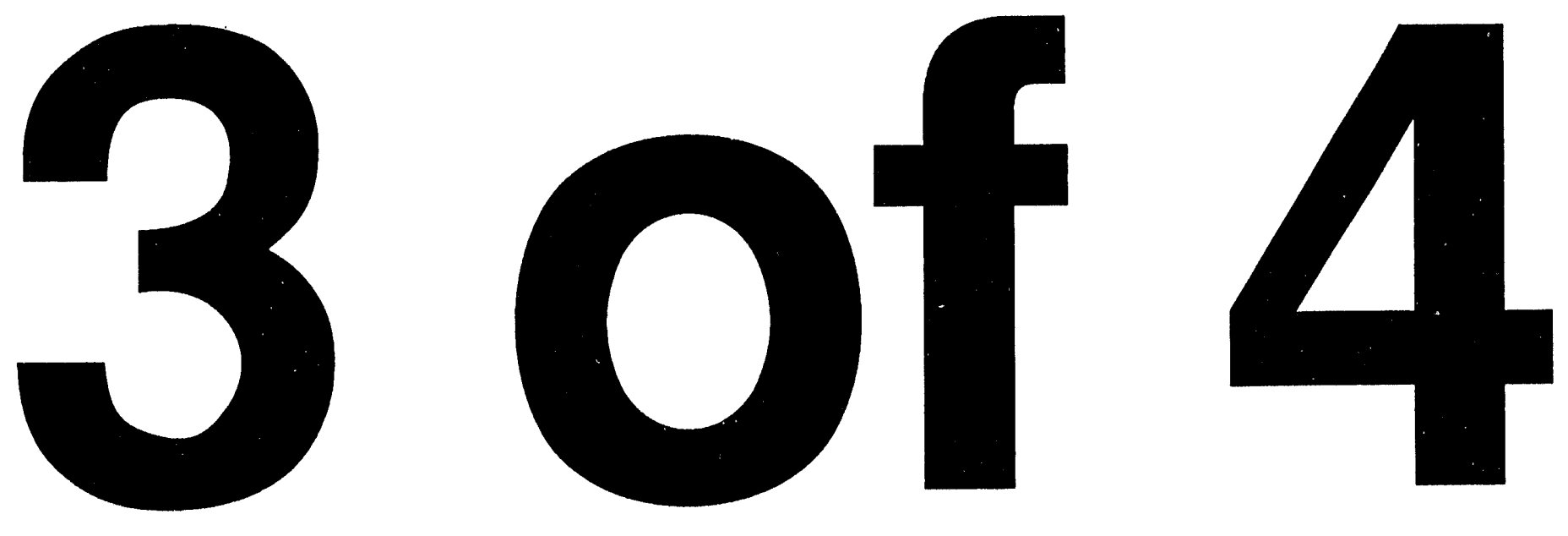
Table 14. Comparison of Percent Variance, 241-C-109 and 241-C-112.

\begin{tabular}{|c|c|c|c|c|}
\hline Tank & $c-109$ & $c-112$ & $c-109$ & $c-112$ \\
\hline Analyte & $x \theta^{2}(A)$ & $x 0^{2}(A)$ & $x \partial^{2}(s)$ & $x \partial^{2}(s)$ \\
\hline $\begin{array}{l}\text { ICP.acid.Al } \\
\text { ICP.acid.Ca } \\
\text { ICP.acid.Fe } \\
\text { ICP.acid. Na } \\
\text { ICP.acid. Ni } \\
\text { ICP.acid.Pb } \\
\text { ICP.acid.U } \\
\text { ICP.acid.P }\end{array}$ & $\begin{array}{c}6 \% \\
19 \% \\
37 \% \\
100 \% \\
33 \% \\
6 \% \\
20 \% \\
100 \% \\
\end{array}$ & $\begin{array}{c}8 \% \\
5 \% \\
100 \% \\
8 \% \\
6 \% \\
1 \% \\
7 \% \\
8 \% \\
\end{array}$ & $\begin{array}{l}94 \% \\
81 \% \\
63 \% \\
0 \% \\
67 \% \\
94 \% \\
80 \% \\
0 \% \\
\end{array}$ & $\begin{array}{l}92 \% \\
95 \% \\
0 \% \\
92 \% \\
94 \% \\
99 \% \\
93 \% \\
92 \%\end{array}$ \\
\hline $\begin{array}{l}\text { ICP. fus. } \mathrm{Al} \\
\text { ICP. fus. } \mathrm{Ca} \\
\text { ICP. fus. } \mathrm{Fe} \\
\text { ICP. fus. } \mathrm{Na} \\
\text { ICP. fus. } \mathrm{Pb} \\
\text { ICP. fus. } \mathrm{U} \\
\text { ICP. fus.P }\end{array}$ & $\begin{array}{c}1 \% \\
3 \% \\
6 \% \\
30 \% \\
0 \% \\
9 \% \\
65 \% \\
\end{array}$ & $\begin{array}{l}0 \% \\
0 \% \\
37 \% \\
1 \% \\
4 \% \\
1 \% \\
0 \% \\
\end{array}$ & $\begin{array}{l}99 \% \\
97 \% \\
94 \% \\
70 \% \\
100 \% \\
91 \% \\
35 \% \\
\end{array}$ & $\begin{array}{c}100 \% \\
100 \% \\
63 \% \\
99 \% \\
96 \% \\
99 \% \\
100 \% \\
\end{array}$ \\
\hline $\begin{array}{l}\text { ICP. water. Al } \\
\text { ICP. water. Ca } \\
\text { ICP. water. Fe } \\
\text { ICP. water. Na } \\
\text { ICP. water. NI } \\
\text { ICP. water.U } \\
\text { ICP. water.P }\end{array}$ & $\begin{array}{l}\text { NA } \\
4 \% \\
3 \% \\
15 \% \\
7 \% \\
N A \\
82 \% \\
\end{array}$ & $\begin{array}{c}30 \% \\
100 \% \\
1 \% \\
51 \% \\
1 \% \\
36 \% \\
24 \% \\
\end{array}$ & $\begin{array}{l}\text { NA } \\
96 \% \\
97 \% \\
85 \% \\
93 \% \\
\text { NA } \\
18 \% \\
\end{array}$ & $\begin{array}{l}70 \% \\
0 \% \\
99 \% \\
49 \% \\
99 \% \\
64 \% \\
76 \% \\
\end{array}$ \\
\hline $\begin{array}{l}\text { Chloride } \\
\text { Nitrite } \\
\text { Nitrate } \\
\text { Phosphate } \\
\text { Sulphate } \\
\text { Total CN } \\
\end{array}$ & $\begin{array}{l}0 \% \\
41 \% \\
14 \% \\
74 \% \\
8 \% \\
0 \%\end{array}$ & $\begin{array}{l}32 \% \\
56 \% \\
52 \% \\
27 \% \\
41 \% \\
N A\end{array}$ & $\begin{array}{l}100 \% \\
59 \% \\
86 \% \\
26 \% \\
92 \% \\
100 \% \\
\end{array}$ & $\begin{array}{l}68 \% \\
44 \% \\
48 \% \\
73 \% \\
59 \% \\
\text { NA }\end{array}$ \\
\hline $\begin{array}{l}U(\mu g / g) \\
\text { Tot.Alpha.Pu } \\
\text { Sr-90 } \\
\text { Pu-238 } \\
\text { Pu-239/240 } \\
\text { Cs-137. water } \\
\text { Cs-137. fusion }\end{array}$ & $\begin{array}{l}4 \% \\
2 \% \\
5 \% \\
N A \\
2 \% \\
22 \% \\
7 \%\end{array}$ & $\begin{array}{l}2 \% \\
\text { NA } \\
0 \% \\
0 X \\
1 \% \\
N A \\
9 \%\end{array}$ & $\begin{array}{l}96 \% \\
98 \% \\
95 \% \\
N A \\
98 \% \\
78 \% \\
93 \%\end{array}$ & $\begin{array}{l}98 \% \\
N A \\
100 \% \\
100 \% \\
99 \% \\
N A \\
91 \%\end{array}$ \\
\hline
\end{tabular}

NA: Not available 
WHC-EP-0668

Table 15. Relative Standard Deviations from Tanks C112 and C109.

\begin{tabular}{|c|c|c|c|c|c|c|}
\hline Analyte & $\operatorname{RSD}(Y)$ & $\operatorname{RSD}(\bar{y})$ & $\operatorname{RSD}(A)$ & RSD (A) & RSD (S) & RSO (S) \\
\hline $\begin{array}{l}\text { ICP. fus. Al } \\
\text { ICP. fus. Co } \\
\text { ICP. fus. Fe } \\
\text { ICP. fus. No } \\
\text { ICP. fus. Pb } \\
\text { ICP. fus. } \\
\text { ICP. fus.P }\end{array}$ & $\begin{array}{l}45 \% \\
15 \% \\
24 \% \\
8 \% \\
80 \% \\
42 \% \\
10 \% \\
\end{array}$ & $\begin{array}{l}46 \% \\
18 \% \\
10 \% \\
12 \% \\
39 \% \\
30 \% \\
18 \% \\
\end{array}$ & $\begin{array}{c}7 \% \\
4 \% \\
10 \% \\
8 \% \\
2 \% \\
21 \% \\
17 \% \\
\end{array}$ & $\begin{array}{c}3 \% \\
2 \% \\
11 \% \\
2 \% \\
13 \% \\
5 \% \\
1 \% \\
\end{array}$ & $\begin{array}{c}78 \% \\
26 \% \\
41 \% \\
12 \% \\
113 \% \\
67 \% \\
12 \% \\
\end{array}$ & $\begin{array}{l}82 \% \\
32 \% \\
15 \% \\
22 \% \\
68 \% \\
52 \% \\
32 \% \\
\end{array}$ \\
\hline 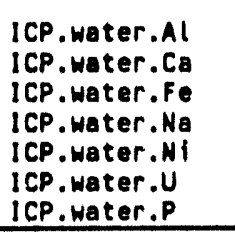 & $\begin{array}{l}N A \\
36 \% \\
8 \% \\
10 \% \\
41 \% \\
N A \\
20 \% \\
\end{array}$ & $\begin{array}{l}33 \% \\
11 \% \\
23 \% \\
18 \% \\
24 \% \\
65 \% \\
36 \% \\
\end{array}$ & $\begin{array}{l}\text { NA } \\
12 \% \\
3 \% \\
7 \% \\
19 \% \\
N A \\
41 \%\end{array}$ & $\begin{array}{l}34 \% \\
58 \% \\
5 \% \\
26 \% \\
5 \% \\
74 \% \\
33 \% \\
\end{array}$ & $\begin{array}{l}\text { NA } \\
62 \% \\
14 \% \\
16 \% \\
69 \% \\
\text { NA } \\
19 \%\end{array}$ & $\begin{array}{l}51 \% \\
0 \% \\
41 \% \\
25 \% \\
43 \% \\
98 \% \\
59 \% \\
\end{array}$ \\
\hline $\begin{array}{l}\text { Chloride } \\
\text { Nitrite } \\
\text { Nitrate } \\
\text { Phosphate } \\
\text { Sulphate } \\
\text { Total CN }\end{array}$ & $\begin{array}{c}5 x \\
5 \% \\
10 x \\
20 \% \\
10 \% \\
34 x \\
\end{array}$ & $\begin{array}{l}15 \% \\
16 \% \\
18 \% \\
35 \% \\
17 \% \\
N A \\
\end{array}$ & $\begin{array}{l}0 \% \\
6 \% \\
6 \% \\
38 \% \\
5 \% \\
2 \% \\
\end{array}$ & $\begin{array}{l}16 \% \\
24 \% \\
25 \% \\
34 \% \\
21 \% \\
\text { NA }\end{array}$ & $\begin{array}{l}8 \% \\
8 \% \\
16 \% \\
22 \% \\
18 \% \\
59 \% \\
\end{array}$ & $\begin{array}{l}23 \% \\
22 \% \\
24 \% \\
56 \% \\
25 \% \\
\text { NA } \\
\end{array}$ \\
\hline
\end{tabular}

NA: Not available 
APPENDIX 2: C109 CORE COMPOSITE AND SUBSEGMENT DATA PLOTS

This appendix contains plots of the core composite and subsegment data for C109. The units for the analytes in the plots are as follows:

\begin{tabular}{|c|c|}
\hline Analyte & Units \\
\hline All ICP (acid, water, fusion) & $\mu \mathrm{g} / \mathrm{g}$ \\
\hline All Anions & $\mu \mathrm{g} / \mathrm{g}$ \\
\hline All Radionuclides (excluding $U$ ) & $\mu \mathrm{Ci} / \mathrm{g}$ \\
\hline$U$ & $\mu \mathrm{g} / \mathrm{g}$ \\
\hline
\end{tabular}


WHC-EP-0668
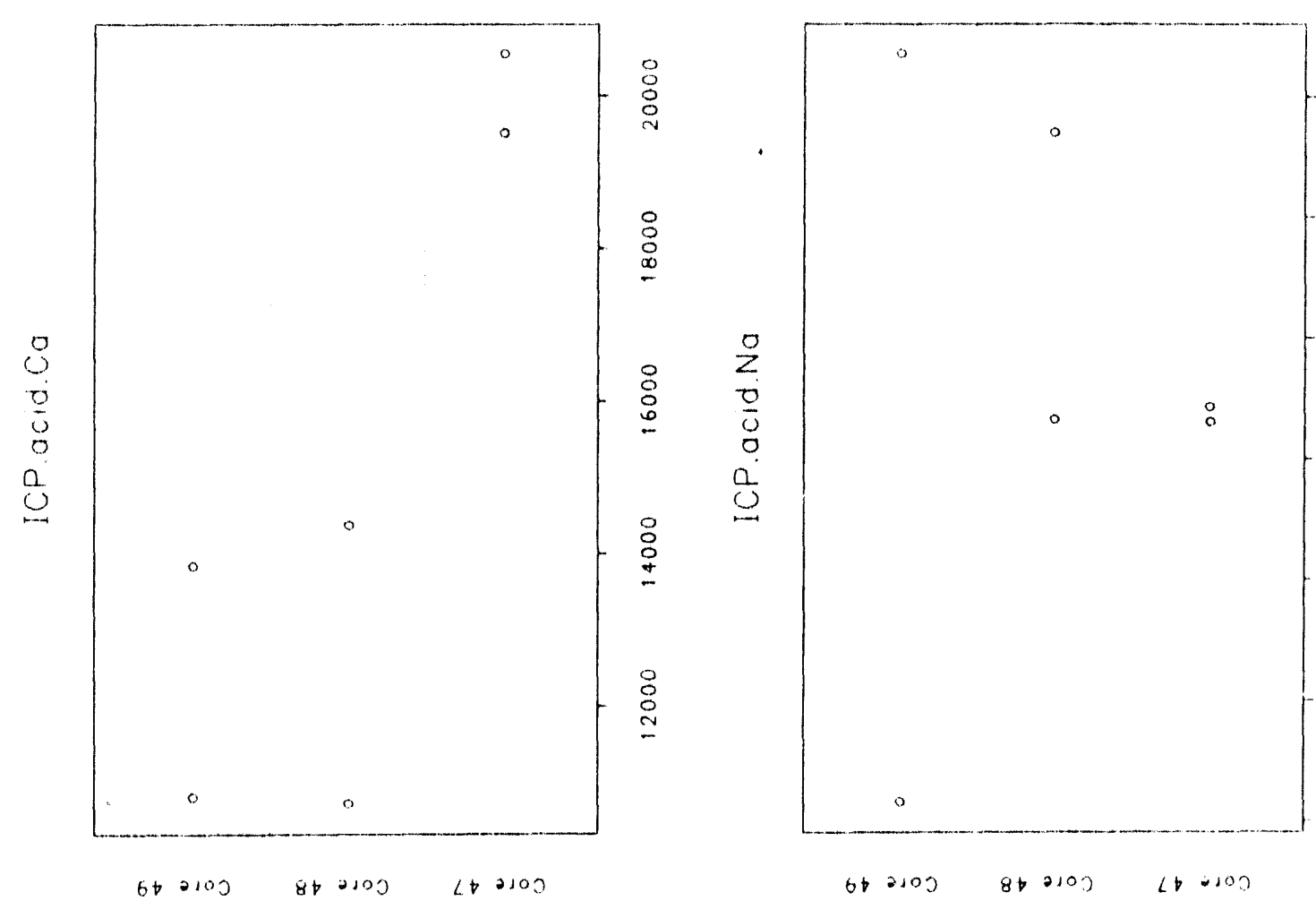

9
8
8
9
9

8
8
8

0
8
0
$\infty$

8

8

8

0
$\cdots$
11
11
$n$
$\vdots$
5
5
0
$\vdots$
5
$\vdots$
$\vdots$
3
3
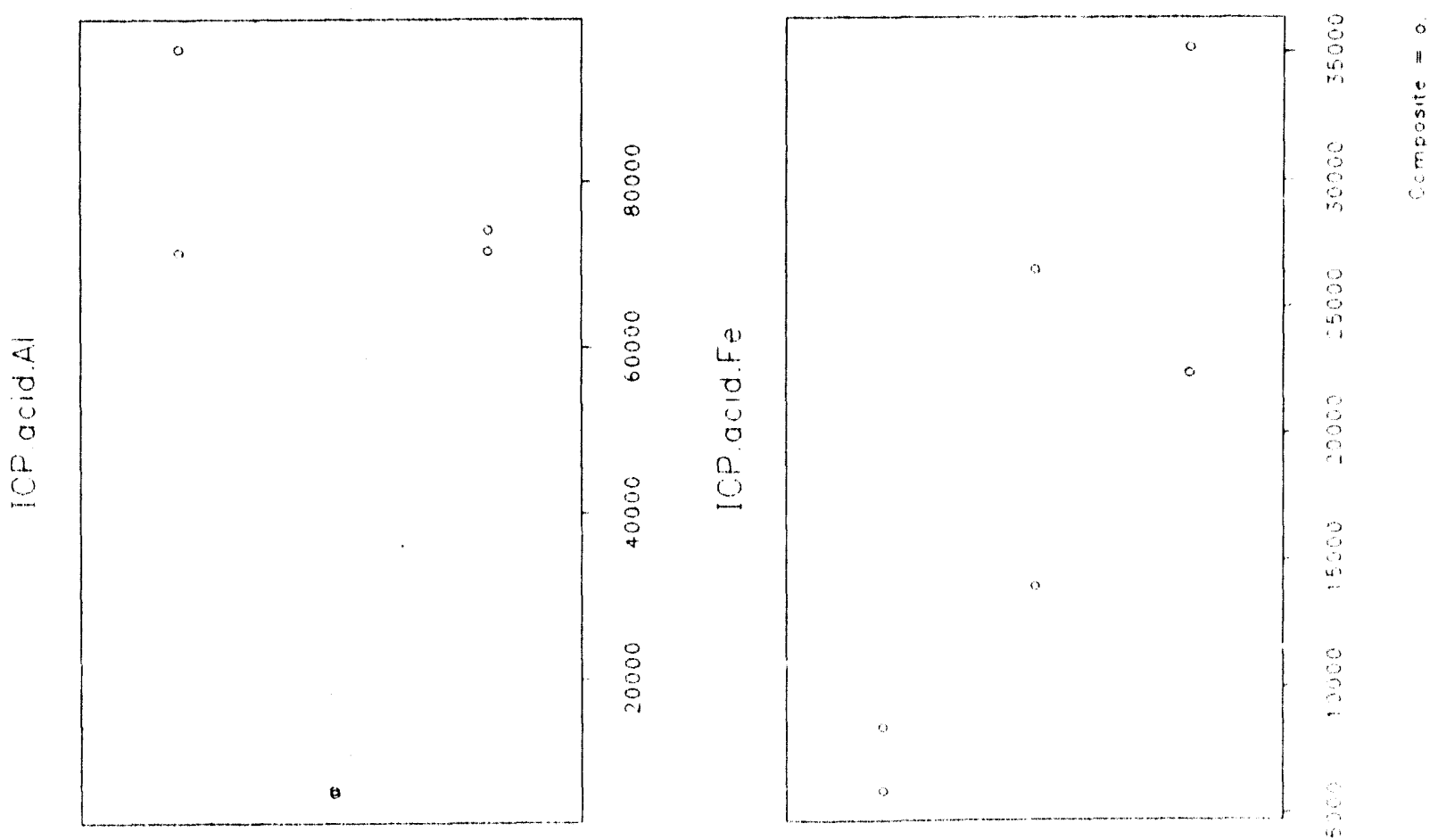

$0+2100 \quad 8+0100 \quad t+0000$

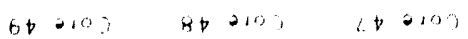


WHC-EP-0668

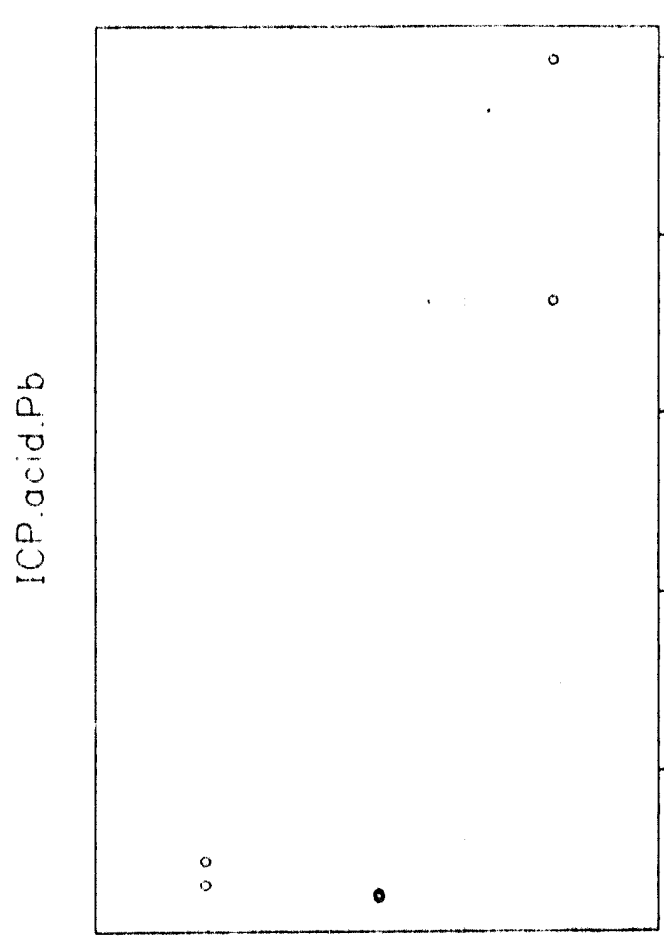

$600100 \quad 8+2100 \quad 100100$
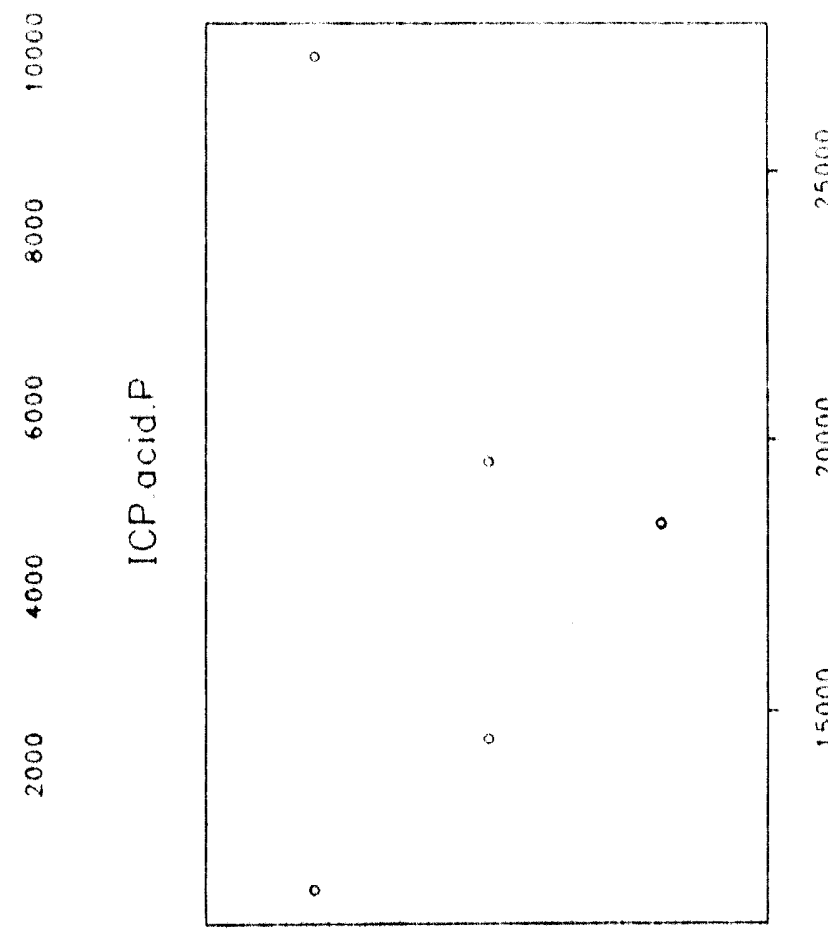

8
8
8
8
8
8
8
8
0
8

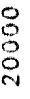

$6+0100 \quad 8+0100 \quad 160100$
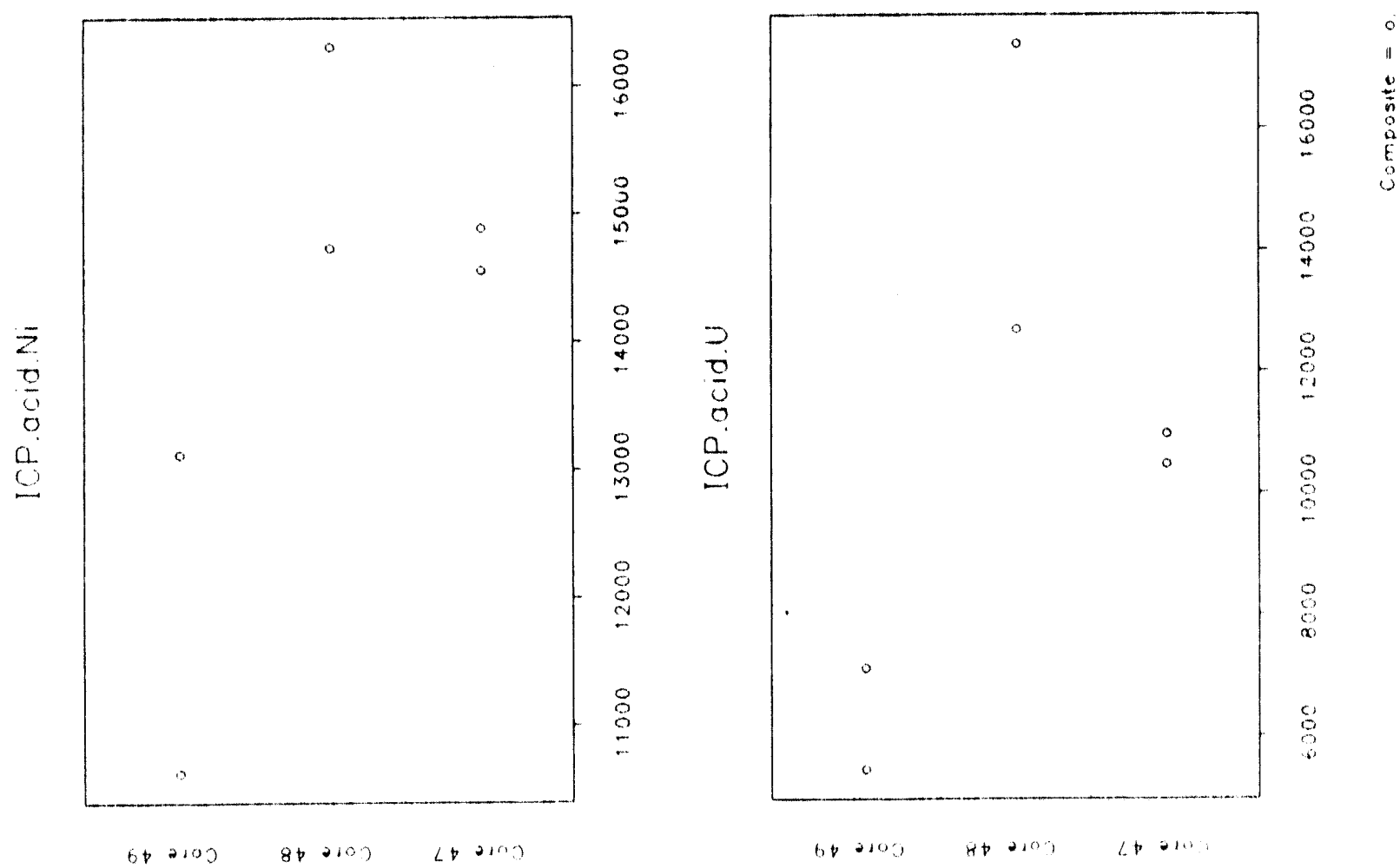
WHC-EP-0668
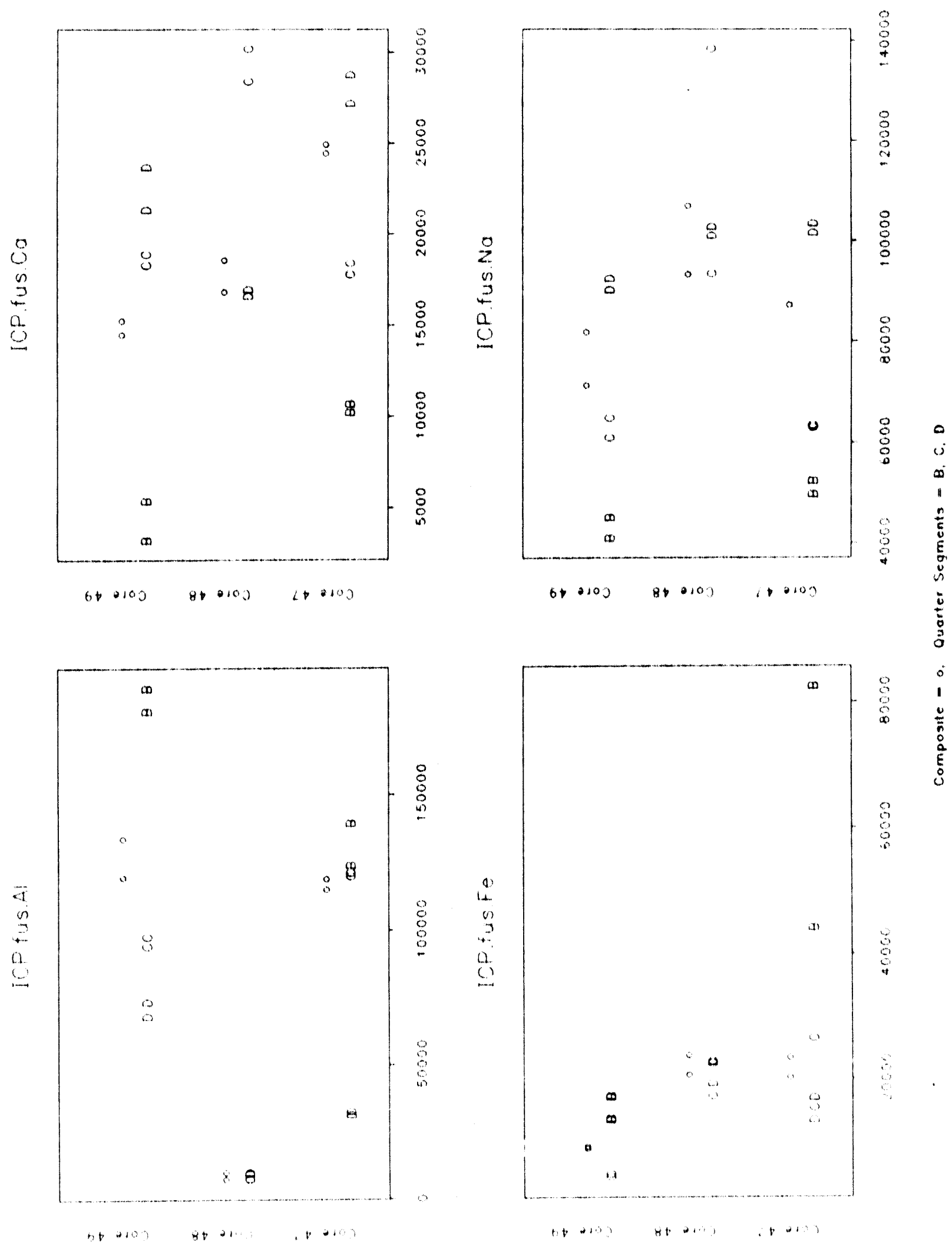
WHC-EP-0668
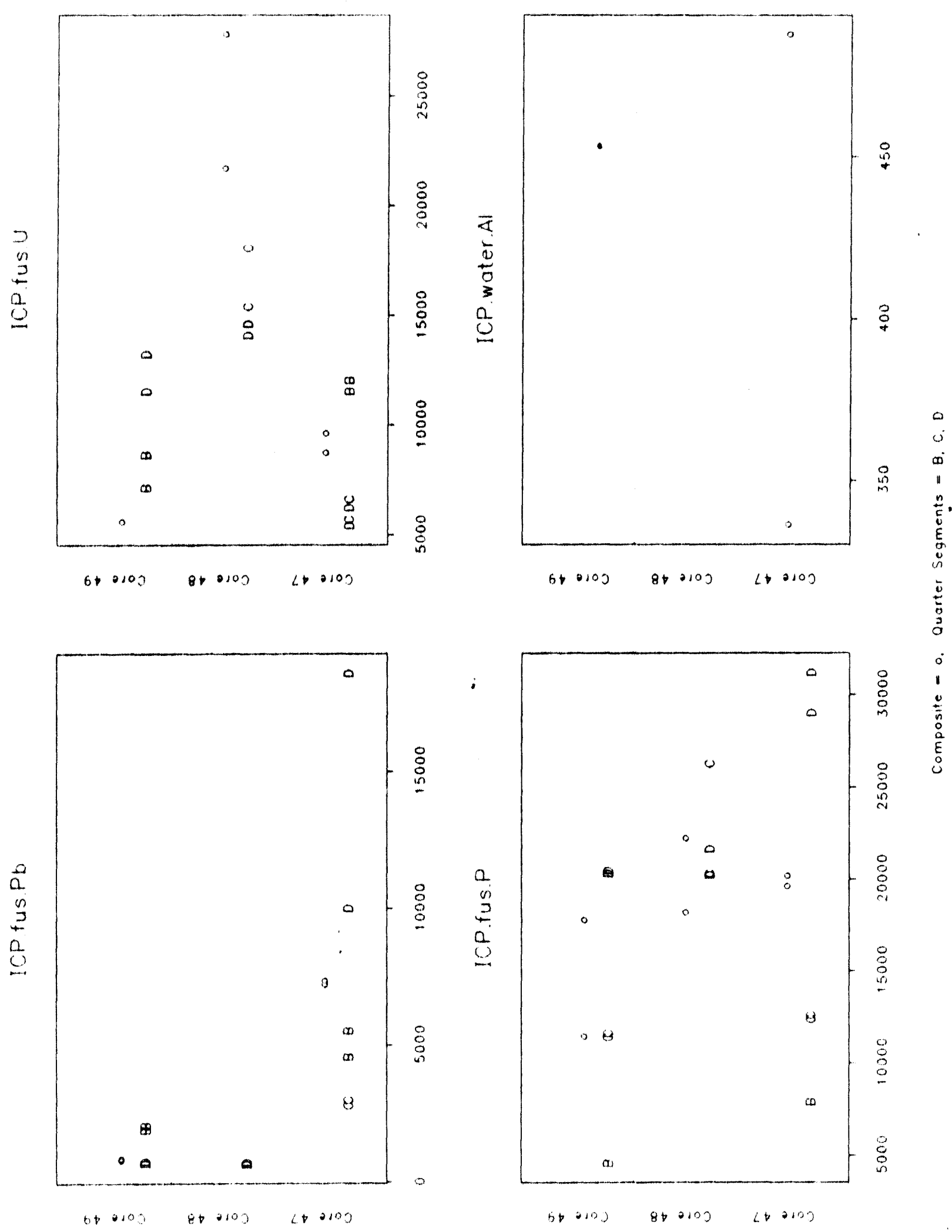
WHC-EP-0668
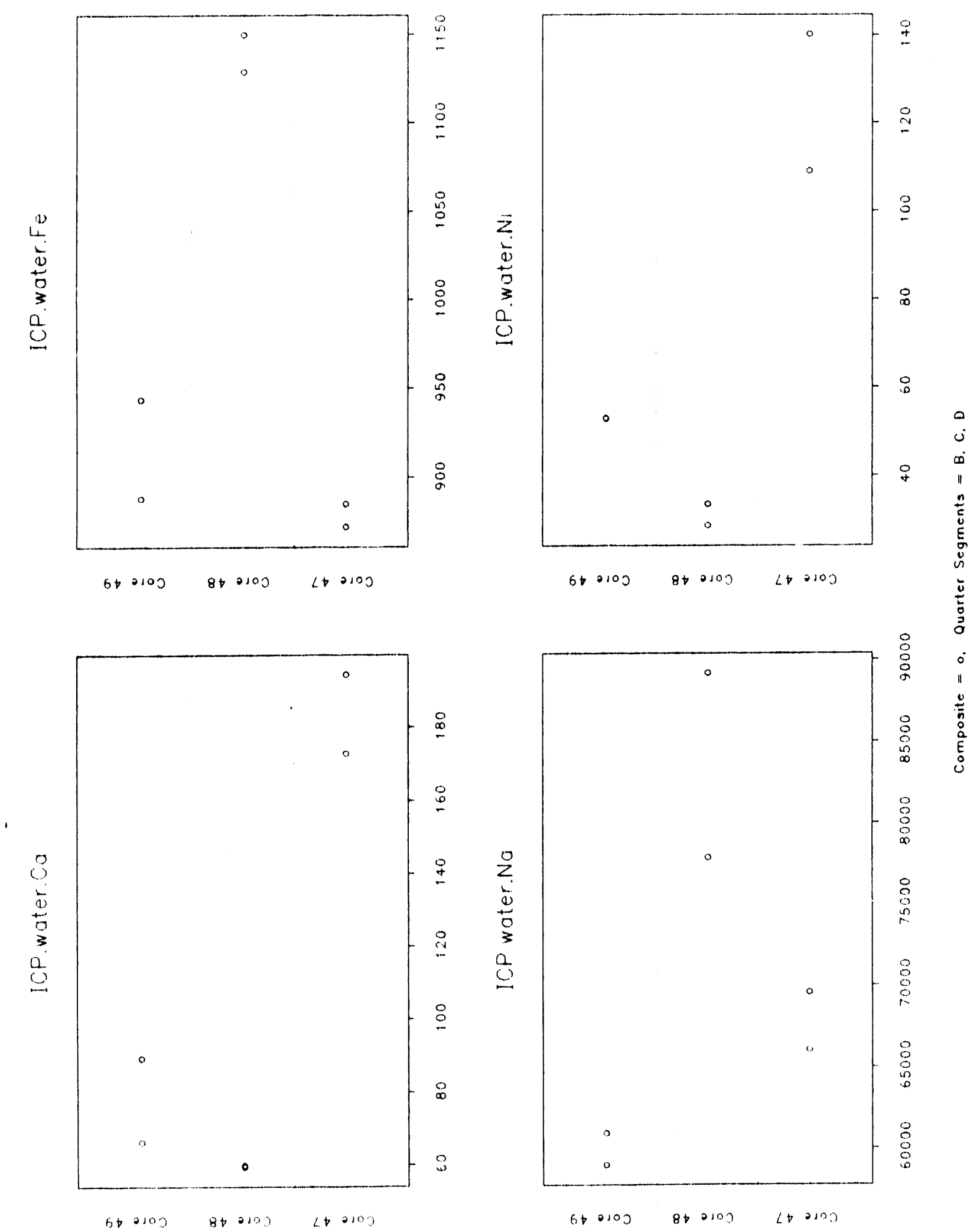


\section{WHC-EP-0668}
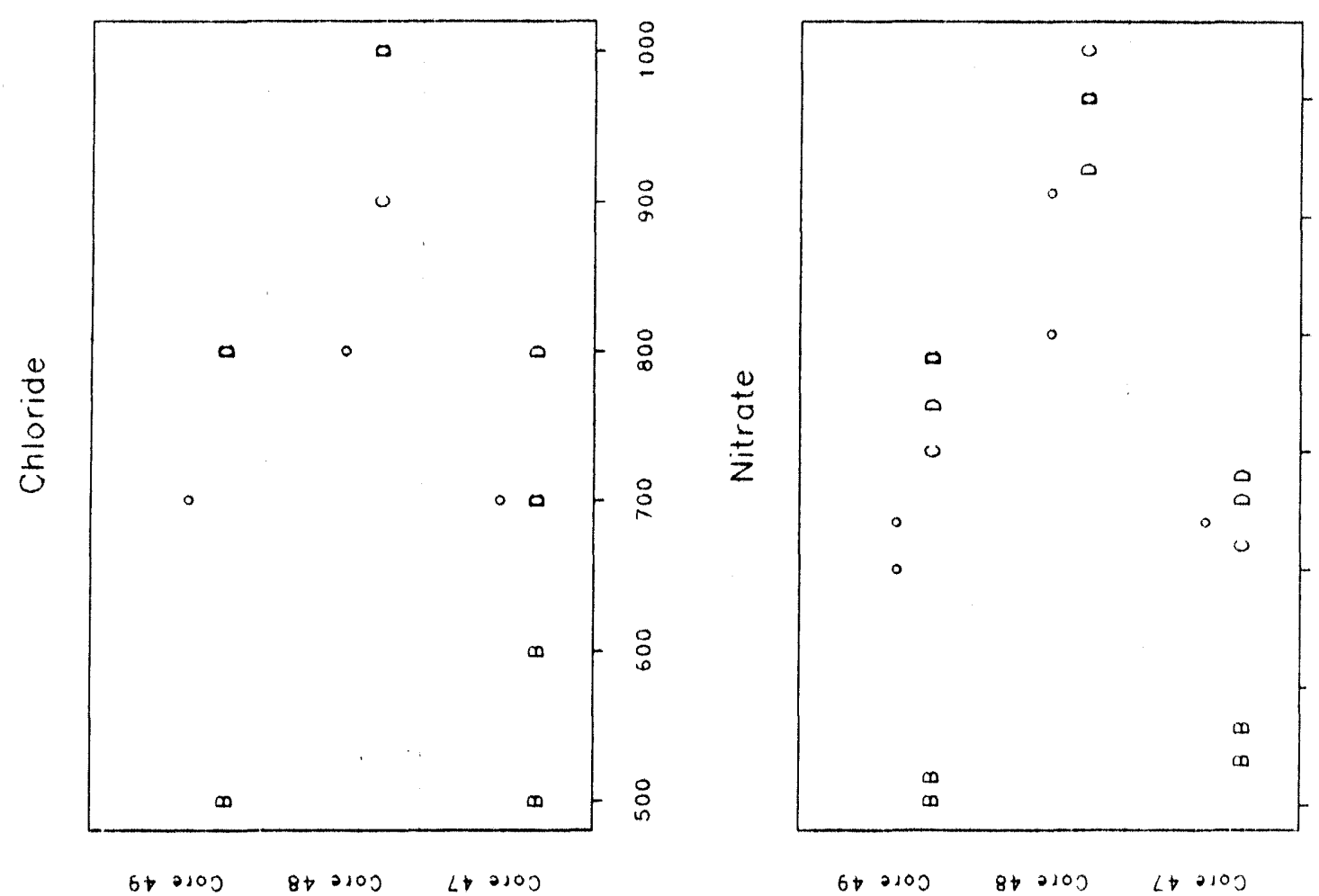

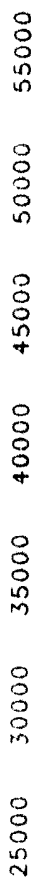

0
0
0
1
1
$\vdots$
0
$\vdots$
0
0
$\vdots$
0
0
0
0
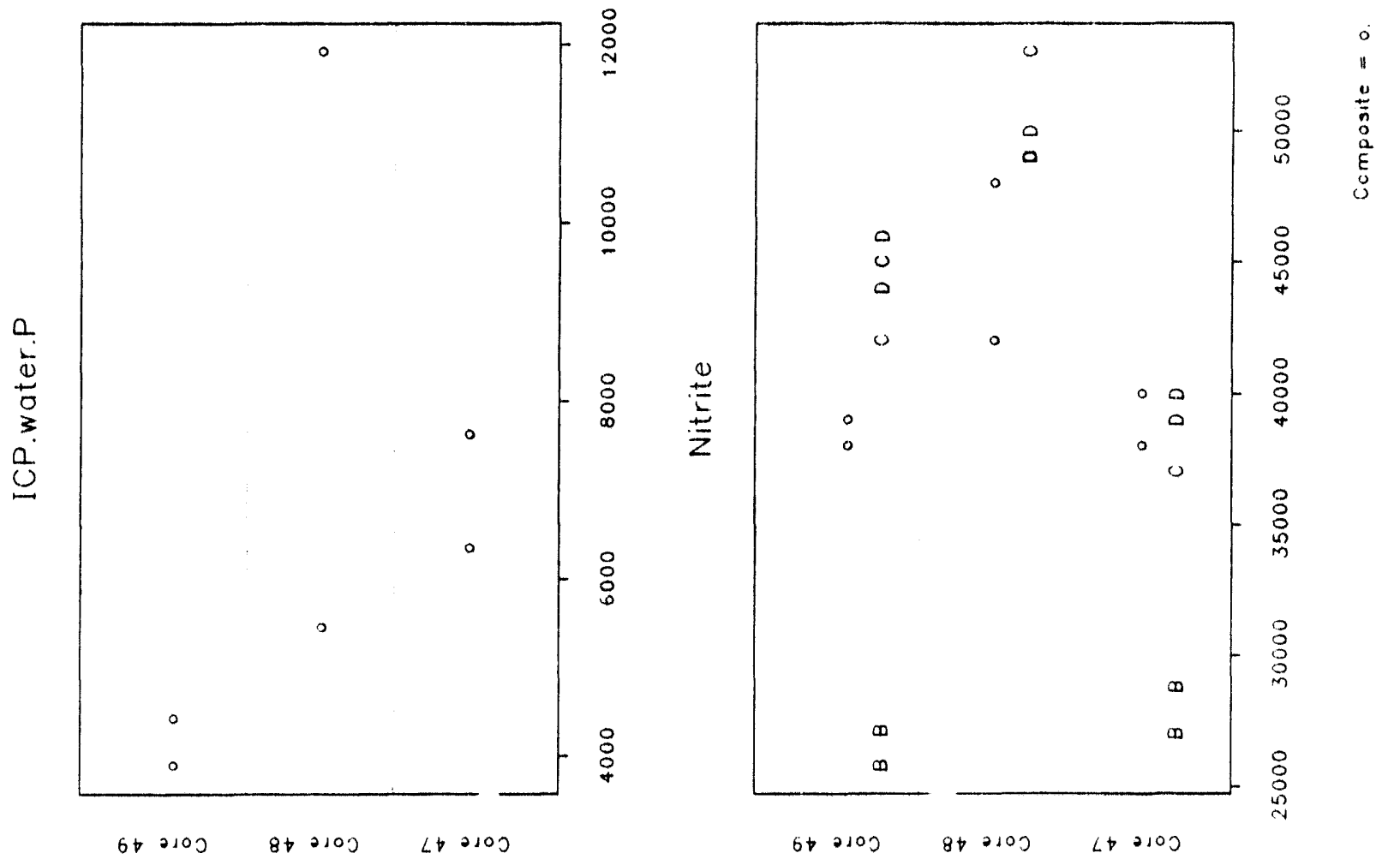
WHC-EP-0668
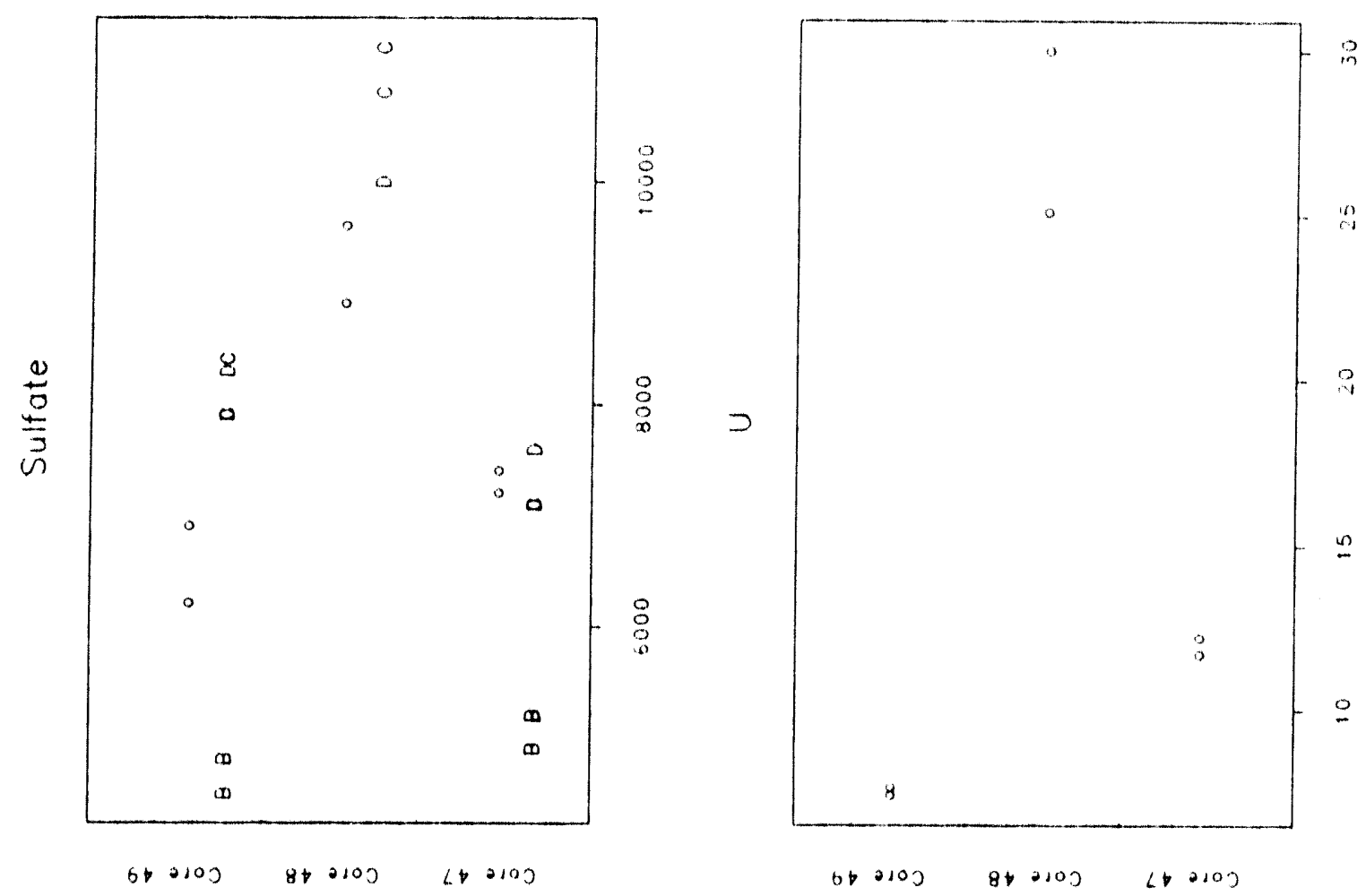

?

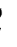
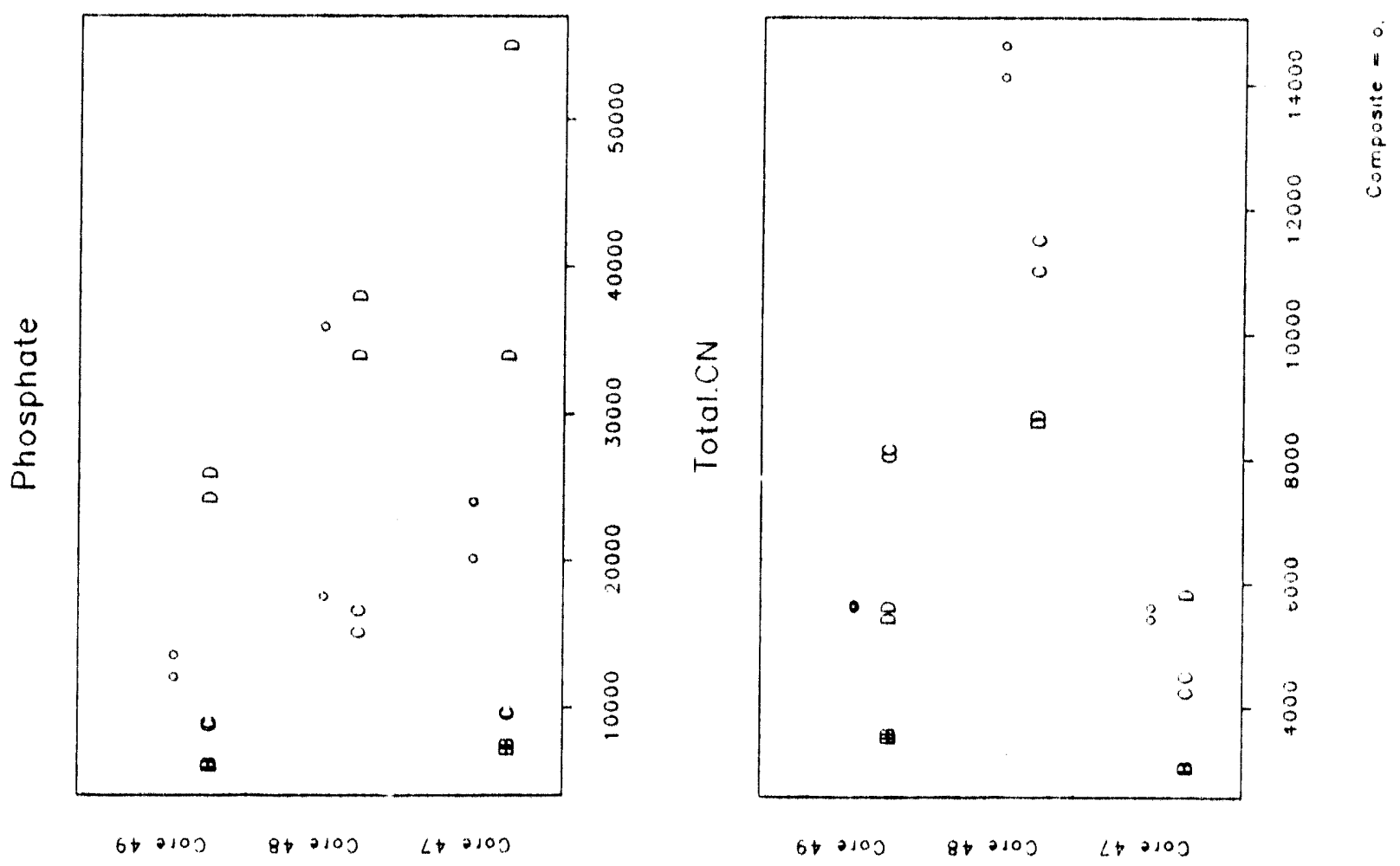
WHC-EP-0668
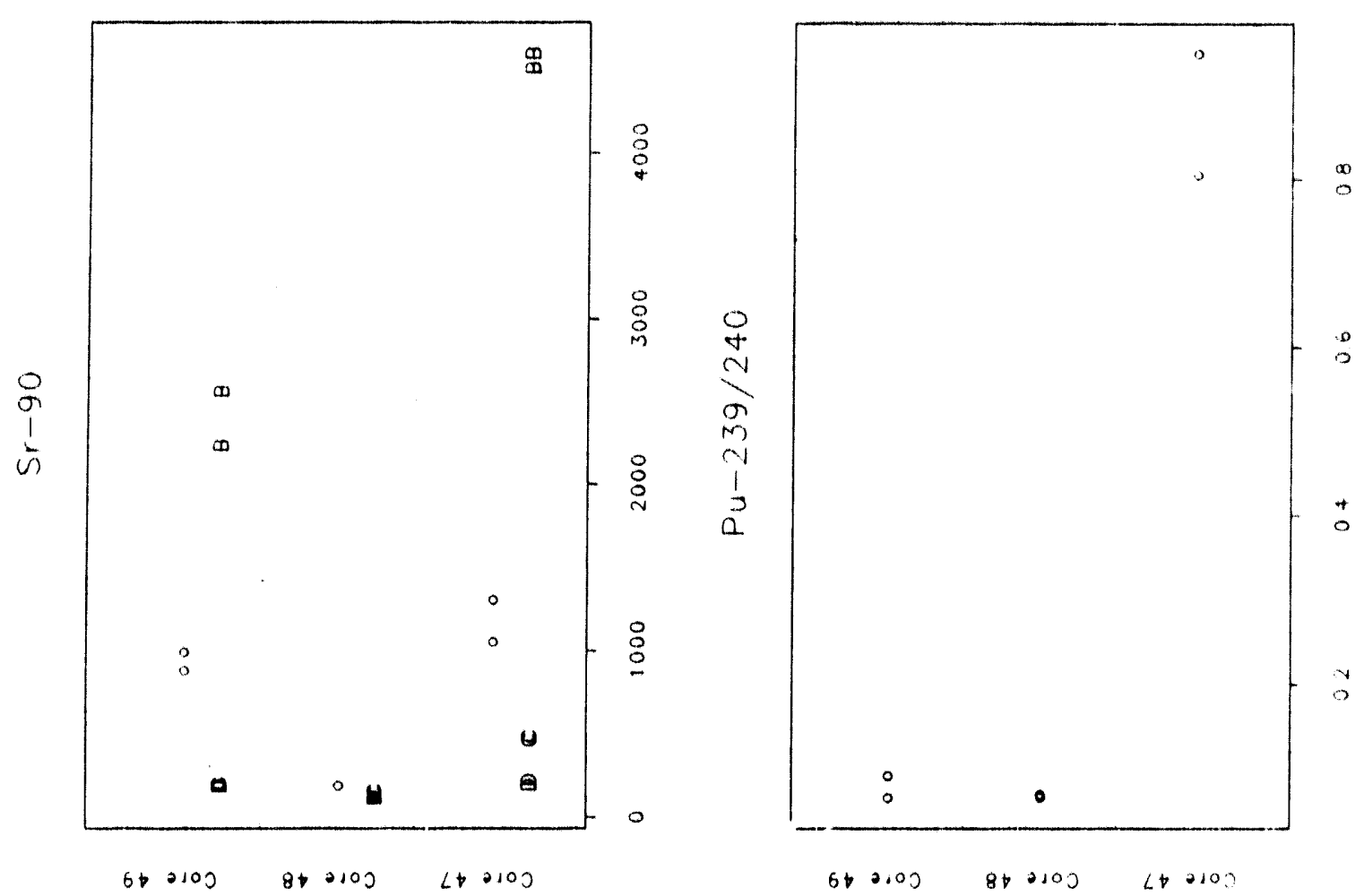

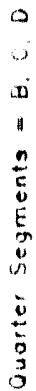
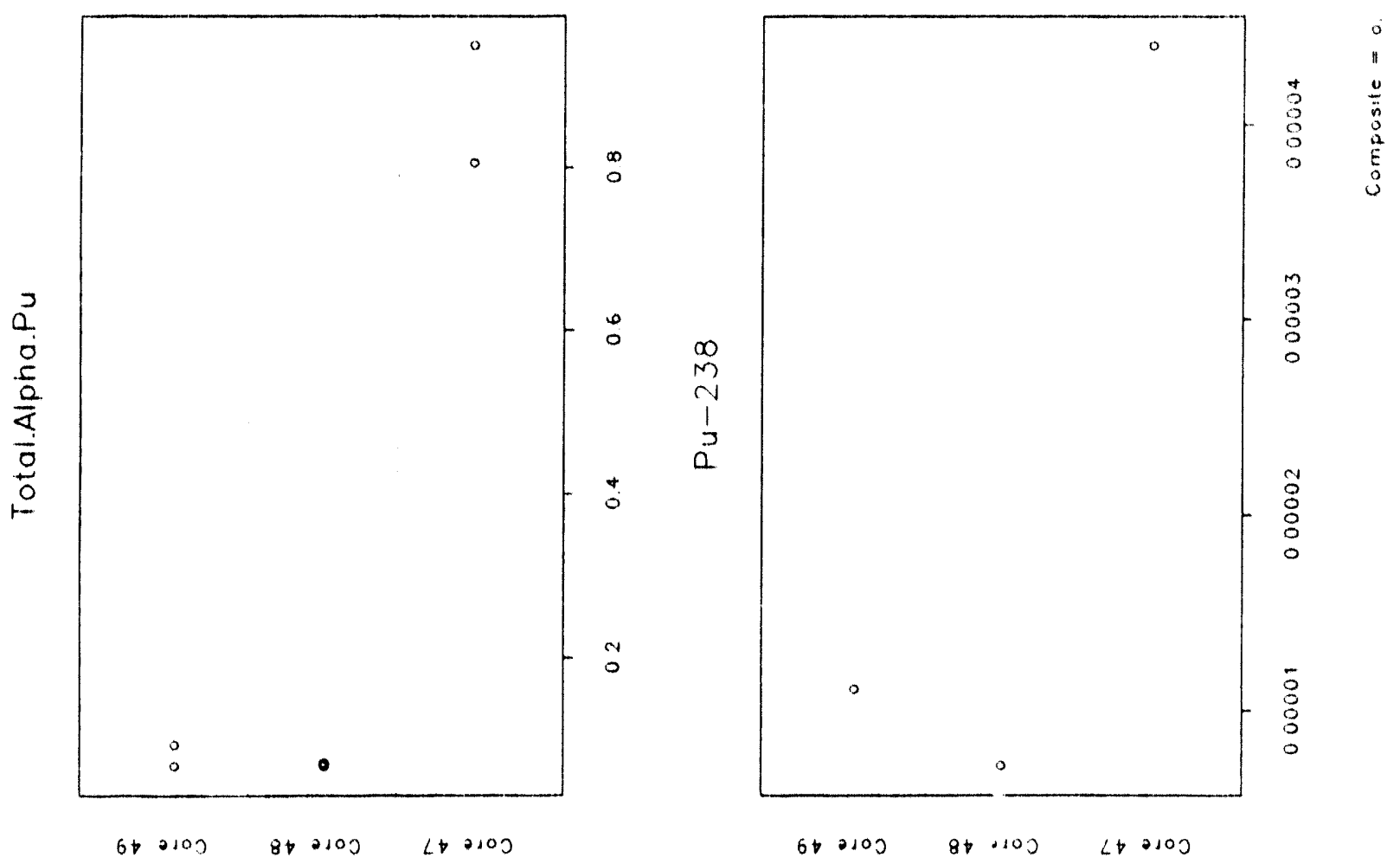


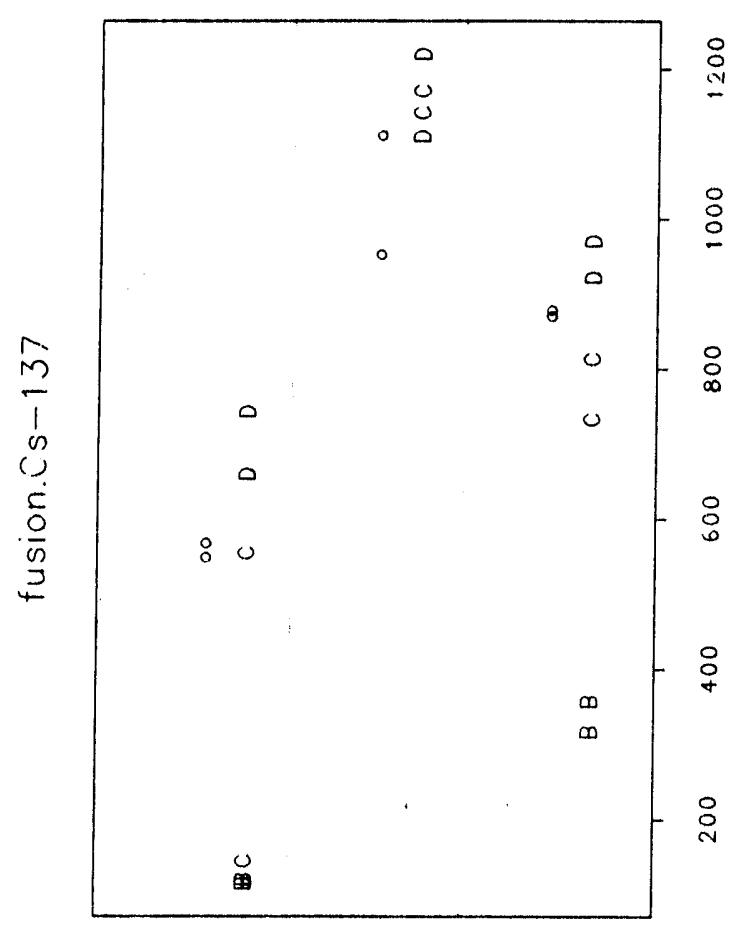

$6 t 2100 \quad 8 t 2100 \quad 4 t 2100$

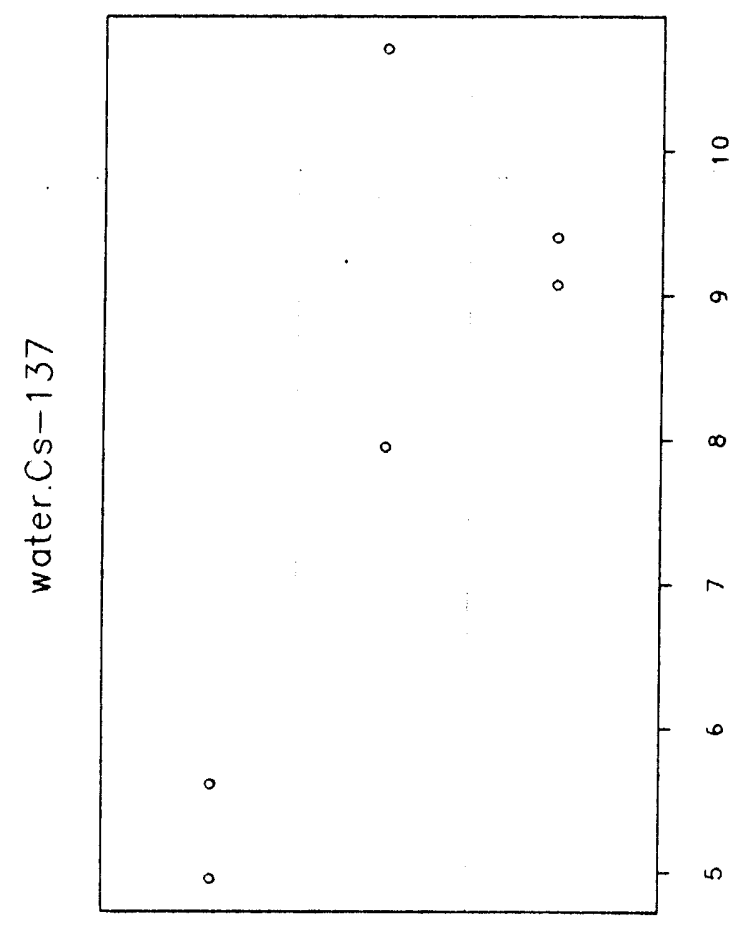

$6 t 0100 \quad 8 t 2100 \quad 6 t 2100$ 
APPENDIX 3: C109 AND C112 CORE COMPOSITE AND SUBSEGMENT DATA PLOTS

This appendix contains plots of the core composite and subsegment data for C109 and C112. The units for the analytes in the plots are as follows:

\begin{tabular}{|c|c|}
\hline Analyte & Units \\
\hline All ICP (acid, water, fusion) & $\mu \mathrm{g} / \mathrm{g}$ \\
\hline All Anions & $\mu \mathrm{g} / \mathrm{g}$ \\
\hline All Radionuclides (excluding $U$ ) & $\mu \mathrm{Ci} / \mathrm{g}$ \\
\hline$U$ & $\mu \mathrm{g} / \mathrm{g}$ \\
\hline
\end{tabular}


WHC-EP-0668
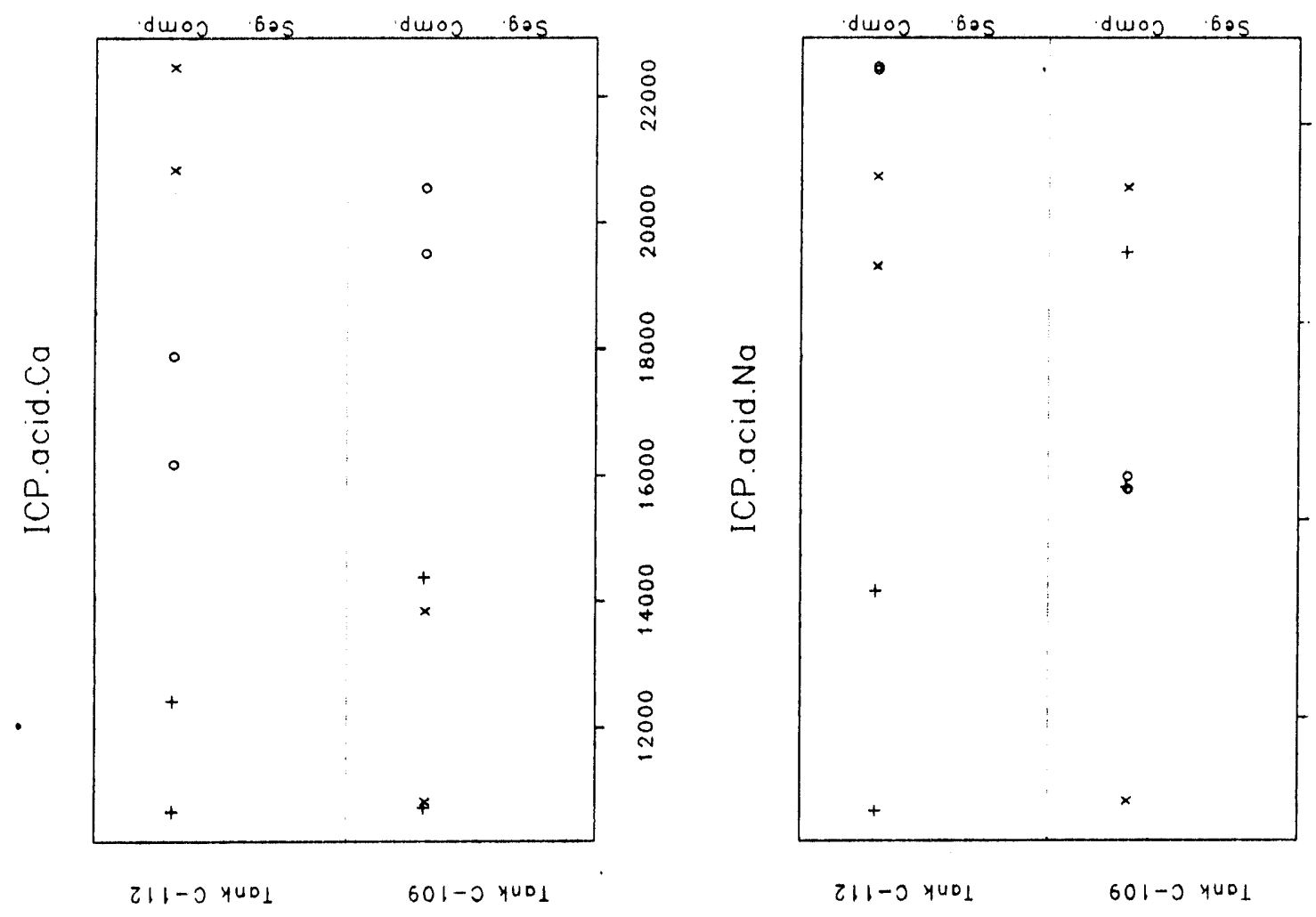

$\circ$
$\circ$
0
0
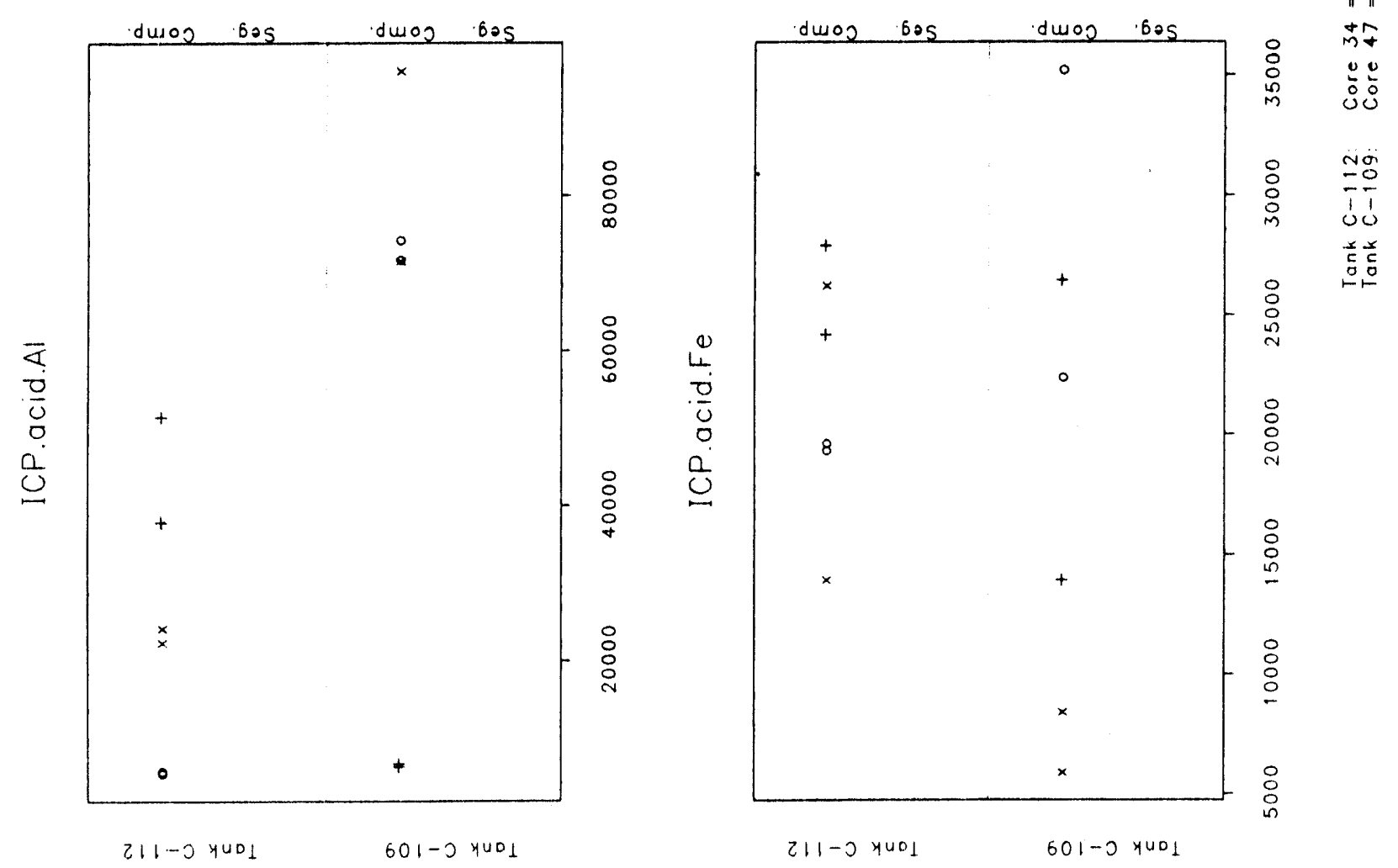


\section{WHC-EP-0668}
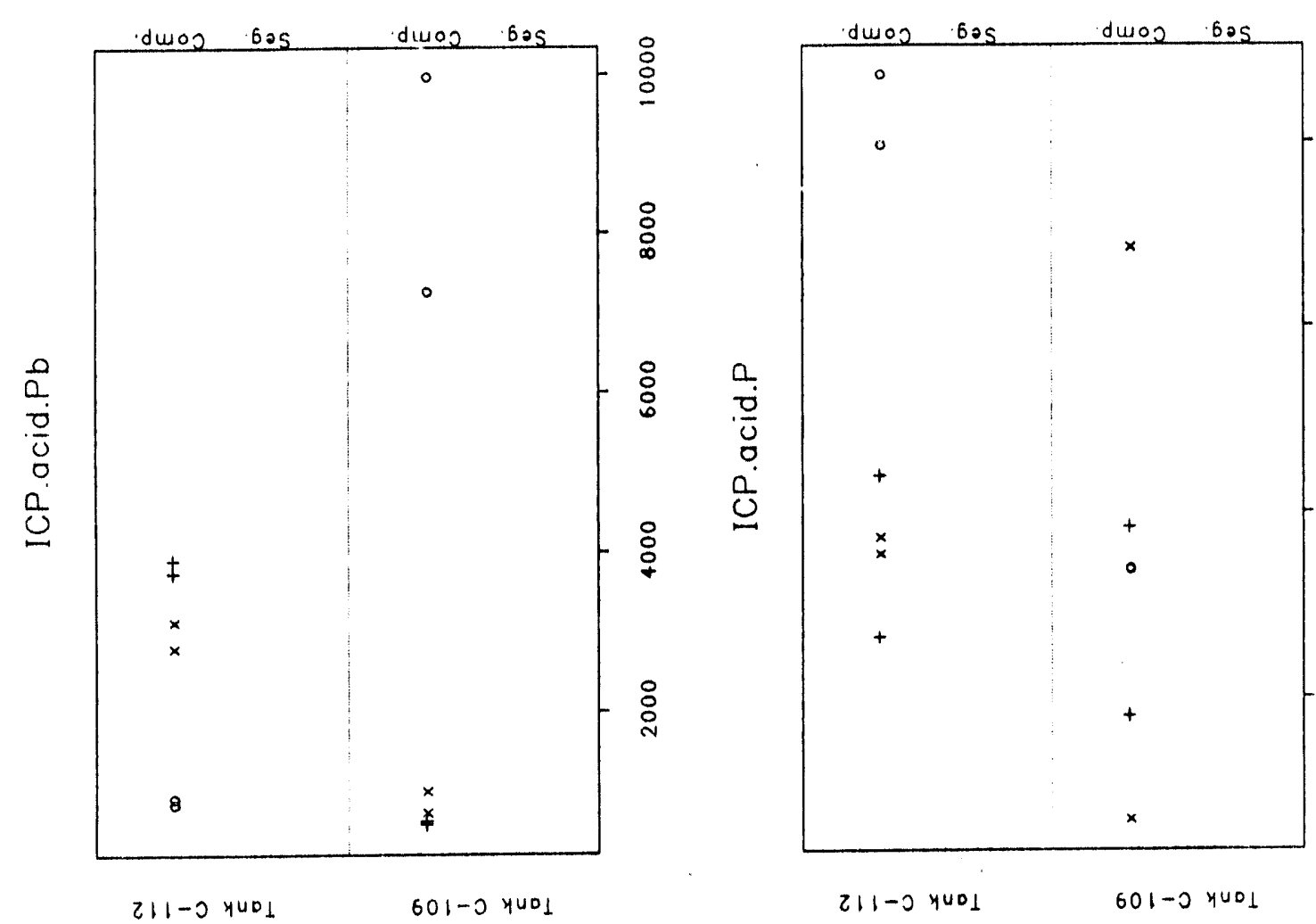

$\circ$
8
$\circ$
0
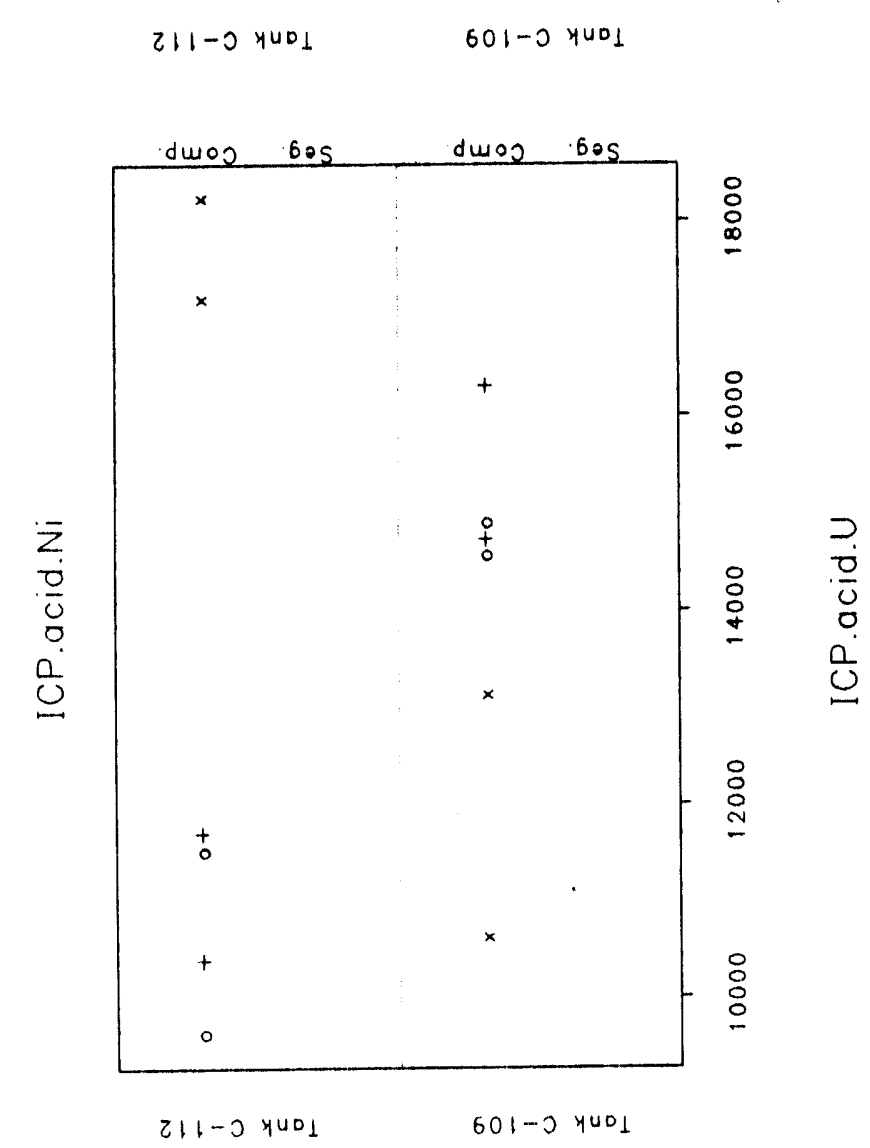

duos bos

duos

bos

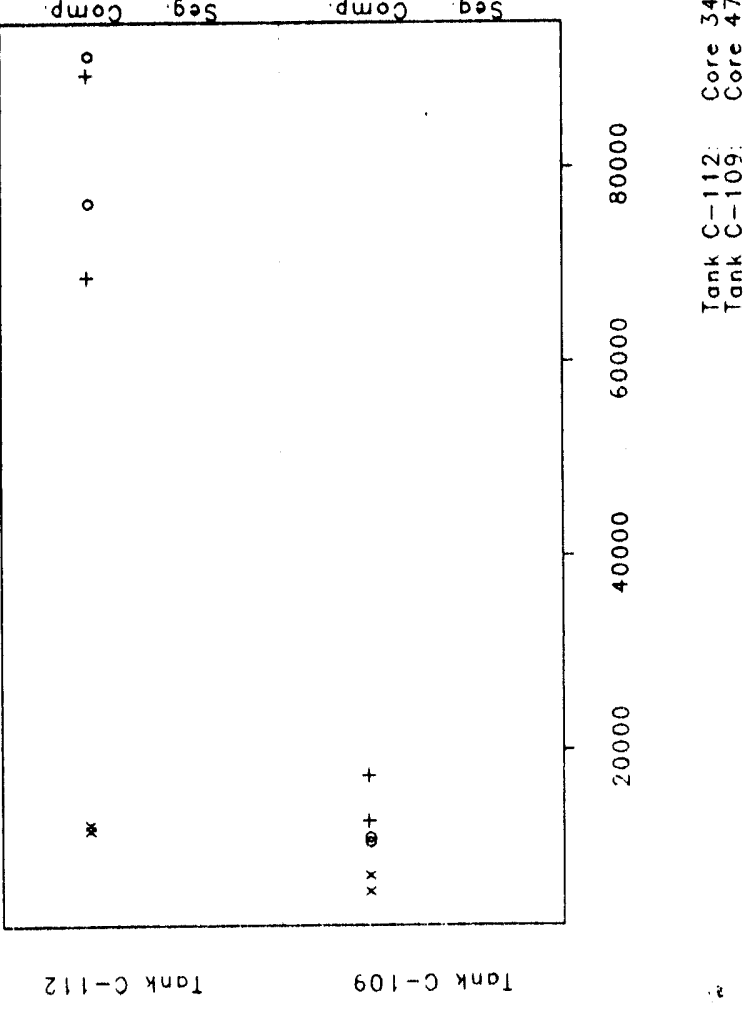


WHC-EP-0668
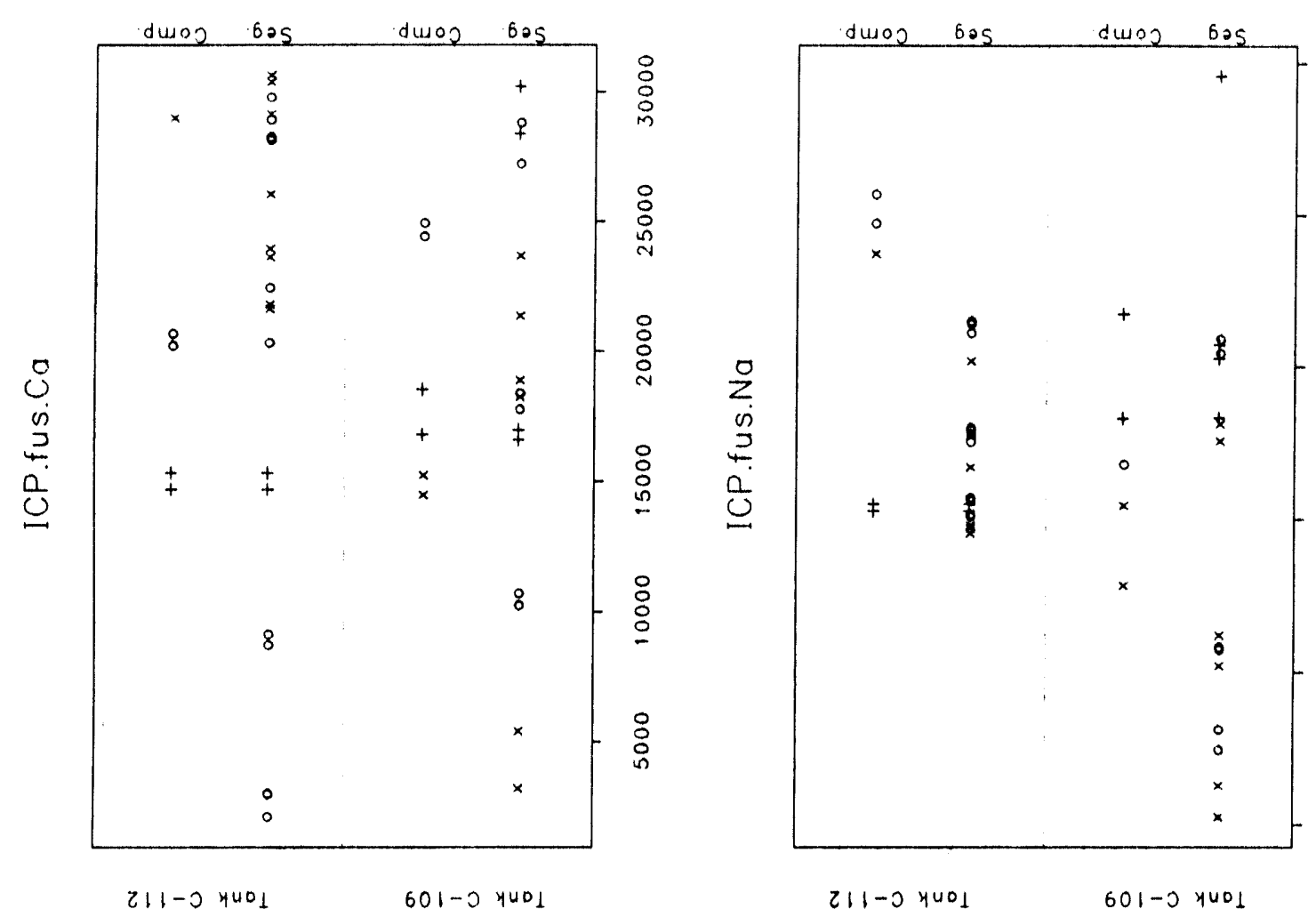

\begin{tabular}{l}
$\circ$ \\
8 \\
8 \\
8 \\
\hline
\end{tabular}
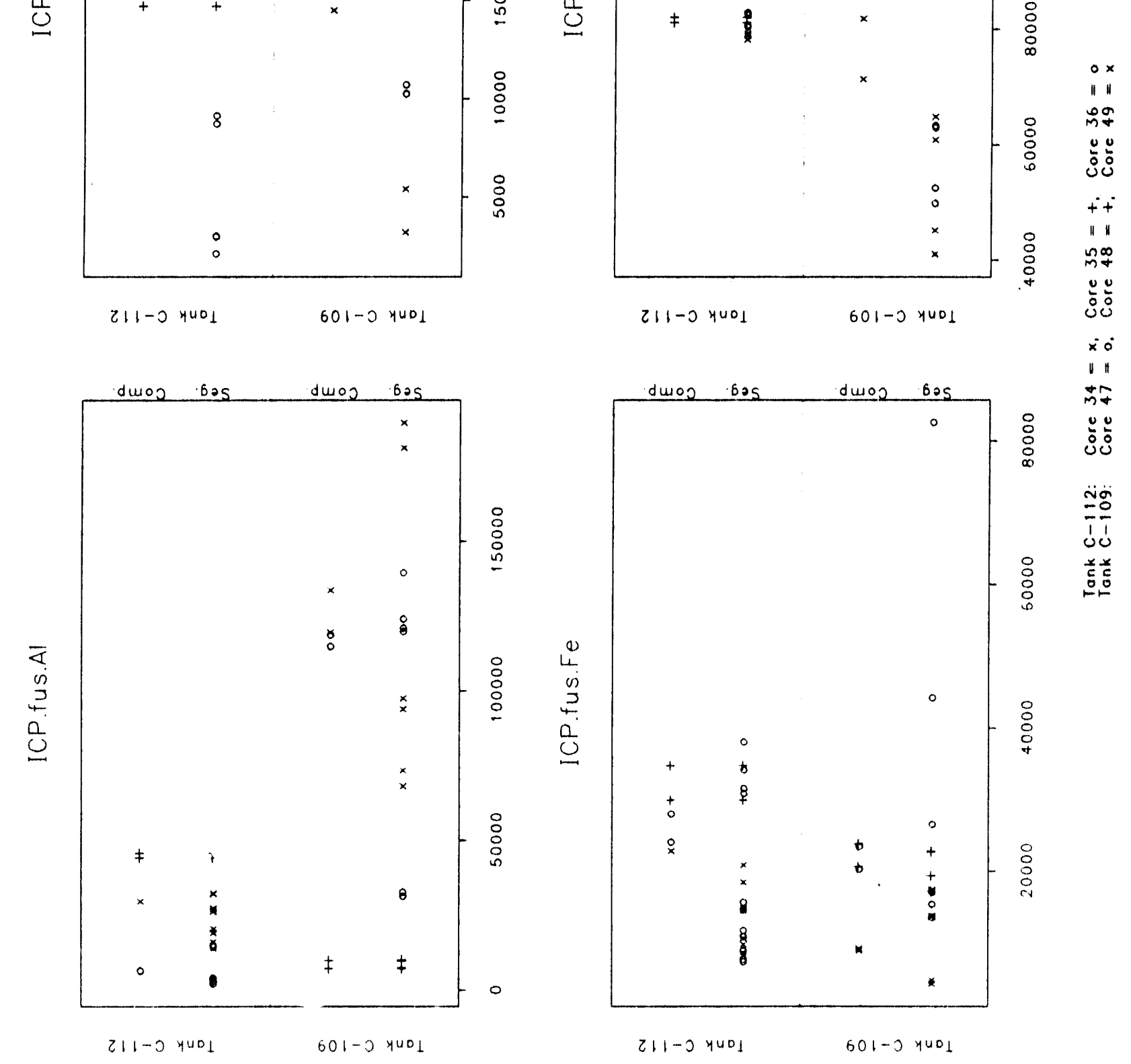

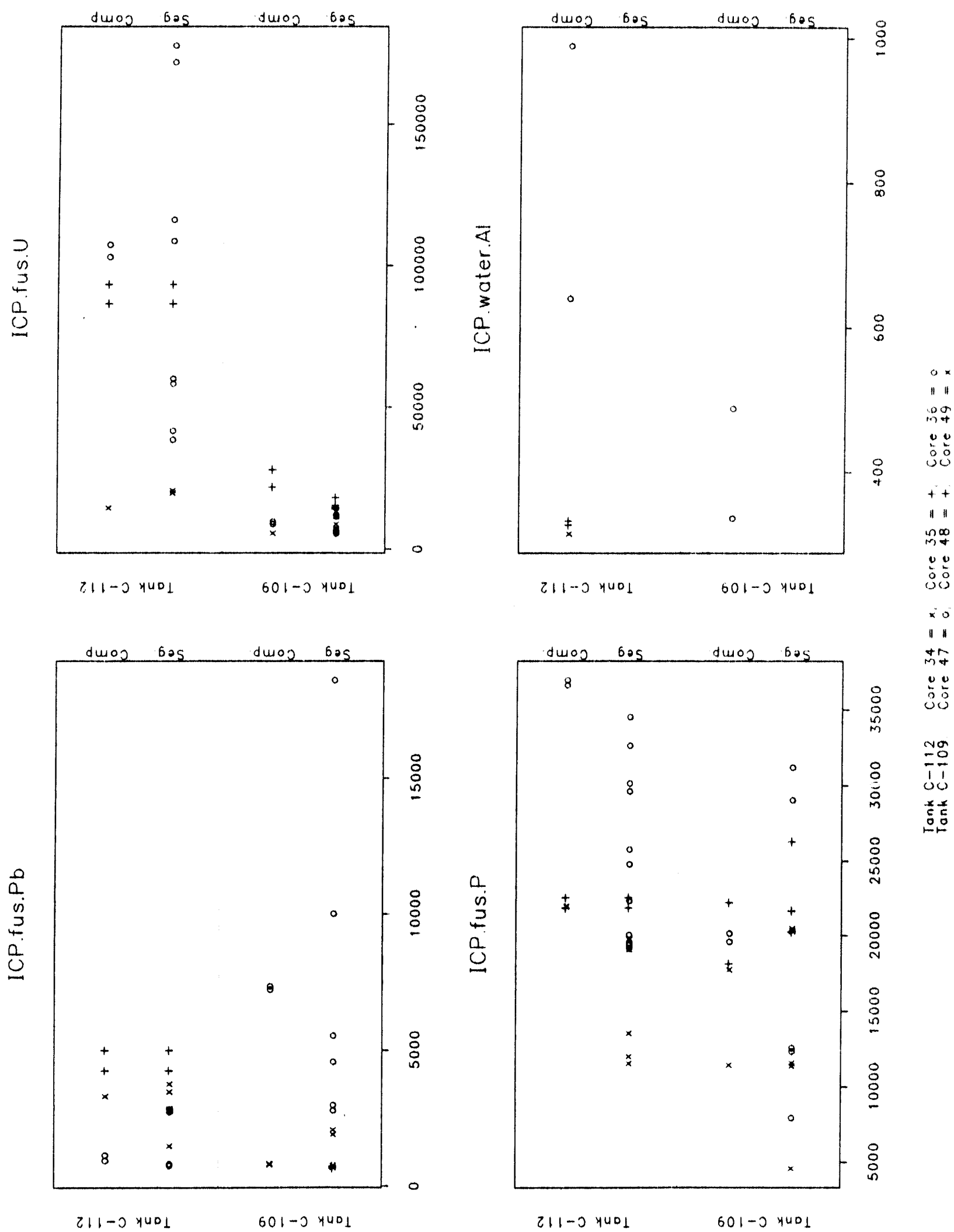


\section{WHC-EP-0668}
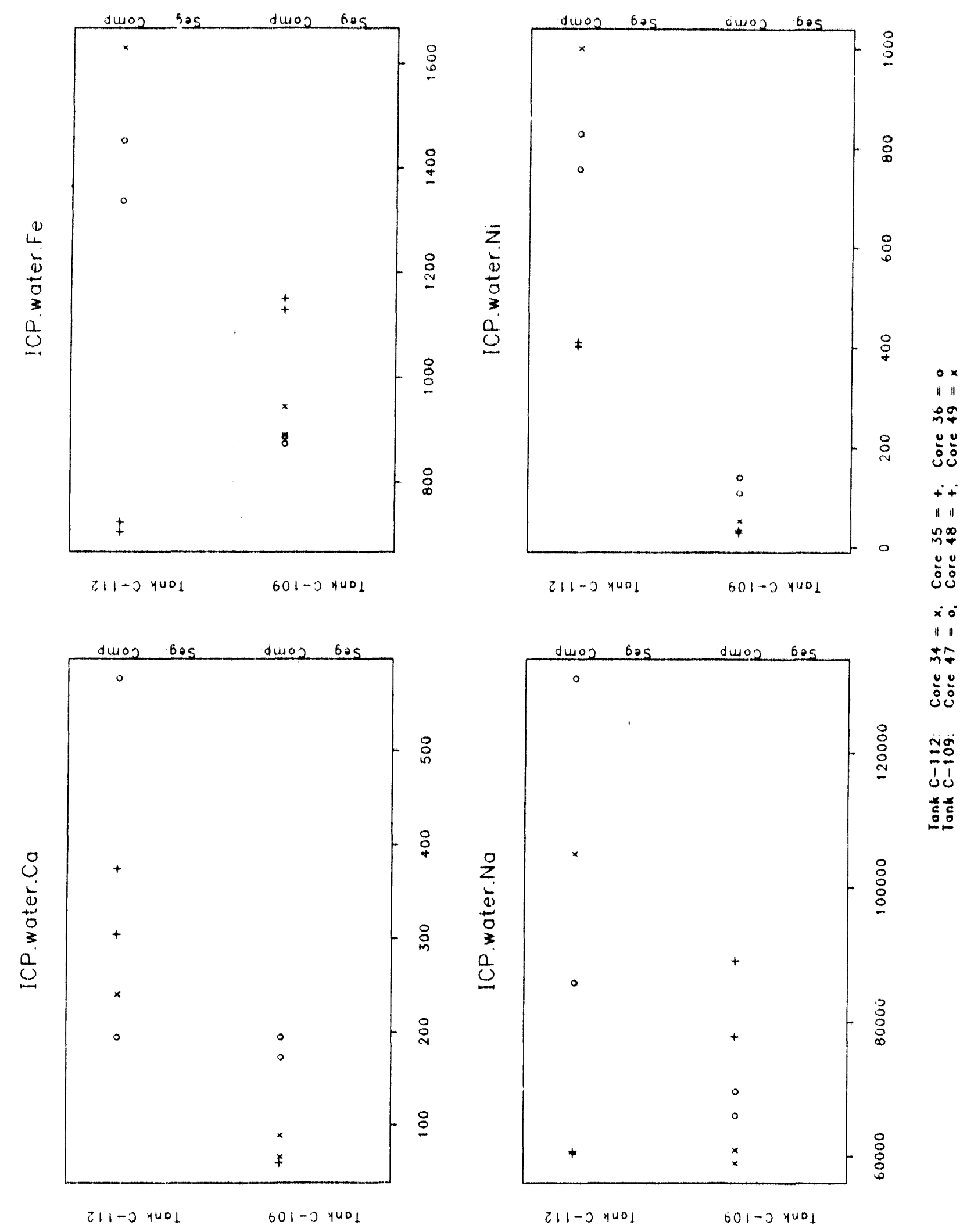


\section{WHC-EP-0668}
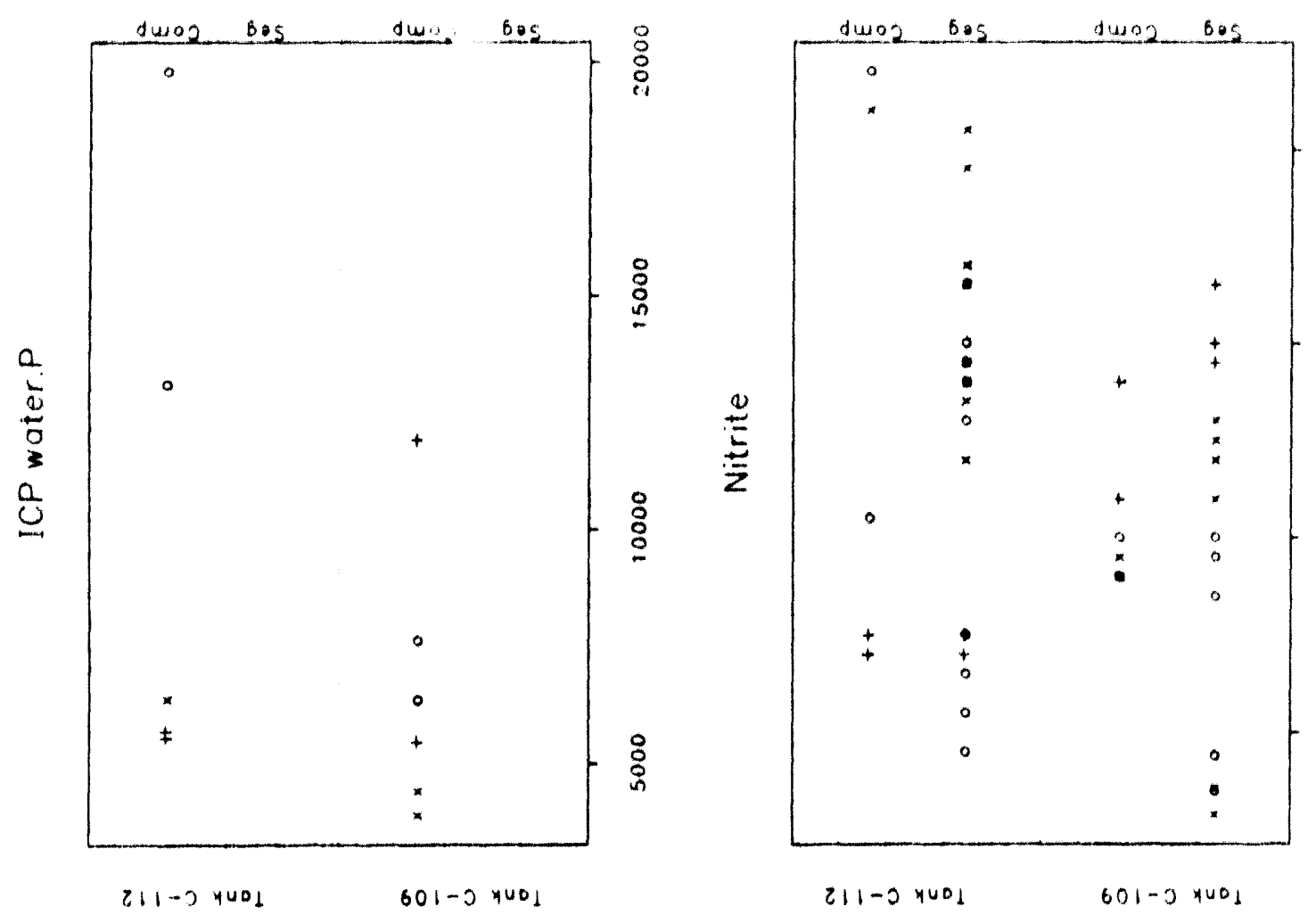

8
8
8
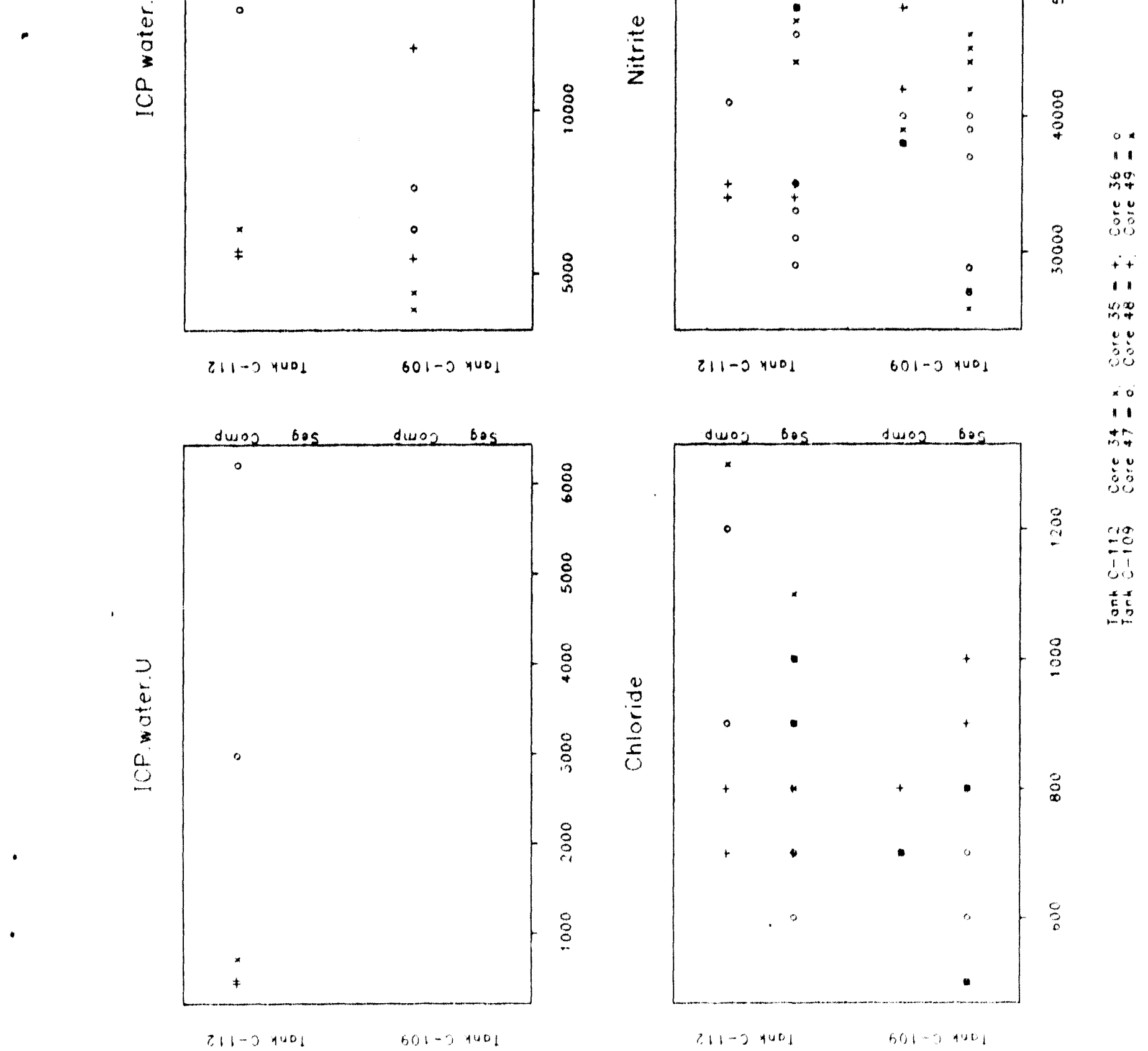

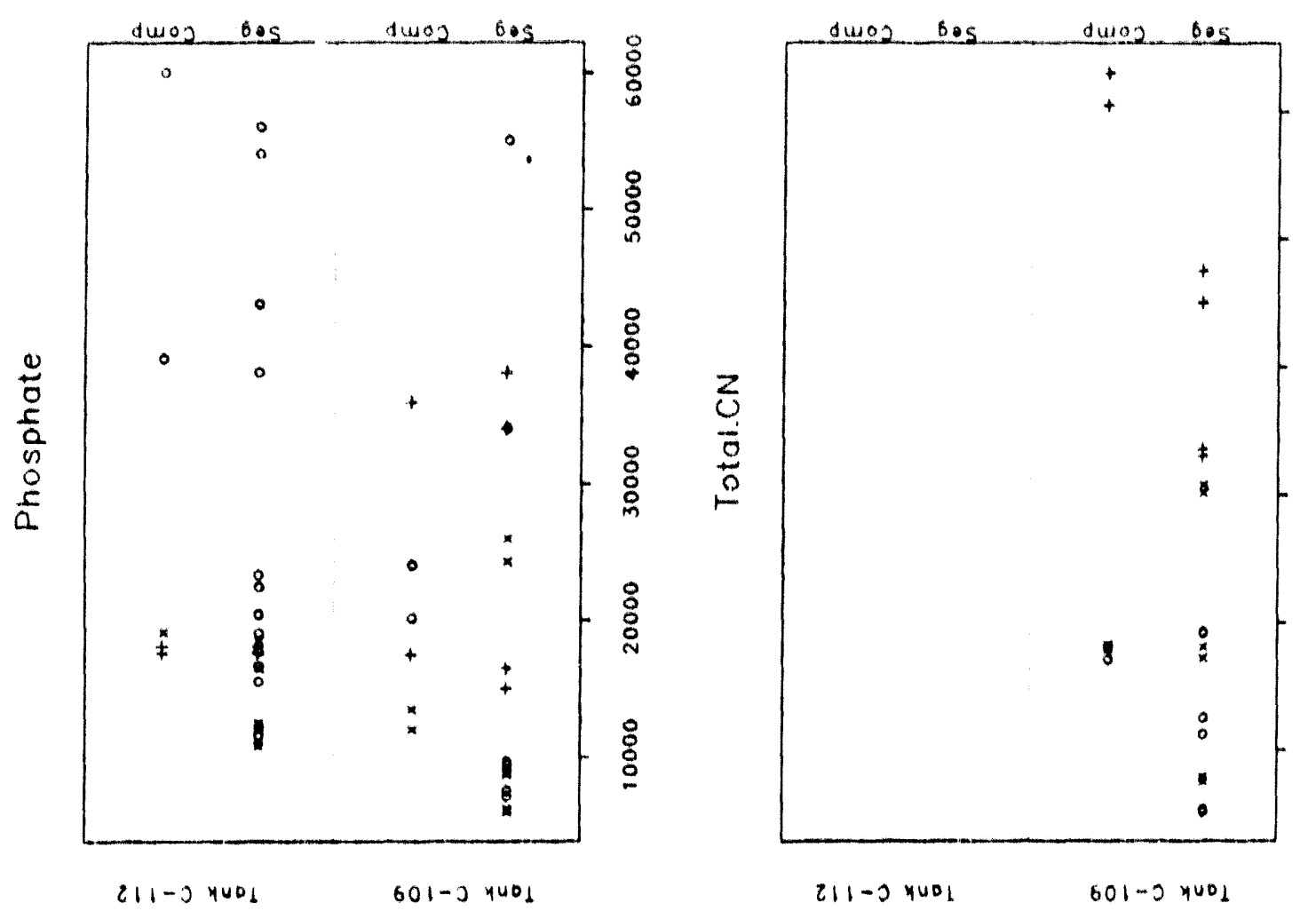

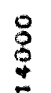
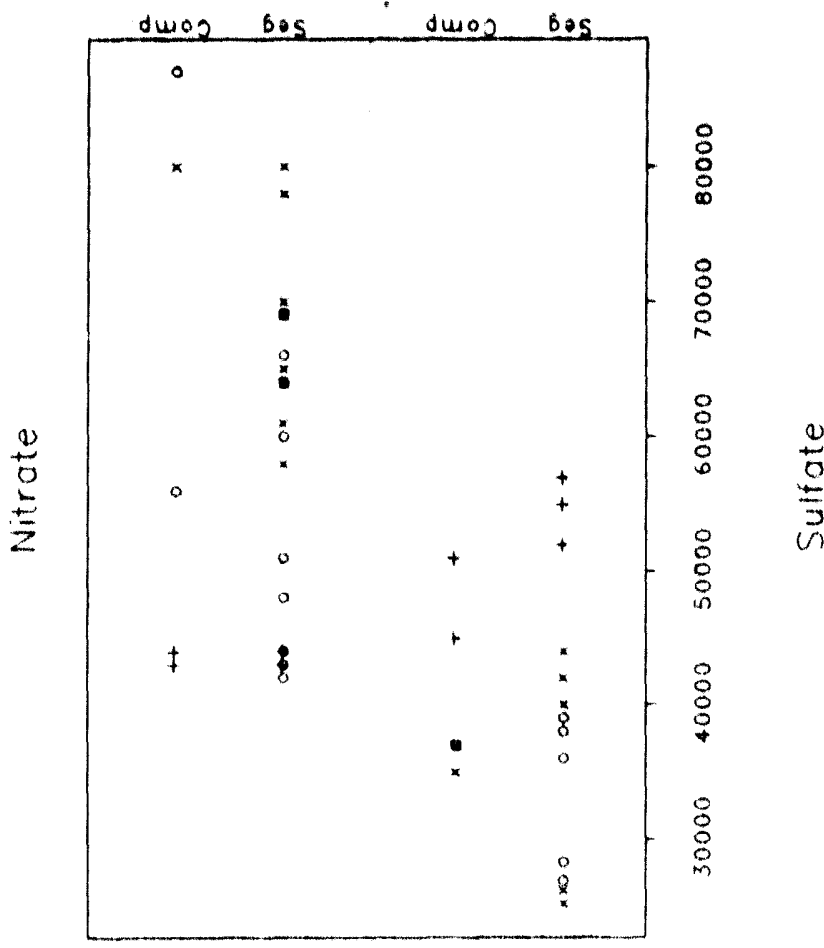

duo

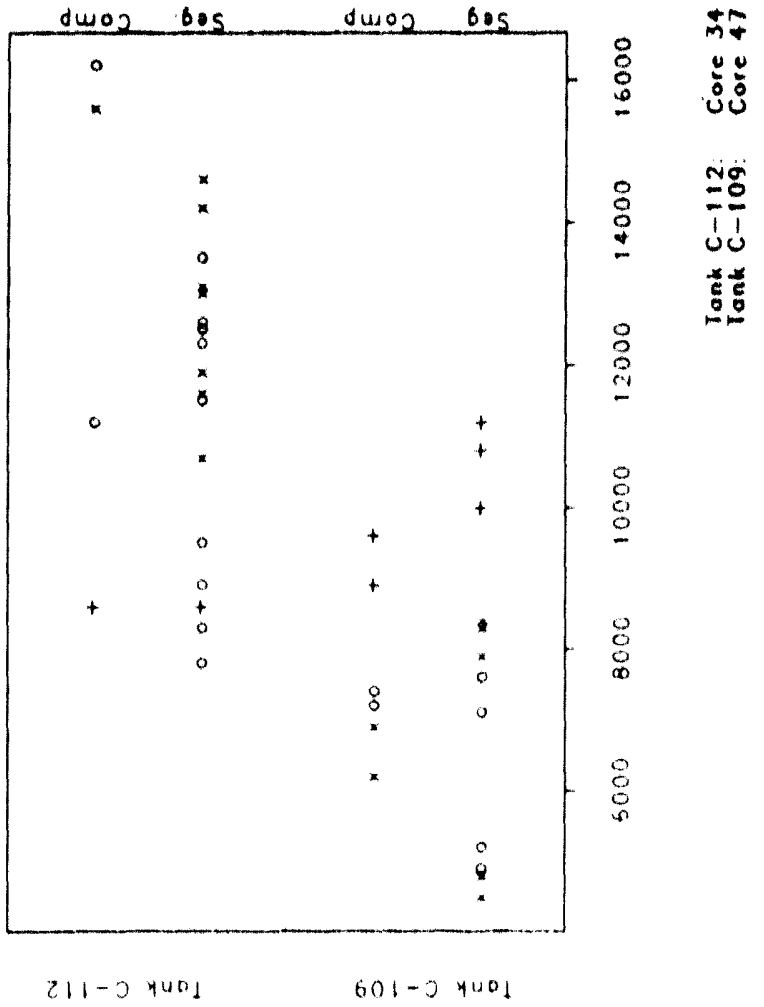

$211-04401$

$601-041001$

$211-0$ 4401

$601-34001$ 


\section{WHC-EP-0668}
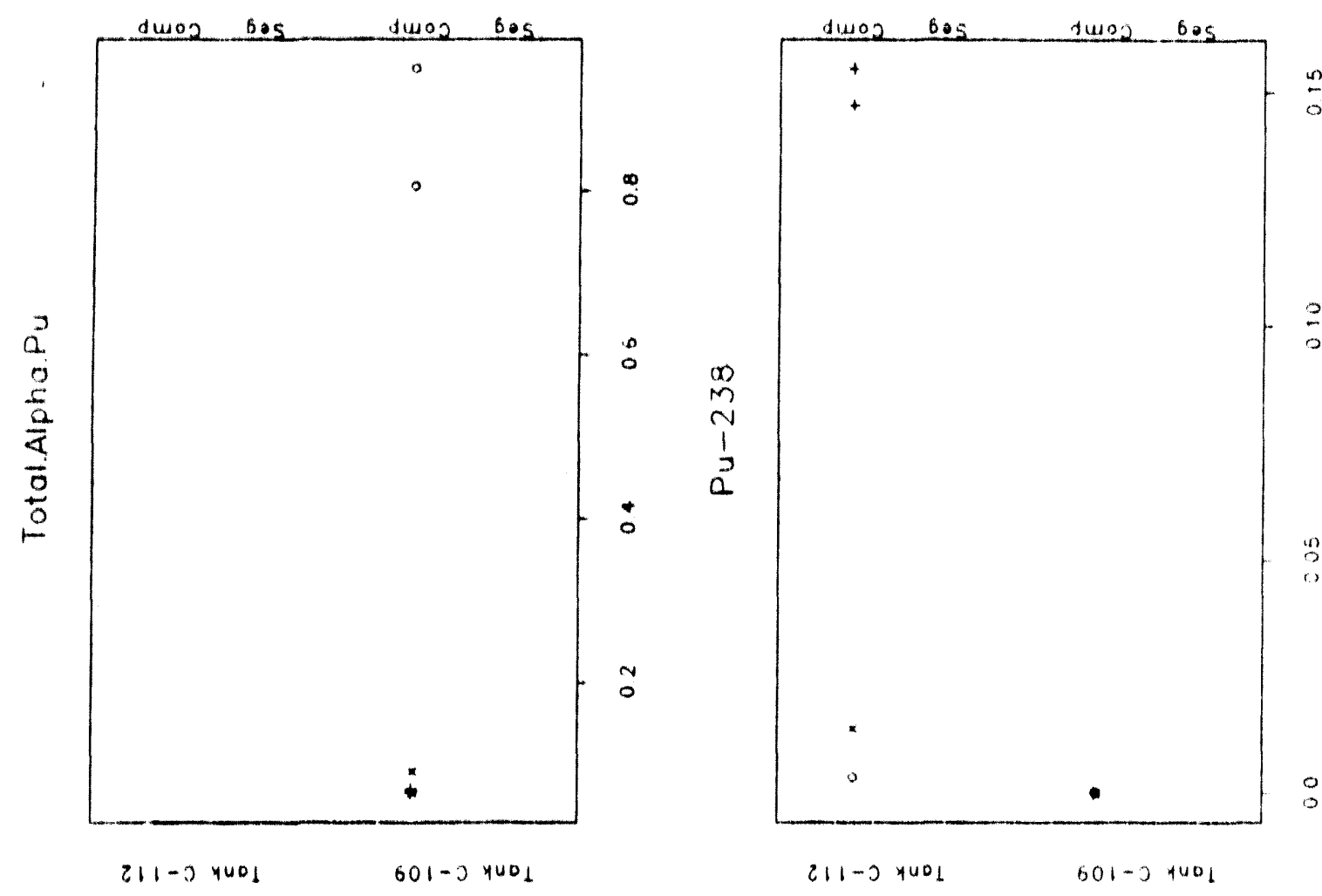

$\frac{1}{0}$

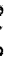
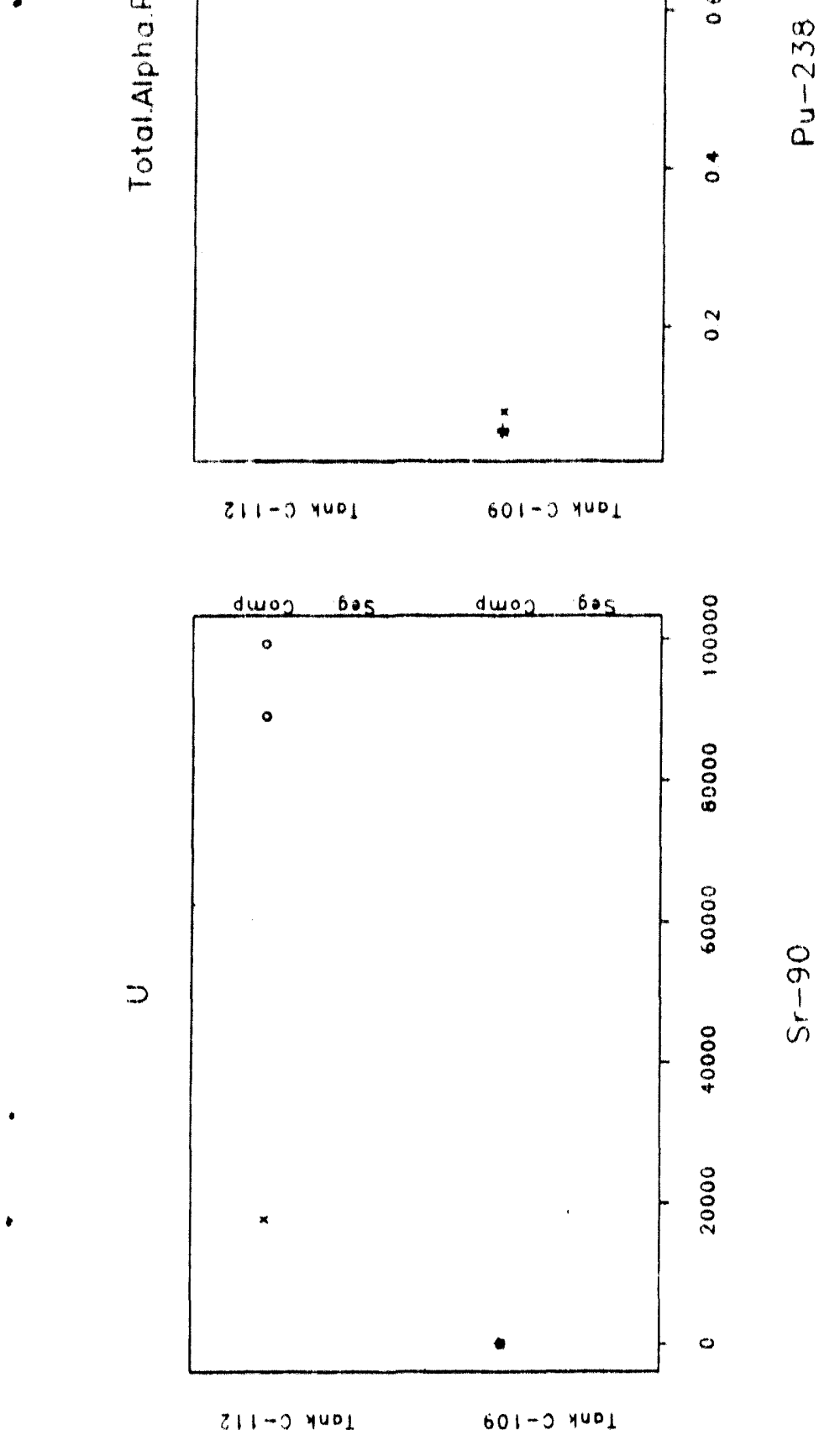

211-2 YUD।

$601-3$ YUD

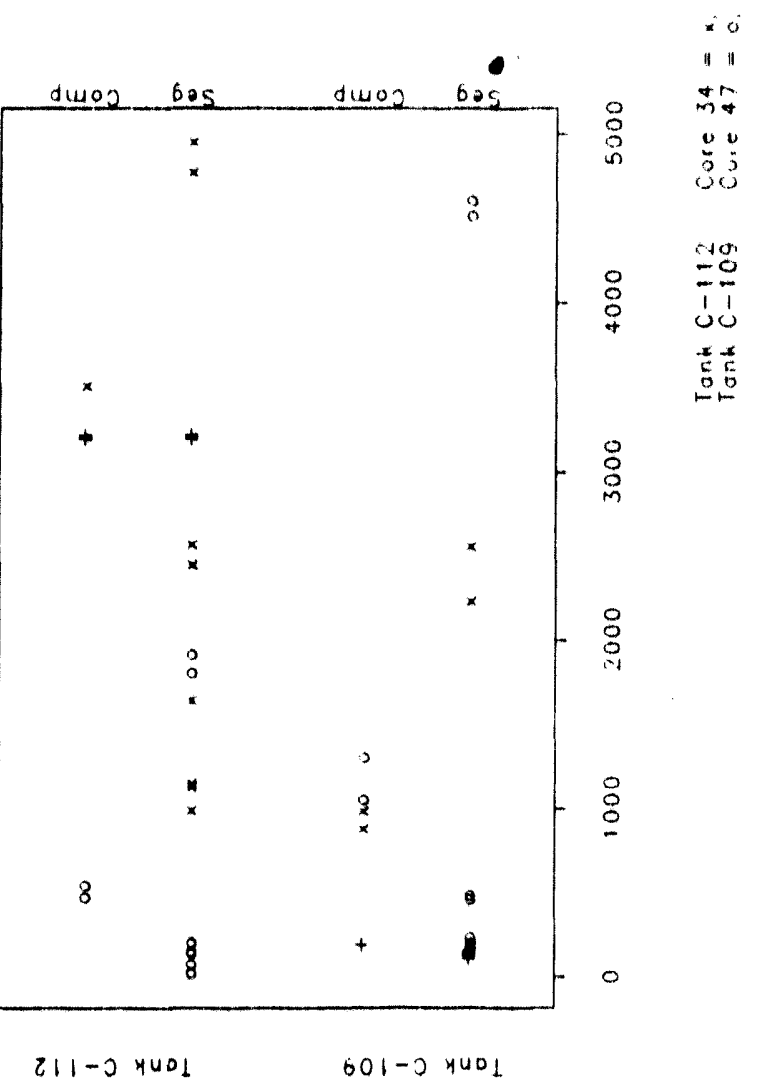



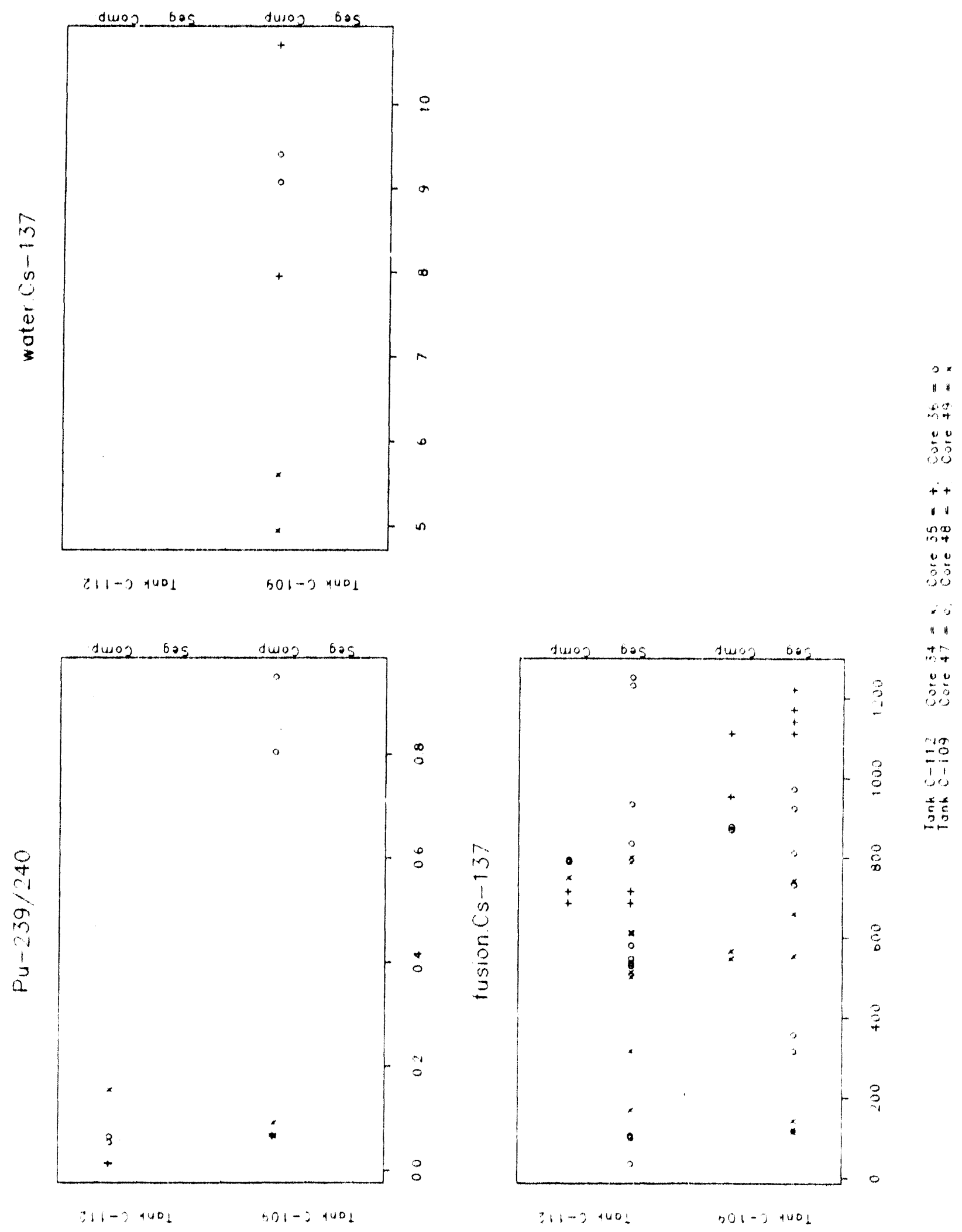
APPENDIX 4: DERIVATIONS OF $\partial^{2}[y(w)]$ AND $\partial^{2}[g(w)-g(c)]$ 
This appendix contains the derivations of $\partial^{2}[\rho(w)]$ and $\partial^{2}[\rho(w)-g(c)]$. For the formulas in this appendix we define the following quantities: $\rho(w)=g_{w 1}$ and $\rho(c)=9 i$. That is, $\partial^{2}[g(w)]=\sigma^{2}\left[g_{w 1}\right]$ and $\partial^{2}[g(w)-g(c)]=\partial^{2}\left[g_{w 1}-\bar{y} 1.\right]$.

Three statistical models are used in the calculation of these two variance estimates. The first model, for the core and quarter segment data is

$$
y_{1 / k}=\mu+c_{1}+s_{1 j}+e_{i j k} \text {. }
$$

The mean of the two al iquots from the $f^{\text {th }}$ quarter segment of the $f^{\text {th }}$ core is ${ }_{11}$. A statistical model for this mean is

$$
\bar{y}_{11 .}=\mu+c_{1}+E_{11}
$$

where

91. - mean of the two aliquots from the $j^{\text {th }}$ quarter segment of the $f^{\text {th }}$
core,

$\mu \quad$ overall mean of all the data,

$c_{1}$ - the effect of the $1^{\text {th }}$ core,

$E_{1\}}-s_{11}+\varepsilon_{11.0}$

$s_{11}$ - the effect of the $j^{\text {th }}$ quarter segment in the $f^{\text {th }}$ core, and

E) - the residual of the $j^{\text {th }}$ quarter segment mean in the $f^{\text {th }}$ core.

The subscripts $1, j$, and $k$ have the following ranges: $1-1, \ldots, a$ (a=number of cores or core composites), $j=1, \ldots, b_{1} \quad\left(b_{1}=\right.$ number of quarter segments in the $i^{\text {th }}$ core), $k=1, \ldots, n$ ( $n=$ number of al qquots taken from each quarter segment).

The third model, for core composite sample data is

$$
y_{i k}^{\prime}=\mu^{\prime}+c_{i}^{\prime}+e_{i k}^{\prime}
$$

where

$$
\begin{aligned}
& y_{i k}^{\prime}=k^{\text {th }} \text { aliquot of the } i^{\text {th }} \text { core composite, } \\
& \mu^{\prime}=\text { the overall mean of the all core composite aliquots, } \\
& c_{i}^{\prime}=f^{\text {th }} \text { core composite effect, and } \\
& e_{i k}^{\prime}=k^{\text {th }} \text { residual of the } i^{\text {th }} \text { core composite. }
\end{aligned}
$$

The subscript ranges are the same as those used for the previous model. 
The variance of $g_{11}$. is

$$
\begin{aligned}
V\left(\bar{y}_{1 j .}\right) & =V\left(\mu+c_{1}+E_{1 j}\right) \\
& =\frac{\sigma^{2}}{n}+\sigma_{3}^{2}+\sigma_{c}^{2}
\end{aligned}
$$

where $\sigma_{G}^{2}$ is the vartance between cores, $\sigma_{a}^{2}$ is the vartance between quarter segments and $\sigma^{2}$ is the analytical error.

A weighted mean representing the simulated core composite (SCC) is

$$
\bar{y}_{w 1}=\sum_{j=1}^{b_{1}} w_{1 j} \bar{y}_{1 j} .
$$

The variance of $g_{w 1}$ is

$$
\begin{aligned}
V\left(\bar{y}_{w 1}\right) & =v\left(\sum_{j=1}^{b_{1}} w_{1 j} \bar{y}_{1 j} \cdot\right]=\sum_{j=1}^{b_{1}} w_{1 j}^{2} v\left(\bar{y}_{1 j} \cdot\right) \\
& =\sum_{j=1}^{b_{1}} w_{1 j}^{2}\left[\frac{\sigma^{2}}{n}+\sigma_{2}^{2}+\sigma_{c}^{2}\right] .
\end{aligned}
$$

The between mean squares (BMS) from model (2) has expectation

$$
E(B M S)=\frac{\sigma^{2}}{n}+\sigma_{c}^{2}+b_{0} \sigma_{c}^{2}
$$

where

$$
b_{0}=\frac{\sum_{i=1}^{\infty} b_{1}-\frac{\sum_{i=1}^{\infty} b_{1}^{2}}{\sum_{i=1}^{\infty} b_{1}}}{a-1} .
$$

The within mean squares (WMS) from model (2) has expectation 


\section{WHC-EP-0668}

$$
E(W M S)=\frac{\sigma^{2}}{n}+\sigma_{s}^{2} \text {. }
$$

By solving a system of two equations with two unknowns, we obtain

$$
\begin{aligned}
\partial_{G}^{2} & =\frac{\text { BMS }-W M S}{b_{0}}, \\
\frac{\partial^{2}}{n}+\partial_{s}^{2} & =\text { WMS }
\end{aligned}
$$

as estimates of $\sigma_{c}^{2}$ and $\left(\sigma^{2} / n+\sigma_{z}^{2}\right)$ respectively.

From the results above we can obtain an estimate of $\sigma^{2}\left(\nabla_{w 1}\right)$, which is

$$
\begin{aligned}
\partial^{2}\left(\bar{y}_{w i}\right) & =\hat{V}\left(\bar{y}_{w i}\right) \\
& =\sum_{j=1}^{b_{i}} w_{i j}^{2}\left[\frac{\partial^{2}}{n}+\partial_{s}^{2}+\partial_{c}^{2}\right] \\
& =\sum_{j=1}^{b_{i}} w_{i j}^{2}\left\{\begin{array}{l}
W M S+\frac{B M S-W M S}{b_{0}} \\
\end{array}=\sum_{j=1}^{b_{i}} w_{i j}^{2}\left\{\frac{B M S+\left(b_{0}-1\right) W M S}{b_{0}}\right] .\right.
\end{aligned}
$$

The variance for $\bar{y}_{i}^{\prime}$, using the structure from model (3), is

$$
V\left(\bar{y}_{i}^{\prime}\right)=\frac{\sigma^{2^{\prime}}+n \sigma_{c}^{2^{\prime}}}{n}
$$

where $\sigma^{21}$ is the analytical error and $\sigma_{c}^{21}$ is the variability between cores. The between mean squares (BMS') expectation for model ( 3 ) is

$$
E\left(B M S^{\prime}\right)=\sigma^{2^{\prime}}+n \sigma_{c}^{2^{\prime}} \text {. }
$$

Using this expectation, an estimate of the variance for $\bar{y}_{i}^{\prime}$ is

$$
\hat{V}\left(\bar{y}_{i .}^{\prime}\right)=\frac{B M S^{\prime}}{n} \text {. }
$$


WHC-EP-0668

The estimated variance of $g_{w i}-g_{i}$. is

$$
\begin{aligned}
\partial^{2}\left(\bar{y}_{w i}-\bar{y}_{i .}^{\prime}\right) & =\partial^{2}\left(\bar{y}_{W i}\right)+\partial^{2}\left(\bar{y}_{1 .}\right) \\
& =\left[\sum_{i=1}^{b_{i}} w_{i j}^{2}\left[\frac{B M S+\left(b_{0}-1\right) W M S}{b_{0}}\right]\right]+\left[\frac{B M S^{\prime}}{n}\right] .
\end{aligned}
$$

We have assumed that the covarlance between the two means is zero. 
WHC-EP-0668

This page intentionally left blank. 
WHC-EP-0668

APPENDIX C

\section{MISCELLANEOUS DATA}

APP $C-1$ 
WHC-EP-0668

This page intentionally left blank. 


\section{MEETING MINUTES}

SUbioce: ENERGY MEASUREMENTS FOR OISQUAL IFYING WASTE TANKS FROH WATCH LISTS

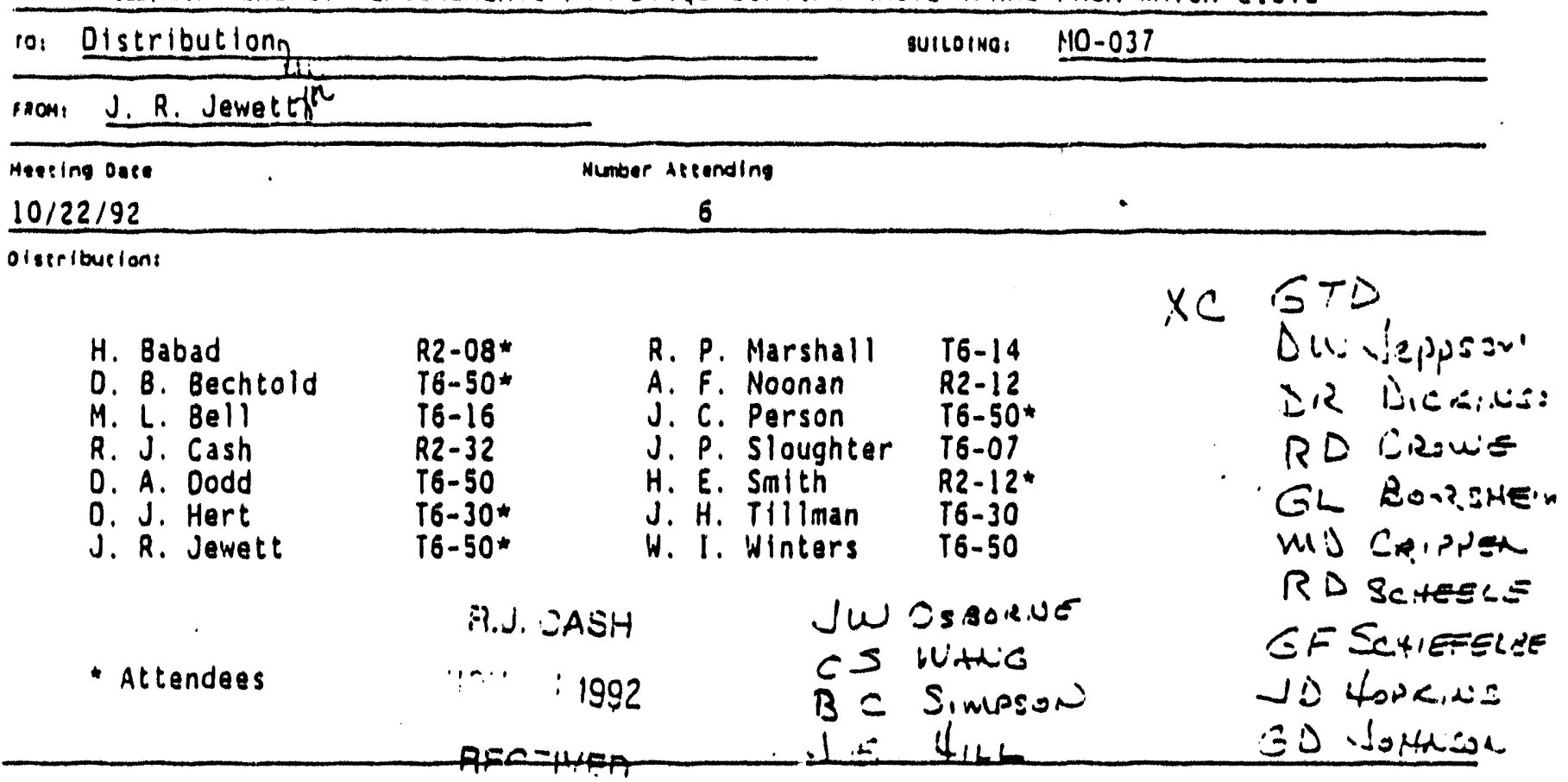

Harry babad is preparing to develop a criterion based on energetic measurements for removing tanks from the watch lists. He wants the labs to be prepared for the sample loads which may occur as a result of this criterion. Initial thoughts about the criterion are as follows:

If the exotherm of the material is $<75 \mathrm{cal} / \mathrm{g}$, there should be no further concern. If moisture is $>25 \%$, the limit of concern may be raised to $125 \mathrm{cal} / \mathrm{g}$. These are figures determined by Babad in consultation with a number of nationally recognized experts in the field.

The suggestion is that if the differential scanning calorimetry exotherms exceed this level, then more in-depth examination, such as adlabatic calorimetry, would be necessary. Adiabatic calorimetry would give such information as inltiation temperature, reaction rate, and propagation rate. Babad estimates that perhaps there might be 20 tanks that exceed these limits. (This number is, of course, open to debate.) There would also be need for measurements to support studies of synthetic materials.

A number of deficlencles of adiabatic calorimetry and thoughts about improvement were mentioned during the meeting. Keeping in spirit of the meeting, which was by and large a brain storming session, the ideas are presented here in no particular order.

1. Do we have enough tools? Adlabatic is slow, labor intensive, dose rata high. It uses too much sample; we have just one. Does the Accelerating Rate Calorimeter (ARC; by Columbla Scientific) offer any advantage over the Fauske Reactive system screening Tool? If it is too big, could it be modified? 
2. Do we have the right tools to work up the results? We should have a bigger computer. Would Chemometric tools help? (Erlc Wyse dt PNL may have an Idea.) Could data work-up be more automated?

3. Do we have enough capacity?

4. Do we have proper documentation for our measurements? the use test plans and test reports now. When sample load increases, we wlll need to use a fast efflctent system to got data to engineers, programs, and external customers. The "data package" system used for single-shell tank characterization is not fast enough.

5. We need to develop back-ups to current thermal analysis staff.

6. We need to have a low-temperature drying method for adlabatic samples that is controlled well enough to allay any susplcion that the samples lose their chemical energy before the actual adlabatlc measurement.

No formal actlons were taken or assigned at this meeting. These minutes are issued as a way to ralse general awareness that needs for direct measurement of waste sample energetics has the potentlal for dramatic growth. The laboratory should be prepared with respect to knowledge of methods, manpower, and equipment. 
Table A-1. Summary of Contents and Status of Ferrocyanide Tanks.

\begin{tabular}{|c|c|c|c|c|c|}
\hline Tank & $\begin{array}{l}\text { Total waste } \\
\text { volume } \\
(1,000 \text { gal })\end{array}$ & $\begin{array}{c}F e C N^{\dagger} \\
(1,0008 \mathrm{~mol})\end{array}$ & $\begin{array}{c}\text { Heat load }(1,000 \\
\text { Btw/h) }\end{array}$ & $\begin{array}{l}\text { Maximum } \\
\text { temp. } \\
\left({ }^{\circ} \mathrm{C}\right)\left({ }^{\circ} \mathrm{F}\right)\end{array}$ & Status of tanka \\
\hline$B X-102$ & 96 & $<1$ & $<10$ & 63 & $S ; A L$ \\
\hline BX-106 & 45 & $<1$ & $<10$ & 62 & NS; Sound \\
\hline $\mathrm{BX}-110$ & 199 & $<1$ & $<10$ & 64 & S; AL \\
\hline $\mathrm{BX}-111$ & 230 & $<1$ & $<10$ & $20 \quad 68$ & NS; AL \\
\hline BY-101 & 387 & $<1$ & 8.2 & $24 \quad 76$ & S; Sound \\
\hline BY-103 & 400 & 66 & 8.6 & $28 \quad 82$ & NS; AL \\
\hline BY-104 & 406 & 83 & $5.5-11.0^{4}$ & $\begin{array}{ll}54 & 129 \\
46^{\prime} & 115\end{array}$ & S; Sound \\
\hline BY-105 & 503 & $\overline{36}$ & $4.0 \cdot 8.0^{4}$ & $\begin{array}{ll}46 & 115 \\
50 & 122\end{array}$ & NS; AL \\
\hline BY-106 & 642 & 70 & $5.5-11.0^{\alpha}$ & \begin{tabular}{|ll}
54 & 130
\end{tabular} & $N S ; A L$ \\
\hline BY-107 & 266 & 42 & 14.5 & \begin{tabular}{|ll}
35 & 95 \\
\end{tabular} & $S ; A L$ \\
\hline BY-108 & 228 & 58 & $4.4 \cdot 8.8^{d}$ & $43 \quad 110$ & $S ; A L$ \\
\hline BY -110 & 398 & 71 & $4.0-8.0^{4}$ & $\begin{array}{ll}49 & 120 \\
43^{\prime} & 109\end{array}$ & S; Sound \\
\hline$B Y-111$ & 459 & 6 & $2.4 \cdot 4.8^{d}$ & $\begin{array}{ll}30 & 86 \\
\end{array}$ & S; Sound \\
\hline BY-112 & 291 & 2 & $<10$ & $28 \quad 82$ & S; Sound \\
\hline$C \cdot 108$ & 66 & 25 & $<10$ & $22 \quad 72$ & S; Sound \\
\hline C. 109 & 66 & 30 & $3.5-7.0^{d}$ & $\begin{array}{ll}23 & 74 \\
26^{\prime} & 78 \\
\end{array}$ & S; Sound \\
\hline$c-111$ & 57 & 33 & $<10$ & $\begin{array}{ll}22 & 71\end{array}$ & $S ; A L$ \\
\hline$C \cdot 112$ & 109 & 31 & $<10$ & $\begin{array}{ll}29 & 84 \\
29 & 85 \\
\end{array}$ & S; Sound \\
\hline$T \cdot 101$ & 133 & $<1$ & $<10$ & 21 & NS; AL \\
\hline$T-107$ & 180 & 5 & $<10$ & 66 & NS; $A L$ \\
\hline$T X-118$ & 347 & $<3$ & 4.9 & 26 & S; Sound \\
\hline
\end{tabular}


Table A-1. Summary of Contents and Status of Ferrocyanide Tanks.

\begin{tabular}{|c|c|c|c|c|c|}
\hline Tank & $\begin{array}{l}\text { Total waste } \\
\text { volume } \\
(1,000 \mathrm{gal})\end{array}$ & $\begin{array}{c}\mathrm{FeCN} \\
(1,000 \mathrm{~g} \mathrm{~mol})\end{array}$ & $\begin{array}{c}\text { Heat load }(1,000 \\
\text { Btu/h) }\end{array}$ & $\begin{array}{l}\text { Maximum } \\
\text { temp. } \\
\left({ }^{\circ} \mathrm{C}\right)\left({ }^{\circ} \mathrm{F}\right)\end{array}$ & Status of tanka \\
\hline TY-101 & 118 & 23 & $<10$ & 18 & $S ; A L$ \\
\hline TY-103 & 162 & 28 & $<10$ & 19 & $S ; A L$ \\
\hline$T Y-104$ & 46 & 12 & $<10$ & 17 & S; AL \\
\hline Totals & $5,834,000 \mathrm{gal}$ & $624 \mathrm{~K}$ 8-mol. & & & \\
\hline
\end{tabular}

'Based on information contained in monthly reports (WHC-EP-0182-XX)

(Hanlon 1993); temperature data as of March 1993.

Inventories from Borsheim and Simpson, 1991.

'Heat load values are conservatively high; new values will be calculated.

New heat load data as of September 1992, showing low and high end of range based upon variances in thermal conductivities for waste and soil.

'S - Interim Stabilized Tank; NS - Not Stabilized; AL - Assumed Leaker Tank; Sound Non-Leaking Tank.

Temperatures recorded for new thermocouple trees installed in September 1992. 
WHC-EP-0668

\section{APPENDIX D}

\section{QUALITY ASSURANCE DOCUMENTATION SUMMARY}

APP D-1 
WHC-EP. 0668

This page intentionally left blank. 
Table 1-1: SST Core 47, PNL-ACL Sample Numbers

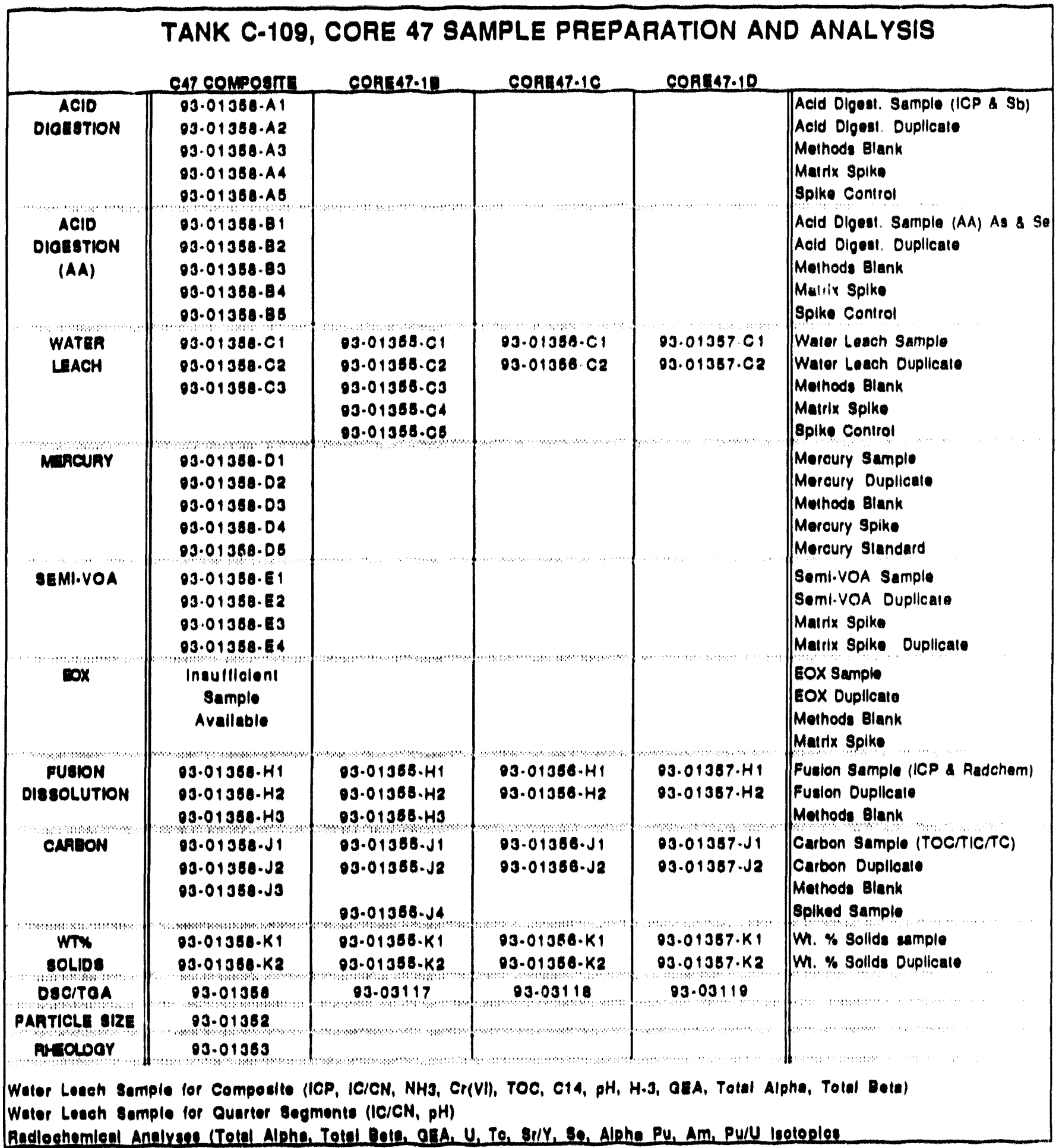


Table 1-2: SST Core 48, PNL-ACL Sample Numbers

\begin{tabular}{|c|c|c|c|c|}
\hline TANK & $\begin{array}{l}\text {-109, COAE } \\
\text { c40 coMPOSTI }\end{array}$ & $\begin{array}{l}\text { SAMPLE } \\
\text { COAE } 40.1 \mathrm{C}\end{array}$ & $\begin{array}{l}\text { REPARATI } \\
\text { COAP } 40.10\end{array}$ & N AND ANA \\
\hline $\begin{array}{c}\text { ACIO } \\
\text { Diaretion }\end{array}$ & $\begin{array}{l}03.01363 . A 1 \\
03.01363 .12 \\
03.01363 .44\end{array}$ & & $\begin{array}{l}03.01361 . A 1 \\
03.01381 . A 2 \\
03.01381 . A 3\end{array}$ & $\begin{array}{l}\text { Acid Olgest. Sample (ICP \& Sb) } \\
\text { Acid Olgess. Oupllate } \\
\text { Meihods Blank } \\
\text { Mairix Splke } \\
\text { Splke Control }\end{array}$ \\
\hline $\begin{array}{l}\text { ACIO } \\
\text { DIOESTION } \\
\text { (AA) }\end{array}$ & $\begin{array}{l}93.01363 .81 \\
03.01363 .82 \\
93.01363 .84\end{array}$ & & & 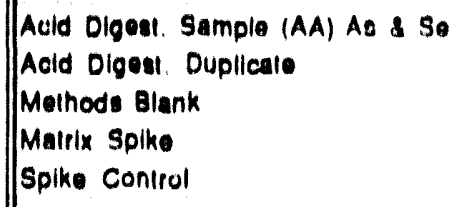 \\
\hline WATER & 93.01363 .01 & 93.01360 .01 & 93.01381 .01 & Water Leach Sample \\
\hline LEACH & 03.01363 .02 & $03.01360 . \mathrm{C2}$ & $\begin{array}{l}03.01361 .02 \\
93.01361 .03 \\
03.01361 .04 \\
93.01361 .03\end{array}$ & $\begin{array}{l}\text { Water Leach Duplicale } \\
\text { Moihods Blank } \\
\text { Mairix Spike } \\
\text { Splke Conirol }\end{array}$ \\
\hline Mencuar & $\begin{array}{l}93.01383 .01 \\
03.01383 .02 \\
03.01383 .04\end{array}$ & & & \begin{tabular}{|l} 
Mercury Sample \\
Mercury Duplicale \\
Melhods Blank \\
Mercury Splke \\
Mercury Slandard
\end{tabular} \\
\hline SEMI.VOA & $\begin{array}{c}\text { Insulllaleni } \\
\text { Sample } \\
\text { Avallable }\end{array}$ & & & $\begin{array}{l}\text { Semi.vOA Sample } \\
\text { Semi.vOA Duplicale } \\
\text { Matrix Spike } \\
\text { Malrix Splke Duplicale }\end{array}$ \\
\hline $\operatorname{cox}$ & $\begin{array}{l}\text { Insullioloni } \\
\text { Sample } \\
\text { Avallable }\end{array}$ & & & $\begin{array}{l}\text { EOX Sample } \\
\text { EOX Duplleate } \\
\text { Mothods Blank } \\
\text { Malrix Spike }\end{array}$ \\
\hline $\begin{array}{l}\text { PUSION } \\
\text { DI8SOLUTION }\end{array}$ & $\begin{array}{l}93.01363 . \mathrm{H1} \\
93.01363 . \mathrm{H2}\end{array}$ & $\begin{array}{l}03.01360 . \mathrm{H1} \\
03.01360 . \mathrm{H2}\end{array}$ & $\begin{array}{l}93.01361 . \mathrm{H} 1 \\
93.01361 . \mathrm{H2} \\
93.01361 . \mathrm{H3}\end{array}$ & $\begin{array}{l}\text { Fualion Sample (ICP \& Radchem) } \\
\text { Fuation Ouplicale } \\
\text { Meihode Blank }\end{array}$ \\
\hline CAMEON & $\begin{array}{l}93.01363 .51 \\
93.01363 .52\end{array}$ & $\begin{array}{l}03.01360 . \mathrm{J} 1 \\
03.01360 . \mathrm{J} 2\end{array}$ & $\begin{array}{l}03.01381 . \mathrm{J1} \\
03.01381 . \mathrm{J} 2 \\
03.01361 . \mathrm{J3} \\
03.01361 . \mathrm{J4}\end{array}$ & $\begin{array}{l}\text { Carbon Sample (ToCritictTC) } \\
\text { Carbon Duplicale } \\
\text { Melhods Blank } \\
\text { Splked Sample }\end{array}$ \\
\hline $\begin{array}{l}\text { Wrx } \\
\text { solios }\end{array}$ & $\begin{array}{l}93.01363 . k 1 \\
03.01363 . K_{2}\end{array}$ & $\begin{array}{l}93.01360 . K_{1} \\
93.01360 . K_{2}\end{array}$ & $\begin{array}{l}93.01381 . \mathrm{K} 1 \\
93.01381 . \mathrm{K} 2\end{array}$ & $\| \begin{array}{l}\text { in. \% Solld sample } \\
\text { m. \% Solide Duplicale }\end{array}$ \\
\hline $\begin{array}{l}\text { DECITOA } \\
\text { PARTICLE SIZE }\end{array}$ & $\begin{array}{l}03.01363 \\
03-01350\end{array}$ & 03.03120 & 93.03121 & \\
\hline \multicolumn{5}{|c|}{ 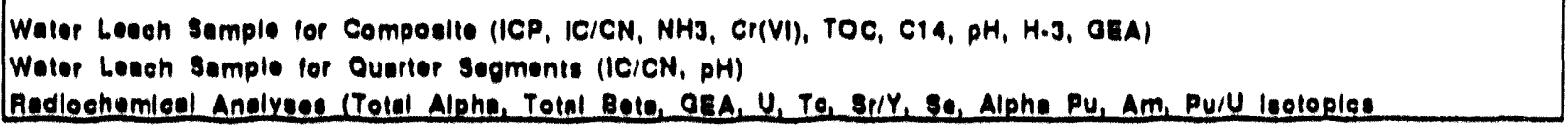 } \\
\hline
\end{tabular}


WHC-EP-0668

Table 1-3: SST Core 49, PNL.ACL Sample Numbers

\begin{tabular}{|c|c|c|c|c|c|}
\hline & $\begin{array}{l}\text { TANK C-109 } \\
\text { C4e composmE }\end{array}$ & $\begin{array}{l}\text { CORE } 498 \\
\text { CORE49.10 } \\
\end{array}$ & $\begin{array}{l}\text { PLE PREF } \\
\text { COAE } 49 \cdot 1 \mathrm{C}\end{array}$ & $\begin{array}{l}\text { IATION ANI } \\
\text { CORE } 40 \cdot 10 \\
\end{array}$ & D ANALYSIS \\
\hline $\begin{array}{c}\text { ACIO } \\
\text { DIOESTION }\end{array}$ & $\begin{array}{l}93.01371 . A 1 \\
93.01371 . A 2 \\
03.01371 . A 3 \\
93.01371 . A 4 \\
93.01371 . A B\end{array}$ & & & $\begin{array}{l}93.01367 . A 1 \\
93.01367 . A 2 \\
93.01367 . A 3\end{array}$ & $\begin{array}{l}\text { Acld Dlgest. Sample (ICP S Sb) } \\
\text { Acld Dlgest. Dupllcate } \\
\text { Molhoda Biank } \\
\text { Maitix Splke } \\
\text { Splke Conitol }\end{array}$ \\
\hline $\begin{array}{l}\text { ACIO } \\
\text { DIOESTION } \\
\text { (AA) }\end{array}$ & $\begin{array}{l}03.01371 .81 \\
03.01371 .82 \\
03.01371 .83 \\
03.01371 .84 \\
03.01371 .86\end{array}$ & & & & $\begin{array}{l}\text { Acld Digeal. Sample (AA) As a So } \\
\text { Acid Olgesl. Duplicalo } \\
\text { Moihode Blank } \\
\text { Malilx Splke } \\
\text { Spike Conliol }\end{array}$ \\
\hline $\begin{array}{l}\text { WATEA } \\
\text { LEACH }\end{array}$ & $\begin{array}{l}93.01371 . c 1 \\
03.01371 .02\end{array}$ & $\begin{array}{l}93.01385 .01 \\
93.01385 .62\end{array}$ & $\begin{array}{l}03.01368 .01 \\
03.01366 .02\end{array}$ & $\begin{array}{l}93.01367 .01 \\
93.01367 .02\end{array}$ & $\begin{array}{l}\text { Warer Leach Samplo } \\
\text { Water I weh Dupllcale } \\
\text { Mainode Elank } \\
\text { Mairix Splke } \\
\text { 8pike Control }\end{array}$ \\
\hline NaACUAY & $\begin{array}{l}03.01371 .01 \\
03.01371 .02 \\
03.01371 .04\end{array}$ & 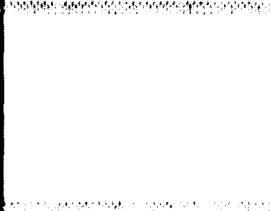 & & 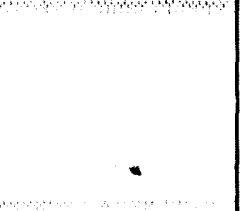 & $\begin{array}{l}\text { Mercury Sample } \\
\text { Mercury Duplicale } \\
\text { Merhode Blenk } \\
\text { Mercury Spike } \\
\text { Mercury Slandard }\end{array}$ \\
\hline SEMI.VOA & $\begin{array}{l}\text { O3.01371.E1 } \\
03.01371 . E 2 \\
03.01371 . E 3 \\
93.01371 . E 4\end{array}$ & & & & $\mid \begin{array}{l}\text { Semi-vOA Sample } \\
\text { Somi-VOA Ouplicaie } \\
\text { Matrix Spike } \\
\text { Matrix Spike Duplleale }\end{array}$ \\
\hline EOX & $\begin{array}{l}03.01371 . F 1 \\
03.01371 .52 \\
03.01371 . F 3 \\
03.01371 . F 4\end{array}$ & & & & $\begin{array}{l}\text { Eox Sample } \\
\text { EOX Dupllcale } \\
\text { Molhode Blank } \\
\text { Maint Splke }\end{array}$ \\
\hline $\begin{array}{l}\text { FUSION } \\
\text { DISBOLUTION }\end{array}$ & $\begin{array}{l}03.01371 . \mathrm{H1} \\
03.01371 . \mathrm{H} 2\end{array}$ & $\begin{array}{l}93.01365 . H 1 \\
93.01365 . H 2\end{array}$ & $\begin{array}{l}93.01366 . \mathrm{H1} \\
03.01366 . \mathrm{H2}\end{array}$ & $\begin{array}{l}03.01367 . \mathrm{H}_{1} \\
03.01367 . \mathrm{H}_{2} \\
03.01367 . \mathrm{H3}\end{array}$ & $\begin{array}{l}\text { Fusion Sample (ICP \& Radchem) } \\
\text { Fusion Duplleale } \\
\text { Meiiods Blank }\end{array}$ \\
\hline CAREON & $\begin{array}{l}03.01371 .51 \\
93.01371 . \mathrm{J2} \\
93.01371 . \mathrm{J3}\end{array}$ & $\begin{array}{l}03.01368 . \mathrm{J1} \\
03.01368 . \mathrm{J} 2 \\
93.01365 . \mathrm{J4}\end{array}$ & $\begin{array}{l}93.01366 . \mathrm{J} 1 \\
93.01366 . \mathrm{J} 2\end{array}$ & $\begin{array}{l}93.01367 . \mathrm{J1} \\
93.01367 . \mathrm{J2} \\
03.01367 . \mathrm{J3}\end{array}$ & $\begin{array}{l}\text { Carbon Sample (TOC/TIC/TC) } \\
\text { Carbon Duplicale } \\
\text { Malhoda Blank } \\
\text { Spiked Sample }\end{array}$ \\
\hline $\begin{array}{l}\text { Wro } \\
\text { solios }\end{array}$ & $\begin{array}{l}03.01371 . K 1 \\
03.01371 . K 2\end{array}$ & $\begin{array}{l}93.01365 \cdot \mathrm{k} 1 \\
93.01365 \cdot \mathrm{k2}\end{array}$ & $\begin{array}{l}93.01366 . \mathrm{K1} \\
03.01366 . \mathrm{K2}\end{array}$ & $\begin{array}{l}93.01367 . \mathrm{K} 1 \\
93.01367 . \mathrm{K} 2\end{array}$ & $\| \begin{array}{l}\text { \% } \% \text { Solida sample } \\
\text { W. } \% \text { Solida Duplicale }\end{array}$ \\
\hline $\begin{array}{c}\text { DSCITOA } \\
\text { PARTICLE SIZE }\end{array}$ & $\begin{array}{l}93.01371 \\
93.01364\end{array}$ & 03.03122 & 03.03123 & 03.03124 & \\
\hline
\end{tabular}


WHC-EP-0668

Table I-4: SST C-109, Liquid Composite and Hot Cell Blank, PNL-ACL Sample Numbers

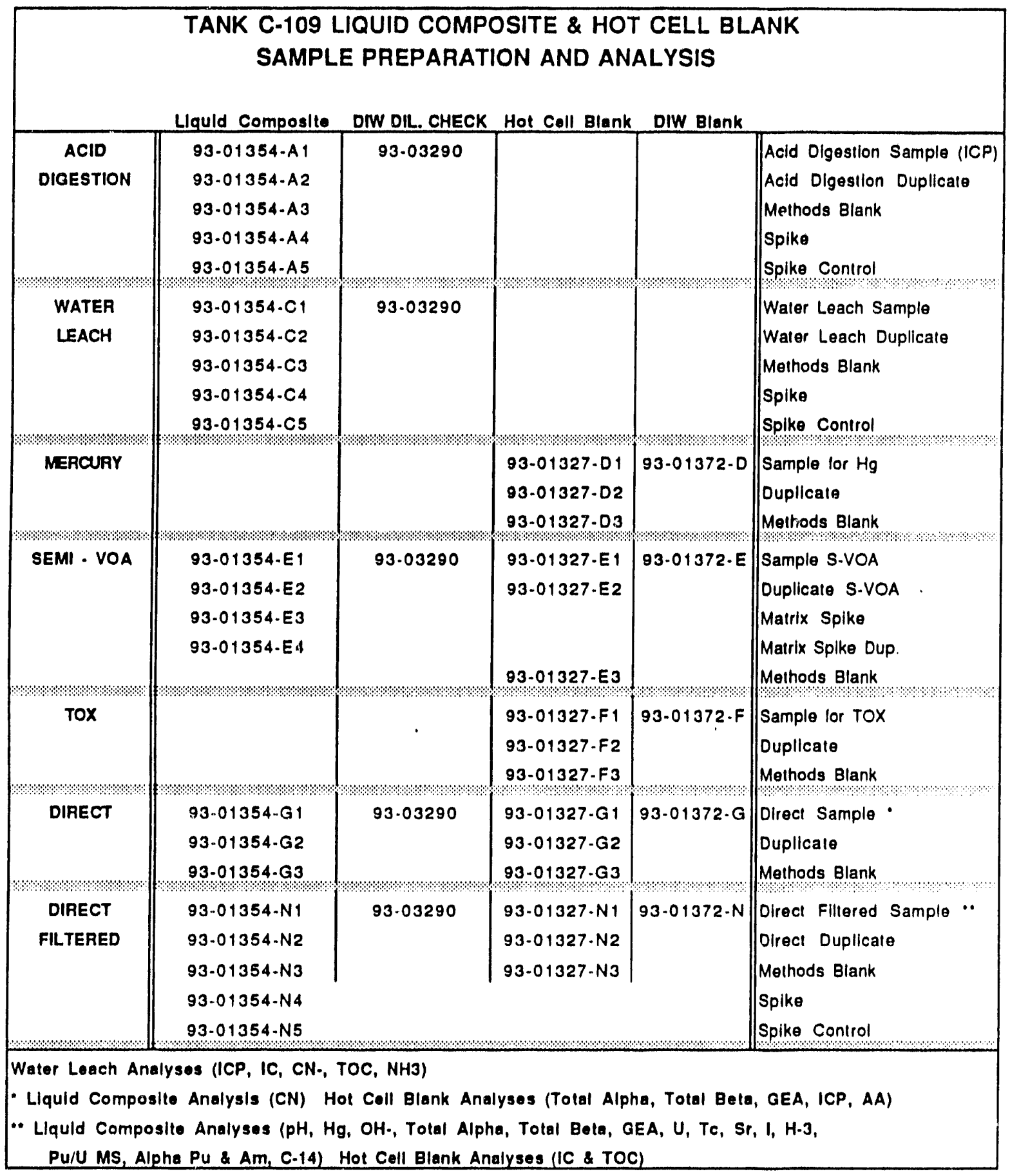


associated with the sludge. Some Liquid Composite and 325-A Hot-Cell Blank samples were prepared for analyses by the $A C L$ technical groups outside of the cells due to their low radioactivity levels and a concern for potential incell contamination problems.

Table 1-2 1ists the procedures that were employed to prepare Tank $\mathrm{C}-109$ samples for analyses or to conduct a limited number of in-cell analytical determinations:

Table 1-2: Shielded Analytical Laboratory Procedure List for Tank C-109

\begin{tabular}{|c|c|}
\hline PNL Procedure Number & Procedure Title \\
\hline PNL-ALO-101, Rev. 1 & Acid Digestion for Metals Analys is \\
\hline PNL-ALO-102, ReV. 0 & Fusion of Hanford Tank Waste Solids \\
\hline PNL-AL0-103, Rev. 1 & $\begin{array}{l}\text { Water Leach of Sludges, Soils, and Other Solid } \\
\text { Samples }\end{array}$ \\
\hline PNL-ALO-213, Rev. 0 & $\begin{array}{l}\text { Mercury in Water, Solids, and Sludges by Manual } \\
\text { Cold Vapor Technique }\end{array}$ \\
\hline PNL-ALO-120, Rev. 0 & $\begin{array}{l}\text { Extraction of Single Shell Tank Samples for the } \\
\text { Analys is of Semi-Volatile Organic Compounds }\end{array}$ \\
\hline PNL-ALO-225, Rev. 0 & Measurement of $\mathrm{pH}$ in Aqueous Solution \\
\hline PNL-ALO-320, Rev. 0 & $\begin{array}{l}\text { Method for Extractable Organic Halides (EOX) in } \\
\text { Solids }\end{array}$ \\
\hline PNL-ALO-504, Rev. 1 & $\begin{array}{l}\text { Percent Solids Determination of Hanford Tank Waste } \\
\text { Sludges }\end{array}$ \\
\hline PNL-7.40.42, Rev. 0 & $\begin{array}{l}\text { Determination of Carbon-14 in Radioactive Liquids, } \\
\text { Soils, and Sludges }\end{array}$ \\
\hline
\end{tabular}

Low sample recovery required that a reduced work scope be performed on Core 47 and Core 48 composite material. The LOI (9258244) from Hanford Analytical Services Management (HASM) resulted in test instructions that prioritized the order in which samples were processed. Acid digestions for ICP and GFAA, fusions, water leaches, and mercury preparations were conducted on all three cores. Subsamples were aliquoted from Cores 47 and 49 for SVOA. Samples from Core 49 were weighed for EOX. 
1) Insufficient sample was available to conduct the analyses per procedure while maintaining the level of quality control requested.

2) Sample weights and/or final volumes were reduced to facilitate waste minimization.

3) Sample weights and/or final volumes were altered to increase the concentration of certain analytes of interest. This was done to meet the procedural concentration ranges needed to perform the analyses.

The following table lists the sample preparatory procedure deviations performed during the processing of Tank $\mathrm{C}-109$ :

Table 1-3: Tank C-109 Sample Preparation Procedure Deviations

\begin{tabular}{|c|c|c|c|c|c|}
\hline $\begin{array}{c}\text { Sample } \\
10\end{array}$ & $\begin{array}{c}\mathrm{ACL} \\
\text { Number }\end{array}$ & $\begin{array}{c}\text { Sample } \\
\text { Size } \\
\text { Deviation }\end{array}$ & $\begin{array}{c}\text { Sample } \\
\text { Volume } \\
\text { Devtation }\end{array}$ & $\begin{array}{c}\text { Reagent } \\
\text { Deviation }\end{array}$ & Observed Effect \\
\hline $47 / 49-L C$ & $93-01354-A$ & No & Yes & No & None \\
\hline $47-C C$ & $93-01358-A$ & Yes & Yes & No & None \\
\hline $48-10$ & $93-01361-A$ & Yes & Yes & No & None \\
\hline $48-C C$ & $93-01363-A$ & Yes & Yes & No & None \\
\hline $49-10$ & $93-01367-A$ & Yes & Yes & No & None \\
\hline $49-C C$ & $93-01371-A$ & Yes & Yes & No & None \\
\hline $47-C C$ & $93-01358-8$ & Yes & Yes & No & None \\
\hline $48-C C$ & $93-01363-8$ & Yes & Yes & No & None \\
\hline $49-C C$ & $93-01371-8$ & Yes & Yes & No & None \\
\hline $47-1 B$ & $93-01355-C$ & Yes & Yes & No & None \\
\hline $47-1 C$ & $93-01356-C$ & Yes & Yes & No & None \\
\hline $47-10$ & $93-01357-C$ & Yes & Yes & No & None \\
\hline $47-C C$ & $93-01358-C$ & No & Yes & No & None \\
\hline $48-1 C$ & $93-01360-C$ & Yes & Yes & No & None \\
\hline $48-10$ & $93-01361-C$ & Yes & Yes & No & None \\
\hline $48-C C$ & $93-01363-C$ & No & Yes & No & None \\
\hline $49-18$ & $93-01365-C$ & Yes & Yes & No & None \\
\hline $49-1 C$ & $93-01366-C$ & Yes & Yes & No & None \\
\hline $49-10$ & $93-01367-C$ & Yes & Yes & No & None \\
\hline $49-C C$ & $93-01371-C$ & No & Yes & No & None \\
\hline
\end{tabular}


Table 1-3: Tank C-109 Sample Preparation Procedure Deviations

\begin{tabular}{|c|c|c|c|c|c|}
\hline $47-C C$ & $93-01358-0$ & No & Yes & No & None \\
\hline $48-C C$ & $93-01363-0$ & No & Yes & No & None \\
\hline $49-C C$ & $93-01371-0$ & No & Yes & No & None \\
\hline $47-18$ & $93-01355-H$ & No & Yes & No & None \\
\hline $47-1 C$ & $93-01356-\mathrm{H}$ & No & Yes & No & None \\
\hline $47-10$ & $93-01357-\mathrm{H}$ & No & Yes & No & None \\
\hline $47-C C$ & $93-01358-H$ & No & Yes & No & None \\
\hline $48-1 C$ & $93-01360-H$ & No & Yes & No & None \\
\hline $48-10$ & $93-01361-H$ & No & Yes & No & None \\
\hline $48-C C$ & $93-01363-H$ & No & Yes & No & None \\
\hline $49-18$ & $93-01365-\mathrm{H}$ & No & Yes & No & None \\
\hline $49-1 C$ & $93-01366-\mathrm{H}$ & No & Yes & No & None \\
\hline $49-10$ & $93-01367-H$ & No & Yes & No & None \\
\hline $49-C C$ & $93-01371-\mathrm{H}$ & No & Yes & No & None \\
\hline $47-18$ & $93-01355-K$ & Yes & No & No & None \\
\hline $47-1 C$ & $93-01356-K$ & Yes & No & No & None \\
\hline $47-10$ & $93-01357-K$ & Yes & No & No & None \\
\hline $47-C C$ & $93-01358-k$ & Yes & No & No & None \\
\hline $48-1 C$ & $93-01360-K$ & Yes & No & No & None \\
\hline $48-10$ & $93-01361-K$ & Yes & No & No & None \\
\hline $48-C C$ & $93-01363-K$ & Yes & No & No & None \\
\hline $49-18$ & $93-01365-k$ & Yes & No & No & None \\
\hline $49-1 C$ & $93-01366-K$ & Yes & No & No & None \\
\hline $49-10$ & $93-01367-K$ & Yes & No & No & None \\
\hline $49-\mathrm{CC}$ & $93-01371-K$ & Yes & No & No & None \\
\hline
\end{tabular}

It should be noted that all deviations performed were minor changes to parameters such as sample size and final volume, and that these changes did not alter the actual chemistry involved. Sample sizes and final volumes for all sample preparations are documented in the project records and are included in Appendix $C$. 


\section{WHC-EP-0668}

Table 1-4a: SST Cores 47 and 49, Differentlal Scanning Calorimetric Data

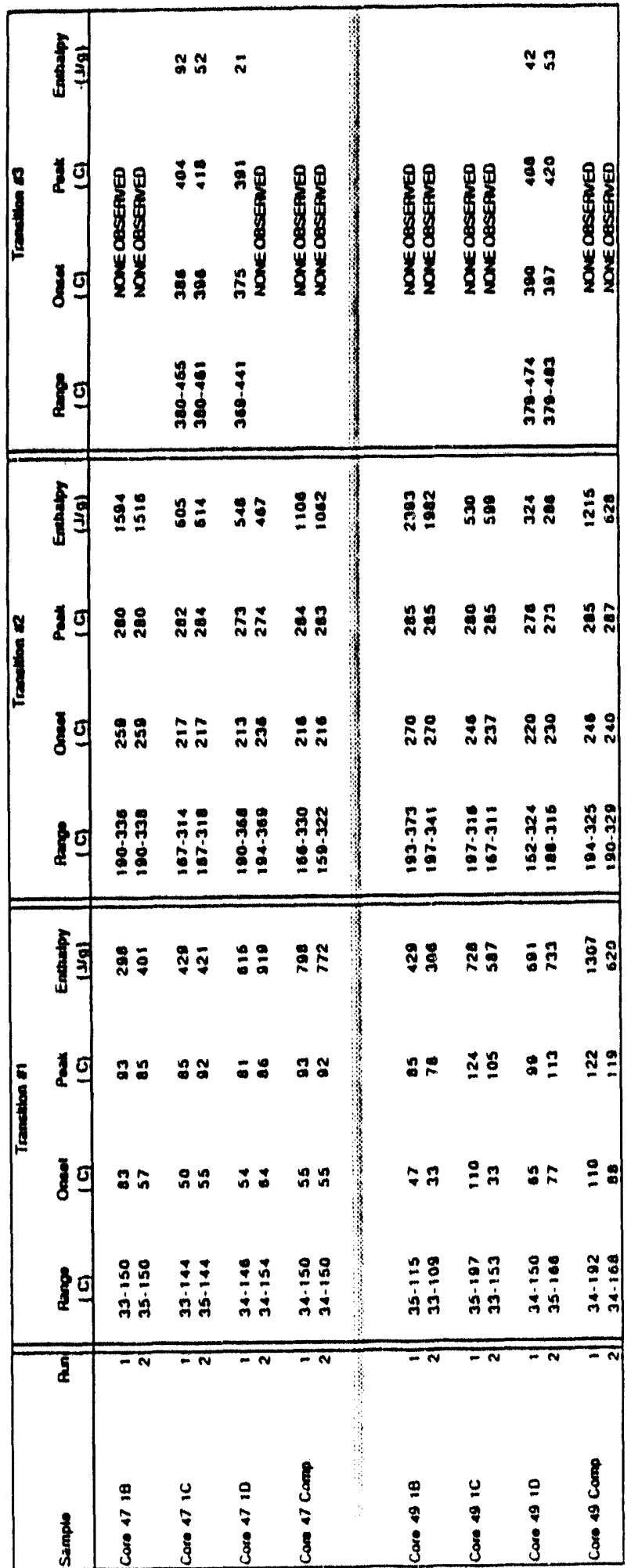




\section{WHC-EP-0668}

Table 1-4b: SST Cores 48, Differentlal Scanning Calorimetric Data

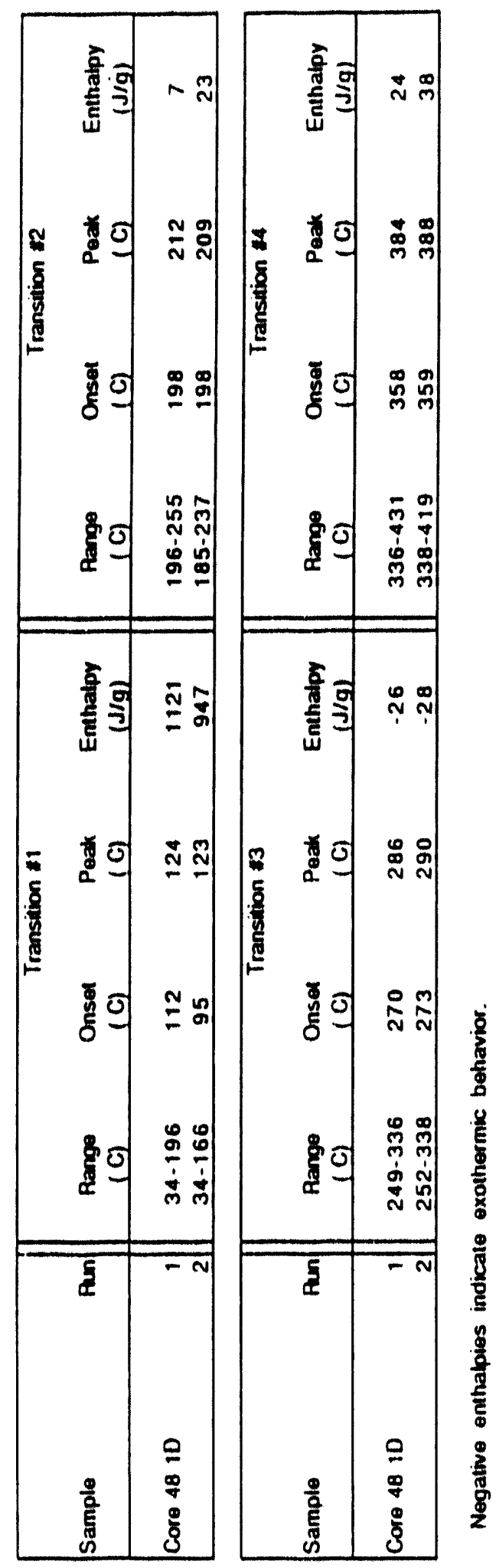


Table 1-5: SST Cores 47, 48, and 49, Scanning Thermogravimetric Data

\begin{tabular}{|c|c|c|c|c|c|c|c|}
\hline \multirow[b]{2}{*}{ Samplo } & \multirow[b]{2}{*}{ Aun } & \multicolumn{2}{|c|}{ Transition 1} & \multicolumn{2}{|c|}{ Transition *2 } & \multicolumn{2}{|c|}{ Transition 13} \\
\hline & & $\begin{array}{l}\text { Range } \\
\text { (C) }\end{array}$ & $\begin{array}{c}\text { Mase Loss } \\
\quad(\%)\end{array}$ & $\begin{array}{l}\text { Range } \\
(\mathrm{C}) \\
\end{array}$ & $\begin{array}{l}\text { Mass Loss } \\
\quad(\%) \\
\end{array}$ & $\begin{array}{l}\text { Range } \\
\text { (C) }\end{array}$ & $\begin{array}{c}\text { Mass Loes ' } \\
(\%)\end{array}$ \\
\hline Core $17 \quad 18$ & $\begin{array}{l}1 \\
2\end{array}$ & $\begin{array}{l}31-180 \\
31.180\end{array}$ & $\begin{array}{l}10.0 \\
10.4\end{array}$ & $\begin{array}{l}180.336 \\
180.336\end{array}$ & $\begin{array}{l}18.0 \\
17.8\end{array}$ & $\begin{array}{l}336.500 \\
336.500\end{array}$ & $\begin{array}{l}3.8 \\
3.1\end{array}$ \\
\hline Core 47 ic & $\begin{array}{l}1 \\
2\end{array}$ & $\begin{array}{l}31 \cdot 180 \\
31 \cdot 150\end{array}$ & $\begin{array}{l}18.1 \\
18.0\end{array}$ & $\begin{array}{l}150.338 \\
180.338\end{array}$ & $\begin{array}{l}17.8 \\
17.4\end{array}$ & $\begin{array}{l}336.500 \\
338.500\end{array}$ & $\begin{array}{l}3.7 \\
3.7\end{array}$ \\
\hline Core 4710 & $\begin{array}{l}1 \\
2\end{array}$ & $\begin{array}{l}31 \cdot 180 \\
31 \cdot 180\end{array}$ & $\begin{array}{l}10.7 \\
10.7\end{array}$ & $\begin{array}{l}180.370 \\
180.370\end{array}$ & $\begin{array}{l}7.0 \\
6.5\end{array}$ & $\begin{array}{l}370.500 \\
370.500\end{array}$ & $\begin{array}{l}1.5 \\
1.8\end{array}$ \\
\hline Core 47 Comp. & $\begin{array}{l}1 \\
2\end{array}$ & $\begin{array}{l}31 \cdot 150 \\
31.150\end{array}$ & $\begin{array}{l}15.6 \\
14.0\end{array}$ & $\begin{array}{l}180.336 \\
150.336\end{array}$ & $\begin{array}{l}14.7 \\
18.1\end{array}$ & $\begin{array}{l}370.500 \\
370.500\end{array}$ & $\begin{array}{l}3.4 \\
4.0\end{array}$ \\
\hline क- & mant: & How & monsmom & Homsnos & manow & monton. & me \\
\hline Core 4810 & $\begin{array}{l}1 \\
2\end{array}$ & $\begin{array}{l}31.180 \\
31.180\end{array}$ & $\begin{array}{l}46.4 \\
43.8\end{array}$ & $\begin{array}{l}180.425 \\
180.425\end{array}$ & $\begin{array}{l}3.2 \\
3.1\end{array}$ & $\begin{array}{r}426.500 \\
428.500\end{array}$ & $\begin{array}{l}.0 .2 \\
.0 .2\end{array}$ \\
\hline 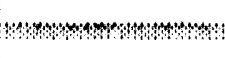 & thentat: & 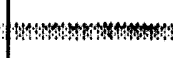 & 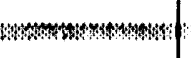 & mowntwontwo & 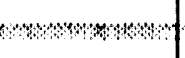 & Whatomos & nowntson \\
\hline Core $40 \quad 18$ & $\begin{array}{l}1 \\
2\end{array}$ & $\begin{array}{l}31 \cdot 180 \\
31 \cdot 180\end{array}$ & $\begin{array}{l}2.4 \\
6.0\end{array}$ & $\begin{array}{l}180.338 \\
180.336\end{array}$ & $\begin{array}{l}26.3 \\
25.3\end{array}$ & $\begin{array}{l}336.500 \\
336.500\end{array}$ & $\begin{array}{l}4.3 \\
3.8\end{array}$ \\
\hline Core $401 C$ & $\begin{array}{l}1 \\
2\end{array}$ & $\begin{array}{l}31.180 \\
31.180\end{array}$ & $\begin{array}{l}28.8 \\
30.6\end{array}$ & $\begin{array}{l}180.338 \\
180.338\end{array}$ & $\begin{array}{l}14.3 \\
14.1\end{array}$ & $\begin{array}{l}336.500 \\
336.500\end{array}$ & $\begin{array}{l}2.7 \\
2.9\end{array}$ \\
\hline Core $40 \quad 10$ & $\begin{array}{l}1 \\
2\end{array}$ & $\begin{array}{l}31.180 \\
31.180\end{array}$ & $\begin{array}{l}29.6 \\
29.0\end{array}$ & $\begin{array}{l}180.360 \\
180.380\end{array}$ & $\begin{array}{l}9.4 \\
9.7\end{array}$ & $\begin{array}{l}350.500 \\
350.500\end{array}$ & $\begin{array}{l}1.1 \\
1.1\end{array}$ \\
\hline Core 40 Comp. & $\begin{array}{l}1 \\
2\end{array}$ & $\begin{array}{l}31.180 \\
31.180 \\
\end{array}$ & $\begin{array}{l}27.5 \\
25.6 \\
\end{array}$ & $\begin{array}{l}180 \cdot 336 \\
180 \cdot 336 \\
\end{array}$ & $\begin{array}{l}13.1 \\
16.4 \\
\end{array}$ & $\begin{array}{l}336.500 \\
336.500 \\
\end{array}$ & $\begin{array}{l}3.5 \\
3.9 \\
\end{array}$ \\
\hline
\end{tabular}




\section{PHYSICAL PROPERIIES}

The physical properties which were measured on this r ure included weight percent solids, $\mathrm{pH}$, and particle size distribution. The wt\% total solids were obtained for each of the quarter segments and the core composites. The total solids analyses were performed according to PNL technical procedure PNL.ALO504, "Weight Percent Solids." This analysis is a gravimetric determination of the wt\% solids as measured by the loss of mass in the sample after being held in a drying oven at $105^{\circ} \mathrm{C}$ for 24 hours. The wt\% water is calculated by subtracting the weight percent solids from 100.

The wt\% water values are given in Table 1.6. The wt\% waters of the core composite from core 48 was significantly higher than the average of the quarter segments from the core 48 . The core composite for Core 48 was the subsample originally taken for VOA. This sample was taken immediately after extrusion and prior to weighing the sample and taking plctures. This difference in handling may account for the higher wt\% water values measured in these samples. The wt\% waters measured on the other core composites (Cores 47 and 49) are lower than was observed in the average of the quarter segment samples. This is due to increased handing of the core composite material in the hot-cell environment.

Table 1.6: Cores 47, 48, and 49, Weight Percent Solids

\begin{tabular}{|c|c|c|c|}
\hline Core & Sumple & ACL Number & ULX Vater \\
\hline 47 & 18 & 33.01355 & 19.3 \\
\hline & $1 C$ & 93.01356 & 28.4 \\
\hline & 10 & 93.01357 & 39.4 \\
\hline & Composite & 93.01358 & 21.5 \\
\hline 48 & $1 C$ & 93.01360 & 52.8 \\
\hline & 10 & 93.01361 & 51.6 \\
\hline 49 & Composite & 93.01363 & 57.1 \\
\hline & 18 & 93.01365 & 19.6 \\
\hline $1 C$ & 93.01366 & 38.3 \\
\hline & 10 & $93-01367$ & 39.6 \\
\hline & Composite & 93.01371 & 21.8 \\
\hline
\end{tabular}


Table 2-1a: SST Core 47, ICP Core Composite Fuston

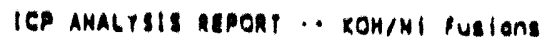

PnOJECT, Ist oroceounE: PHL-ALO-211
Anclyzed oetet $01 / 06 / 93$

notli: vas3672

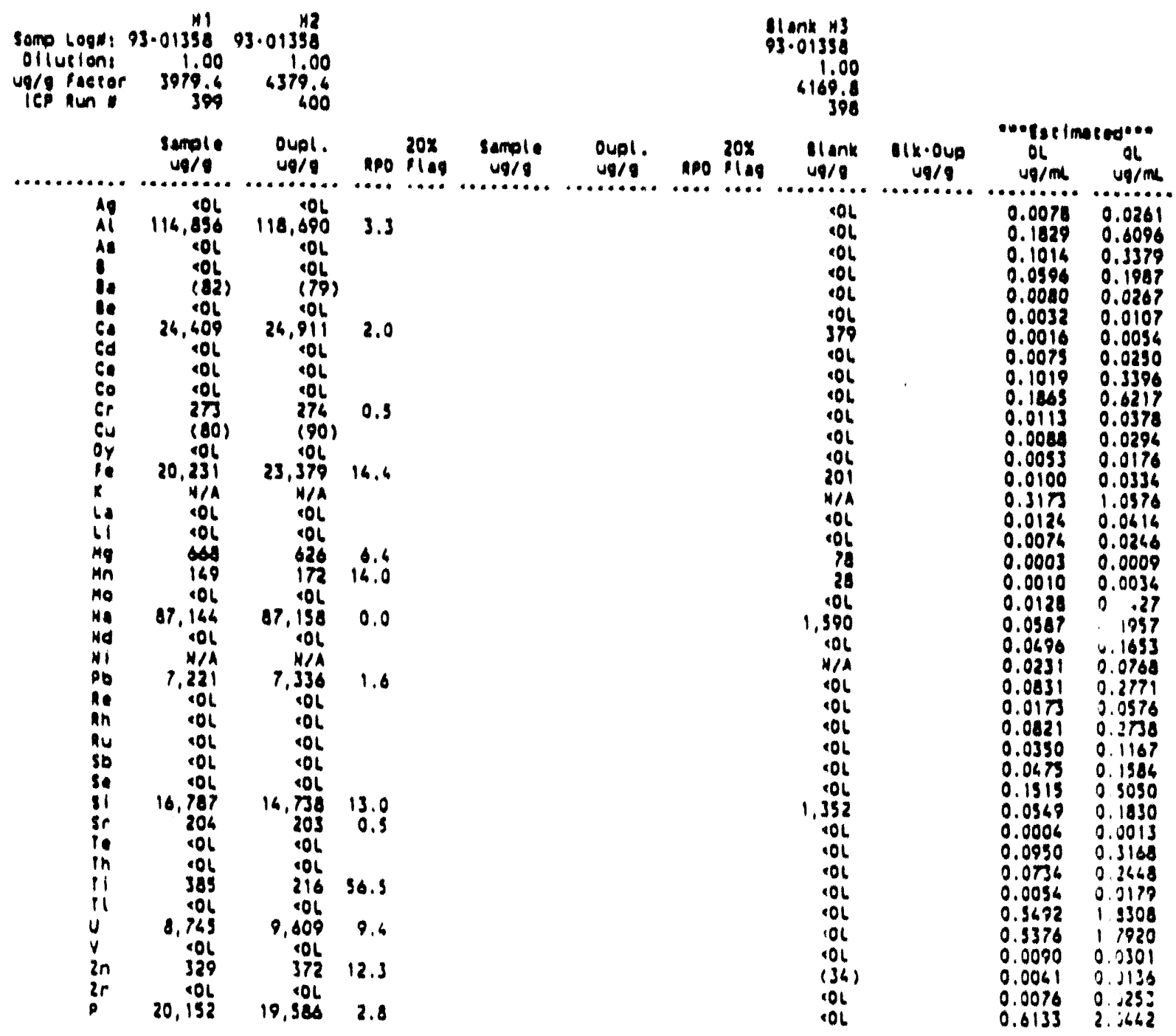

Mote: 1) Values relloble $1021 / 2$ slgnificane digies. Arackesed results (, ore qualizative

2) Ilonk is reported in ug/g "ravivelence" po indicate blant etfect on samole.

3) sample results have not been adjusted for "blank" conericuetion.

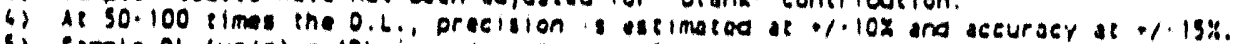

5) Sample ol (ug/g) - (OL in vg/mL) (ug/g pocsor)

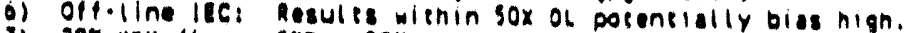

7) $20 x$ 11" flag: RPO, 20x and both sumble results? joot.

Oaes, including ealibration/0C, orenived 11 . 1CP.325.\$01.01/06/93 
Table 2-1b: SST Core 48 and 49, ICP Core Composite Fusion

\author{
16. ANALYSIS AtPOAT $\cdots$ KOH/Ni fustons
}

project $8 \mathrm{ser}$

phoctount, onL ALO-211

Anatyaes oseg! $01 / 96 / 93$

Here, Wass6r?

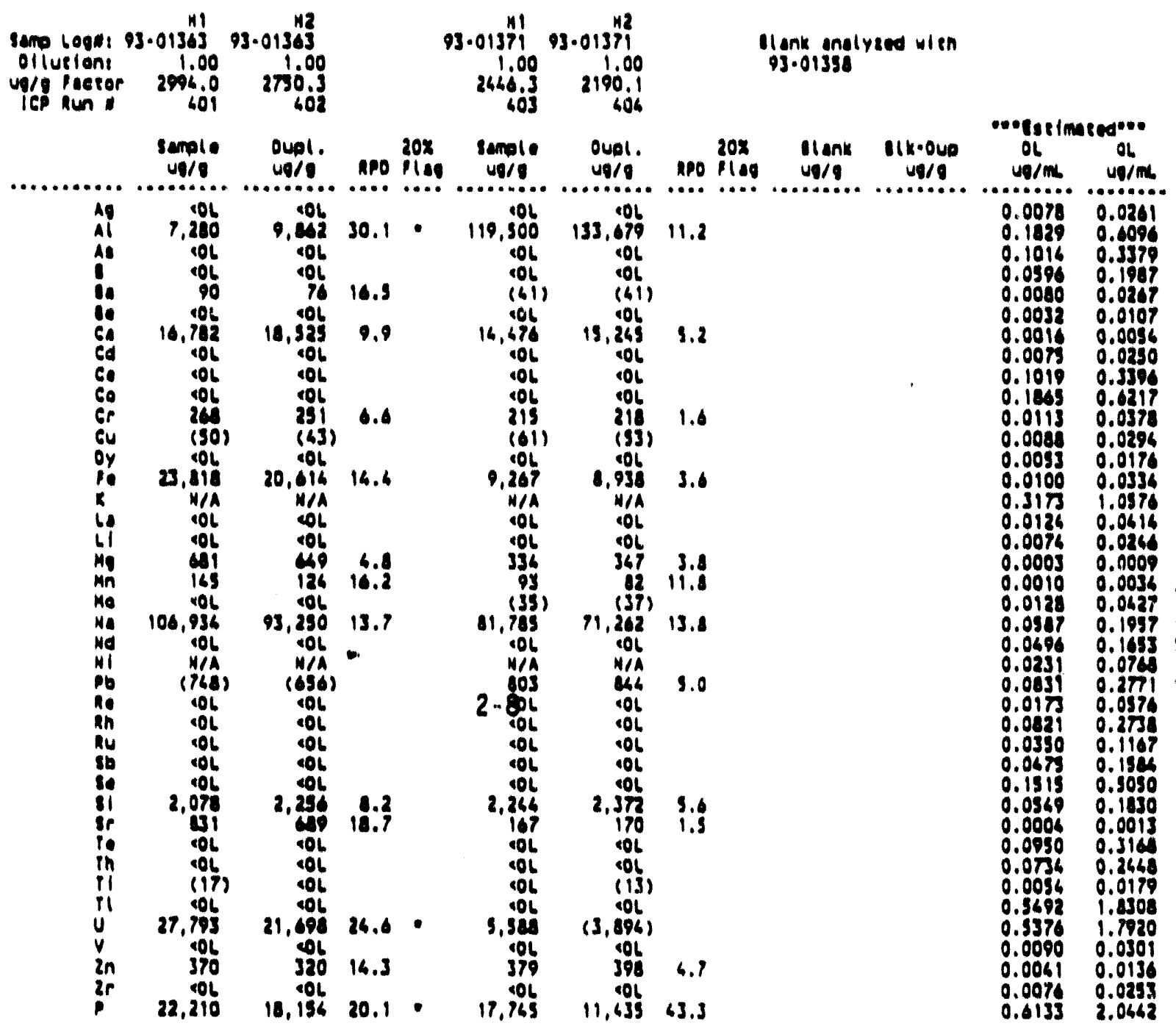

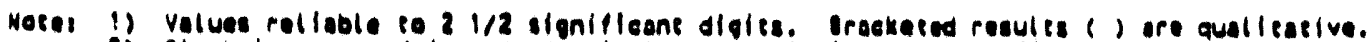

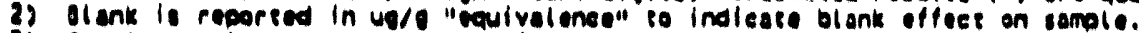

3) Senole results have not ben ad lused for "olank" contribusion.

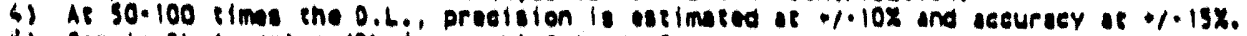

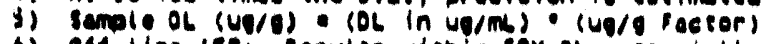

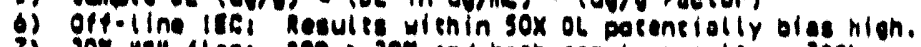

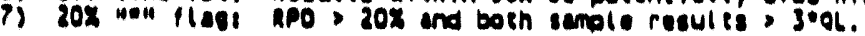

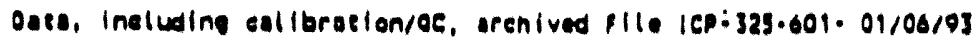


Table 2-1C: SST Core 47 and 48, ICP Quarter Segments Fusion

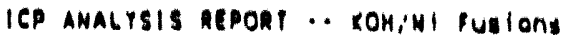

PHOdect: SEt

PROCEOURE: PNL.ALO-211
Anal ried outel $01 / 08 / 93$

MSte1 WAS5672

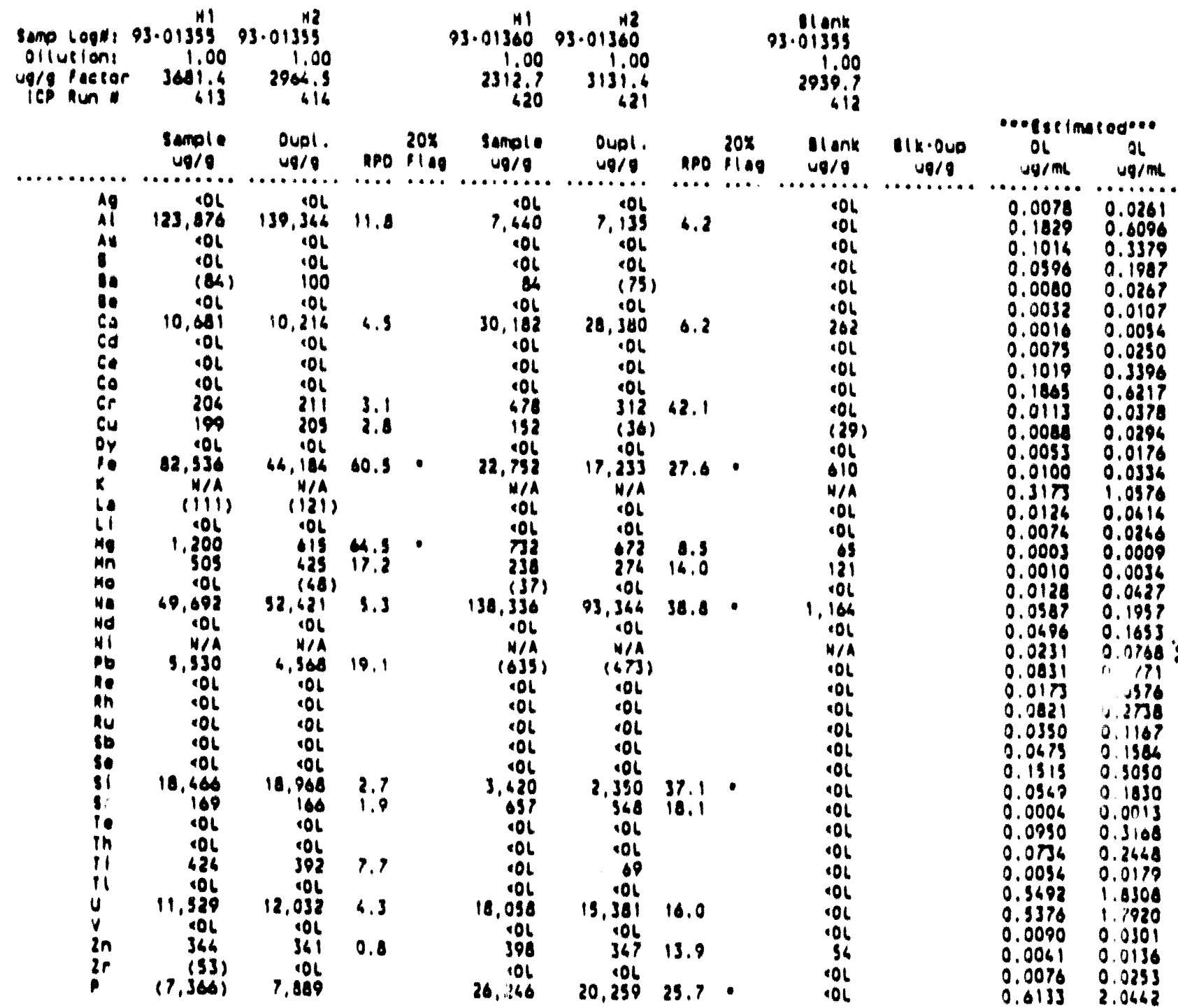

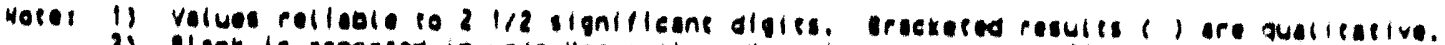

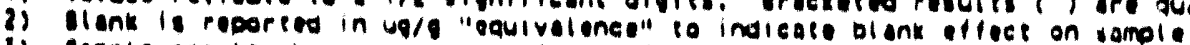

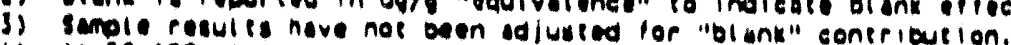

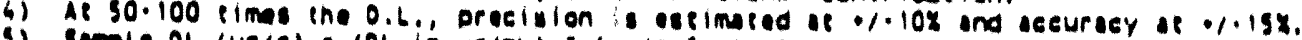

s)

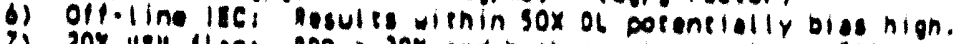

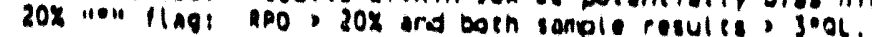

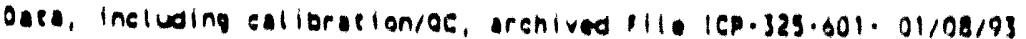




\section{Table 2-1d: SST Core 47, ICP Quarter Segments Fusion}

ICP AMALTSIS RePORT - KOH/MI PUHIONA

Project $88 \mathrm{~T}$

PAOCLDUNI: PNL-ALO-211
Analved oseel 01/08/93

MBte: Wass672

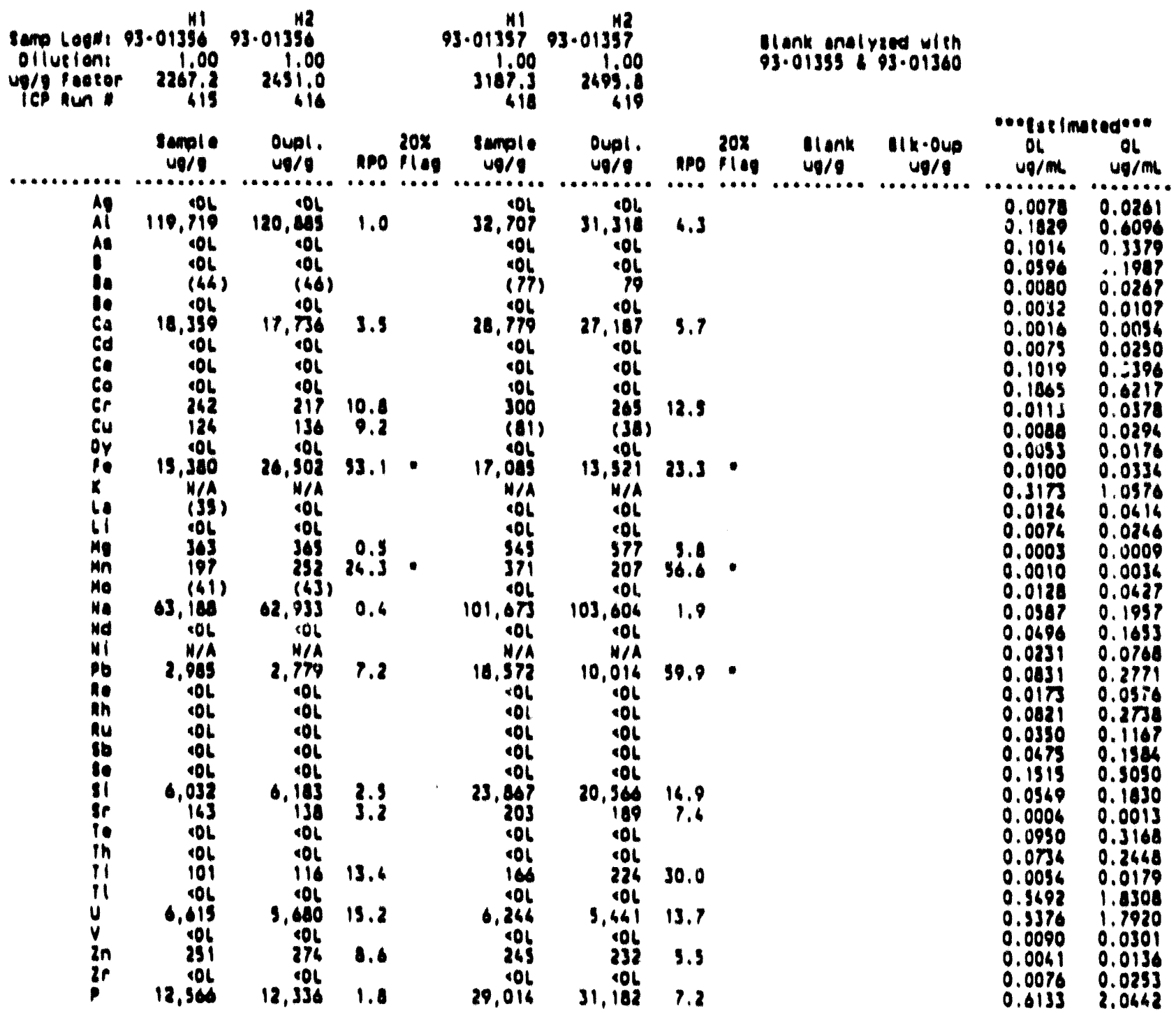

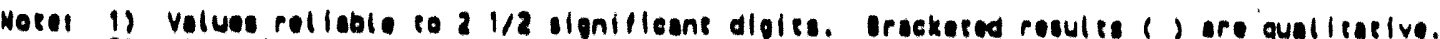

2) Clenk is reperted in ve/e "equivelenea" to indleste blonk tlees on semple

semple results have nof ben adjuted for "blank" centribution.

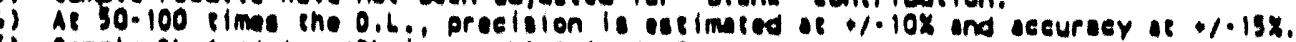

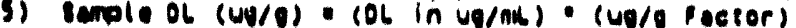

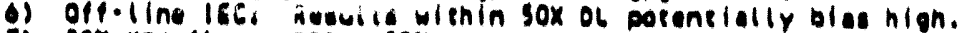

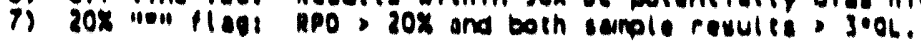

Oefa, Ineluding eallbraplen/OC, orehived 1/le 1CP.325.601. 01/08/93 
Phojtct: str

Proctounti PNL+ALO-211
Analyeed oecel $01 / 03 / 93$

MBII! WAS3672

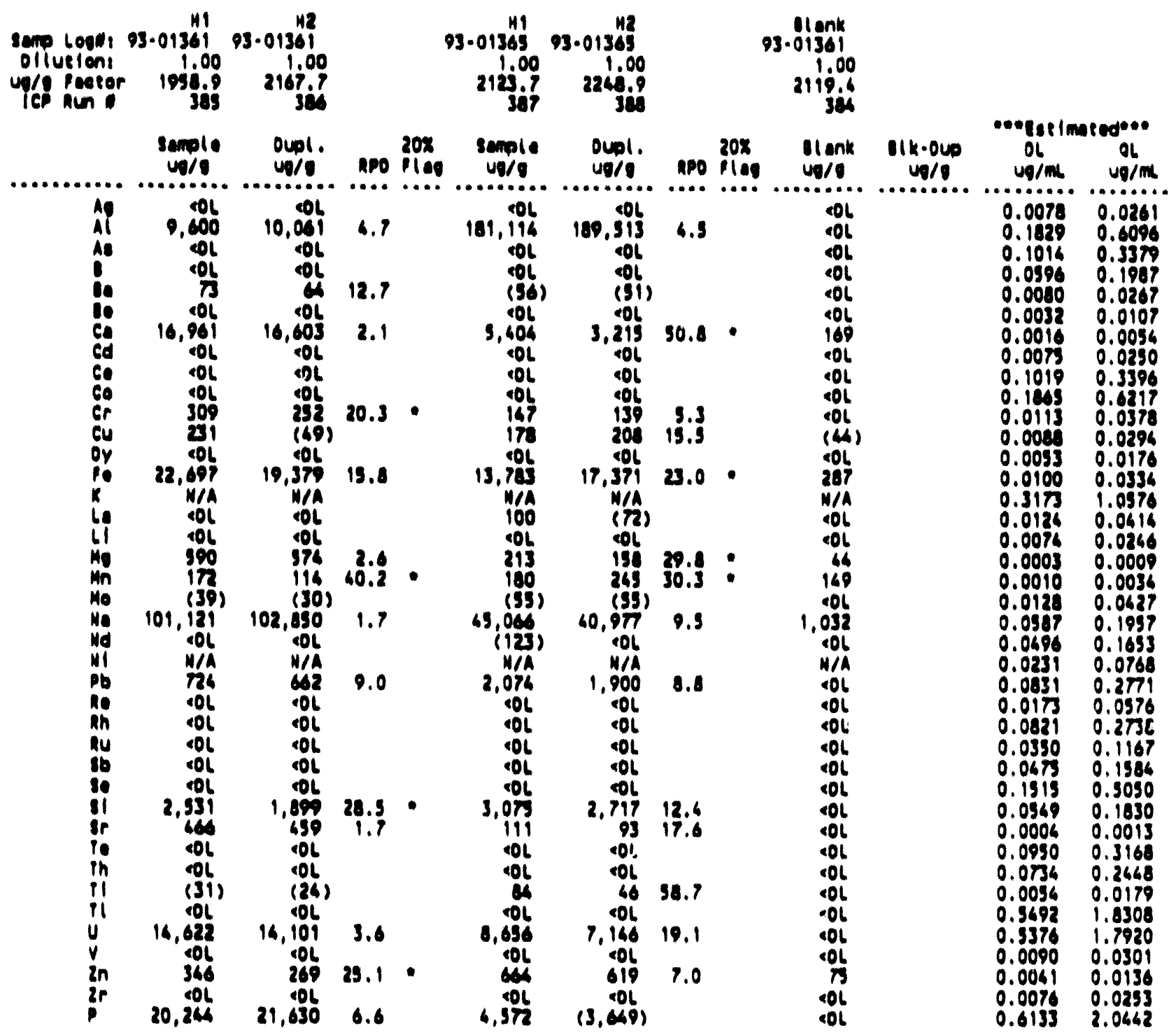

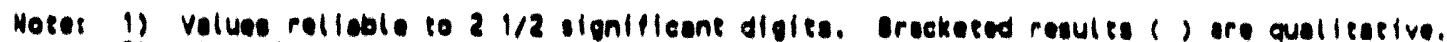

2) Blank ls reported in ug/g "equivalence" to indleate blank of foes on sample.

3) semple resules have noe baen edjused for "blenk" contribuetion.

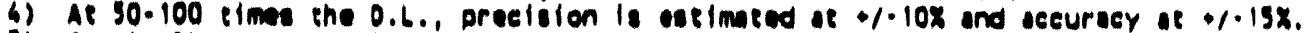

3) semple ol (Ug/g) : (DL in vo/mh) " (vo/g Pactor)

6) off-lim ilcs houvite withingox of potemelally bles high.

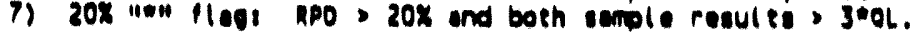

Oete, Including callbrotion/Q6, arehived Blle 160.323.601.01/05/93 
Table 2-1f: SST Core 49, ICP Quarter Segments Fuston

ICP AHALYSTS REPORT ... KOH/NI PUElone

PROJECT! Sst

PROCLDUREI PHL·ALO-211
Analyed Datei 01/05/93

METE! WAS5672

\begin{tabular}{|c|c|c|c|c|c|c|c|c|c|c|c|c|}
\hline $\begin{array}{l}\text { semp logil } \\
\text { ollut loni } \\
\text { ug/g prosor } \\
\text { tep Run }\end{array}$ & $\begin{array}{r}111 \\
03.01366 \\
1.00 \\
2108.6 \\
389\end{array}$ & $\begin{array}{r}12 \\
93.01368 \\
1.00 \\
2204.3 \\
390\end{array}$ & & & $\begin{array}{r}141 \\
-01367 \\
1.00 \\
2228.6 \\
391\end{array}$ & $\begin{array}{r}142 \\
93.01367 \\
1.00 \\
2282.2 \\
302\end{array}$ & & & is & $\begin{array}{l}\text { ed with } \\
\text { 3.01365 }\end{array}$ & & \\
\hline & $\begin{array}{l}\text { semple } \\
\text { ug/8 }\end{array}$ & $\begin{array}{l}\text { Dupl. } \\
\text { uq/9 }\end{array}$ & APO & $\begin{array}{l}20 x \\
1109\end{array}$ & $\operatorname{sanplo}_{u=1 / 0}$ & $\begin{array}{l}\text { Dupl. } \\
\text { ug/s }\end{array}$ & APD & $\begin{array}{l}20 x \\
\text { Plas }\end{array}$ & $\begin{array}{l}\text { llank } \\
\text { ug/g }\end{array}$ & $\begin{array}{c}\text { Blk-oup } \\
\text { ug/g }\end{array}$ & Of & Ug $/ \mathrm{m}$ \\
\hline 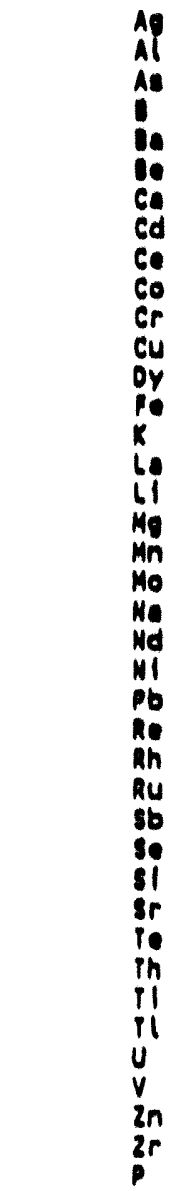 & 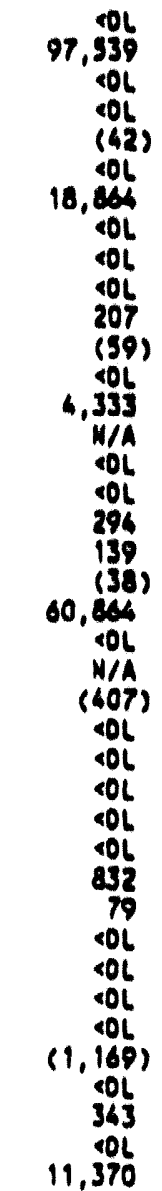 & 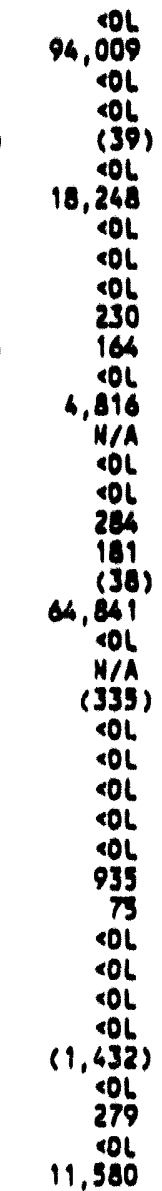 & $\begin{array}{l}10.3 \\
10.6\end{array}$ & - & 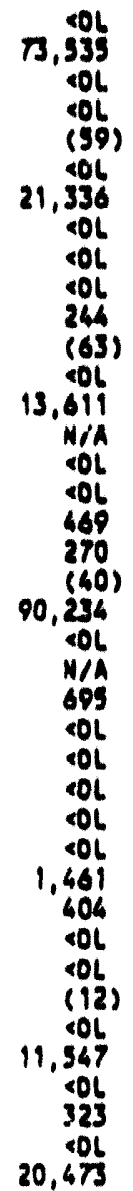 & 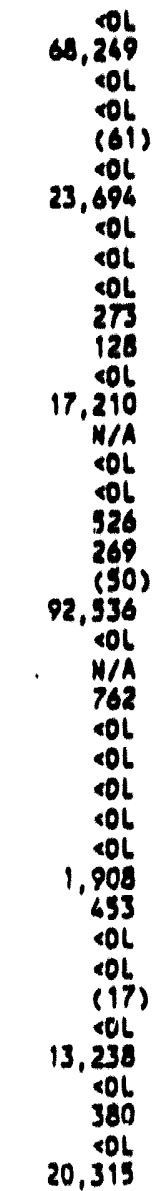 & $\begin{array}{r}11.3 \\
0.4 \\
2.3 \\
0.2\end{array}$ & - & & & $\begin{array}{l}0.0078 \\
0.1829 \\
0.1016 \\
0.0596 \\
0.0080 \\
0.0032 \\
0.0016 \\
0.0075 \\
0.1019 \\
0.1865 \\
0.0113 \\
0.0088 \\
0.0093 \\
0.0100 \\
0.3173 \\
0.0124 \\
0.0074 \\
0.0003 \\
0.0010 \\
0.0128 \\
0.0987 \\
0.0496 \\
0.0231 \\
0.0031 \\
0.0173 \\
0.0081 \\
0.0350 \\
0.0673 \\
0.1515 \\
0.0549 \\
0.0004 \\
0.0990 \\
0.0734 \\
0.0054 \\
0.3492 \\
0.5376 \\
0.0090 \\
0.0041 \\
0.0076 \\
0.0133\end{array}$ & $\begin{array}{l}0.0261 \\
0.0096 \\
0.3379 \\
0.1997 \\
0.0267 \\
0.0107 \\
0.0094 \\
0.0250 \\
0.3396 \\
0.6217 \\
0.0378 \\
0.0294 \\
0.0176 \\
0.0336 \\
1.0576 \\
0.0416 \\
0.0266 \\
0.0009 \\
0.0036 \\
0.0627 \\
0.1997 \\
0.1693 \\
0.0768 \\
0.2771 \\
0.0976 \\
0.2738 \\
0.1167 \\
0.1584 \\
0.5090 \\
0.1830 \\
0.0013 \\
0.3168 \\
0.2648 \\
0.0170 \\
1.8308 \\
1.7920 \\
0.0301 \\
0.0136 \\
0.0233 \\
2.0442\end{array}$ \\
\hline
\end{tabular}

Noter 1) Volues rellable to 2 1/2 ilanlfleane digles. Bracketed rasults () are qualltaplve.

2) Blank 1s reported in ug/g "equivalence" to Ind leate blank offect on semple.

3) sample results have not been odjusted for "blank" coneribution.

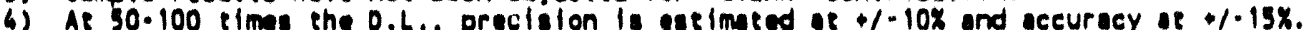

5) semple DL (Ug/g) - (DL in ug/mh) (ug/g Pactor)

6) off-lina Ire? Results within sox of potentiolly bias high.

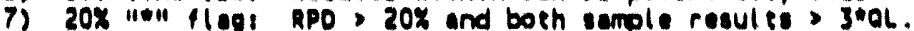

Dats, Ineluding callbrasion/QC, orehived ille ICP.325.601. 01/05/93 
Table 2-1g: SST Core 49, ICP Quarter Segment ID, Top and Bottom, Re-Homogenization Test, Fusion

ICP ANALYSIS REPORT $\cdots \mathrm{KOH} / \mathrm{KI}$ FUSIONS

PROJECT: SST

PROCEDURE : PNL-ALO-211

Analyzed Date: $12 / 02 / 92$

M\&TE: WAS5672

93- 93 -

Samp Log\#: 01367-H1T 01367-H2T

$\begin{array}{lrr}\text { Dilution: } \quad 1.00 & 1.00 \\ & \end{array}$

$\begin{array}{rrr}\text { ug/g Factor } & 2156.4 & 2151.4 \\ \text { ICP Run \# } & 232 & 231\end{array}$

$93-$

$93-$

93.

sample oupl.

$\mathrm{ug} / \mathrm{g} \quad \mathrm{ug} / \mathrm{g}$

Ag $\quad$ SOL $\quad 62$.

$\begin{array}{rrr}\text { Al } & 61,744 & 62,999 \\ \text { As } & <0 L & <0 L\end{array}$

$<\mathrm{CL}$

$20 \%$

01367-H1B $01367-H 28$

$\begin{array}{rr}1.00 & 1.00 \\ 2185.1 & 2193.9\end{array}$

$233 \quad 234$

$01367 \cdot H 3$

(54) (51)

$\begin{array}{ll}<0 L & <0 L \\ 21,659 & 22,196\end{array}$

$\begin{array}{rr}21,659 \quad 22,196 \\ \angle O L & <O L\end{array}$

$\angle O L \quad \angle O L$

$\angle O L \quad \angle D L$

$255 \quad 263$

(58) $\quad 154$

\begin{tabular}{rr}
$<0 L$ & $<14$ \\
$N / A$ & 14,447 \\
\hline & N/A
\end{tabular}

$\angle O L \quad \angle O L$

$\begin{array}{ll}\angle O L & \angle O L \\ 471 & 486\end{array}$

$\begin{array}{ll}471 & 486 \\ 178 & 169\end{array}$

(32)

90,812

90,543

543
$\angle O L$

N/A $\quad$ N/A

N/A
625

$\angle \mathrm{OL}$

$N / A$
745

745
$\angle O L$

$\angle O L \quad \angle O L$

$\angle O L \quad \angle O L$

$<O L \quad<O L$

$\begin{array}{rr}\angle O L & \angle O L \\ 1,257 & 1,477\end{array}$

1,477
412

0.6

Flag

Sample Dupl.

2.0

ug/g

ug/g

$20 x$

230

$\angle O L \quad \angle O L$

$\angle O L \quad \angle D L$

$<O L$

$<\mathrm{OL}$

12,251

$<\mathrm{OL}$
317

$\angle O L$
$\angle O L$
13,080

372

8,653

$<O L$

19,072

2.4

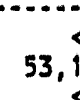

$<\mathrm{LL} \quad \mathrm{OL}$

RPD Flag

Blank Blk-oup

- Estimated"*

$O L \quad Q L$ Ug/g $\quad$ Ug/mL Ug/m.

5.1

$<\mathrm{OL}$

$<\mathrm{OL}$

0.0078

0.0261

$8 \mathrm{~L} \quad 55,933$

$<O L$

(49) (48)

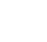

$$
21,443
$$

21,741

1.4

3.1

$<\mathrm{OL}$

$<20$

241
$(56)$
$<01$

5.2

12,753

248
$(48)$
401

12,811

3.1

$\angle O L$
$\angle O L$
$\angle O L$

0.1829

$\begin{array}{lll}0.1014 & 0.3379\end{array}$

$\begin{array}{ll}0.0596 & 0.1987\end{array}$

$0.0080 \quad 0.0267$

$\begin{array}{lll}0.0032 & 0.0107\end{array}$

$\begin{array}{ll}0.0032 & 0.0107 \\ 0.0016 & 0.0054\end{array}$

$0.0075 \quad 0.0250$

$\begin{array}{lll}0.1019 & 0.3396\end{array}$

$\begin{array}{ll}0.1865 & 0.6217\end{array}$

0.01130 .0378

$0.0088 \quad 0.0294$

$\begin{array}{ll}0.0083 & 0.0294 \\ 0.0053 & 0.0176\end{array}$

$0.0100 \quad 0.0334$

$0.3173 \quad 1.0576$

$0.0124 \quad 0.0414$

$0.0074 \quad 0.0246$

$3.2 \quad 40 \mathrm{C}$

5.1

454
128
$<0 L$

0.3

90,231

17.6

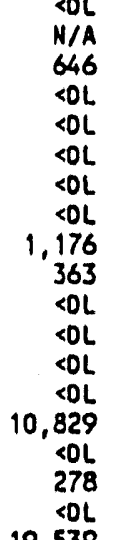

$\angle O L$
$\angle O L$
465

465
102
$<0 L$

22.4

89,172

1.2

NOL

$N / A$
650

0.6

$<O L$
$\angle O L$

0.6

$\begin{array}{ll}0.0003 & 0.0009\end{array}$

$0.0010 \quad 0.0034$

$\begin{array}{lll}0.0128 & 0.0427\end{array}$

0.05870 .1957$.

$\begin{array}{ll}0.0587 & 0.1957 \\ 0.0496 & 0.1653\end{array}$

0.0231 .0 .0768

$\begin{array}{ll}0.0831 & 0.2771\end{array}$

$0.0173 \quad 0.0576$

0.08210 .2738

$0.0350 \quad 0.1167$

0.04750 .1584

0.15150 .5050

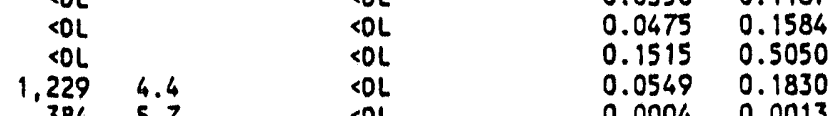

$1.229 \quad 4.4 \quad<0 L$

$\begin{array}{llll}<O L & \angle O L & 0.0950 & 0.3168 \\ \angle O L & \angle O L & 0.0734 & 0.2448\end{array}$

$\begin{array}{llll}<O L & \angle O L & 0.0734 & 0.2448 \\ \angle O L & \angle O L & 0.0054 & 0.0179\end{array}$

$6.5 \quad 10,829$

$11,783 \quad 8,4$

16.0

2.2

19,539

$<0 L$
273
$<0 L$
18,624

$8.4 \quad \angle O L$

$\begin{array}{lll}0.5492 & 1.8308\end{array}$

$0.5376 \quad 1.7920$

$0.0090 \quad 0.0301$

0.00410 .0136

$0.0076 \quad 0.0253$

$0.6133 \quad 2.0442$

Note: 1) Values rellable to $21 / 2$ significant digits. Bracketed results () are qualitative.

2) Blank is reported in ug/g "equivalence" to indicate blank effect on sample.

3) Sample results have not been adjusted for "blank" coneribution.

4) At 50-100 times the $0 . L$.. precision is estimated at $+1-10 \%$ and accuracy at $+1-15 \%$

5) Sample $O L(\mathrm{ug} / \mathrm{g})=(\mathrm{DL}$ in $\mathrm{ug} / \mathrm{mL}$ ) * (ug/g Factor)

6) Off-line IEC: Results within 50X DL potentially bias high.

7) $20 \%$ "1*1" flag: RPD > 20\% and both sample results > 3*QL.

Data, including calibration/OC, archived file ICP-325-601-12/02/92 
Table 2-2a: SST Core 47, ICP Core Composite Acid Digestion

ICP ANALYSIS REPORT $\cdots$ ACID OIGESTION

Projece: SST

Procactura: PHL-ALO-211
Analyzed Oare: $01 / 18 / 93$

MGTE: WASS6T⿱

Page 1 of 2

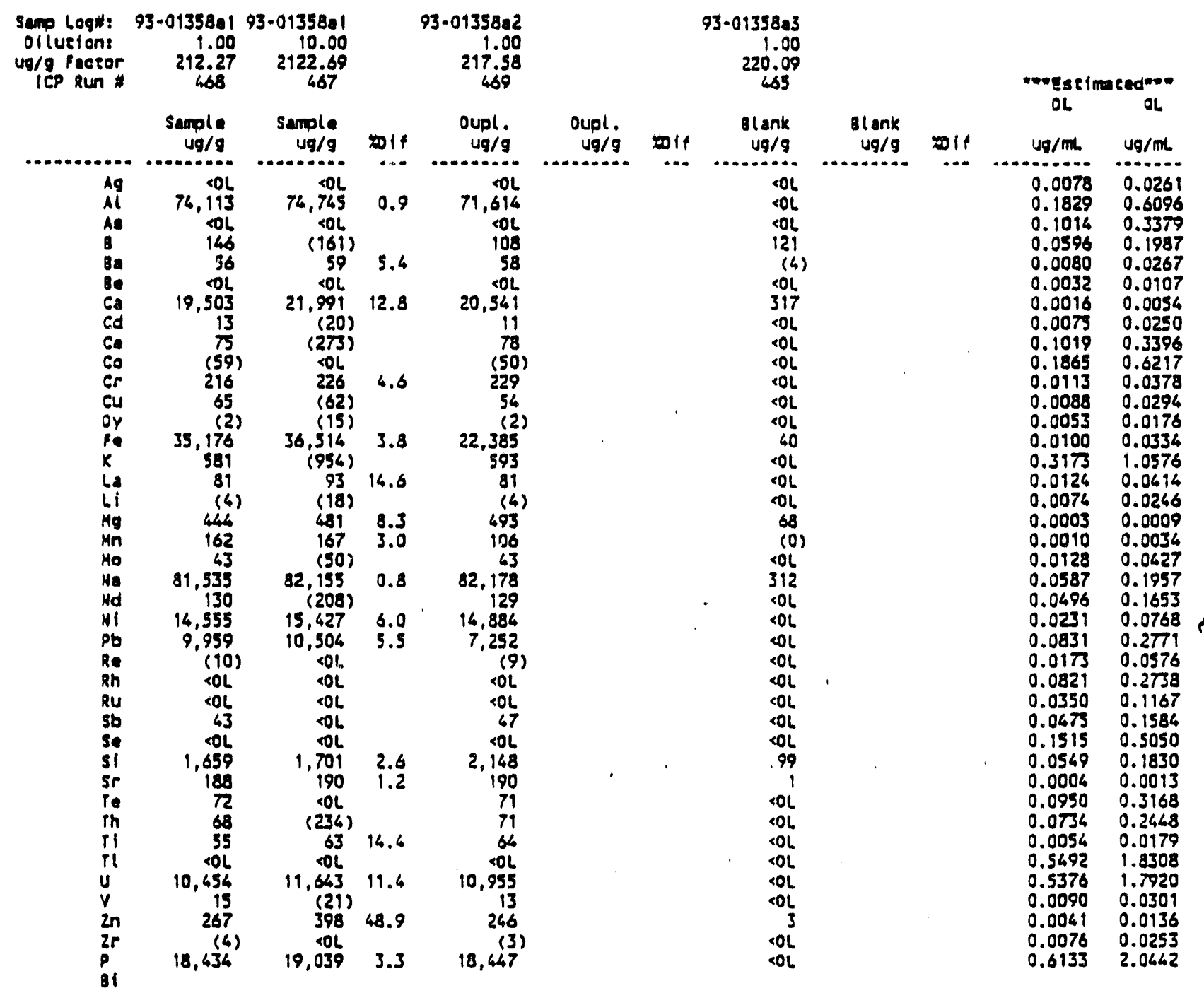

Note: 1) Values reliable to 2 1/2 significant digits. Bracketed results () are qualitacive.

2) alank is repored in ug/g "equivalence" to indicate blank effect on sample.

3) The process "glank" has not been suberacted from the "Sanole o Ouplicata" results.

4) At 50-100 times the 0.L., precision is estimated at $+1 \cdot 10 \%$ and aceuracy at $+1 \cdot 15 \%$.

5) "Eseimared" sample Oececetion Limie (ug/g) = (OL in ug/mh) " (ug/g Factor)

6) off-line IEC: Results within 5OX oL porentially bias high.

Daca, including calibracion/OC, archived File ICP-325-601 01/18/93

$01 / 21 / 93$ 


\section{WHC-EP-0668}

Table 2-2b: SST Core 47, ICP Core Composite Acid Digestion QC Results

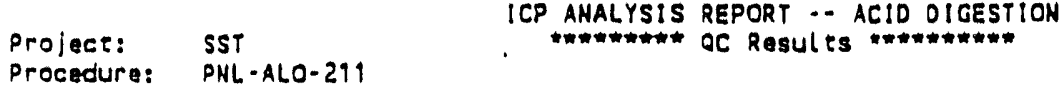

Analyzed: $01 / 18 / 93$

M\&TE: HAS5672

Page 2 of 2

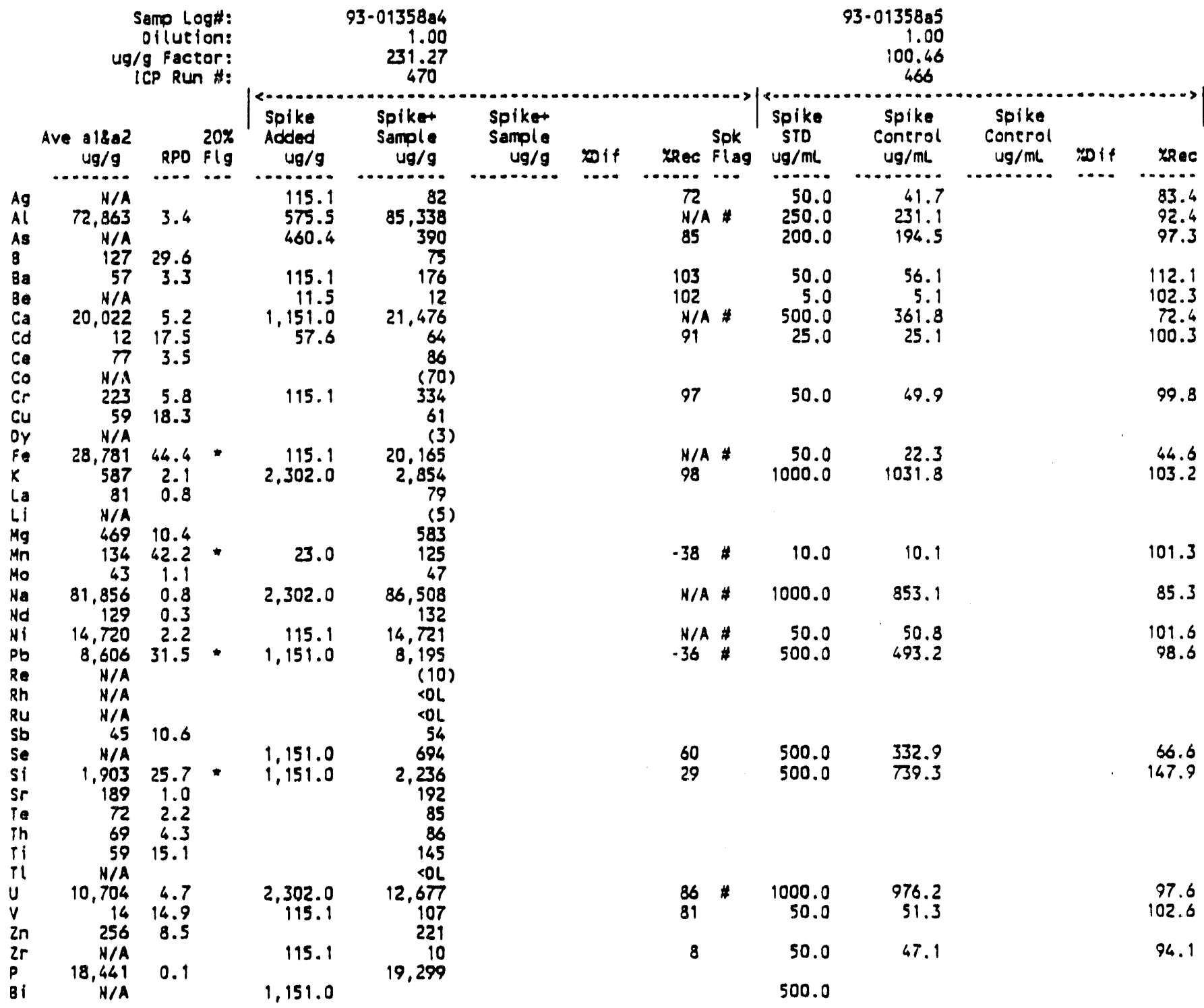

Note: 1) Values reliable to 2 1/2 significant digits. Bracketed results () are qualitative.

2) At 50-100 times the $0 . \mathrm{L}$.. precision is estimated at $+/-10 \%$ and accuracy at $+/-15 \%$.

3) The process "glank" has been subtracted from the "Spike Control" results.

4) Spike flag (\$): Spike is less than $25 \%$ of sample concentration; Xrecovery for information only.

5) 20\% Flag (*): RPD > 20\% and both sample and duolicate results> 3*QL.

6) If spike is <10\% of samole concentration, yRec is not calculated as indicated by the "n/a". 
Table 2-2c: SST Core 48, ICP Core Composite Acid Digestion

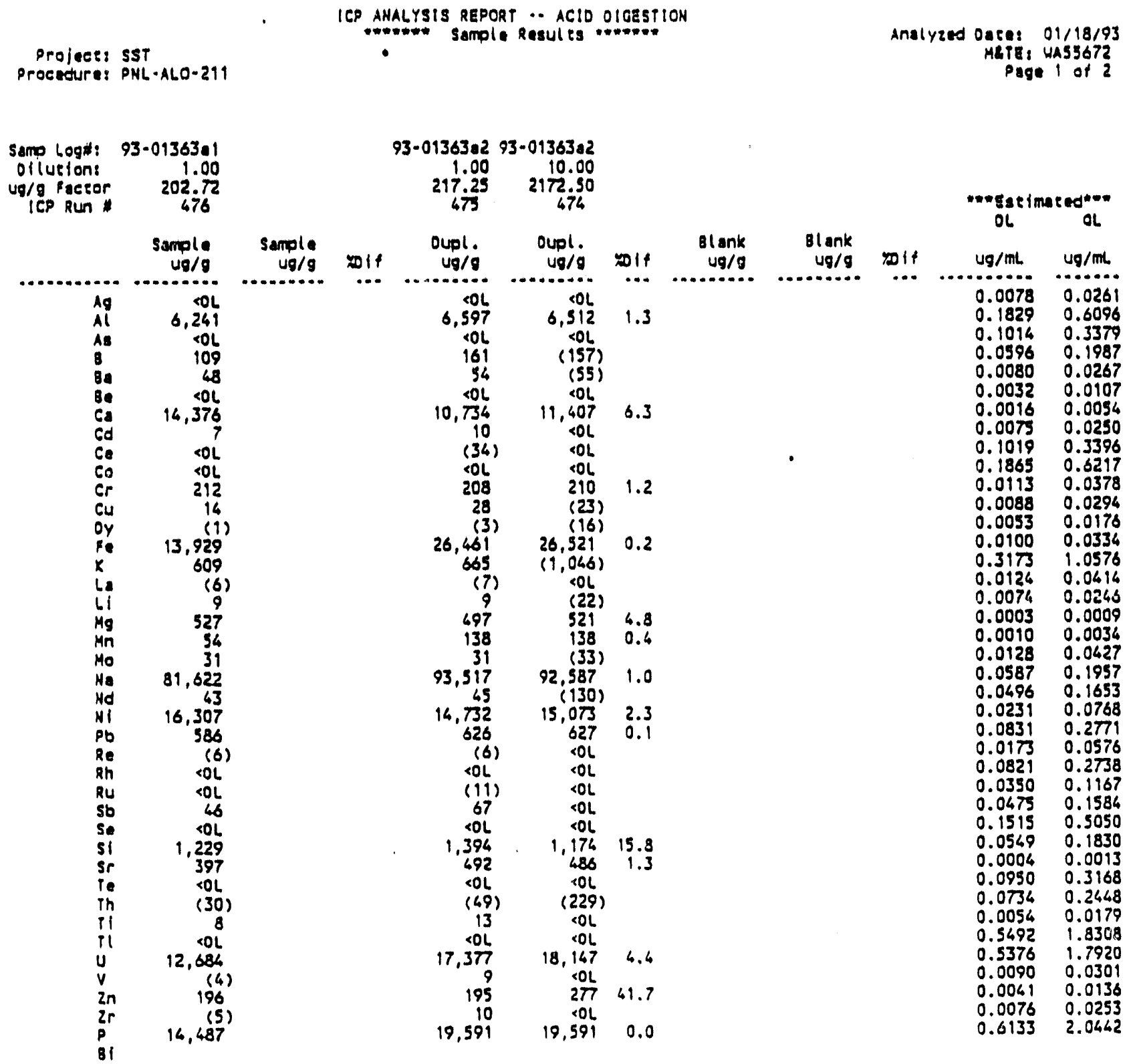

Hote: 1) Vatues reliable to 2 1/2 signiticant digits. Bracketed results () are qualitative.

2) Blank is reported in ug/g "equivalence" to indicate blank effect on samole.

3) The process "glank" has not been suberacied from the "Samole \& ouplicace" results.

6) At $50-100$ eimes the $0 . L$. precision is escimated at $+1.10 \%$ and accuracy at $+1-15 \%$.

5) "Estimated" Samole oetection Limit (ug/g) = (DL in ug/mL) - (ug/g Factor)

6) off-line IEC: Results within $50 x$ ol potencially bias high.

Oata, Including callbration/OC, arehived flle 1CP-325-601 01/18/93 
Table 2-2d: SST Core 48, ICP Core Composite Acid Digestion QC Results

Prolects SST

Procedure: PNL.ALO-211 ICP ANALYSIS REPORT * ACIO DIOESTION
Analyzivd $01 / 18 / 93$

Meis: WA53672

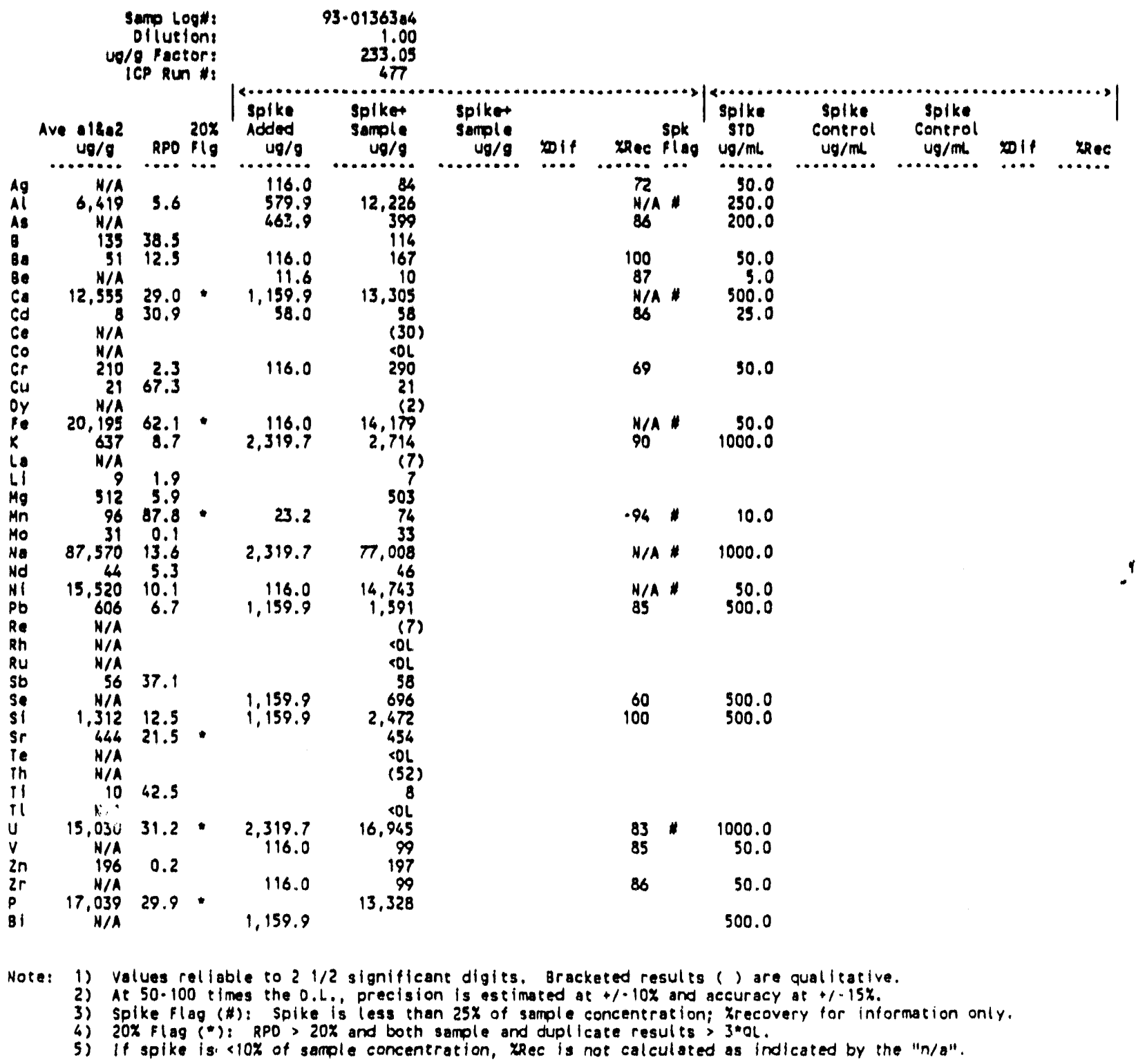

$01 / 21 / 93$ 
Table 2-2e: SST Core 49, ICP Core Composite Acid Digestion

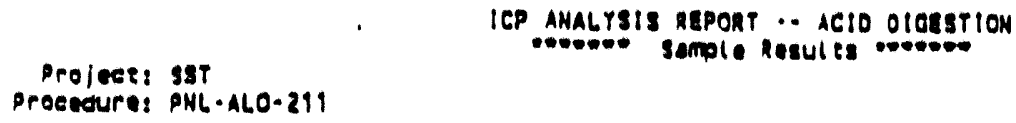

Hote:

1) Voluas rellable to 2 1/2 signiflcant digies. Bracketed resules ( ) are qualleacive.

2) Blank is reported in ug/g "equivalence" to indicate blank offece on samole.

3) The process "glank" has not baen suberaced from the "Sample oupl icace" resules.

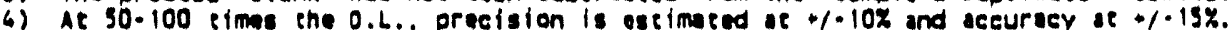

5) "Estimared" semple Oetection Limit (ug/g) " (OL in ug/mh) " (ug/g Factor)

b) ofteline lec: Rasules wienin sox oL porenelally bias high.

Qaea, Inctuding callbracion/OC, archived flle $1 \mathrm{CP} \cdot 325 \cdot 60101 / 18 / 93$ 


\section{WHC-EP-0668}

Table 2-2f: SST Core 49, ICP Core Composite Acid Digestion QC Results

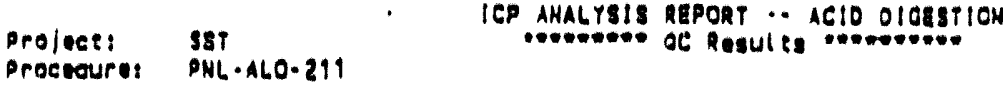

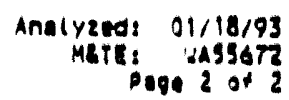

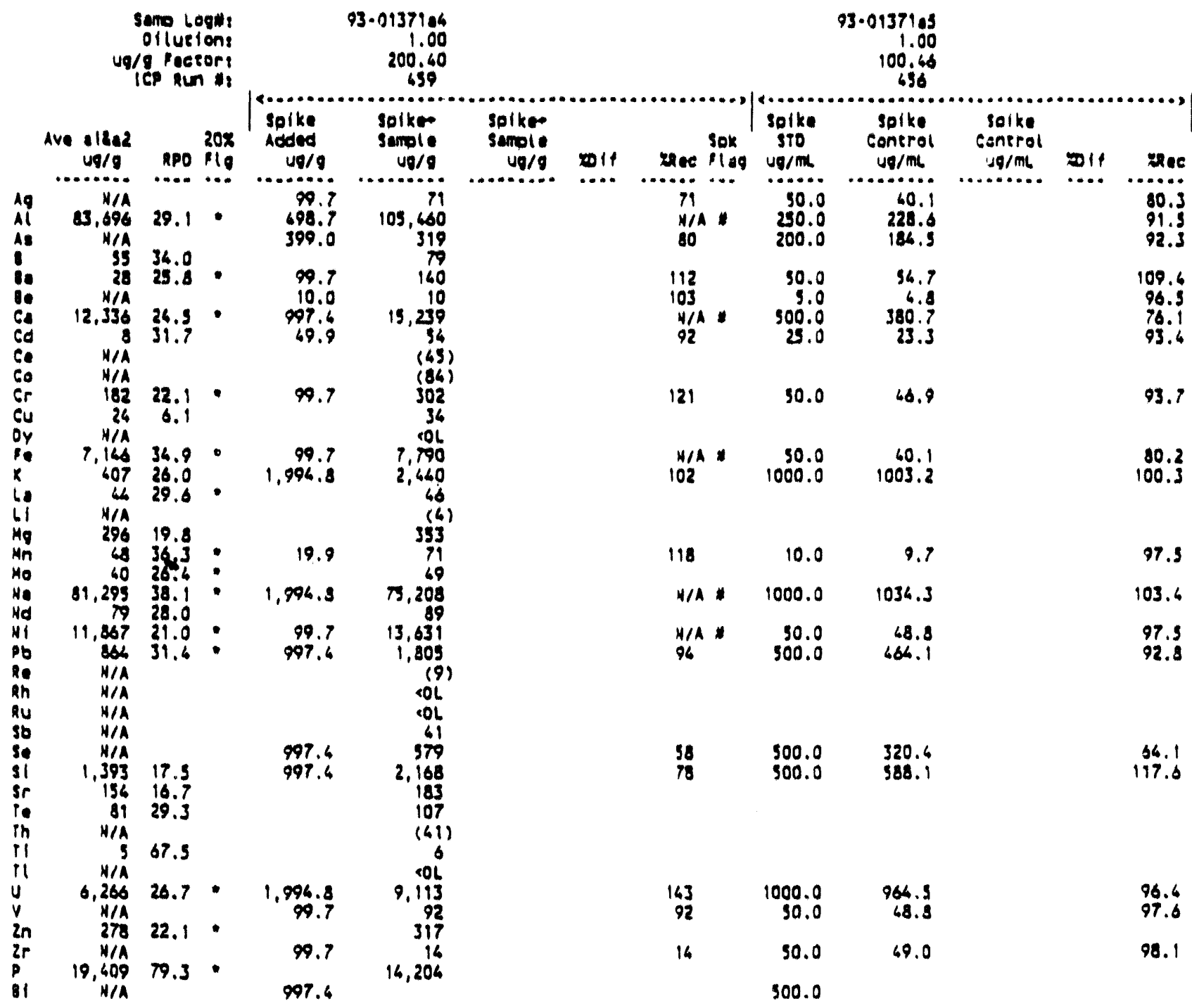

Wotes 1) Values rellable to 2 1/2 significant digits. Brackefed resules ( ) are qualitative.

2) At 50-100 eimes the 0.6 . precision is eseimated at $* 1 \cdot 10 x$ and sceuracy at $+1.15 \%$.

3) The process "glank" has been subtracend trom the "Spike Conerol" results.

6) Soike flap (t): soike is lese then $25 x$ of semple coneeneracion; yrecovery for information only.

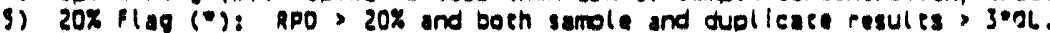

6) If spike is e10x of sample concentration, thee is not calculated as indicated by the "n/a". 
WHC-EP-0668

Table 2-2g: SST C-109, ICP Llquid Composite Actd Digestion

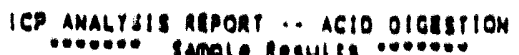

Proleets ist

Procodures OHL. ALO-211

\author{
Anolved oacet $01 / 22 / 93$ \\ Mert: wassor? \\ ouge 1 of 2
}

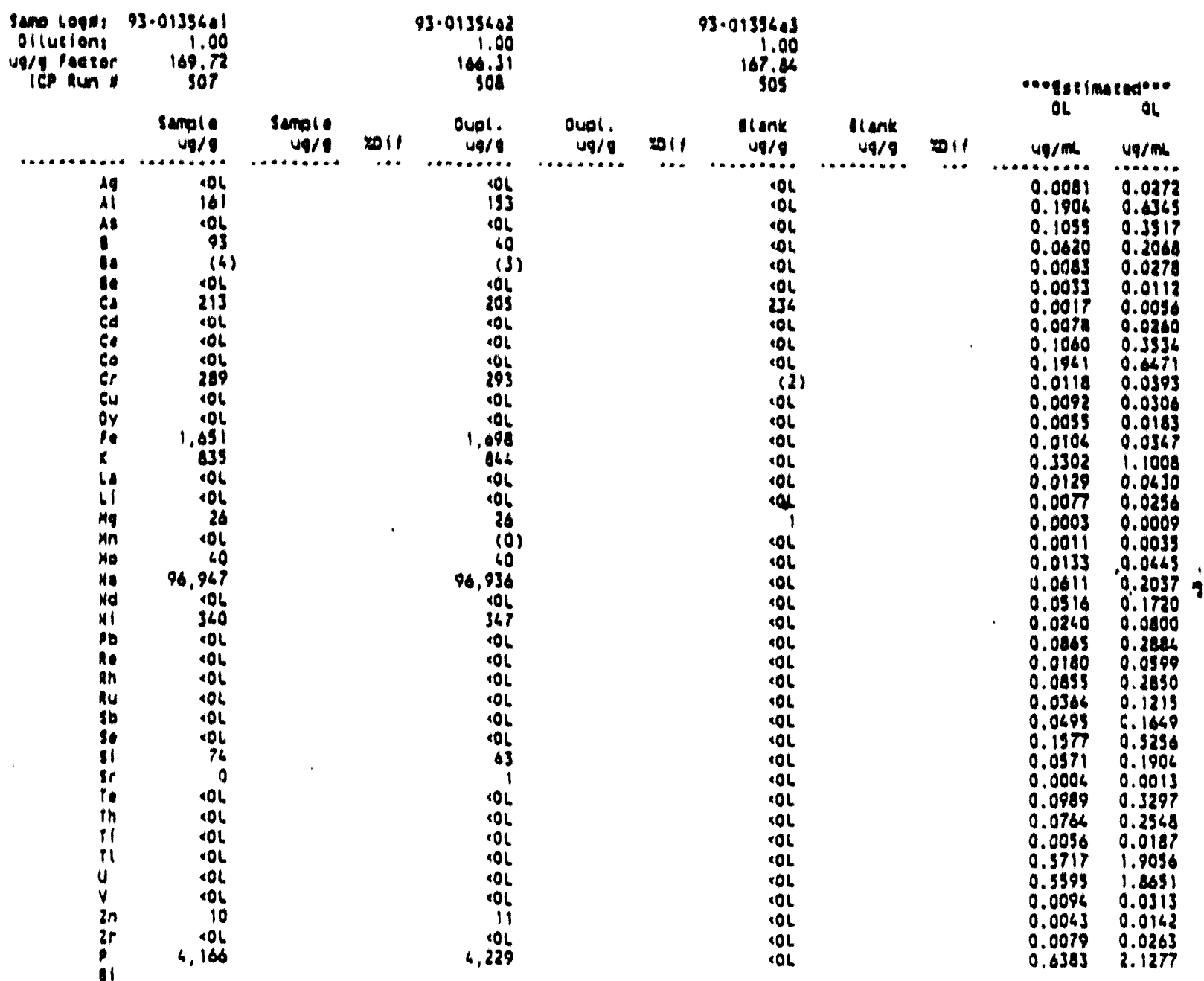

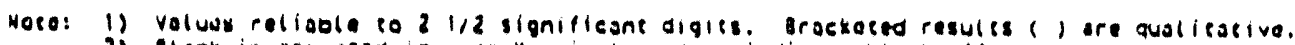

2) Ilank it reported in wg/g "equivalenea" 10 indicase blank effece on sainole.

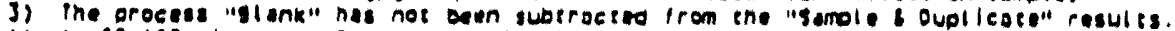

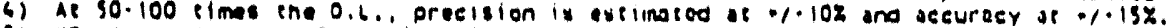

5) "Estimacea" samola Oecection limis (ug/g). (OL in vg/mh) " (ug/g Iac:or)

b) Off.line les: Resules dithin sox ob porencially bias hign.

Oata, including salibroeion/OC, arenived file 1CP.325.601 01/22/93 
Table 2.2h: SST C-109, ICP Llquid Composite Acld Digestion QC Results

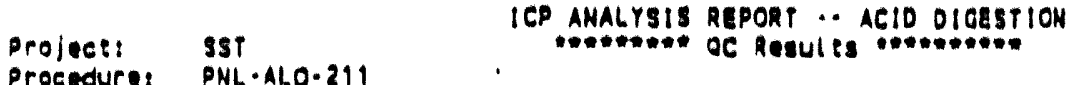

Analyzed $01 / 22 / 93$

MEIE! WABSOT2

Page 2 of 2

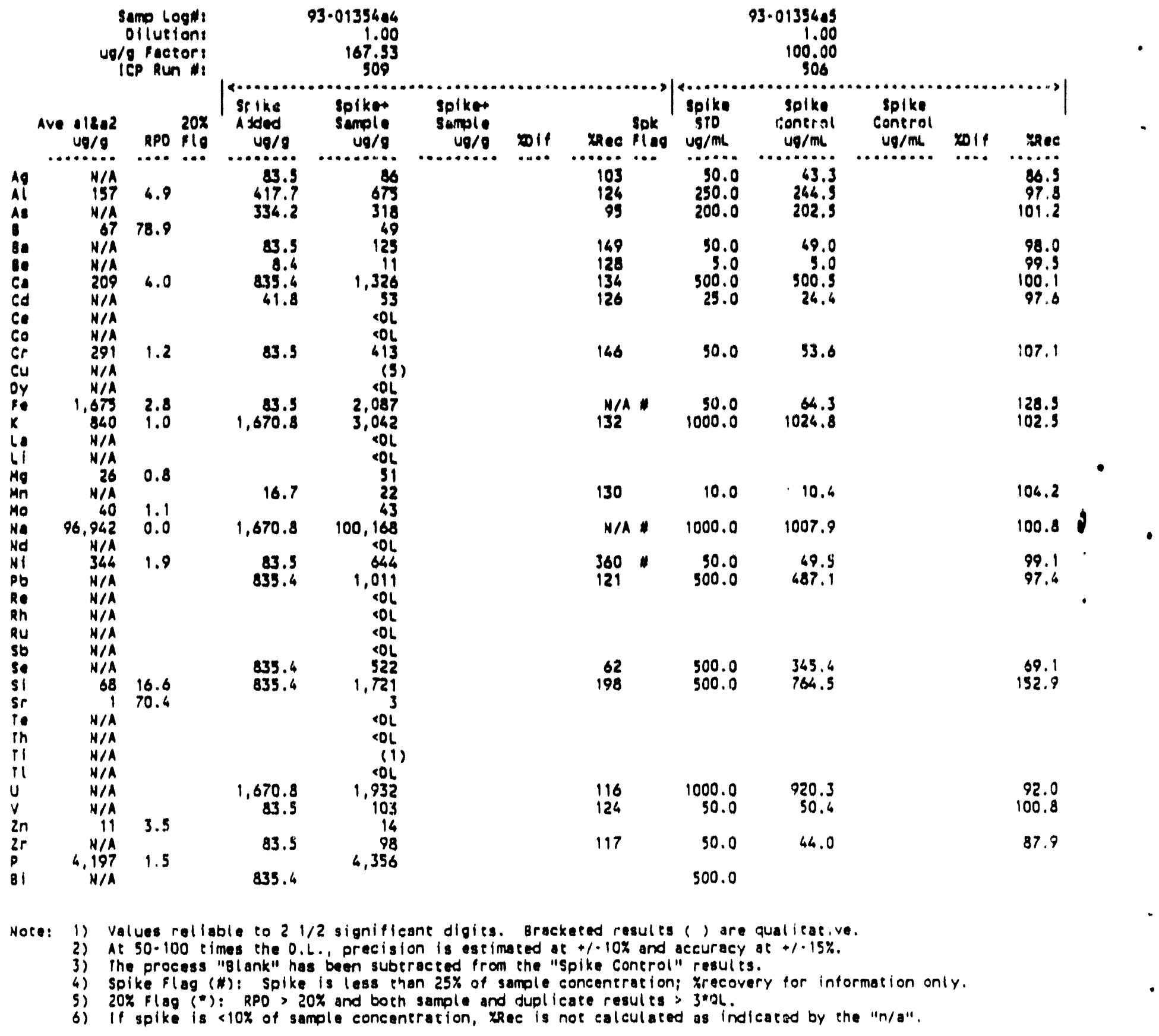


Table 2.21: SST Core 48, ICP Quarter Segment 10, Top, Homogenization Test, Acid Digestion

ICP ANALYsis mepont *. Aeld Olgoseton

PhOJECT! IET

MROCEDURII PNL-ALO-211

93.93

seme loght i361-A1t i361-A1t

vollueton: 199.009 .00

ug/g neeser $199.3 \quad 997.6$ $\begin{array}{cr}93 . & 93 . \\ 1361 \cdot 127 & 1361 \cdot 129 \\ 1.00 & 9.00 \\ 199.9 & 179.0 \\ 153 & 179\end{array}$

senple semple semple semple

semple semple temple Semple

semple semple

$06 \quad 04$

.76

111

45

.260

13,260

106

201
218

06

23,4

(7) 06

986

102
31

119.982

$7,(31)$

120,108

(3) 406

$.01 \quad 06$

$\begin{array}{cc}.06 & 80 L \\ 63 & 01\end{array}$

912

43

401
.01

15,380

(3)

207

26,887 49/9 mit .....

ug/9 up/s wolf

.062

(116)

462.6

7.07211.

(8)

01
227 4.3

(10)

401

24,893

(371)

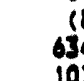

(8) 836.

(35)

)

18,131

6513.8

806.06

14 olank $\operatorname{llan}$

$7,800.9$

(ol

(a2)

89

63
.01
193

16,193

ob

230

.230

.06
.06

1960

OCL

ot

$13,270.1$

$\begin{array}{rr}13,747 & 13,727 \\ 527 & (393)\end{array}$

327

(196)

(ii)

398
60
27

(28)

$121, \frac{27}{357}$

120,622

$19,782 \quad 1.6$

3842.8

.06

ol

$\underset{01}{\infty}$

89617.

4091.2

ol

ob

(b)

.01

432.9

201

19,802

$\begin{array}{llll}2.7 \quad 16,305 \quad 16,48 & 0.6\end{array}$

26929.7

$28,242 \quad 3.0 \quad 30,819$

$28,242 \quad 3.0 \quad 30,819$
.01

24629.3

(16)

$31,0150$.
Analyeed oocel 11/13/92

Mbit! Wasgarz

Hotes 1) Volues rallable to a $1 / 2$ signifleane digles. Bracketed resules ( ) ore guelieaclve.

2) Blank la reporead in ug/g "equivalenea" co indleate blank effece on samole.

3) Semple results hove not been adjusted for "blank" coneribution.

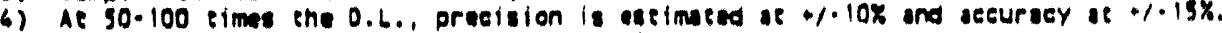

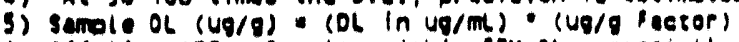

6) Off-line IEC: Regulte viehin gox ol poemeially bies high.

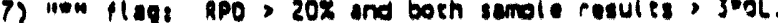

8) Berelenium Channal nan-funetional.

Dets, ineluating ealibration/oc, arenived flle 160.323.601. 11/13/92 
Table 2.2J: SST Core 48, ICP Quarter Segment 1D, Bottom, Homogenization Test. Acld Digestion

16P ANALPSIS atpont -. Aeld OIpostion

MONEST, 881

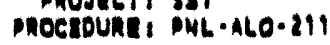

93. 93.

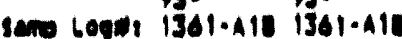

ollueton: $1.00 \quad 9.00$

vele Peetor $200.5 \quad 1002.6$

teping ist 178

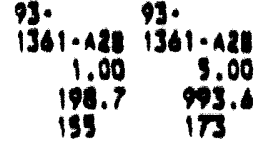

Analyzed Oefel $11 / 13 / 92$ metli wassore

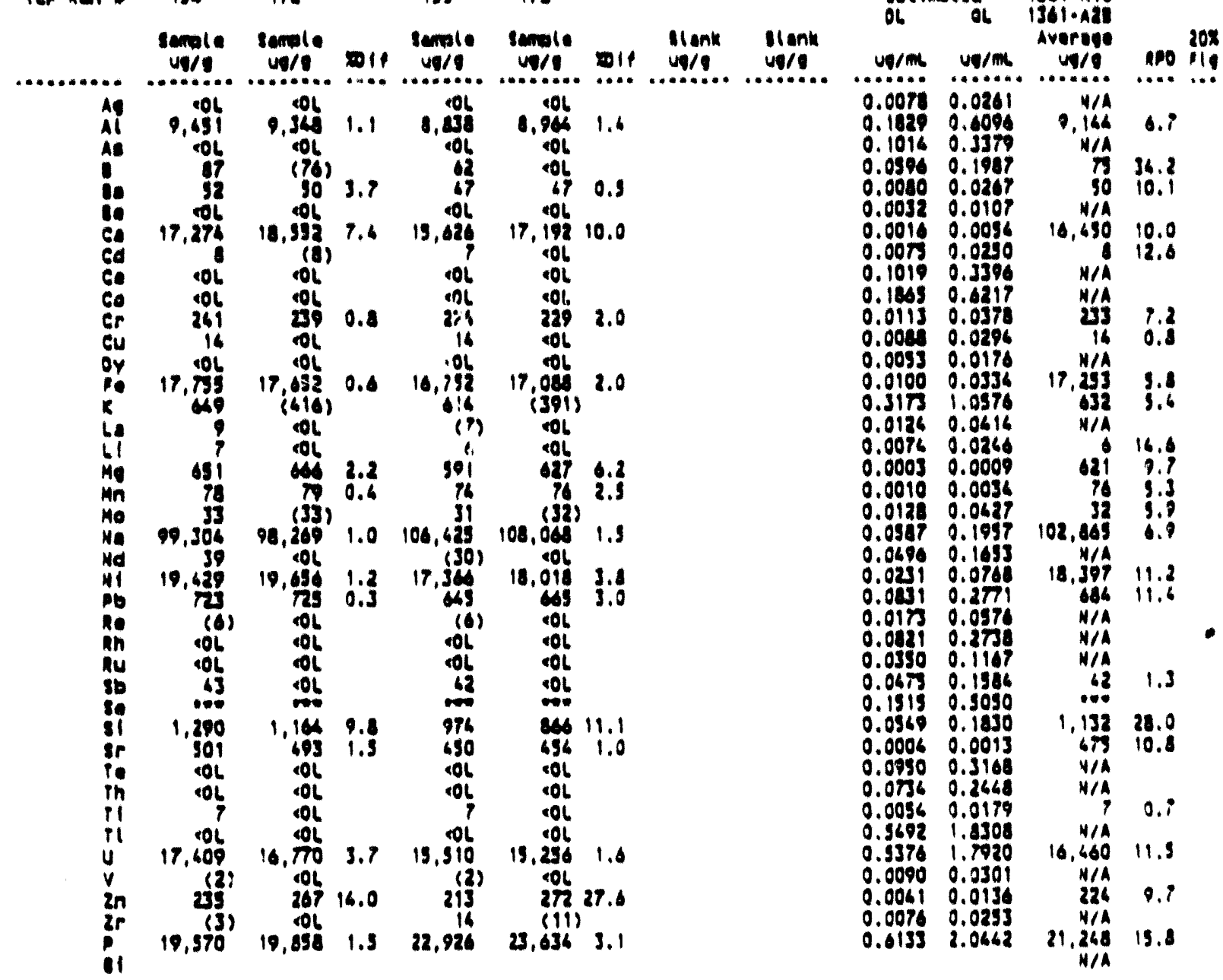

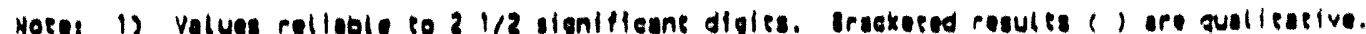

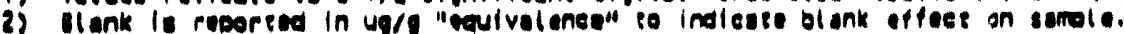

3) semple peaults have not boen adlused lor "blank" coneribuelon.

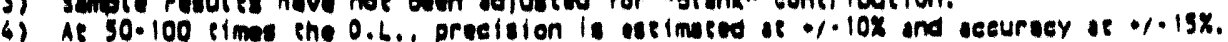

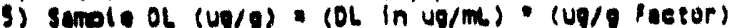

6) Off-lina leci Resules wienin gox ol poesenerally bias nigh.

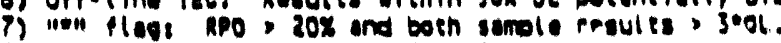

8) W. Selenium channal nen-funational.

Onea, Ineluding eallbration/oc, arehived flle 168.325.501. 11/13/92 
Table 2-2k: SST Core 49, ICP Quarter Segment 10, TOp, Homogenization Test, Acld Digestion

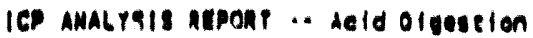

mojets gst

Mnocioune: PNL.ALO-211

samp tond1 1367-A1t i367-A1t

olluetons $1.00 \quad 9.00$

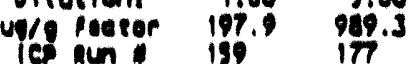

semple serple semple somple

43. 93. $367 \cdot$-121 1367.127

$$
\begin{array}{r}
1.00 \quad 5.00 \\
191.0 \quad 98.0
\end{array}
$$

..............

w/.

39.896

39.402

0.7

4,980

Al $39,402 \quad 30,010$

io

e. 16,06

cu

oy

is

in

$M_{M_{0}}$

115,2

16 (12)

0.06

0.961

309

48

.30

(113)

of

06

2.3

68

0.04

730.6

ot

of

30.9

.06

$.6 \% 11$.

(a)

10,37

106
206

$\infty 6$

2231.

(16)

iog 1.5

(980)

(14)

(13)

60

cos 4.

(36)

$116.000 \quad 0.7$

(33)

11.07

12. 208

$504 \quad 6.0$

(s) 201

$.06 \quad 06$

(25)

(2)

11

297

(39)

(ol

(3)

0,908

170

32,270

(96)

290.3

106

ol

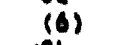

(6)
.06

이

21728.1

(10)

$33,3613.6$

11.938

925
10

696

5233.9

o1 2.7

4,98

4313.0

0.800 .3

(7)

14.1983 .6

-OL

OL

(36)

(1)

a.9 3.4

4060.2

106

- Ob

(7)

201

13.616

(4)

13,31

273.7

(16)

13
982

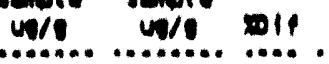

ca $14,4615,91$

co ob it it

nI 11,87

at 1.8

$19,1033.1$ untent dienk

93. 93.

$\begin{array}{rr}367 \cdot 43 & 1367: 43 \\ 1.00 & 9.00 \\ 104.0 & 97.9\end{array}$

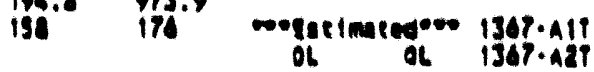

49/8.

ve/m ve/m average

$40.007 \quad 0.0261$

0.10290 .6096

0.10140 .3379

0.09960 .1909

0.00900 .0267

0.00320 .0107

0.00160 .0056

0.0070 .0290

$0.1019 \quad 0.3396$

0.18930 .0217

0.01130 .0370

0.0040 .0294

0.00530 .0176

$0.0100 \quad 0.0334$

0.3175 i.0576

0.01260 .0616

0.00740 .0266

0.00030 .0009

$0.0010 \quad 0.0034$

$0.0128 \quad 0.0627$

0.09870 .1997

0.06960 .1653

0.02310 .076

0.04310 .277

0.01730 .0576

0.08210 .2738

$0.0350 \quad 0.1167$

0.04730 .1984

$0.0560 \quad 0.1830$

$0.0006 \quad 0.0013$

$0.0950 \quad 0.3168$

$0.0736 \quad 0.2648$

$0.0054 \quad 0.0179$

0.33761 .7920

$0.0090 \quad 0.0301$

0.00610 .0136

0.00760 .0233

106

.OL
0.19190 .5050

0.96921 .8308

$0.0133 \quad 2.0442$
N/A

42, 998

N/A

73

N/A

17,009

$n / 4$

$n / A$

196

is

10. 18/

, 189

?6

N/A

461

36
, 215

01,215

13.78

in

$M / A$

WIA

N/A

7130.9

39230.8 .

W/A

N/A

M/A

11,962

N/A

10926.6.

1166.8

29.630

16.7

3.1

27.8 .

32.4

26.2 .

35.2

23.9 .

$11.3:$

28.8.
$20 x$ 10011

26.6.

27.1 .

32.0 .

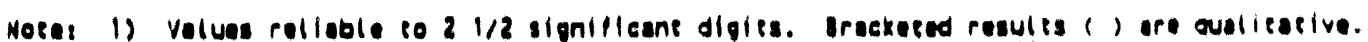

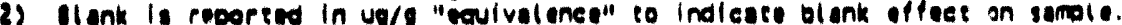

3) semple resules have not been adjusted for "blank" ceneribuetion.

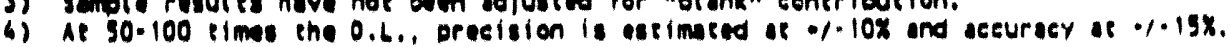

5) senole OL (Ug/g) . (OL in Ug/ms) " (Ug/g loctor)

6) Off-line lies Resules wienin gox ol doceneially bias nigh.

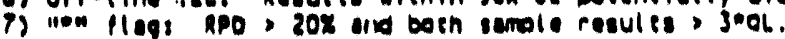

b) -.e. selenium chamel non.funesional.

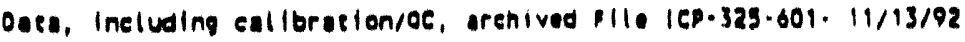

$11 / 24 / 92$ 
Table 2-21: SST Core 49, ICP Quarter Segment 10, Bottom, Homogenization Test, Acld Digestion

16. AHALYSIS REPOAP .. Aeld Oigestion

phouget, int onoctounti PNL-ALO-211

93. 93. seme legen 1367-410 1367:A18 olluetent $1.00 \quad 9.00$ ye laeser 196.3 ing latur 161 in

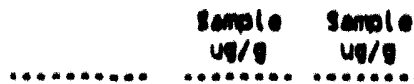<smiles>CC1CCCC1CO</smiles>

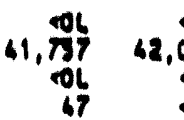
06 , 086 क6. 30

16,998 106

11,670

106

06

1803

(12)

104

9,050

9,195

(463)

$(7)$

41

(17)

07,982

12.918

9.912

508

ol ol ol

37

023

312

(39)

106

(3)

10,027

$\begin{array}{ll}43 & 0.1 \\ 4 & 3.2\end{array}$ (3)

19,697 (5.)

13.3993 .8

oL.

01

106

$\begin{array}{ll}369 & 0.6 \\ 313 & 0.9\end{array}$

.06

(6)

(3)

10.317

117

$\begin{aligned} & 04 \\ & 220\end{aligned} 22$.

20,901

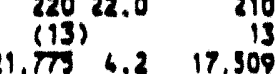

91. 93.

1367.428 1347.429

198.1

162100

-ongelmateace 1367.410

Ienite stingle $4 / 9$

elank vienk ........... volo vele

of at $\begin{array}{r}1367 \cdot a 21 \\ \text { Average }\end{array}$

ve/me ve/mi

0.00780 .0261

0.18290 .6098

$0.1014 \quad 0.337 \%$

0.05460 .1907

$0.0080 \quad 0.0267$

0.00320 .0107

0.00160 .0056

0.00750 .0290

0.10190 .339

0.18450 .6217

0.01130 .0378

0.0040 .0296

0.00530 .0176

$0.0100 \quad 0.0336$

0.3171 .0576

0.01260 .0416

0.00760 .0266

0.00030 .0009

$0.0010 \quad 0.0036$

0.01280 .0427

0.03870 .1957

0.04960 .1653

0.02310 .0760

0.00310 .2771

0.0170 .0576

0.08210 .278

$0.0350 \quad 0.1167$

0.0670 .1984

0.13150 .5050

0.03690 .1830

$0.0006 \quad 0.0013$

$0.0950 \quad 0.3164$

$0.0736 \quad 0.2468$

0.00560 .0178

0.56921 .8308

$0.5376 \quad 1.7920$

$0.0090 \quad 0.0301$

0.00610 .0136

0.00760 .0233

0.61332 .0462

ve/9.

46,279

11.4

$\begin{array}{rr}46 \\ 12 & 6.6\end{array}$

N/A

17,797

10.8

NIA

N/A

$1998 . ?$

N/A

10,112

21.0 .

68616.0

N/A

6211.2

3221.2

$0,023 \quad 9.6$

3917.1

13.87313 .8

362

N/A

N/A

$4 / 4$

60

673

360

$N / A$

N/A

11,070

N/A

19519.2

20928.1

(13)

0.61333 .0442

19. 205

20x

110

, 4

.6

6.9

$?$

0

3.3

13.3

16.8

18.7

26.6

Noest i) Values rellable to $21 / 2$ signifleane digles. Brackesed pesules ( ) ore oualleatlve,

2) Dlank is regores in ug/g "cevivivelence" so indieate blank effect on sample.

3) Semple results have nop been adjusted for "blank" centribueion.

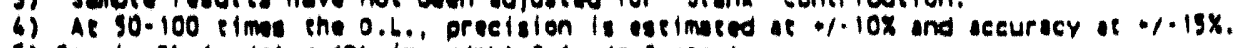

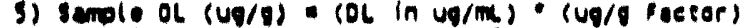

6) offelline leci Resules within sox or poenelally bles high.

7) $110+$ flagt $900,20 x$ and boen sample resules, $300 \mathrm{~L}$.

8) *wo seteniun channal non.funetional.

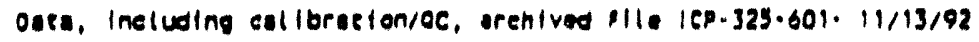


Table 2-3a: SST Core 47, ICP Core Compost te Water Leach

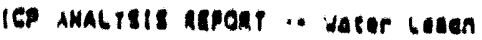

Mojt67: ser

MROGLOURE: MHL.ALO-211

Anotyen ogetei/21/93 Merti waghers

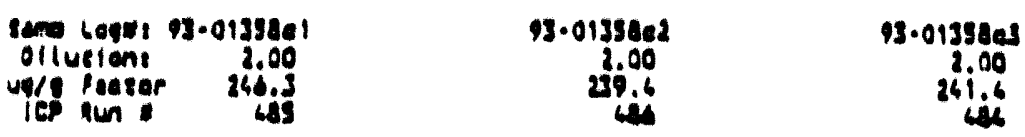

ies in

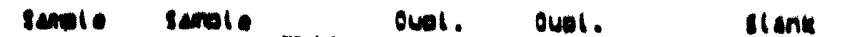

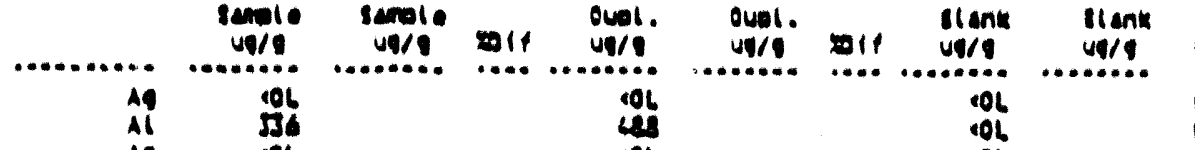

A1

(14)

1806

1211

173

196

196

cd 01

$\begin{array}{ll}60 & 06 \\ 60 & 196\end{array}$

06

106
176

06

196

gr.

406

106

86

26

4,028

106

21

69,353

806
109

(41)

(5s)

01
01
$0 L$

106

106
112

ot

.01

at

122

.06

.06

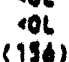

(196)

106

0,369

7.629

106
06
01

of of ivertige

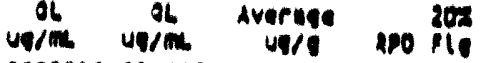

0.0081 0.027z v/A

0.19060 .1365

$0.10350 .3917 \quad \mathrm{~N} / \mathrm{A}$

$0.0620 \quad 0.206 \mathrm{~N}$ N/A

0.0040 .0270 n/A

$0.0033 \quad 0.0112 \quad$ N/A

0.00170 .005

0.00780 .0260

îs

43

$0.1080 \quad 0.3536$

0.19610 .471

0.01180 .0393

0.00920 .0100

0.0095
0.0085
0.0 .0183

0.01040 .0347

$0.3302 \quad 1.1004$

0.01990 .0630

0.00770 .025

0.00030 .0009

0.00110 .003

0.01330 .0468

0.06110 .2037

0.03160 .178

$0.0260 \quad 0.0800$

0.08450 .2846

0.01800 .0599

0.04550 .2850

0.03460 .1215

0.06950 .146

0.15770 .5256

0.09710 .1906

0.00060 .0013

0.09890 .3297

0.07460 .2548

$0.0056 \quad 0.0187$

$0.5717 \quad 1.9056$

0.95951 .845

$0.0096 \quad 0.0313$

0.00630 .014

0.00790 .0263

$0.6383 \quad 2.1277$

Y/A

W/A

V/A

1761.8

M/A

N/A

87.1 .3

M/A

80.8

2

67,790

VIA

125

3.1

3.2

3,0

N/A

$N / A$

$M / A$

$4 / A$

1179.9

M/A

26.7 .

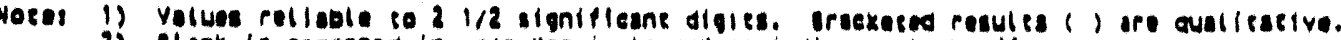

3) Blank is regarred in va/g "revivolenen" so indiease blank offect on iumple.

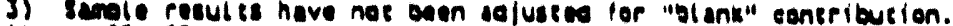

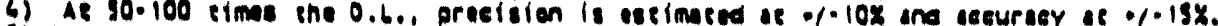

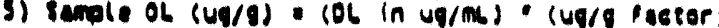

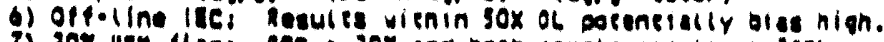

7) $20 x$ now flagi heo, $20 x$ and boen sanale resules? jogl.

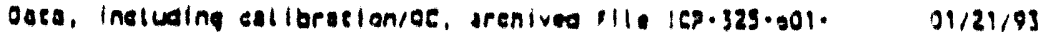


Table 2-3b: SST Core 48, ICP Core Composite Water Leach

ICP ANALYSIS REPORT $\cdots$ WaCer beach

PROJECT: SST

PROCEDURE: PHL·ALO-211
Analyzed oace:01/21/93

METE: 'HA55672 $\begin{array}{rr}93-01363 \mathrm{cl} & 93.01363 \mathrm{c2} \\ 2.00 & 2.00 \\ 229.9 & 235.6 \\ 487 & 688\end{array}$

Sample

ug/

Sampla

ug/g wit

Oupl.

oupl.

$(106)$

(115)

$<O L$
86

$<06$

$50 L$

59
$<0 L$

$<0 L$

$<06$

217

$\triangle O L$

406
1,128

1,128

$\angle O L$

$<04$

$<06$

89,161
801
33

33
$<06$

$<O L$

$\triangle O L$

$\triangle O L$

$\triangle O L$

$<04$
303

303

$\angle O L$

$\angle O L$

$\angle O L$
$\angle O L$

$\triangle O L$

$\angle O L$

$<04$

11,918
401
90

$\angle O L$

$\angle O L$
60
$\angle O L$

$\angle O L$

201
236

$<06$

1,169

576

$\angle O L$
$\times O L$
7

31

77.859

$\times 01$
29

$\triangle O L$

SOL

$\triangle O L$

$\angle O L$

$\therefore \mathrm{CL}$

91

$\angle 0 L$

$\triangle O L$

$\angle O L$

$\triangle O L$

9

$<0 L$
5,461

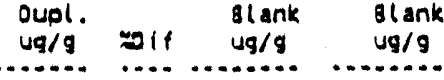

Slank
ug/9

ol ol Average

ug/ $\mathrm{m}^{2}$ ug $/ \mathrm{m}$ Average

.................... vg/g

0.00810 .0272

$0.1906 \quad 0.636 \%$

$0.1055 \quad 0.3517$

$0.0620 \quad 0.2068$

$0.0083 \quad 0.0278$

$0.0033 \quad 0.0112$

0.00170 .0056

0.00780 .0260

$0.1060 \quad 0.3536$

0.19410 .6479

$0.0118 \quad 0.0393$

$0.0092 \quad 0.0306$

$0.0 n 53 \quad 0.0183$

$0.0106 \quad 0.0367$

0.33021 .1008

0.01290 .0430

0.00770 .0256

0.00030 .0009

0.00110 .0035

0.01330 .0465

0.06110 .2037

$0.0516 \quad 0.1720$

$0.0260 \quad 0.0800$

$0.0865 \quad 0.2884$

$0.0180 \quad 0.0599$

0.08550 .2850

$0.0366 \quad 0.1215$

0.04950 .1649

0.15770 .5256

0.05710 .1904

$0.0006 \quad 0.0013$

0.09890 .3297

$0.0764 \quad 0.2548$

$0.0056 \quad 0.0187$

$0.5717 \quad 1.9056$

0.55951 .8651

$0.0096 \quad 0.0313$

$0.00430 .014 i$

0.00790 .0263

$0.6383 \quad 2.1277$
N/A

N/A

$\begin{array}{rr}H / A & \\ 87 & 6.3\end{array}$

H/A

Y $/ A$

.40
60

N/A

M/A

2257.6

N/A

$N / A$
1,130

$558 \quad 6.9$

N/A

H/A

H/A

30

83.510

HIA

31
$H / A$

$H / A$

$H / A$

H/A

H/A

$197 \quad 107: 3$

15.1

H/A

$H / A$

H/A

$N / A$

$H / A$

$\begin{array}{ll}\text { W/A } & \\ \text { HIA } & \end{array}$

N/A

8,690 74.3.

Note:

1) Values reliable so 2 1/2 significans digits. Bracketed resulis () are gualitative.

2) 8 lank is reported in ug/g "equivalence" to inaicate olank effect on sample.

3) Samole results have not been adjused for "blank" concriburion.

6) Ae 50.100 times the $0.6 .$. precision is estimoced at -1.102 and aceuracy $3 e+1.15 \%$.

5) Sample OL (Ug/g) = (OL in vg/mL) " (ug/g factor)

16) Off-line IEC: Results within $50 x$ OL porentially bias hign.

7) $20 x$ "1" flag: RPO, $20 x$ and boen samole resules, $3 \cdot 0 L$.

Oata, inctuding calibracion/OC, arenived file 1CP.325.001. 01/21/93 
Table 2-3C: SST Core 49, ICP Core Composite Water Leach

ICP ANALYSIS REPORT . WOCOR GEDCh

PROJECT: SST

PROCEDURE: PNL.ALO-211
Analyzad oase:01/21/93

METE: WAS3672

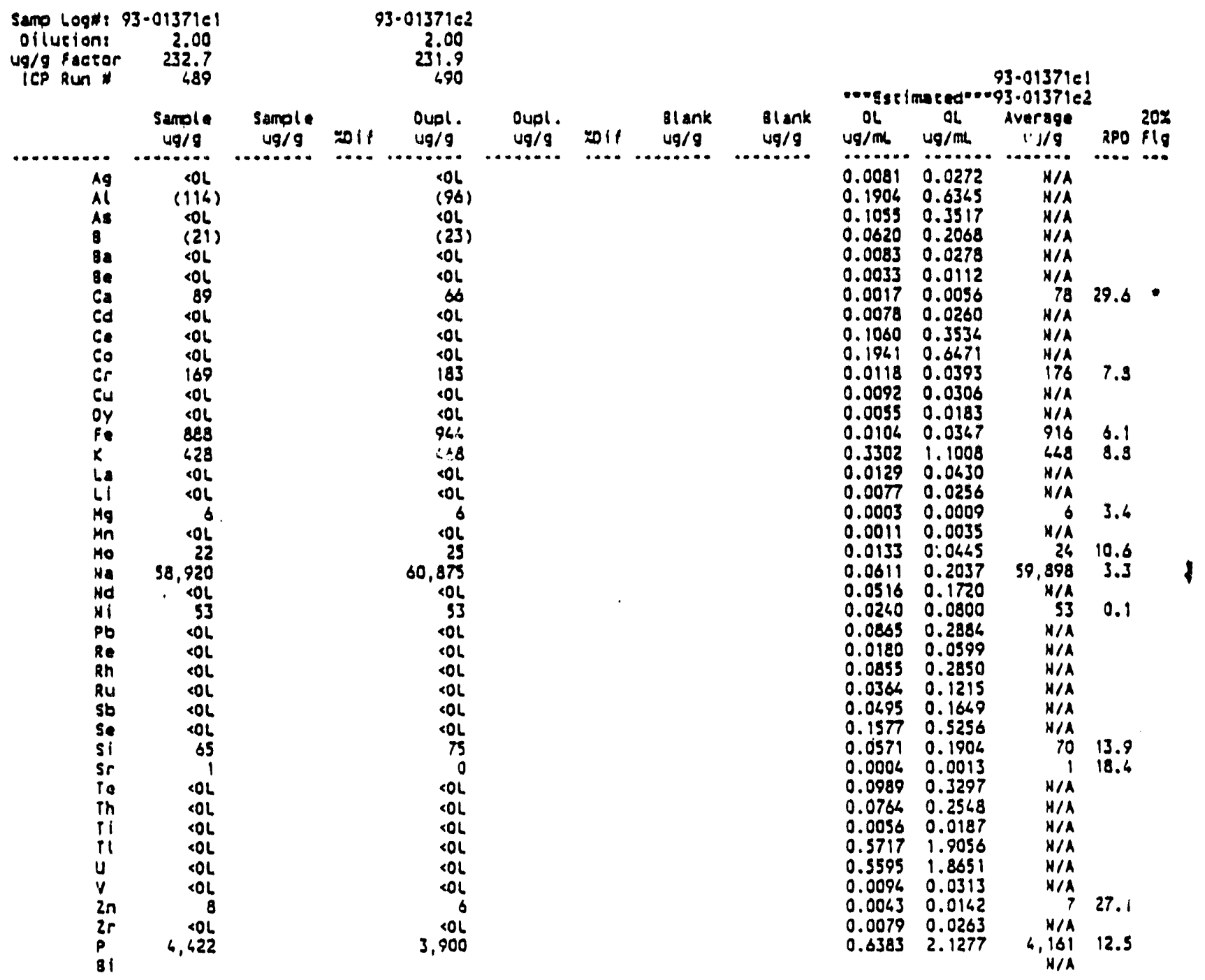

Hoce: 1) Values rellable to $21 / 2$ significane digits. Brackeced results ( ) ore qualieacive.

2) Blank is reported in ug/g "equivalence" po indicata blank effect on sample.

3) Samole resules have nop been adjusted for "blank" sontriburion.

4) Ae 50.100 cimes the $0 . L$. precision is estimated se $+1.10 x$ and aceuracy at $\% 1.15 \%$

5) Sample OL (Ug/g) = (OL in ug/mL). (ug/g Facsor)

6) off-line IEC: Resules vithin 50x ol porentially bias high.

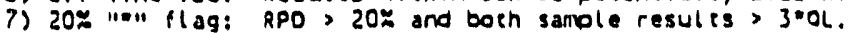

oaca, including ealibrocion/OC, arenived file lep.325.601. 01/21/93 
Table 2-3d: SST C-109, ICP Hot-Cell Blank, Water Leach

ICP ANALYSIS REPORT - - Watar Leach

PROJECT: SST

PROCEDURE: PNL-ALO-211
Analyzed Dace:01/22/93

M\&TE: WA55672

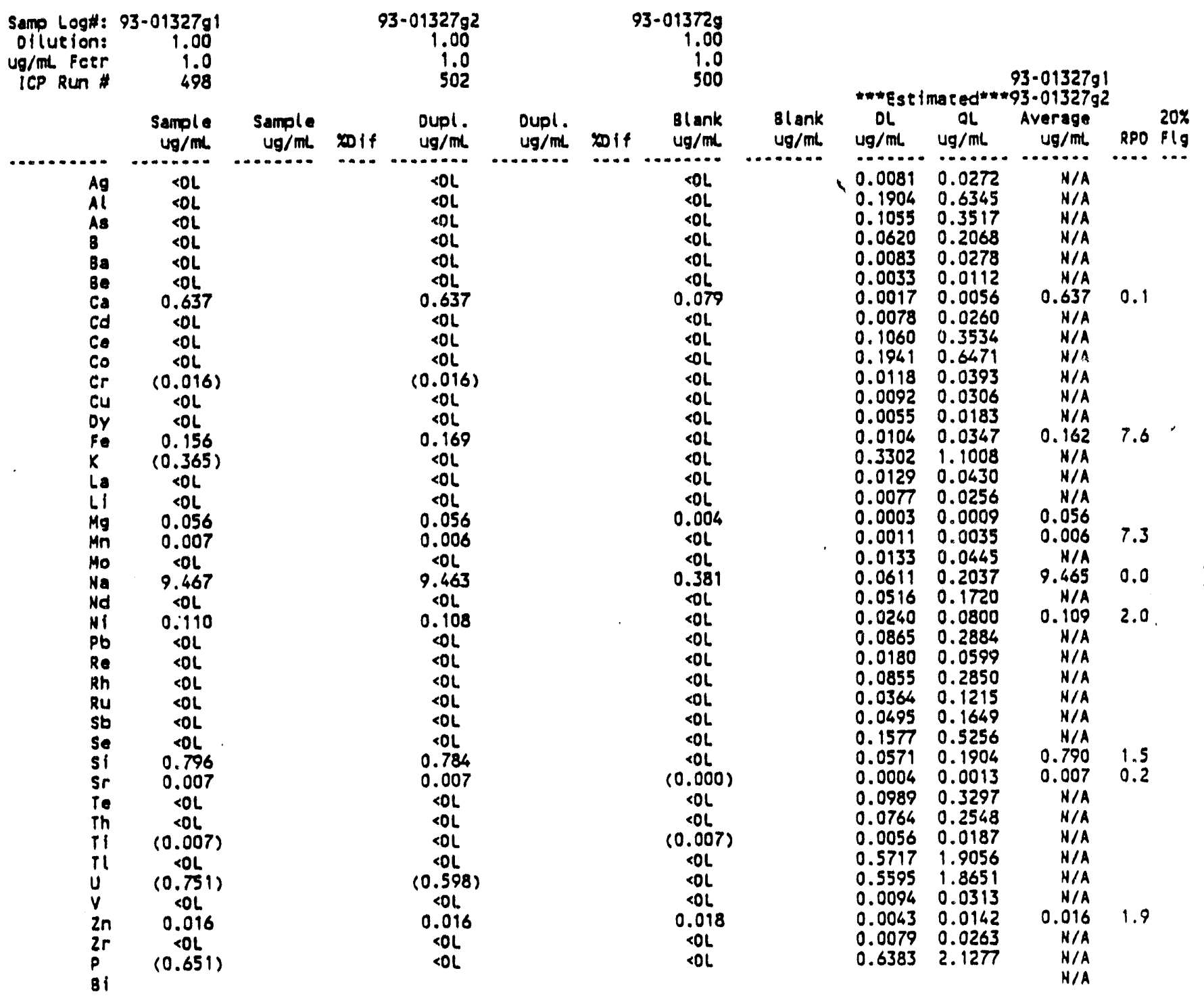

Note: 1) Values reliable to $21 / 2$ significant digits. Bracketed results () are qualitative.

2) Blank is reported in ug/g "equivalence" to indicate blank effect on sample.

3) Sample results have not been adjusted for "blank" contribution.

4) At 50-100 times the D.L., precision is estimated at $+1.10 \%$ and accuracy at $+1-15 \%$.

5) Sample $D L$ (ug/mL) $=$ (DL in ug/mL) (ug/mL fctr)

6) Off-line IEC: Results within 50X OL potentially bias high.

7) 20\% "mil flag: RPO > 20\% and both sample results > 3*OL.

Data, including calibration/OC, archived File ICP-325-601- 01/22/93 
Table 2-4a: SST Cores 47, 48, and 49, Core Composites, Quarter Segments, and Liquid Composite, IC Fluoride
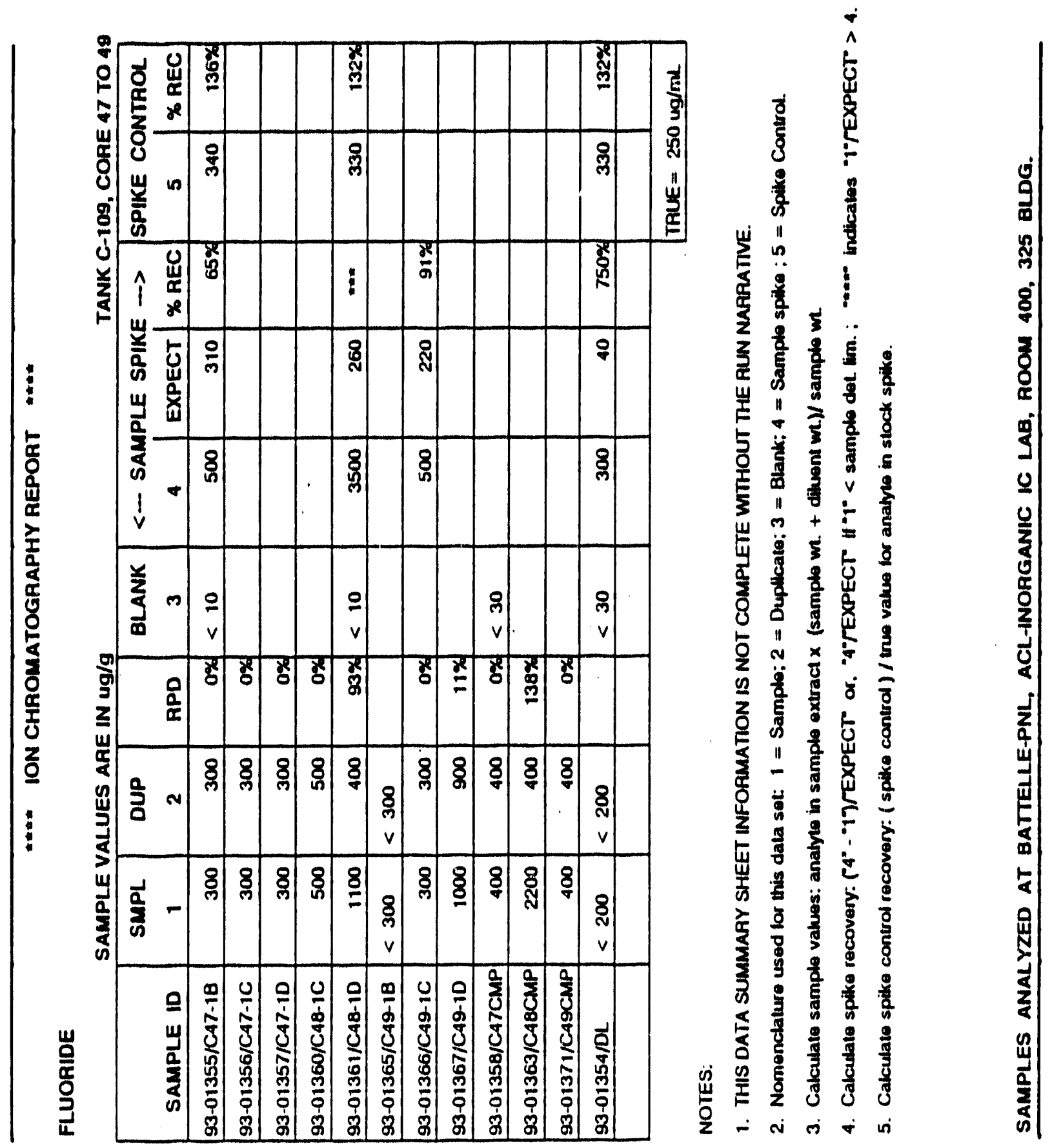
Table 2-4b: SST Cores 47, 48, and 49, Core Composites, Quarter Serjments, and Liquid Composite, IC Chloride
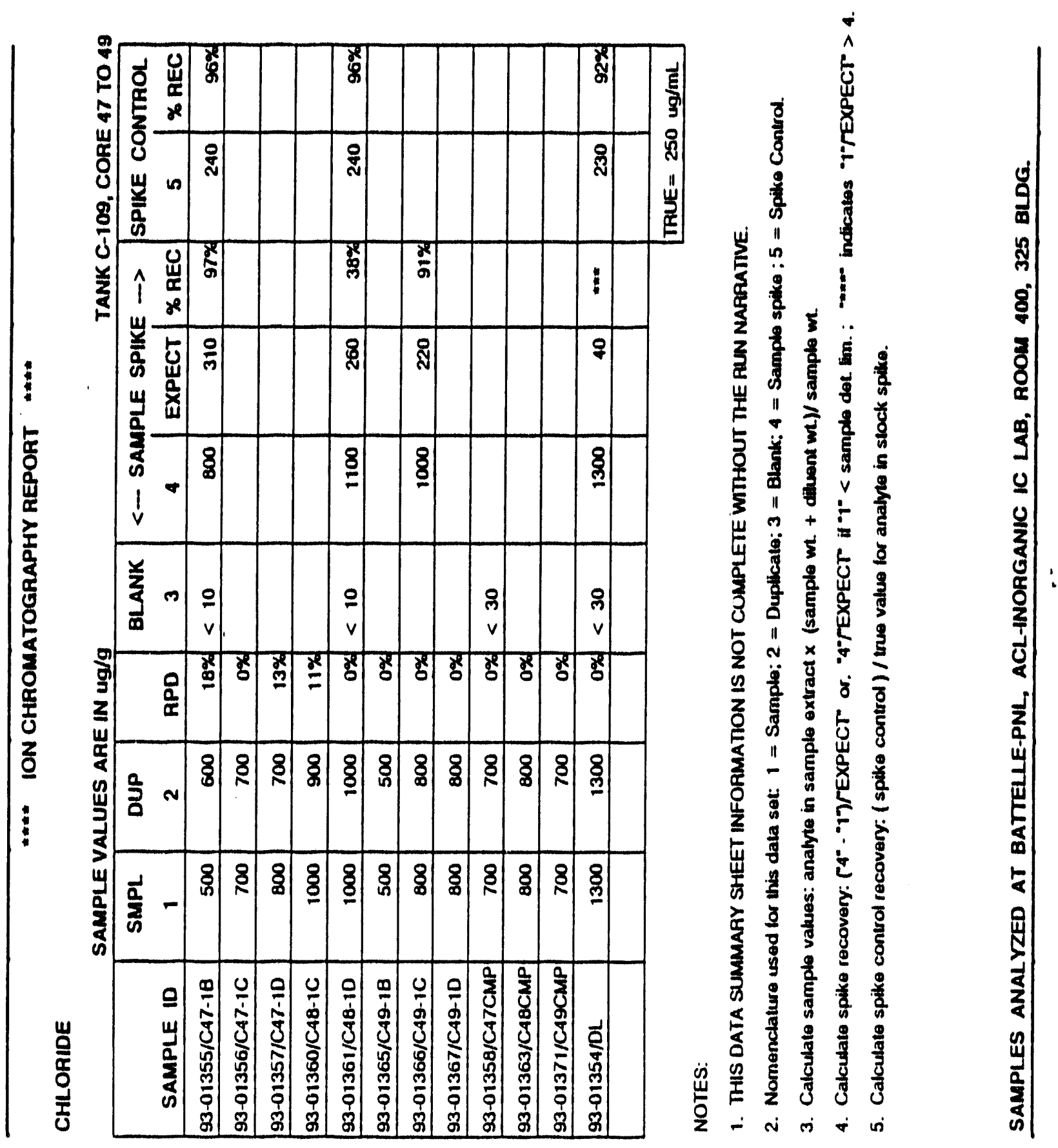
Table 2-4c: SST Cores 47, 48, and 49, Core Composites, Quarter Segments, and Liquid Composite, IC Nitrite
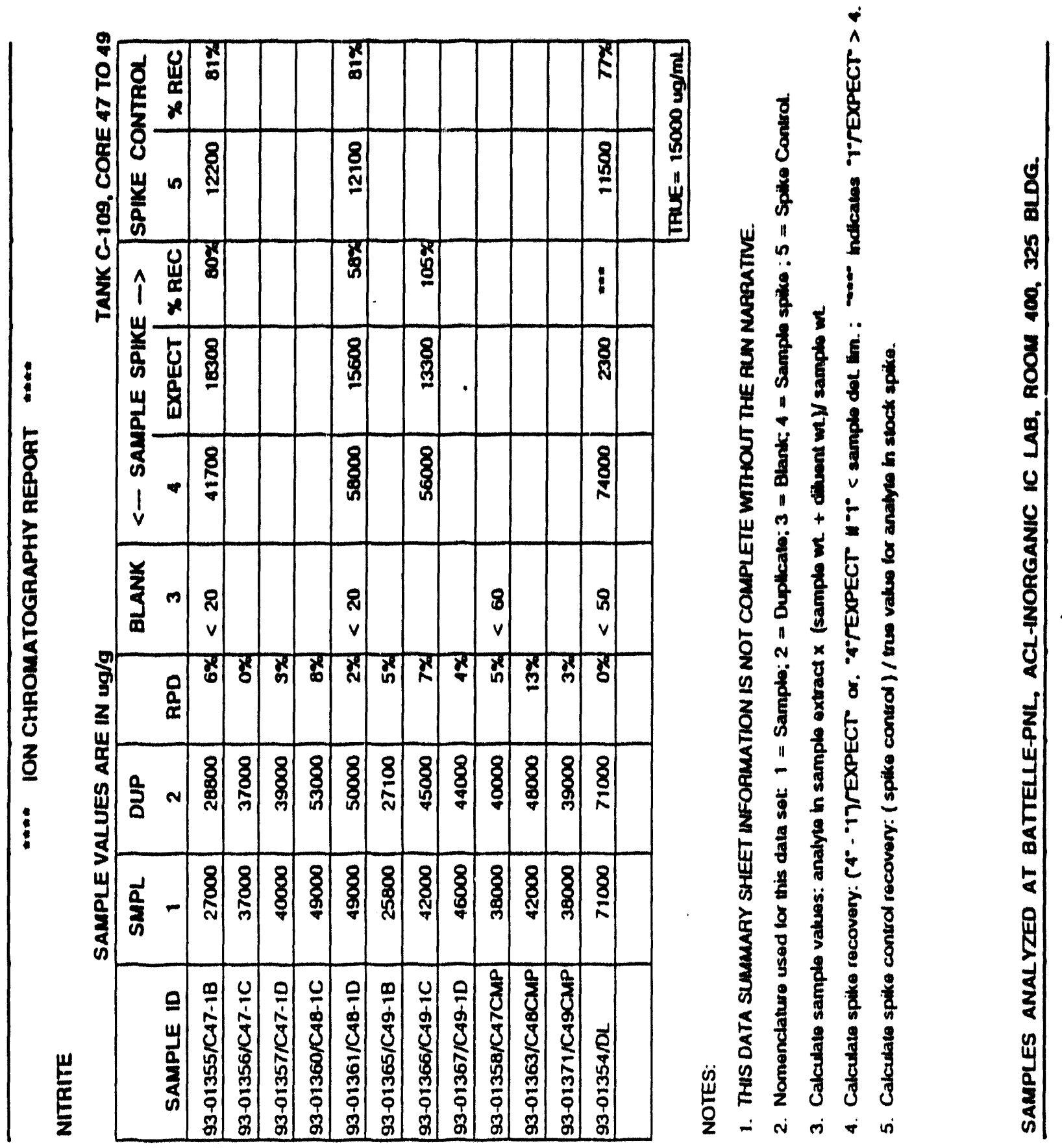
Table 2.4d: SST cores 47, 48, and 49, Core Composites, Quarter Segments, and Llquid Composite, IC Nitrate
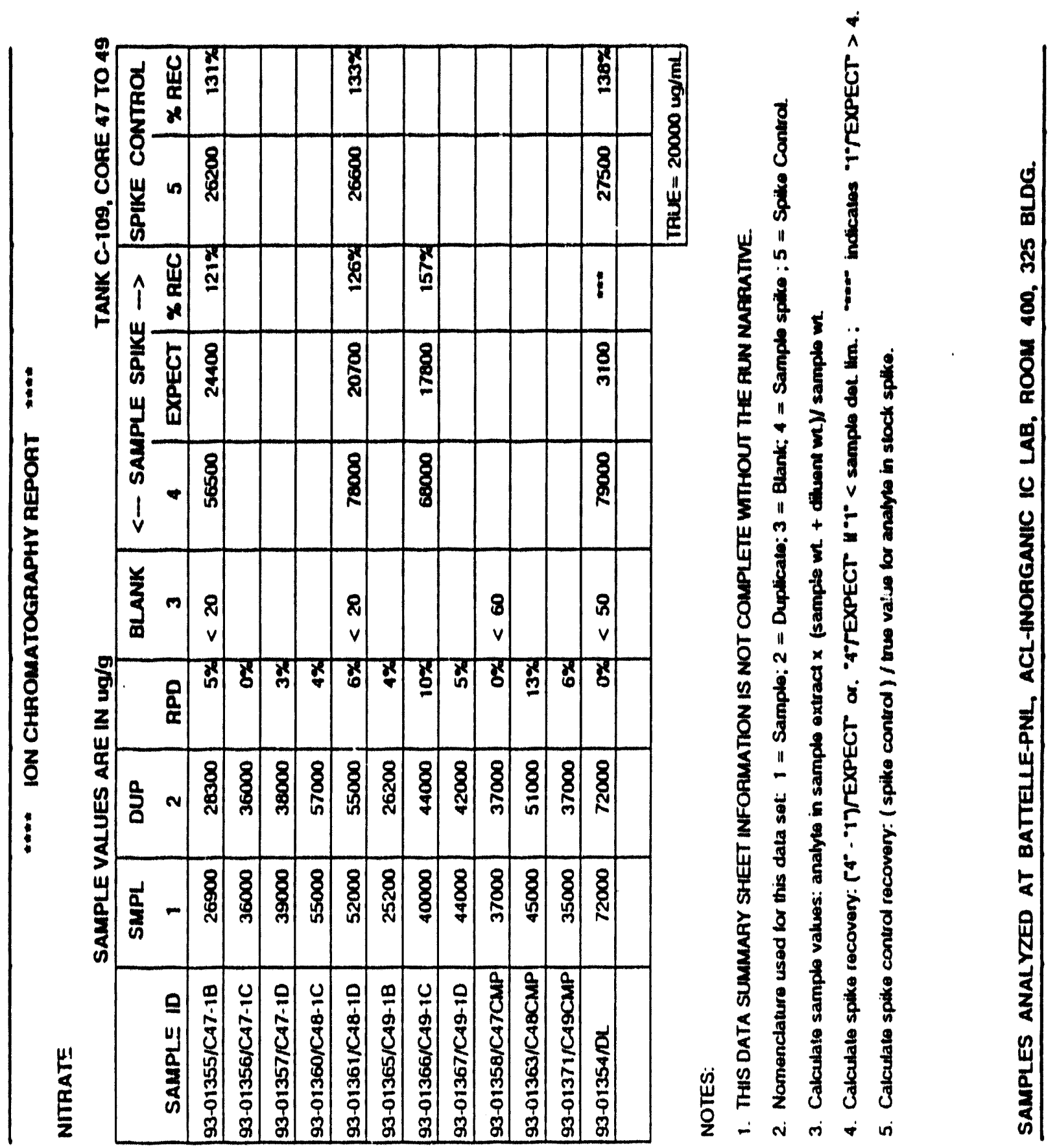
Table 2.4e: SST cores 47, 48, and 49, Core Composites, Quarter Segments, and Liquid Composite, IC Phosphate
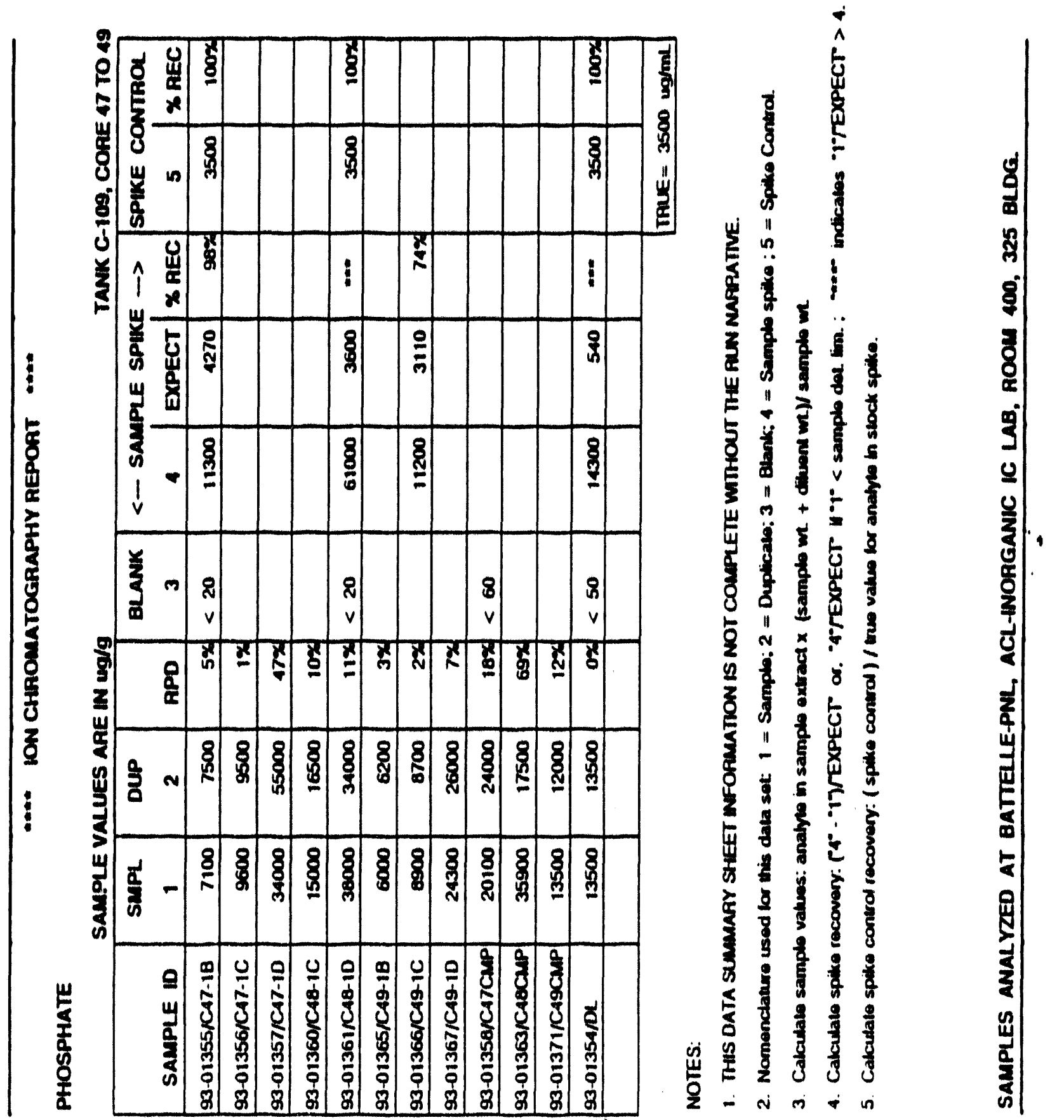
Table 2-4f: SST Cores 47, 48, and 49, Core Composites, Quarter Segments, and Liquid Composite, IC Sulfate
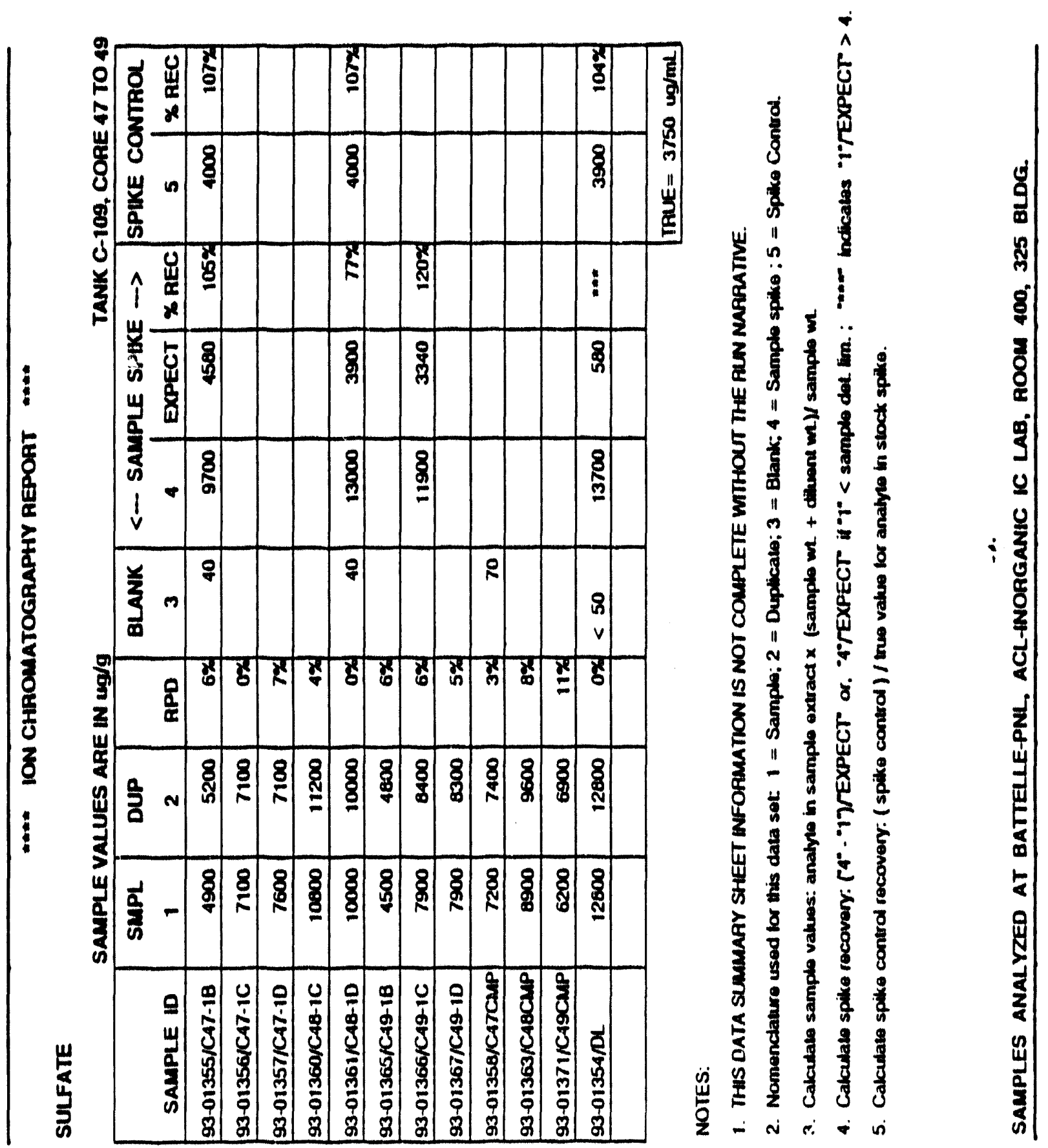
Table 2-4g: SST Cores 47, 48, and 49, Core Composttes, Quarter Segments, and Liquid Composite, IC Free CN
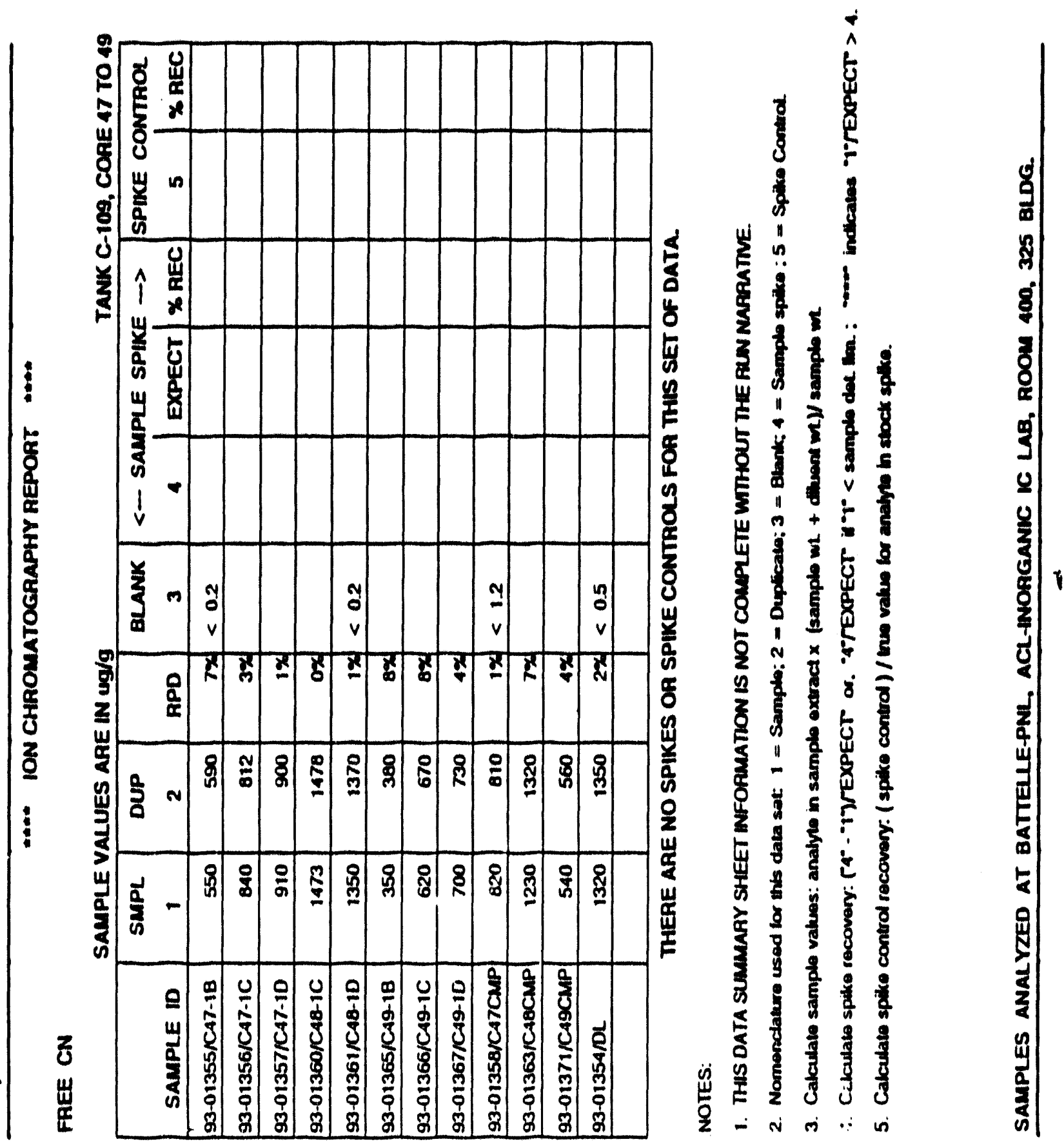


\section{WHC-EP-0663}

Table 2-4h: SST C-109, Hot.Cell Blank, IC

ION Chromatography Report

Simple values are in $\mu \mathrm{g} / \mathrm{ml}$.

\begin{tabular}{|c|c|c|c|c|c|c|c|}
\hline SAMPLE $1 D$ & $F$ & $C L$ & $\mathrm{NO}_{2}$ & $\mathrm{NO}_{2}$ & $\mathrm{PO}_{\mathrm{A}} \mathrm{C}-\mathrm{r}$ & so, & $\mathrm{CN}$ \\
\hline 93-01327-N1, Sample & $<0.5$ & 0.5 & 2.3 & 1 & 2 & 2 & 0.14 \\
\hline 93-01327-N2, Duplicate & $<0.5$ & 0.5 & 2.3 & 7 & 2 & 2 & 0.15 \\
\hline 93-01372-NI, DIW Blank & $<0.5$ & $<0.5$ & $<1$ & $<1$ & $<!$ & $<1$ & $<0.05$ \\
\hline
\end{tabular}


Table 2-5: SST Cores 47, 48, and 49 Core Composites GFAA Results $\frac{\operatorname{Lab} 10 \#}{93-01358-A 1 / 81}$ $-A 2 / B 2$ $. A 3 / B 3$

$93-01363-A 1 / B 1$ $. A 2 / B 2$

$93.01371-A 1 / B 1$ $-A 2 / B 2$ $-A 3 / B 3$

Samole 10

Core 47 Composite

Dupl icate

Process Blank

Core 48 Composite

Duplicate

Core 49 Composite

Duplicate

Process Blank

$93 \cdot 01327 \cdot 61$

93.01372 .6

Hot Cell Blank

DIW BI ank sb

$\frac{\mu a / q}{2.1}$

$<3.2$

$<0.6$

$<0.6$

$<0.6$

$<2.9$

$<2.9$

$<0.6$

nd

nd

YRes

$n / a$

93\%

$71 \%$

$n / a$

$91 \%$
As
$\mu g / 9$
$\frac{73}{73}$
89
$<0.5$

1.4

2.3

118

110

1.0

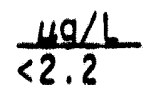

$<2.2$

$<1.2$
Lab 10.1

$93-01358-A 4 / B 4$ $-A 5 / B 5$

Core 47 Spiked Sample Splke Blank

$93 \cdot 01363 \cdot A 4 / B 4$

Core 48 Splked Sample

Core 49 Splked Sample Spike Blank

Notes:

Sample designator - "A" for Sb and "B" for As and Se.

Process Blank: $\mu \mathrm{g} / \mathrm{g}$ results adjusted for sample dilution factors. "n/a" - splke less than $25 \%$ of sample result or diluted below IDL. nd - not determined 
Table 2-6: SST Cores 47, 48, and 49 Core Compost te $\mathrm{Hg}, \mathrm{Cr}$ (VI), and $\mathrm{NH}_{3} \cdot \mathrm{N}$ Inorganic Results

MERCURY, core Composites. Llould Composite, and Gell Blank

\begin{tabular}{|c|c|c|c|c|c|c|c|}
\hline \multirow[b]{3}{*}{$\begin{array}{l}\text { Core } 47 \text { Composite } \\
93.01358-D 1 . D S\end{array}$} & & \multirow{2}{*}{\multicolumn{4}{|c|}{ •..." Results $\ldots \ldots \ldots}}$. & \multicolumn{2}{|c|}{ "Recovery" } \\
\hline & & & & & & $\begin{array}{l}\text { Splke } \\
\text { Sample }\end{array}$ & $\begin{array}{l}\text { Spike } \\
\text { Control }\end{array}$ \\
\hline & $(\mu g / g)$ & 8.5 & 9.2 & & & (a) & $128 \%$ \\
\hline $\begin{array}{l}\text { Core } 48 \text { Composite } \\
93.01363 . \mathrm{D} 1 / \mathrm{D}_{2} / \mathrm{D}_{4}\end{array}$ & $(\mu g / 8)$ & 6.3 & 6.6 & & $2.2 \%$ & (a) & \\
\hline $\begin{array}{l}\text { Core } 49 \text { Composite } \\
93.01371 \cdot D 1 / D 2 / D 4\end{array}$ & $(\mu g / g)$ & 6.5 & 6.8 & & $4.2 \%$ & (a) & \\
\hline $\begin{array}{l}\text { Liquild Composite } \\
\text { 93.01354-N1.NS }\end{array}$ & $\begin{array}{l}(\mu g / g) \\
(\mu g /))\end{array}$ & $\begin{array}{l}0.090 \\
110\end{array}$ & $\begin{array}{c}0.092 \\
112\end{array}$ & $\begin{array}{l}<0.001 \\
<0.6\end{array}$ & $1.4 \%$ & $129 \%$ & $96 \%$ \\
\hline $\begin{array}{l}\text { Blank } \\
93.01327 . D 1 . D 3\end{array}$ & $(\mu g \Omega)$ & $<0.3$ & $<0.3$ & $<0.3$ & & (b) & \\
\hline
\end{tabular}

Chromium (VI) and Ammonia $\left(\mathrm{NH}_{3}-\mathrm{N}\right)_{2}$ core composites

Core 47 Composite

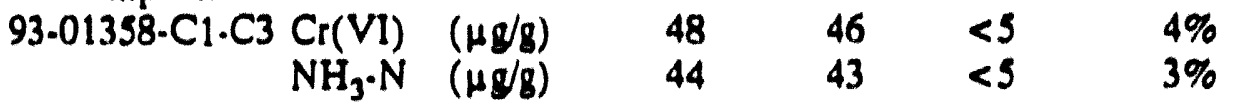

Core 48 Composite

$\begin{array}{rrrrr}93.01363 \cdot \mathrm{Cl} \cdot \mathrm{C} 2 \underset{\mathrm{Cr}(\mathrm{VI})}{\mathrm{C}} & (\mu \mathrm{g} / \mathrm{g}) & 36 & 37 & 3 \% \\ \mathrm{NH}_{3} \cdot \mathrm{N} & (\mu \mathrm{g} / \mathrm{g}) & 64 & 58 & 11 \%\end{array}$

Core 49 Composite

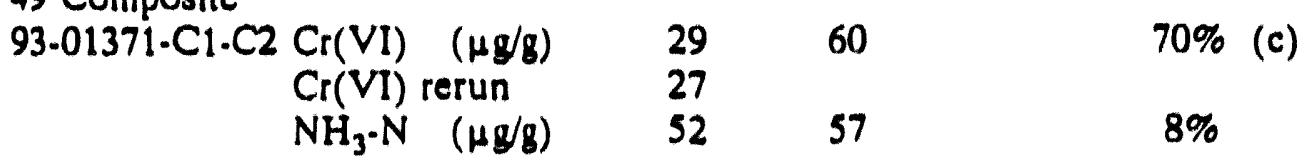

Notes:

(a) $\mathrm{Hg}$ splke $<25 \%$ of sample $\mathrm{Hg}$ concentration; spike unrecoverable.

(b) Since both Hg results are less than Detection Limit, RPD is N/A.

(c) Reason for high RPD is unknown; insufficient sample to rerun Duplicate. 


\section{WHC-EP-0668}

Table 2-7: SST Cores 47, 48, and 49, TOC/TIC/TC Results

\section{Direct - Quarter segments Core 47}

IOC (ug/a) IIC (ug/g) IC (ug/a)

18 93-01355-J1

.-32

.04 Splked Spl

IC $93-01356-J 1$

.32

$10 \quad 93-01357-31$

.-32

2200

2100

5500

7800

127\% Recov 87\% Recov

7400

$2000 \quad 5000 \quad 7100$

2000

5400

7300

2200

2200

5300

5400

7500

7700

Core 48

IC $93-01360-\mathrm{Jl}$

$-32$

3500

3800

8300

9000

12000

13000

$10 \quad 93.01361-31$

$-32$

- J3 Method BIk

-J4 Splked Spl

3800

3200

99

7100

7800

11000

11000

170

111\% Recov 96\% Recov

10 93-01361-J1 (repeat)

-J2 (repeat)

-J3 (repeat)

3000

3100

6500

6300

9500

9400

16

22

Core 49

IB 93.01365-J1

$-32$

.$J 4$ Splked Spl

1700

1900

$118 \%$ Recov

3900

3900

$120 \%$ Recov

5600

5800

IC $93.01366-\mathrm{Jl}$

2100

6500

8600

2300

6700

9000

$10 \quad 93-01367-\mathrm{Jl}$

2600

2500

6600

7000

9200

9600

-J3 Method BIk

54

17

71 
WHC-EP-0668

Table 2-7: SST Cores 47, 48, and 49, TOC/TIC/TC Results, cont'd

Direct - Core Composites

93-01358-J1

$-\mathrm{J} 2$

$-\mathrm{J3}$ Method BIk

Core 48 Composite

93-01363-J1

$-32$

Core 49 Composite

93-01371-J1

$-\mathrm{J} 2$

-J3 Method Blk
$\operatorname{IOC}(\mu \mathrm{g} / \mathrm{g}) \quad$ IIC $(\mu \mathrm{g} / \mathrm{g}) \quad$ IC $(\mu \mathrm{g} / \mathrm{g})$

3000

3300

$<50$

2900

3000

2100

2800

$<50$
8800

9100

$<50$

7900

8300

7200

8500

53
2460

2150

90

Core 47 Composite
$93-01358-C 1$
$-C 2$
$-C 3$

Cor: 48 Composite
$93-01363-C 1$
$-C 2$
Core 49 Composite
$93-01371-C 1$
$-C 2$

Core 47 Composite
$93-01358-C 1$
$-C 2$
$-C 3$

Cor: 48 Composite
$93-01363-C 1$
$-C 2$
Core 49 Composite
$93-01371-C 1$
$-C 2$

Core 47 Composite
$93-01358-C 1$
$-C 2$
$-C 3$

Cor: 48 Composite
$93-01363-C 1$
$-C 2$
Core 49 Composite
$93-01371-C 1$
$-C 2$

Core 47 Composite
$93-01358-C 1$
$-C 2$
$-C 3$

Cor: 48 Composite
$93-01363-C 1$
$-C 2$
Core 49 Composite
$93-01371-C 1$
$-C 2$

Core 47 Composite
$93-01358-C 1$
$-C 2$
$-C 3$

Cor: 48 Composite
$93-01363-C 1$
$-C 2$
Core 49 Composite
$93-01371-C 1$
$-C 2$

Core 47 Composite
$93-01358-C 1$
$-C 2$
$-C 3$

Cor: 48 Composite
$93-01363-C 1$
$-C 2$
Core 49 Composite
$93-01371-C 1$
$-C 2$

Liquid Composite (Water Leach)

93-01354-C1

$-C 2 \quad 2700$

3330

2830

2210

2440

4540

4290

6750

6730
2500

2700

$<10$
6300

6000

$<10$
7880

8140

240

8850

8600

5770

5990

150

- C3 Method B1k

Hot Cell Blank

93-01327

93-01372 DIW Blank
$\operatorname{TOC}(\mu \mathrm{g} / \mathrm{ml}) \quad$ IIC $(\mu \mathrm{g} / \mathrm{m} I)$ IC $(\mu \mathrm{g} / \mathrm{m}])$

$3 \quad<0.5$

8800

8700

$<10$ 


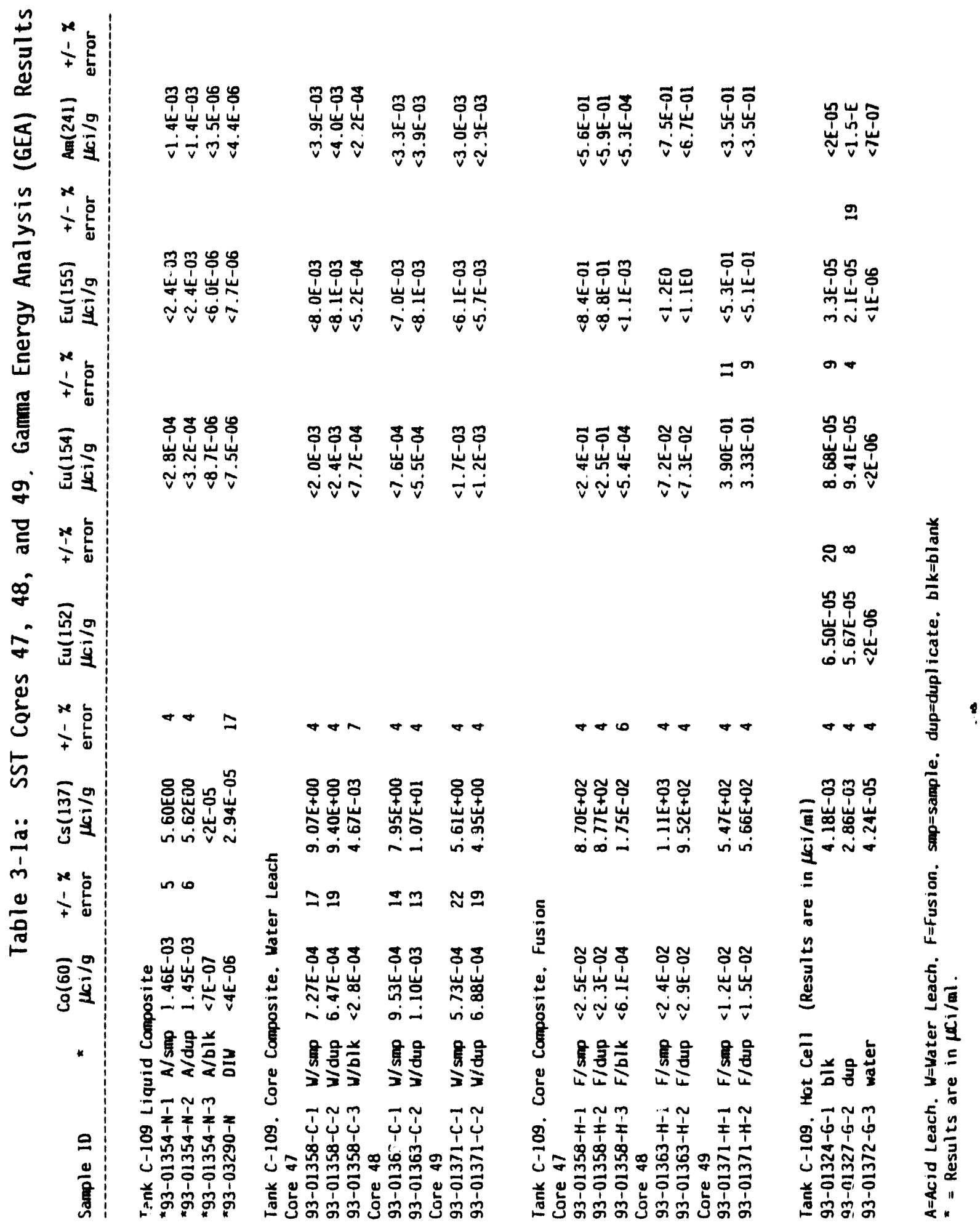


Table 3-1b: SST cores 47, 48, and 49, GEA Results, cont'd

\begin{tabular}{|c|c|c|c|c|c|c|c|c|c|c|c|}
\hline Sample 10 & . & $\begin{array}{r}\operatorname{Co}(60) \\
\mu_{C} t / g\end{array}$ & $\begin{array}{l}+1-x \\
\text { error }\end{array}$ & $\begin{array}{c}\operatorname{Cs}(137) \\
\mu_{C} 1 / 9\end{array}$ & $\begin{array}{l}+1-\% \\
\text { orror }\end{array}$ & $\begin{array}{c}E u(154) \\
\mu c_{1} 1 / g\end{array}$ & $\begin{array}{l}+/-x \\
\text { error }\end{array}$ & $\begin{array}{c}E u(155) \\
\mu<1 / 9\end{array}$ & $\begin{array}{l}+1-x \\
\text { orror }\end{array}$ & $\underset{\mu m(1 / g}{A m(241)}$ & $\begin{array}{l}+1-x \\
\text { error }\end{array}$ \\
\hline
\end{tabular}

Tank C-109, Quarter Segments, Fusion

Core $47-18$

93-01355-H-1 F/smp <3.2E-02

$93-01355-H-2$ F/dup $<2.3 E-02$

$3.17 E+02 \quad 4 \quad 9.54 E-01$

93-01355-H-3 F/blk <6.5E-04

$3.57 E+02$

4 8.10E-01

$6 \quad 8.82 E-01$

$8.82 E-01$
$1.43 E+00$

16

$<2,4 E-03$

8.09E-01

$3.80 E-01$

$<1.3 E-03$

$<8.6 \mathrm{E}-01$

93-01356-H-1 F/smp <2.2E-02

$8.12 E+02 \quad 4<1.3 E-01$

$\begin{array}{lll}8.12 E+02 & 4 & <1.3 E-01 \\ 7.31 E+02 & 4 & <1.3 E-01\end{array}$

$<8.6 \mathrm{E}-01$

. $92 \mathrm{E}-01$

$<1.3 E-03$

20

93-01356-H-2 F/dup $<2.7 E-02$

$<1.1 E 0$

$<4.8 E-01$

$93-01357-H-1 \quad F / s m p<2.3 E-02$

$9.71 E+02 \quad 4 \quad<1.2 E-01$

$<4,8 E-01$

93-01357-H-2 F/dup el.6E-02

$9.23 E+02$

$<1.0 E-01$

$<1.0 E O$

$<6.0 E-01$

Core $48-1 \mathrm{C}$

93-01360-H-1 F/smp <1.7E-02

$1.17 E+03$

$4 \quad<7.7 E-02$

$<5.1 E-01$

93-01360-H-2

1.14E+03

$<7,4 E-02$

$<1.2 E 0$

$<5.5 E-01$

Core $48-10$

93-01361-H-1 F/smp $<1.6 \mathrm{E}-02$

1. $22 E+03$

$4<9.0 E-02$

$<1.2 E 0$

$<6.3 E-01$

93-01361-H-2 F/dup <1.5E-02

1. $11 E+03$

$4<1.0 E-01$

$<1.2 E 0$

$<6.3 E-01$

$15 \quad 1.31 E+00$

$<7.0 E-04$

$<3.8 \mathrm{E}-03$

$<6.3 E-01$

Core $49-1 B$

93-01365-H-1 F/smp <1.3E-02

1. $21 E+02$

$4 \quad 9.49 E-01$

1. $19 E+00$

$<1.8 E-03$

93-01365-H-2 F/dup <1.3E-02

1. $15 E+02$

6. OgE-0I

6. 67E-01

5. $94 E-01$

4. $46 E-01$

18

Cors $49-1 \mathrm{C}$

93-01366-H-1 F/smp \& I.1E-02

$5.53 E+02$

$4<6.4 E-02$

<4. 2E- 01

$<2.3 E-01$

1. $44 E+02$

$<8.3 E-02$

C4. $2 E-02$

Core $49-10$

93-01367-H-1 F/smp <1.1E-02

$\begin{array}{lll}6.60 E+02 & 4 & <6.3 E-02 \\ 7.43 E+02 & 4 & <6.1 E-02\end{array}$

$<1.3 E-02$

C4.7E-01

$<2,6 \mathrm{E}-01$

93-01367-H-2 F/dup <1. IE-02

<5. 1E-01

$<2.7 \mathrm{E}-01$

Tank C-109. Quarter Segment Homogenization Test, Acid

Core $48-10$

$93-01361-A-1 T$ A/smp

$8.52 E+00$

93-01361-A-2T A/dup

$1.66 E+01$

93-01361-A-1B A/smp

$8.81 E+00$

$93-0136\lfloor-A-2 B \quad A /$ dup

$1.43 E+01$

$93-01361-A-3$ A/blk

$8.73 E-01$

Core $49-10$

93-01367-A-1T A/smp

$3.54 E+01$

93-01367-A-2T A/dup

4. $34 E+01$

93-01367-A-1B A/smp

$1.93 E+01$

$93-01367-A-2 B$ A/dup

$2.74 E+01$

93-01367-A-3 A/blk

$1.59 E+00$

Tank C-109. Cores 47-48-49 Quarter Segment Homogenization Test. Fusion

Core $49-10$

93-01367-H-1T F/smp

93-01367-H-2T F/dup

$93-01367-H-18 \mathrm{~F} / \mathrm{smp}$

7. $13 E+02$

$7.50 E+02$

93-01367-H-2B F/dup

$6.96 E+02$

$7.00 E+02$

93-01367-H-3 F/blk

1. $99 E+00$

$A=$ hicid Leach, WaWater Leach, Fafusion, smp=sample, dup=dupllcate, blk=blank 
Table 3-2: SST Cores 47, 48, and 49, Alpha Analys is Results

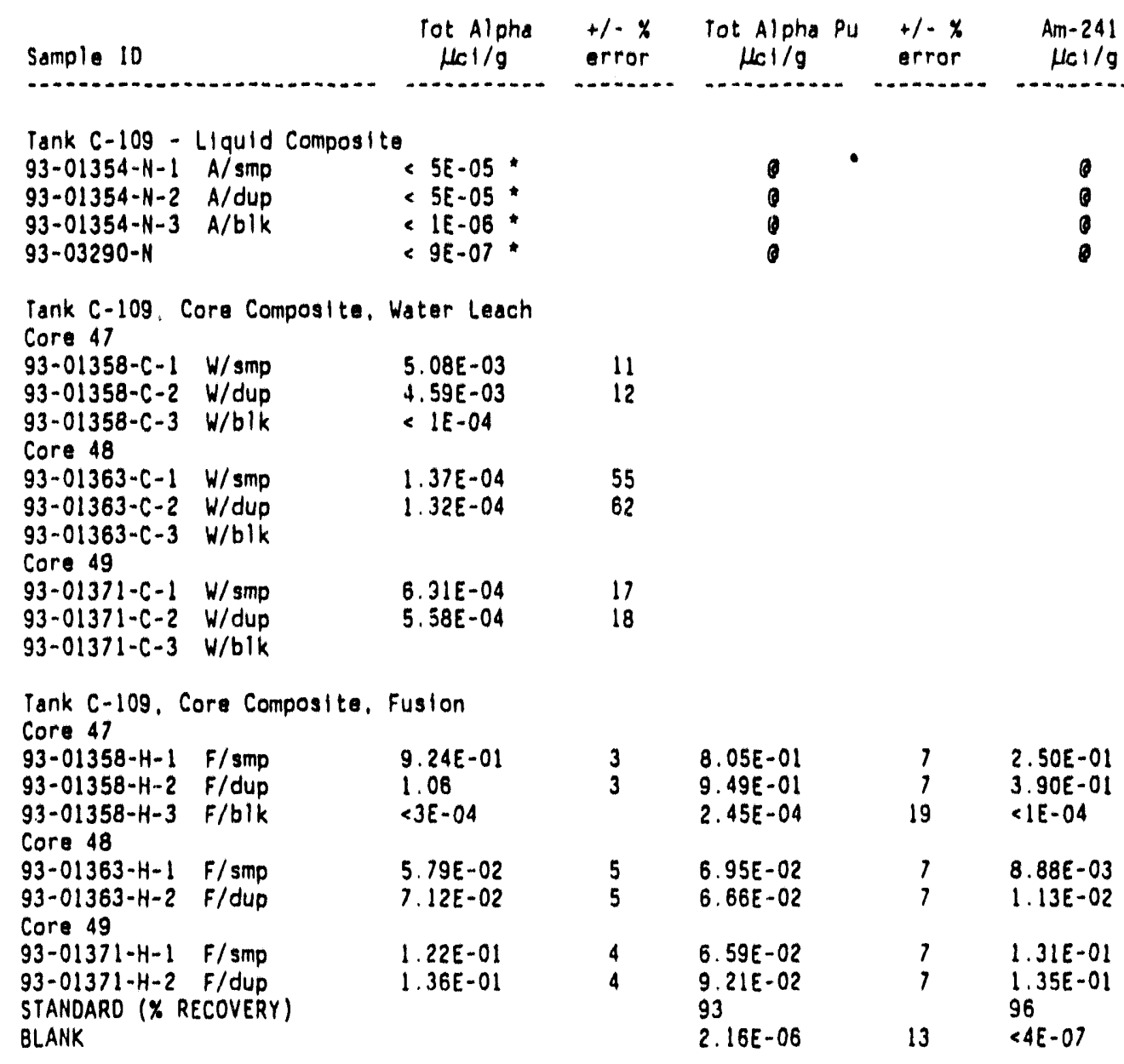

Tank C-109, Quarter Segment Homogentzation Test. Acid

Core 48

93-01361-A-1T

$93-01361-A-1 B$

93-01361-A-2T

$93-01361-A-2 B$

$93-01361-A-3$

Core 49

93-01367:A-1T

$93-01367-A-1 B$

93-01367-A-2T

$93-01367-A-2 B$

$93-01367-A-3$

$\begin{array}{ll}6.18 E-02 & 5 \\ 6.74 E-02 & 5 \\ 5.00 E-02 & 5 \\ 5.26 E-02 & 5 \\ 3.25 E-04 & 42 \\ 3.58 E-02 & 6 \\ 4.46 E-02 & 5 \\ 5.94 E-02 & 5 \\ 5.23 E-02 & 5 \\ 4.52 E-04 & 30\end{array}$

Tank C-109. Hot Cell Blank

93-01327-G-1 blk

$93-01327-0-2$ dup

93-01372-G-3 water

$12 E-05 * \quad 10$
$1.0 E-05 * \quad 12$
$C 2 E-07 *$

$A=A c i d$ Leach, W=Water Leach, Fafusion, smp=sample, dup=duplicate, blk=blank

- Total alpha concentration is so low that the analysis of alpha emitting isotopes was not performed.

* Results are in $\mu_{c} \mid / m i$. 
Table 3-3a: SST Cores 47, 48, and 49, Beta Analys is Results

\begin{tabular}{|c|c|c|}
\hline Sample 10 & $\begin{array}{c}\text { Tot } 8 \mathrm{eta} \\
\mu_{\mathrm{c}} 1 / \mathrm{g}\end{array}$ & \\
\hline $\begin{array}{l}\text { Tank } C-109-1 \text { l quild Composit } \\
93-01354-N-1 \text { A/smp } \\
93-01354-N-2 \text { A/dup } \\
93-01354-N-3 \text { A/blk } \\
93-03290-N \\
\text { STANOARD (X RECOVERY) } \\
\text { BLANK }\end{array}$ & $\begin{array}{l}5.40 E 00 \\
5.46 E 00 \\
4.48 E-0 B \\
1.94 E-04\end{array}$ & * \\
\hline 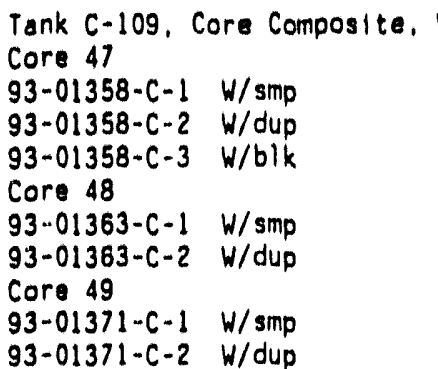 & $\begin{array}{l}\text { Water Leact } \\
\begin{array}{l}1.38 E+01 \\
2.09 E+01 \\
66 E-03 \\
7.49 E+00 \\
9.70 E+00 \\
9.04 E+00 \\
8.43 E+00\end{array}\end{array}$ & \\
\hline
\end{tabular}

Tank C-109. Core Composite, Fusion

Core 47

93-01358-H-1 F/smp

93-01358-H-2 F/dup

2. 94.03

2. $55 E 03$

2. $65 E-02$

$+1-x$

$S r-90$

$+1-\%$

$\mu \mathrm{ce} / \mathrm{g}$

93-01358-H-3 F/blk

1. 41503

1. $20 E 03$

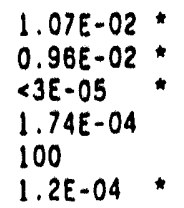

error

$\mu \mathrm{c} 1 / \mathrm{g}$

93-01363-H-1 F/smp

93-01363-H-2 F/dup

2. $42 E 03$

$\begin{array}{ll}4 & 1.07 E-02 \\ 4 & 0.96 E-02 \\ 30 & <3 E-05 \\ 8 & 1.74 E-04 \\ & 100 \\ & 1.2 E-04\end{array}$
$11 \quad 1.54 E-01 *$
$1 \quad 1.58 E-01$
$44 \quad \angle 3 E-06$
$1 \quad 106$

Core 49

$93-01371 \cdot H-1 \quad F / s m p$

93-01371-H-2 F/dup

2. $17 E 03$

3

3

STANDARD (\% RECOVERY)

3

BLANK $\left(\mu_{C} 1 / \mathrm{ml}\right)$

Tank C- 109 Hot Call Blank

93-01327-G-1 blk

93-01327-G-2 dup

93-01372-G

water

\begin{tabular}{l}
$3.08 E-02 *$ \\
$3.27 E-02 * 3$ \\
$8.21 E-05 * \quad 3$ \\
\hline
\end{tabular}

+ Reported as Sr-90 - Y-90

AxAcid Leach, W=Water Leach, $F=F u s i o n, s m p=s a m p l e$, dup=dupllate, blk=blank

- Results are in $\mu_{c i} / \mathrm{ml}$. 


\section{WHC-EP-0668}

Table 3-3b: SST Cores 47, 48, and 49, Beta Analysis Results, cont'd

\begin{tabular}{|c|c|}
\hline Sample 10 & $\begin{array}{l}S r-90 \\
\mu \mathrm{Cl} / \mathrm{g}\end{array}$ \\
\hline 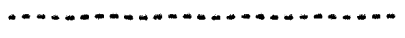 & 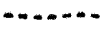 \\
\hline
\end{tabular}

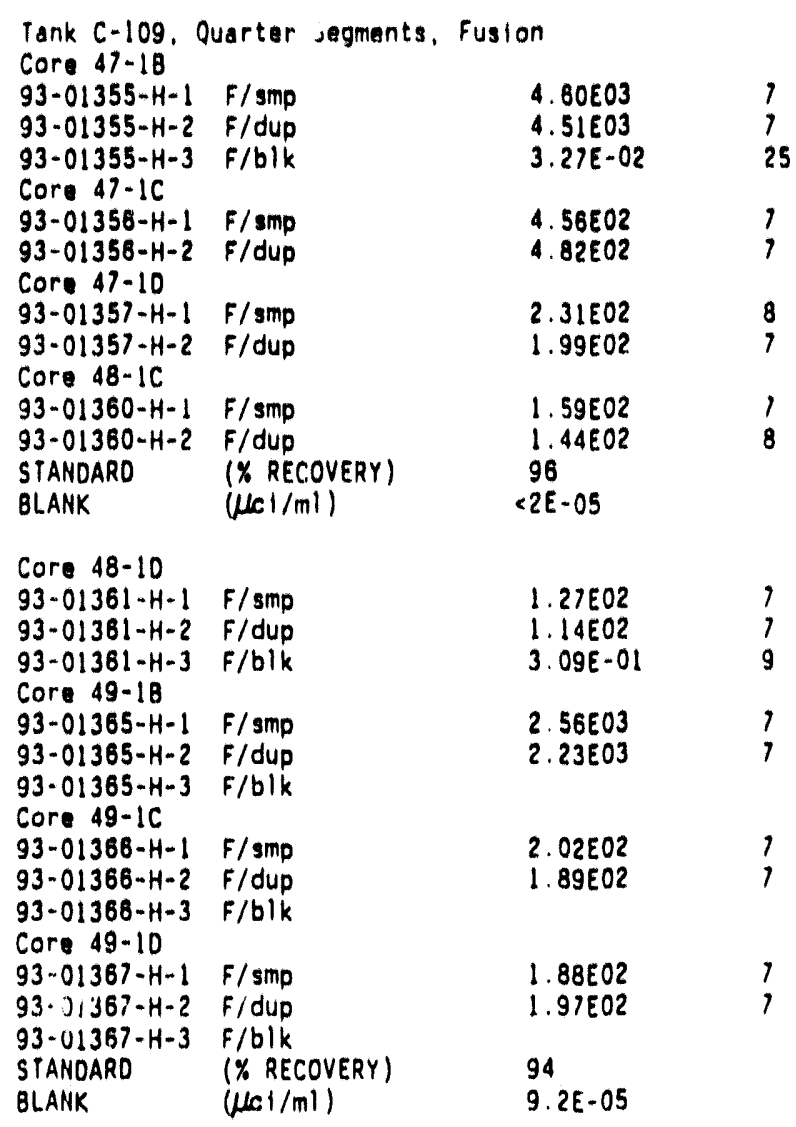

$A=A c i d$ Leach, WeWater Leach, F=Fusion, smp=sample, dup=dupllate, blk=blank 


\section{WHC-SD-WM-DP.036, REV O}

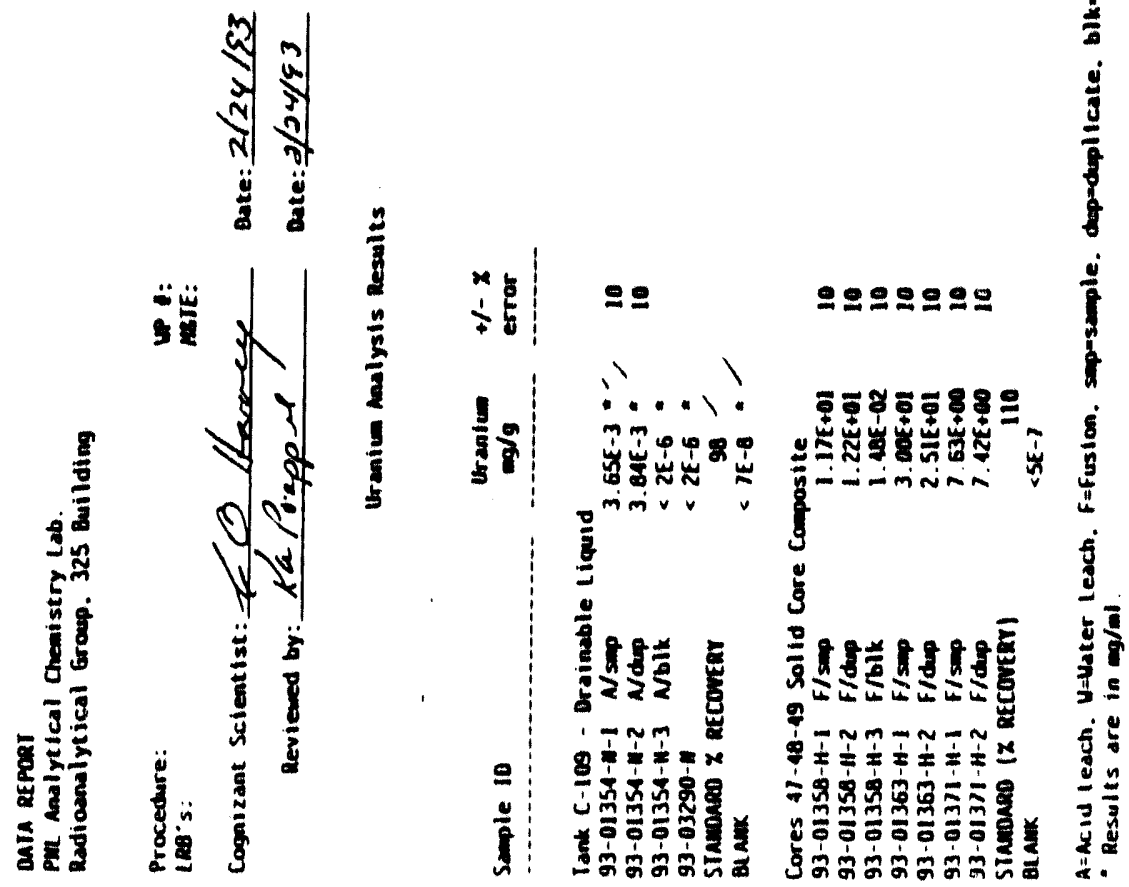

E06-002 


\section{WHC-EP-0668}

Table 3-5: SST Cores 47, 48, and 49, Liquid Scintillation Counting Analysis Results

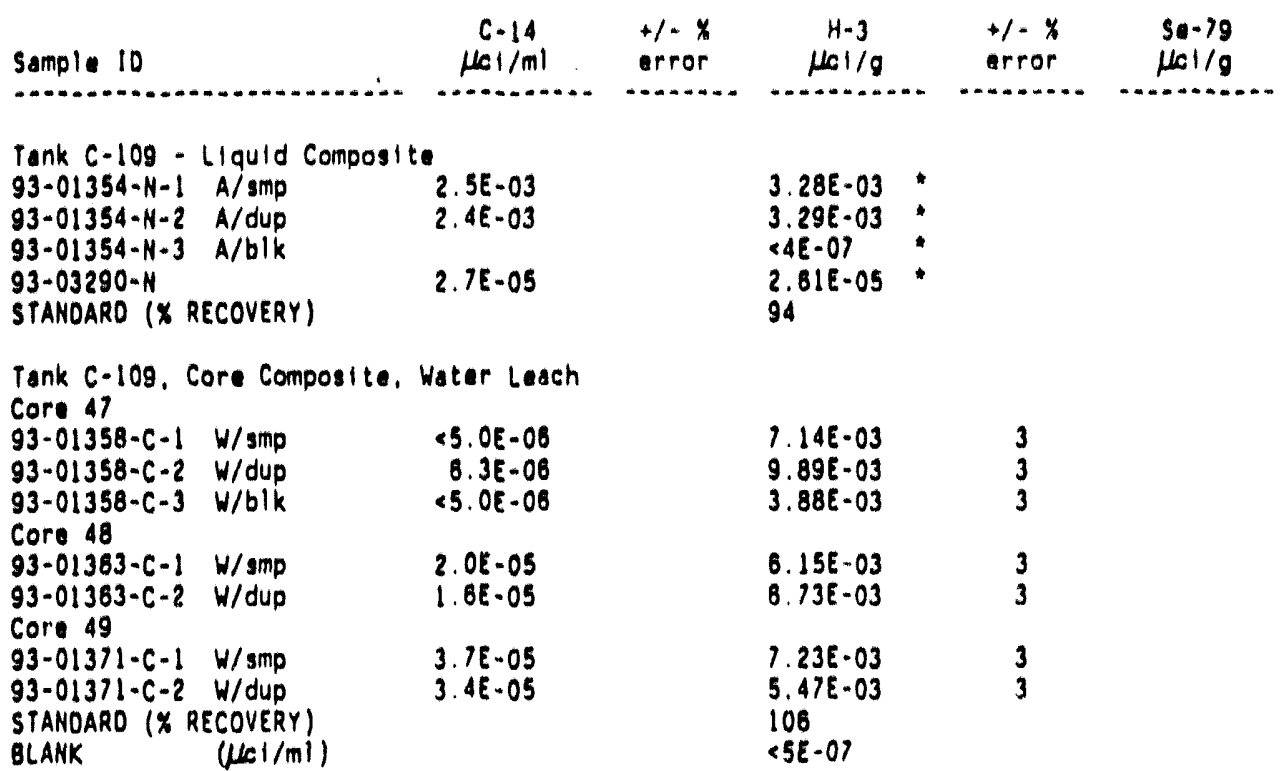

Tank C.109, Core Composite. Fusion

Core 47

93-01358-H-1 F/smp

93-01358-H-2 F/dup

93-01358-H-3 F/blk

Core 48

93-01363-H-1 F/smp

93-01363-H-2 F/dup

Core 49

93-01311-H-1 F/smp

$93-01371-\mathrm{H}-2 \mathrm{~F} / \mathrm{dup}$

BLANK ( $\mu \subset 1 / \mathrm{ml})$

$\angle 8 E-05$

$<8 E-05$

$\angle 8 E-05$

$6 E-05$

$<5 E-05$

< $5 E-05$

SE-05

СE-07.

A-Acid Leach, Wawater lesch, FuFusion, smpesample, dup=duplicate, blk=blank

- Results are in $\mu \mathrm{el} / \mathrm{ml}$. 


\section{WHC-EP-0668}

Table 3-6: SST Cores 47, 48, and 49, Pu MS Isotopic Percent

\begin{tabular}{|c|c|c|c|c|c|}
\hline \multicolumn{2}{|l|}{ Sample 10} & 234 & 235 & 236 & 238 \\
\hline $\begin{array}{l}\text { Tank } C-109- \\
93-01354-N-1 \\
93-01354-N-2 \\
93-01354-N-3 \\
93-03290-N\end{array}$ & $\begin{array}{l}\text { Llquid Compos } 1 \\
A / \text { smp } \\
A / \text { dup } \\
A / b / k\end{array}$ & $U$ cone & itration & too low for Mass & Spec an \\
\hline \multicolumn{6}{|c|}{ Tank C-109, Core Composite, Fusion } \\
\hline $\begin{array}{l}93-01358-H-1 \\
93-01358-H-2 \\
93-01358-H-3\end{array}$ & $\begin{array}{l}F / \text { smp } \\
F / \text { dup } \\
F / b \mid k\end{array}$ & $\begin{array}{l}0.0059 \\
0.0062\end{array}$ & $\begin{array}{l}0.6580 \\
0.6566\end{array}$ & $\begin{array}{l}0.0100 \\
0.0107\end{array}$ & $\begin{array}{l}99.3261 \\
99.3265\end{array}$ \\
\hline $\begin{array}{l}\text { Core } 48 \\
93-01363-H-1\end{array}$ & $F /$ smp & 0.0056 & 0.682 & 0.0059 & 99.3065 \\
\hline $\begin{array}{l}93-01363-\mathrm{H}-2 \\
\text { Cor } 49\end{array}$ & F/dup & 0.0058 & 0.6883 & 0.0049 & 99.3010 \\
\hline $\begin{array}{l}93-01371-\mathrm{H}-1 \\
93-01371-\mathrm{H}-2\end{array}$ & $\begin{array}{l}\mathrm{F} / \text { smp } \\
\mathrm{F} / \text { dup }\end{array}$ & $\begin{array}{l}0.0051 \\
0.0056\end{array}$ & $\begin{array}{l}0.6792 \\
0.6713\end{array}$ & $\begin{array}{l}0.0079 \\
0.0089\end{array}$ & $\begin{array}{l}99.3077 \\
99.3141\end{array}$ \\
\hline
\end{tabular}

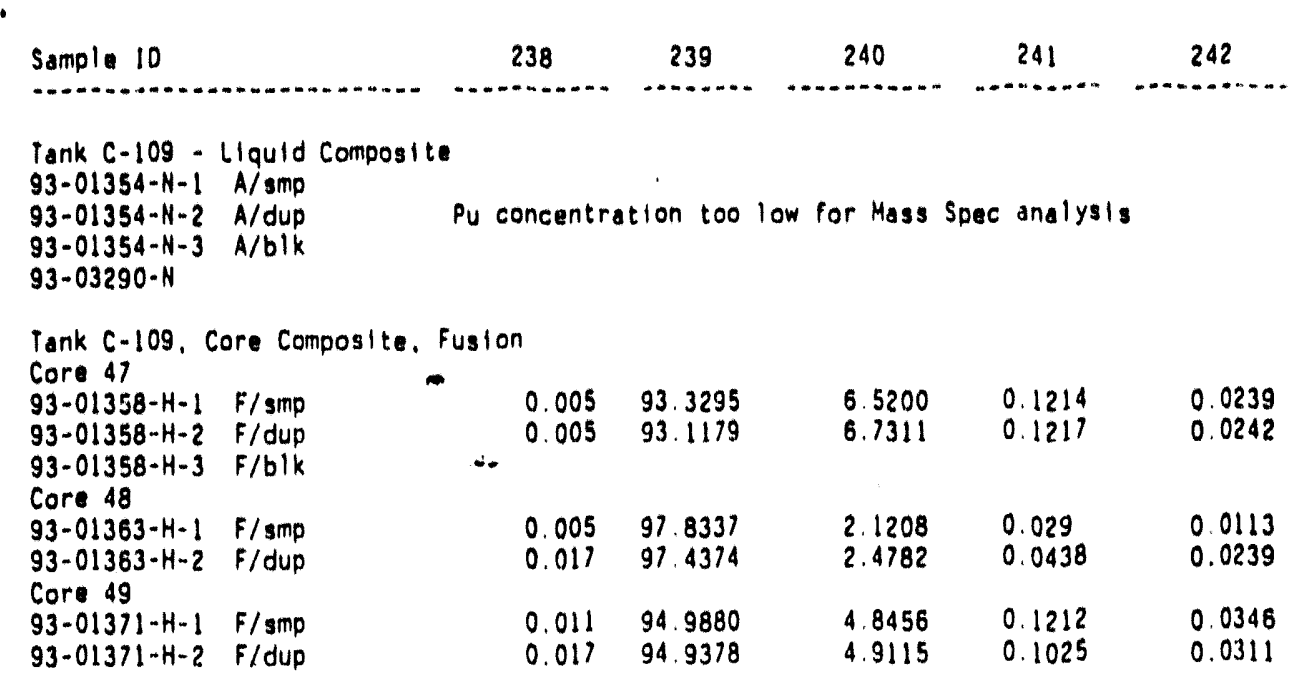

$A=A c l d$ Lach, Wewater Leach, FaFusion, smp=sample, dupaduplicate, blk=blank 


\section{Extractable Oraanic Hallde Analys is Results}

The core 49 core composite (93-01371) was analyzed in duplicate for the presence of extractable organic halides. Insufficient sample was avallable from the core 47 and 48 composites to perform this analysis. Three al iquots of the sample were extracted in the SAL according to procedure PNL-ALO-320, "Extractable Organic Halides." These samples (a blank, sample, sample duplicate, matrix spike) were then analyzed using method PNL-ALO-320 using a Dohrmann, microcoulometric titration, halogen analyzer.

Table 4-1: SST Core 49, Extractable Organic Halide Data

$\begin{array}{lll}\text { ACL Samole Number } & \text { Descriotion } & \text { Halide Conc. } \\ 93-01371-F 1 & \text { CORE-49 SAMPLE } & 11 \mu \mathrm{g} / \mathrm{g} \\ 93-01371-\mathrm{F} 2 & \text { CORE-49 SAMPLE DUPE } & <10 \mu \mathrm{g} / \mathrm{g} \\ 93.01371 . \mathrm{F} 3 & \text { METHOD BLANK } & <10 \mu \mathrm{g} / \mathrm{g} \\ 93-01371 . \mathrm{F} 4 & \text { CORE-49 MATRIX SPIKE } & 91 \% \text { Recovery }\end{array}$

The Halide concentrations are based on the total wet weight of the .. sample al iquot received from the hot cells.

Each al qquot from Sample 93-01371 appeared to be simflar in color and consistency. The color of the sample was tan and appeared very dry. $A \mathrm{pH}$ adjustment was required prior to extraction. Halide was detected at the detection $1 \mathrm{im}$ t for this method, which is $10 \mu \mathrm{g} / \mathrm{g}$. The spike recovery was within the current established guidelines for this procedure. 


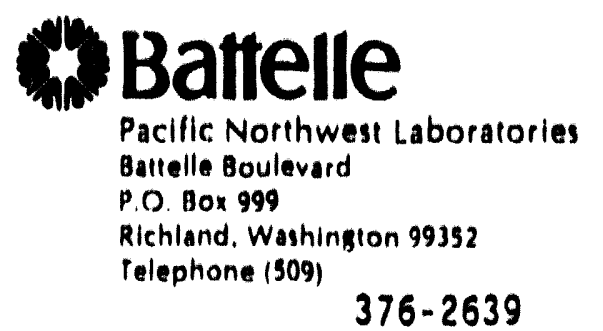

September 9, 1993

Brett C. Simpson, R2-12

Westinghouse Hanford Company

P. O. Box 1970

Richiand, WA 99352

Dear Brett:

ACL RESPONSE TO THE C-109 DATA VALIDATION REPORT

Please find attached the Pacific Northwest Laboratory Analytical Chemistry Laboratory response to the HASM validation report of the Tank C. 109 data. This response was originally issued to $K$. N. Pool (HASM). The content of tiis document is only a response to the issues ralsed in the validation report and in no way does our response requalify the data. We have asked in this document that the usability of the radiochemical data be reovaluated in terms of its adequacy for its intended use.

Please foel free to call if you have questions regarding the C.109 data or the at tached document.

sincerely,

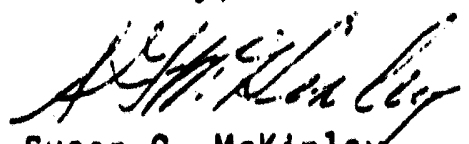

Susan G. Mckinley

PNL TWC Project Manager

Analytical Chemistry Laboratory

$S G M / r m n$

Attachment

cc: K. J. Kuhl-Klinger

Project Flle - 16021

File/LB 


\section{ACL RESPONSE TO C.109 DATA VALIDATION REPORT}

The following response is based upon the Chemlcal and Radlochemlcal Data Validation Narrative portions of the C. 109 Data Validation Report. This response is formatted in the exact order as presented in the Repnrt.

Lnduct vely Coupled Argen Plasma (ICP)

Regarding IEC Corrections: The application of quallfiers to IEC corrected data had minimal impact on this data package. Therefore, no response is warranted.

Arsenic by ICP: The Valldator quallfled arsenic results as "R" (Unreliable) because of unacceptable initial callbration verification (ICV) results. please note that the ICV does not contain arsenic; the "true" concentration reported was actually that for bartum, not arsenic. The arsenic is compared using a "MCV" standard at $10 \mathrm{ppm}$. A "Don't Say It..Write It" (DSI) to flle is attached to this response for inclusion in front of the ICP raw data. This DSI alerts reviewers to the error. It should be noted that arsenlc was reported from the GFAA analysis as well. Since GFAA is more sensitive than ICP for arsenic, the GFAA data should be used for assessment.

No additional issues of significance were noted for the remaining inorganic analyses.

\section{Badjochemical Data Validation}

The Validator qualifled most radiochemical data as "R" (unrellable) due to lack of evidence of splkes, carrlers, or tracers.

Ietal Alpha/Beta: The Validator references a requirement for matrix splkes in WHC-EP-210; the 1 aboratory does not follow this plan. The ACL follows the Technical Project Plan (TPP) and Quallty Assurance Project Plan (QAPJP). However, the qualification of data as "unrellable" due to lack of a matrix spike appears extreme; no chemical separations are performed, and alpha and beta can be compared against the major contributing isotopes. The sample is evaporated onto a counting plate and total count rate is reported.

The Valldator references the lack of Counter Control data. Counter control data start on page E04-204 for alpha and E05-174 for beta; this control data is used as the dally instrument performance check and confirms valldity of the original calibration. Initial callbration data is not a required submission under this project; counter control data is a required submission.

Americium-24l: Matrix spikes, tracers or carriers were not performed and the data was qualifled as "unrellable." A standard and blank were processed similarly to the samples. This standard recovered at $96 \%$, Indicating that no processing errors occurred. Plutonlum and americium-24l account for the major alpha present, and the sum of these 1sotopes compares well with the total alpha. The $A C L$ does not belleve qualification of the data as "unrellable" is justifled.

Iotal plutenfum: Matrix spikes, tracers or carrlers were not performed and the data was qualified as "unreliable." As noted abovis, total pluton um and 
americlum generally account for most of the alpha activity, and this data compares well with the total alpha measurements. The $\mathrm{ACL}$ does not belleve qualification of the data as "unrellable" is justifled.

Neptunfum-237: Tracers were not run and the data was therefore qualifled as "unrellable." A standard prepared simflarly to the samples recovered well, indicating adequate sample processing technique. The low levels of neptunfum-237 detected appear reasonable when added to plutonfum and americium for comparison to the total alpha. Qualification of the low-level neptuntum-237 does not appear to be reasonable.

Strontium-90: Carriers were not run and the data was therefore qualified as "unrellable." Good agreement was noted between the sum of the stront fum-90/yttrium-90 and cesium-137 with the total beta, three independent techniques. For this reason, the $A C L$ does not bel leve qualification of results as "unreliable" is justified.

Iechnicium-99: Spikes or carriers were not performed and the data was therefore qualified as "unreliable." The laboratory has not found a sultable tracer for routine use. Standards processed similarly to the samples recovered well, indicating acceptable sample processing. The technicium-99 and strontfum-90 together compare well with the total beta. Qualification of the results as "unreliable" does not appear to be justified.

Carbon-14: Matrix splkes were not performed and the data was therefore qualified as "unreliable." The National Institute of Standards and Tethnology (NIST) standards are prepared and analyzed simflarly to the samples. Recoveries were good, indicating acceptable preparation and analysis. Qualification of the results as "unreliable" does not appear to be. justified.

Selenjum-79: A carrier was not run and the data was therefore qualified as "unreliable." This statement is incorrect. The ACL adds metal carrier to every sample and determines the yield gravimetrically. No data should have been qualified as "unreliable."

Letal Urantum: No problems were noted. No response required.

Gamme Energy Analysts (GEA): No problems were noted. No response required.

Mass Spectrometry: All data was qualified as "unreliable" because of missing data for dally standard run. A standard is run dally, when in use, for this technique. See pages E09.026 through E09.034 for daily standards.

Physical Testing: No problems were noted. No response required.

Additional Concerns: The Validator noted that the radiochenical calculations were extremely difficult to verify because units were not included. The $A C L$. takes exception to the Validator's comment. The raw data indicates counts, time in minutes and all sample processing factors. The only units missing are $d / c$ or $c / d$ for the effictency; $d / c$ or $c / d$ can be ascertained quile easily by noting whether the efficiency is greater or less than 1.0. 


\section{ACL SUMMARY}

The ACL is most conterned by the "unreliable" qualification of the radlochemlcal data. Although carriers, tracers and/or splkes were not performed for the majority of isotopes tested, the agreement between independent techniques should be supportive of the rellabllity of results. Consideration should also be given to the fact that standards are processed similarly to the samples after hot-cell preparation. Standard recoveries were acceptable for all isotopes reported, indlcating acceptable sample processing technique. If one assumes acceptable sample processing technique, then matrix problems would be the final area of concern. Again, the fact that comparison of results across multiple, independent techniques showed consistency in agreement should further support data rellabllity. The ACL would therefore ask that usabllity of the radiochemical data be reevaluated in terms of adequacy for its intended use.

It is not our intent to question whether tracers, carriers and/or spikes would have given more credence to the data, but rather that these quality control checks were not performed based upon verbal agreements between Westinghouse and the ACL at the time. This data package is consistent with previous submissions; unt 11 your validation report was recelved, there was no indication that problem existed. It has been the $A C L$ 's perception that previous data were found to be asequate for the intended use. 


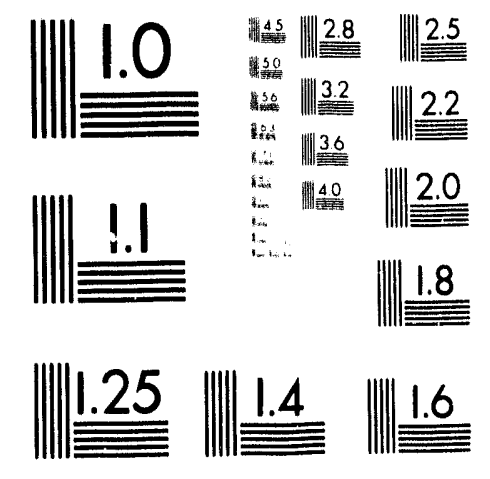



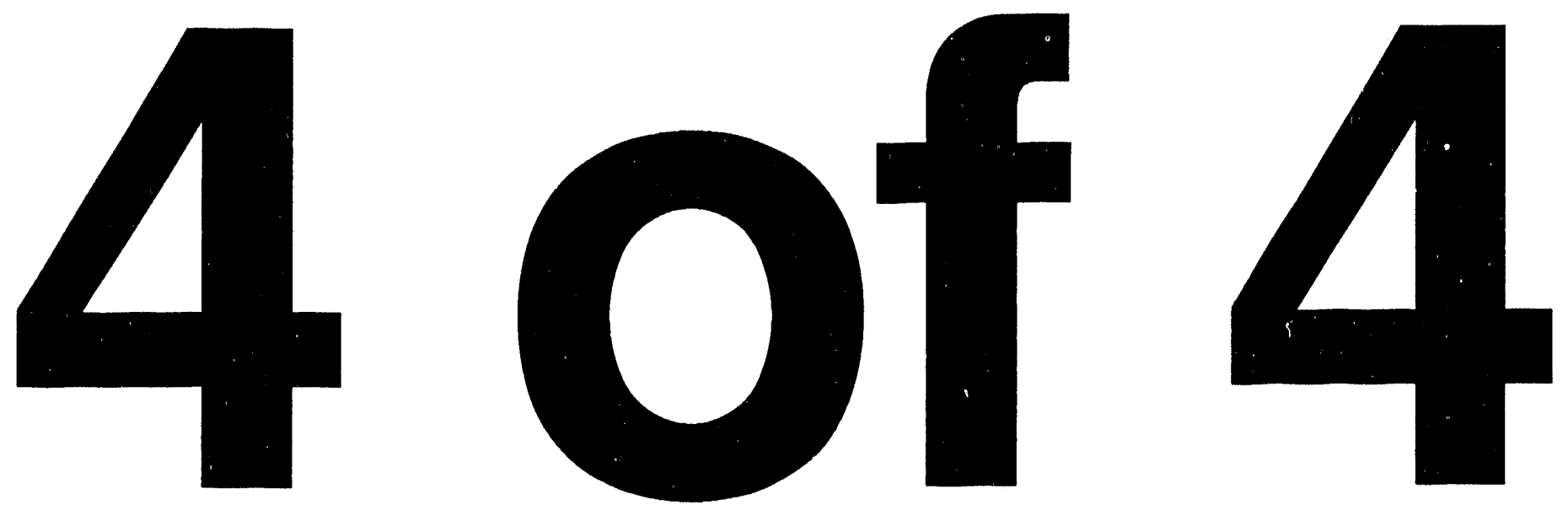
WHC-EP-0668

This page intentionally left blank. 
WHC-EP-0668

DISTRIBUTION

Number of Copies

OFFSITE

25

U.S. Department of Energy

EM-35, Trevion II

Washington, D.C. 20585

John C. Tseng

1

U.S. Department of Energy

Savannah River Operations office

P.O. Box A

Aiken, South Carolina 29808

Thomas C. Temṕle

1

Charles S. Abrams

1987 Virginia

Idaho Falls, ID 83404

1

David 0. Campbell

102 Windham Road

Oak Ridge, TN 37830

1

Fred N. Carlson

6965 North 5 th West

Idaho Falls, ID 83401

1

Donald T. Oakley

409 12th Street SW, Suite 310

Washington, DC 20024-2188

1

Arl in K. Postma

3640 Ballard Road

Dallis, Oregon 97338

1

William R. Prindle

1556 Crestline Drive

Santa Barbara, CA 93105

1

Alfred Schneider

5005 Hidden Branches Drive

Dunwoody, GA 30338 


\section{DISTRIBUTION (Continued)}

Number of Copies

\section{OFFSITE}

2

Argonne National Laboratory 9700 South Cass Avenue CMT/205

Argonne, IL 60439-4837

James $C$. Cunnane

Theodore R. Krouse

1

Air Products \& Chemicals. Inc. 7201 Hamilton Bivd

Allentown, PA 18195-1501

George E. Schmauch

1

Battelle columbus Laboratories 505 King Avenue

Columbus, $\mathrm{OH}$ 43201-2693

James A. Gieseke

2

Brookhaven National Laboratory Upton, NY 11973

Kamal K. Bandyopadhyay Morris Reich

1

Design Science, Inc. 163 Witherow Road Sewickley, PA 15143

Gary Powers

1

Fauske and Associates, Inc. 16 W070 W. 83rd St.

Burr Ridge, IL 60521

Hans K. Fauske

1

Florida State University Department of Chemistry B-164 Tallahassee, FL 32306

Greg R. Choppin 
WHC-EP-0668

\section{DISTRIBUTION (Continued)}

Number of Copies

OFFSITE

1

1

1

4

1

1
Harvard University

295 Upland Avenue

Newton Highlands, MA 02161

Melvin W. First

Hazards Research Corporation

200 Valley Road, Suite 301

Mt. Arlington, NJ 07856

Chester Grelecki

Lawrence Livermore National Laboratory

P.0. Box 808, L-221

Livermore, CA 94550

Billy C. Hudson

Los Alamos National Laboratory

P.0. Box 1663

Los Alamos, NM 87545

Steve F. Agnew

Steve W. Eisenhawer

Thomas E. Larson

L. Harold Sullivan

MIT/Department of Nuclear Engineering

77 Massachusetts Ave.

Room 24-102

Cambridge, MA 02139

Mujid S. Kazimi

Nuclear Consulting Services, Inc.

P.0. Box 2915]

Columbus, $\mathrm{OH} 43229$

J. Louis Kovach 


\section{DISTRIBUTION (Continued)}

\section{Number of Copies}

\section{OFFSITE}

3

1

4

1
Oak Ridge National Laboratory

Emory D. Coll ins

P.0. Box 2008

7930, MS -6385

Oak Ridge, TN 37831-6385

Charles W. Forsberg

P.0. Box 2008

MS-6495

Oak Ridge, TN 37831-6495

Thomas S. Kress

P.0. Box 2009

9108, MS -8088

Oak Ridge, TN 37831-8088

Bice University

5211 Paisley

Houston, TX 77096

Andrew S. Veletsos

Sandia National Laboratory

P.0. Box 5800

Albuquerque, NM 87185

Scott E. Slezak

Science Applications International Corporation 12850 Middlebrook Road

Trevion 1, Suite 300

Germantown, MD 20874

Ray S. Daniels (3)

John M. Savel and

University of South Carolina Department of Electrical and Computer Engineering Swearingen Engineering Center

Columbia, SC 29208

Joseph S. Byrd 
WHC-EP-0668

DISTRIBUTION (Continued)

Number of Copies

OFFSITE

1

Untversity of Washington

Center for Process Analytical Chemistry

Chemistry Department BG-10

Seattle, WA 98195

Bruce R. Kowalski

1

Vanderbilt University

P.0. Box 1596, Station B

Nashville, TN 37235

Frank L. Parker

ONSITE

18

U.S. Department of Energy. Richland Field office

R. F. Christensen (8)

R3-72

J. M. Clark (3)

R. E. Gerton

R3-72

R3-72

A. G. Krasopoulos

A4-81

T. Noble

R. 0 . Puthoff

Public Reading Room

R3-72

A5- 10

RL Docket File (2)

A1 -65

A3-11

\section{Pacific Northwest Laboratory}

R. T. Allemann

K7- 15

S. A. Bryan

$P 7-25$

N. G. Colton

B. M. Johnson

P8-30

M. A. Lilga

K $1-78$

S. G. McKinley

P8-38

K. H. Pool

P7-22

P8 -44

R. D. Scheele

G. F. Schiefelbein

P7 -25

D. M. Strachan

P8-38

J. M. Tingey

PNL Technical Files

K2-38

K2 -44

KI-11 
WHC-EP-0668

DISTRIBUTION (Continued)

Number of Cooles

ONSITE

104

Westinghouse Hanford Company

W. T. Alumkal

R2-52

H. Babad

D. B. Bechtold

J. R. Bell

J. B. Billetdeaux

R. J. Bl anchard

D. C. Board

G. L. Borsheim

V. C. Boyles

J. G. Burk

R. J. Cash (5)

M. D. Crippen

G. M. Chrtstensen

R. D. Crowe

S. J. Decliter

C. DeFigh-Price

G. T. Dukelow (2)

G. L. Dunford

C. J. Forbes

K. D. Fowler

G. L. Fox

G. T. Frater

J. C. Fulton

K. A. Gasper

S. D. Godfrey

J. M. Grigsby

T. W. Halverson

R2-78

T6-09

R3-09

R2-08

$\mathrm{R} 1-17$

S1-57

R2-11

$\mathrm{RI}-49$

B3-25

R2-78

L5-3!

H4 - 21

H4 -68

R2-54

R2-31

$R 2-78$

$R 1-51$

RI -08

R2-11

L5-0]

RI-51

R2-31

R2-08

RI- 51

H4-62

R2-54

D. G. Hamrick

H. D. Harmon

S6- 15

R2-52

J. M. Held

R3-09

J. M. Henderson

$54-55$

D. L. Herting

T6-09

J. D. Hopkins

R2-11

R. D. House

M. W. Howard

RI -05

M. N. Islam

D. W. Jeppson

J. R. Jewett

D. R. Johnson

N. W. Kirch

W. L. Knecht

GI -75

R3-08

L5-3!

T6-09

R2-08

R2-11

HO-34

C. A. Kuhlman

B3-30

M. Kummerer

$\mathrm{H} 4-62$

D. L. Lenseigne

R2-75 


\section{DISTRIBUTION (Continued)}

Number of Contes

ONSITE

Westinghouse Hanford Company (continued)

D. A. Marsh

J. D. McCormack

A3-05

N. G. McDuffie

J. M. McLaren

L5-31

J. E. Meacham

R2-78

$\mathrm{HO}-34$

S. J. Mech

R2-78

J. P. Menard

L5-55

J. W. Neskas

R2- -40

N. J. Milliken

R2-11

A. F. Noonan

H4-63

P. C. Ohl

R2-12

M. A. Payne

R. S. Popielarczyk

D. N. Price

J. G. Propson

R. E. Raymond

I. E. Reep

F. R. Reich

E. L. Renner

D. A. Reynolds

J. H. Roecker

C. C. Scalef

C. P. Schroeder

M. H. Shannon

N. L. Simon

B. C. Simpson (10)

S. R. Tifft

H. Toffer

J. D. Thomson

R. E. Vandercook

W. T. Watson

R. K. Welty

W. P. Whiting

J. C. Wiborg

W. D. Winkeiman

R1-30

R2-50

R1-30

R2-14

R2-18

R2-54

R2-08

L5-63

R2-.08

R2-11

B1-59

L7-06

L7-06

H4-61

R2-78

R2-12

H6-26

HO-38

RI-30

S6-17

HO- 38

R1-80

B3-25

H4-60

L5-55

T6-50

W. I. Winters

D. D. Wodrich

D. D. Wodrich

W. F. Zuroff

Central files

R2-31

HO- 30

R2-14

L8-04

Document Processing and Distribution (2) EDMC

L8-15

H6- 08

Information Release Administration (3)

RI-08

TFIC

R1-20 
WHC-EP-0668

This page intentionally left blank.

Distr-8 

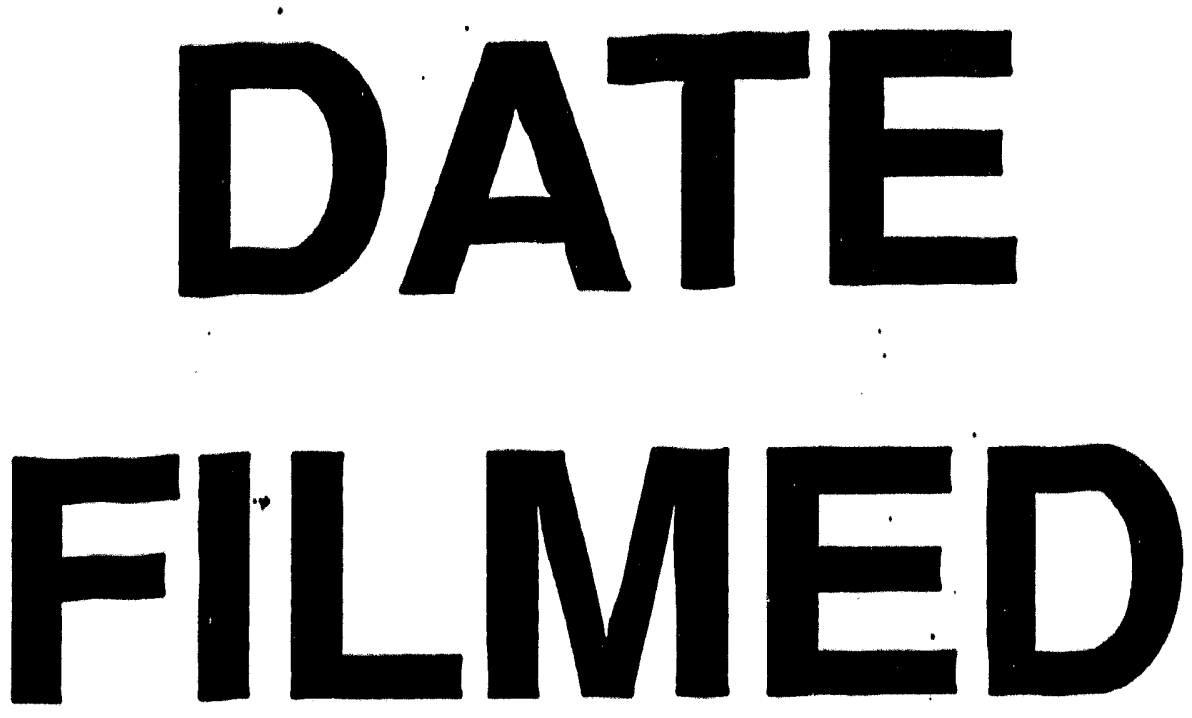

$1 / 6 / 94$
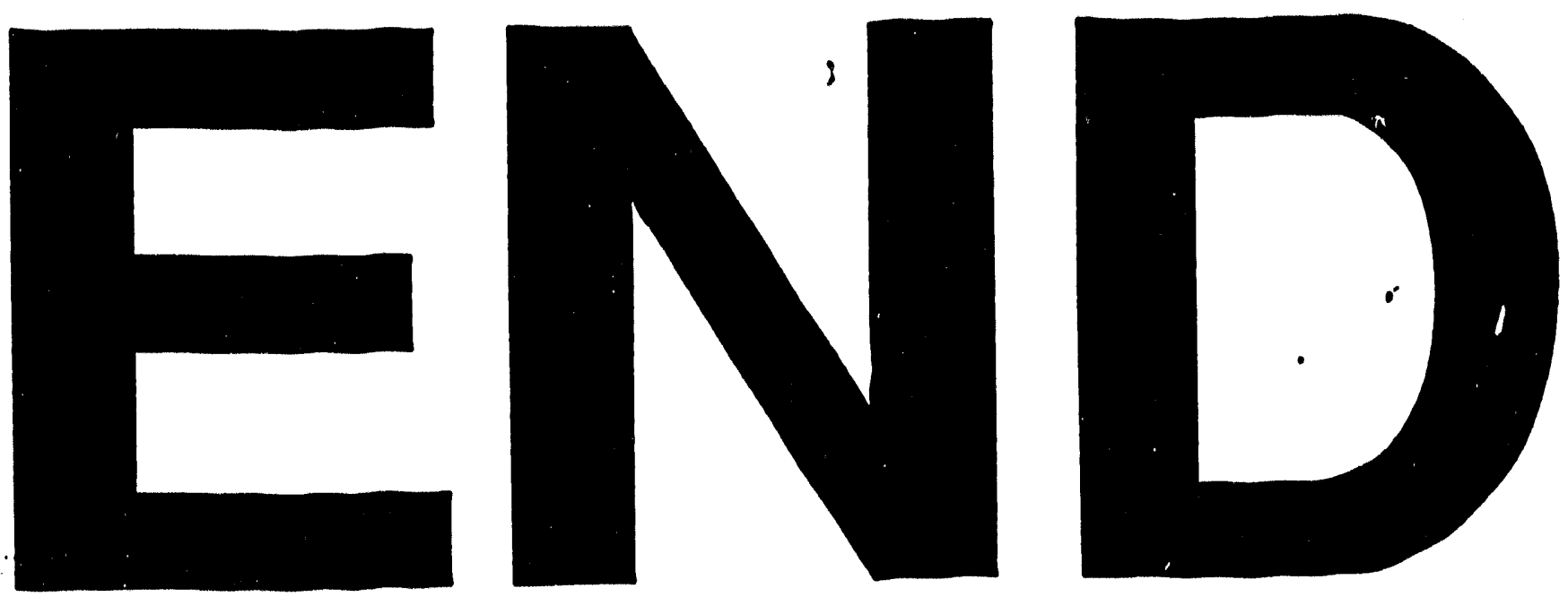
